Prepared for the U.S. Department of Energy under Contract DE-AC05-76RL01830

\title{
Characterization of Vadose Zone Sediment: Uncontaminated RCRA Borehole Core Samples and Composite Samples
}

RJ Serne
BN Bjornstad
HT Schaef
BA Williams
DC Lanigan
DG Horton
RE Clayton

AV Mitroshkov JN Serne

VL LeGore GV Last

MJ O'Hara SC Smith

CF Brown CW Lindenmeier

KE Parker

JM Zachara

IV Kutnyakov DS Burke

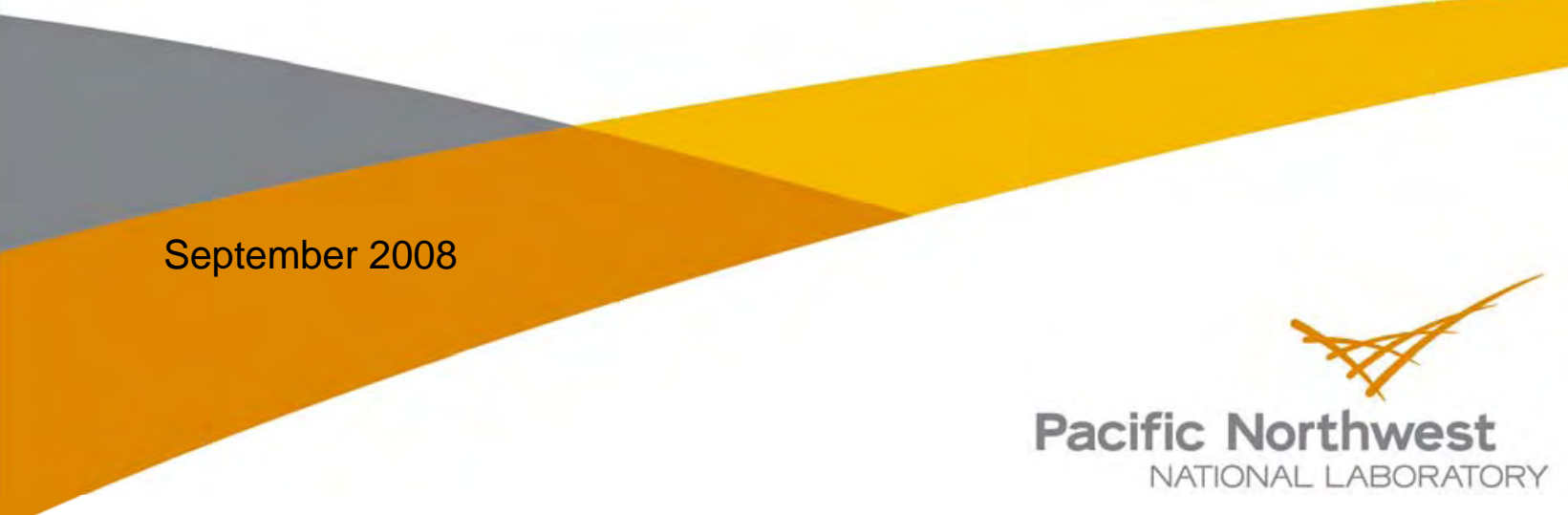




\title{
DISCLAIMER
}

This report was prepared as an account of work sponsored by an agency of the United States Government. Neither the United States Government nor any agency thereof, nor Battelle Memorial Institute, nor any of their employees, makes any warranty, express or implied, or assumes any legal liability or responsibility for the accuracy, completeness, or usefulness of any information, apparatus, product, or process disclosed, or represents that its use would not infringe privately owned rights. Reference herein to any specific commercial product, process, or service by trade name, trademark, manufacturer, or otherwise does not necessarily constitute or imply its endorsement, recommendation, or favoring by the United States Government or any agency thereof, or Battelle Memorial Institute. The views and opinions of authors expressed herein do not necessarily state or reflect those of the United States Government or any agency thereof.

\author{
PACIFIC NORTHWEST NATIONAL LABORATORY \\ operated by \\ BATTELLE \\ for the \\ UNITED STATES DEPARTMENT OF ENERGY \\ under Contract DE-AC06-76RL01830
}

This document was printed on recycled paper. 
PNNL-13757-1, Rev.1

\section{Characterization of Vadose Zone Sediment: Uncontaminated RCRA Borehole Core Samples and Composite Samples}

$\begin{array}{lll}\text { R. J. Serne } & \text { A. V. Mitroshkov } & \text { J. N. Serne } \\ \text { B. N. Bjornstad } & \text { V. L. LeGore } & \text { G. V. Last } \\ \text { H. T. Schaef } & \text { M. J. O'Hara } & \text { S. C. Smith } \\ \text { B. A. Williams } & \text { C. F. Brown } & \text { C. W. Lindenmeier } \\ \text { D. C. Lanigan } & \text { K. E. Parker } & \text { J. M. Zachara } \\ \text { D. G. Horton } & \text { I. V. Kutnyakov } & \text { D. S. Burke } \\ \text { R. E. Clayton } & & \end{array}$

September 2008

Prepared for CH2M HILL Hanford Group, Inc. and the U.S. Department of Energy under Contract DEAC06-76RL01830

Pacific Northwest National Laboratory

Richland, Washington 99352 


\section{Executive Summary}

This report was revised in September 2008 to remove acid-extractable sodium data from Tables $4.14,4.16,5.20,5.22,5.43$, and 5.45. The sodium data was removed due to potential contamination introduced during the acid extraction process. The rest of the text remains unchanged from the original report issued in February 2002.

The overall goal of the of the Tank Farm Vadose Zone Project, led by CH2M HILL Hanford Group, Inc., is to define risks from past and future single-shell tank farm activities. To meet this goal, CH2M HILL Hanford Group, Inc. asked scientists from Pacific Northwest National Laboratory to perform detailed analyses on vadose zone sediment from within the S-SX Waste Management Area. This report is one in a series of four reports to present the results of these analyses. Specifically, this report contains all the geologic, geochemical, and selected physical characterization data collected on vadose zone sediment recovered from Resource Conservation and Recovery Act (RCRA) borehole bore samples and composite samples.

Intact cores from two "clean" RCRA boreholes (299-W22-48 and 299-W22-50) near the SX Tank Farm and four, large-quantity grab samples from outcrop sediment on the Hanford Site were sampled to better understand the fate of contaminants in the vadose zone beneath underground storage tanks at the Hanford Site. Borehole and outcrop samples analyzed for this report are located outside the tank farms, and therefore may be considered standard or background samples from which to compare contaminated sediments within the tank farms themselves. This report presents our interpretation of the physical, chemical, and mineralogical properties of the uncontaminated vadose zone sediments, and variations in the vertical distribution of these properties. The information presented in this report is intended to support preparation of the S-SX field investigation report prepared by CH2M HILL Hanford Group, Inc. as well as future remediation actions at the S-SX Tank Farm.

The geology under the SX Tank Farm forms the framework through which the contaminants move, and provides the basis with which to interpret and extrapolate the physical and geochemical properties that control the migration and distribution of contaminants. Of particular interest are the interrelationships between the coarser- and finer-grained facies, and the degree of contrast in their physical and geochemical properties. For the two boreholes, lithologic sections were constructed using detailed geologic descriptions and geophysical logs. In some cases the results of laboratory analyses (e.g., particle-size distribution, moisture, calcium carbonate content) helped to refine the resulting stratigraphic and lithologic interpretations.

Our conceptual model of the 67-meter (220-foot)-thick vadose zone beneath the SX Tank Farm consists of seven stratigraphic units. These include two members of the Ringold Formation (member of Wooded Island/Unit E [Rwi(e)] and member of Taylor Flat [Rtf]), two Plio-Pleistocene subunits (very fine sand to mud sequence [PPlz] and a carbonate-rich paleosol sequence [PPlc]), and three units of the Hanford formation (H1a, H1, and $\mathrm{H} 2$ units). Most of the Hanford formation H1a unit was removed during excavation of the SX Tank Farm and replaced with backfill to a depth of about 17 meters (55 feet). All but the Hanford formation strata dip slightly toward the southwest.

(a) Draft Field Investigation Report for Waste Management Area S-SX. RPP-7884, Draft, Volume 2, Appendix D, CH2M HILL Hanford Group, Inc., Richland, Washington. 
Sediment samples from the various stratigraphic units were analyzed and characterized in the laboratory for the following parameters:

- mass water content

- particle-size distribution

- particle density

- calcium carbonate and organic carbon contents

- bulk chemical composition

- mineralogy

- cation exchange capacity

- exchangeable base cation distribution

- water leach (1:1 sediment-to-water extraction)

- acid leach (8 M nitric acid extraction)

- unsaturated flow apparatus- (UFA)-extracted porewater composition.

Physical properties, such as particle-size distribution and moisture content, also vary according to lithology. Strata with finer particle sizes (e.g., lower Hanford formation), and the top of PPlc subunit with its high cement/clay content, retain more moisture in the vadose zone. High moisture is also associated with a subvertical clastic dike within the upper Ringold unit (Rtf) in borehole 299-W22-48. Of the two methods used to determine particle-size distribution (dry sieve and wet sieve/hydrometer), the wet sieve method is superior to the dry sieve method, especially in fine-grained sediments, which tend to cling together during dry sieving.

Past studies have shown that sediments in the vadose zone are dominated by quartz, potassium- and plagioclase-feldspar, basalt, and other lithic fragments with minor amounts of mica, amphibole, calcite, and other trace minerals (Tallman et al. 1979). The x-ray diffraction (XRD) work done for this study is in agreement with past work and shows that the sediment is 25 to $95 \mathrm{wt} \%$ quartz, 5 to (possibly) $40 \mathrm{wt} \%$ potassium feldspar, 10 to $20 \mathrm{wt} \%$ plagioclase feldspar, and 0 to $40 \mathrm{wt} \%$ calcite with trace to minor amounts of amphibole, mica, and chlorite.

Mineralogical and geochemical variations, some significant, exist between the different stratigraphic units, as a result of differing depositional environments and sources for the sediments. For example, calcite-rich samples are associated with the lower Plio-Pleistocene subunit (PPlc), which unlike other stratigraphic units, underwent significant pedogenic alteration. In addition to high calcium oxide the PPlc subunit is relatively high in magnesium oxide, which co-precipitated with calcium during pedogenesis. Vadose-zone sediments contain very little organic carbon (average $0.05 \mathrm{wt} \%$ ). The organic carbon is slightly greater for the PPlc subunit (up to $0.2 \mathrm{wt} \%$ ), compared to all the other units, which are all $<0.1$ wt $\%$ carbon. Calcium carbonate content, calculated from the amount of inorganic carbon present, approaches $40 \mathrm{wt} \%$ for the PPlc subunit; all other units are generally less than a few wt\% calcium carbonate. The concentration of major elements such as silica, iron, and calcium, varies significantly because of different ratios of quartzo-feldspathic to basaltic detritus in the Hanford versus Ringold formations. Samples high in potassium oxide may reflect the relatively high illite content of the Ringold Formation and finer-grained portions of the Hanford formation. 
Clay minerals, measured semiquantitatively using XRD, include smectite, illite, chlorite, and kaolinite. Overall in the clay-sized fraction of the vadose zone sediments, smectite ranged in concentration from 10 to 30 (wt $\%$ ). Illite concentrations ranged from $\sim 10 \%$ to $50 \%$ and chlorite concentrations were a little less ( $\sim 5$ to $35 \mathrm{wt} \%)$. Minor amounts of kaolinite ( $\sim 5 \%$ to $10 \%)$ were also detected. Quartz, feldspar, and amphiboles made up less than $\sim 15 \mathrm{wt} \%$ of the clay fraction. The only consistent trend in the mineral content of samples is the substantial increase in calcite, relative to other minerals, for the PPlc subunit. This trend is noted in both the bulk sample as well as the $\leq 2$-micron fraction.

Base cations, displaced via ammonium acetate extraction, are dominated by alkaline earth elements (calcium and magnesium), especially within the PPlc subunit. The relative contribution of the alkali metals (sodium and potassium) to the natural distribution of exchangeable cations is small $(<10 \%)$. Though some relationships can be made comparing cation exchange capacity to the lithology, mineralogy and grain-size distribution of some samples, enough discrepancies exist to make most comparisons tentative. Cation exchange capacity was measured using two analytical techniques, each of which provided significantly different results. More work is needed to establish the best way to measure cation exchange capacities on sediments from the Hanford Site.

The results from the 1:1 sediment-to-water extracts are similar for samples from both of the clean boreholes. This gives credence to the representativeness of the results. Also, most, but not all, results yield a reasonable charge balance among cations and anions. There is one sample in borehole 299-W22-50 near the base of the coarse-grained Hanford formation $\mathrm{H} 1$ unit that shows high $\mathrm{pH}$, electrical conductivity (EC), and water-leachable cations and anions, but it appears to be natural and perhaps was caused by dissolution of natural evaporates (see below).

Porewater in the vadose zone was evaluated via a comparison of a few actual UFA-extracted porewater samples with a larger data set of 1:1 sediment-to-water extracts. Water extracts are in agreement with actual porewaters for only a limited number of constituents and the water extracts generally produced higher chemical concentrations than those found in the actual porewater sampled from the same interval and thus the water extracts should be considered maximum values. The concentrations of many constituents in the water extracts of the four composite sediment samples are similar to those in the two sampled boreholes. A few exceptions are higher calcium, chloride, magnesium, sodium, and sulfate in the sediment composite samples relative to the clean borehole samples, probably as a result of natural near-surface recharge and leaching, which does not occur at depth within borehole samples. As expected, the calcic PPLc subunit yielded significantly different water extract results than the Hanford or Ringold formation samples. Water leachate from the PPlc produced relatively higher EC, alkalinity, cations (silicon, calcium, magnesium), anions (nitrate and sulfate), as well as trace elements (selenium, strontium, copper, manganese, and uranium). Elevated concentrations of these parameters, combined with depleted aluminum, are a reflection of the pedogenic origin for the PPLc subunit. Differences among samples from the Ringold and Hanford formations are generally small (except water-extractable magnesium and potassium, which are higher for the older Ringold Formation) and not consistent among all samples. This is not surprising considering the wide range in mineral and physical properties for these samples. 
Most noteworthy in the water extract profile for borehole $299 \mathrm{~W} 22-50$ is high water-leachable $\mathrm{pH}$, alkalinity, EC, calcium, chloride, chromium, strontium, and sulfate at the base of the coarser-grained facies (Hanford formation H1 unit) of the Hanford formation.

In general, acid extraction is effective at removing from sediment samples, in decreasing order, $25 \%$ to $70 \%$ of the total trace metals, $40 \%$ to $60 \%$ of the iron and manganese, about $25 \%$ of the major alkaline earth metals (calcium and magnesium), about $15 \%$ of the aluminum and titantium, about $10 \%$ to $15 \%$ of the minor alkaline earths (barium and strontium), $1 \%$ to $10 \%$ of the alkali metals (potassium and sodium). In contrast, negligible amounts of silicon $(<0.03 \%)$ are removed during acid extraction. The amount of any element removed from the coarse-grained Hanford formation $\mathrm{H} 1$ unit by acid digestion is less than for the other stratigraphic units, perhaps due to the larger particle sizes, which have overall less surface area and are thus less prone to leaching. Acid extraction within the calcic PPLc releases almost all the calcium and strontium and slightly more of several of the other elements when compared to other noncalcic sediment samples. Most calcium and strontium in the PPlc subunit are combined with carbonate, which readily decomposes in contact with acid. Calcium in the other units is associated with silicates (e.g., pyroxene, plagioclase, etc.), which do not readily react with the acid leach.

The high concentrations of these parameters may be natural from past pedogenic/evaporitic processes or perhaps they represent lateral spreading along the $\mathrm{H} 1 / \mathrm{H} 2$ contact of fluids disposed to nearby facilities or fluids from pipe leaks. 


\section{Acknowledgements}

This work was conducted as part of the Tank Farm Vadose Zone Project led by CH2M HILL Hanford Group, Inc., in support of the U.S. Department of Energy's Office of River Protection. The authors wish to thank Anthony J. Knepp, Fredrick M. Mann, David A. Myers, Thomas E. Jones, and Harold A. Sydnor with CH2M HILL Hanford Group, Inc. and Marc I. Wood with Fluor Hanford for their support of this work. We would also like to express our gratitude to Robert Yasek with DOE's Office of River Protection.

We would especially like to thank Kent D. Reynolds (Duratek Federal Services Inc.) for his efforts in design and construction of the sampler breakdown table and core extruder, and Kevin A. Lindsey (Kennedy Jenkes Consultants, Inc.) for his insights on the geologic nature of the materials penetrated by this borehole.

Finally, we would like to thank Bruce J. Bjornstad and Duane G. Horton for their technical review of this document, Launa F. Morasch for her editorial and document production support, and Kathy Neiderhiser and Rose M. Watt for publication design support. 


\section{Acronyms and Abbreviations}

\begin{tabular}{|c|c|}
\hline amsl & above mean sea level \\
\hline ASA & American Society of Agronomy \\
\hline ASTM & American Society for Testing and Materials \\
\hline bgs & below ground surface \\
\hline BHI & Bechtel Hanford, Inc. \\
\hline DOE & U.S. Department of Energy \\
\hline $\mathrm{EC}$ & electrical conductivity \\
\hline EMSP & Environmental Management Science Program \\
\hline EPA & U.S. Environmental Protection Agency \\
\hline ERDF & Environmental Restoration Disposal Facility \\
\hline FIR & field investigation report \\
\hline FY & fiscal year \\
\hline IC & ion chromatography \\
\hline $\mathrm{ICP}$ & inductively coupled plasma \\
\hline ICP-AES & inductively coupled plasma atomic emission spectrometry \\
\hline ICP-MS & inductively coupled plasma mass spectrometry \\
\hline msl & mean sea level \\
\hline PNNL & Pacific Northwest National Laboratory \\
\hline PPlc & Plio-Pleistocene carbonate \\
\hline $\mathrm{PPlz}$ & Plio-Pleistocene mud \\
\hline PPUcp & Plio-Pleistocene calcic paleosol facies \\
\hline PPUoe & Plio-Pleistocene unit overbank-eolian facies \\
\hline PPUsa & Plio-Pleistocene side-stream alluvial facies \\
\hline RCRA & Resource Conservation and Recovery Act \\
\hline Rtf & Ringold Member of Taylor Flat \\
\hline Rwi(e) & Ringold Member of Wooded Island (Unit E) \\
\hline TEM & transmission electron microscopy \\
\hline UFA & unsaturated flow apparatus \\
\hline
\end{tabular}


XRD

XRF

$\mathrm{x}$-ray diffraction $\mathrm{x}$-ray fluorescence 


\section{Contents}

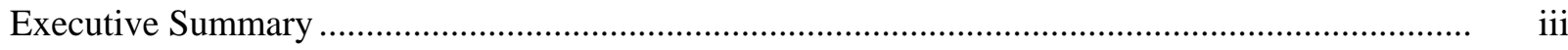

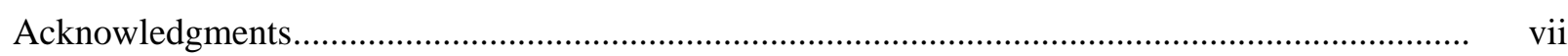

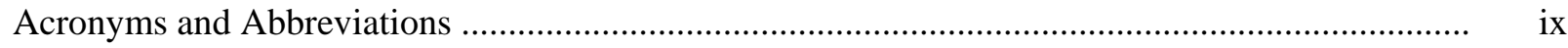

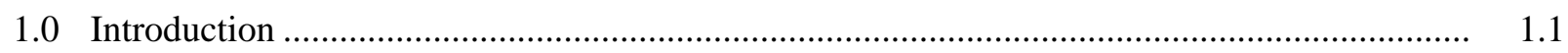

2.0 Geology

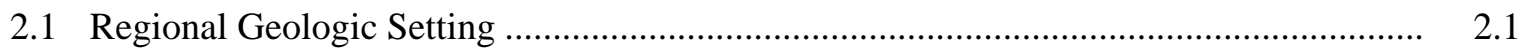

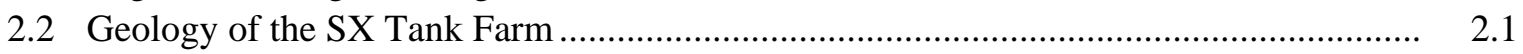

2.1.1 Columbia River Basalt Group .............................................................. 2.8

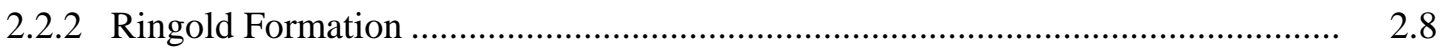

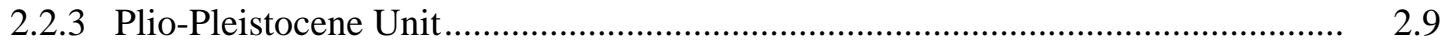

2.2.4 Hanford Formation ......................................................................... 2.14

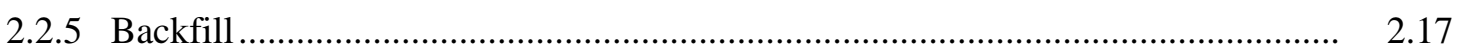

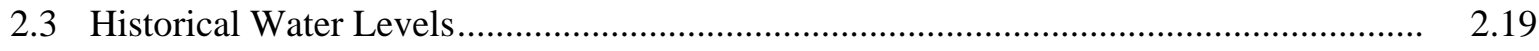

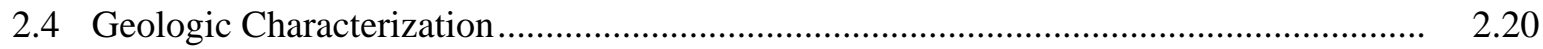

2.4.1 Composite Samples ............................................................................. 2.20

2.4.2 Geologic Characterization of Clean Boreholes ................................................. 2.29

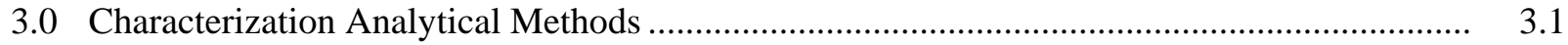

3.1 Post Sampling Sediment Preparation ..................................................................... 3.1

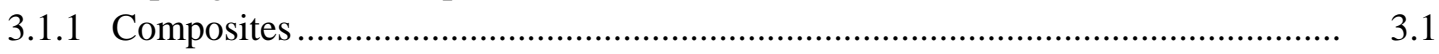

3.1.2 Borehole Core Samples ................................................................................. 3.1

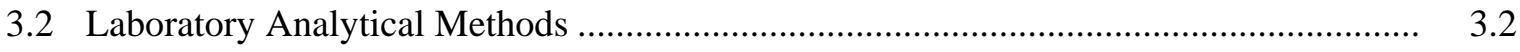

3.2.1 Mass Water Content ..................................................................................... $\quad 3.2$

3.2.2 Particle Size Distribution ........................................................................... 3.2

3.2.3 Particle Density ....................................................................................... 3.3

3.2.4 Calcium Carbonate and Organic Carbon Content ............................................ 3.3

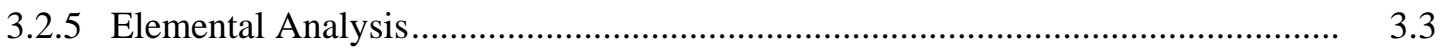

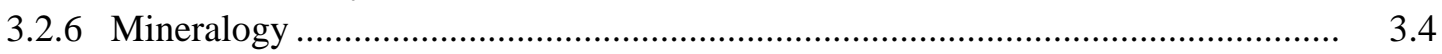

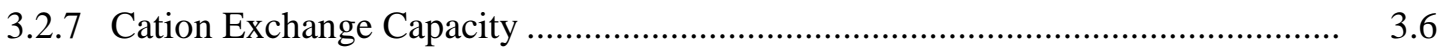

3.2.8 Ammonium Acetate Extract ...................................................................... 3.7

3.2.9 1:1 Sediment-to-Water Extract................................................................ 3.8

3.2.10 8 M Nitric Acid Extract........................................................................ 3.8

3.2.11 Porewater Composition ......................................................................... 3.8 
4.0 Analytical Results for Composite Sediment Samples .................................................... 4.1

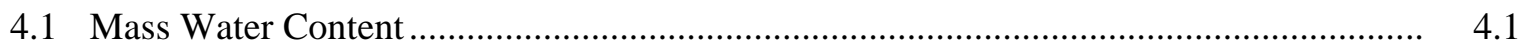

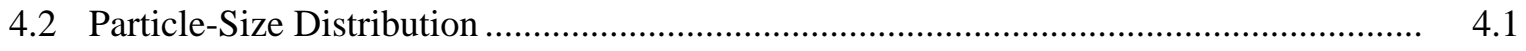

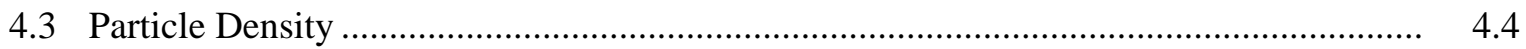

4.4 Calcium Carbonate and Organic Carbon Content ................................................................. 4.5

4.5 Bulk Chemical Composition .................................................................................... 4.6

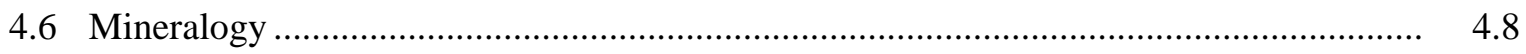

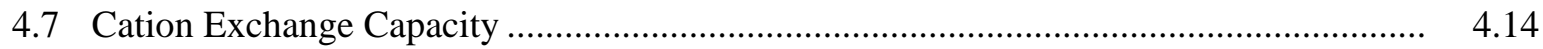

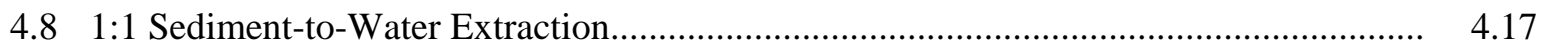

4.9 8 M Nitrate Acid Extraction..................................................................................... 4.19

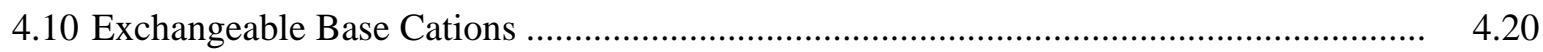

5.0 Analytical Results for Clean Borehole Samples............................................................. 5.1

5.1 Analytical Results for Borehole 299-W22-48 ..................................................... 5.1

5.1 .1 Mass Water Content .......................................................................... 5.2

5.1.2 Particle-Size Distribution ....................................................................... 5.4

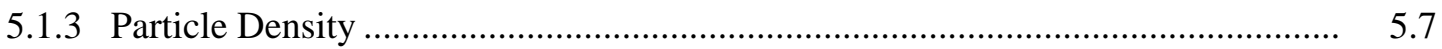

5.1.4 Calcium Carbonate and Organic Carbon Content ............................................ 5.7

5.1.5 Bulk Chemical Composition .................................................................. 5.8

5.1.6 Mineralogy ......................................................................................... $\quad 5.10$

5.1.7 Cation Exchange Capacity ............................................................................ 5.16

5.1.8 Exchangeable Base Cations........................................................................... 5.17

5.1.9 1:1 Sediment-to-Water Extraction.................................................................. 5.18

5.1.10 Acid Extraction ........................................................................................ 5.22

5.1.11 Porewater Composition ................................................................................ 5.25

5.2 Analytical Results for Borehole 299-W22-50 ............................................................ 5.33

5.2.1 Mass Water Content ............................................................................. 5.33

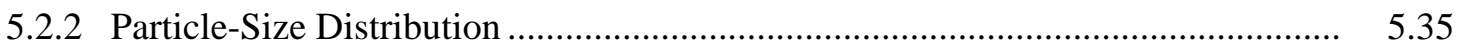

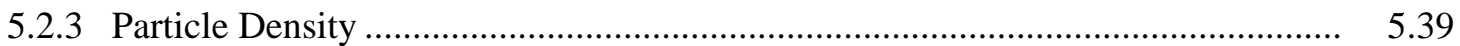

5.2.4 Calcium Carbonate and Organic Carbon Content ............................................... 5.40

5.2.5 Bulk Chemical Composition ......................................................................... 5.41

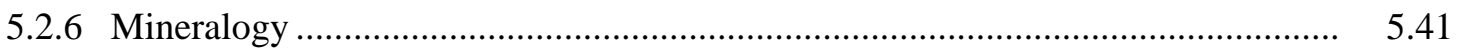

5.2.7 Cation Exchange Capacity ........................................................................ 5.4 .1

5.2.8 Exchangeable Base Cations......................................................................... 5.43

5.2.9 1:1 Sediment-to-Water Extraction................................................................ 5.44

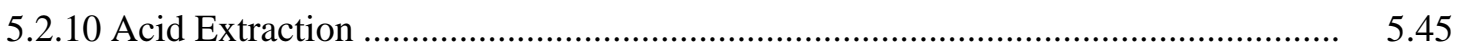

5.2.11 Porewater Composition .............................................................................. 5.53

5.3 Discussion: Comparison Between Boreholes 299-W22-48 and 299-W22-50 ............... 5.59

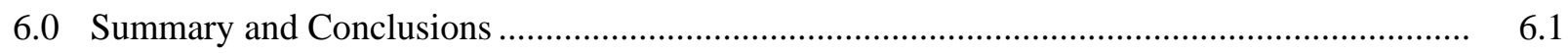

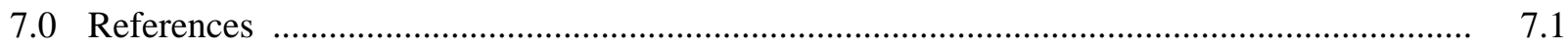


Appendix A - Summary of Field Geologists' Sample Descriptions for Borehole 299-W22-48 and Borehole 299-W22-50

Appendix B - Summary of Geologists' Core Sample Descriptions from Borehole 299-W22-48 ... B.1 Appendix C - Summary Geophysical Logs for Borehole 299-W22-48 and Borehole 299-W22-50C.1 Appendix D - Particles-Size Results from Seven Boreholes in Vicinity of the S-SX Tank Farm ... D.1 Appendix E - Inventory of Core Sleeves from Borehole 299-W22-48

Appendix F - Inventory of Core Sleeves from Borehole 299-W22-50 F.1

Appendix G - Some Mineralogical Analyses of the Composite Sediment Sample G. 1

Appendix H - Some Mineralogical Analyses from Boreholes 299-W22-48 and -50 H. 1 


\section{Figures}

2.1 Generalized, Composite Stratigraphy for the Late Cenozoic Sediments Overlying the Columbia

River Basalt Group on the Hanford Site.

2.2 Location Map and Hydrogeologic Cross Sections Through the SX Tank Farm ..................... 2.3

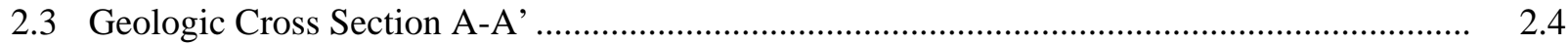

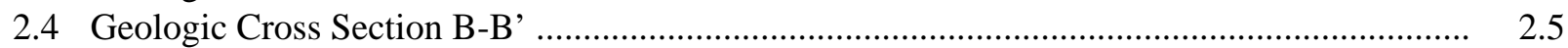

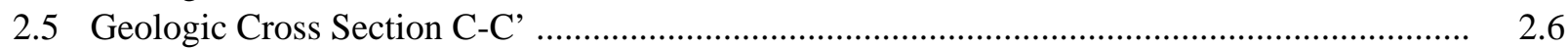

2.6 Lithofacies Distribution for the Lower Plio-Pleistocene Unit (PPlc) ..................................... 2.12

2.7 Digital Elevation Model (DEM) Map of a Portion of the Pasco Basin Showing Routes and Facies Distributions for the Last Pleistocene Cataclysmic Floods .................................. 2.15

2.8 Historic Water Levels Beneath the SX Tank Farm ................................................................ 2.20

2.9 Locations for the Four Composite Sediment Samples.......................................................... 2.22

2.10 Stratigraphic Column of the Upper Portion of the White Bluffs Showing

Sample Collection Depths

2.11 Location of Sample Collected from Lacustrine Laminated Silt of the Ringold Formation....... $\quad 2.23$

2.12 Series of Buried Giant Current Ripples at the 218-E-12B Site ............................................ 2.25

2.13 Example of Pebbly Sand Facies as it Appears In Situ ..................................................... 2.25

2.14 Representation of All Three Facies of the Hanford Formation at the 218-E-12B Site............. 2.26

2.15 Lower Silty Sand Layer at 218-E-12B Site ................................................................. 2.26

2.16 Samples Obtained for Detailed Characterization from the 218-E-12B Site ............................ 2.27

2.17 Environmental Restoration Disposal Facility Sampling Site ............................................. 2.28

2.18 Vadose Zone Stratigraphy for Borehole 299-W22-50 ...................................................... 2.29

2.19 Vadose Zone Stratigraphy for Borehole 299-W22-48.......................................................... 2.33

2.20 Split-Spoon Sample from Within Coarse-Grained Hanford Formation H1 Unit in Borehole 299-W22-48

2.21 Split-Spoon Sample from Within Hanford Formation H2 Unit in Borehole 299-W22-48 ....... 2.34

2.22 Split-Spoon Sample from Within Plio-Pleistocene Mud (PPlz) Unit in Borehole 299-W22-48

2.23 Split-Spoon Samples Representing a) Plio-Pleistocene Mud (PPlz) and Plio-Pleistocene Carbonate (PPlc) Subunits Contact (white dashed line), and b) Plio-Pleistocene Carbonate (PPlc) in Borehole 299-W22-48.

2.24 Split-Spoon Samples Representing Ringold Formation Unit E (Rwi[e]) in Borehole 299-W22-48

2.25 Split-Spoon Sample Representing Upper Ringold Formation (Rtf) in Borehole 299-W22-48

2.26 Split-Spoon Sample Illustrating Contrasts Within the Hanford Formation H2 Unit............... 2.38

2.27 Upper Portion of Subvertical Clastic Dike Completely Filling Core Liner

Within Ringold Formation from 51.4 to 51.7 Meters (168.5 to 169.5 feet) bgs ..................... 2.40

2.28 Split-Spoon Sample of Sandy Gravel from the Hanford Formation H1 Unit.......................... 2.41

2.29 Split-Spoon Sample from Within Hanford Formation H2 Unit in Borehole 299-W22-50 ....... 2.42 
2.30 Split-Spoon Sample from Within Upper Plio-Pleistocene Unit (PPlz) in Borehole 299-W22-50

2.31 Split-Spoon Sample Containing the Contact Between the Plio-Pleistocene Mud (PPlz) and Carbonate (PPlc) Subunits in Borehole 299-W22-50.

4.1 Ringold Silt Composite Sample After Air Drying and Disaggregation .....

4.2 Hanford Coarse Sand Composite Sample After Air Drying and Disaggregation

4.3 Hanford Fine Sand Composite Sample After Air Drying and Disaggregation

4.4 Borehole Fine Sand Composite Sample After Air Drying and Disaggregation

4.5 Particle-Size Distributions for the Four Composite Sediment Samples .....

4.6 Typical Illite Particle ( $\sim 5$ microns long) Common to the

Hanford Fine Sand Composite Sample.

4.7 Typical Illite Particle ( 3 microns long) from Clay Fraction of the Borehole Fine Sand Composite Sample

4.8 Chlorite Particle ( 1.5 micron) from the Borehole Fine Sand Composite Sample

4.9 A Thick, Hexagonal Kaolinite Particle ( 1 micron) from the Borehole Fine Sand Composite Sample

5.1 Particle-Size Distributions Curves of Hanford Formation Sediment Samples from Borehole 299-W22-48

5.2 Particle-Size Distribution Curves of Sediment Samples below 41.4 meters bgs in Borehole 299-W22-48

5.3 Typical Illite Particle from Borehole 299-W22-48

5.4 Chlorite Particle from Borehole 299-W22-48

5.5 Thin Smectite Flakes from the Rtf Unit in Borehole 299-W22-48

5.6 Kaolinite Particle from the H2 Unit in Borehole 299-W22-48

5.7 Moisture Content and Comparison of $\mathrm{pH}$ and Dilution-Corrected Electrical Conductivity of 1:1 Sediment-to-Water Extracts and UFA-Extracted Porewater from Sediment Samples in Borehole 299-W22-48

5.8 Comparison of Dilution-Corrected Anion Concentration of 1:1 Sediment to Water Extracts and UFA-Extracted Porewaters from Sediment Samples in Borehole 299-W22-48

5.9 Comparison of Dilution-Corrected Cation Concentrations of 1:1 Water Extracts and UFA-Extracted Porewaters from Sediment Samples in Borehole 299-W22-48

5.10 Particle-Size Distribution Curves of Sediment Samples from the Hanford Formation at Borehole 299-W22-50

5.11 Particle-Size Distribution Curves of Sediment Samples from the Plio-Pleistocene Unit and Ringold Formation at Borehole 299-W22-50

5.12 Moisture Content, 1:1 Sediment-to-Water Extract, pH, and Electrical Conductivity Data Versus Depth in Borehole 299-W22-50

5.13 Calculated and UFA-Extracted Porewater Concentration of Anions Versus Depth in Borehole 299-W22-50

5.14 Calculated and UFA-Extracted Porewater Concentrations of Cations Versus Depth in Borehole 299-W22-50 . 


\section{Tables}

2.1 Stratigraphy of the Vadose Zone Beneath the SX Tank Farm

2.2 Granulometric Data from Core Samples of Ringold Unit E Encountered Within the 200 West Area

2.3 Example of Granulometric and Calcium Carbonate Data from Samples of the Lower Plio-Pleistocene (PPlc) Unit Encountered Beneath the SX Tank Farm.

2.4 Example of Granulometric and Calcium Carbonate Data from Drive-Barrel Samples of the Upper Plio-Pleistocene Unit (PPlz) Encountered Beneath the SX Tank Farm

2.5 Granulometric and Calcium Carbonate Data from Core Samples of the Hanford Formation Beneath SX Tank Farm and Average Bulk Densities....

2.6 Summary of Recent Particle Size Analytical Results from Seven Boreholes in and Around the SX Tank Farm....

2.7 Composite Sediment Sample Descriptions........

4.1 Moisture Content of Composite Sediment Samples After Air Drying....

4.2 Particle-Size Distributions for Composite Sediment Samples Determined by Dry Sieve Method...

4.3 Particle-Size Distributions for Composite Sediment Samples Determined by Wet Sieving/Hydrometer Method

4.4 Particle Densities for Composite Sediment Samples.

4.5 Calcium Carbonate and Organic Carbon Content (\% wt.) for Composite Samples .

4.6 Bulk Chemical Composition of Composite Sediment Samples (\% as Oxides)

4.7 Semiquantitative Mineral Content of Composite Sediment Samples

4.8 Bulk Chemical Composition of Clay Fraction ( $\%$ as Oxides) in Composite Sediment Samples .....

4.9 Results of Cation Exchange Capacity (meq/100 g) of Composite Sediment Samples Using Two Different Techniques

$4.10 \mathrm{pH}$, Electrical Conductivity, Alkalinity, and Anions in 1:1 Sediment to Water Extracts for Composite Sediment Samples

4.11 Major Cations in 1:1 Sediment to Water Extracts (ICP) for Composite Sediment Samples.....

4.12 Trace Metals in 1:1 Sediment to Water Extracts of Composite Sediment Samples...

4.13 Charge Balance for Water Extracts of Composite Sediment Samples

4.14 Major Cations in Acid Extracts for Composite Sediment Samples

4.15 Trace Metals in Acid Extracts of Composite Sediment Samples

4.16 Percentage of the Total Element that Dissolves During Acid Extraction of Composite Sediment Samples

4.17 Chemical Composition of Ammonium Acetate Extraction for Composite Sediment Samples

4.18 Exchangeable Base Cations Compared to Cation Exchange Capacities Estimates for Composite Sediment Samples. 
5.1 Sediment Core Samples Selected from Borehole 299-W22-48 for Laboratory Analysis

5.2 Moisture Content (wt\%) Measured in Laboratory for Sediment Samples from Borehole 299-W22-48.

5.3 Dry Sieve Results from Borehole 299-W22-48...

5.4 Particle-Size Distribution Determined by Wet Sieving/Hydrometer Method ........................ 5.5

5.5 Comparison of Particle-Size Distributions for Dry Versus Wet Sieving ............................... 5.5

5.6 Particle Densities for Selected Sediment Samples from Borehole 299-W22-48.................... 5.7

5.7 Calcium Carbonate and Organic Carbon Content (wt\%) for Sediment Samples from Borehole 299-W22-48.

5.8 Bulk Chemical Composition of Sediment Samples from Borehole 299-W22-48.....

5.9 Semiquantitative Mineral Content (wt\%) for Sediment Samples from Borehole 299-W22-48-Bulk Sediment Sample

5.10 Semiquantitative Mineral Content (wt\%) for Sediment Samples from Borehole 299-W22-48-Clay-Size Fraction Only

5.11 Comparison of Cation Exchange Capacity (meq/100 g) Between Sediment Samples from Borehole 299-W22-48 Using Two-Different Analytical Methods ....

5.12 Additional Cation Exchange Capacity Data Obtained from Sediment Samples in Borehole 41-09-39.

5.13 Exchangeable Base Cation Composition of Sediment Samples in Borehole 299-W22-48 .......

5.14 Comparison of the Base Cation Sum and Cation Exchange Capacity Measurements from Sediment Samples in Borehole 299-W22-48

$5.15 \mathrm{pH}$, Electrical Conductivity, Alkalinity, and Anions in Water Extracts from Sediment Samples in Borehole 299-W22-48

5.16 Major Cations in Water Extracts from Sediment Samples in Borehole 299-W22-48.

5.17 Trace Metals in Water Extracts of Sediment Samples from Borehole 299-W22-48.

5.18 Charge Balance in Water Extracts of Sediment Samples from Borehole 299-W22-48

5.19 Ranges of Parameters and Selected Ions Found in Water Extracts for Stratigraphic Units Sampled within Borehole 299-W22-48.

5.21 Trace Metals $(\mu \mathrm{g} / \mathrm{g}$ ) in Acid Extracts of Sediment Samples from Borehole 299-W22-48........

5.22 Mass Percent of Total Element Leached by Acid Extraction Compared to Bulk Chemical Composition

$5.23 \mathrm{pH}$, Electrical Conductivity, Alkalinity, Anions, Cations, and Trace Metals Measured in UFA-Extracted Porewater from Two Samples in Borehole 299-W22-48.

5.24 Charge Balance for UFA-Extracted Porewater from Two Sediment Samples in Borehole 299-W22-48.

5.25 Theoretically Calculated Composition of Vadose-Zone Porewater

5.26 Comparison of UFA-Extracted Porewater to Theoretically Calculated Porewater from the Hanford Formation H2 Unit in Borehole 299-W22-48.

5.27 Sediment Core Samples Selected from Borehole 299-W22-50 for Laboratory Analysis ...

5.28 Moisture Content (wt\%) Measured in the Laboratory for Sediment Samples from Borehole 299-W22-50

5.29 Particle-Size Distributions for Sediment Samples from Borehole 299-W22-50

5.30 Particle-Size Distributions Determined by Wet Sieving/Hydrometer Method for Borehole 299-W22-50 
5.31 Comparison of Particle-Size Distributions Using the Dry Versus

Wet Sieving/Hydrometer Methods for Borehole 299-W22-50 .

5.32 Particle Densities for Sediment Samples from Borehole 299-W22-50 ......

5.33 Calcium Carbonate and Organic Carbon Content (wt\%) for Sediment Samples from Borehole 299-W22-50

5.34 Bulk Chemical Composition of Sediment Samples from Borehole 299-W22-50 ...

5.35 Semiquantitative Mineral Content of Sediment Samples from Borehole 299-W22-50

5.36 Exchangeable Base Cations for Sediment Samples from Borehole 299-W22-50

5.37 Comparison of the Base Cation Sum and Cation Exchange Capacity Measurements from Borehole 299-W22-50

$5.38 \mathrm{pH}$, Electrical Conductivity, Alkalinity, and Anions in Water Extracts of Sediment Samples from Borehole 299-W22-50

5.39 Major Cations in Water Extracts of Sediment Samples from Borehole 299-W22-50.

5.40 Trace Metals in Water Extracts of Sediment Samples from Borehole 299-W22-50

5.41 Charge Balance for Water Extracts of Sediment Samples from Borehole 299-W22-50.....

5.42 Ranges of Parameters and Selected Ions Found in Water Extracts for Stratigraphic Units Sampled Within Borehole 299-W22-50

5.43 Major Cations $(\mu \mathrm{g} / \mathrm{g})$ in Acid Extracts of Sediment Samples from Borehole 299-W22-50......

5.44 Trace Metals $(\mu \mathrm{g} / \mathrm{g})$ in Acid Extracts of Sediment Samples from Borehole 299-W22-50.

5.45 Percent of Total Element (XRF) in Sediment Samples Leached by Acid Extraction of Sediment Samples in Borehole 299-W22-50

$5.46 \mathrm{pH}$, Electrical Conductivity, Alkalinity, Cations, Anions, and Trace Metals for UFA-Extracted Porewater from Sediment Samples within Borehole 299-W22-50

5.47 Charge Balance for UFA-Extracted Porewater from Sediment Samples in Borehole 299-W22-50

48 Calculated Composition of Vadose-Zone Porewater.

5.49 Comparison of UFA-Extracted Porewater to Calculated Porewater Based on Water Extract Data from Sediment Samples in Borehole 299-W22-50

5.50 Comparison of UFA-Extracted Porewater to Calculated Porewater Charge Balance Based on Water Extracts of Sediment Samples from Borehole 299-W22-50 ...... 


\subsection{Introduction}

In fiscal year 1999, several offices within the U.S. Department of Energy (DOE) initiated and funded coordinated activities at the Hanford Reservation to study the vadose zone to better understand the fate of contaminants that have leaked from underground storage tanks. As part of this effort, the Pacific Northwest National Laboratory (PNNL), Bechtel Hanford Inc., and CH2M HILL Hanford Group, Inc., collected intact sediment cores from the subsurface in the vicinity of the S-SX Waste Management Area. These cores were collected from two new monitoring wells surrounding the S-SX Waste Management Area. In addition, large quantities of sediment were collected from outcrops in the Pasco Basin that may be representative of strata beneath the S-SX Waste Management Area. Location maps and more details on sampling locations are presented in Section 2.0.

Outcrop and borehole samples were collected and analyzed for their physical, mineralogical, and chemical properties to serve as Hanford Site standards. The characterized standards are available to researchers for experiments relative to environmental problems at the Hanford Site. To obtain sediment, contact Clark Lindenmeier at PNNL by the following venues: telephone (509) 376-8419, fax (509) 376-5368, or email clark.lindenmeier@pnl.gov.

This report describes samples and documents the results of characterization activities completed to date. This document is considered a living document because any characterization data from other researchers should be added to the data reported here. The addition of analytical results to the current characterization database will significantly increase our confidence in the physical, mineralogical, and geochemical characterization of the standards. The goal is to produce a set of comprehensive, wellcharacterized uncontaminated Hanford Site sediment to serve as standards for future experimental work.

Primary support of this work was provided by CH2M HILL Hanford Group, Inc., specifically the Tank Farm Vadose Zone Project, and the Science and Technology Program portion of the Groundwater/Vadose Zone/Columbia River Integration Project. The overall goal of the of the Tank Farm Vadose Zone Project is to define risks from past and future single-shell tank farm activities, to identify and evaluate the efficacy of interim measures, and to aid future decisions that must be made by DOE regarding the near-term operations, future waste retrieval, and final closure activities for the single-shell tank Waste Management Areas. For a more complete discussion of the goals of the Tank Farm Vadose Zone Project, see the overall work plan, Phase 1 Resource Conservation and Recovery Act (RCRA) Facility Investigation/Corrective Measures Study Work Plan for the Single-Shell Tank Waste Management Areas (DOE/RL 1999).

The overall goal of the Groundwater/Vadose Zone/Columbia River Integration Project is to assess the cumulative effects of all Hanford activities on the Columbia River and to aid in making remediation decisions that consider all project activities. The Science and Technology Program portion of the integration project emphasizes applied research to evaluate the mechanisms that control the fate of contaminants released into the Hanford ecosystem. 
This document is the first in a series of four PNNL reports that characterizes sediments beneath the S-SX Waste Management Area. The objective of these documents is to present recent data from vadose zone sediments, both uncontaminated and contaminated sediment, from the S-SX Waste Management Area. The information will be used in single-shell tank Waste Management Area field investigation reports.

This report summarizes the findings for uncontaminated subsurface sediment immediately adjacent to the S-SX Waste Management Area. Three other reports in the series summarize results from sediment directly affected by waste leaks from the S-SX tank farms. Each of the other reports in this series summarizes results from a separate borehole: (1) the single-shell tank SX-115 borehole (299-W23-19) (Serne et al. 2002c), (2) the 41-09-39 borehole (299-W23-234) drilled between single-shell tanks SX-109 and -112 (Serne et al. 2002a), and (3) a slant borehole that penetrated below single-shell tank SX-108 (Serne et al. 2002b). In addition, large-volume grab or "composite" samples were collected from various outcrops/excavations within the Pasco Basin as well as from a nearly continuous, uncontaminated 10centimeter (4-inch) core from a borehole nearby the S-SX Waste Management Area.

The grab samples and cores were obtained for the DOE Environmental Management Science Program, Science and Technology Program, and CH2M HILL Hanford Group, Inc., Tank Farm Vadose Zone research. This report documents the characterization performed to date on those samples. A second objective was to determine depth-variant physical and geochemical characteristics of uncontaminated sediments from the Hanford formation, Plio-Pleistocene unit, and Ringold Formation strata in the vadose zone so that changes caused by interaction with tank fluids can be more clearly understood.

Two RCRA boreholes (299-W22-48 and 299-W22-50) summarized in this report provided 104 meters (340 feet) of vadose zone core for characterization; borehole 299-W22-48 provided 50 meters (164 feet) and borehole 299-W22-50 provided 54 meters (176 feet) of core, respectively. The stratigraphy and lithology in these boreholes is summarized in Section 3.2. Discrete sampling points for geochemical analysis were selected from the cores with emphasis on delineating the range and magnitude of differences observed within the various lithologies whenever possible. Physical, geochemical, and mineralogical analyses included the following:

1. mass water content

2. particle-size distribution

3. particle density

4. calcium carbonate and organic carbon content

5. chemical composition of the bulk sediment by x-ray fluorescence

6. crystalline mineralogy of the bulk sediment, and silt- and clay-size fractions by x-ray diffraction techniques

7. cation exchange capacity

8. exchangeable base cation distribution

9. 1:1 water extract $\mathrm{pH}$, electrical conductivity, major cation and anion and trace metal composition,

10. $8 \mathrm{M}$ nitric acid extract composition

11. geochemical composition of porewater after ultra centrifugation. 
A few selected intact core sleeves also were exclusively analyzed by others to measure hydraulic conductivity as a function of moisture content. The results of these analyses will be documented elsewhere. We also provide our interpretation of the data in the context of determining the appropriate geologic conceptual model, the vertical extent of contamination, the migration potential of the contaminants that still reside in the vadose zone, and the correlation of the contaminant distribution in the borehole sediment in relationship to groundwater plumes in the aquifer proximate and downgradient from the SX Tank Farm.

This report is organized into seven sections that describe the geology, analytical methods, analytical results, and summary and conclusions, references cited, in addition to eight appendices. 


\subsection{Geology}

This section presents a general discussion on the regional geology as well as the geology of the vadose zone in the vicinity of the SX Tank Farm. The history of water-level fluctuations is also discussed. Also presented is a discussion of the geologic context of the composite samples and geologic characteristics of the vadose-zone materials penetrated by boreholes 299-W22-48 and -50.

\subsection{Regional Geologic Setting}

The Hanford Site is located within the Columbia Plateau of southeastern Washington State. This broad plain, situated between the Cascade Mountains to the west and the Rocky Mountains to the east, is underlain by a thick sequence of Miocene age tholeiitic basalt flows (the Columbia River Basalt Group) (Myers and Price 1979, Myers et al. 1981, DOE 1988, Tolan et al. 1989, Reidel et al. 1989). These basalt flows have been folded and faulted creating broad structural and topographic basins, separated by asymmetric anticlinal ridges. Sediments of late Miocene, Pliocene, and Pleistocene age have accumulated up to 518 meters (1700 feet) thick in some of these basins. The Hanford Site lies within one of the larger of these basins, the Pasco Basin. This basin is partially bisected by the Umtanum-Gable Mountain anticline creating two subordinate synclinal basins. The largest of these is the Cold Creek syncline, which is further subdivided into two basins, the Wye Barricade depression and the Cold Creek depression. The Cold Creek depression underlies the principal waste management areas (200 East and 200 West Areas) of the Hanford Site.

The generalized stratigraphy beneath the Hanford Site consists of, in ascending order, the Columbia River Basalt Group, the Ringold Formation, the Plio-Pleistocene unit, and the Hanford formation (Figure 2.1). Thin veneers of Holocene alluvium, colluvium, and/or eolian sediments discontinuously overlie these principal geologic units. More thorough discussions of the regional geology, including the saturated zone, of the area are documented elsewhere (Tallman et al. 1979, DOE 1988, DOE 1993, Lindsey et al. 1994).

\subsection{Geology of the SX Tank Farm}

The SX Tank Farm is an excavation cut into the upper Hanford formation sediments underlying 200 West Area, along the north limb of the Cold Creek syncline. Stratigraphic units underlying or adjacent to the tank farm (in descending order), include backfill materials, Hanford formation, the PlioPleistocene unit, the Miocene- to Pliocene-age Ringold Formation, and the Columbia River Basalt Group.

The geology beneath this tank farm has been the subject of numerous reports. Price and Fecht (1976) and Fech and Price (1977) presented an initial detailed interpretation of the geology. DOE (1996) presented an interpretation of the geology based primarily on groundwater monitoring wells constructed 


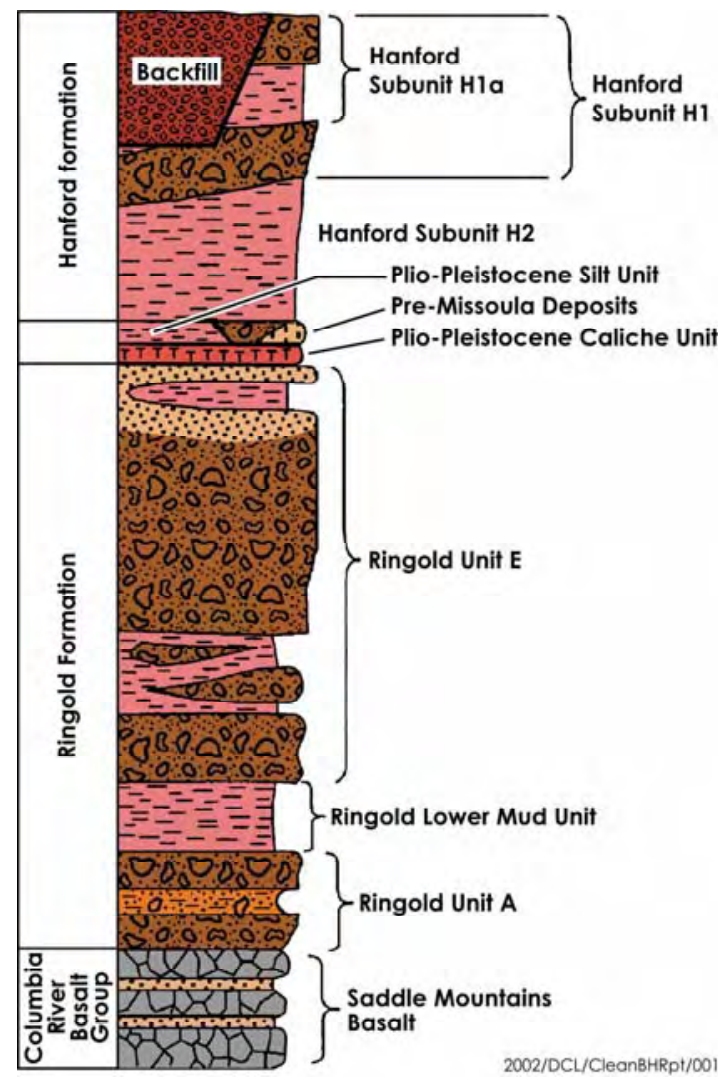

Figure 2.1. Generalized, Composite Stratigraphy for the Late Cenozoic Sediments Overlying the Columbia River Basalt Group on the Hanford Site (After Johnson and Chou 1998, 1999).

around the perimeter of the tank farm in the early 1990s. Johnson and Chou (1998) updated and refined the geologic interpretation. Myers et al. (1998) and Part 3 in this series present detailed discussions on the geologic materials penetrated by the extension of borehole 41-09-39 (299-W23-234). Johnson et al. (1999) further described the geology and other subsurface contaminants. Lindsey et al. (2000) provided additional interpretations on the geology, facilitated by the collection of near continuous split-spoon samples from two boreholes (299-W22-50 and 299-W23-19). Comprehensive and detailed physical, mineralogical, and geochemical analyses on vadose zone samples are presented in the present series. This report, Part 1 in the four-part series, presents results from boreholes 299-W22-48 and -50, drilled just outside the SX Tank Farm (Figure 2.2). Subsequent parts of the series present results of similar analyses for contaminated boreholes drilled within the SX Tank Farm, including the 299-W23-19 (Part 2), SX 4109-39 (Part 3), and SX-108 Slant Borehole (Part 4).

Horton and Johnson (2000) compiled a data package on three ground-water monitoring wells (299-W22-48, -49, and -50) completed near the SX Tank Farm in 1999/2000. Most recently, Sobczyk (2000) presented a reinterpretation on the geology based on gross gamma-ray logs of 98 boreholes within the SX Tank Farm and published geology reports of the area (e.g., Johnson et al. 1999 and Lindsey et al. 2000). 


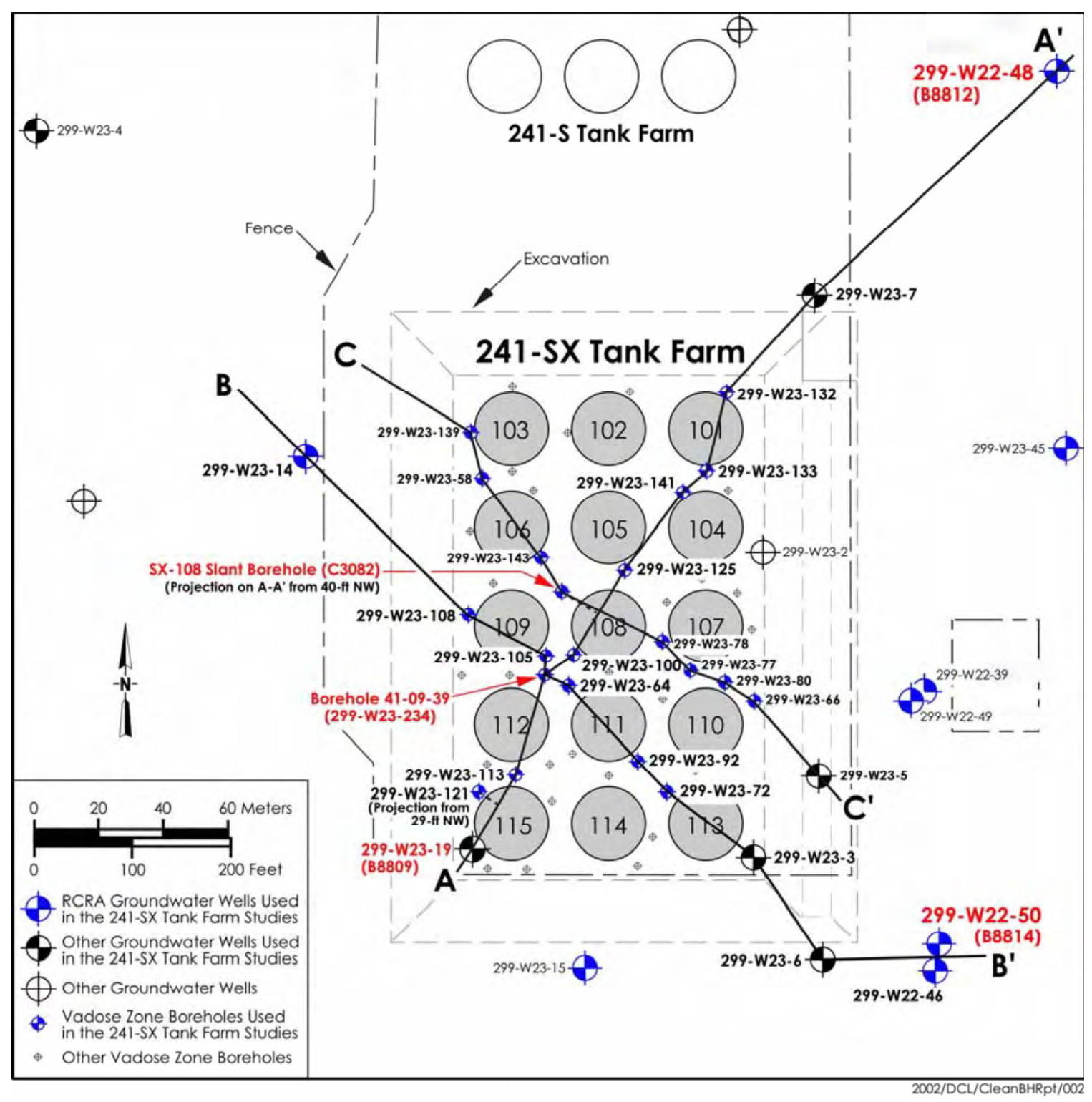

Figure 2.2. Location Map and Hydrogeologic Cross Sections Through the SX Tank Farm. Cross Section A-A' through C-C' are presented in Figures 2.3 through 2.5, respectively.

Several hydrogeologic cross sections, constructed from a series of densely spaced boreholes beneath the SX Tank Farm, are presented in Figures 2.3 through 2.5. Some differences in interpretation occur between the depths of the geologic contacts presented here, and those presented by other authors, due to the various source of uncertainty in the geologic data sets and the individual geologist's interpretation.

The stratigraphic terminology used in this report is summarized in Table 2.1. The general stratigraphic interpretation presented here differs somewhat from that presented by Lindsey et al. (2000). 


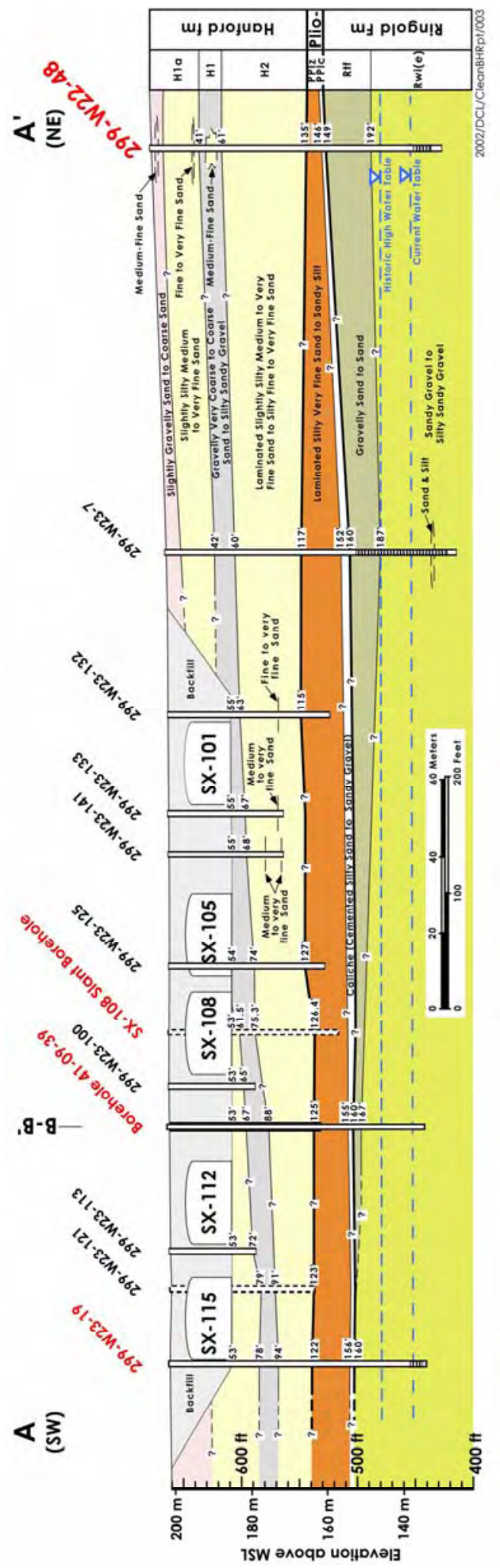

Figure 2.3. Geologic Cross Section A-A' 


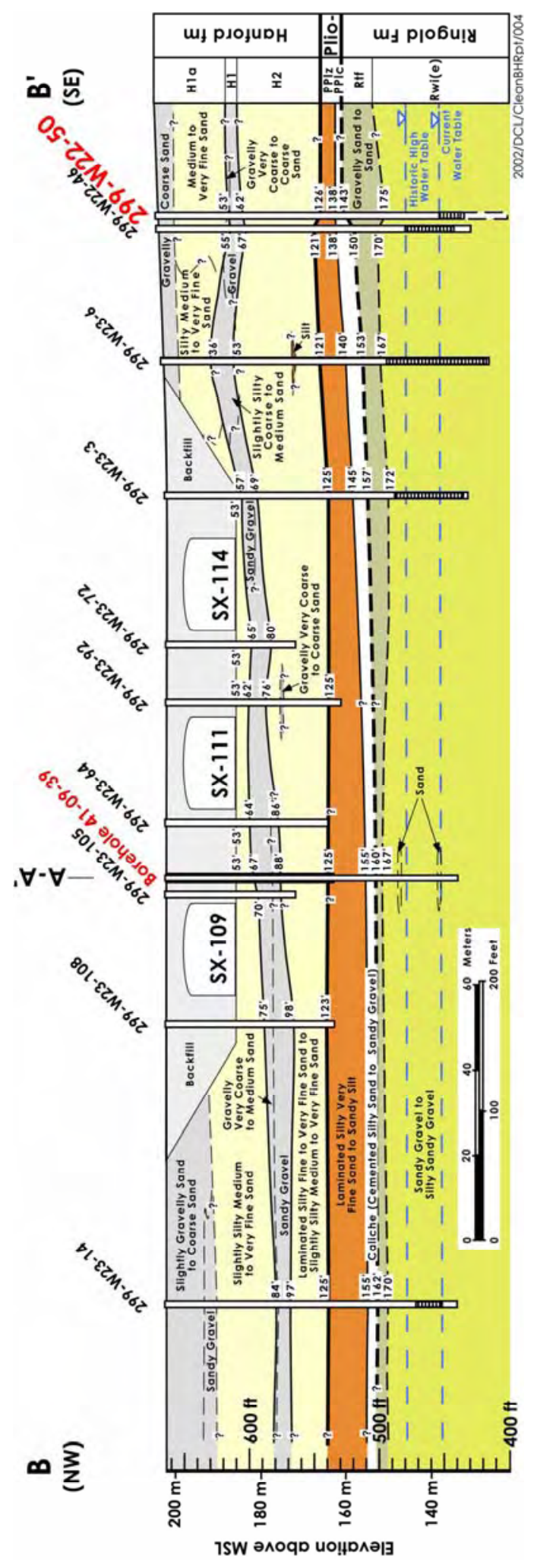

Figure 2.4. Geologic Cross Section B-B' 


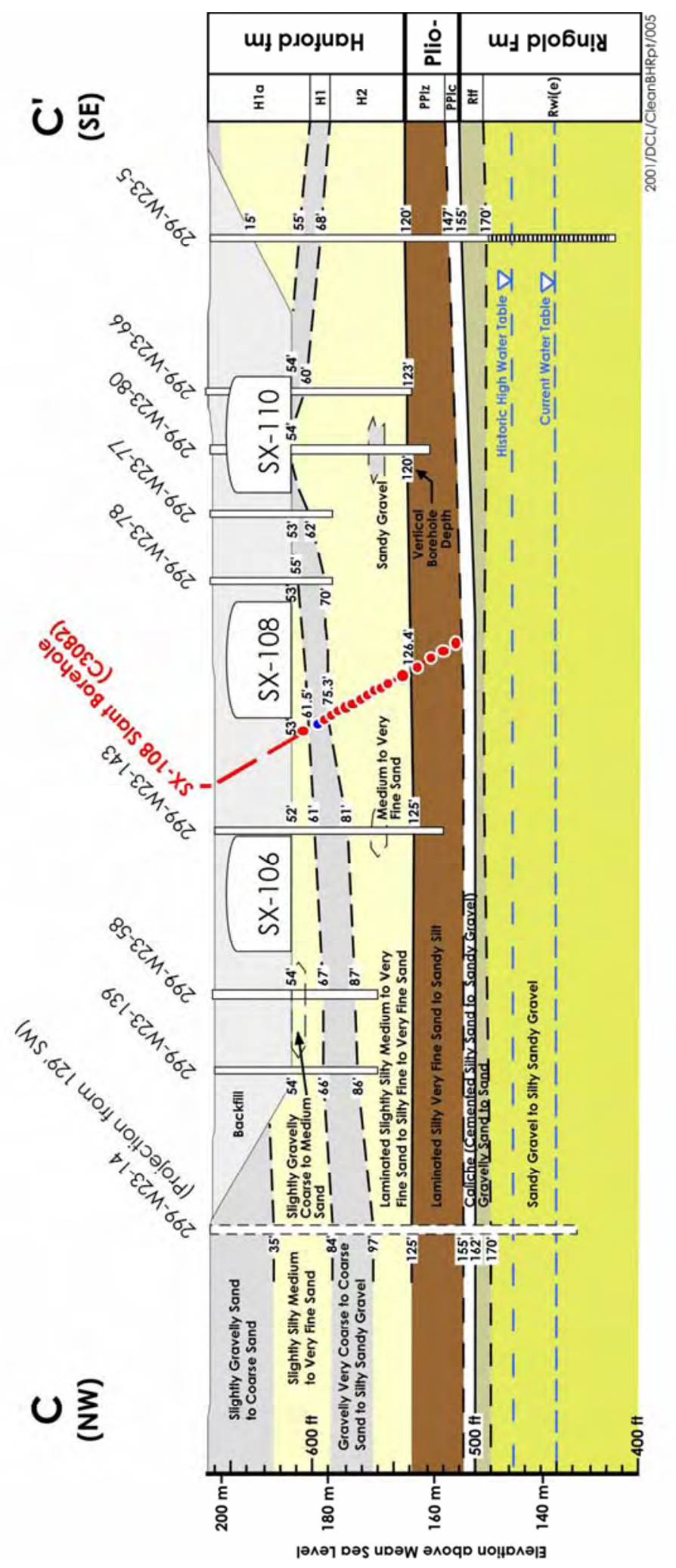

Figure 2.5. Geologic Cross Section C-C' 
Table 2.1. Stratigraphy of the Vadose Zone Beneath the SX Tank Farm.

\begin{tabular}{|c|c|c|c|c|}
\hline $\begin{array}{c}\text { Stratigraphic } \\
\text { Symbol }^{(a)}\end{array}$ & Formation & Facies/Subunit & Description & Genesis \\
\hline Holocene/Fill & NA & Backfill & $\begin{array}{l}\text { Poorly sorted gravel to medium sands and } \\
\text { silt derived from the Hanford formation } \\
\text { (Price and Fecht, 1976a) }\end{array}$ & Anthropogenic \\
\hline \multirow[t]{2}{*}{ H1a } & \multirow{4}{*}{$\begin{array}{l}\text { Hanford } \\
\text { formation }\end{array}$} & $\begin{array}{l}\text { Unit H1a - gravelly } \\
\text { sand }\end{array}$ & $\begin{array}{l}\text { Upper coarse-grained sequence equilvalent } \\
\text { to Johnson et al.'s (1999) “Hanford Gravel } \\
\text { Unit B" and Sobczyk's (2000) "Hanford Unit } \\
\text { B" }\end{array}$ & \multirow{4}{*}{$\begin{array}{l}\text { Cataclysmic Flood } \\
\text { Deposits }\end{array}$} \\
\hline & & $\begin{array}{l}\text { Unit H1a - slightly } \\
\text { silty sand }\end{array}$ & $\begin{array}{l}\text { Upper fine sand and silt sequence. } \\
\text { Equivalent to "Hanford silty sand" of } \\
\text { Sobcyzk (2000) }\end{array}$ & \\
\hline H1 & & Unit H1 & $\begin{array}{l}\text { Lower coarse-grained sequence equivalent } \\
\text { to "Gravel Unit A" described by Johnson et } \\
\text { al. (1999) and "Hanford Unit A" described by } \\
\text { Sobcyzk (2000). }\end{array}$ & \\
\hline $\mathrm{H} 2$ & & Unit H2 & $\begin{array}{l}\text { Lower fine sand and silt sequence. } \\
\text { Equivalent to "Lower Hanford" of Sobcyzk } \\
\text { (2000) }\end{array}$ & \\
\hline $\begin{array}{l}\mathrm{PPlz} \text { and/or } \\
\mathrm{H} / \mathrm{PPl}\end{array}$ & \multirow[t]{2}{*}{$\begin{array}{l}\text { Plio-Pleistocene } \\
\text { Unit }\end{array}$} & Upper & $\begin{array}{l}\text { Very fine sand to mud sequence. } \\
\text { Interstratified silt to silty very fine sand and } \\
\text { clay deposits at least partially correlative with } \\
\text { the "early Palouse soil" described by Tallman } \\
\text { et al. (1979) and DOE (1988) and the } \\
\text { "unnamed Hanford formation or Plio- } \\
\text { Pleistocene Deposits" described by Lindsey } \\
\text { et al. (2000), and the H/PP deposits in Wood } \\
\text { et al. (2001) }\end{array}$ & $\begin{array}{l}\text { Fluvial and/or } \\
\text { Eolian Deposits } \\
\text { (with some weakly } \\
\text { developed } \\
\text { paleosols) }\end{array}$ \\
\hline PPlc & & Lower & $\begin{array}{l}\text { Carbonate-rich sequence. Weathered and } \\
\text { naturally altered sandy silt to sandy gravel, } \\
\text { moderately to strongly cemented with } \\
\text { secondary pedogenic calcium carbonate }\end{array}$ & $\begin{array}{l}\text { Well-developed } \\
\text { calcic paleosol or } \\
\text { sequence of calcic } \\
\text { soils. }\end{array}$ \\
\hline Rwi(e) & $\begin{array}{l}\text { Ringold } \\
\text { Formation }\end{array}$ & $\begin{array}{l}\text { Member of } \\
\text { Wooded Island, } \\
\text { subunit E }\end{array}$ & $\begin{array}{l}\text { Moderate to strongly cemented well } \\
\text { rounded gravel and sand deposits, and } \\
\text { interstratified finer-grained deposits }\end{array}$ & Fluvial \\
\hline
\end{tabular}

As with Price and Fecht (1976a), Johnson and Chou (1998), Myers et al. (1998), Johnson et al. (1999), Khaleel et al. (2000), and Sobczyk (2000), the coarse (gravelly) materials found near the middle of the Hanford formation (correlative with Hanford formation H1 unit of Lindsey et al. (2000)) are interpreted to correlate across the tank farm, and to represent a laterally continuous coarse unit distinct from the overlying and underlying finer sand units. Lindsey et al. (2000) suggest that these coarser materials are not continuous, but rather represent thin, lenticular, discontinuous gravelly beds within stratified sand sheets of the Hanford formation. Additional discussion to support correlation of this coarse unit is discussed below and in the borehole 41-09-39 report (Part 3 of this series). 


\subsubsection{Columbia River Basalt Group}

The Columbia River Basalt Group, composed of hundreds of individual basalt flows, forms the bedrock beneath the site. The surface of the Columbia River Basalt Group lies at an elevation of approximately 26 meters ( 85 feet) above mean sea level (msl) beneath the SX Tank Farm (a depth of approximately 175 meters (575 feet)) and dips gently to the southwest towards the axis of the Cold Creek syncline (Price and Fecht 1976a, Myers and Price 1979, Myers et al. 1981, DOE 1988, DOE 1993).

\subsubsection{Ringold Formation}

The Ringold Formation lies directly on top of the Columbia River Basalt Group and is approximately 125 meters (410 feet) thick beneath the SX Tank Farm. It locally consists of three principal stratigraphic units, which combined form the informal Ringold member of Wooded Island (Lindsey 1996): (1) the fluvial gravels of unit A, (2) a fine-grained, paleosol-lacustrine sequence referred to as the lower mud unit, and (3) fluvial gravels of unit E (Figure 2.1). Ringold unit E grades upwards into fluvial sands of the upper Ringold unit (DOE 1993), interpreted as an equivalent to the informal Ringold member of Taylor Flat. Ringold Unit E forms the main unconfined aquifer beneath the 200 West Area.

The thickness of fluvial Ringold unit A is on the order of 30 meters (100 feet) (DOE 1993). Tallman et al. (1979) described this unit as a silty-sandy gravel, which is composed predominantly of gravel supported by a coarse-to-fine sand matrix with intercalated, lenticular beds of sand and silt. The unit is occasionally cemented and/or compacted into a conglomerate.

The thickness of the lower mud unit is on the order of 12 to 30 meters (40 to 100 feet) (Tallman 1979 DOE 1993). This unit consists of predominantly mud (i.e., silt and clay); the lower portion contains welldeveloped argillic to calcic paleosol sequence (DOE 1988). The high clay content (up to $43 \mathrm{wt} \%$ ) and the low hydraulic conductivity (perhaps as low as $10^{-12}$ feet per day) of this sequence acts to locally confine groundwater within unit A and form a base for the uppermost unconfined aquifer (Last et al. 1989).

The thickness of unit $\mathrm{E}$ is estimated to be on the order of 75 to 85 meters ( 250 to 280 feet) (Tallman et al. 1979, DOE 1993). This unit consists of well-rounded, clast-supported pebbles and small cobbles, in a matrix of mostly sand (Table 2.2). The amount of consolidation is variable, with the lower portion of this unit described as moderate to well indurated conglomerate (Tallman et al. 1979). However, zones of poorly indurated gravel and sand also occur within this zone. The upper part of the unit is generally poorly indurated. Borehole data in the immediate vicinity of the SX Tank Farm indicate that this upper portion is dominated by sandy gravel and muddy sandy gravel, with sand to muddy sand beds becoming more prevalent toward the top of the unit. 
Table 2.2. Granulometric Data from Core Samples of Ringold Unit E Encountered Within the 200 West Area (from Lindsey 1996)

\begin{tabular}{|c|c|c|c|c|c|c|c|c|}
\hline \multirow[b]{2}{*}{$\begin{array}{l}\text { Borehole/ } \\
\text { Depth }\end{array}$} & \multirow[b]{2}{*}{$\begin{array}{l}\text { Gravel } \\
>2 \mathrm{~mm}\end{array}$} & \multicolumn{5}{|c|}{ Sand } & \multirow[b]{2}{*}{$\begin{array}{l}\text { Mud } \\
<0.06 \\
3 \mathrm{~mm} \\
\end{array}$} & \multirow[b]{2}{*}{ Class } \\
\hline & & $\begin{array}{c}\text { Very } \\
\text { Coarse } \\
1-2 \mathrm{~mm}\end{array}$ & $\begin{array}{c}\text { Coarse } \\
0.5-1.0 \\
\mathrm{~mm}\end{array}$ & $\begin{array}{c}\text { Medium } \\
0.25-0.5 \\
\mathrm{~mm}\end{array}$ & $\begin{array}{c}\text { Fine } \\
0.125- \\
0.25 \mathrm{~mm}\end{array}$ & $\begin{array}{c}\text { Very Fine } \\
0.063- \\
0.125 \mathrm{~mm}\end{array}$ & & \\
\hline $\begin{array}{l}299-W 11-26 \\
(\mathrm{DH}-6) 178 \mathrm{ft}\end{array}$ & 76 & 0 & 0 & 9 & 8 & 5 & 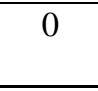 & sG \\
\hline $\begin{array}{c}299-\mathrm{W} 14-7 \\
(\mathrm{DH}-12) 243 \mathrm{ft}\end{array}$ & 90 & 1 & 1 & 2 & 4 & 1 & 1 & $\mathrm{G}$ \\
\hline
\end{tabular}

A relict erosional and weathered surface occurs at the top of the Ringold Formation beneath the SX Tank Farm (DOE 1988, Slate 1996, 2000). The uppermost portion of this paleosurface is highly weathered and often cemented with secondary pedogenic calcium carbonate, referred to in this report as the carbonate-rich facies (PPlc) of the Plio-Pleistocene unit (Table 2.1). The northwest-southeast trending trough-shaped surface appears to conform to an ancestral Cold Creek channel and drainage system that developed following late Pliocene incision of the Ringold Formation, and prior to early Pleistocene cataclysmic flooding. The SX Tank Farm lies north of the ancestral Cold Creek paleochannel and the eroded Ringold paleosurface dips to the southwest beneath the SX Tank Farm (DOE 1988).

\subsubsection{Plio-Pleistocene Unit}

The Plio-Pleistocene unit lies unconformably on the tilted and truncated Ringold Formation. The Ringold Formation was tilted both during and following deposition of the Ringold. The Plio-Pleistocene unit includes all material overlying the Ringold Formation, including the weathered horizon at the top of the Ringold Formation, and beneath cataclysmic flood deposits of the Hanford formation (Lindsey et al. 1994). The Plio-Pleistocene unit includes the "Early Palouse Soil" described by Brown (1960), Tallman et al. (1979), and DOE (1988), the "Pre-Missoula Gravels" (or equivalent), the "unnamed Hanford formation or Plio-Pleistocene Deposits" described by Lindsey et al. (2000), and H/PP deposits of Wood et al. (2001).

Two distinct facies of the Plio-Pleistocene unit are recognized beneath the SX Tank Farm; these consist of an upper (PPlz) and lower (PPlc) subunit (Table 2.1). The upper subunit is characterized by an abundance of silt, signified by the letter " $z$," and the lower unit is characterized by an abundance of pedogenic calcium-carbonate cement, signified by the letter "c." The combined total thickness of the Plio-Pleistocene unit is up to 13.1 meters (43 feet) in the vicinity of the SX Tank Farm (Figures 2.3 through 2.5). The PPlz subunit is relatively thick (up to 10.7 meters [35 feet]), compared to the PPlc, which measures only 1 to 4 meters (4 to 13 feet) in thickness. 


\subsubsection{Lower Subunit (PPIc)}

The lower Plio-Pleistocene unit (PPlc) subunit represents a highly weathered paleosurface that developed atop the Ringold Formation (Brown 1959, 1960), which represents a long period of surficial weathering in a semi-arid climate, similar to climatic conditions that exist today. Root traces and animal burrows, as well as other relict soil structures, point to a pedogenic origin for the $\mathrm{CaCO}_{3}$, although Slate (1996, 2000) has also suggested the $\mathrm{CaCO}_{3}$ could be associated with moisture from paleo-groundwater levels. Calcium carbonate contents as high as $70 \mathrm{wt} \%$ have been reported within the PPlc subunit elsewhere within the 200 West Area; however, in the vicinity of the SX Tank Farm, the $\mathrm{CaCO}_{3}$ content generally does not exceed $25 \mathrm{wt} \%$. The $\mathrm{CaCO}_{3}$ content from three randomly chosen boreholes within the SX Tank Farm did not exceed $10 \mathrm{wt} \%$ (Table 2.3). Other names used for the PPlc subunit, including "caliche" and "calcrete," are somewhat misleading since they imply a single, homogeneously cemented layer, which is not the case. Considerable internal variation exists within the PPlc subunit, often with multiple carbonate-cemented zones present (Bjornstad 1990, Lindsey et al. 1994, Slate 1996, 2000, Wood et al. 2001).

Table 2.3. Example of Granulometric and Calcium Carbonate Data from Samples of the Lower PlioPleistocene (PPlc) Unit Encountered Beneath the SX Tank Farm

\begin{tabular}{|c|c|c|c|c|c|c|c|c|c|}
\hline \multirow[b]{2}{*}{$\begin{array}{c}\text { Borehole } \\
\text { /Depth }\end{array}$} & \multirow[b]{2}{*}{$\begin{array}{c}\mathrm{CaCO}_{3} \\
\% \\
\end{array}$} & \multirow[b]{2}{*}{$\begin{array}{l}\text { Gravel } \\
>2 \mathrm{~mm} \\
\end{array}$} & \multicolumn{5}{|c|}{ Sand } & \multirow[b]{2}{*}{$\begin{array}{c}\text { Mud } \\
<0.063 \\
\mathrm{~mm} \\
\end{array}$} & \multirow[b]{2}{*}{ Class } \\
\hline & & & $\begin{array}{c}\text { Very } \\
\text { Coarse } \\
1-2 \mathrm{~mm}\end{array}$ & $\begin{array}{c}\text { Coarse } \\
0.5-1.0 \\
\mathrm{~mm}\end{array}$ & $\begin{array}{c}\text { Medium } \\
0.25-0.5 \\
\mathrm{~mm}\end{array}$ & $\begin{array}{c}\text { Fine } \\
0.125- \\
0.25 \mathrm{~mm}\end{array}$ & $\begin{array}{c}\text { Very Fine } \\
0.063-0.125 \\
\mathrm{~mm}\end{array}$ & & \\
\hline $\begin{array}{c}299-W 23-2 \\
135 \mathrm{ft}^{(\mathrm{a})} \\
\end{array}$ & 9.3 & 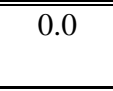 & 2.1 & 44.3 & 5.9 & 9.1 & 25.2 & 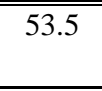 & 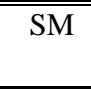 \\
\hline $\begin{array}{c}299-W 23-5 \\
150 \mathrm{ft}^{(\mathrm{a})}\end{array}$ & 9.4 & 5.3 & 5.8 & 17.6 & 25.1 & 10.5 & 8.8 & 26.9 & (g)mS \\
\hline $\begin{array}{c}299-\mathrm{W} 23-6 \\
140 \mathrm{ft}^{(\mathrm{a})}\end{array}$ & 4.4 & 6.4 & 1.3 & 3.9 & 9.8 & 10.7 & 16.9 & 51.0 & $\overline{(\mathrm{g}) \mathrm{sM}}$ \\
\hline
\end{tabular}

The $\mathrm{CaCO}_{3}$ overprint may occur on a variety of lithologies, including silt, sand, felsic sand and gravel, as well as basaltic sand and gravel (Lindsey et al. 2000). In places, pedogenic alteration occurs directly on top of Ringold gravels (Rwi(e)) or sands (Rtf). In other places, the carbonate horizons occur within younger, pedogenically altered, fine-grained, eolian or sidestream-alluvial deposits overlying the Ringold Formation. The top of the PPlc subunit is well defined by a coincident significant increase in $\mathrm{CaCO}_{3}$ and decrease in mud content and sorting, accompanied by a sudden and sustained decrease in background gamma counts (i.e., ${ }^{40} \mathrm{~K}$ ) on borehole geophysical logs (DOE 1988, Last et al. 1989, Bjornstad 1990, Wood et al. 2001). While the top of the PPlc unit is relatively easy to recognize, considerable variation may exist internally within the subunit due to natural heterogeneity inherent in soils and soil processes, which vary under different physical, chemical, and biological conditions (e.g., moisture, grain size, aspect, mineralogy, bioturbation, microbial activity, etc.). Added to this is the complicating factor that the land surface during Plio-Pleistocene time was undergoing many changes under the influence of local fluvial and eolian activity resulting in variable rates of aggradation, degradation, and soil development. Normally, only a single paleosol horizon is present within the lower 
Plio-Pleistocene unit within the SX Tank Farm, suggesting slow or negligible aggradation and/or subsequent erosion during paleosol development. This is in contrast to other areas to the west and south, which show up to five separate calcic horizons (Figure 2.6), separated by relatively non-calcareous, uncemented sand, silt and even indigenous, basaltic sand and/or gravel (Slate 1996, 2000; Wood et al. 2001). Multiple carbonate horizons within the lower Plio-Pleistocene are indicative of several periods of calcic-soil development interrupted temporarily by periodic aggradational events (i.e., localized overbank flood, eolian accumulation, channel fill, etc.). The evolution of calcic paleosols and their morphogenetic development are discussed further in Slate $(1996,2000)$ and Wood et al. (2001).

In the T-TX-TY Waste Management Area, 1800 meters (5900 feet) north of the SX Tank Farm, the top of the lower Plio-Pleistocene slopes to the southwest at about 1 degree (Wood et al. 2001). At least some of the slope reflects the paleotopography that existed during subaerial weathering of the eroded Ringold surface. This is inferred based on the relief on top of the lower Plio-Pleistocene, which is almost double that of the underlying Ringold lower mud unit. Therefore, it appears that during development of the lower Plio-Pleistocene unit there was a gentle slope to the land surface to the southwest, toward the Cold Creek valley axis. Since Plio-Pleistocene time this surface has been steepened further by continued long-term downwarping along the north limb of the Cold Creek syncline (DOE 1988).

Another recognized facies of the Plio-Pleistocene unit is a coarse-grained side-stream-alluvial facies (Bjornstad 1984, DOE 1988, Slate 1996, 2000), which is laterally equivalent to the PPlc subunit to the south and west of SX Tank Farm. The side-stream alluvial facies (gravel facies in Figure 2.6) fills and is restricted to the northwest-southeast trending, ancestral Cold Creek channel, located south and west of the 200 West Area. The eastern edge of this gravel facies occurs along the southwest boundary of 200 West Area near the SX Tank Farm (Figure 2.6). North and east of the 200 West Area the Plio-Pleistocene unit is generally not present, and is interpreted to have been scoured away during either post-Ringold erosion and/or Pleistocene cataclysmic flooding.

\subsubsection{Upper Subunit (PPlz)}

Unconformably overlying the lower subunit of the Plio-Pleistocene unit is the upper subunit (PPlz), which consists of interstratified, uncemented fine sand, silt, and/or clay that only displays occasional, very weak soil development in the vicinity of the SX Tank Farm. Based on its fine-grained texture and relatively high natural-gamma activity on geophysical logs, this unit can be correlated across most of the 200 West Area (Wood et al. 2001). The PPlz sediments appear to be predominantly fluvial-overbanktype deposits intercalated with some eolian deposits (Lindsey et al. 2000, Slate 2000, Wood et al. 2001). The PPlz subunit is at least partially correlative with the "early Palouse soil" described by previous reports (Brown 1960, Tallman et al. 1979, Bjornstad 1984, Last et al. 1989, Bjornstad 1990, DOE 1988), the "unnamed Hanford Formation or Plio-Pleistocene Deposits" described by Lindsey et al. (2000), and the H/PP unit in Wood et al (2001). 


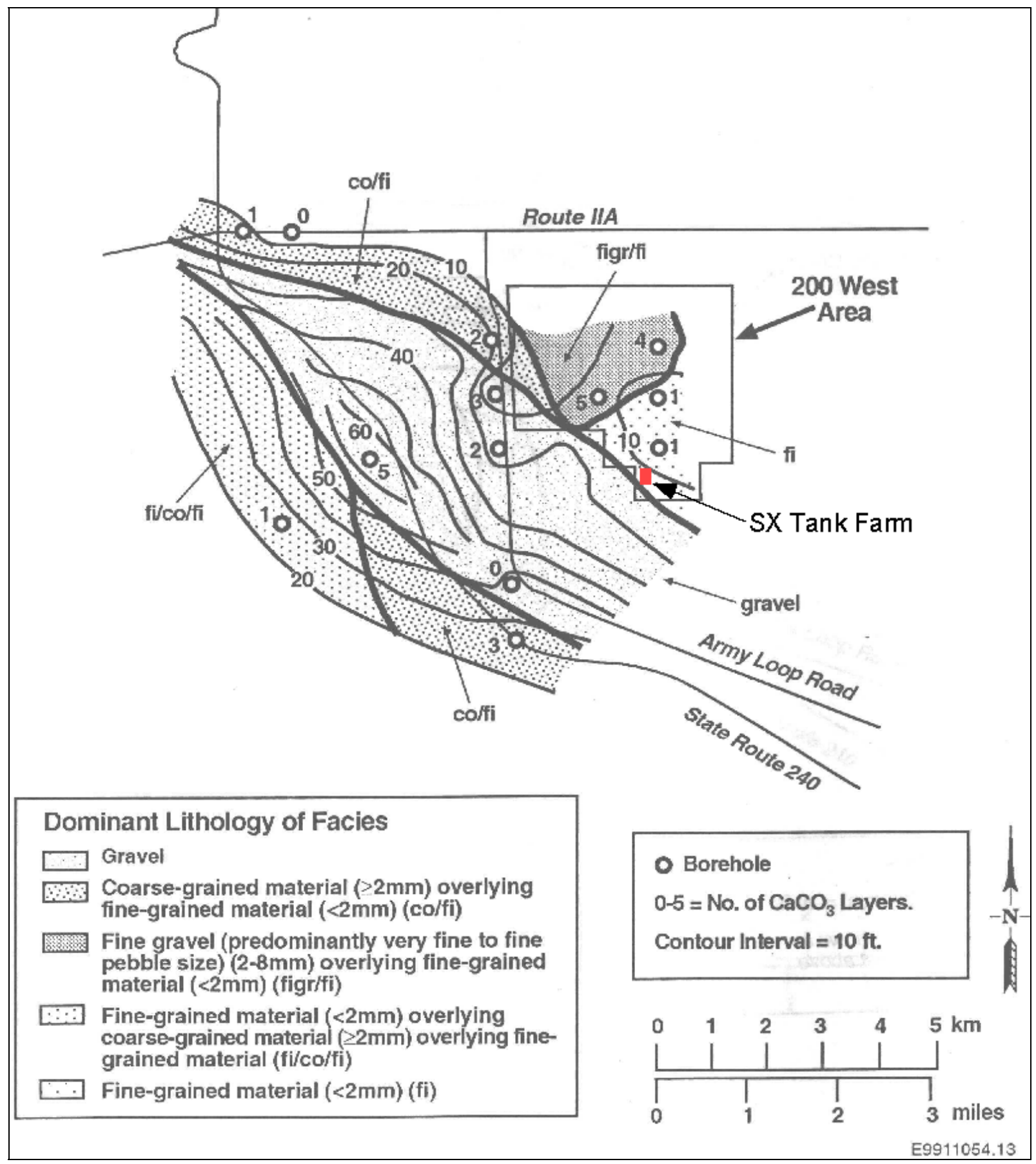

Figure 2.6. Lithofacies Distribution for the Lower Plio-Pleistocene Unit (PPlc). Modified after Slate (2000). Heavy weight lines mark facies boundaries, lighter weight lines are isopach contours. 
The upper Plio-Pleistocene unit contains moderate amounts (up to a few wt \%) of $\mathrm{CaCO}_{3}$ (Table 2.4), generally more than the overlying Hanford formation. The source of the $\mathrm{CaCO}_{3}$ within the two subunits of the Plio-Pleistocene unit appears distinctly different. Within the PPlc subunit, most of the $\mathrm{CaCO}_{3}$ appears as stringers or in massive horizons, which formed in situ as a result of pedogenesis (Wood et al. 2001). Within the PPlz subunit, on the other hand, the $\mathrm{CaCO}_{3}$ is evenly disseminated and does not occur in discrete zones, and therefore is interpreted to be detrital in origin (Wood et al. 2001). In fact, the bulk of the detrital, $\mathrm{CaCO}_{3}$ mineral grains in the $\mathrm{PPlz}$ unit are probably derived from the disintegration and mechanical reworking and redeposition of the underlying PPlc subunit.

Table 2.4. Example of Granulometric and Calcium Carbonate Data from Drive-Barrel Samples of the Upper Plio-Pleistocene Unit (PPlz) Encountered Beneath the SX Tank Farm

\begin{tabular}{|c|c|c|c|c|c|c|c|c|c||}
\hline \multirow{2}{*}{$\begin{array}{c}\text { Borehole/ } \\
\text { Depth }\end{array}$} & $\begin{array}{c}\mathrm{CaCO}_{3} \\
\%\end{array}$ & \begin{tabular}{c} 
Gravel \\
\cline { 3 - 9 }
\end{tabular} & $\begin{array}{c}\text { Very } \\
\text { Coarse } \\
1-2 \mathrm{~mm}\end{array}$ & $\begin{array}{c}\text { Coarse } \\
0.5-1.0 \\
\mathrm{~mm}\end{array}$ & $\begin{array}{c}\text { Medium } \\
0.25-0.5 \\
\mathrm{~mm}\end{array}$ & $\begin{array}{c}\text { Fine } \\
0.125- \\
0.25 \mathrm{~mm}\end{array}$ & $\begin{array}{c}\text { Very Fine } \\
0.063- \\
0.125 \mathrm{~mm}\end{array}$ & $\begin{array}{c}\text { Mud } \\
<0.063 \\
\mathrm{~mm}\end{array}$ & Class \\
\hline $\begin{array}{c}299-\mathrm{W} 23-5 \\
120 \mathrm{ft}\end{array}$ & 2.6 & 0.0 & 1.8 & 1.9 & 4.8 & 12.3 & 31.1 & 48 & $\mathrm{mS}$ \\
\hline $\begin{array}{c}299-\mathrm{W} 23-5 \\
125 \mathrm{ft}\end{array}$ & 2.3 & 0.0 & 1.6 & 7.0 & 9.2 & 7.3 & 8.1 & 66.8 & $\mathrm{sM}$ \\
\hline $\begin{array}{c}299-\mathrm{W} 23-6 \\
125 \mathrm{ft}\end{array}$ & 2.4 & 0.0 & 0.1 & 2.0 & 7.7 & 10.1 & 23.5 & 56.5 & $\mathrm{sM}$ \\
\hline
\end{tabular}

(a) Hard-Tool Sample, Use for Indication Only. Multiply by 0.3048 to convert to meters.

The contact between the PPlz and PPlc subunits is distinctive and easily identified. The PPlz subunit consists of relatively loose, stratified, non-pedogenically altered, well-sorted silt to very fine sand in contrast to poorly sorted, weathered, and carbonate-cemented deposits of the PPlc subunit. Also distinctive is a sudden increase in total gamma activity upward across the contact (DOE 1988, Last et al. 1989, Bjornstad 1990, Johnson et al. 1999). The upper contact of the PPlz subunit with the overlying Hanford formation, on the other hand, often appears gradational, both texturally and structurally, and thus is often difficult to identify based on lithologic observations alone, especially in the vicinity of the SX Tank Farm. Because of this uncertainty, the upper Plio-Pleistocene unit in the past has been combined and queried with the lower Hanford formation in some recent reports (Lindsey et al. 2000, Wood et al. 2001). However, we believe the total gamma activity on borehole geophysical logs can effectively be used to identify the upper contact for the Plio-Pleistocene unit. Accordingly, a subtle decrease in total gamma activity appears to be associated with the top of the PPlz subunit, probably as a result of a lower silt/clay content within the Hanford formation. Therefore, we recommend that this change in background gamma counts and grain size be used to define the upper contact for the upper Plio-Pleistocene unit. 


\subsubsection{Hanford Formation}

Pleistocene-age deposits of the Hanford formation overlie the Plio-Pleistocene unit directly beneath the SX tank farm. The Hanford formation is the informal name given to all deposits from Ice-Age cataclysmic floods including any intercalated non-flood deposits.

The Hanford formation can generally be divided into three facies: 1) gravel-dominated, 2) sanddominated, and 3 ) silt-dominated, also referred to as coarse-grained deposits, plane-laminated sand facies, and rhythmite facies, respectively (Baker et al. 1991). The coarse-grained facies have also been referred to as the "Pasco gravels," and the rhythmite facies as Touchet Beds.

The gravel-dominated facies generally consists of poorly sorted coarse-grained basaltic sand and granule-to boulder-size gravel. These deposits often display an open framework texture, massive bedding, plane to low-angle bedding, and large-scale fore-set bedding in outcrop. The gravel clasts (dominated by basalt) are usually subangular to subrounded. The gravel-dominated facies was deposited by high-energy floodwaters in or immediately adjacent to the main cataclysmic flood channel ways (Figure 2.7).

The sand-dominated facies consists of fine- to coarse-grained sand and granule gravel displaying horizontal lamination and bedding and less commonly planar to trough laminations. These sands may contain small pebbles and rip-up clasts in addition to pebble-gravel interbeds and silty interbeds less than 1 meter ( 3 feet) thick. The silt content of these sands is variable, but where it is low, a well sorted and open framework texture of the gravel is common. These sands typically are basaltic, commonly being referred to as black, gray, or "salt-and-pepper" sands. The laminated sand facies was deposited at higher elevations where the floodwaters were starved of gravel, and/or adjacent to main flood channel ways during the waning stages of flooding (Figure 2.7). This is a transitional facies between the graveldominated facies and the silt-dominated facies. The sand-dominated facies is the predominant facies of the Hanford formation beneath the SX Tank Farm.

The silt-dominated facies consists of rhythmically bedded, ripple-cross-laminated sand and silt, and fine- to coarse-grained sand grading upward to plane laminated silt. Individual rhythmites range from a few centimeters to several tens of centimeters thick (Myers and Price 1979, DOE 1988, Baker et al. 1991). These sediments were deposited under slack-water conditions and in back-flooded areas (DOE 1988), mostly around the margins of the basins (Figure 2.7). The silt-dominated facies is the predominant facies of the Hanford formation south and west of the SX Tank Farm.

The Hanford formation beneath the SX Tank Farm is mostly represented by sand-dominated facies consisting of fine-grained sands intercalated with coarse sand and gravel, and thinner lenses of silt. The basal portion of the Hanford formation is predominantly silty fine sand, described by DOE (1996) and Lindsey et al. (2000) as the Hanford formation H2 unit (Table 2.1). A sandy gravel facies dominates the middle portion of the Hanford formation, which is then overlain by a slightly silty medium sand and finally by a slightly gravelly coarse sand. The sandy gravel facies makes up the Hanford formation H1 


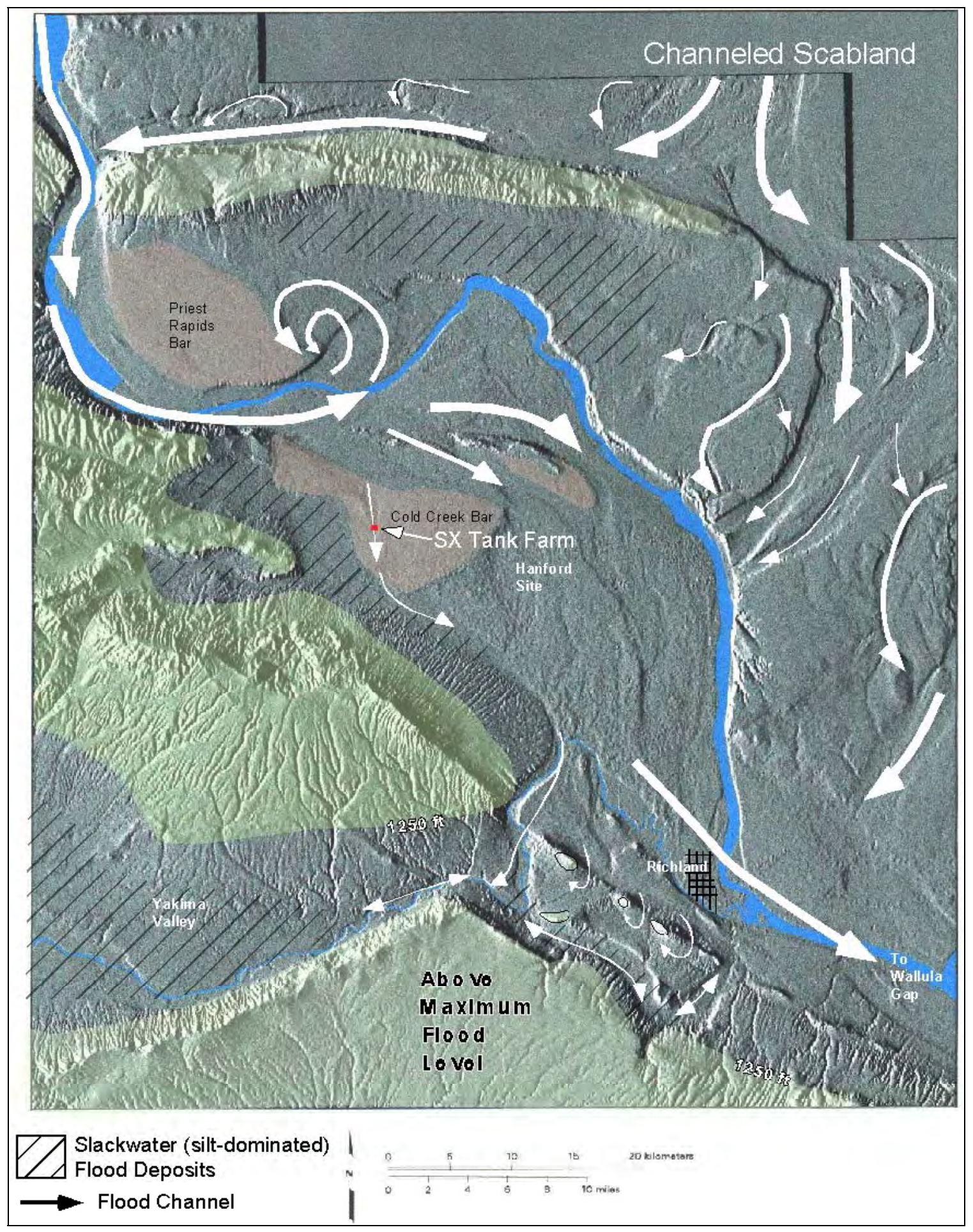

Figure 2.7. Digital Elevation Model (DEM) Map of a Portion of the Pasco Basin Showing Routes and Facies Distributions for the Last Pleistocene Cataclysmic Floods (i.e., Hanford formation). 
unit described by DOE (1996), Johnson et al. (1999) and Lindsey et al. (2000). The slightly silty medium sand and overlying slightly gravelly coarse sand is equivalent to the Hanford formation H1a unit (Johnson et al. 1999, Lindsey et al. 2000).

\subsubsection{Lower Fine Sand and Silt Sequence (Hanford Formation H2 Unit)}

The lower portion of the Hanford formation (equivalent to the Hanford formation $\mathrm{H} 2$ unit) consists primarily of interstratified silty sands. This sequence generally thins from about 24.3 meters ( 80 feet) east of the SX Tank Farm to approximately 10.7 meters (35 feet) west of the tank farm (Figures 2.3 through 2.5). Johnson and Chou (1998) suggested that this thinning may signify some scouring on top of the unit, perhaps associated with a secondary flood channel, similar to the north-south trending flood channel that bisects Cold Creek bar in Figure 2.7. The grain size within the Hanford formation H2 unit appears to coarsen upward slightly (see Table 2.5). Sobcyzk (2000) and Johnson et al. (1999) found that the top of this unit generally slopes about six degrees to the southwest, with some local relative highs and lows present throughout. Below the Hanford formation $\mathrm{H} 2$ unit are slightly finer-grained deposits of interstratified very fine sand, silt and clay, associated with the upper Plio-Pleistocene unit. As mentioned previously, the base of the Hanford formation is indicated by a diagnostic increase in background gamma counts on borehole geophysical logs.

\subsubsection{Lower Coarse-Grained Sequence (Hanford Formation H1 Unit)}

The lower fine sand and silt sequence (Hanford formation $\mathrm{H} 2$ unit) is bounded above by a coarse unit dominated by sandy gravel to gravelly sand (Table 2.5) that appears to correlate beneath the SX Tank Farm (Figures 2.3 through 2.5). This sequence, referred to as "Gravel Unit A" by Johnson et al. (1999) and as "Hanford Unit A" by Sobcyzk (2000), is equivalent to the Hanford formation H1 unit described by DOE (1996) and Lindsey et al. (2000) and ranges in thickness from 1 meter to nearly 10 meters (3 to 30 feet) beneath the tank farm. The Hanford formation H1 unit is thickest beneath the SX-102 tank where coarse-grained flood deposits backfilled an apparent channel eroded into the top of the underlying Hanford formation H2 unit (Johnson et al. 1999, Sobcyzk 2000).

Recent particle-size results using dry sieving for 100 selected samples from seven boreholes drilled in and around the tank farm suggest the coarse-grained Hanford formation $\mathrm{H} 1$ unit is continuous beneath the SX Tank Farm, as indicated by Johnson et al. (1999) and Sobcyzk (2000). Accordingly, the Hanford formation $\mathrm{H} 1$ unit averages $\sim 30 \%$ gravel, $66 \%$ sand, and only $4 \%$ mud (Table 2.6 ). This is compared to the materials directly above and below it, that both average <1\% gravel, nearly $90 \%$ sand, and $9 \%$ mud. Based on the modified Folk/Wentworth classification scheme, traditionally used for geologic studies on the Hanford Site, the classification of the average particle size for this unit falls near the boundary between the sandy gravel and gravelly sand classes. Furthermore, a zone with low background gamma counts appears to correlate beneath the SX Tank Farm, which is interpreted to conform to the gravel-rich Hanford formation H1 unit, is interpreted to be continuous in this area (Sobcyzk 2000). Granulometric data from all seven wells used in the compilation of Table 2.6 is presented in Appendix D. 


\subsubsection{Upper Fine Sand and Silt Sequence (Hanford Formation H1a Unit [fine])}

Above the middle coarse facies of the Hanford formation $\mathrm{H} 1$ unit lies an upper fine sand to silty-sand sequence, equivalent to the Hanford formation H1a unit described by Lindsey et al. $(1994,2000)$, and the "Hanford silty sand" described by Sobcyzk (2000). This sequence consists predominantly of interstratified slightly silty medium to very fine sands (Table 2.5) and ranges in thickness from 0 meter, where it was removed during excavation of the tank farm, to about 9 to 12 meters (30 to 40 feet) to the southwest (Figures 2.3 through 2.5 ). The top of this unit slopes slightly ( 2 degrees) to the southwest (Johnson et al. 1999, Sobcyzk 2000). Sobcyzk (2000) also suggests that this unit may become coarser textured to the west.

\subsubsection{Upper Coarse-Grained Sequence (Hanford Formation H1a Unit [Coarse])}

A coarse-grained sand to gravelly sand unit (Table 2.5) overlies the fine sand sequence of the Hanford formation H1a subunit, and may be intercalated with some sandy gravel to the west. This unit is equivalent to Gravel Unit B (Johnson et al. 1999) and Hanford Unit B (Sobcyzk 2000). It is the uppermost stratigraphic unit in the tank farm area, but is completely missing beneath the tank farm, where it was removed during construction. In surrounding boreholes, however, this unit ranges from a few meters in thickness to east to up 12 meters (40 feet) to the west.

\subsubsection{Backfill}

Price and Fecht (1976a) described the backfill surrounding the high-level waste tanks of the SX Tank Farm as consisting predominantly of poorly sorted cobbles, pebbles, and coarse to medium sands to silt derived from the Hanford formation. Lindsey et al. (2000) described the backfill as relatively noncohesive, friable, massive sand with variable amounts of silt and pebbles. They also observed a hardened zone at the base of the backfill, extending to a depth of approximately 18.6 meters (61 feet) that was significantly harder and drier than the overlying materials. However, this hardened zone has not been observed in adjacent boreholes, so it may or may not extend laterally.

Engineering drawings H-237985 Sheet 1 and 2 show that the tank farm was excavated to create three terraces for construction of the cascading tanks. This excavation extended to an elevation of 185.3 meters (608 feet) on the west side and 185.9 meters (610 feet) on the east side. 
Table 2.5. Granulometric and Calcium Carbonate Data from Core Samples of the Hanford Formation Beneath SX Tank Farm and Average Bulk Densities

\begin{tabular}{|c|c|c|c|c|c|c|c|c|c|c|c|}
\hline \multirow[b]{2}{*}{$\begin{array}{l}\text { Hanford } \\
\text { Formation } \\
\text { Subunit }\end{array}$} & \multirow[b]{2}{*}{$\begin{array}{l}\text { Borehole } \\
\text { /Depth }\end{array}$} & \multirow[b]{2}{*}{$\begin{array}{c}\mathrm{CaCO}_{3} \\
\%\end{array}$} & \multirow[b]{2}{*}{$\begin{array}{l}\text { Gravel } \\
>2 \mathrm{~mm}\end{array}$} & \multicolumn{5}{|c|}{ Sand (mm) } & \multirow[b]{2}{*}{$\begin{array}{l}\text { Mud } \\
<0.06 \\
3 \mathrm{~mm}\end{array}$} & \multirow[b]{2}{*}{ Class } & \multirow[b]{2}{*}{$\begin{array}{l}\text { Average Bulk } \\
\text { Density from } \\
299-\mathrm{W} 22-50^{(\mathrm{a}}\end{array}$} \\
\hline & & & & $\begin{array}{c}\text { Very } \\
\text { Coarse } \\
1-2 \mathrm{~mm}\end{array}$ & $\begin{array}{c}\text { Coarse } \\
0.5-1.0 \\
\mathrm{~mm}\end{array}$ & $\begin{array}{l}\text { Medium } \\
0.25-0.5 \\
\mathrm{~mm}\end{array}$ & $\begin{array}{c}\text { Fine } \\
0.125- \\
0.25\end{array}$ & $\begin{array}{c}\text { Very Fine } \\
0.063- \\
0.125 \mathrm{~mm}\end{array}$ & & & \\
\hline $\begin{array}{c}\text { H1a - } \\
\text { gravelly sand }\end{array}$ & $\begin{array}{c}299-\mathrm{W} 23-5 \\
5 \mathrm{ft}^{\mathrm{b}, \mathrm{c})}\end{array}$ & 1.2 & 6.7 & 4.8 & 10.5 & 8.6 & 20.7 & 30.9 & 17.9 & $\overline{(\mathrm{gm}) \mathrm{S}}$ & NA \\
\hline \multirow{2}{*}{$\begin{array}{l}\text { H1a - sligthly } \\
\text { silty sand }\end{array}$} & $\begin{array}{c}\text { 299-W23-72 } \\
55 \mathrm{ft}^{(\mathrm{c})}\end{array}$ & 1.4 & 0.4 & 0.5 & 1 & 19.1 & 43.1 & 22.1 & 13.9 & $(\mathrm{~m}) \mathrm{S}$ & \multirow{2}{*}{1.95} \\
\hline & $\begin{array}{c}299-\mathrm{W} 23-92 \\
80 \mathrm{ft}^{(\mathrm{c})}\end{array}$ & NA & 2.1 & 3 & 12.1 & 20.4 & 31.2 & 19.8 & 11.4 & $(\mathrm{~m}) \mathrm{S}$ & \\
\hline \multirow{3}{*}{$\mathrm{H} 1$} & $\begin{array}{c}\text { 299-W23-72 } \\
70 \mathrm{ft}^{(\mathrm{c})}\end{array}$ & 1.7 & 10.7 & 23.7 & 28.7 & 16.7 & 8.3 & 6.0 & 6.0 & $\mathrm{gS}$ & \multirow{3}{*}{2.27} \\
\hline & $\begin{array}{c}\text { 299-W23-92 } \\
90 \mathrm{ft}^{(\mathrm{c})}\end{array}$ & NA & 16.3 & 16.9 & 27.9 & 18.5 & 8.1 & 5.7 & 6.6 & $\overline{\mathrm{gS}}$ & \\
\hline & $\begin{array}{c}\text { 299-W23-108 } \\
85 \mathrm{ft}^{(\mathrm{c})}\end{array}$ & NA & 41.8 & 24.5 & 14.5 & 7.1 & 3.9 & 3.3 & 5.0 & sG & \\
\hline \multirow{4}{*}{$\mathrm{H} 2$} & $\begin{array}{c}\text { 299-W23-72 } \\
100 \mathrm{ft}^{(\mathrm{c})}\end{array}$ & 1.7 & 0.0 & 0.2 & 2.1 & 37.6 & 29.7 & 15.2 & 15.3 & $(\mathrm{~m}) \mathrm{S}$ & \multirow{4}{*}{2.05} \\
\hline & $\begin{array}{c}\text { 299-W23-92 } \\
110 \mathrm{ft}^{(\mathrm{c})}\end{array}$ & NA & 0.8 & 1.0 & 9.4 & 40.0 & 22.2 & 14.6 & 12.0 & $(\mathrm{~m}) \mathrm{S}$ & \\
\hline & $\begin{array}{c}\text { 299-W23-92 } \\
120 \mathrm{ft}^{(\mathrm{c})}\end{array}$ & NA & 2.8 & 2.2 & 1.7 & 9.6 & 33.5 & 34.9 & 15.4 & $(\mathrm{~m}) \mathrm{S}$ & \\
\hline & $\begin{array}{c}299-\mathrm{W} 23-108 \\
110 \mathrm{ft}\end{array}$ & NA & 1.8 & 0.1 & 1.8 & 13.2 & 26.6 & 30.9 & 15.7 & $\mathrm{mS}$ & \\
\hline \multicolumn{12}{|c|}{$\begin{array}{l}\text { (a) After Horton and Johnson (2000) } \\
\text { (b) Hard-Tool Sample, Use For Indication Only } \\
\text { (c) Multiply by } 0.3048 \text { to convert to meters. } \\
\text { NA = Not Analyzed }\end{array}$} \\
\hline
\end{tabular}


Table 2.6. Summary of Recent Particle Size Analytical Results from Seven Boreholes in and Around the SX Tank Farm

\begin{tabular}{|c|c|c|c|}
\hline & $\%$ Gravel & $\%$ Sand & $\% \mathrm{Mud}$ \\
\hline \multicolumn{4}{|l|}{$\mathrm{H} 1 \mathrm{a}$} \\
\hline Min & 0.00 & 76.76 & 2.54 \\
\hline Max & 5.38 & 97.15 & 23.14 \\
\hline Average & 0.94 & 89.18 & 9.88 \\
\hline STDEV & 1.43 & 6.13 & 6.51 \\
\hline \multicolumn{4}{|l|}{ H1 } \\
\hline Min & 0.13 & 2.64 & 0.00 \\
\hline Max & 97.27 & 96.05 & 22.34 \\
\hline Average & 30.88 & 66.87 & 4.14 \\
\hline STDEV & 28.33 & 26.34 & 4.77 \\
\hline \multicolumn{4}{|l|}{ H1 } \\
\hline Min & 0.00 & 62.13 & 1.55 \\
\hline Max & 13.99 & 98.11 & 37.84 \\
\hline Average & 0.94 & 89.75 & 9.30 \\
\hline STDEV & 2.38 & 7.19 & 7.17 \\
\hline
\end{tabular}

\subsection{Historical Water Levels}

Figure 2.8 illustrates hydrographs for wells 299-W23-3 and -4. Since a complete water level record is unavailable for either well, their water level behavior was extrapolated from each other to complete the record. This is justified by the similar behaviors of their common data sets. Based on this extrapolation between the two data sets, and a linear interpolation over the distance between the two wells, it is estimated that the peak water elevation beneath the SX-115 tank was approximately 146 meters (479 feet). This occurred in 1976 and places the water table approximately 55 to 56 meters (182 feet) below ground surface (bgs) or 40 meters (132 feet) beneath the bottom of the tank. A secondary maximum occurred in 1984, just before the 216-U-10 Pond was decommissioned. At this time the water table was estimated to have been almost as high as it was in 1976. The water table was encountered at a depth of approximately 64.5 meters (212 feet) in borehole 299-W23-19, in August 1999. Thus, the water table has dropped an estimated 8 to 9 meters ( 28.5 feet) over the last 14 years. An examination of the hydrographs since about 1988 suggests that the water level is dropping at a rate of 0.5 to 0.6 meters (1.5 to 1.9 feet) per year. 


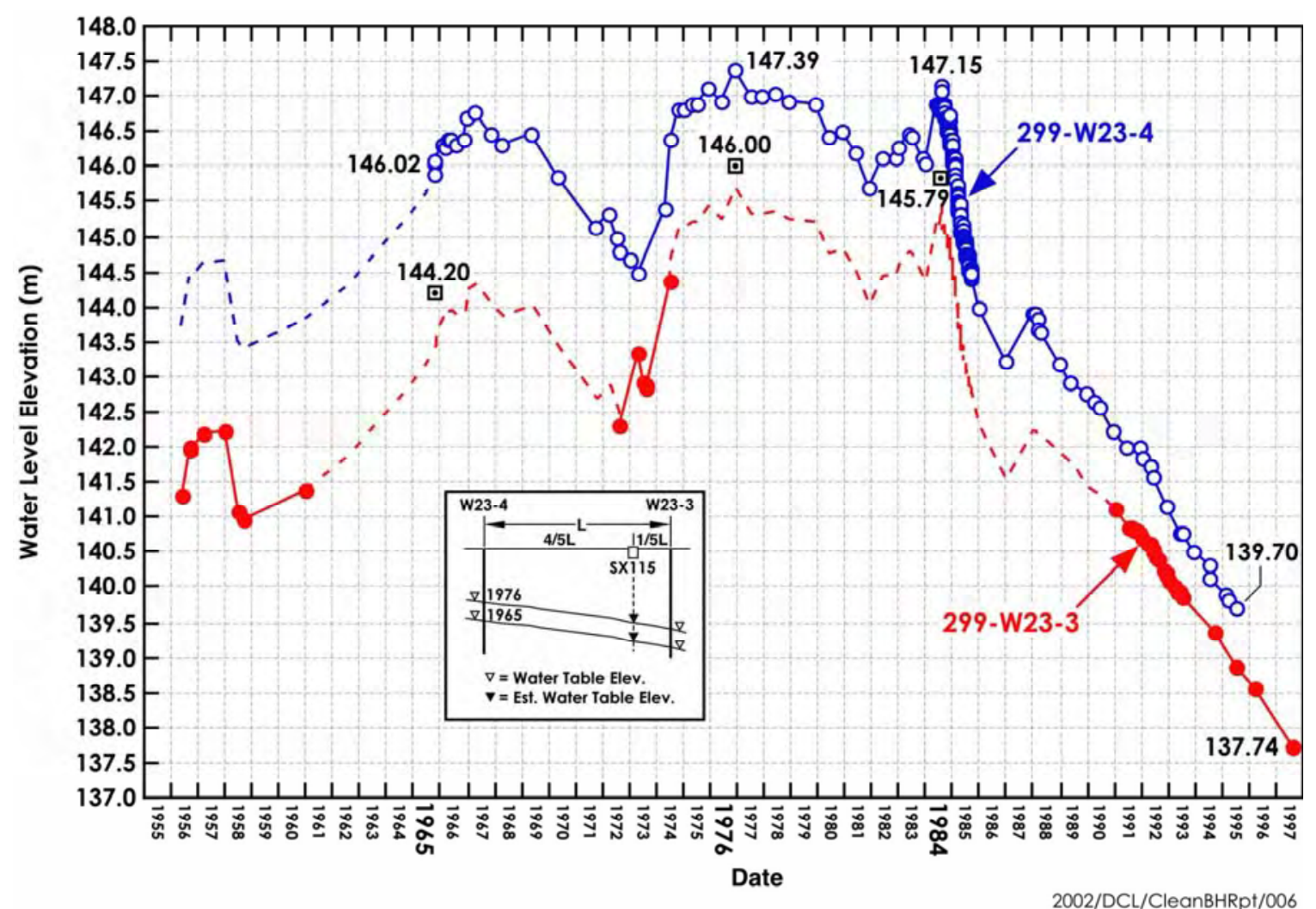

Figure 2.8. Historic Water Levels Beneath the SX Tank Farm

\subsection{Geologic Characterization}

The following sections describe the geologic characteristics for four composite sediment samples and two Resource Conservation and Recovery Act (RCRA) boreholes (299-W22-48 and -50) analyzed for this report, one of a four-part series of reports for the SX Tank Farm.

\subsubsection{Composite Samples}

Three surface outcrops or excavation sidewalls and one borehole on the Hanford Site were sampled to obtain large volumes of uncontaminated sediment that could be well homogenized for dispensing to Environmental Management Science Program (EMSP) and Science and Technology Program scientists across the country. A total of five composite samples were obtained from four sampling sites; only four of the five composite samples were analyzed for this report. The samples contained sediment that is somewhat representative of those underlying the S-SX Tank Farm including the following: 1) the White Bluffs, 2) the 218-E-12B burial ground, 3) the Environmental Restoration Disposal Facility (ERDF), and 4) borehole 299-W22-50. Geographic and stratigraphic information associated with the composite samples is summarized in Table 2.7. 
All of the composite samples are from the Hanford formation (Pleistocene cataclysmic flood deposits), except for one sample of the lacustrine Ringold Formation from the White Bluffs. Detailed characterization data is reported herein for: (1) Ringold silt from the White Bluffs, (2) Hanford coarse sand, (3) Hanford fine sand from the 218-E-12B burial ground, and (4) borehole fine sand from a 34.5foot-core interval in borehole 299-W22-50 from within the S-SX Waste Management Area. The fifth composite sample, collected from the ERDF excavation, was sent to Dr. Tetsu Tokunaga at Lawrence Berkeley National Laboratory for use in geohydrologic studies and no characterization is reported here.

\subsubsection{White Bluffs Site}

The White Bluffs occur along the eastern side of the Columbia River (see Figure 2.9). An exposed vertical face, toward the top of the bluffs, has been created by a road that cuts diagonally up the side of the bluffs. The roadcut conveniently exposes the sedimentary layers belonging to the upper Ringold Formation (member of Taylor Flat) and lower Plio-Pleistocene unit (PPlc). Three samples, one from each of the different sedimentary facies (Figure 2.10), were collected on January 11, 2000, into 5-gallon buckets. To date, only one of the samples (Ringold silt) has been characterized in detail. The relative stratigraphic position where this sample was obtained is shown in Figure 2.11.

Table 2.7. Composite Sediment Sample Descriptions

\begin{tabular}{|c|c|c|c|c|}
\hline & White Bluffs & 218-E-12B & ERDF & $299-W 22-50$ \\
\hline Sample name & Ringold Silt & $\begin{array}{l}\text { 1) Hanford Coarse Sand } \\
\text { 2) Hanford Fine Sand }\end{array}$ & $\begin{array}{l}\text { Not characterized; } \\
\text { therefore, no name } \\
\text { given here }\end{array}$ & $\begin{array}{l}\text { Borehole Fine } \\
\text { Sand }\end{array}$ \\
\hline Sample date & $1 / 11 / 00$ & $1 / 27 / 00$ & $2 / 3 / 00$ & \\
\hline Location & $\begin{array}{l}\text { NE1/4 Sec. 11, } \\
\text { T.13 N., R.27 E. }\end{array}$ & $\begin{array}{l}\text { SE1/4 Sec 35, T.13 N., } \\
\text { R.26 E. }\end{array}$ & $\begin{array}{l}\text { NE1/4 Sec 7,T.12 } \\
\text { N., R.26 E. }\end{array}$ & $\begin{array}{l}\mathrm{N} 134,139 \\
\text { E566,904 }\end{array}$ \\
\hline $\begin{array}{l}\text { Surface elevation } \\
\text { (ft amsl) }\end{array}$ & 900 & 590 & 720 & 670 \\
\hline $\begin{array}{l}\text { Sampling depth } \\
\text { below top of } \\
\text { stratigraphic } \\
\text { sequence }(\mathrm{ft})\end{array}$ & $\sim 15$ & $\sim 25$ & $\sim 20$ & $62.5-97$ \\
\hline $\begin{array}{l}\text { Stratigraphic } \\
\text { unit/facies } \\
\text { (depositional } \\
\text { environment) } \\
\text { sampled }\end{array}$ & $\begin{array}{l}\text { Upper Ringold } \\
\text { unit/ laminated } \\
\text { silt (lacustrine) }\end{array}$ & $\begin{array}{l}\text { 1) Hanford } \\
\text { formation/pebbly sand } \\
\text { (cataclysmic flood) } \\
\text { 2) Hanford formation/silty } \\
\text { sand (cataclysmic flood) }\end{array}$ & $\begin{array}{l}\text { Hanford formation/ } \\
\text { sand (cataclysmic } \\
\text { flood) }\end{array}$ & $\begin{array}{l}\text { Hanford } \\
\text { formation/sand } \\
\text { (cataclysmic } \\
\text { flood) }\end{array}$ \\
\hline
\end{tabular}




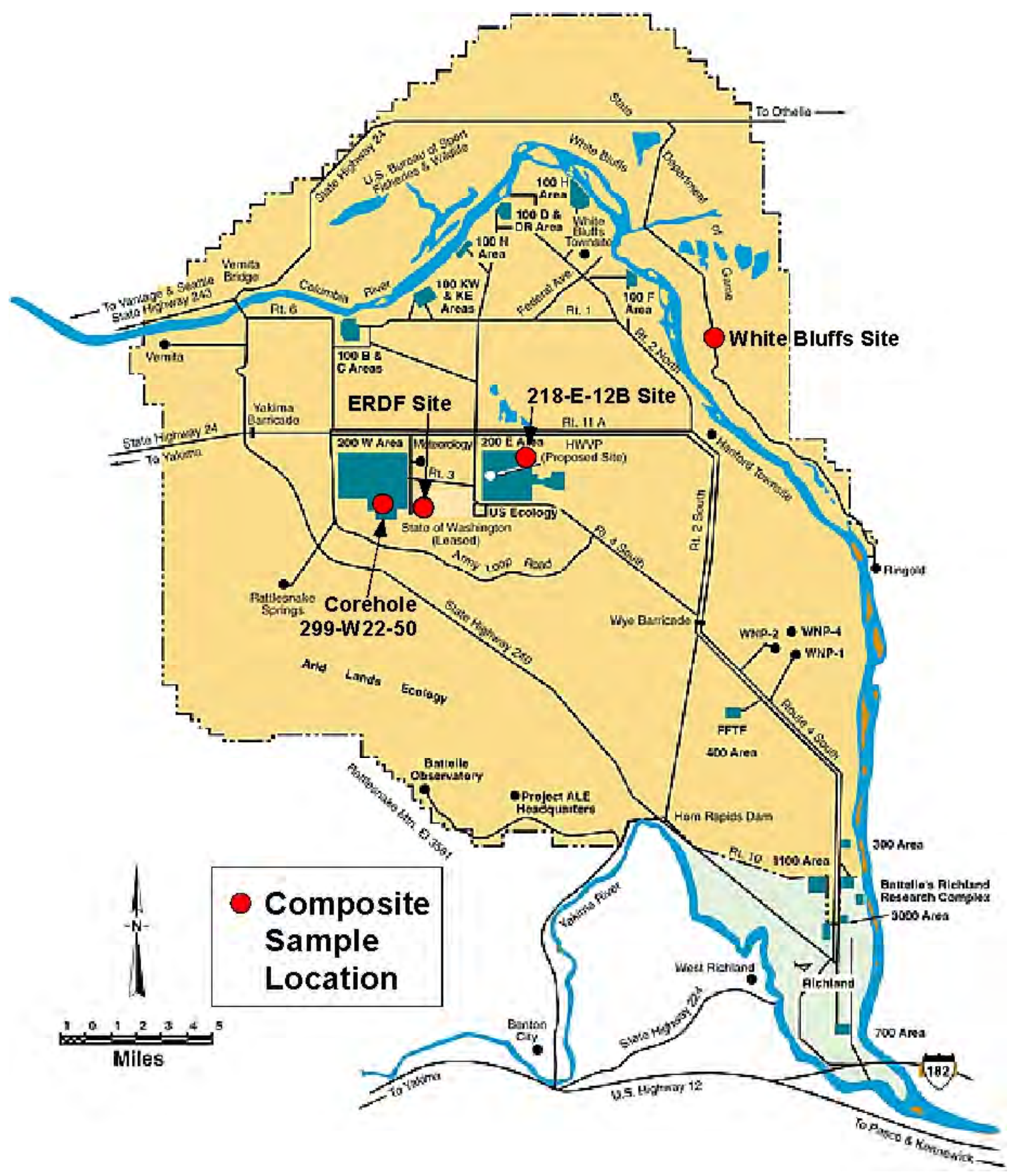

Figure 2.9. Locations for the Four Composite Sediment Samples 


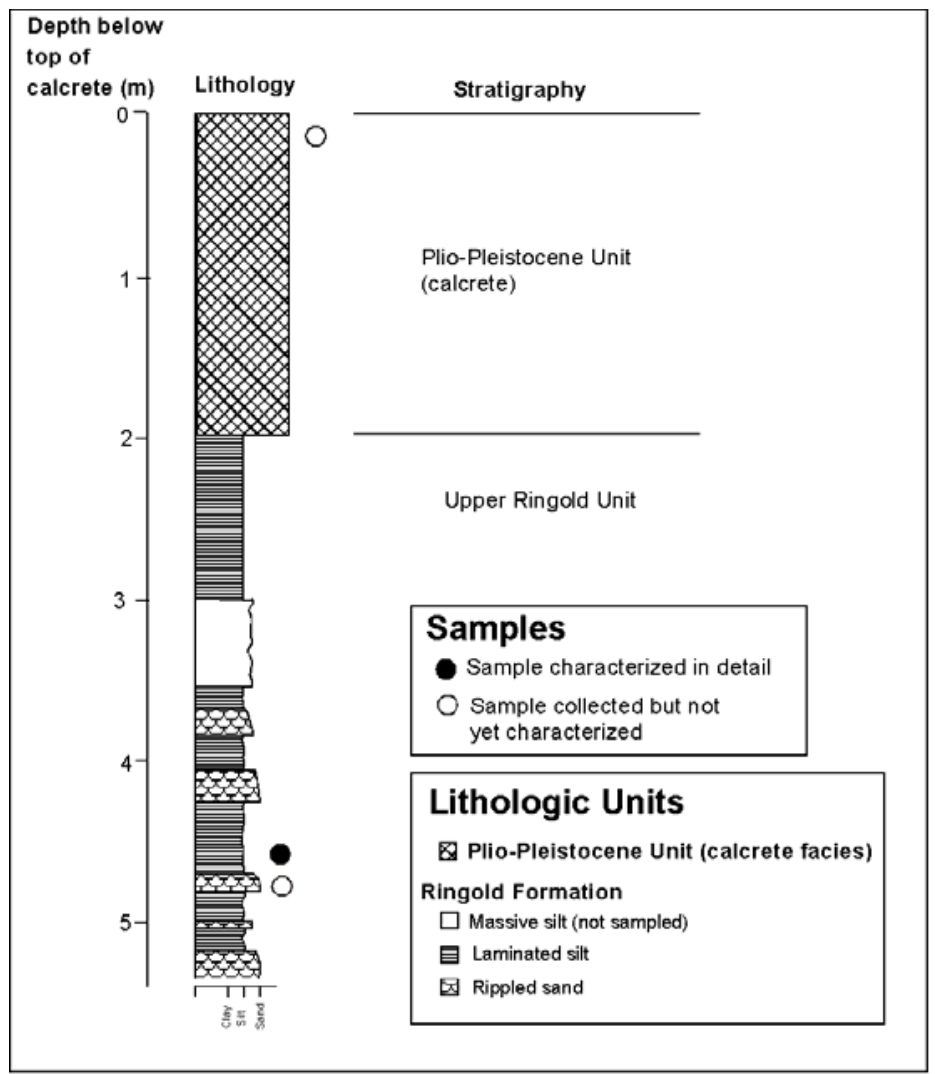

Figure 2.10. Stratigraphic Column of the Upper Portion of the White Bluffs Showing Sample Collection Depths. Samples were collected from a laminated silt and rippled sand within the Ringold Formation, as well as the calcrete cap. Only the Ringold laminated silt has been characterized in detail, thus far. Calcrete cap on the White Bluffs is likely equivalent to Plio-Pleistocene unit carbonate-rich horizon (PPlc) beneath the SX Tank Farm.

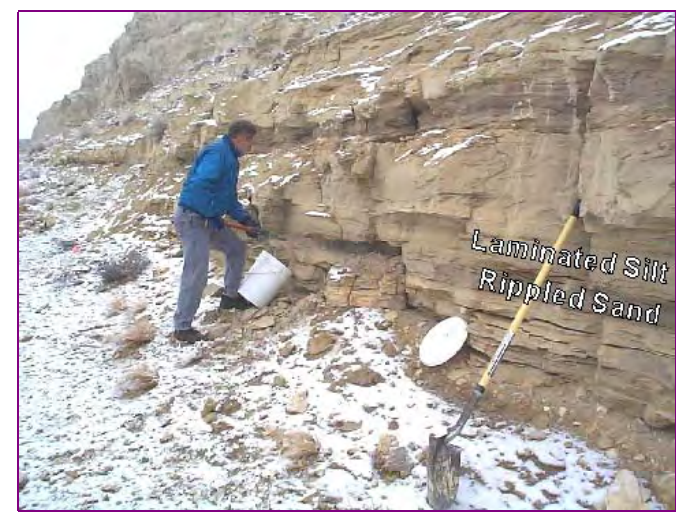

Figure 2.11. Location of Sample Collected from Lacustrine Laminated Silt of the Ringold Formation (Ringold Silt). Underlying rippled sand also was collected but not characterized for this study. 
The laminated silt sample was characterized in detail and is the composite sample referred to as Ringold silt in the rest of the document. Silt from the Ringold Formation, similar to that at White Bluffs, is present locally within the 200 West Area, including S-SX Tank Farm, associated with the informal Ringold member of Taylor Flat unit (unit Rtf) within the vadose zone. Three 5-gallon buckets were filled with Ringold silt. The white-, gray-, and tan-colored Ringold silt sample is interpreted as lacustrine (i.e., lake environment) in origin, indicated by the continuous and finely laminated nature of these deposits.

Layers of light-brown, rippled sand, interbedded with the laminated silt, are probable deltaic deposits that formed during flash-flood events from nearby streams that emptied into the lake that existed in the Pasco Basin during Pliocene time. The adjacent Ringold rippled sand (two 5-gallon buckets) is available for use but has not been characterized. Compared to the Pleistocene-age Hanford formation, where other composite samples were obtained, the Ringold silt is generally finer grained, displays more compaction, cementation, and/or alteration because of its much older age (late Pliocene, 3 to 4 million years ago).

\subsubsection{218-E-12B Site}

Near-surface samples of cataclysmic flood deposits (Hanford formation) were collected from the 218-E-12B burial ground excavation. The Hanford formation can be divided into three facies types: gravel-dominated, sand-dominated, and silt-dominated. Two samples, referred to in this document as Hanford coarse sand and Hanford fine sand (Figures 3.4 through 3.7), were collected and characterized in detail and are representative of the sand-dominated and silt-dominated facies, respectively, which underlie the SX Tank Farm. After the first batch of samples collected in January 2000 was exhausted, an additional forty 5-gallon buckets (20 each of the coarse and fine sand) were collected in May 2001.

Because of its proximity to high-energy flood channels, most of the 15 meters (50 feet) of cataclysmic flood deposits exposed at this site are coarse-grained sand and gravel associated with the graveldominated facies of the Hanford formation (Rhoads et al. 1992). About halfway down the exposure lie two beds of finer-grained sand and silt, separated by coarse-grained pebbly sand. Samples collected for characterization were collected from this fine-coarse-fine interval.

The two fine-grained layers vary in thickness and are associated with the slackwater flood deposition that occurred atop a set of giant current ripples during the waning stages of a late-Pleistocene cataclysmic flood (Lewis et al. 1993) (Figure 2.12). These fine-grained deposits were later buried during a subsequent cataclysmic flood.

Deposits are predominantly coarse sand and gravel. The exception is two layers of fine-grained sand and silt, which are draped over a series of buried, giant-current ripples. The upper fine-grained layer is thicker in the troughs (T) and thins along the crests (C) of the ripple train. Vegetation (brown) preferentially grows along the fine-grained layers, which retain more moisture. (Photo taken December 1992.)

Two facies types were sampled at the 218-E-12B site: (1) pebbly sand (referred to as Hanford coarse sand) and (2) silty sand (referred to as Hanford fine sand). These facies are representative of the 


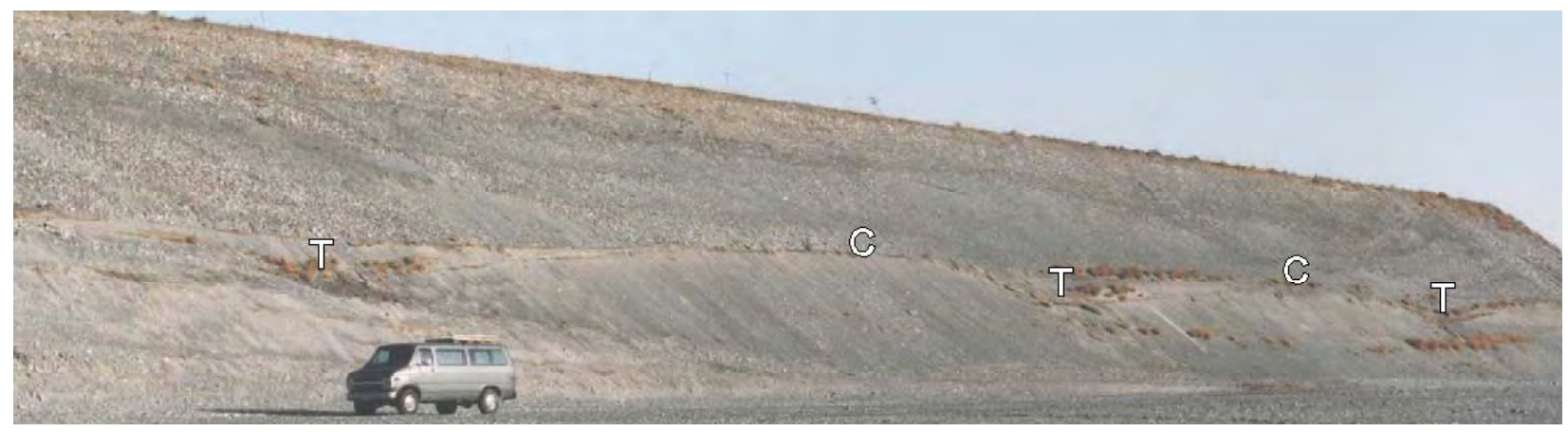

Figure 2.12. Series of Buried Giant Current Ripples at the 218-E-12B Site.

Hanford formation in the southern portions of the 200 East and 200 West Areas, where a higher ratio of sand and silt to gravel exists. The pebbly sand facies is predominantly a grayish brown, matrixsupported, medium to coarse sand with occasional pebbles floating in the matrix (Figure 2.13). Most of the pebbles are composed of basalt or caliche clasts. Sedimentary structures include well-developed horizontal laminations to planar-tabular cross bedding (see Figures 2.13 and 2.14).

The silty sand facies (see Figures 2.15 and 2.16), characterized and referred to as Hanford fine sand in this report, consists of two layers of moist, brown, laminated silty fine sand. Several feet of coarsegrained pebbly sand (Hanford coarse sand) separate the two fine-grained layers. The higher moisture content for this unit is the result of its finer particle size, which translates to a higher moisture retention capacity. Zones with higher moisture are directly associated with areas that support recent vegetation growth along the walls of the 218-E-12B trench (see Figure 2.12). Overlying the upper silty sand in sharp contact is a sandy gravel, which represents a high-energy, gravel-dominated flood facies, probably deposited during a subsequent flood. Deposits from the overlying sandy gravel were not characterized as

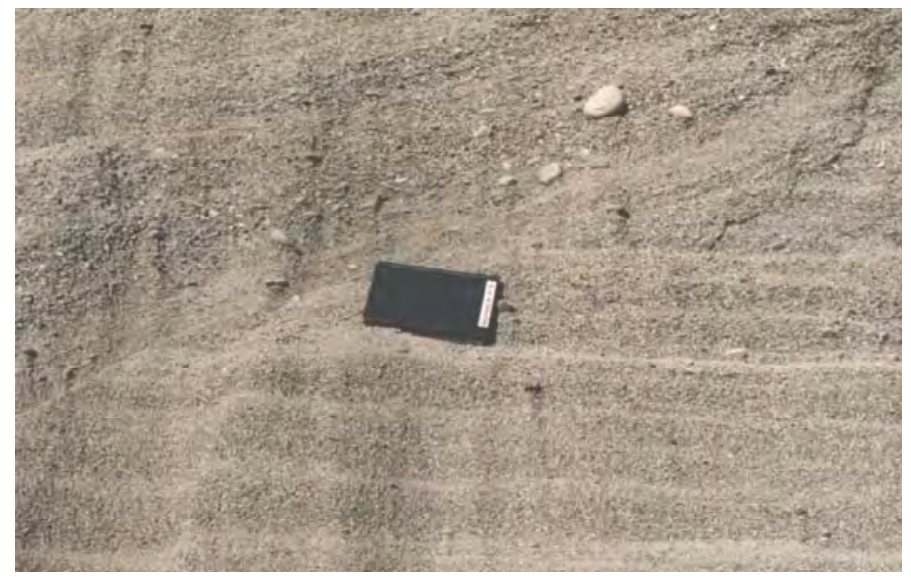

Figure 2.13. Example of Pebbly Sand Facies (referred to as Hanford Coarse Sand in this report) as it Appears In Situ. Horizontally laminated pebbly sand at the bottom is cut and filled with a layer of cross-bedded pebbly sand, above. Notebook for scale is 18 centimeters ( 7 inches) long. (Photo taken January 2000.) 


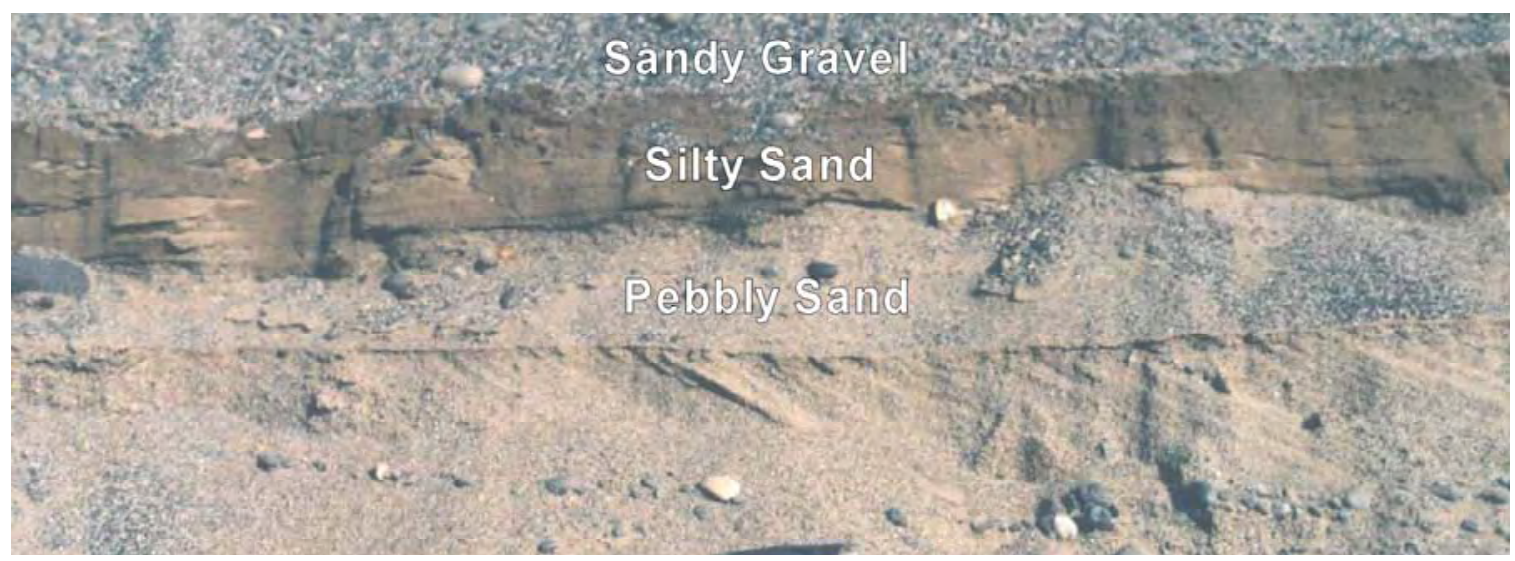

Figure 2.14. Representation of All Three Facies of the Hanford Formation at the 218-E-12B Site. Planar-tabular cross bedding in the pebbly sand facies indicates a paleoflood direction from left (west) to right (east). Stratigraphically, the pebbly sand (i.e., sand-dominated facies) lies directly beneath, and grades upward into, the upper silty sand layer (siltdominated facies). The silty sand is overlain in sharp contact by sandy gravel (i.e., graveldominated facies) along an erosional unconformity. An unknown amount of the silty sand was probably removed prior to deposition of the overlying sandy gravel during a subsequent cataclysmic flood. (Note knife in the bottom center of photo for scale.) The Hanford coarse sand and Hanford fine sand, two samples characterized in detail for this report, came from the pebbly sand and silty sand layers, respectively. Note that the silty sand layer is darker due to its higher moisture content resulting from preferential absorption of meteoric recharge groundwater. (Photo taken January 2000.)

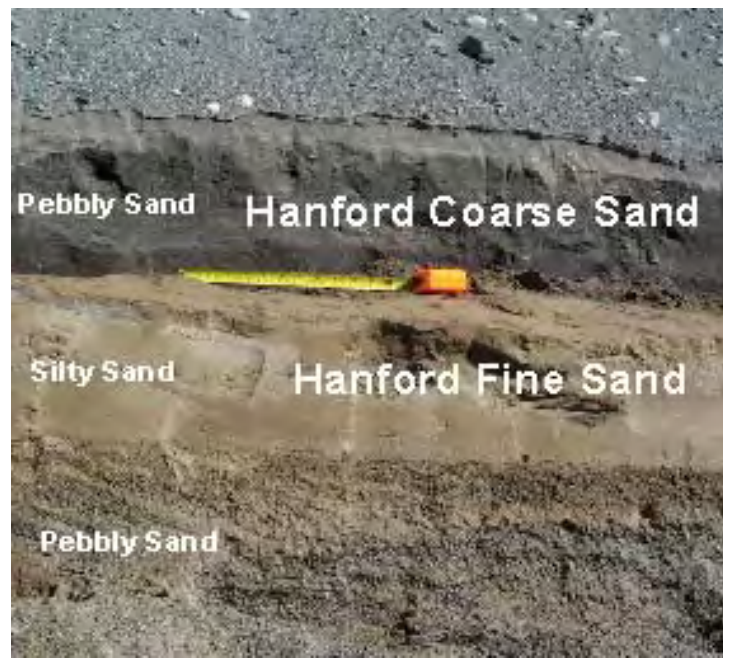

Figure 2.15. Lower Silty Sand Layer at 218-E-12B Site. Lower silty sand layer is sedimentologically identical to upper silty sand layer in Figure 3.6. (Photo taken May 2001.) 


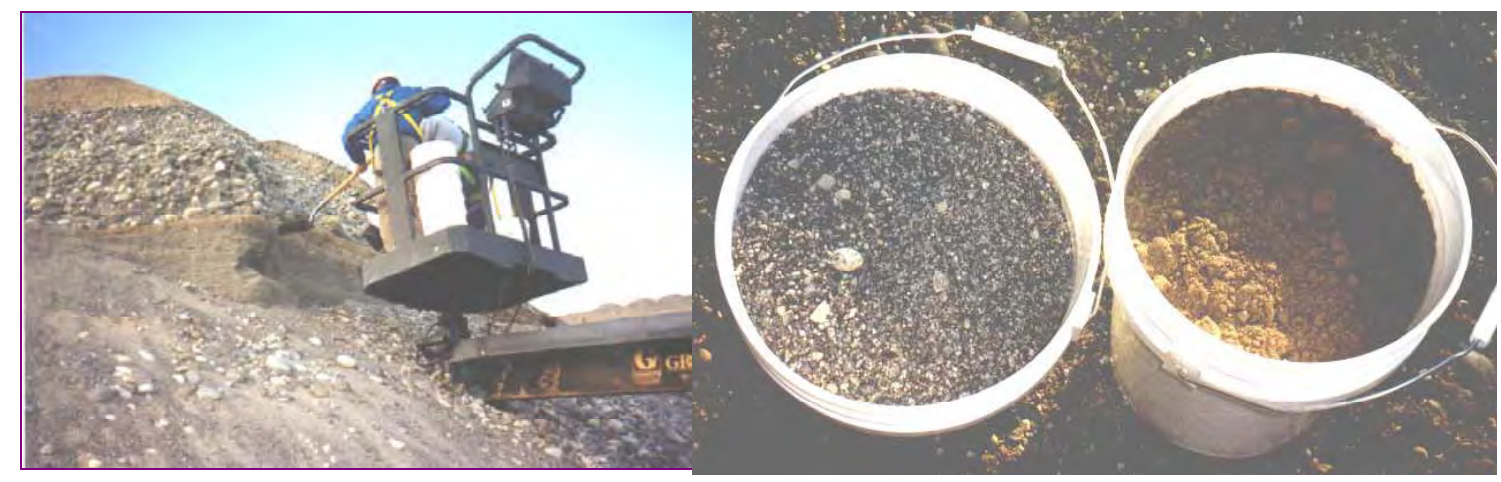

Figure 2.16. Samples Obtained for Detailed Characterization from the 218-E-12B Site. Left photo: collected with the aid of a lift and placed into 5-gallon buckets. Brownish layer at the same height as the shovel blade is the upper silty sand (Hanford fine sand); pebbly sand (Hanford coarse sand) was collected from the immediately underlying layer. Right photo: Example of how samples appeared after collection from the pebbly sand and silty sand facies. The pebbly sand (left bucket) is equivalent to the Hanford coarse sand and the silty sand (right bucket) is referred to as Hanford fine sand, both characterized in this report. (Photos taken January 2000.)

part of this study. These three facies occur together over a relatively short interval of several feet within the 218-E-12B excavation (see Figures 2.14 and 2.15). While layers of either flood gravel and sand, or sand and silt, are often observed together, it is rare to find all three facies occurring together in the same outcrop. Despite this rare occurrence, the pebbly sand and silty sand deposits preserved at the 218-E-12B site still appear to be representative of the sand- and silt-dominated facies, respectively, of the Hanford formation, which are more dominant in the southern portions of the 200 Areas beneath many of the tank farms, including the SX Tank Farm.

\subsubsection{Environmental Restoration Disposal Facility Site}

The ERDF site exposes up to 18 meters (60 feet) of predominantly sand-dominated facies (mostly fine- to medium-grained sand) of the Hanford formation. In contrast to the 218-E-12B site, sanddominated cataclysmic flood deposits at ERDF are finer grained and formed farther from the flood channel ways. The sediment obtained at the ERDF site were sent to EMSP scientists at Lawrence Berkeley National Laboratory without any detailed characterization being performed at PNNL.

A total of twenty 5-gallon buckets of sediment were collected at the ERDF pit on February 3, 2000. Samples came from the base of a single graded bed ( $\geq 1$ meter [ 3 feet] thick) within the flood sequence consisting of unconsolidated, horizontally laminated, fine-to coarse-grained sand at the base grading upward into a slightly pebbly sandy silt at the top (Figure 2.17). The moderately sorted sand has the characteristic salt-and-pepper appearance due to its mineralogy, which contains an abundance of dark basaltic grains (40\% to $70 \%$ ). Contrasting light-colored minerals include quartz, feldspar, mica, and caliche (i.e., cemented calcium carbonate) fragments (Fecht and Weekes 1996). Due to its relatively 


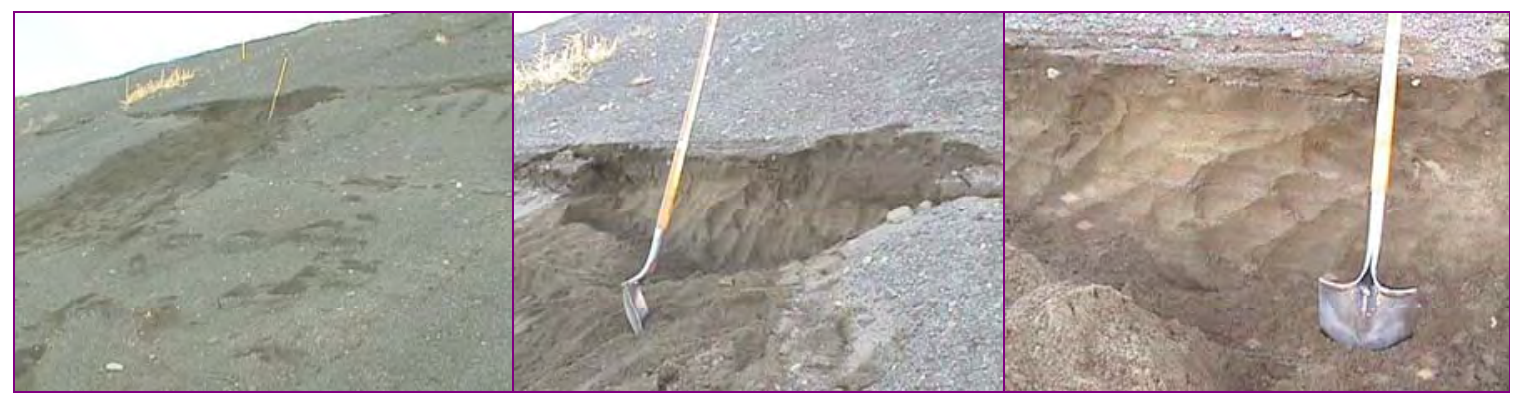

Figure 2.17. Environmental Restoration Disposal Facility Sampling Site. Sampling was restricted to the sand-dominated facies of the Hanford formation. The horizontally laminated structure of the mostly medium-grained sand is apparent in the photo on the right.

young age ( 13,000 years B.P.), the material is generally fresh and unweathered. The sampled bed was about 6 meters ( 20 feet) bgs along a road that cut diagonally down the side of the excavation. Several feet of sloughed surface material were removed with a shovel to expose the fresh, undisturbed sediment underneath for sampling. More detailed descriptions of the ERDF site are presented in Fecht and Weekes (1996) and Weekes et al. (1996).

\subsubsection{Borehole Fine Sand}

A fourth composite sediment sample, referred to as borehole fine sand, is a composite of all the sediment from the 299-W22-50 borehole core sleeves between the depths of 19 and 29.5 meters (62.5 and 97 feet), excepting one 0.3-meter (1-foot)-long sleeve between 25.9 and 26.2 meters ( 85 and 86 feet). The sleeve from 25.9 and 26.2 meters ( 85 to 86 feet) was previously reserved by hydrologists to perform hydraulic conductivity measurements on the intact sediment. The contents of twenty-seven, 10-centimeter (4-inch)-diameter sleeves were composited.

Based on a cursory, visual inspection, the 27 cores showed fairly uniform lithologic consistency, although thin stringers and bedding planes were frequently observed. The borehole fine sand consists of laminated, slightly silty medium- to fine-grained, sand represented between the 19 and 29.5-meter (62.5and 97-foot) depth in Borehole 299-W22-50 (Figure 2.18). This borehole is located just southeast of the SX Tank Farm (Figure 2.2). The borehole fine sand composite sample is part of the Hanford formation $\mathrm{H} 2$ unit of the Hanford formation as described in Lindsey et al. 2000. This unit lies below the backfill and a gravelly zone directly underlying the SX Tank Farm. These strata contain much of the contamination currently found in the vadose zone sediment directly beneath leaking single-shell tanks in the S-SX Tank Farm; therefore, this composite sample is very representative of the Hanford formation in this area. A more detailed discussion of borehole 299-W22-50 is presented in Section 2.4.2.2. 


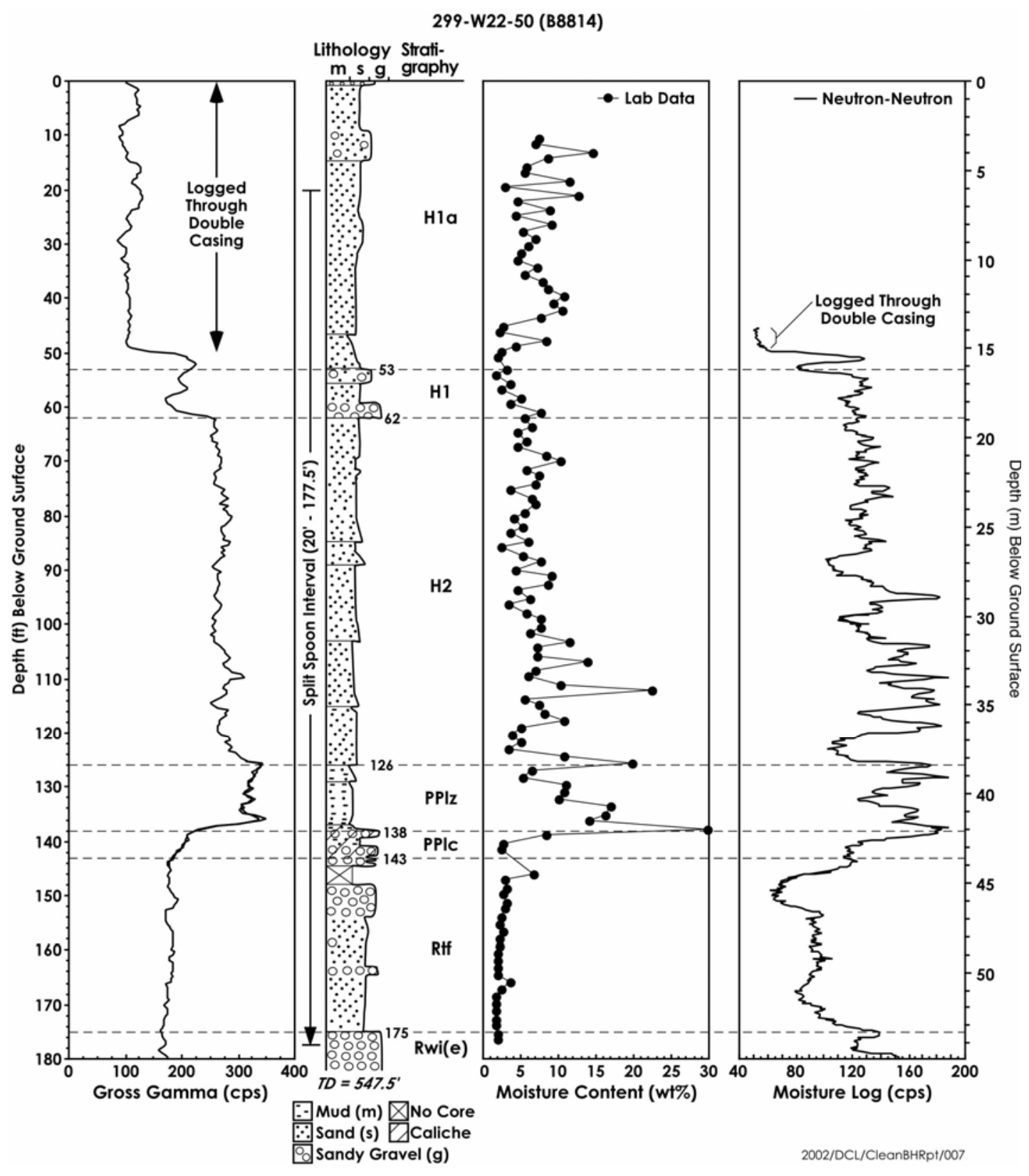

Figure 2.18. Vadose Zone Stratigraphy for Borehole 299-W22-50. See Figure 2.2 for borehole location.

\subsubsection{Geologic Characterization of Clean Boreholes}

This section describes the borehole locations, drilling, sediment sampling, borehole geophysical logging, and geologic characterization for clean boreholes 299-W22-48 (B8812) and -50 (B8814). These boreholes (locations in Figure 2.2) were drilled as part of an integrated effort to (1) collect intact subsurface core samples for detailed vadose zone characterization and (2) installation of downgradient RCRA groundwater monitoring wells in the uppermost-unconfined aquifer, and (3) create a composite 
sample (i.e., borehole fine sand discussed in previous section) for geochemical characterization. Additional well completion, aquifer testing, and water sampling information and results are reported in Horton and Johnson (2000).

The vadose zone portions of these boreholes were drilled using the core- (drive-) barrel cable-tool technique wherever possible. The boreholes were drilled without the aid of drilling fluids such as water or mud, unless noted in the logs, to minimize the introduction of artificial moisture into the sediment samples and core. The lower portion of 299-W22-50 (i.e., below the water table) was drilled using the air rotary technique. After drilling but prior to well construction, the boreholes were geophysically logged with spectral gamma (total gamma and potassium, uranium, thorium [KUT]) and neutron-neutron (moisture) probes.

Borehole sampling consisted of near continuous split-spoon coring and/or sediment grab sampling throughout the borehole. Sediment cores were collected by driving a 10-centimeter (4-inch)-diameter by 76-centimeter (2.5-foot)-long split-spoon sampling device ahead of the drilled borehole. The borehole was then cleaned to the bottom of the cored interval prior to sampling the next interval. Split-spoon core refusal occurred within the Ringold Formation gravel facies (Rwi[e]) in both wells; cable-tool drilling continued to at least the water table using the hard-tool bit. The split-spoon cores are contained in either 15-centimeter (6-inch) or 30-centimeter (1-foot)-long, transparent, Lexan core barrel liners (core sleeves). Core recovery was nearly $100 \%$. All cores were sealed and labeled in the field and transported in ice chests to PNNL's characterization laboratory in the 3720 Building (300 Area) for refrigerated storage and further sampling and analysis.

In addition to Lexan-lined core samples, sediment grab samples were collected in the field from cuttings recovered during drilling and/or from the split-spoon drive shoe. Several types of samples were labeled and contained from each sample interval. Samples for geologic descriptions were collected in 2.5-centimeter (1-inch) plastic chip-sample trays from surface to total depth. With the exception of the drive shoe grab samples, most of the grab samples are composite samples composed of sediment that are churned up and mixed during the drilling and sampling process.

Lexan-lined cores provide the most representative intact samples of the subsurface available and the core depth intervals are believed to be accurate to within 15 centimeters ( 0.5 foot) of actual depth. Geophysical logs were used to verify contacts. Fine sediment structure and subtle facies variations are usually well preserved in the split-spoon cores. In the laboratory, the Lexan liners were cut lengthwise with a saw and the core split into two slabs or halves. Subsamples for physical and geochemical characterization were collected from the middle (inside) of these core slabs.

Photographs were taken after opening each core. Often some downward sediment deformation (drilling-induced drag) was observed (up to 2.5 to 5 centimeters [1 to 2 inches]) along the outside surface of some of the cores. Grab samples are less representative of subsurface lithology and sample depth accuracy can be limited to \pm 1.5 meters ( 5 feet), depending on the length of the cable-tool core barrel. Lithologic structure and contact boundaries may not be as easily identified with grab samples. 
A field geologist prepared a geologic description (lithologic log) during drilling and coring of the boreholes (Appendix A). These lithologic log descriptions are based on visual inspection of material from the split-spoon core shoe, drill cuttings, and the grab samples. These logs provide a general indication of the lithology encountered. In addition to these field descriptions, a more rigorous and detailed analysis of the vadose-zone stratigraphy was performed by geologists in the laboratory, based on cores observed within opened Lexan liners. Appendix B provides the borehole geologic log for 299W22-48, which was created based on an examination of every third or fourth intact split-spoon core (opened in the laboratory). Table 2.1 provides the generalized stratigraphic nomenclature used in the correlations. All depths and correlations reported in this section are rounded to the nearest tenth of a meter (.33 foot).

Borehole geophysical surveys were conducted after the boreholes reached total depth and before well construction. A spectral gamma probe was run from total depth to the surface at a rate of 30 centimeters (1 foot) per minute (15-centimeter [6-inch] sampling interval) and a neutron-neutron moisture probe was run from the water table to the surface, at a rate of 30 centimeters ( 1 foot) per minute (7.6-centimeter [3-inch] sampling interval). Geophysical log profiles for each of the two boreholes are attached in Appendix C. Prior to opening the Lexan-lined cores, geophysical profiles were evaluated for lithostratigraphy, moisture content, and manmade radionuclides. Core subsamples for chemical and physical analysis were collected from specific lithologic intervals as identified from the geophysical and lithologic log evaluations (lithostratigraphy) confirmed by the geologic examination during core opening.

Spectral gamma logs provide a continuous record of the naturally occurring gamma radioactivity emitted from formations encountered in the borehole. In addition, the spectral gamma logs can be evaluated to determine the presence of specific manmade gamma-emitting radionuclides. The gamma-log data is plotted as a continuous curve versus depth, which is referenced to ground surface. This reference can be used to correlate lithologic changes and depth to within 0.5 meters ( 1 or 2 feet). Gamma-log changes are related to the grain size, mineralogical makeup, and moisture content of the lithofacies encountered. Thin lithologic units $(<0.5$ meters [ 1.5 feet]) cannot be easily identified by the gamma logs because they are averaged into the data bounding them.

The neutron-neutron log is also referenced to ground surface and represents a function of relative moisture content (Figure 2.18, Appendix C). Depth resolution can be determined to within 0.3 meters ( 1 foot). In combination with the geologic log and the total gamma type log, the neutron moisture data can reveal moisture relationships relative to lithologic unit boundaries and grain size (assumes fine-grained intervals retain higher moisture content than coarse-grained intervals). For example, the neutron-moisture curves may display peaks of elevated moisture, which correspond to fine-grained silt and/or sand lenses, and/or lithologic contacts with contrasting grain-size boundaries. Anomalously high moisture intervals signal areas that may be influenced by artificial recharge. These areas are good targets for follow-up sampling and analysis if intact cores are preserved. 


\subsubsection{Borehole 299-W22-48}

Borehole 299-W22-48 is located 135 meters (443 feet) east of tank 110 (S Tank Farm) and $\sim 100$ meters (328 feet) north of the SX Tank Farm (see Figure 2.2). UTM coordinates are 566,996.641 east and 134,425.096 north [datum is NAD83 (91)]. Land surface elevation is 207.132 meters (679.567 feet) above msl.

Vadose zone sediment samples obtained for borehole 299-W22-48, along with 299-W22-50, are considered the most comprehensive and representative for the S-SX Tank Farm. Stratigraphic interpretations are based on data from a near continuous intact core, laboratory parameter analysis from selected intact core samples, continuous geophysical gamma and neutron logs, and field data.

This borehole was drilled using the core barrel cable-tool technique, wherever possible. Total depth of the borehole is 76 meters ( 249 feet) bgs. The water table was encountered at $\sim 69$ meters ( 226 feet) bgs. The borehole was completed as a well in December 1999; it is composed of a 10-centimeter (4inch)-diameter well casing with a 4.6 meter- (15-foot)-long well screen placed at the water table (see also Horton and Johnson 2000).

Continuous split-spoon coring occurred from ground surface to a depth of 59 meters (193.5 feet) and grab samples were collected at $\sim 1.5$-meter (5-foot) intervals throughout the drilling and coring of the borehole. Split-spoon core refusal occurred at 59 meters (193.5 feet). For this interval, 197 core sleeves (132 6-inch-long sleeves and 65 12-inch-long sleeves), each with nearly 100\% recovery, were produced. The depths and identification number of the individual core sleeve is summarized in Appendix E. In addition to these samples, eight grab samples of cuttings were collected at 1.5 -meter (5-foot) intervals from 59 through 70 meters (195 through 230 feet) bgs. The lithologic log in Appendix A also provides a borehole profile that illustrates the depth of each of the recovered split-spoon cores.

Moisture grab samples were collected, and sealed in moisture tins, at least every 1.5 meters ( 5 feet) from the split-spoon drive shoe between depths of $\sim 3$ to 58.5 meters ( 10 feet to 192 feet) bgs. Archive samples were collected every 1.5 meters ( 5 feet) below the cored interval from 58.5 meters (192 feet) to total depth (76 meters [249 feet]) and are contained in labeled, 1-pint glass jars.

Appendix C contains the geophysical logs for borehole 299-W22-48. The only apparent manmade radionuclide identified by gamma logging in this borehole is cesium-137, which is located within a meter ( 3 feet) of the surface at a concentration of $5 \mathrm{pCi} / \mathrm{g}$. This is interpreted as surface contamination, which is a common occurrence around the tank farms. The lithologic log was used as a guide to evaluate the total gamma log for lithology (Figure 2.19).

Beginning from 3 meters (10 feet) bgs, two distinct coarse-grained intervals (gravelly sand to gravel) were identified within relatively uniform medium-grained sand, one at 12.5 to 15 meters (41 to 50 feet) (Figure 2.20), and the second from 17.5 to 18.5 meters (58 to 61 feet). The gravelly interval(s) also are identified in surrounding vadose boreholes and wells based on geophysical log correlations (see Sobczyk 2000) but have not been easily or clearly identified in the geologic grab samples. The base of the lower gravelly unit correlates with the base of Lindsey's Hanford formation H1 unit. 


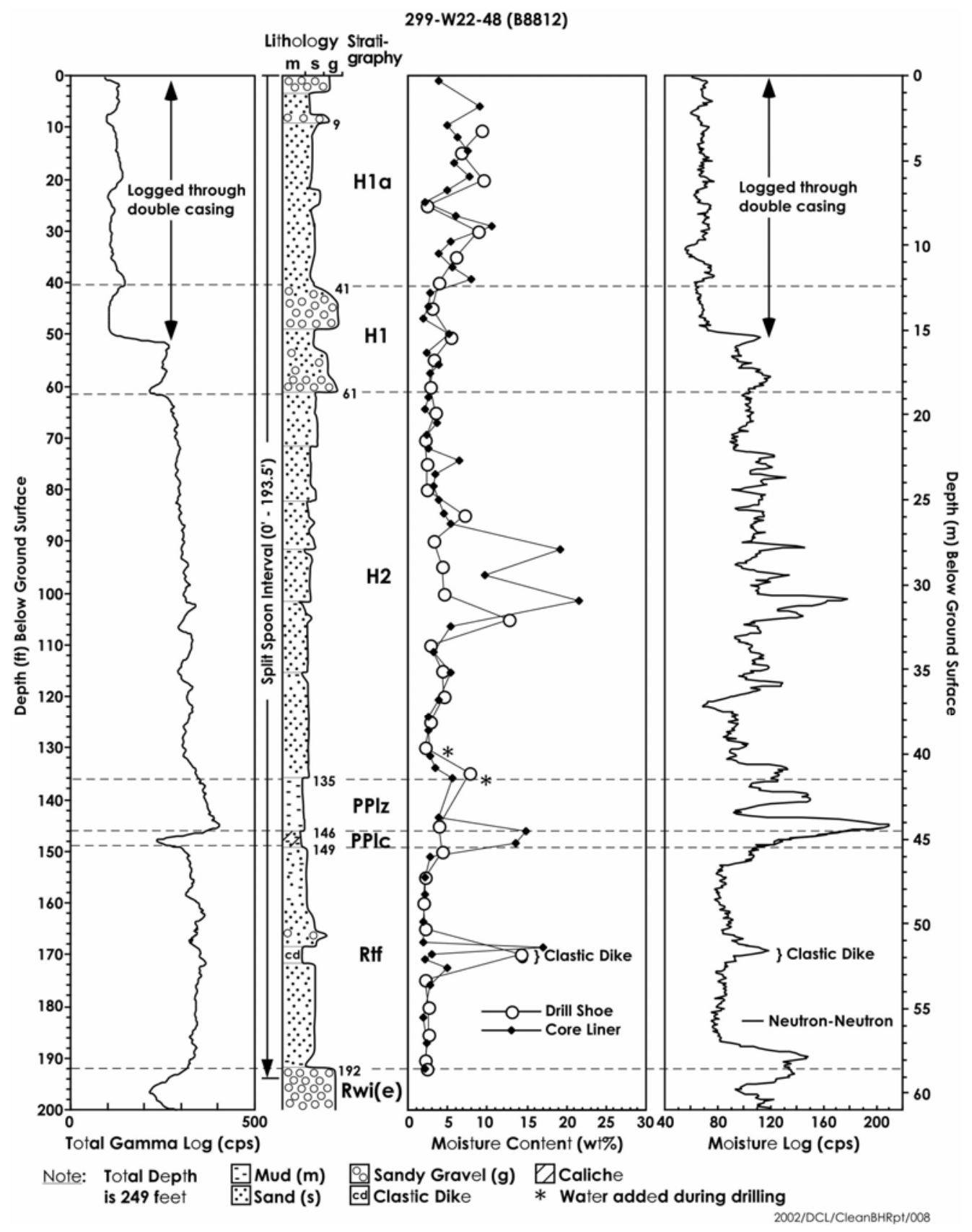

Figure 2.19. Vadose Zone Stratigraphy for Borehole 299-W22-48. See Figure 2.2 for borehole location.

The gravelly units are believed to be a key geologic control for the vertical and lateral dispersion of liquid effluent leaking from beneath the S-SX Tank Farm. The Vadose Characterization Project's geophysical spectral logging campaign provides the data to corroborate this. Many of the vadose-zone boreholes logged within the S-SX Tank Farm have high levels of cesium-137 contamination associated with this coarse-grained unit (Johnson and Chou 1998, Sobczyk 2000). Below the Hanford formation H1 unit is fine- to medium-grained sand (Figure 2.21), which decreases slightly in grain size with depth. 
299-W22-48 (B8812): 44.5' - 45.0'

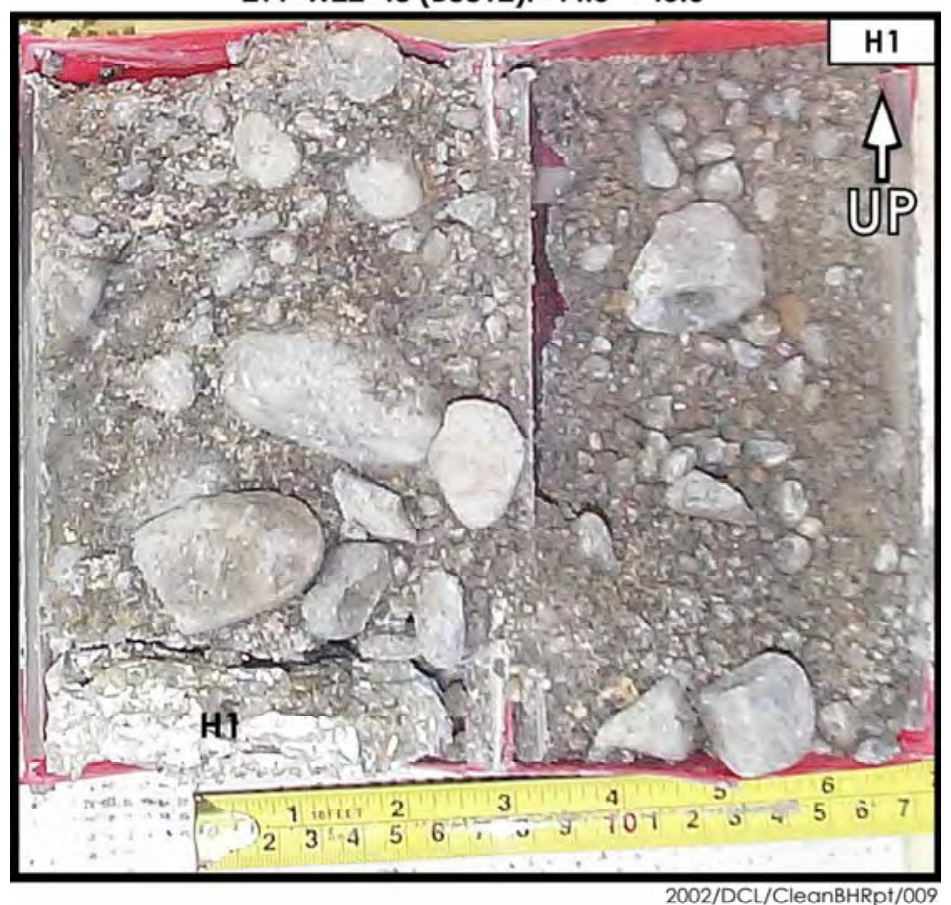

Figure 2.20. Split-Spoon Sample from Within Coarse-Grained Hanford Formation H1 Unit in Borehole 299-W22-48.

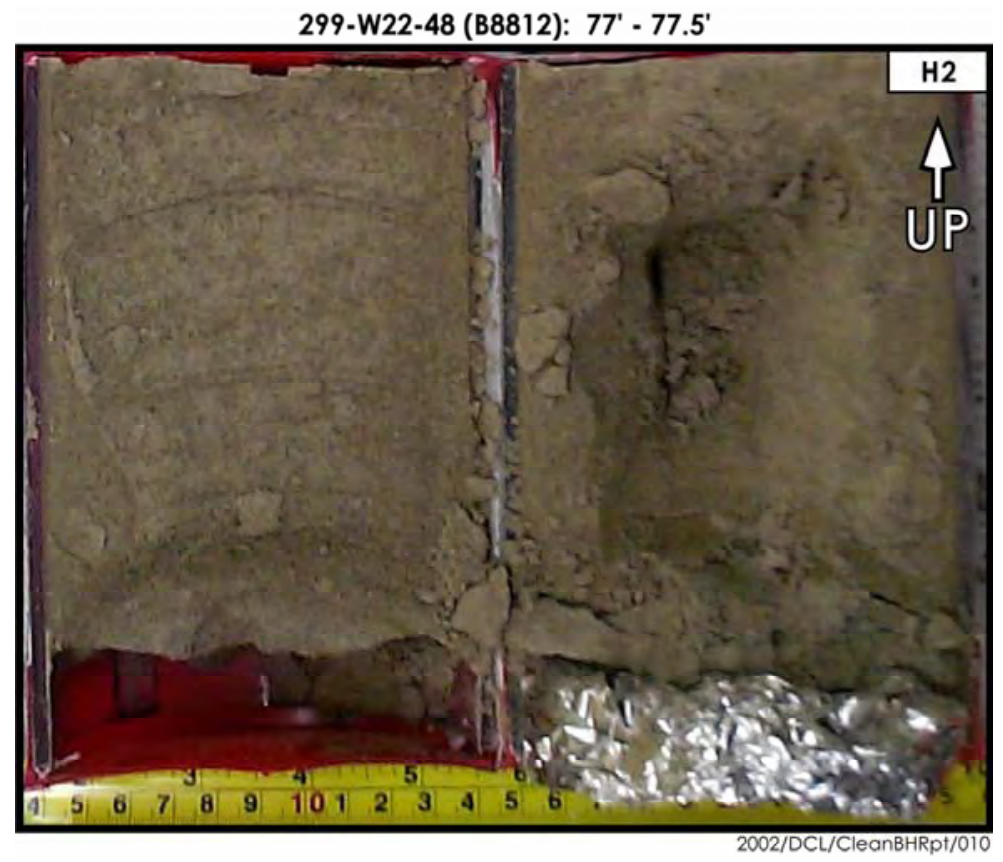

Figure 2.21. Split-Spoon Sample from Within Hanford Formation H2 Unit in Borehole 299-W22-48. 
This unit is correlated as the Hanford formation $\mathrm{H} 2$ unit, which is interpreted to occur between 18.5 to 41 meters (61 to 135 feet) bgs. The next notable change in the gamma logs occurs from 41 to 44.5 meters (135 to 146 feet) bgs. This easily recognizable and characteristic gamma increase reflects a downward decreasing grain size from silty sand to silt (Figure 2.22). This unit represents a gradational coarsening upward contact between the Plio-Pleistocene mud (PPlz) subunit and younger, coarsergrained, cataclyamic flood deposits of the overlying Hanford formation.

The distinctive Plio-Pleistocene carbonate-rich sequence (PPlc), correlates to a thin interval between 44.5 to 45.4 meters (146 to 149 feet) bgs (Figures 2.23). More discussion is provided on the correlation of this unit below. The reduced gamma signal beginning at 58.5 meters (192 feet) bgs identifies the top of the Ringold Formation Unit E (Rwi[e]) as a silty sandy gravel interval (Figure 2.24).

The interval between the PPlc subunit and the top of the Rwi(e), between 45.4 to 58.5 meters (149 to 192 feet) bgs, is described as fairly uniform slightly silty sand (Figure 2.25) and correlates to the upper Ringold unit or Ringold member of Taylor Flat (Rtf).

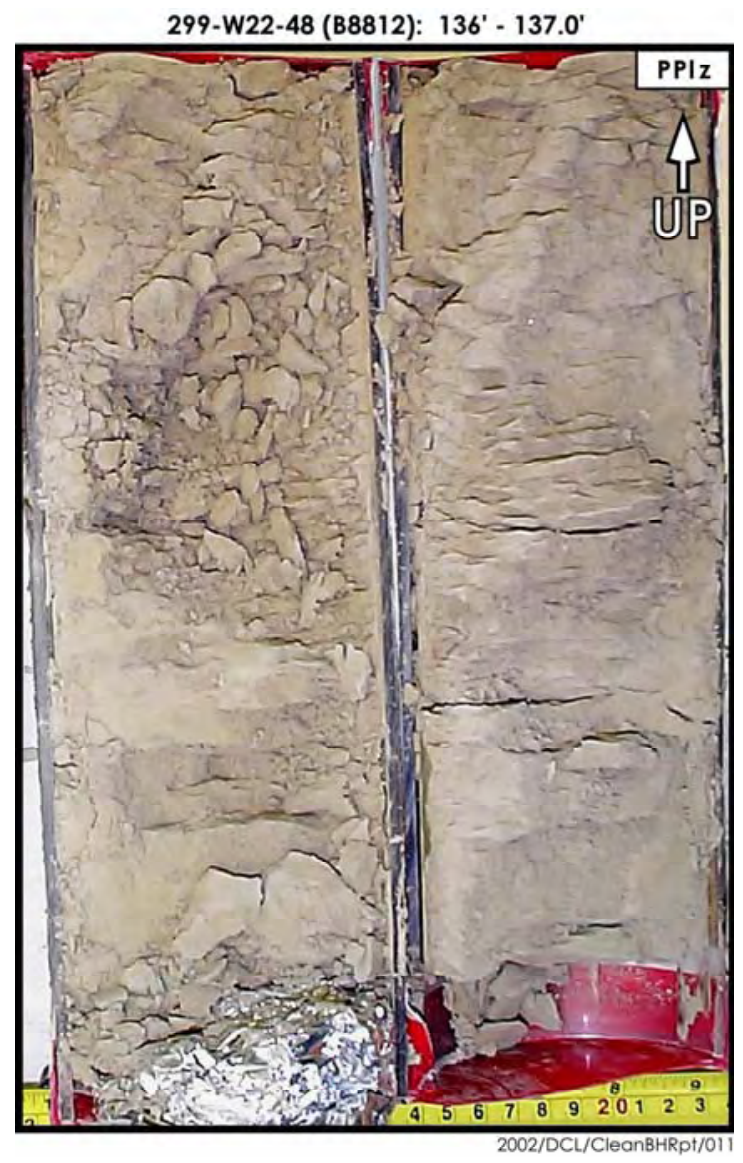

Figure 2.22. Split-Spoon Sample from Within Plio-Pleistocene Mud (PPlz) Subunit in Borehole 299-W22-48. 


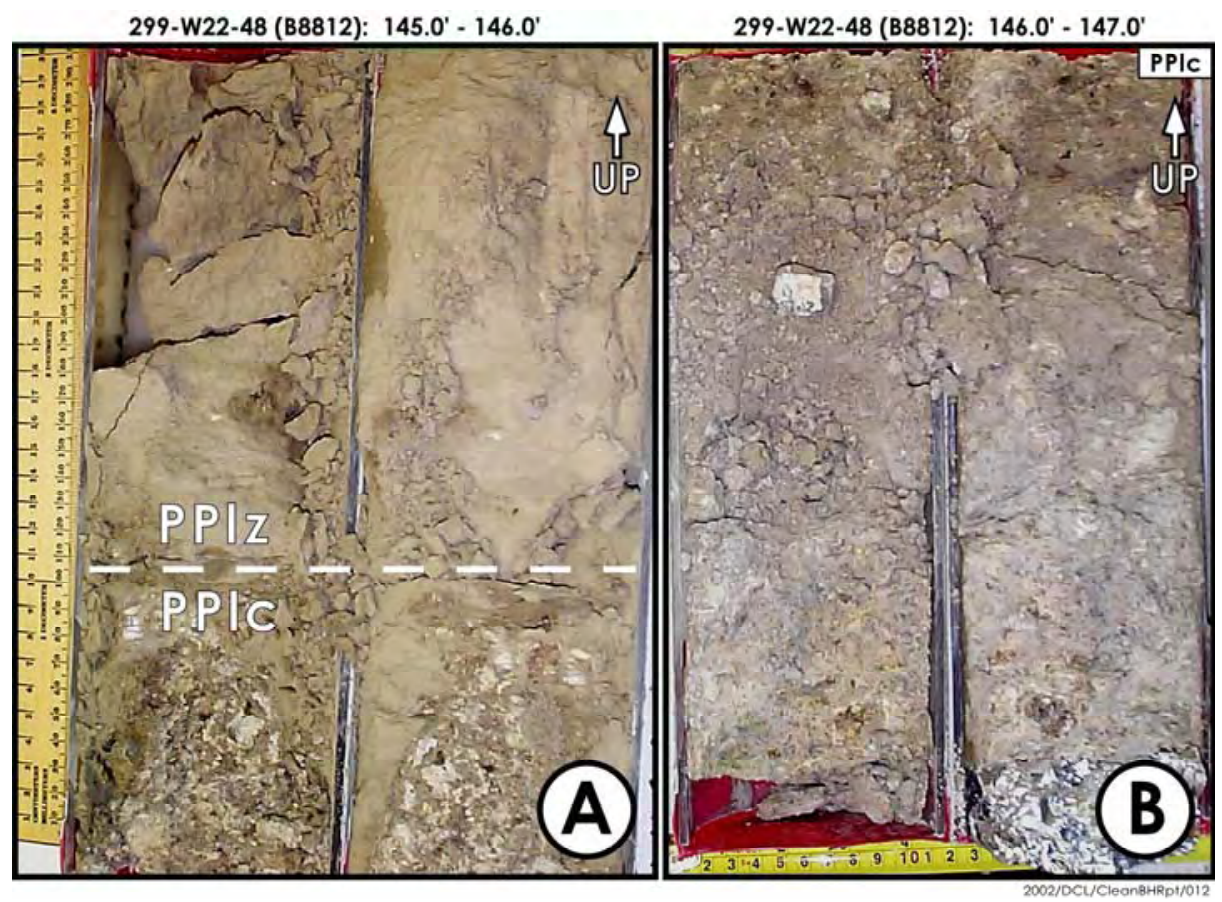

Figure 2.23. Split-Spoon Samples Representing a) Plio-Pleistocene Mud (PPlz) and Plio-Pleistocene Carbonate (PPlc) Subunits Contact (white dashed line), and b) Plio-Pleistocene Carbonate (PPlc) in Borehole 299-W22-48.
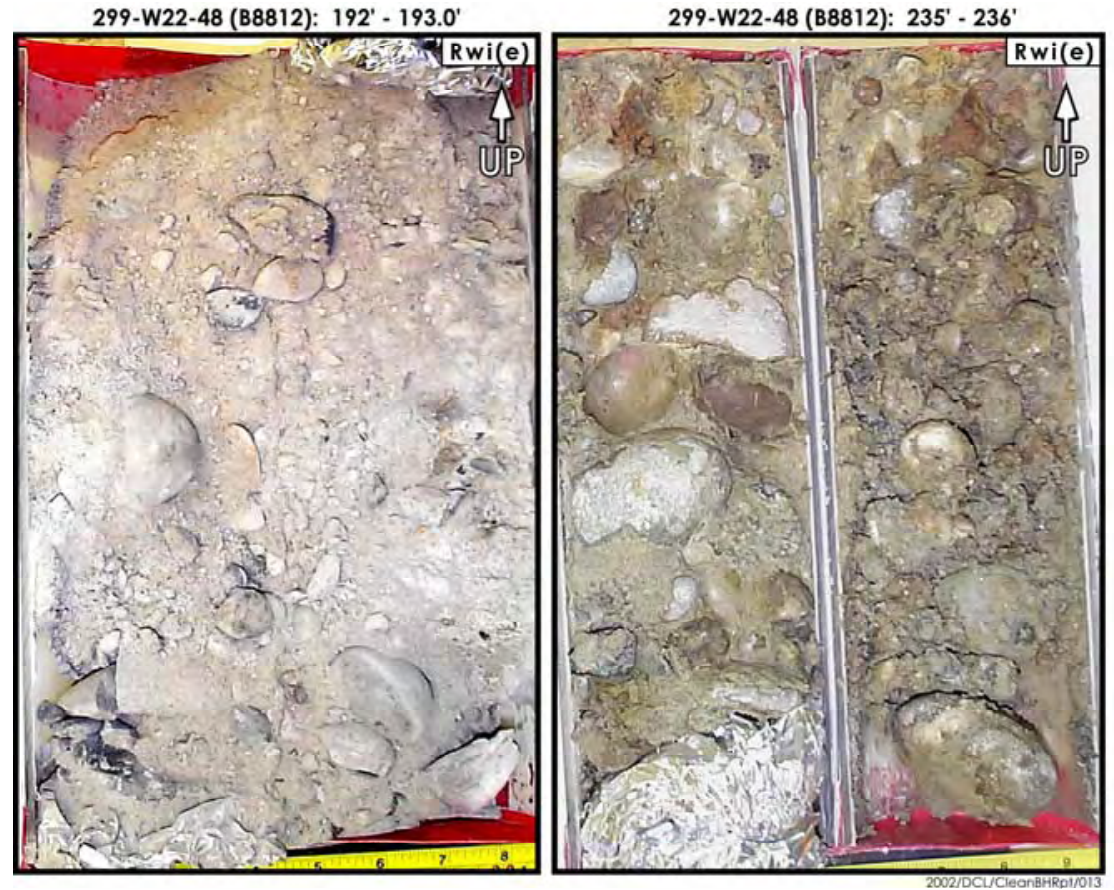

Figure 2.24. Split-Spoon Samples Representing Ringold Formation Unit E (Rwi[e]) in Borehole 299-W22-48. 


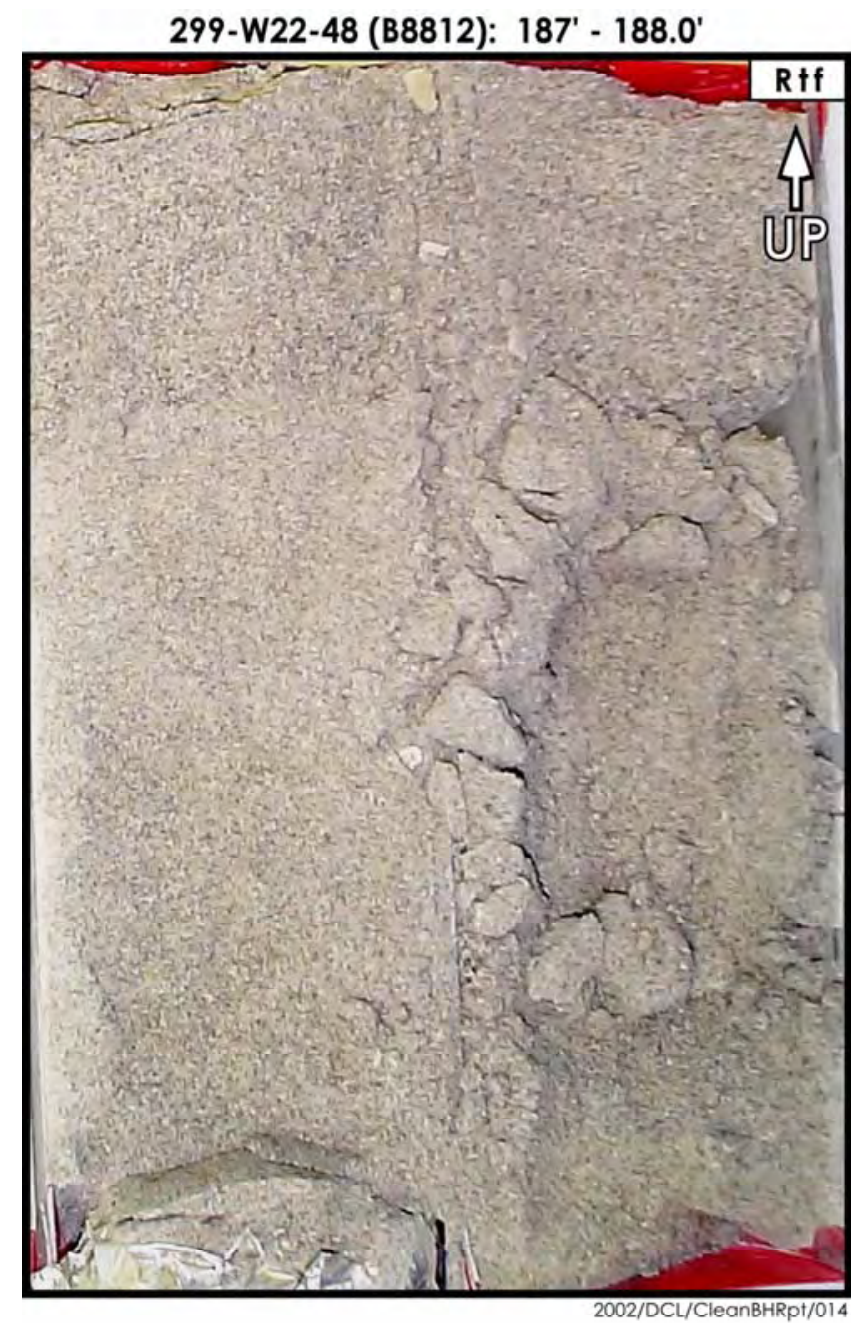

Figure 2.25. Split-Spoon Sample Representing Upper Ringold Formation (Rtf) in Borehole 299-W22-48.

The addition of the neutron moisture data to the interpretation resulted in some additional observations and features. Due to the dual surface casing in borehole 299-W22-48, only the moisture data between 15.5 meters ( 51 feet) depth and the water table (69.3 meters [ 227.5 feet]) are calibrated and are representative of borehole moisture conditions. That is, the neutron moisture probe is not calibrated for conditions where two layers of metal casing are present. Based on the calibrated interval (15.5 to 69.3 meters [51 to 227.5 feet]) the average overall moisture content in borehole 299-W22-48 is less than 5\% (by volume). This average moisture probably represents the natural background moisture for the units encountered and indicates that the vadose zone has a relatively low moisture content at this location. A few minor peaks, averaging about $2.5 \%$ higher than the background, are in the sand interval between about 21 to 36.5 meters ( 70 to 120 feet); these probably represent alternating laminae and beds of fine sand and silt, which possess varying moisture-retention properties (e.g., Figure 2.26). One larger peak (10\% moisture) located at 31 meters (102 feet) bgs was also recorded in the field geologists' log as a bedding contact, which is also visible on the gamma log (Figure 2.19). Anomalously high moisture intervals between 36.5 and 42.5 meters (120 and 140 feet) bgs may correspond to zones where it was 


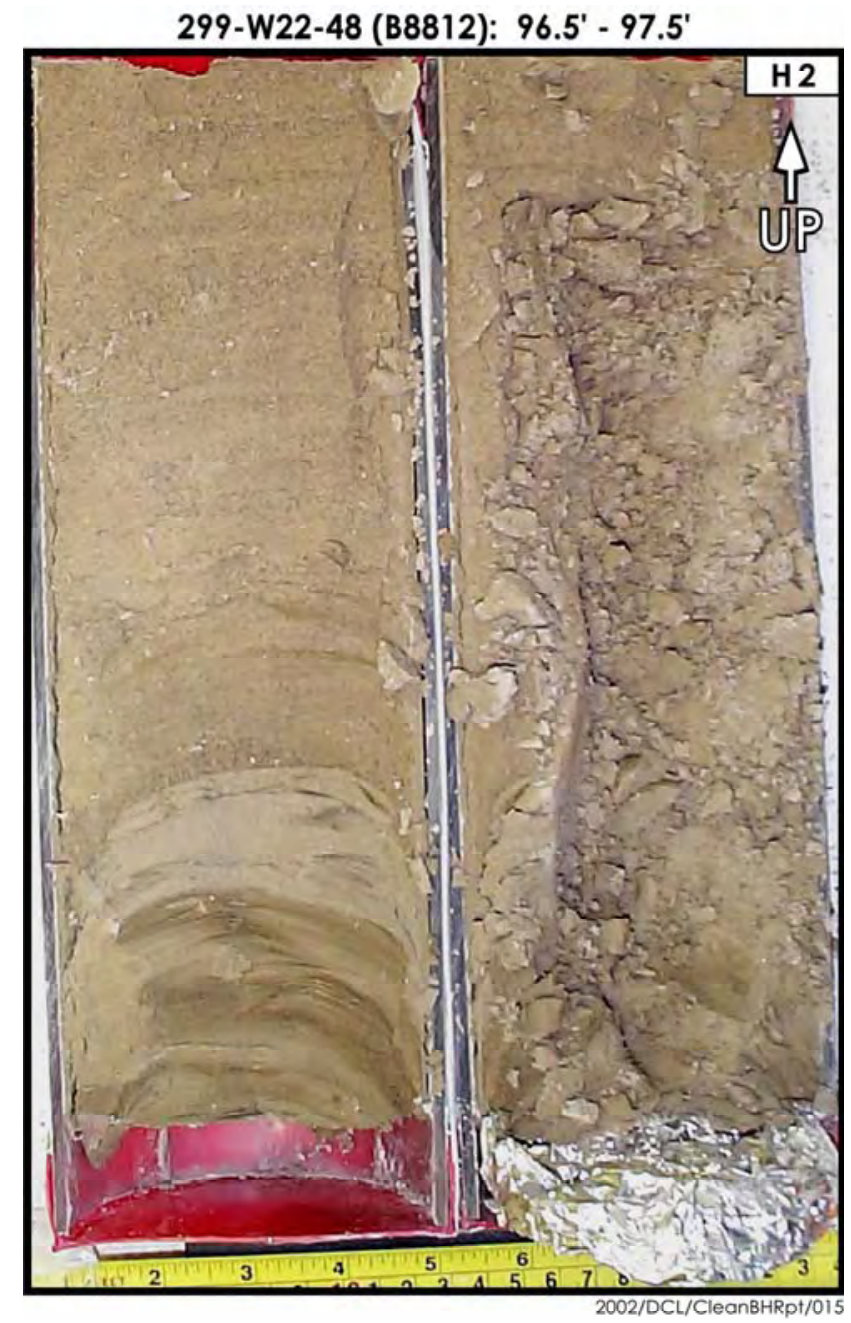

Figure 2.26. Split-Spoon Sample Illustrating Contrasts Within the Hanford Formation H2 Unit. Laminated, darker, high-moisture retention silt occurs at bottom, in contrast to fine sand at top.

necessary to add water to the borehole during drilling. The PPlc subunit between 45.4 to 58.5 meters (146 to 149 feet) bgs displays a characteristic inverse relationship between the total gamma and neutronneutron geophysical logs.

The contact with Rwi(e) (silty sandy gravel interval) unit also can be correlated to the increase in moisture at 58.5 meters (192 feet) bgs. Moisture values increase anomalously from 66 meters (216 feet) bgs to the water table at 69 meters (226 feet) bgs (see neutron-neutron $\log$ in Appendix C). This increase may be due to previously saturated Ringold sediment (when the water table was higher during high liquid waste disposal periods) that are now draining and, thus, have a higher overall residual moisture content than overlying Ringold sediments that have not been completely saturated. 
A discordant clastic dike was intersected near the 52-meter (171.0-foot) depth in borehole 299-W2248 within a sandy sequence of the upper Rtf unit (Figure 3.11). The dike completely fills one core sleeve (Figure 2.27) and partially fills the underlying core sleeve. The dike, up to 0.75 meter ( 2.5 feet) thick, is characterized by vertical to subvertical laminations alternating between olive clay and silt to pale yellow silt and sand. Dike laminations are weakly to strongly calcareous. The dike contains a distinctly higher moisture content $(\sim 15 \mathrm{wt} \%)$, as corroborated on the neutron-neutron geophysical log, yet is only slightly elevated on the total gamma log (see Figure 2.19).

Clastic dikes, which are usually associated with cataclysmic ice-age flood deposits of the Hanford formation, are sometimes reported in underlying stratigraphic units, including the Ringold Formation (Fecht et al. 1999). Of particular significance is the fact that this clastic dike lies 10.7 meters (35 feet) below the base of the flood deposits and 6 meters (20 feet) below the indurated Plio-Pleistocene caliche (PPlc) unit (see Figure 2.19). While it is possible this dike is connected with Pleistocene cataclysmic flooding, the possibility also exists that the dike is of Ringold age and occurred prior to ice-age flooding. If the dike formed during Pleistocene time, the implication is that clastic dikes (i.e., preferential pathways) might be connected from the near surface to the water table beneath the southern portion of the 200 Area's Plateau. Alternatively, if the dike is Ringold in age, it is probably truncated along the overlying Plio-Pleistocene unit and/or Hanford formation boundaries.

To identify the relative age and origin of the dike, as well as any possible manmade contaminants present, detailed sampling and measurements will be performed for grain size, mineralogy, major and trace element composition, and paleomagnetic field orientation of the dike and immediately adjacent material. The hydraulic properties of the cored dike material will also be measured.

\subsubsection{Borehole 299-W22-50}

Well 299-W22-50 is located 25 meters (82 feet) southeast of the southeast corner of the S-SX Tank Farm fence (see Figure 2.2). UTM coordinates are 566,904.261 east and 134,139.756 north [datum is NAD83 (91)]. Land surface elevation is 204.14 meters (669.75 feet) above msl.

This borehole was drilled from the surface to 73.5 meters ( 241 feet) bgs using the core-barrel cable tool technique and from 73.5 to 167 meters ( 241 feet to 547.5 feet) bgs using the air rotary technique. Total depth was 167 meters (547.5 feet) bgs. The water table was encountered at 67 meters ( 219 feet) bgs. The borehole was completed as a well in January 2000; it is composed of a 10-centimeter (4-inch)diameter well casing with a 4.6 meter (15-foot)-long sampling screen placed at the water table (see Horton and Johnson 2000). 


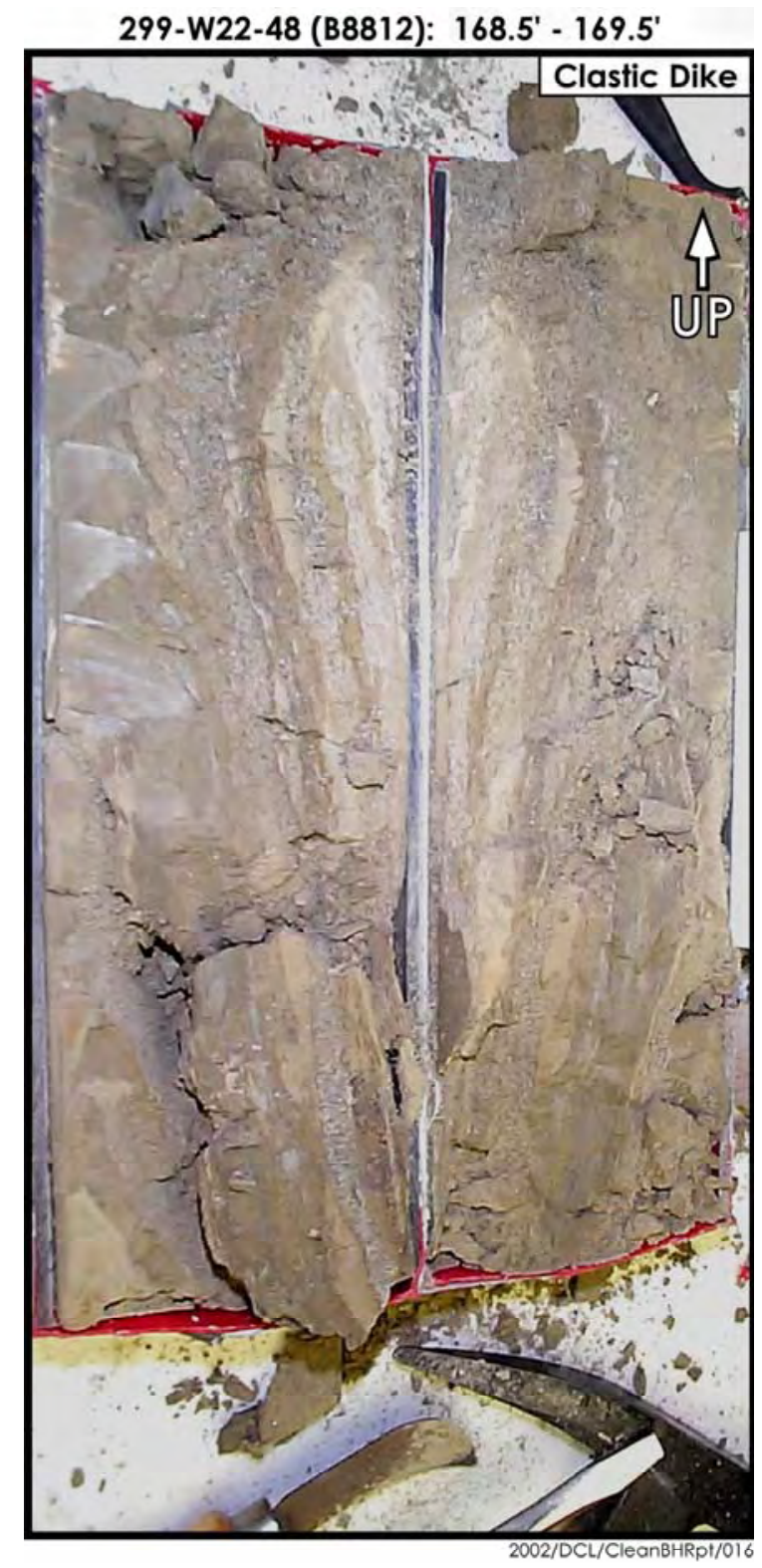

Figure 2.27. Upper Portion of Subvertical Clastic Dike Completely Filling Core Liner Within Ringold Formation from 51.4 to 51.7 Meters (168.5 to 169.5 feet) bgs.

Borehole sampling consisted of near continuous split-spoon coring from $\sim 6$ meters (20 feet) bgs to a depth of 54 meters (177.5 feet) bgs and sediment grab samples collected at $\sim 5$-foot intervals throughout the drilling and coring of the borehole. Split-spoon core refusal occurred at 54 meters (177.5 feet) bgs atop Ringold Formation Unit E (Rwi[e]); cable-tool drilling continued below this depth with a hard-tool bit to $\sim 74$ meters ( 243 feet) bgs. Drilling continued with the air rotary technique to total depth (166.9 meters [547.5 feet] bgs). Within the split-spoon cored interval, 124 Lexan core sleeves (30-centimeter [12-inch] liners) were recovered. The depths and identification number of the individual core sleeves are summarized in Appendix F. The lithologic log in Appendix A also provides a borehole 
profile that illustrates the depth of each of the recovered split-spoon cores. Archive grab samples were collected at $\sim 1.5$-meter (5-foot) intervals from surface to 6 meters ( 20 feet) bgs and below the cored interval, from 55 meters (180.5 feet) to total depth (166.9 meters [547.5 feet] bgs).

Lindsey et al. (2000) provides a detailed discussion and geologic log for 299-W22-50. The geophysical logs for this borehole are presented in Appendix C. Stratigraphic, lithologic, and geophysical-log information is summarized in Figure 2.18. The only manmade radionuclide identified by gamma logging in borehole 299-W22-50 is cesium-137, which is located at the surface at a concentration of $19 \mathrm{pCi} / \mathrm{g}$. This radioactivity is likely surface contamination from nearby tank farm operations.

The total gamma log reflects the lithology, which for the Hanford formation is mostly sand. An exception is a relatively coarse-grained unit (gravelly sand) at a depth between 2.4 and 4.3 meters ( 8 and 14 feet) bgs. This unit, also noted in the lithologic field log, belongs to a coarse facies of the Hanford formation H1a unit (Lindsey et al. 2000). Another coarse-grained facies, defined as sandy gravel in the lithology log, is present between 16 and 19 meters (53 and 62 feet) bgs and represents the Hanford formation $\mathrm{H} 1$ unit (Figure 2.28). This gravelly interval is thinner in this borehole but can be correlated to a comparable coarse-grained interval in surrounding vadose boreholes (Sobczyk 2000), including borehole 299-W22-48 (Figure 2.19). The base of the gravelly unit at 19 meters (62 feet) bgs defines the base of the Hanford formation $\mathrm{H} 1$ unit.

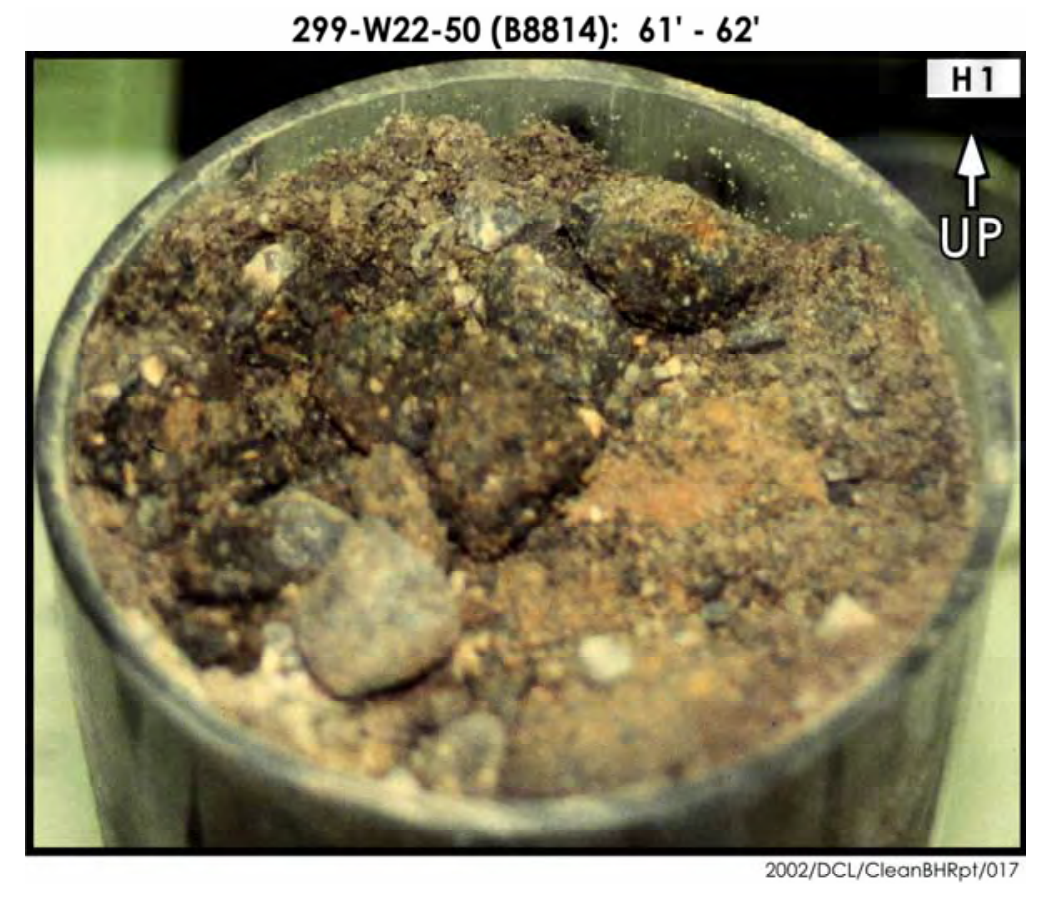

Figure 2.28. Split-Spoon Sample of Sandy Gravel from the Hanford Formation H1 Unit. 
The underlying Hanford formation $\mathrm{H} 2$ unit, which occurs between a depth of 19 to 38.5 meters (62 to 126 feet) bgs, is predominantly medium-grained sand (Figure 2.29), which decreases slightly in grain size with depth (see Figure 2.18).

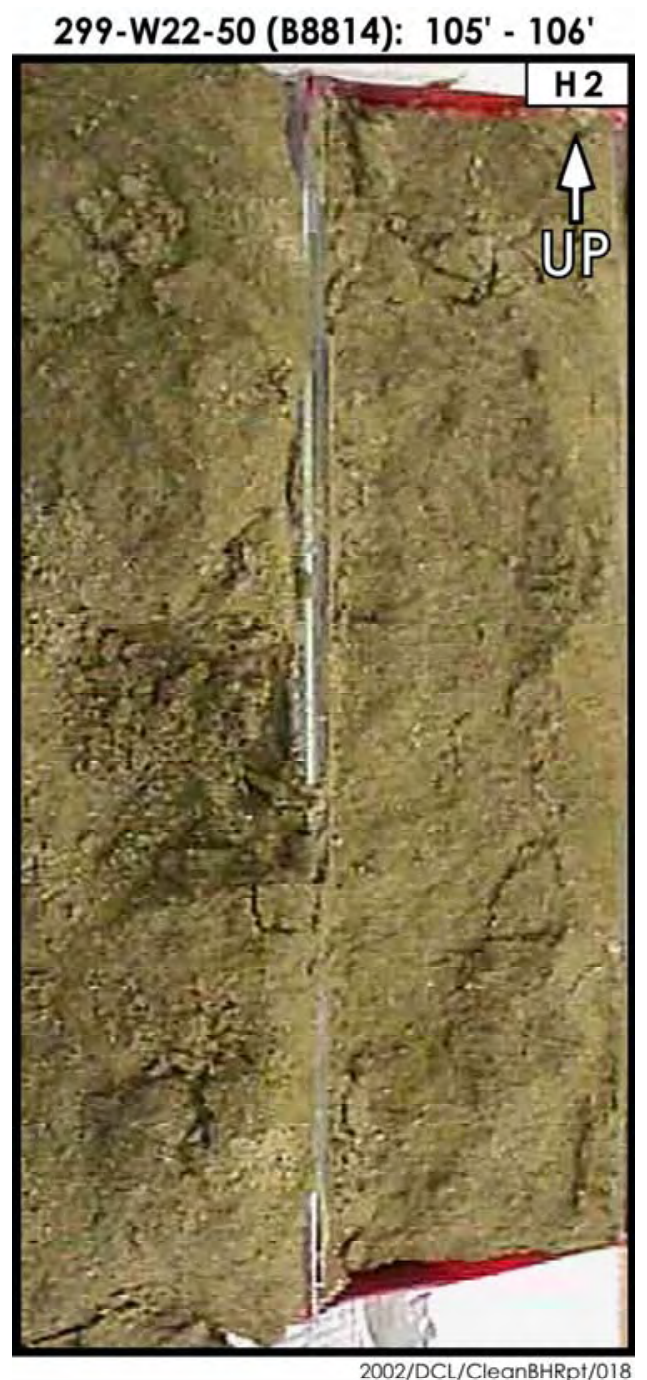

Figure 2.29. Split-Spoon Sample from Within Hanford Formation H2 Unit in Borehole 299-W22-50.

The contact between the Hanford formation and the underlying Plio-Pleistocene unit occurs at or near 38.5 meters (126 feet) bgs based on a decrease in grain size, accompanied by an increase in total gamma activity, and an abrupt increase in moisture content. The upper Plio Pleistocene unit (Figure 2.30), equivalent to the Plio Pleistocene Mud (PPlz) subunit, occurs from 38.5 to 42 meters (126 feet to 138 feet) bgs (Figure 2.18), while the lower Plio-Pleistocene unit (PPlc) lies between 42 and 43.6 meters (138 and 143 feet) bgs. 


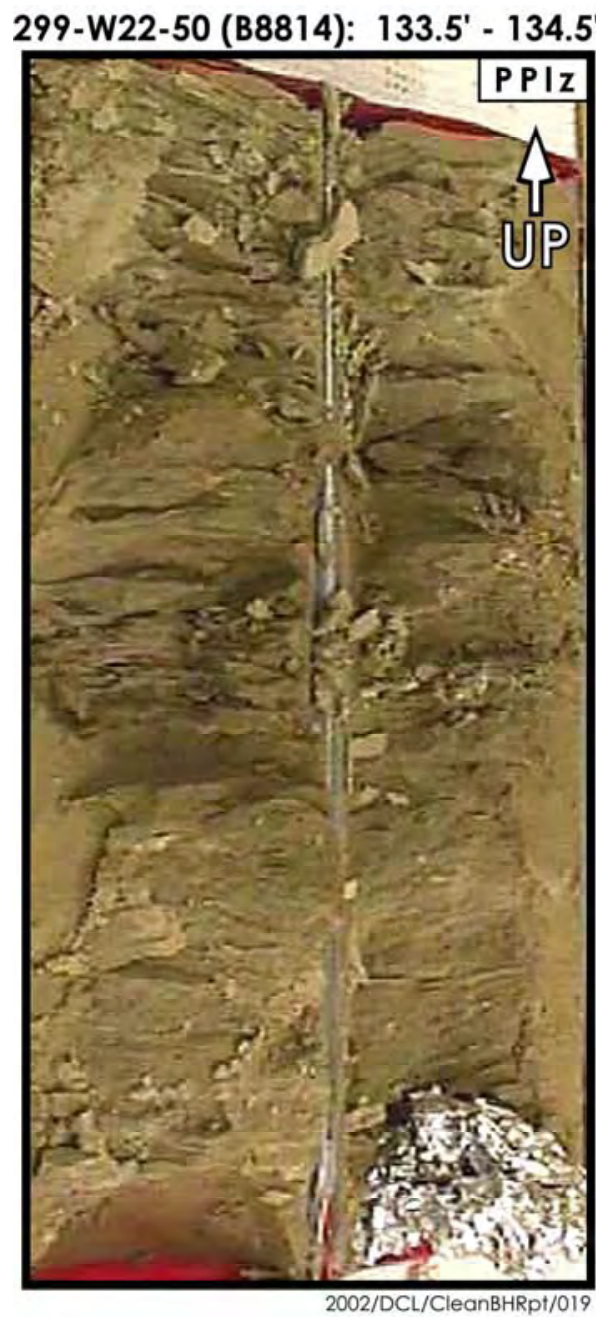

Figure 2.30. Split-Spoon Sample from Within Upper Plio-Pleistocene Subunit (PPlz) in Borehole 299-W22-50.

The contact between the loose PPlz and carbonate-cemented PPlc subunits is sharp and distinct (Figure 2.31). Unlike the carbonate-rich horizon in 299-W22-48, which is developed exclusively in finegrained sediment, pedogenic carbonate in 299-W22-50 appears to be overprinted and developed onto a gravelly lag deposit of the Ringold Formation. Below the PPlc subunit, from 43.6 to 53 meters (143 to 175 feet) bgs, are quartzofeldspathic sands and gravels of the upper Ringold (Rtf) unit. The top of the Rwi(e) silty sandy gravel is defined as the top of a relatively thick gravel sequence accompanied by an increase in moisture on the neutron-neutron log starting at 53 meters (175 feet) bgs (see Figure 2.18). 


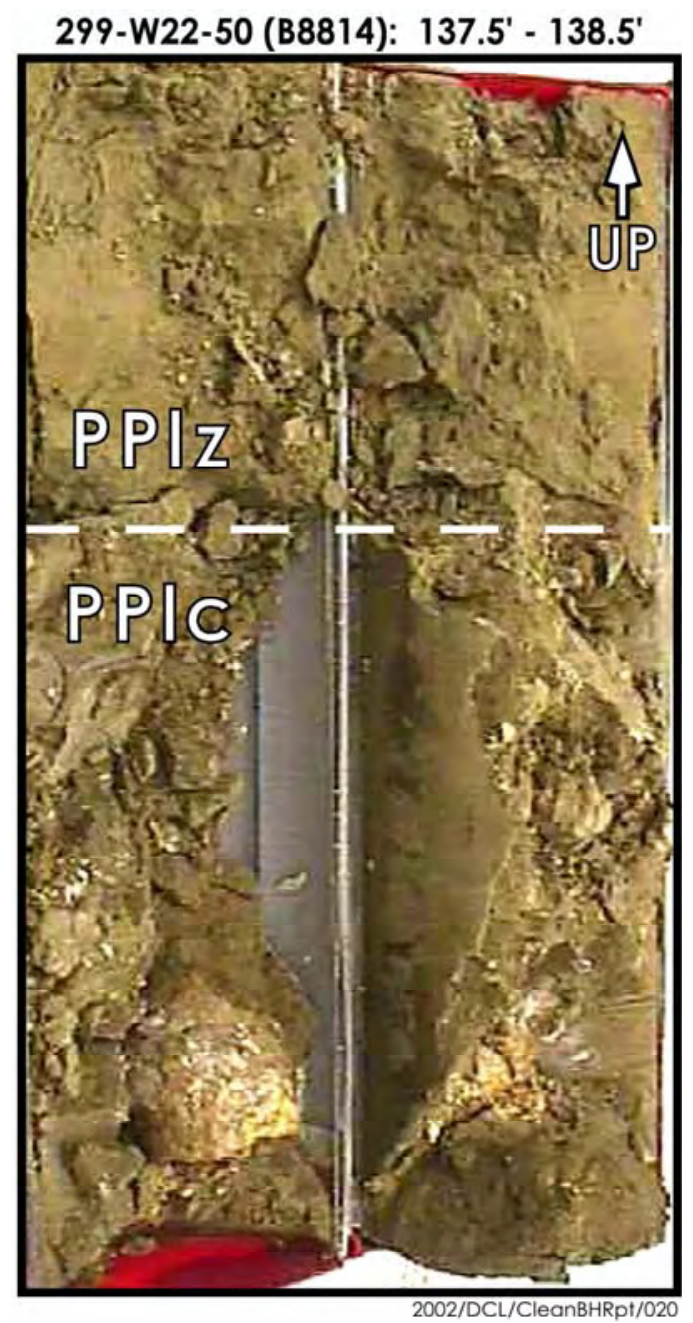

Figure 2.31. Split-Spoon Sample Containing the Contact Between the Plio-Pleistocene Mud (PPlz) and Carbonate (PPlc) Subunits in Borehole 299-W22-50. The PPlz unit is composed of loose, variably calcareous, overbank-eolian fine sand and silt while the PPlc unit consists of calcium carbonate cemented muddy sandy gravel.

The addition of the neutron moisture data to the interpretation resulted in some additional observations and features. Due to the dual surface casing in borehole 299-W22-50, only the borehole below 15 meters ( 50 feet) to the water table ( 66.5 meters [ 218.3 feet]) was logged and calibrated. Within the logged interval, the average overall moisture content in borehole 299-W22-50 is slightly higher than that found in 299-W22-48. Logged moisture between 29 to 38 meters (95 to 124 feet) bgs, is anomalously high, by comparison to the same interval in 299-W22-48. Peaks in moisture are twice as high as the apparent background values at 299-W22-48, suggesting more moisture in the vadose zone in this area. Relatively high moisture occurs in the lower portion of the Hanford formation $\mathrm{H} 2$ unit below $\sim 27$ meters (90 feet) and the Plio-Pleistocene unit down to a depth of $\sim 43$ meters (140 feet) bgs. Similar to borehole 299-W22-48, the top of the carbonate (PPlc) in borehole 299-W22-50 is characterized by a sudden decrease in total gamma activity and an increase in neutron-neutron moisture (see Figure 2.18). 


\subsection{Characterization Analytical Methods}

\subsection{Post Sampling Sediment Preparation}

Preparation and processing of sediment samples, performed prior to analysis in the laboratory, is discussed in this section.

\subsubsection{Composites}

The four composite samples were spread out on polyethylene tarps inside a large empty room in the laboratory. After air drying for several days, the sand composites were individually mixed by repeated cone and quartering. A few root hairs and small pieces of organic matter were removed by handpicking from the Hanford coarse sand and Hanford fine sand composites. The Hanford coarse sand composite is comparable to the Hanford formation H1a (coarse facies) unit while the Hanford fine sand is comparable to the Hanford formation H1a (fine facies) and H2 units in the SX Tank Farm geologic model presented in Section 2.2. The Ringold silt composite sample air dried into hard aggregates. These aggregates were crushed with a flat-ended tamper until all the aggregates were disaggregated particles smaller than 2 millimeters. The Ringold silt was then mixed several times using the cone and quartering method. These three composites were not sieved. However, the air-dried borehole fine sand was dry sieved through a 2millimeter sieve. Out of a total air-dry weight of 68,170 grams, 270 grams of coarse (>2-millimeter) particles were discarded to make this composite conform to traditional soil scientists' sample protocol. The >2-millimeter particles represented only $0.4 \%$ of the air-dried material; thus, there should be very little difference in the properties of the Hanford fine sand and the borehole fine sand composites caused by the removal of $>2$ millimeters of material from the latter composite.

The air-dried composite samples were then stored in 5-gallon plastic buckets until needed. Each time an aliquot was needed the whole contents of one 5-gallon bucket was spread on a polyethylene tarp and the entire sample remixed by cone and quartering with small aliquots taken randomly out of each quarter of the mixed sample.

\subsubsection{Borehole Core Samples}

The samples that were characterized from the two Resource Conservation and Recovery Act (RCRA) boreholes (299-W22-48 and -50) were obtained during the geologic description process immediately upon opening the sealed liners. The split-spoon samples were obtained in clear, plastic Lexan liners that were either 6 or 12 inches long. Plastic end caps were removed, and the liners were cut down both sides with a circular saw. The core was opened in a fashion similar to opening a clam shell, facilitated by the relatively unconsolidated nature of the sediment. The two halves of the liner were laid on a table and quickly subsampled to avoid excessive loss of moisture. Small aliquots were removed from the halves of sediment in an attempt to construct a representative sample for the entire sleeve. When distinct contacts 
were observed in a core sample, the sampling was performed separately on the different lithologies. After sampling and geologic description was completed, the two halves of the liner were reassembled and retaped to prevent further disturbance or escape of moisture. Liners were then returned to refrigerated storage in the dark at $4^{\circ} \mathrm{C}$.

Selected split-spoon sleeves from the borehole 299-W22-48 and 299-W22-50 were subsampled using stainless steel spatulas. The depths and corresponding stratigraphic unit designations from the conceptual geologic model described in Section 2.0 are shown in Tables 6.1 and 6.2. In most cases, field moist sediment was used to measure the various parameters discussed below but the results are reported on an oven-dry weight basis. In a few cases, aliquots of the borehole sleeves were oven dried before testing was performed (e.g., particle density and dry sieving).

Core sleeves selected for characterization were chosen so that each of the principal stratigraphic units were analyzed and each of the two boreholes were characterized about equally. The available budget allowed for the detailed characterization of approximately 6 to 8 core samples from each of the boreholes. Emphasis on characterization was placed on the Hanford formation units $\mathrm{H} 1$ and $\mathrm{H} 2$ because preliminary information suggested that contaminants beneath leaking tanks in the S-SX Tank Farm are concentrated within these two units.

\subsection{Laboratory Analytical Methods}

Analytical methods used in the laboratory to characterize the composite and core sediment samples are discussed in this section. Physical properties analyzed include mass water content, particle-size distribution, and particle density. A variety of geochemical techniques were performed on sediment as well as porewater including elemental analysis, cation exchange capacity, ammonium acetate extraction, 1:1 sediment to water extraction, and $8 \mathrm{M}$ nitric acid extraction. Mineralogical analyses were performed using $\mathrm{x}$-ray fluorescence (XRF) and $\mathrm{x}$-ray diffraction (XRD).

\subsubsection{Mass Water Content}

All geochemical characterization data in this document are reported on an oven-dry basis; however, the composite samples were stored in an air-dried state. Thus, we determined the amount of moisture in the air-dry composite sediment or field moist core materials using the traditional moisture content method in Methods of Soil Analysis, Part 1, Method 21-2.2 Gravimetry with Oven Drying (pages 503-507) (American Society of Agronomy [ASA] 1986).

\subsubsection{Particle Size Distribution}

Both dry sieving and wet sieving/hydrometer methods were used to determine the particle-size distribution. For the dry sieving, an aliquot of the oven-dry sediment was sieved through the following sequence of sieves: 4, 2, 1, 0.5, 0.25, 0.212, 0.125, 0.063 millimeter, and pan. Between 120 and 210 grams of oven-dry sediment were used and total mass recovery was measured. An auto shaker, either 
Rotap Model RX-29 or Gilson SS-8R, was used. The method is similar to that in (ASTM D 421-85). The second particle-size measurement technique used the wet sieve/hydrometer method (ASA [1996], Part 1; Method 15-5 Hydrometer Method [pages 404-408]) and concentrated on quantifying the silt and clay distribution. The silt and clay separates were saved for mineralogical analyses. Samples from the two RCRA boreholes that were used for the hydrometer method were not air or oven dried to minimize the effects of particle aggregation that can affect the separation of clay grains from the coarser material. A more qualitative estimate of particle-size distribution was also determined in the field and upon opening core sleeves using a visual-manual technique by geologists logging the core (ASTM 1993). Geologists' estimates of particle-size distribution are summarized onto the geologic logs in Appendices A and $\mathrm{B}$.

\subsubsection{Particle Density}

The particle density of bulk grains was determined using pychnometers (see ASA 1986, Part 1; Method 14-3 Pychnometer Method [pages 378-379]) and oven-dried material.

\subsubsection{Calcium Carbonate and Organic Carbon Content}

The calcium carbonate equivalent and organic carbon content of the bulk sediment (oven dried) were determined using ASTM Procedure D-513, Method G "Carbon Dioxide $\left(\mathrm{CO}_{2}\right)$ Evolution" and ASTM Procedure D-4129-98, "Standard Test Method for Total and Organic Carbon in Water by HighTemperature Oxidation and by Coulometric Detection." Analyses were performed on a Coulometrics Inc. Carbon Analyzer Model 5010. Using reagent-grade calcium carbonate, the evolved carbon dioxide gas is used to generate calibration curves for calcite equivalent content in the sediment.

\subsubsection{Elemental Analysis}

The elemental composition of the bulk sediment was determined by a combination of energy- and wavelength-dispersive XRF. Samples analyzed by the energy-dispersive XRF method follow the KLM Procedure XRF-01, which utilizes a Kevex 0810A commercial XRF excitation and detection subsystem. Sample preparation involved mixing the sample in a Coors high-density alumina (aluminum oxide) mortar and pestle. Six hundred milligrams of the mixed sample were removed and further ground to $\sim 300$ mesh size, placed between two sheets of stretched para-film, and loaded into the 0810A XRF unit. Acquisition times ranged between 600 and 3,000 seconds, depending on the targets (gadolinium, iron, silver, zirconium). Forty-one elements (aluminum, antimony, arsenic, barium, bromine, cadmium, calcium, cerium, cesium, chlorine, chromium, copper, gallium, iodine, indium, iron, lanthanum, lead, manganese, molybdenum, nickel, niobium, palladium, potassium, phosphorous, rhodium, rubidium, ruthenium, selenium, silicon, silver, strontium, sulfur, tellurium, thorium, tin, titanium, uranium, vanadium, yittrium, and zinc) were analyzed on each sample and the spectrum interpretation was by the backscatter fundamental parameter approach (described in KLM-01, pages 2-3). Sample analysis by the wavelength method was accomplished using a Siemens Spectra 3000 instrument, equipped with both a flow counter detector to detect soft radiation of the low $\mathrm{Z}$ elements and a scintillation counter detector for the harder radiation of the higher $Z$ elements. Bulk solid samples were prepared by taking 180 to 1,500 milligrams of $\sim 300$ mesh ground sample and pressing it into a 3.2-centimeter (1.3-inch)-diameter pellet, using a 
27,000-kilogram laboratory press. Standard addition and similar matrix methods were used to generate calibration curves for sodium and magnesium, which were then used to process the data. Additional discussion of XRF techniques for quantitative analysis of sediment are found in Section 7.0, "Elemental Analysis by X-Ray Fluorescence Spectroscopy" of ASA (1996), Part 3, pages 161-223 and in the Siemens Spectra 3000 Reference Manual (1994).

\subsubsection{Mineralogy}

The mineralogy of the bulk sample, silt and clay-size fractions of the sediment was determined by XRD techniques. Bulk sediment samples were dispersed by transferring 100 grams of sediment into a 1-liter bottle and mixing with $1.0 \mathrm{~L}$ of $0.001 \mathrm{M}$ solution of sodium hexametaphosphate. The suspensions were allowed to shake overnight to ensure complete dispersion. The sand fraction was separated from the dispersed sample by wet sieving through a \#230 sieve. The silt fractions were separated from the clay fractions by using Stoke's settling law described in Jackson (1969). The lower limit of the fraction was taken at $>2$ microns. Sand and silt fractions were oven dried at $110^{\circ} \mathrm{C}$ and prepared for XRD and XRF analysis.

Each clay suspension was concentrated to an approximate volume of 10 milliliters by adding a few drops of 10-N magnesium chloride to the dispersing solution. Concentrations of the clay in the concentrated suspensions were determined by drying known volumes and weighing the dried sediment. The density of the slurry was calculated from the volume pipetted and the final weight of dried sediment. Volumes of slurry equaling 250 milligrams of clay were transferred into centrifuge tubes and treated to remove carbonates following Jackson (1969). The carbonate-free clay was then saturated with either magnesium (II) or potassium cations. Clay samples were prepared using the Drever (1973) method and placed onto an aluminum slide for XRD analysis. Due to the tendency of the clay film to peel and curl, the specimens saturated with magnesium (II) were solvated with a few drops of a 10\% solution of ethylene glycol in ethanol and placed into a dessiccator containing excess ethylene glycol for a minimum of 24 hours. After the analysis of the magnesium (II) -saturated, ethylene glycol-solvated specimen, two of the samples (Hanford fine sand composite and borehole B8812 composite) were allowed to air dry overnight before reanalysis. Potassium-saturated slides were air dried and analyzed, then heated to $575^{\circ}$ $\mathrm{C}$ and reanalyzed.

All samples were analyzed on a Scintag XRD unit equipped with a Pelter thermoelectrically cooled detector and a copper x-ray tube. Slides of preferentially oriented clay were scanned from 2 to 45 degrees $2 \theta$, and randomly oriented powder mounts were scanned from 2 to 75 degrees $2 \theta$. The bulk samples were prepared by crushing approximately 0.5 gram of sample to a fine powder that was then packed into a small circular holder. After air-drying $~ 0.5$ gram of the clay slurry, a random mount was prepared and analyzed from 2 to 75 degrees $2 \theta$. 
Semiquantification of mineral phases by XRD was performed according to Brindley and Brown (1980). The relationship of intensity and mass absorption to the weight fraction of an unknown phase is expressed as:

$$
\mathrm{I} / \mathrm{I}_{\mathrm{p}}=\mu_{\mathrm{p}} / \mu(\mathrm{wf})
$$

where

I is the intensity of the unknown phase

$\mathrm{I}_{\mathrm{p}}$ is the intensity of the pure phase

$\mu_{\mathrm{p}}$ is the mass absorption of the pure phase

$\mu$ is the average mass absorption of the unknown mixture

wf is the weight fraction of the unknown.

Pure mineral phases of illite, smectite, kaolinite, and chlorite were obtained from the Clay Mineral Society's source clays repository (operated from the University of Missouri in Columbia, Missouri) and analyzed under the same conditions as the sediment samples. Quartz, feldspars, and calcite standards were purchased from the Excalibur Mineral Company, Peekskill, New York, ground and analyzed on the diffractometer to obtain intensities for pure non-clay phases.

The mass attenuation coefficients of selected samples were measured according to Brindley and Brown (1980). Ground bulk powders and air-dried clays were packed into a 0.94-inch-thick circular holder with no backing. The holder was placed in front of the detector and positioned to allow the x-ray beam, diffracted from pure quartz, to pass through the sample and into the detector. The scan was analyzed from 26.0 to 27.0 degrees $2 \theta$. The mass attenuation coefficients were measured directly using the following equation:

$$
\mu=(1 / \rho x) \ln \left(\mathrm{I}_{\mathrm{o}} / \mathrm{I}_{\mathrm{x}}\right)
$$

where

$1 / \rho x$ is the mass per unit area as the sample is prepared

$\mathrm{I}_{\mathrm{o}}$ is the intensity of the incident beam

$I_{x}$ is the intensity of the transmitted beam through sample thickness $x$.

In addition to XRD, transmission electron microscopy (TEM) characterization of selected samples was conducted on a JEOL 1200X electron microscope equipped with a Links detector system. Samples were prepared for TEM by transferring a small aliquot of a dilute clay slurry onto a formvar carboncoated 3-millimeter copper support grid. The clay solution contained $0.15 \%$ tert-butylamine to reduce the surface tension of water.

Structural formulas were derived from data collected from the TEM analysis. On average, an energydispersive $\mathrm{x}$-ray spectra was collected from a minimum of five particles from the same mineral phase common to the sample. The x-ray spectra were collected and processed using the Cliff-Lorimer Ratio Thin Section method and then converted to a structural formula (based on half-unit cell $\left(\mathrm{O}_{10}(\mathrm{OH})_{2}\right)$ by the method described in Reynolds and Reynolds (1989) and Newman (1987). 


\subsubsection{Cation Exchange Capacity}

The cation exchange capacity of the sediment was determined using two different procedures, Polemio and Rhoades (1977) and Amrhein and Suarez (1990), both developed to accommodate calcareous sediment. Five grams of each sediment, oven dried, was used in triplicate determinations using both methods.

Rhoades (1982) describes a method to measure the cation exchange capacity of arid land soil that contains carbonates, gypsum, and zeolites. The first step is to saturate the cation exchange sites with sodium by equilibration of the soil sample with a $\mathrm{pH}=8.2,60 \%$ ethanol and $40 \%$ salt solution. The alcohol/aqueous mixture has a total concentration of $0.4 \mathrm{~N}$ sodium acetate- $0.1 \mathrm{~N}$ sodium chloride. The second step is to displace the sodium and other cations with a $0.5 \mathrm{~N}$ magnesium nitrate solution. Sodium and chloride analyses are performed on the extracted solutions and on the excess saturating solution. The chloride determination in the extracting solution is used to deduce the amount of excess sodium left in the soil pores after saturation. After correction, the remaining sodium (the exchangeable sodium) represents the cation exchange capacity. The cation exchange capacity is determined using equation 1 for the Polemio and Rhoades (1977) method.

$$
\text { cation exchange capacity }=\mathrm{Na}_{\mathrm{t}}-\left(\mathrm{Cl}_{\mathrm{t}}\right) *(\mathrm{Na} / \mathrm{Cl})_{\text {sat soln }}
$$

where

$\mathrm{Na}_{\mathrm{t}}$ and $\mathrm{Cl}_{\mathrm{t}}$ are the total sodium and chloride, respectively, in the extraction solution $(\mathrm{Na} / \mathrm{Cl})_{\text {sat soln }}$ is the sodium-to-chloride ratio in the saturating solution.

Amrhein and Suarez (1990) describe a method for measuring the cation exchange capacity of arid soil by taking into account the dissolution of carbonates and gypsum in the saturation and extraction steps.

Five grams of each sediment were weighed and placed into a centrifuge tube along with 20 milliliters of a $0.2 \mathrm{M}$ calcium chloride/ $0.0125 \mathrm{M}$ calcium sulfate adjusted to a $\mathrm{pH}$ of 8.2. The saturating solution was carefully removed from the centrifuge tubes, to avoid resuspending the sediment, and poured into separate 100-milliliter (3.4-ounce) volumetric flasks. The saturating, shaking, and centrifuging steps were repeated so that the sediment contacted the saturation solution four times. Saturation solutions were saved to measure magnesium, potassium, and sodium.

After transferring the concentrated saturation solution for the final time, 30 milliliters (1.01 ounces) of a dilute saturating solution of $0.025-\mathrm{M}$ calcium chloride was added to each centrifuge tube. The centrifuge tubes were placed on a shaker table for 30 minutes and then centrifuged. The dilute solution was decanted and discarded. The sediment was contacted three times with the dilute solution; however, the final dilute contact solution was saved to determine calcium, sulfate, chloride, and alkalinity. 
Next, the tubes were reweighed to determine the amount of entrained solution. After weighing the tubes, the calcium was extracted with a $0.5-\mathrm{M}$ magnesium nitrate solution. Twenty milliliters (.68 ounces) of the extraction solution were added to the centrifuge tubes and shaken for 30 minutes. The extraction solution was then decanted into separate 100-milliliter (3.4-ounce) volumetric flasks. The sediment was contacted with the extraction solution five times. Calcium, sodium, sulfate, chloride, and alkalinity were measured in the extracted solution so that the amount of exchangeable and dissolved calcium and any sodium that might have remained on exchange sites after calcium saturating can be determined.

The cations in the saturating solution ( $0.2 \mathrm{M}$ calcium chloride $-0.0125 \mathrm{M}$ calcium sulfite $)$, dilute rinse solution ( $0.025 \mathrm{M}$ calclium chloride ), and the exchange solution ( $0.5 \mathrm{M}$ magnesium nitrate ) were measured by inductively coupled plasma atomic emission spectrometry (ICP-AES). The anions were measured by ion chromatography (IC). The equation for calculating cation exchange capacity is:

$$
\begin{aligned}
& \mathrm{CEC}=\left\{\mathrm{T}_{\mathrm{Ca}}-\mathrm{T}_{\mathrm{HCO}_{3}}-\mathrm{T}_{\mathrm{SO}_{4}}+\mathrm{V}\left(\left[\mathrm{HCO}_{3}\right]+\left[\mathrm{SO}_{4}\right]-[\mathrm{Ca}]\right)-\left(\mathrm{T}_{\mathrm{Cl}}-\mathrm{V}[\mathrm{Cl}]\right)\right. \\
& \left.-\left[\mathrm{SO}_{4}\right]\left(\mathrm{T}_{\mathrm{Cl}}-\mathrm{V}[\mathrm{Cl}]\right) /[\mathrm{Cl}]-\left[\mathrm{HCO}_{3}\right]\left(\mathrm{T}_{\mathrm{Cl}}-\mathrm{V}[\mathrm{Cl}]\right) /[\mathrm{Cl}]\right\} / 10
\end{aligned}
$$

where

$T_{I}$ is the concentration of the specified species in the magnesium-nitrate extraction solution in units of millimoles charge $/ \mathrm{kg}$ of soil

[i] is the concentration of the specified ion in the final rinse of the diluting solution in millimoles of charge per liter of solution

$\mathrm{V}$ is the residual entrained diluting solution in the vial just prior to addition of the magnesium-nitrate extracting solution in liters per kilogram of sediment.

\subsubsection{Ammonium Acetate Extract (Exchangeable Base Cations)}

The exchangeable base cations adsorbed on the composite sediment were determined by exchanging them with high ionic strength ammonium acetate. The cations in the ammonium acetate extract were then measured by the inductively coupled plasma (ICP) technique and the results converted to meq of each cation displaced. The cations were then summed to get another estimate of the total cation exchange capacity of the composite sediment.

Our method to determine the exchangeable base cations (barium, calcium, potassium, magnesium, sodium, and strontium) is similar to the ammonium acetate procedure in ASA (1996, Part 3, pages 582584). We used 20 grams of air-dried sediment to 50 milliliters of $0.5 \mathrm{M}$ ammonium acetate adjusted to $\mathrm{pH}$ 7. The slurries were shaken for $\sim 1$ hour, centrifuged, and then filtered through 0.2-micron membranes. The cation concentrations were then measured by the ICP technique. Unlike the method in ASA (1996), we did not repeat the extraction three times to ensure complete removal of base cations from exchange sites. We felt that additional extractions would be influenced by dissolution of more calcite rather than extracting more recalcitrant-exchangeable cations from the low exchange capacity sediment. 


\subsubsection{1:1 Sediment-to-Water Extract}

The 1:1 sediment-to-water extracts of the samples were prepared using the procedure described in ASA (1996, Part 3 pages 417-422). For the borehole samples, field moist aliquots were used and, based on the known moisture contents, just enough deionized water was added to get the 1:1 ratio based on oven-dry weight. The extracts were then analyzed for $\mathrm{pH}$, electrical conductivity (EC), major cation and anion, and trace metal composition using standard electrodes, titrators, IC, ICP, and inductively coupled plasma mass spectrometry (ICP-MS). Approximately 50 to 100 grams of air-dried sediment was mixed with an equal amount of deionized water (corrected for the small amount of porewater in the air-dry sediment).

\subsubsection{M Nitric Acid Extract}

Approximately 20 grams of oven-dry sediment was contacted with $8 \mathrm{M}$ nitric acid at a ratio of $\sim 5$ parts acid to 1 part sediment. The slurries were heated to $\sim 80^{\circ} \mathrm{C}$ for several hours, and then the fluid was separated by centrifugation and filtration through 0.2 micrometer membranes. The acid extracts were analyzed for major cations and trace metals using ICP and ICP-MS, respectively. In a few instances, both instruments could measure the concentrations leached so that independent method results could be compared. For example, both instruments measured chromium and lead and both results are shown to allow comparison. We are quite pleased with the agreement. The acid digestion procedure is based on EPA SW-846 method 3050B (EPA 2000) that can be accessed online at http://www.epa.gov/epaoswer/hazwaste/test/sw846.htm.

\subsubsection{Porewater Composition}

Selected samples from the two boreholes were packed in drainable cells that were inserted into an ultracentrifuge (Beckman Model LM-8, Beckman Instruments, Fullerton, California). The sample was centrifuged for up to 8 hours and several thousand g's to extract the porewater from the sediment. The $\mathrm{pH}, \mathrm{EC}$, cation, trace metals, and anions were measured using the same techniques as used for the 1:1 sediment-to-water extracts. 


\subsection{Analytical Results for Composite Sediment Samples}

\subsection{Mass Water Content}

Because of the large volume of the composite sediment samples, their moisture content was determined after they were air dried. This is in contrast to the discrete borehole samples (discussed in Section 5.0) whose moisture content was determined after oven drying. Slightly more moisture is probably removed during oven drying (i.e., lower humidity) compared to air drying, therefore the results are not exactly the same. The results, presented in Table 4.1, are typical of the residual water contents found in air-dry coarse materials in the relatively low humidity conditions found in the laboratory. As one would expect, the finest grain-size composite, the Ringold silt, retained the highest amount of moisture upon air drying for the composite samples.

All the measured moisture contents from the composite samples are low compared to measurements made on discrete samples from the field and geophysical logs because the samples were air dried to aid in homogenization. The values in Table 4.1 have no bearing on natural conditions and are reported here only to aid scientists who will work with the samples in laboratory experiments. The reported air-dry water contents would be expected to change if the samples are stored in different relative humidity conditions.

Photographs of the four composite samples in their air-dried state are shown in Figures 4.1 through 4.4 .

Table 4.1. Moisture Content of Composite Sediment Samples After Air Drying

\begin{tabular}{||l|l|c||}
\hline \multicolumn{1}{|c|}{ Composite Name } & Representative Stratigraphic Unit (lithology) & Water (wt\%) \\
\hline \hline Ringold Silt & Upper Ringold Unit (silt) & 2.17 \\
\hline Hanford Coarse Sand & Hanford Formation Unit H1 (gravelly sand) & 1.12 \\
\hline Hanford Fine Sand & Hanford Formation Unit H2 (silty sand) & 1.50 \\
\hline Borehole Fine Sand & Hanford Formation Unit H2 (silty sand) & 0.80 \\
\hline
\end{tabular}

\subsection{Particle-Size Distribution}

Both dry sieving and the hydrometer methods were used to determine the particle-size distributions of the composite samples. The dry sieving results are shown in Table 4.2 and the hydrometer/wet sieve results are shown in Table 4.3 and Figure 4.5. 


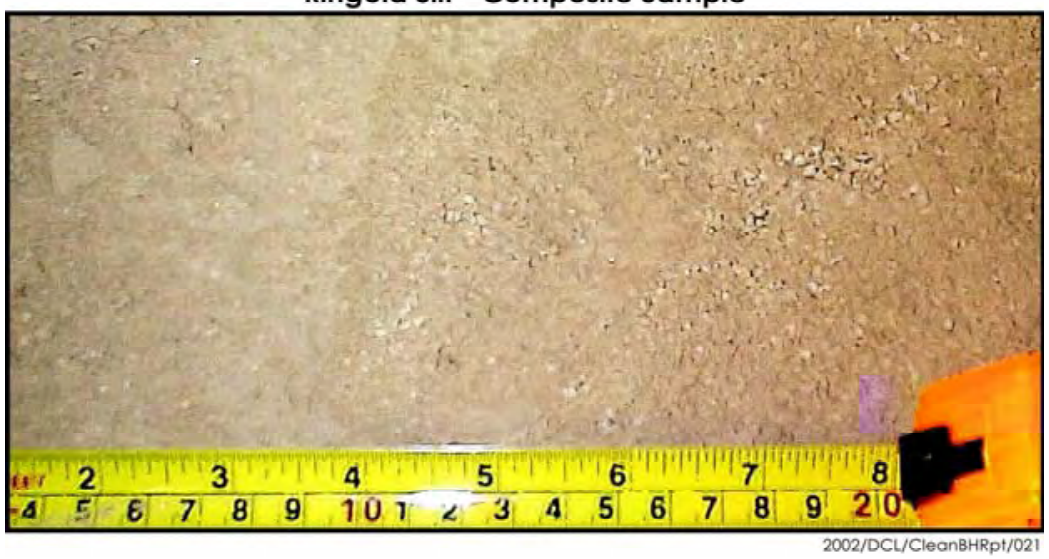

Figure 4.1. Ringold Silt Composite Sample After Air Drying and Disaggregation.

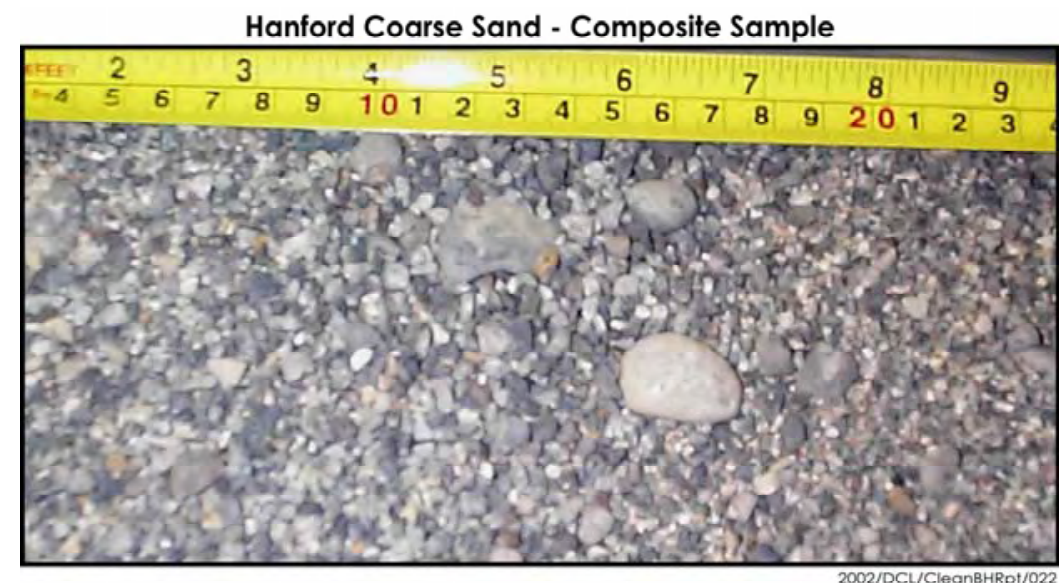

Figure 4.2. Hanford Coarse Sand Composite Sample After Air Drying and Disaggregation.

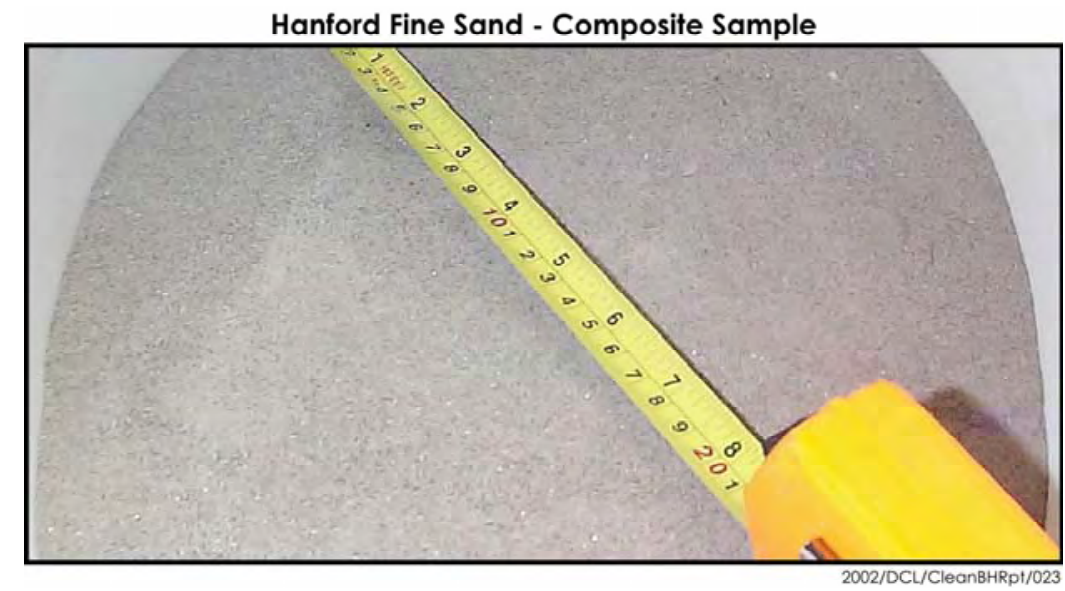

Figure 4.3. Hanford Fine Sand Composite Sample After Air Drying and Disaggregation. 
Borehole 299-W22-50 (B8814) Flne Sand - Composite Sample

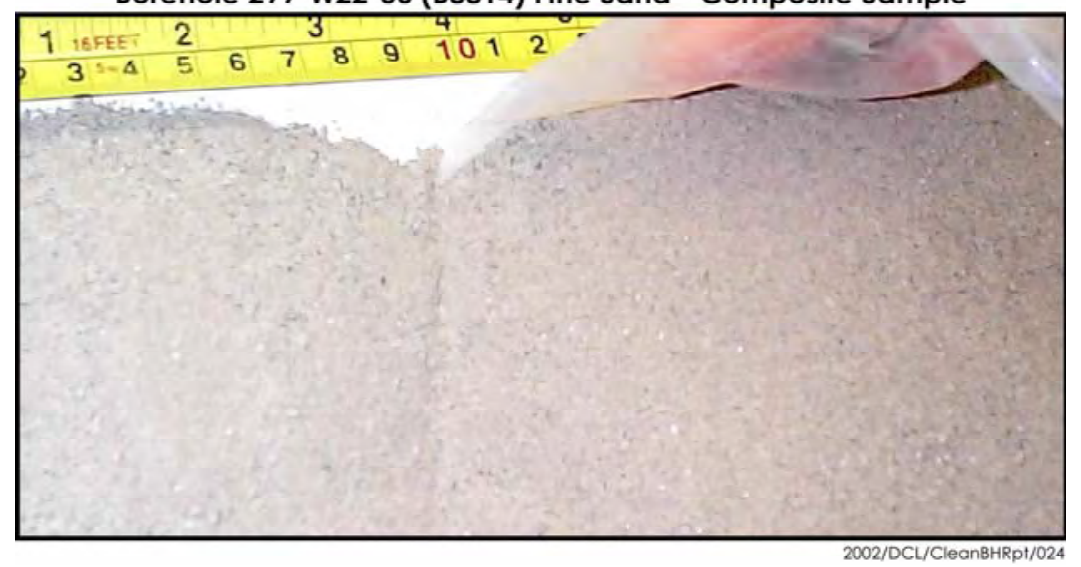

Figure 4.4. Borehole Fine Sand Composite Sample After Air Drying and Disaggregation.

Table 4.2. Particle-Size Distributions for Composite Sediment Samples Determined by Dry Sieve Method

\begin{tabular}{||l|c|c|c|c|c|c|c|c|c||}
\hline \multicolumn{10}{|c|}{ Weight Percent Retained on Each Sieve } \\
\hline \multicolumn{1}{|c|}{ Composite Name } & $4.00 \mathrm{~mm}$ & $2.00 \mathrm{~mm}$ & $1.00 \mathrm{~mm}$ & $500 \mathrm{um}$ & $250 \mathrm{um}$ & $212 \mathrm{um}$ & $125 \mathrm{um}$ & $63 \mathrm{um}$ & $<63 \mathrm{um}$ \\
\hline \hline Ringold Silt & 0.01 & 0.08 & 18.05 & 13.01 & 8.90 & 1.55 & 3.54 & 4.61 & 50.26 \\
\hline Hanford Coarse Sand & 0.87 & 30.17 & 41.26 & 17.72 & 6.96 & 0.22 & 1.20 & 0.71 & 0.89 \\
\hline Hanford Fine Sand & 0.01 & 0.17 & 0.18 & 0.43 & 4.32 & 5.86 & 29.22 & 42.57 & 17.26 \\
\hline Borehole Fine Sand & 0.00 & 0.02 & 1.99 & 5.95 & 18.97 & 7.14 & 23.47 & 29.25 & 13.21 \\
\hline
\end{tabular}

\begin{tabular}{||l|c|c|c|c|l||}
\hline \multicolumn{1}{|c|}{ Composite Name } & $\%$ Gravel & \% Coarse Sand & $\begin{array}{c}\text { \% Med. + Fine } \\
\text { Sand }\end{array}$ & \% Silt+Clay & $\begin{array}{c}\text { Classification } \\
\text { (Folk 1968) }\end{array}$ \\
\hline \hline Ringold Silt* & 0.09 & 31.06 & 18.60 & 50.26 & Sandy mud \\
\hline Hanford Coarse Sand & 31.04 & 58.98 & 9.09 & 0.89 & Gravelly sand \\
\hline Hanford Fine Sand & 0.18 & 0.61 & 81.95 & 17.26 & Slightly muddy sand \\
\hline Borehole Fine Sand & 0.02 & 7.94 & 78.83 & 13.21 & Slightly muddy sand \\
\hline $\begin{array}{l}\text { * Results in Table 4.3 are more representative of actual particle-size distribution since dry sieving apparently did not } \\
\text { completely disaggregate sample. }\end{array}$
\end{tabular}

Table 4.3. Particle-Size Distributions for Composite Sediment Samples Determined by Wet Sieving/Hydrometer Method

\begin{tabular}{||l|c|c|c|c|l||}
\hline \multicolumn{1}{|c|}{ Composite Name } & \% Gravel & \% Sand & \% Silt & \% Clay & $\begin{array}{c}\text { Classification } \\
\text { (Folk 1968) }\end{array}$ \\
\hline \hline Ringold Silt & 0.00 & 1.82 & 83.91 & 14.27 & Clayey silt \\
\hline Hanford Coarse Sand & 42.82 & 53.01 & 1.68 & 2.49 & Gravelly sand \\
\hline Hanford Fine Sand & 0.23 & 72.61 & 20.57 & 6.59 & Muddy sand \\
\hline Borehole Fine Sand & 0.00 & 77.43 & 18.19 & 4.38 & Muddy sand \\
\hline
\end{tabular}




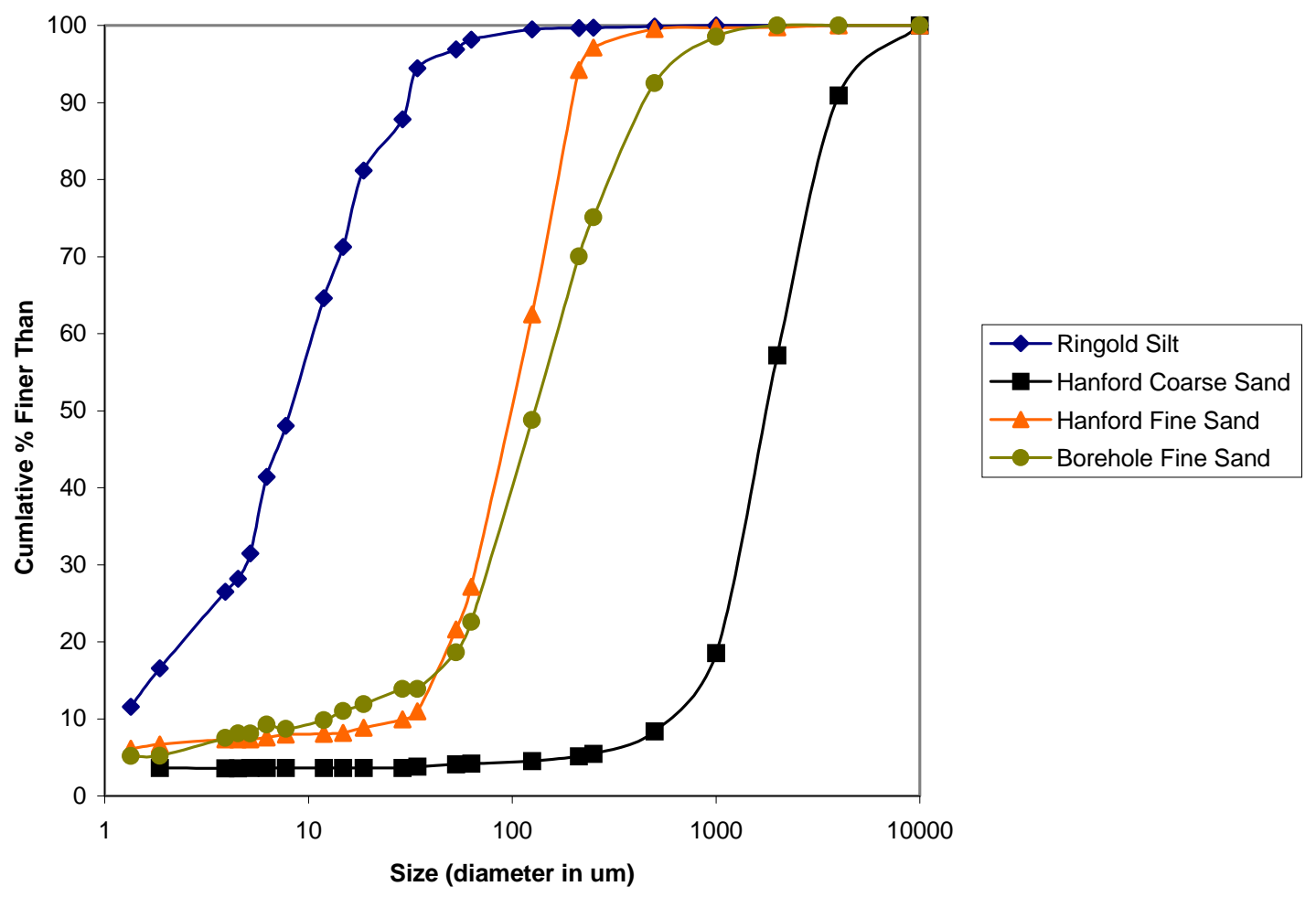

Figure 4.5. Particle-Size Distributions for the Four Composite Sediment Samples

There is a large difference between the dry sieving and the wet sieving in the particle-size distribution for fine-grained samples, which often tend to form sedimentary aggregates. The dispersant used to facilitate particle separation during the wet sieving/hydrometer analysis was more effective at disaggregating the sample than was the dry sieving technique; therefore, the data in Table 4.3 is more representative of the true particle size, especially for the Ringold silt composite. There also appears to be measurable agglomeration in the two fine sands that is also broken down when wet sieving is used. Thus, we suggest that the wet sieving/hydrometer data are more accurate and useful, at least for the analysis of fine-grained sediment.

Particle sorting is indicated by the shape of the curves in Figure 4.5. Samples that are well sorted (e.g., Hanford fine sand) show a particle-size distribution curve with a steep midsection and flat tails on either end of the curve. The borehole fine sand is less well sorted, which probably reflects the fact that this sample was composited over a relatively long (10.5-meter or 34.5-foot) interval whereby many different strata were mixed together. The Ringold silt composite is also less well sorted than the two composites from the Hanford formation (i.e., Hanford coarse sand and Hanford fine sand).

\subsection{Particle Density}

The particle density results are shown in Table 4.4 . 
Table 4.4. Particle Densities for Composite Sediment Samples

\begin{tabular}{||l|c|c||}
\hline \multicolumn{1}{|c|}{ Sample Name } & Particle Density $\left(\mathrm{g} / \mathrm{cm}^{3}\right)$ & Standard Deviation (3 trials) \\
\hline \hline Ringold Silt & 2.612 & 0.008 \\
\hline Hanford Coarse Sand & 2.742 & 0.005 \\
\hline Hanford Fine Sand & 2.662 & 0.010 \\
\hline Borehole Fine Sand & 2.675 & 0.011 \\
\hline
\end{tabular}

Clastic sediment of the Hanford and Ringold Formations is composed mostly of quartz, plagioclase, and rock fragments (see Tallman et al. 1979; Bjornstad 1990). However, the coarser-grained fractions of the Hanford formation generally contain relatively higher percentages of mafic (i.e., basaltic) rock fragments. These minerals and rock fragments have particle densities similar to those in Table 4.4.

The values for Hanford formation sediment in Table 4.4 are slightly lower than values reported by Serne et al. (1993) (2.70 to $\left.2.82 \mathrm{~g} / \mathrm{cm}^{3}\right)$, but the differences are small and are not considered significant for most experimental applications in which the Hanford formation standards would be used. It is encouraging to note, however, that the particle density measurements for the composite samples in Table 4.4 compare favorably with the particle density measurements made on discrete samples from boreholes 299-W22-48 and 299-W22-50 (see Tables 5.6 and 5.32). We suspect that the small differences between the current work and measurements in 1993 are caused by slight differences in analytical technique.

\subsection{Calcium Carbonate and Organic Carbon Content}

The carbon results are shown in Table 4.5. In general, the measurements were made on triplicate aliquots; in some cases, more than three measurements were averaged. The calcium carbonate equivalent (in terms of grams of calcite per gram of oven-dry sediment) is low but within the normal range for nonpedogenically altered Hanford formation sediment. The amount of calcium carbonate is a function of (1) how much soil development has taken place or (2) how much carbonate-cemented detrital material has been transported and redeposited. The Hanford formation generally contains more detrital calcium carbonate than the Ringold, because the cataclysmic floods were more effective at eroding cemented calcic paleosols and redistributing the material. In the case of our composite samples, the Ringold has a higher calcium carbonate content, because it is located just below (slightly over 2 meters or 6.6 feet) a welldeveloped calcic paleosol sequence (equivalent to Plio-Pleistocene PPlc subunit) that caps the Ringold Formation on the White Bluffs (see Figure 2.2). Normally the Ringold Formation contains less than 1\% calcium carbonate, regardless of grain size, unless near a paloesol (Last et al. 1989).

Although the calcium carbonate content of Hanford formation sediment varies greatly depending on the degree of calcic-soil development, typical values are on the order of 1 to $5 \mathrm{wt} \%$ (Last et al. 1989). Thus, the values for the composite samples in Table 4.5 are reasonable. More normally, however, the Ringold Formation will contain $<1 \mathrm{wt} \%$ calcium carbonate. 
Table 4.5. Calcium Carbonate and Organic Carbon Content (wt\%) for Composite Sediment Samples

\begin{tabular}{||l|c|c|c|c|c|c||}
\hline \multicolumn{1}{|c|}{ Sample Name } & $\begin{array}{c}\text { Total } \\
\text { Carbon }\end{array}$ & $\begin{array}{c}\text { Standard } \\
\text { Deviation }\end{array}$ & $\begin{array}{c}\mathrm{CaCO}_{3} \\
\text { Equivalent }\end{array}$ & $\begin{array}{c}\text { Standard } \\
\text { Deviation }\end{array}$ & $\begin{array}{c}\text { Organic C (by } \\
\text { difference) }\end{array}$ & $\begin{array}{c}\text { Standard } \\
\text { Deviation }\end{array}$ \\
\hline \hline Ringold Silt & 0.39 & 0.006 & 2.75 & 0.05 & 0.06 & 0.01 \\
\hline Hanford Coarse Sand & 0.11 & 0.00 & 0.75 & 0.08 & 0.02 & 0.01 \\
\hline Hanford Fine Sand & 0.25 & 0.013 & 1.75 & 0.11 & 0.04 & 0.02 \\
\hline Borehole Fine Sand & 0.28 & 0.007 & 1.92 & 0.06 & 0.05 & 0.01 \\
\hline
\end{tabular}

The organic carbon content of the bulk composite sediment samples is quite low. The method used to measure the organic carbon relies on subtracting the inorganic carbon from the total carbon in the sample and for such low $\mathrm{C}$ values is not accurate. The low values are within the ranges generally reported for Hanford formation sediment but if more accurate values are desired a different method that is more sensitive should be used.

The values for total carbon, calcium carbonate, and organic carbon for the borehole fine sand agree well with measurements of discrete samples analyzed from borehole 299-W22-50 (see Table 5.33) from which the composite sample was constructed.

\subsection{Bulk Chemical Composition}

The bulk chemical compositions of the composite sediment samples, as determined by x-ray fluorescence (XRF) and converted to oxides (see Section 3.2.5), are presented in Table 4.6. We have assumed that all iron is ferric oxide, though a large proportion of the iron is probably associated with the basaltic component of the sediment; and that iron is mostly ferrous oxide. Depending on the types of experiments for which the Hanford Site composites are used, the assumption that all iron is ferric iron will not be adequate. We have adjusted the total content to reflect the presence of some calcium carbonate by converting the calcium carbonate in Table 4.5 back to percent carbonate and adding it to the XRF totals.

The three Hanford formation sediment composites show slightly more than $100 \%$ mass balance using the stated assumptions and the Ringold silt shows about $97 \%$ of the total composition accounted for. The major element concentrations in the composite samples of the Hanford formation generally are similar to the concentrations in discrete core samples from boreholes 299-W22-48 and -50 (compare Table 4.6 with Tables 5.8 and 5.34). Comparing the composite borehole fine sand sample with the discrete samples from borehole 299-W22-50 from which the composite was derived, shows that the elemental concentrations in the composite sample fall within the range of the concentrations of the discrete samples except for silicon dioxide, which is slightly high, and calcium oxide, which is slightly low (neither difference is very significant). 
Table 4.6. Bulk Chemical Composition of Composite Sediment Samples (\% as Oxides)

\begin{tabular}{|l|c|c|c|c||}
\hline \multicolumn{1}{|c|}{ Oxide } & Ringold Silt & $\begin{array}{c}\text { Hanford Coarse } \\
\text { Sand }\end{array}$ & $\begin{array}{c}\text { Hanford Fine } \\
\text { Sand }\end{array}$ & $\begin{array}{c}\text { Borehole Fine } \\
\text { Sand }\end{array}$ \\
\hline \hline $\mathrm{Na}_{2} \mathrm{O}$ & 0.97 & 3.09 & 2.26 & 2.37 \\
\hline $\mathrm{MgO}$ & 5.19 & 3.20 & 3.70 & 3.12 \\
\hline $\mathrm{CO}_{3}$ & 1.65 & 0.45 & 1.05 & 1.15 \\
\hline $\mathrm{Al}_{2} \mathrm{O}_{3}$ & 16.82 & 14.06 & 13.79 & 13.25 \\
\hline $\mathrm{SiO}_{2}$ & 58.94 & 66.24 & 68.67 & 71.03 \\
\hline $\mathrm{P}_{2} \mathrm{O}_{5}$ & $<0.18$ & $<0.22$ & $<0.22$ & $<0.20$ \\
\hline $\mathrm{SO}_{3}$ & 0.06 & 0.07 & 0.11 & 0.06 \\
\hline $\mathrm{Cl}$ & 0.04 & 0.03 & 0.04 & 0.04 \\
\hline $\mathrm{K}_{2} \mathrm{O}$ & 2.88 & 1.92 & 1.92 & 2.39 \\
\hline $\mathrm{CaO}$ & 2.44 & 4.39 & 3.93 & 3.13 \\
\hline $\mathrm{TiO}_{2}$ & 0.71 & 0.89 & 0.78 & 0.55 \\
\hline $\mathrm{V}_{2} \mathrm{O}_{5}$ & 0.02 & 0.02 & 0.02 & 0.01 \\
\hline $\mathrm{Cr} \mathrm{O}_{3}$ & 0.01 & 0.01 & 0.01 & 0.01 \\
\hline $\mathrm{MnO}$ & 0.08 & 0.09 & 0.09 & 0.06 \\
\hline $\mathrm{Fe}{ }_{2} \mathrm{O}_{3}$ & 6.10 & 6.15 & 5.00 & 3.54 \\
\hline $\mathrm{SrO}$ & 0.02 & 0.05 & 0.04 & 0.04 \\
\hline $\mathrm{BaO}$ & 0.09 & 0.08 & 0.07 & 0.08 \\
\hline $\mathrm{Total}$ & 96.92 & 102.26 & 102.50 & 101.58 \\
\hline $\mathrm{Note}$ that other trace metals are present but contribute $<0.1 \%$. & \\
\hline \hline
\end{tabular}

The Ringold silt shows slight differences in the concentrations of some elements compared to the Hanford formation composites. The Ringold silt composite is lower in sodium oxide and calcium oxide and higher in aluminum oxide, silicon dioxide, and potassium oxide than the Hanford formation composites. These differences reflect differences in mineral content, which is due to differences in the particle-size makeup of the samples, and in provenance. The relatively low sodium oxide and calcium oxide reflect the lower plagioclase feldspar composition of the Ringold silt sample and the high potassium oxide reflects the relatively high illite content of the Ringold silt compared to the Hanford formation composites (see discussions in the mineralogy section).

Because the number of major element analyses of Hanford and Ringold Formation sediment are limited, a larger database and experience base are needed to better account for slight differences in composition such as are shown in Table 4.6. The bulk chemical composition of other near-surface samples from the Hanford Site are reported in DOE/RL (1994). 


\subsection{Mineralogy}

The mineralogy of the bulk and silt and clay-size fractions of the composite sediment was determined by x-ray diffraction (XRD) techniques. The XRD analyses show the Hanford formation composite samples are dominated by quartz (30\% to $80 \%$ ), and plagioclase feldspar (5\% to 20\%), with minor amounts $(<10 \%)$ of potassium feldspar (Table 4.7$)$.

The XRD results are in agreement with petrographic analyses of the coarser fraction of the Hanford formation, which after rock fragments (30\% to $50 \%$ of the total), is followed by approximately equal amounts of quartz and plagioclase feldspar (15\% to 30\%), followed by biotite (2\% to 6\%) and pyroxene (0.5\% to $2.5 \%$ ) (Bjornstad 1990). Additionally, calcite was identified in the Ringold silt sediment at $<5 \%$. Clay minerals identified in the bulk sample, but not quantified, were mica and chlorite.

Comparison of the XRD tracings shows the mica and chlorite phases are more abundant in the Ringold silt composite than any Hanford formation composites. This reflects the larger contribution of felsic igneous and low-grade metamorphic detritus in the Ringold Formation. Micas also tend to weather and break up into fine sand to silt-size particles and thus are more concentrated in strata with sediments in this range. Examples of XRD tracings and semiquantification of the major minerals (quartz, feldspar, and calcite) are provided in Appendix G. The mineralogy of other near-surface samples from the Hanford Site are reported in DOE/RL (1994).

The clay fraction ( $<2$ microns) of the composites is dominated by four clay minerals: illite $(10 \AA)$, smectite $(15 \AA)$, chlorite $(14.1 \AA)$, and kaolinite $(7 \AA)$ with minor amounts of quartz $(3.34 \AA)$, feldspar (3.18 $\AA$ ), and amphibole ( $8.4 \AA)$. The smectites, when saturated with magnesium (II) ion, gave a basal reflection of $15.0 \AA$ A, overlapping the chlorite $14.1 \AA$ peak (see Appendix G). When solvated with

Table 4.7. Semiquantitative Mineral Content of Composite Sediment Samples

\begin{tabular}{||l|c|c|c|c||}
\hline \multicolumn{5}{|c|}{ Semiquantification of Minerals in Bulk Composite Samples (wt\%) } \\
\hline \multicolumn{1}{||c|}{ Sample ID } & Quartz & K-Feldspar & Na-Feldspar & Calcite \\
\hline \hline Borehole Fine Sand & 50 & 10 & 20 & ND \\
\hline Hanford Fine Sand & 80 & 10 & 20 & ND \\
\hline Hanford Coarse Sand & 55 & 5 & 15 & ND \\
\hline Ringold Silt & 30 & 5 & 5 & $<5$ \\
\hline
\end{tabular}

Semiquantification of Minerals in the Clay Fraction from Composite Samples (wt\%)

\begin{tabular}{||l|c|c|c|c|c|c||}
\hline Sample ID & Quartz & Feldspar & Smectite & Illite & Chlorite & Kaolinite \\
\hline \hline Borehole Fine Sand & 5 & $<5$ & 30 & 40 & 20 & 5 \\
\hline Hanford Fine Sand & 5 & $<5$ & 30 & 15 & 15 & 10 \\
\hline Hanford Coarse Sand & 5 & $<5$ & 30 & 15 & 15 & 5 \\
\hline Ringold Silt & 10 & $<5$ & 35 & 35 & 20 & ND \\
\hline
\end{tabular}

$\mathrm{ND}=$ not detected 
ethylene glycol, the smectite structure expanded up to $17 \AA$ leaving the chlorite $(14.1 \AA)$ and illite (10 $⿱$ A) reflections unchanged. An additional analysis with potassium ion as the interlayer cation shifted the smectite peak to approximately $12 \AA$ and again the chlorite and illite reflections remain unaffected. Sample cracking on the potassium ion-saturated slide for the Hanford fine sand composite prevented analysis of that sample. Heating the potassium ion-saturated slide collapses the smectite structure from $12 \AA$ to $10 \AA$ and the $7.01 \AA$ and $3.58 \AA$ kaolinite peaks disappear. The chlorite reflection at $14.1 \AA$ remained constant whereas the $7.1 \AA$ and $3.54 \AA$ peaks almost disappear. The identification of kaolinite is based primarily on XRD data (the separation of two peaks at $3.58 \AA$ and $3.55 \AA$, the latter belonging to chlorite), and by transmission electron microscopy (TEM) analysis. Kaolinite was not identified in the Ringold silt composite. Additionally, trace amounts of apatite, iron oxides, and sepiolite were detected in the clay fraction during the TEM analysis of the Hanford formation composites.

The semiquantitative analysis of minerals in the clay fraction of the composite sediment is given in Appendix G. Overall, smectite was the dominant mineral in the clay fraction for all the composites (30 to $40 \mathrm{wt} \%$ ). This is in general agreement with the clay-mineral composition reported in Bjornstad (1990). Illite ranged in concentrations from a high of $40 \mathrm{wt} \%$ (borehole fine sand) to a low of $15 \mathrm{wt} \%$ and chlorite averaged between $\sim 15$ to $20 \mathrm{wt} \%$. Minor amounts of kaolinite ( $<10 \mathrm{wt} \%)$ were detected in all three Hanford formation composite samples. Kaolinite was not identified by XRD in the Ringold silt. Quartz and feldspar made up 5 to $10 \mathrm{wt} \%$ of the clay fraction. Amphibole was identified in the clay fraction in minor amounts; however, it was not quantified. Total recovery for the clay fraction ranged from a low of $69 \mathrm{wt} \%$ (Hanford fine sand) to a high of $106 \mathrm{wt} \%$ (borehole fine sand). Recoveries ranging from 80 to $120 \mathrm{wt} \%$ are acceptable for XRD semiquantification.

XRF analysis on the <2-micron fraction was conducted on both Hanford fine sand, Hanford coarse sand, and the borehole fine sand composite samples. The results, converted to oxides, are presented in Table 4.8. Overall, approximately $45 \mathrm{wt} \%$ of the clay fraction consists of silicon, followed by lesser amounts of aluminum $(\sim 15 \mathrm{wt} \%)$ and iron $(\sim 12 \mathrm{wt} \%)$. The clay fraction contains $<1 \mathrm{wt} \%$ of the total iron oxide and $<1.2 \mathrm{wt} \%$ of the total aluminum oxide in the bulk sample. Iron oxides were detected in only trace amounts during the TEM analysis of the clay fraction, which suggests that most of the iron in the $<2$-micron fraction is incorporated into the clay mineral structures (smectites, chlorites, and illites). Based on XRF data, semiquantitative estimates of illite in the <2-micron fraction (assuming all potassium resides in the illite structure) show 15 and $10 \mathrm{wt} \%$ in the Hanford coarse sand and Hanford fine sand composite samples, respectively. This agrees well with the XRD quantification for illite in the same samples. However, for the borehole fine sand composite sample, illite concentration of $20 \mathrm{wt} \%$ is much lower than the value of $40 \mathrm{wt} \%$ reported by XRD.

Analysis of illites from the Hanford fine sand by TEM showed a variation of iron content as well as particle morphology. Dominating the illitic material were large (>1-micron)-thick platy mica particles (Figure 4.6). 
Table 4.8. Bulk Chemical Composition of Clay Fraction (\% as Oxides) in Composite Sediment Samples

\begin{tabular}{||l|c|c|c||}
\hline Oxide & $\begin{array}{c}\text { Hanford Coarse } \\
\text { Sand }\end{array}$ & $\begin{array}{c}\text { Hanford Fine } \\
\text { Sand }\end{array}$ & $\begin{array}{c}\text { Borehole Fine } \\
\text { Sand }\end{array}$ \\
\hline \hline $\mathrm{Na}_{2} \mathrm{O}$ & $\mathrm{NM}$ & $\mathrm{NM}$ & $\mathrm{NM}$ \\
\hline $\mathrm{MgO}$ & $\mathrm{NM}$ & $\mathrm{NM}$ & $\mathrm{NM}$ \\
\hline $\mathrm{CO}_{3}$ & $\mathrm{NM}$ & $\mathrm{NM}$ & $\mathrm{NM}$ \\
\hline $\mathrm{Al}_{2} \mathrm{O}_{3}$ & 12.80 & 14.31 & 16.79 \\
\hline $\mathrm{SiO}_{2}$ & 45.25 & 43.86 & 47.60 \\
\hline $\mathrm{P}_{2} \mathrm{O}_{5}$ & 2.66 & 3.17 & 1.23 \\
\hline $\mathrm{SO}_{3}$ & 0.07 & 0.09 & 0.06 \\
\hline $\mathrm{Cl}$ & 0.14 & 0.23 & 0.14 \\
\hline $\mathrm{K}_{2} \mathrm{O}$ & 1.61 & 1.21 & 2.49 \\
\hline $\mathrm{CaO}$ & 1.83 & 1.77 & 1.00 \\
\hline $\mathrm{TiO}_{2}$ & 0.61 & 0.49 & 0.58 \\
\hline $\mathrm{V}_{2} \mathrm{O}_{5}$ & 0.02 & 0.01 & 0.02 \\
\hline $\mathrm{Cr}_{2} \mathrm{O}_{3}$ & 0.01 & 0.01 & 0.01 \\
\hline $\mathrm{MnO}$ & 0.13 & 0.19 & 0.21 \\
\hline $\mathrm{Fe} \mathrm{O}_{3}$ & 12.37 & 10.17 & 11.80 \\
\hline $\mathrm{SrO}$ & 0.03 & 0.02 & 0.02 \\
\hline $\mathrm{BaO}$ & 0.06 & 0.04 & 0.05 \\
\hline $\begin{array}{l}\mathrm{Note} \text { that other trace metals are present but contribute } \\
\mathrm{NM}=\mathrm{Analyte}\end{array}$ & & \\
\hline \hline
\end{tabular}

These particles were abundant and easily distinguished from other clay minerals. The following structural formula was developed from several illites containing approximately the same amount of ferric iron:

$$
\left[\left(\mathrm{K}_{0.70} \mathrm{Ca}_{0.02} \mathrm{Na}_{0.02}\right)\right]^{+0.76}\left[\left(\mathrm{Al}_{1.48} \mathrm{Fe}_{0.27} \mathrm{Mg}_{0.39}\right)^{+0.03}\left(\mathrm{Si}_{3.24} \mathrm{Al}_{0.76}\right)^{-0.76}\right]^{-0.73} \mathrm{O}_{10}(\mathrm{OH})_{2}
$$

The tetrahedral sheet has a charge of -0.76 . The octahedral sheet has a charge of +0.03 and the interlayer cations have a charge of +0.76 . Ferric iron content in the octahedral site ranged from 0.01 atoms to as high as 0.50 atoms per $\mathrm{O}_{10}(\mathrm{OH})_{2}$ and $\mathrm{Al}^{3+}$ (for both tetrahedral and octahedral positions) varied between 1.96 and 3.13 atoms per $\mathrm{O}_{10}(\mathrm{OH})_{2}$. Illites in the Hanford coarse sand displayed much the same characteristics as the Hanford fine sand.

Illites examined in the borehole fine sand could be divided into two types based on $\mathrm{Fe}^{3+}$ content: $<0.3$ $\mathrm{Fe}^{3+}$ atoms per $\mathrm{O}_{10}(\mathrm{OH})_{2}$ and $>0.3 \mathrm{Fe}^{3+}$ atoms per $\mathrm{O}_{10}(\mathrm{OH})_{2}$. Figure 4.7 is a common illite particle from the borehole fine sand with a low $\mathrm{Fe}^{3+}$ content $\left(0.09\right.$ atoms per $\left.\mathrm{O}_{10}[\mathrm{OH}]_{2}\right)$. 


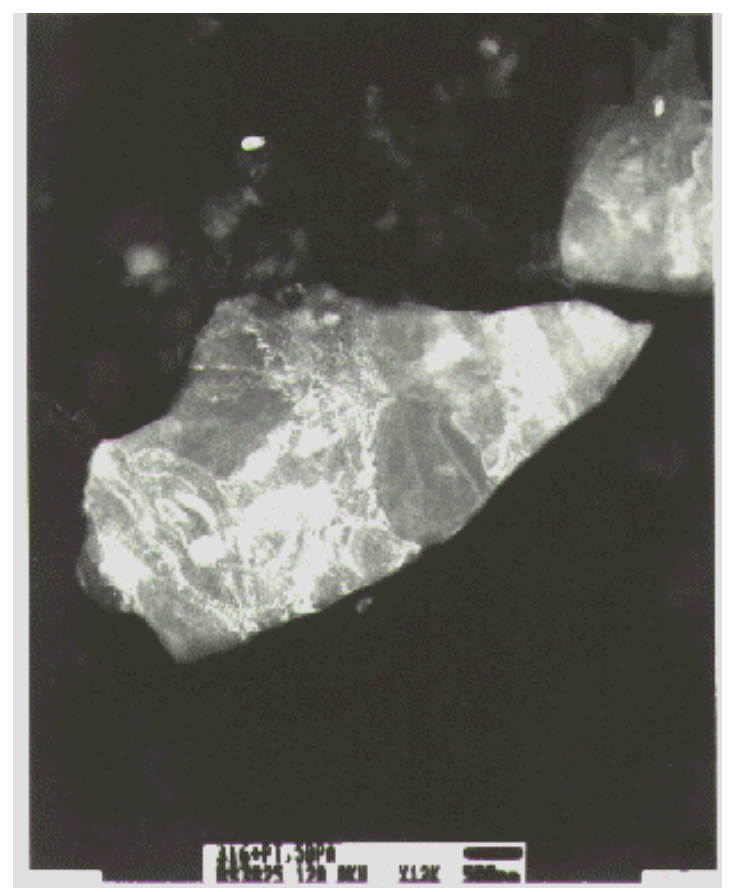

Figure 4.6. Typical Illite Particle ( $\sim 5$ microns long) Common to the Hanford Fine Sand Composite Sample

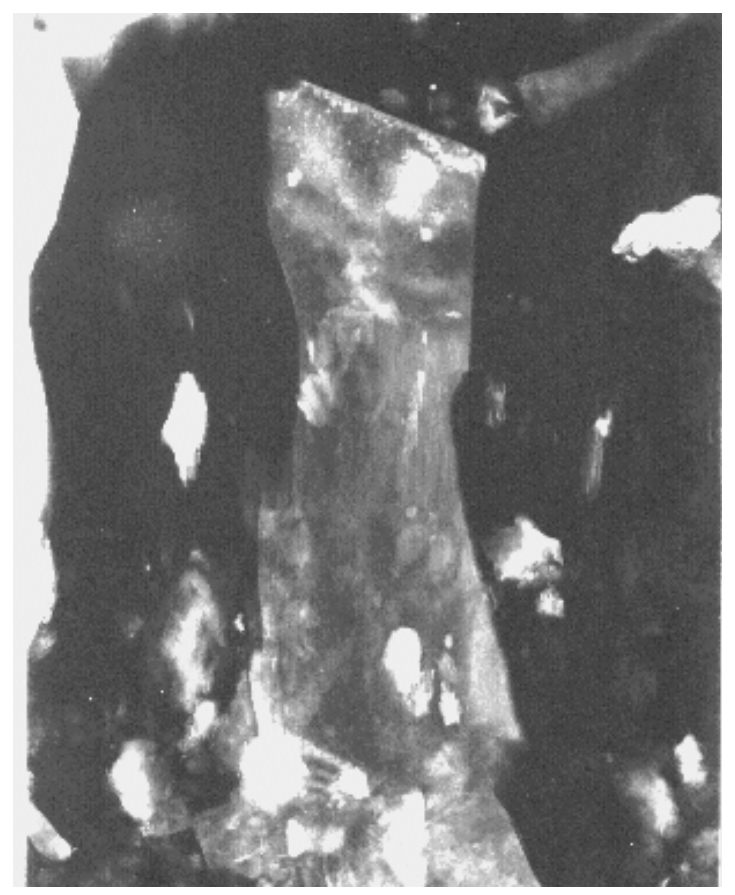

Figure 4.7. Typical Illite Particle ( $\sim 3$ microns long) from Clay Fraction of the Borehole Fine Sand Composite Sample 
The structural formula derived from five TEM analysis of the low iron phase is:

$$
\left[\left(\mathrm{K}_{0.74} \mathrm{Ca}_{0.02}\right)\right]^{+0.78}\left[\left(\mathrm{Al}_{1.79} \mathrm{Fe}_{0.09} \mathrm{Mg}_{0.21} \mathrm{Ti}_{0.02}\right)^{+0.14}\left(\mathrm{Si}_{3.13} \mathrm{Al}_{0.87}\right)^{-0.87}\right]^{+0.73} \mathrm{O}_{10}(\mathrm{OH})_{2}
$$

The tetrahedral sheet has a charge of -0.87 ; the octahedral sheet has a charge of +0.14 and an interlayer cation charge of +0.78 . High iron illites $\left(\sim 0.3\right.$ atoms per $\left.\mathrm{O}_{10}(\mathrm{OH})_{2}\right)$ had similar particle morphology, with a slight tendency to be thicker and larger in size. These illites also tended to have less $\mathrm{Al}^{3+}$ substitution in the tetrahedral sites $\left(\sim 1.52\right.$ atoms per $\left.\mathrm{O}_{10}(\mathrm{OH})_{2}\right)$ and slightly more magnesium (II) ion $\left(\sim 0.30\right.$ atoms per $\left.\mathrm{O}_{10}(\mathrm{OH})_{2}\right)$.

Chlorites common to the Hanford fine sand, Hanford coarse sand, and the borehole fine sand have chemistry ranging between a chamosite (iron-rich chlorite) to a chlinochlore (magnesium-rich chlorite). Platy chlorite particles averaging in size from 0.5 to $>2.0$ microns were common throughout the samples. Figure 4.8 is a typical example an iron-rich, platy chlorite from the borehole fine sand.

Assuming all iron as iron (II), an average structural formula was developed from TEM data collected from six chlorite particles from the borehole fine sand:

$$
\left[\left(\mathrm{K}_{0.11} \mathrm{Ca}_{0.02}\right)\right]^{+0.15}\left[\left(\mathrm{Al}_{1.46} \mathrm{Fe}_{1.45} \mathrm{Mg}_{2.57} \mathrm{Ti}_{0.07}\right)^{+0.70}\left(\mathrm{Si}_{3.14} \mathrm{Al}_{0.86}\right)^{-0.86}\right]^{-0.16} \mathrm{O}_{10}(\mathrm{OH})_{8}
$$

Most of the layer charge derived from the substitution of $\mathrm{Al}^{3+}$ for $\mathrm{Si}^{+4}$ in the tetrahedral sheet is balanced by the substitution of $\mathrm{Mg}^{2+}$ and $\mathrm{Fe}^{2+}$ for $\mathrm{Al}^{3+}$ in the octahedral sheets. There was a considerable range of cation substitution in both octahedral sheets for chlorites examined by TEM. Iron concentrations ranged from 0.80 to as high as 2.58 atoms per $\mathrm{O}_{10}(\mathrm{OH})_{8}$ and $\mathrm{Mg}^{2+}$ ranged between 1.29 and 3.46 atoms per $\mathrm{O}_{10}(\mathrm{OH})_{8}$. For this structural formula, trace amounts of $\mathrm{K}^{+}$and $\mathrm{Ca}^{2+}$ were placed into interlayer cations, assuming some mixed layering material to be present in the chlorite. However, it is possible that these cations are a part of the chlorite structure where they would occupy positions in the octahedral sheets. Chlorites in both the Hanford fine sand and Hanford coarse sand composites tended to be richer in $\mathrm{Fe}^{2+}$, but were otherwise similar in chemistry and morphology to chlorites in the borehole fine sand.

Kaolinite was initially identified by XRD in the Hanford formation composites, then subsequently by TEM analysis. Kaolinites typically appear as hexagonally shaped crystals as shown in Figure 4.9.

An average structural formula derived from kaolinites examined from each of the three composite soils appear to have a minor amount of $\mathrm{Fe}^{3+}$ substituting for $\mathrm{Al}^{3+}$ in the octahedral sheet:

$$
\left[\left(\mathrm{Al}_{1.98} \mathrm{Fe}_{0.02}\right)\left(\mathrm{Si}_{2.0}\right)\right] \mathrm{O}_{5}(\mathrm{OH})_{4}
$$

Smectites occurred either as large aggregates of thin films or as discrete particles $<0.1$ micron in size. Figure 4.10 shows a $\sim 2$-micron-size smectite aggregate from the Hanford coarse sand. Smectites are identifiable from other clay minerals by the curled edges of individual smectite flakes. 


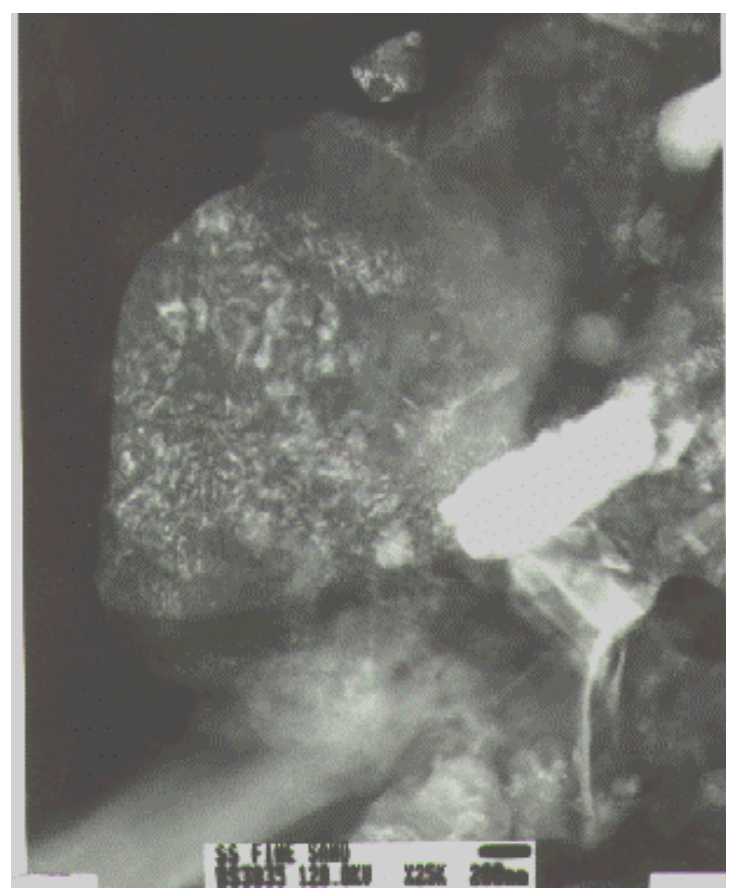

Figure 4.8. Chlorite Particle ( 1.5 micron) from the Borehole Fine Sand Composite Sample.

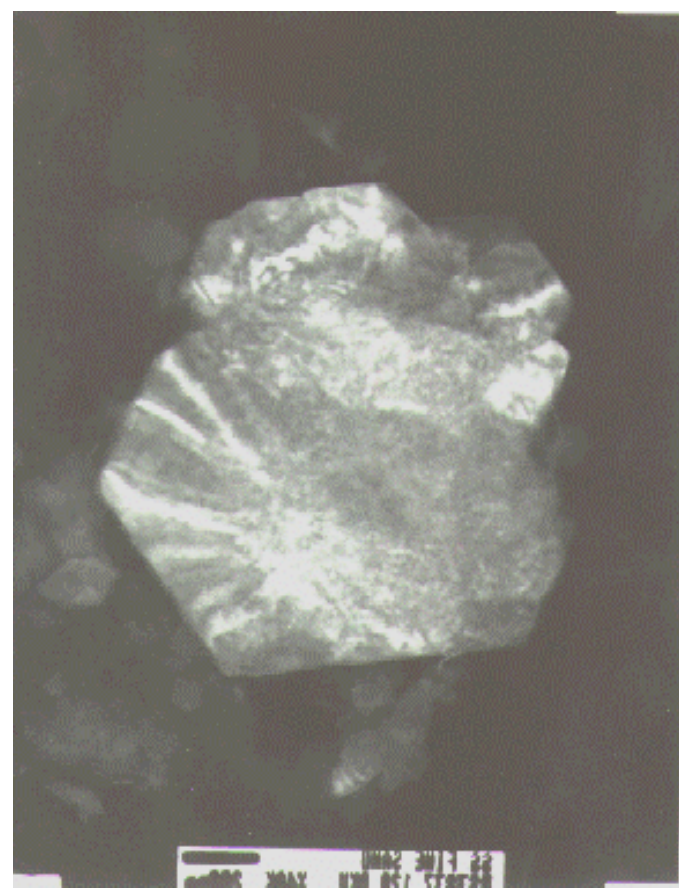

Figure 4.9. A Thick, Hexagonal Kaolinite Particle ( 1 micron) from the Borehole Fine Sand Composite Sample. 


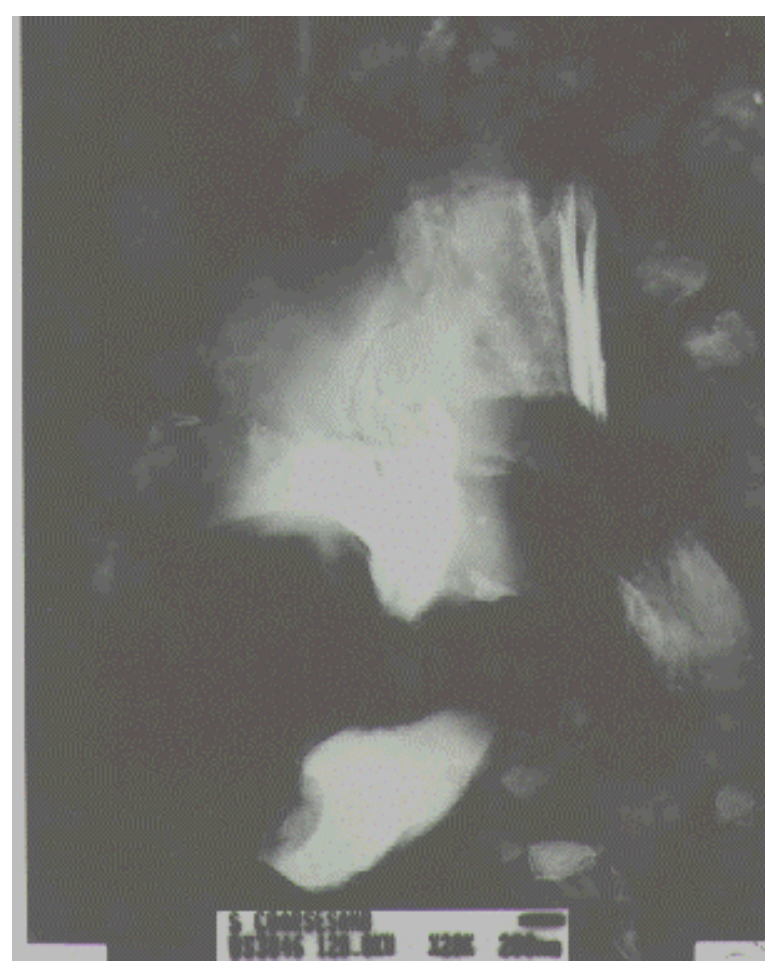

Figure 4.10. Smectite Aggregate ( 2 microns) from the Hanford Coarse Sand Composite Sample

Chemical composition of the smectites was hard to establish due, in part, to isolating the particle during the TEM analysis. Considering this limitation, and assuming all iron as $\mathrm{Fe}^{3+}$, an average structural formula was developed for the smectites using data from all three Hanford formation composites: Hanford fine sand, Hanford coarse sand, and borehole fine sand:

$$
\left[\left(\mathrm{K}_{0.01} \mathrm{Na}_{0.02} \mathrm{Ca}_{0.16}\right)\right]^{+0.35}\left[\left(\mathrm{Al}_{1.35} \mathrm{Fe}_{0.12} \mathrm{Mg}_{0.66} \mathrm{Ti}_{0.02}\right)^{-0.19}\left(\mathrm{Si}_{3.86} \mathrm{Al}_{0.14}\right)^{-0.14}\right]^{-0.33} \mathrm{O}_{10}(\mathrm{OH})_{2}
$$

The tetrahedral sheet has a layer charge of -0.14 and the octahedral sheet has a layer charge of -0.19 . Balancing out the sheet charges are interlay cations: potassium, sodium, and calcium. This type of smectite is classified as a calcium-rich montmorillonite because more than half of the charge originates in the octahedral sheet.

\subsection{Cation Exchange Capacity}

Five grams of each sediment were used in triplicate determinations using the two methods (Polemia and Rhoades (1977) and Amrhein and Suarez (1990)) discussed in Section 3.2. The results for the four composite sediment samples are summarized in Table 4.9.

The cation exchange capacity results, as determined by the two methods, vary significantly. The Amrhein and Suarez method yields lower results than the Polemio and Rhoades technique. There is a 
Table 4.9. Results of Cation Exchange Capacity (meq/100 g) of Composite Sediment Samples Using Two Different Techniques

\begin{tabular}{||l|c|c||}
\hline \multicolumn{1}{|c|}{ Composite Name } & Polemio and Rhoades (1977) & Amrhein and Suarez (1990) \\
\hline \hline Ringold Silt & $28.5 \pm 2.4$ & $11.6 \pm 1.1$ \\
\hline Hanford Coarse Sand & $12.2 \pm 2.1$ & $1.7 \pm 0.3$ \\
\hline Hanford Fine Sand & $18.4 \pm 2.7$ & $7.8 \pm 3.8$ \\
\hline Borehole Fine Sand & $9.2 \pm 8.9$ & $2.9 \pm 0.6$ \\
\hline
\end{tabular}

large variation in the Polemio and Rhoades results for the borehole fine sand but, in general, the reproducibility for the other five sets of triplicates is good. Not surprisingly, both methods result in significantly larger cation exchange capacity values for the Ringold silt compared to the Hanford formation composites, due to the greater reactive surface area for silt. From other testing where known amounts of reagent-grade calcium carbonate were added to sediment, we found that the Polemio and Rhoades values may not adequately correct for calcium carbonate dissolution and the Amrhein and Suarez method overcorrects. These observations were made for sediment that was spiked with 6 to 20 $\mathrm{wt} \%$ calcium carbonate. At this time, we have not determined which method is more accurate for the low exchange capacity Hanford formation sediment with low calcite contents.

The cation exchange capacity measured on the Hanford fine sand composite is comparable to those measured on Hanford formation sediment from borehole 299-W22-48 (see Table 5.11, depths 39 to 136 feet below ground surface [bgs]). The borehole fine sand composite, on the other hand, has a much lower cation exchange capacity than either the Hanford fine sand composite or the samples from borehole 299W22-48. We do not yet understand the discrepancy.

The Hanford fine sand came from a zone that has absorbed (and evaporated) a lot of meteoric water. As a result, it has a higher concentration of water-extractable anions (and cations) as shown in Tables 4.10 and 4.11. Whether this has any influence on cation exchange capacity is not known.

The low cation exchange capacity for the Hanford coarse sand reflects the larger grain size (i.e., less overall reactive surface area). The differences in cation exchange capacity may be the result of differences in grain size and surface area rather than clay content. There are relatively few clay-size particles in the Hanford coarse sand, borehole fine sand, or Hanford fine sand composites, as demonstrated in Table 4.3. The Hanford formation does not contain much clay because (1) it is a young deposit, geologically, so there has been insufficient time for diagenetic alteration either via groundwater or soil development, and (2) it was deposited very rapidly during cataclysmic flooding (geologists speculate that each flood lasted no more than a week), so that clay-size particles did not have enough time to settle out of suspension before all the floodwater had drained out of the basin.

Cation exchange capacities for Hanford formation sediment that have been reported in the literature in general are between the range of values reported in Table 4.9 for the two methods. That is, other 
Table 4.10. pH, Electrical Conductivity, Alkalinity, and Anions in 1:1 Sediment-to-Water Extracts for Composite Sediment Samples

\begin{tabular}{||l|c|c|c|c|c||}
\hline \multicolumn{1}{|c|}{ Constituent } & Units & Ringold Silt & $\begin{array}{c}\text { Hanford } \\
\text { Coarse Sand }\end{array}$ & $\begin{array}{c}\text { Hanford Fine } \\
\text { Sand }\end{array}$ & $\begin{array}{c}\text { Borehole Fine } \\
\text { Sand }\end{array}$ \\
\hline \hline $\mathrm{pH}$ & & 7.87 & 7.83 & 7.55 & 7.84 \\
\hline $\mathrm{EC}$ & $\mu \mathrm{S} / \mathrm{cm}$ & 441 & 150 & 1218 & 219 \\
\hline Alkalinity & $\mathrm{mg} / \mathrm{L} \mathrm{HCO}{ }_{3}$ & 113 & 74 & 113 & 86 \\
\hline $\mathrm{F}$ & $\mathrm{mg} / \mathrm{L}$ & 0.27 & 0.26 & 0.26 & 0.44 \\
\hline $\mathrm{Cl}$ & $\mathrm{mg} / \mathrm{L}$ & 12 & 6.8 & 180 & 6.1 \\
\hline $\mathrm{Br}$ & $\mathrm{mg} / \mathrm{L}$ & 0.07 & 0.06 & 1.2 & 0.04 \\
\hline $\mathrm{NO}_{2}$ & $\mathrm{mg} / \mathrm{L}$ & $<0.1$ & $<0.1$ & $<0.1$ & $<0.1$ \\
\hline $\mathrm{NO}_{3}$ & $\mathrm{mg} / \mathrm{L}$ & 42.7 & 4.5 & 32.8 & 8.3 \\
\hline $\mathrm{PO}_{4}$ & $\mathrm{mg} / \mathrm{L}$ & 0.23 & 0.15 & 0.16 & 0.16 \\
\hline $\mathrm{SO}_{4}$ & $\mathrm{mg} / \mathrm{L}$ & 73.9 & 11.7 & 289 & 23.8 \\
\hline formate & $\mathrm{mg} / \mathrm{L}$ & 1.38 & 0.20 & 0.06 & 0.86 \\
\hline acetate & $\mathrm{mg} / \mathrm{L}$ & 15.8 & $<0.1$ & $<0.1$ & $<0.1$ \\
\hline oxalate & $\mathrm{mg} / \mathrm{L}$ & 1.01 & 0.10 & 0.29 & 0.27 \\
\hline
\end{tabular}

Table 4.11. Major Cations in 1:1 Sediment-to-Water Extracts (ICP) for Composite Sediment Samples

\begin{tabular}{|c|c|c|c|c|c|}
\hline Constituent & Units & Ringold Silt & $\begin{array}{l}\text { Hanford } \\
\text { Coarse Sand }\end{array}$ & $\begin{array}{c}\text { Hanford Fine } \\
\text { Sand }\end{array}$ & $\begin{array}{c}\text { Borehole Fine } \\
\text { Sand }\end{array}$ \\
\hline $\mathrm{Na}$ & $\mu \mathrm{g} / \mathrm{L}$ & 31,261 & 8,140 & 27,825 & 16,510 \\
\hline $\mathrm{Mg}$ & $\mu \mathrm{g} / \mathrm{L}$ & 5,193 & 2,487 & 32,558 & 3,233 \\
\hline $\mathrm{Al}$ & $\mu \mathrm{g} / \mathrm{L}$ & $(42)^{(\mathrm{A})}$ & 204 & $<50$ & 115 \\
\hline $\mathrm{Si}$ & $\mu \mathrm{g} / \mathrm{L}$ & 9,633 & 12,150 & 18,638 & 3,233 \\
\hline $\mathrm{P}$ & $\mu \mathrm{g} / \mathrm{L}$ & 378 & 256 & 280 & 332 \\
\hline$S$ & $\mu \mathrm{g} / \mathrm{L}$ & 26,075 & 4,754 & 102,162 & 8,872 \\
\hline K & $\mu \mathrm{g} / \mathrm{L}$ & 5,673 & $(3,294)^{(\mathrm{a})}$ & 8,630 & $(3,844)^{(\mathrm{a})}$ \\
\hline $\mathrm{Ca}$ & $\mu \mathrm{g} / \mathrm{L}$ & 43,675 & 11,003 & 156,136 & 15,455 \\
\hline $\mathrm{Ti}$ & $\mu \mathrm{g} / \mathrm{L}$ & $<20$ & $<20$ & $<20$ & $<20$ \\
\hline $\mathrm{Mn}$ & $\mu \mathrm{g} / \mathrm{L}$ & $<5$ & $<5$ & $<5$ & $<5$ \\
\hline $\mathrm{Fe}$ & $\mu \mathrm{g} / \mathrm{L}$ & 90 & 220 & 13 & 77 \\
\hline $\mathrm{Sr}$ & $\mu \mathrm{g} / \mathrm{L}$ & 173 & 52 & 663 & 73 \\
\hline $\mathrm{Ba}$ & $\mu \mathrm{g} / \mathrm{L}$ & 33 & 15 & 64 & 17 \\
\hline $\begin{array}{l}\text { (a) Values in } \\
\text { value was }\end{array}$ & $\begin{array}{l}\text { sis are } \\
\text { d to d }\end{array}$ & w level of $\mathrm{q}$ & ication but & looked good. & hus, a tentative \\
\hline
\end{tabular}


literature suggests that the Polemio and Rhoades technique yields cation exchange capacity values biased high and the Amrhein and Suarez method yields values that are biased low. Therefore, the true cation exchange capacity may lie between the values reported for the two methods in Table 4.9.

\subsection{1:1 Sediment-to-Water Extraction}

The 1:1 sediment-to-water extract results for the composite samples are shown in Tables 4.10 to 4.13. Approximately 50 to 100 grams of air-dried sediment were mixed with an equal amount of deionized water (corrected for the small amount of porewater in the air-dry sediment). In the discussion on the characterization of the core materials, we will compare the chemical composition of the 1:1 water extracts with actual porewater obtained by ultracentrifugation and the calculated equivalent pore chemistry from dilution correction of the 1:1 extracts. For some constituents, the 1:1 water extracts, when corrected for dilution with deionized water, give an accurate measure of the concentration within the native porewater. For other constituents, the amount found in the 1:1 water extract, when dilution-corrected back to the

Table 4.12. Trace Metals in 1:1 Sediment-to-Water Extracts of Composite Sediment Samples. Analyzed using ICP or ICP-MS methods.

\begin{tabular}{|c|c|c|c|c|c|}
\hline Constituent & Units & Ringold Silt & $\begin{array}{l}\text { Hanford Coarse } \\
\text { Sand }\end{array}$ & $\begin{array}{l}\text { Hanford Fine } \\
\text { Sand }\end{array}$ & $\begin{array}{c}\text { Borehole Fine } \\
\text { Sand }\end{array}$ \\
\hline $\mathrm{Be}$ & $\mu \mathrm{g} / \mathrm{L}$ & $<1$ & $<1$ & $<1$ & $<1$ \\
\hline B & $\mu \mathrm{g} / \mathrm{L}$ & $<20$ & $<20$ & $<20$ & $<20$ \\
\hline $\mathrm{Cr}^{(\mathrm{A})}$ & $\mu \mathrm{g} / \mathrm{L}$ & 13.3 & 0.85 & 3.1 & 1.4 \\
\hline Co & $\mu \mathrm{g} / \mathrm{L}$ & $<1$ & $<1$ & $<1$ & $<1$ \\
\hline $\mathrm{Ni}$ & $\mu \mathrm{g} / \mathrm{L}$ & $<5$ & $<5$ & $<5$ & $<5$ \\
\hline $\mathrm{Cu}$ & $\mu \mathrm{g} / \mathrm{L}$ & $<5$ & $<5$ & $<5$ & $<5$ \\
\hline $\mathrm{Zn}$ & $\mu \mathrm{g} / \mathrm{L}$ & $<5$ & $<5$ & $<5$ & $<5$ \\
\hline $\mathrm{As}^{(\mathrm{a})}$ & $\mu \mathrm{g} / \mathrm{L}$ & 3.1 & 6.6 & 6.7 & 14.2 \\
\hline $\mathrm{Se}^{(\mathrm{a})}$ & $\mu \mathrm{g} / \mathrm{L}$ & $(1.2)^{(\mathrm{b})}$ & $(0.7)^{(\mathrm{b})}$ & 12.3 & $(0.8)^{(b)}$ \\
\hline $\mathrm{Mo}^{(\mathrm{a})}$ & $\mu \mathrm{g} / \mathrm{L}$ & 5.4 & $(1.0)$ & 2.0 & 8.9 \\
\hline $\mathrm{Tc}^{(\mathrm{a})}$ & $\mu \mathrm{g} / \mathrm{L}$ & $<0.1$ & $<0.1$ & $<0.1$ & $<0.1$ \\
\hline $\mathrm{Ru}^{(\mathrm{a})}$ & $\mu \mathrm{g} / \mathrm{L}$ & $<0.01$ & $<0.01$ & $<0.01$ & $<0.01$ \\
\hline $\mathrm{Ag}^{(\mathrm{a})}$ & $\mu \mathrm{g} / \mathrm{L}$ & $<0.25$ & $<0.25$ & $<0.25$ & $<0.25$ \\
\hline $\mathrm{Cd}^{(\mathrm{a})}$ & $\mu \mathrm{g} / \mathrm{L}$ & $<0.08$ & $<0.08$ & $<0.08$ & $<0.08$ \\
\hline $\mathrm{Pb}^{(\mathrm{a})}$ & $\mu \mathrm{g} / \mathrm{L}$ & 0.69 & 1.44 & $(0.28)^{(\mathrm{b})}$ & $(0.41)^{(\mathrm{b})}$ \\
\hline $\mathrm{Bi}$ & $\mu \mathrm{g} / \mathrm{L}$ & $<20$ & $<20$ & $<20$ & $<20$ \\
\hline $\mathrm{U}^{(\mathrm{a})}$ & $\mu \mathrm{g} / \mathrm{L}$ & 0.38 & 0.29 & 0.29 & 0.58 \\
\hline
\end{tabular}

(a) ICP-MS = inductively coupled plasma mass spectrometry method was used.

(b) Values in parenthesis are just below level of quantification but spectra looked good. Thus, a tentative value was attributed to data. 
Table 4.13. Charge Balance for Water Extracts of Composite Sediment Samples

\begin{tabular}{||l|c|c|c|c|c||}
\hline \multicolumn{1}{|c|}{ Constituent } & Units & Ringold Silt & $\begin{array}{c}\text { Hanford Coarse } \\
\text { Sand }\end{array}$ & $\begin{array}{c}\text { Hanford Fine } \\
\text { Sand }\end{array}$ & $\begin{array}{c}\text { Borehole Fine } \\
\text { Sand }\end{array}$ \\
\hline \hline Alkalinity & meq/L & 1.86 & 1.21 & 1.86 & 1.41 \\
\hline $\mathrm{Cl}$ & $\mathrm{meq} / \mathrm{L}$ & 0.34 & 0.19 & 5.08 & 0.17 \\
\hline $\mathrm{NO}_{3}$ & $\mathrm{meq} / \mathrm{L}$ & 0.69 & 0.07 & 0.53 & 0.13 \\
\hline $\mathrm{SO}_{4}$ & $\mathrm{meq} / \mathrm{L}$ & 1.54 & 0.24 & 6.02 & 0.50 \\
\hline Total Anions & $\mathrm{meq} / \mathrm{L}$ & 4.45 & 1.74 & 13.52 & 2.24 \\
\hline $\mathrm{Na}$ & $\mathrm{meq} / \mathrm{L}$ & 1.36 & 0.35 & 1.21 & 0.72 \\
\hline $\mathrm{Mg}$ & $\mathrm{meq} / \mathrm{L}$ & 0.43 & 0.20 & 2.68 & 0.27 \\
\hline $\mathrm{K}$ & $\mathrm{meq} / \mathrm{L}$ & 0.15 & 0.08 & 0.22 & 0.10 \\
\hline $\mathrm{Ca}$ & $\mathrm{meq} / \mathrm{L}$ & 2.18 & 0.55 & 7.79 & 0.77 \\
\hline Total Cations & $\mathrm{meq} / \mathrm{L}$ & 4.12 & 1.21 & 11.92 & 1.86 \\
\hline
\end{tabular}

porewater, over-predicts the porewater concentration because of dissolution of salts/minerals in the sediment. For these composite sediment samples, which were air dried, we will not make comparisons and will only report the observed chemical composition of the 1:1 water extracts. We also have converted them to a per gram of oven-dry sediment and related the values reported on a sediment basis to the amount extracted by strong nitric acid and the total sediment content as determined by XRF measurements.

The data in Tables 4.10 to 4.13 show that the water extracts are dominated by calcium, sodium, magnesium, bicarbonate, and sulfate. There are minor amounts of chloride, nitrate, potassium, and silicon but no highly water-leachable levels of trace metals in the extracts. The water extract from the Hanford fine sand shows high concentrations of calcium, magnesium, sodium, chloride, and sulfate compared to the other Hanford formation sediment. There are no waste sites nearby that could have realistically contaminated this shallow depth where the Hanford fine sand composite came from. The source for the higher anion and cation concentrations in the Hanford fine sand sample is interpreted as evaporitic (absorption and subsequent evaporation of naturally occurring meteoric water). The fact that this unit retains more meteoric water is demonstrated by the presence of vegetation in Figure 2.12 and a darker color due to a higher moisture content shown in Figure 2.14. The only source for this water is natural recharge (i.e., percolating rain and snowmelt from the surface). Over time, the zone containing the Hanford fine sand behaves like a sponge, absorbing a constant supply of constituents dissolved in the groundwater and/or leached from the overlying deposits of the Hanford formation. Simultaneous evaporation of this water over time would lead to a concentration of the dissolved constituents. In contrast, the anions and cations are not elevated in the Hanford coarse sand composite sample, which immediately underlies the Hanford fine sand (see Figure 2.14). This would suggest that either (1) all the recharge water is effectively retained by the Hanford fine sand, or (2) excess recharge water is not absorbed by, and rapidly drains through, the Hanford coarse sand. 
The Ringold silt also shows moderate amounts of the same three cations but no elevated chlorine. Instead, there is elevated sulfate and nitrate. As shown in Table 4.13, there is an excess of anions in all the water extracts when comparing the electrical charge balance. The inductively coupled plasma (ICP) sulfur value shown in Table 4.11 compares quite favorably with the sulfate value measured by ion chromatography (IC) shown in Table 4.10. The ICP phosphorous value shown in Table 4.11 is biased high when converted to phosphate and compared to the IC data shown in Table 4.10. Because the ratio of water to sediment used in the water extracts was 1:1, the data in Tables 4.10 to 4.13 with the units of milligrams per liter or meq per liter also represent $\mu \mathrm{g}$ or microequivalents per gram of soil.

The data in Tables 4.10 and 4.11 show that the Ringold silt and the Hanford fine sand are relatively similar compared to the Hanford coarse sand and borehole fine sand especially with respect to EC, alkalinity, calcium, nitrate, potassium, sodium, and sulfate. The Hanford fine sand has particularly high concentrations of calcium, chloride, magnesium, and sulfate. In general, the concentrations of various constituents in the water extracts of the composite samples are similar to those in samples from boreholes 299-W22-48 and 299-W22-50, though several differences exist. For example, chloride and nitrate are lower in the extracts from the discrete boreholes than from the composite samples. This is probably because borehole samples are from depths beyond the influence of near-surface recharge. Other reasons for the differences and similarities among samples may be a function of variables including grain size (surface area), mineralogy, degree of weathering, and man-induced influences. Variations among samples will be better understood as the database of analyses increases.

\section{9 $8 \mathrm{M}$ Nitric Acid Extraction}

The results of the acid extracts are shown in Tables 4.14 and 4.15. Table 4.16 compares the percentage of each element dissolved by the nitric acid extract compared to the total elemental composition in the sediment as determined by XRF. In general, the acid extraction removes only a few percent of the total alkali metals (potassium and sodium ), about half of the major alkaline earth metals (calcium and magnesium), and less (about 10\% to 15\%) of the minor alkaline earths (barium and strontium), very little of the silicon, about $15 \%$ of the aluminum and titanium, about $70 \%$ of the iron and manganese, and $25 \%$ to $70 \%$ of the various trace metals. The amount of any element removed from the Hanford coarse sand by acid digestion is less than the other three composite sediment samples. This may be a function of mineralogy, whereby the Hanford coarse sand contains significantly more indigenous basalt, which is depleted in trace metals, compared to the more quartz-feldspar-rich Hanford fine sand and Ringold silt composite samples. Alternatively, the larger particles have less available surface area to react with the acid. The Ringold silt releases a higher percentage of its elements into the acid extract, perhaps as a result of its more highly weathered state. 
Table 4.14. Major Cations in Acid Extracts for Composite Sediment Samples. Analyzed using the ICP method.

\begin{tabular}{|c|c|c|c|c|c|}
\hline Constituent & Units & Ringold Silt & $\begin{array}{l}\text { Hanford Coarse } \\
\text { Sand }\end{array}$ & $\begin{array}{l}\text { Hanford Fine } \\
\text { Sand }\end{array}$ & $\begin{array}{c}\text { Borehole Fine } \\
\text { Sand }\end{array}$ \\
\hline $\mathrm{Na}$ & $\mu \mathrm{g} / \mathrm{g}$ & - - - & - - - & - - - & $-\ldots$ \\
\hline $\mathrm{Mg}$ & $\mu \mathrm{g} / \mathrm{g}$ & 12,553 & 3,029 & 6,537 & 5,690 \\
\hline $\mathrm{Al}$ & $\mu \mathrm{g} / \mathrm{g}$ & 23,256 & 4,067 & 11,908 & 8,954 \\
\hline $\mathrm{Si}$ & $\mu \mathrm{g} / \mathrm{g}$ & 11.1 & 82.3 & 20.0 & 38.1 \\
\hline $\mathrm{P}$ & $\mu \mathrm{g} / \mathrm{g}$ & $316^{(a)}$ & $766^{(a)}$ & $647^{(a)}$ & $539^{(a)}$ \\
\hline$S$ & $\mu \mathrm{g} / \mathrm{g}$ & 43.5 & 62.7 & 142.5 & 47.9 \\
\hline K & $\mu \mathrm{g} / \mathrm{g}$ & 2,455 & 704 & 2,079 & 1915 \\
\hline $\mathrm{Ca}$ & $\mu \mathrm{g} / \mathrm{g}$ & 15,168 & 4,922 & 11,101 & 9674 \\
\hline $\mathrm{Ti}$ & $\mu \mathrm{g} / \mathrm{g}$ & 541 & 681 & 1,029 & 696 \\
\hline $\mathrm{Mn}$ & $\mu \mathrm{g} / \mathrm{g}$ & 648 & 187 & 429 & 316 \\
\hline $\mathrm{Fe}$ & $\mu \mathrm{g} / \mathrm{g}$ & 34,626 & 12,814 & 19,741 & 15,094 \\
\hline $\mathrm{Sr}$ & $\mu \mathrm{g} / \mathrm{g}$ & 41.2 & 19.9 & 50.8 & 37.3 \\
\hline $\mathrm{Ba}$ & $\mu \mathrm{g} / \mathrm{g}$ & 110 & 43.9 & 97.3 & 81.2 \\
\hline
\end{tabular}

(a) Phosphorous data is suspect from spectral/matrix interferences.

\subsection{Exchangeable Base Cations}

Exchangeable base cation data are shown in Tables 4.17 and 4.18. The sum of the base exchange cations gives intermediate values between the two cation exchange capacity measurements that were discussed in Section 4.7. The ammonium acetate extracts show that calcium is the dominant cation ( $~ 80 \%$ to $90 \%$ of the total) that can be displaced and magnesium also accounts for about $10 \%$ of the displaceable cations. The potassium and sodium make up the remainder of the cations. Barium and strontium make up less than $0.1 \%$ of the base exchangeable cations. In general, the ammonium acetate extraction yields an upper limit for the cation exchange capacity for calcareous sediment because it also dissolves some of the calcium carbonate present. 
Table 4.15. Trace Metals in Acid Extracts of Composite Sediment Samples. Analyzed using ICP or ICP-MS methods.

\begin{tabular}{||l|c|c|c|c|c||}
\hline \multicolumn{1}{|c|}{ Constituent } & Units & Ringold Silt & $\begin{array}{c}\text { Hanford Coarse } \\
\text { Sand }\end{array}$ & $\begin{array}{c}\text { Hanford Fine } \\
\text { Sand }\end{array}$ & $\begin{array}{c}\text { Borehole Fine } \\
\text { Sand }\end{array}$ \\
\hline \hline $\mathrm{Be}$ & $\mu \mathrm{g} / \mathrm{g}$ & 0.94 & 0.16 & 0.41 & 0.34 \\
\hline $\mathrm{B}$ & $\mu \mathrm{g} / \mathrm{g}$ & 2.09 & 10.42 & 7.25 & 8.55 \\
\hline $\mathrm{Cr}{ }^{(\mathrm{a})}$ & $\mu \mathrm{g} / \mathrm{g}$ & 39.7 & 4.3 & 17.2 & 14.9 \\
\hline $\mathrm{Cr}$ & $\mu \mathrm{g} / \mathrm{g}$ & 40.5 & 4.5 & 16.7 & 14.5 \\
\hline $\mathrm{Co}$ & $\mu \mathrm{g} / \mathrm{g}$ & 16.2 & 6.5 & 11.5 & 7.6 \\
\hline $\mathrm{Ni}$ & $\mu \mathrm{g} / \mathrm{g}$ & 35.4 & 5.7 & 16.6 & 12.8 \\
\hline $\mathrm{Cu}$ & $\mu \mathrm{g} / \mathrm{g}$ & 27.4 & 9.2 & 12.7 & 8.9 \\
\hline $\mathrm{Zn}$ & $\mu \mathrm{g} / \mathrm{g}$ & $\mathrm{Conflict}{ }^{(\mathrm{b})}$ & Conflict & Conflict & Conflict \\
\hline $\mathrm{As}^{(\mathrm{b})}$ & $\mu \mathrm{g} / \mathrm{g}$ & 15.9 & 1.0 & 2.9 & 3.9 \\
\hline $\mathrm{Se}^{(\mathrm{a})}$ & $\mu \mathrm{g} / \mathrm{g}$ & $<0.3$ & $<0.3$ & $<0.3$ & $<0.3$ \\
\hline $\mathrm{Mo}^{(\mathrm{a})}$ & $\mu \mathrm{g} / \mathrm{g}$ & 0.27 & 0.14 & 0.17 & 0.24 \\
\hline $\mathrm{Tc}^{(\mathrm{a}, \mathrm{c})}$ & $\mathbf{p C i} / \mathrm{g}$ & $<\mathbf{0 . 0 3}$ & $<\mathbf{0 . 0 3}$ & $<\mathbf{0 . 0 3}$ & $<\mathbf{0 . 0 3}$ \\
\hline $\mathrm{Ru}^{(\mathrm{a})}$ & $\mu \mathrm{g} / \mathrm{g}$ & $<0.001$ & $<0.001$ & $<0.001$ & $<0.001$ \\
\hline $\mathrm{Ag}^{(\mathrm{a})}$ & $\mu \mathrm{g} / \mathrm{g}$ & 0.022 & 0.038 & 0.055 & 0.045 \\
\hline $\mathrm{Cd}^{(\mathrm{a})}$ & $\mu \mathrm{g} / \mathrm{g}$ & 0.137 & 0.044 & 0.077 & 0.080 \\
\hline $\mathrm{Pb}^{(\mathrm{a})}$ & $\mu \mathrm{g} / \mathrm{g}$ & 14.90 & 2.45 & 6.38 & 5.93 \\
\hline $\mathrm{Pb}^{(\mathrm{ab}}$ & $\mu \mathrm{g} / \mathrm{g}$ & 14.22 & 2.84 & 6.07 & 5.40 \\
\hline $\mathrm{U}^{(\mathrm{a})}$ & $\mu \mathrm{g} / \mathrm{g}$ & 0.95 & 0.32 & 0.59 & 0.62 \\
\hline$(\mathrm{a})$ & & & & \\
\hline
\end{tabular}

(a) Inductively coupled plasma mass spectrometry (ICP-MS) instrument was used; when not noted, ICP was used.

(b) There were two spectral lines for zinc that were monitored and they gave conflicting data for samples and standards. We did not feel it was useful to pursue resolution of this problem at this time.

(c) Values in bold are converted to activity per gram. 
Table 4.16. Percentage of the Total Element that Dissolves During Acid Extraction of Composite Sediment Samples

\begin{tabular}{|c|c|c|c|c|}
\hline Constituent & Ringold Silt & $\begin{array}{c}\text { Hanford } \\
\text { Coarse Sand }\end{array}$ & $\begin{array}{l}\text { Hanford Fine } \\
\text { Sand }\end{array}$ & $\begin{array}{l}\text { Borehole } \\
\text { Fine Sand }\end{array}$ \\
\hline $\mathrm{Na}$ & -- &.- & -- & -- \\
\hline $\mathrm{Mg}$ & $40 \%$ & $16 \%$ & $29 \%$ & $30 \%$ \\
\hline $\mathrm{Al}$ & $26 \%$ & $5 \%$ & $16 \%$ & $13 \%$ \\
\hline $\mathrm{Si}$ & $0 \%$ & $0 \%$ & $0 \%$ & $0 \%$ \\
\hline $\mathrm{P}$ & $40 \%$ & $81 \%$ & $67 \%$ & $61 \%$ \\
\hline$S$ & $19 \%$ & $22 \%$ & $31 \%$ & $20 \%$ \\
\hline K & $10 \%$ & $4 \%$ & $13 \%$ & $10 \%$ \\
\hline $\mathrm{Ca}$ & $87 \%$ & $16 \%$ & $40 \%$ & $43 \%$ \\
\hline $\mathrm{Ti}$ & $13 \%$ & $13 \%$ & $22 \%$ & $21 \%$ \\
\hline $\mathrm{Mn}$ & $101 \%$ & $27 \%$ & $65 \%$ & $68 \%$ \\
\hline $\mathrm{Fe}$ & $81 \%$ & $30 \%$ & $56 \%$ & $61 \%$ \\
\hline $\mathrm{Sr}$ & $26 \%$ & $4 \%$ & $14 \%$ & $11 \%$ \\
\hline $\mathrm{Ba}$ & $14 \%$ & $6 \%$ & $16 \%$ & $12 \%$ \\
\hline $\mathrm{Cr}^{(\mathrm{a})}$ & $43 \%$ & $10 \%$ & $28 \%$ & $25 \%$ \\
\hline $\mathrm{Cr}$ & $44 \%$ & $11 \%$ & $27 \%$ & $24 \%$ \\
\hline $\mathrm{Co}$ & $>25 \%$ & $>10 \%$ & $19 \%$ & $>15 \%$ \\
\hline $\mathrm{Ni}$ & $75 \%$ & $26 \%$ & $53 \%$ & $61 \%$ \\
\hline $\mathrm{Cu}$ & $77 \%$ & $45 \%$ & $56 \%$ & $67 \%$ \\
\hline$A s^{(a)}$ & $69 \%$ & $28 \%$ & $65 \%$ & $111 \%$ \\
\hline $\mathrm{Se}^{(\mathrm{a})}$ & -- & -- & -- & -- \\
\hline $\mathrm{Mo}^{(\mathrm{a})}$ & $>11 \%$ & $>6 \%$ & $>7 \%$ & $>10 \%$ \\
\hline $\mathrm{Ag}^{(\mathrm{a})}$ & $>0 \%$ & $>0 \%$ & $>1 \%$ & $>1 \%$ \\
\hline $\mathrm{Cd}^{(\mathrm{a})}$ & $>1 \%$ & $>0 \%$ & $>1 \%$ & $>1 \%$ \\
\hline $\mathrm{Pb}^{(\mathrm{a})}$ & $60 \%$ & $19 \%$ & $47 \%$ & $35 \%$ \\
\hline $\mathrm{Pb}$ & $57 \%$ & $23 \%$ & $45 \%$ & $32 \%$ \\
\hline $\mathrm{U}^{(\mathrm{a})}$ & $>12 \%$ & $>5 \%$ & $9 \%$ & $>9 \%$ \\
\hline \multicolumn{5}{|c|}{$\begin{array}{l}\text { (a) Inductively coupled plasma mass spectrometry (ICP-MS) } \\
\text { instrument was used; when not noted, ICP was used. } \\
--=\text { selenium concentration in both measurements were < values. }\end{array}$} \\
\hline
\end{tabular}


Table 4.17. Chemical Composition of Ammonium Acetate Extraction for Composite Sediment Samples

\begin{tabular}{|c|c|c|c|c|c|c|c|c|c|}
\hline \multirow{2}{*}{ Composite Name } & \multicolumn{6}{|c|}{$\mathrm{meq} / \mathrm{L}$} & \multicolumn{3}{|c|}{$\mu \mathrm{g} / \mathrm{L}$} \\
\hline & $\mathrm{Ba}$ & $\mathrm{Ca}$ & $\mathrm{K}$ & $\mathrm{Mg}$ & $\mathrm{Sr}$ & $\mathrm{Na}$ & $\mathrm{Fe}$ & $\mathrm{Mn}$ & $\mathrm{Si}$ \\
\hline Ringold Silt & 0.10 & 60.09 & 1.48 & 8.30 & 0.11 & 1.51 & $<0.25$ & 0.001 & 9.03 \\
\hline Hanford Coarse Sand & 0.05 & 28.80 & 1.36 & 4.67 & 0.06 & 0.53 & $<0.25$ & 1.336 & 7.53 \\
\hline Hanford Fine Sand & 0.06 & 43.87 & 1.32 & 9.23 & 0.09 & 1.03 & $<0.25$ & 0.026 & 13.03 \\
\hline $\begin{array}{l}\text { Hanford Fine Sand } \\
\text { (duplicate) }\end{array}$ & 0.06 & 44.89 & 1.35 & 9.33 & 0.10 & 1.06 & $<0.25$ & 0.026 & 13.04 \\
\hline Borehole Fine Sand & 0.08 & 30.01 & 0.84 & 3.87 & 0.06 & 0.84 & 0.02 & 0.490 & 8.12 \\
\hline
\end{tabular}

Table 4.18. Exchangable Base Cations Compared to Cation Exchange Capacities Estimates for Composite Sediment Samples

\begin{tabular}{|c|c|c|c|c|c|c|c|c|c|}
\hline \multirow{3}{*}{ Composite Name } & \multicolumn{7}{|c|}{ Ammonium Acetate } & $\begin{array}{l}\text { Polemio and } \\
\text { Rhoades (1977) }\end{array}$ & $\begin{array}{l}\text { Amrhein and } \\
\text { Suarez (1990) }\end{array}$ \\
\hline & \multicolumn{7}{|c|}{ meq/100 g } & \multicolumn{2}{|c|}{ meq/100 g } \\
\hline & $\mathrm{Ba}$ & $\mathrm{Ca}$ & K & $\mathrm{Mg}$ & $\mathrm{Sr}$ & $\mathrm{Na}$ & Sum & & \\
\hline Ringold Silt & 0.024 & 14.057 & 0.347 & 1.941 & 0.026 & 0.353 & 16.75 & $28.5 \pm 2.4$ & $11.6 \pm 1.1$ \\
\hline $\begin{array}{l}\text { Hanford Coarse } \\
\text { Sand }\end{array}$ & 0.012 & 6.743 & 0.317 & 1.094 & 0.014 & 0.124 & 8.30 & $12.2 \pm 2.1$ & $1.7 \pm 0.3$ \\
\hline Hanford Fine Sand & 0.014 & 10.431 & 0.314 & 2.181 & 0.022 & 0.246 & 13.21 & $18.4 \pm 2.7$ & $7.8 \pm 3.8$ \\
\hline Borehole Fine Sand & 0.019 & 6.992 & 0.196 & 0.902 & 0.013 & 0.196 & 8.32 & $9.2 \pm 8.9$ & $2.9 \pm 0.6$ \\
\hline
\end{tabular}




\subsection{Analytical Results for Clean Borehole Samples}

\subsection{Analytical Results for Borehole 299-W22-48}

Laboratory analytical results of core samples from clean borehole 299-W22-48 are presented in this section. Sample depths, stratigraphic unit, and types of laboratory analyses performed are summarized in Table 5.1. Sampling depths for laboratory moisture analysis are listed in a separate table (Table 5.2).

Table 5.1. Sediment Core Samples Selected from Borehole 299-W22-48 for Laboratory Analysis

\begin{tabular}{|c|c|c|}
\hline Depth (ft bgs) $)^{(\mathbf{a})}$ & Stratigraphic Unit* & Analysis \\
\hline 1 & H1a & WL \\
\hline 6 & H1a & WL \\
\hline 9.5 & H1a & WL \\
\hline 12.5 & H1a & WL \\
\hline 14.5 & H1a & WL \\
\hline 17 & H1a & WL \\
\hline 19.5 & H1a & WL \\
\hline 22 & H1a & WL \\
\hline 24.5 & H1a & WL \\
\hline 27 & H1a & WL \\
\hline 29.5 & H1a & $\mathrm{CaCO} 3, \mathrm{WL}$ \\
\hline 32 & H1a & $\mathrm{CaCO} 3, \mathrm{WL}$ \\
\hline 37 & H1a & DS, WL \\
\hline 39.5 & H1a & DS, AL, WL, HY, XRD, XRF, CEC, PD, CaCO3, EBC, WL \\
\hline 42 & H1 & DS, WL \\
\hline 44.5 & H1 & DS, WL \\
\hline 47 & H1 & DS, AL, WL, HY, XRD, XRF, PD, CaCO3, EBC, WL \\
\hline 50 & H1 & DS, WL \\
\hline 53.5 & H1 & DS, WL \\
\hline 56 & H1 & $\mathrm{DS}, \mathrm{CaCO} 3, \mathrm{WL}$ \\
\hline 57.5 & $\mathrm{H} 1$ & DS, WL \\
\hline 62 & $\mathrm{H} 2$ & DS \\
\hline 64.5 & $\mathrm{H} 2$ & DS \\
\hline 67 & $\mathrm{H} 2$ & DS \\
\hline 69.5 & $\mathrm{H} 2$ & DS \\
\hline 70 & $\mathrm{H} 2$ & DS \\
\hline 74.5 & $\mathrm{H} 2$ & $\mathrm{DS}, \mathrm{CaCO} 3, \mathrm{WL}$ \\
\hline 77 & $\mathrm{H} 2$ & $\mathrm{DS}, \mathrm{AL}$ \\
\hline 91.5 & $\mathrm{H} 2$ & DS, AL, WL, HY, XRD, XRF, CEC, PD, CaCO3, EBC, WL, PW \\
\hline 101.5 & $\mathrm{H} 2$ & DS, AL, WL, HY, XRD, XRF, CEC, PD, CaCO3, EBC, WL, PW \\
\hline 106.5 & $\mathrm{H} 2$ & $\mathrm{CaCO} 3, \mathrm{WL}$ \\
\hline
\end{tabular}


Table 5.1. (Contd)

\begin{tabular}{|c|c|c|}
\hline Depth (ft bgs) & Stratigraphic Unit* & Analysis \\
\hline 115.5 & $\mathrm{H} 2$ & $\mathrm{CaCO} 3, \mathrm{WL}$ \\
\hline 136 & $\mathrm{PPlz}$ & DS, AL, WL, HY, XRD, XRF, CEC, PD, CaCO3, EBC, WL \\
\hline 143.5 & $\mathrm{PPlz}$ & $\mathrm{CaCO} 3, \mathrm{WL}$ \\
\hline 146 & PPlc & AL, WL, HY, XRD, XRF, CEC, PD, CaCO3, EBC, WL \\
\hline 148.5 & PPlc & AL, WL, HY, XRD, XRF, CEC, PD, CaCO3, EBC, WL \\
\hline 151 & Rtf & $\mathrm{CaCO} 3, \mathrm{WL}$ \\
\hline 163.5 & Rtf & $\mathrm{DS}, \mathrm{AL}, \mathrm{WL}, \mathrm{HY}, \mathrm{XRD}, \mathrm{XRF}, \mathrm{CEC}, \mathrm{PD}, \mathrm{CaCO} 3, \mathrm{EBC}, \mathrm{WL}$ \\
\hline 170 & Rtf & $\mathrm{CaCO} 3, \mathrm{WL}$ \\
\hline 172.5 & Rtf & $\mathrm{CaCO} 3, \mathrm{WL}$ \\
\hline 187 & Rtf & $\mathrm{CaCO} 3, \mathrm{WL}$ \\
\hline 192 & Rwi(e) & $\mathrm{AL}, \mathrm{CaCO} 3, \mathrm{EBC}, \mathrm{WL}$ \\
\hline $\begin{array}{l}\text { (a) Multiply by } \\
* \text { See Table } 2.1 \\
\text { AL }=\text { Acid } \\
\text { CEC }=\text { Catio } \\
\text { CaCO3 }=\text { Calci } \\
\text { DS }=\text { Dry s } \\
\text { EBC }=\text { Exch } \\
\mathrm{HY}=\text { Hydr } \\
\text { PD }=\text { Partic } \\
\text { PW }=\text { Porev } \\
\text { WL }=\text { Wate } \\
\text { XRD }=\text { Mine } \\
\text { XRF }=\text { Bulk }\end{array}$ & $\begin{array}{l}0.3048 \text { to convert to } \mathrm{m} \\
\text { leach ( } 8 \mathrm{M} \text { Nitric Acid } \\
\text { n Exchange Capacity } \\
\text { um Carbonate and Org } \\
\text { ieve } \\
\text { angeable Base Cations } \\
\text { ometer/wet sieve } \\
\text { cle Density } \\
\text { vater Analysis } \\
\text { r leach ( } 1: 1 \text { Sediment-t } \\
\text { ralogy } \\
\text { chemical composition }\end{array}$ & $\begin{array}{l}\text { raction) } \\
\text { Carbon } \\
\text { nmonium Acetate Extraction) } \\
\text { Jater Extraction) }\end{array}$ \\
\hline
\end{tabular}

\subsubsection{Mass Water Content}

For borehole 299-W22-48, only about $25 \%$ of the cores were opened in the laboratory and sampled for moisture, along with other parameters. However, moisture samples were collected at least every 1.6 meters ( 5 feet) in the field from the drive shoe of the split-spoon during drilling. Thus, a relatively complete moisture profile is available for borehole 299-W22-48. Moisture data for borehole 299-W22-48 are listed in Table 5.2; a vertical profile of the moisture distribution is illustrated in Figure 2.19. In Figure 2.19 , moisture samples collected in the field from the drill shoe are distinguished from those collected later in the laboratory from core liners.

The moisture data in Figure 2.19 show two zones of higher moisture within the Hanford formation $\mathrm{H} 2$ unit at about 90 and 105 feet below ground surface (bgs). These are probably associated with thin lenses of fine sand and/or silt that often occur at the tops of graded sand beds within the Hanford formation. The PPlc subunit between 44.4 to 44.9 meters (146 to 149 feet) bgs, displays relatively high moisture content, as does a clastic dike within the upper Ringold unit (Rtf) at 151.8 meters (170 feet) bgs. There is moderate agreement between the laboratory-measured moisture samples and the moisture 
Table 5.2. Moisture Content (wt \%) Measured in Laboratory for Sediment Samples from Borehole 299-W22-48

\begin{tabular}{|c|c|c|c|c|c|c|c|}
\hline \multicolumn{4}{|c|}{ Core Liner } & \multicolumn{4}{|c|}{ Drill Shoe } \\
\hline $\begin{array}{c}\text { Depth } \\
\text { (ft bgs) }^{(\text {a) }}\end{array}$ & $\begin{array}{c}\text { Moisture } \\
\text { Content } \\
\text { (wt\%) }\end{array}$ & $\begin{array}{c}\text { Depth } \\
\text { (ft bgs) }\end{array}$ & $\begin{array}{c}\text { Moisture } \\
\text { Content } \\
\text { (wt\%) }\end{array}$ & $\begin{array}{c}\text { Depth } \\
\text { (ft bgs) }\end{array}$ & $\begin{array}{c}\text { Moisture } \\
\text { Content } \\
\text { (wt\%) }\end{array}$ & $\begin{array}{c}\text { Depth } \\
\text { (ft bgs) }\end{array}$ & $\begin{array}{c}\text { Moisture } \\
\text { Content } \\
(\mathbf{w t} \%)\end{array}$ \\
\hline 1 & 3.87 & 82 & 3.90 & 10.5 & 9.22 & 105 & 12.76 \\
\hline 6 & 9.12 & 84.5 & 4.46 & 15 & 6.67 & 110 & 2.79 \\
\hline 9.5 & 4.86 & 86.5 & 5.43 & 20 & 9.46 & 115 & 4.37 \\
\hline 12 & 6.21 & 91.5 & 19.14 & 25 & 2.41 & 120 & 4.56 \\
\hline 14.5 & 7.63 & 96.5 & 9.62 & 30 & 8.77 & 125 & 2.79 \\
\hline 17 & 5.92 & 101.5 & 21.62 & 35 & 6.06 & 130 & 2.14 \\
\hline 19.5 & 7.70 & 106.5 & 5.50 & 40 & 3.97 & 135 & 7.79 \\
\hline 22 & 5.03 & 111.5 & 3.14 & 45 & 3.08 & 145 & 3.80 \\
\hline 24.5 & 2.22 & 115.5 & 5.29 & 50.5 & 5.31 & 150 & 4.25 \\
\hline 27 & 6.04 & 120.5 & 3.81 & 55 & 3.31 & 155 & 2.24 \\
\hline 29 & 10.60 & 124 & 2.66 & 60 & 2.83 & 160 & 1.99 \\
\hline 32 & 5.33 & 126.5 & 2.60 & 65 & 3.50 & 165 & 2.24 \\
\hline 34.5 & 3.85 & 131.5 & 2.88 & 70.5 & 2.15 & 170 & 14.29 \\
\hline 37 & 5.58 & 134 & 3.51 & 75 & 2.36 & 175 & 2.14 \\
\hline 39.5 & 7.90 & 136 & 5.70 & 80 & 2.40 & 180 & 2.52 \\
\hline 42 & 2.80 & 143.5 & 3.83 & 85 & 7.20 & 185.5 & 2.65 \\
\hline 44.5 & 2.53 & 146 & 14.86 & 90 & 3.15 & 190.5 & 2.22 \\
\hline 47 & 1.88 & 148.5 & 13.58 & 95 & 4.36 & 192 & 2.34 \\
\hline 50 & 5.25 & 151 & 2.81 & 100 & 4.50 & & \\
\hline 53.5 & 2.41 & 155 & 2.11 & & & & \\
\hline 56 & 3.91 & 158.5 & 2.18 & & & & \\
\hline 57.5 & 2.83 & 163.5 & 1.88 & & & & \\
\hline 62 & 2.56 & 167.5 & 1.87 & & & & \\
\hline 64.5 & 2.23 & 170 & 2.99 & & & & \\
\hline 67 & 3.68 & 172.5 & 4.97 & & & & \\
\hline 69.5 & 2.43 & 176 & 2.84 & & & & \\
\hline 72 & 2.64 & 182 & 1.84 & & & & \\
\hline 74.5 & 6.56 & 187 & 2.32 & & & & \\
\hline 77 & 3.55 & 192 & 2.21 & & & & \\
\hline 79.5 & 3.24 & 235 & 10.47 & & & & \\
\hline
\end{tabular}


content as determined with the neutron probe (see Appendix C and Horton and Johnson 2000), though maxima in one set of data are frequently not observed in the other set (see Figure 2.19).

\subsubsection{Particle-Size Distribution}

Both dry sieving and the wet sieving/hydrometer methods were used to determine the particle-size distribution for selected depths in borehole 299-W22-48. The results for dry sieving are presented in Table 5.3 and wet sieving in Table 5.4. An estimate of particle-size distribution, using visual-manual techniques, is also standard practice during geologic logging of the borehole (Appendices A and B). The results of geologic logging and dry sieve analysis helps to define the top contact of the coarse-grained Hanford formation $\mathrm{H} 1$ unit at 12.4 meters (41 feet) bgs; the bottom contact appears less pronounced at about 18.6 meters or 61 feet (Figure 2.19).

The wet sieving data presented in Table 5.4 are skewed toward finer particle-size distributions, compared to the results of dry sieving (see Table 5.3). This is a similar trend observed for composite sediment samples (see Section 4.2). Table 5.5 shows a comparison between the wet sieving/hydrometer data and the dry sieving data. The most significant difference in results between the two methods occurs for the PPlz subunit sample (41.4 meters or 136 feet bgs) where the sand content decreases from $60 \%$ to

Table 5.3. Dry Sieve Results from Borehole 299-W22-48

\begin{tabular}{||c|c|c|c|c||}
\hline $\begin{array}{c}\text { Depth } \\
\text { ft bgs) }^{(\mathbf{a})}\end{array}$ & $\begin{array}{c}\text { Stratigraphic } \\
\text { Unit }\end{array}$ & $\begin{array}{c}\text { Gravel } \\
\text { (wt\%) }\end{array}$ & $\begin{array}{c}\text { Sand } \\
\text { (wt\%) }\end{array}$ & $\begin{array}{c}\text { Silt/Clay } \\
\text { (wt\%) }\end{array}$ \\
\hline 37 & H1a & 0.60 & 91.40 & 7.74 \\
\hline 39.5 & H1a & 1.42 & 89.80 & 8.78 \\
\hline 42.5 & H1 & 63.17 & 36.83 & \\
\hline 44.5 & H1 & 63.26 & 36.74 & 3.64 \\
\hline 47 & H1 & 73.38 & 22.98 & 3.84 \\
\hline 50 & H1 & 19.46 & 76.70 & 1.07 \\
\hline 53.5 & H1 & 21.22 & 77.71 & 2.52 \\
\hline 56 & H1 & 9.46 & 88.02 & 4.66 \\
\hline 57.5 & H1 & 2.96 & 92.39 & 5.19 \\
\hline 62 & H2 & 0.29 & 94.52 & 4.56 \\
\hline 64.5 & H2 & 0.06 & 95.38 & 2.95 \\
\hline 67 & H2 & 0.99 & 96.06 & 2.89 \\
\hline 70 & H2 & 0.96 & 99.04 & 4.17 \\
\hline 69.5 & H2 & 1.58 & 94.26 & 11.81 \\
\hline 74.5 & H2 & 1.74 & 86.46 & 10.21 \\
\hline 77 & H2 & 0.02 & 89.77 & 5.01 \\
\hline 91.5 & H2 & 0.39 & 94.60 & 1.88 \\
\hline 101.5 & H2 & 0.01 & 98.11 & 38.56 \\
\hline 136 & PPlz & 1.06 & 60.33 & 5.79 \\
\hline 163.5 & Rtf & 0.00 & 94.18 & \\
\hline (a) Multiply by 0.3048 to convert to meters. & \multicolumn{3}{|l||}{} \\
\hline
\end{tabular}


Table 5.4. Particle-Size Distribution Determined by Wet Sieving/Hydrometer Method

\begin{tabular}{|c|c|c|c|c|c|}
\hline $\begin{array}{c}\text { Sample } \\
\text { (ft bgs) }^{(a)}\end{array}$ & $\begin{array}{c}\text { Stratigraphic } \\
\text { Unit } \\
\end{array}$ & $\begin{array}{l}\text { Gravel } \\
\text { (wt\%) }\end{array}$ & $\begin{array}{c}\text { Sand } \\
(w t \%)\end{array}$ & $\begin{array}{c}\text { Silt } \\
(w t \%)\end{array}$ & $\begin{array}{c}\text { Clay } \\
(\mathrm{wt} \%)\end{array}$ \\
\hline 39.5 & H1a & 0.16 & 77.59 & 20.58 & 1.68 \\
\hline 47 & $\mathrm{H} 1 \mathrm{a}$ & 64.64 & 18.69 & 15.13 & 1.55 \\
\hline 91.5 & $\mathrm{H} 2$ & 0.25 & 70.65 & 26.99 & 2.11 \\
\hline 101.5 & $\mathrm{H} 2$ & 0 & 78.71 & 18.82 & 2.47 \\
\hline 136 & $\mathrm{PPlz}$ & 0.01 & 18.45 & 75.89 & 5.65 \\
\hline 146 & PPlc* & 52.36 & 27.11 & 15.23 & 5.3 \\
\hline 148.5 & PPlc* & 26.31 & 59.86 & 10.32 & 3.5 \\
\hline 163.5 & Rtf & 0.01 & 89.00 & 9.67 & 1.32 \\
\hline
\end{tabular}

(a) Multiply by 0.3048 to convert to meters.

* Wet sieving samples with high wt $\%$ of calcium carbonate dissolves several wt $\%$ of the starting mass, which may affect reported values.

Table 5.5. Comparison of Particle-Size Distributions for Dry Versus Wet Sieving

\begin{tabular}{|c|c|c|c|c|c|}
\hline Depth $^{(a)}$ & $\begin{array}{c}\text { Stratigraphic } \\
\text { Unit }\end{array}$ & Type & $\begin{array}{c}\text { Gravel } \\
\text { (wt\%) }\end{array}$ & $\begin{array}{l}\text { Sand } \\
\text { (wt\%) }\end{array}$ & $\begin{array}{c}\text { Silt/Clay } \\
\text { (wt \%) }\end{array}$ \\
\hline \multirow[t]{2}{*}{39.5} & \multirow[t]{2}{*}{ H1a } & Dry & 1.42 & 89.8 & 8.78 \\
\hline & & Wet & 0.16 & 77.6 & 22.24 \\
\hline \multirow[t]{2}{*}{47} & \multirow[t]{2}{*}{ H1 } & Dry & 73.4 & 23.0 & 3.6 \\
\hline & & Wet & 64.6 & 18.7 & 16.7 \\
\hline \multirow[t]{2}{*}{91.5} & \multirow[t]{2}{*}{$\mathrm{H} 2$} & Dry & 0.39 & 94.6 & 5.01 \\
\hline & & Wet & 0.25 & 70.6 & 29.2 \\
\hline \multirow[t]{2}{*}{101.5} & \multirow[t]{2}{*}{$\mathrm{H} 2$} & Dry & 0.01 & 98.11 & 1.88 \\
\hline & & Wet & 0 & 78.7 & 21.3 \\
\hline \multirow[t]{2}{*}{136} & \multirow[t]{2}{*}{ PPlz } & Dry & 1.06 & 60.33 & 38.56 \\
\hline & & Wet & 0.01 & 18.4 & 81.6 \\
\hline \multirow[t]{2}{*}{163.5} & \multirow[t]{2}{*}{ Rtf } & Dry & 0 & 94.18 & 5.79 \\
\hline & & Wet & 0.01 & 89.0 & 11.0 \\
\hline
\end{tabular}

$18 \%$ upon wet sieving. At the same time there is an increase in the silt /clay content with the wet sieved sample. This suggests that the PPlz subunit sample contained many sand-sized aggregates of silt/clay that tend to cling together, perhaps via static electrical forces generated during dry sieving. These electrical forces leading to aggregation disperse upon being wetted with a sodium hexametaphosphate dispersing agent. Thus, the wet sieve method appears superior to the dry sieve method. Most particle-size distributions of Hanford sediment have used the dry sieving technique; the particle-size distributions for the fine-grained fractions of these samples may underestimate the amount of fines in these samples. 
Figure 5.1 graphically shows the particle-size distribution (based on wet sieving/hydrometer data) of the four shallower samples (i.e., Hanford formation), and Figure 5.2 shows the distribution for four of the samples collected for particle-size analysis from the Plio Pleistocene unit and Ringold Formation. As

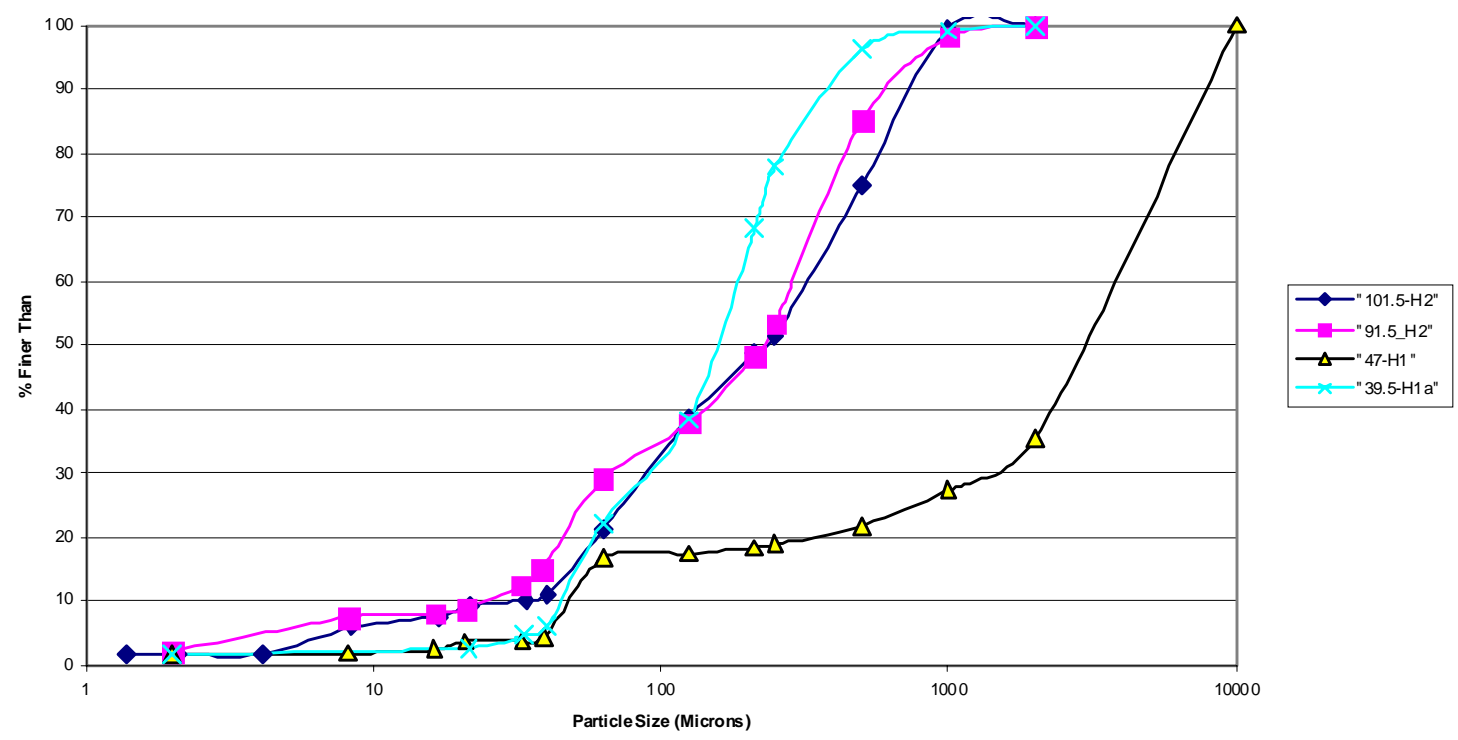

Figure 5.1. Particle-Size Distributions Curves of Hanford Formation Sediment Samples from Borehole 299-W22-48

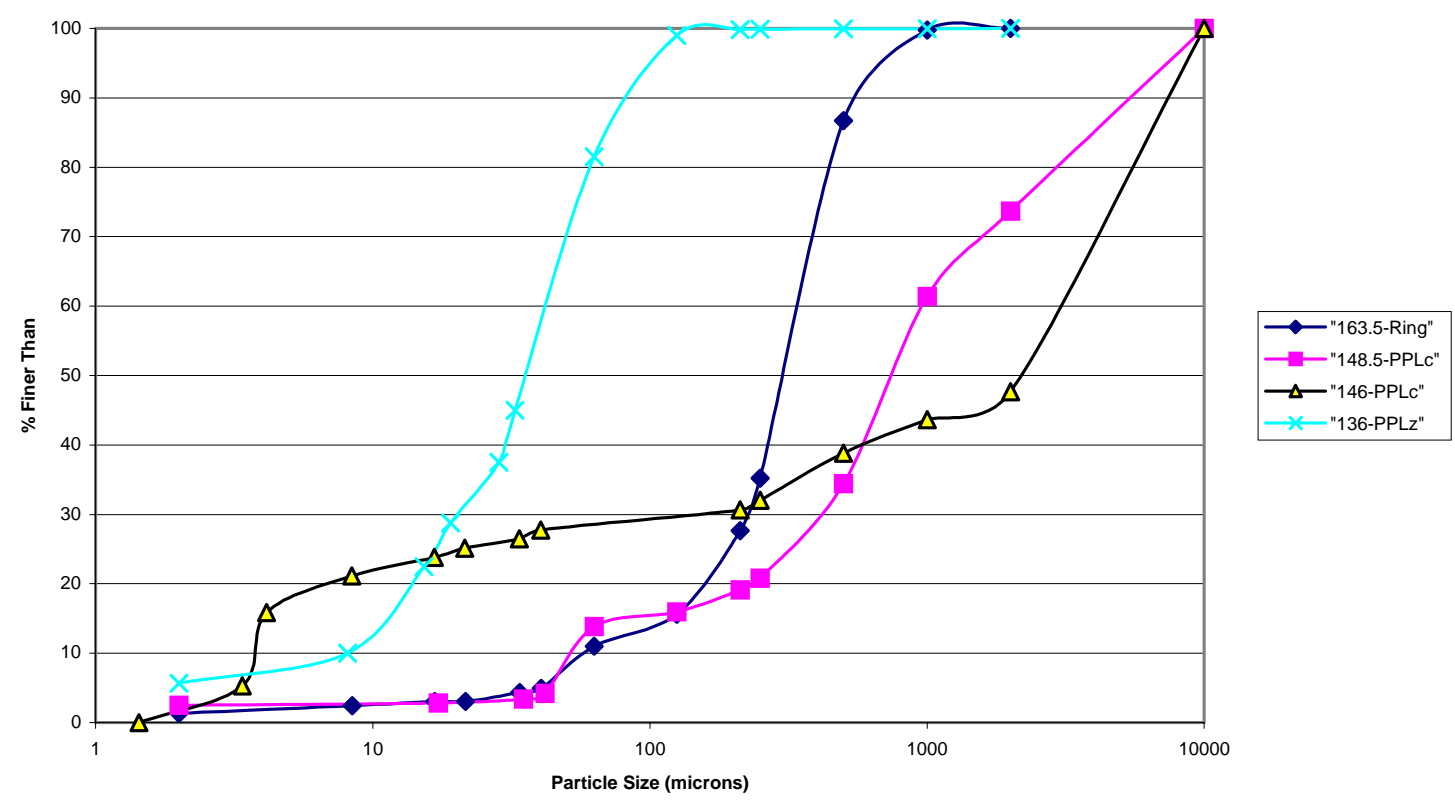

Figure 5.2. Particle-Size Distribution Curves of Sediment Samples below 41.4 meters (136 feet) bgs in Borehole 299-W22-48. Cemented samples from the PPlc subunit could not be completely disaggregated, and, therefore, are not considered representative of the true particle-size distribution of this unit. 
represented in Figure 5.1, gravelly sand of the Hanford formation H1 unit is much coarser than strata directly above or below this unit. Figure 5.2 illustrates how the PPlz and Rtf unit samples consist of many fine-grained sedimentary aggregates, compared to the PPlc subunit, which consists of many calcium-carbonate cemented aggregates of widely varying sizes. Because particles within the PPlc subunit are cemented together with pedogenic calcium carbonate an accurate grain-size distribution cannot be obtained for the PPlc via either sieving method. Another more accurate method to determine the particle-size distribution for the PPLc subunit would be to perform a petrographic analysis, or totally dissolve away all the carbonate cement, which makes up the bulk of the sample, and sieve the remaining solid particles.

\subsubsection{Particle Density}

The particle density of bulk sediment samples was determined for selected aliquots from the borehole 299-W22-48 using pychnometers. The results are shown in Table 5.6.

The particle densities in Table 5.6 reflect the mineral composition of the Hanford formation, PlioPleistocene, and upper Ringold units, which are composed of mostly quartz, plagioclase, and potassium feldspar (discussed in Section 5.1.6). Although the values in Table 5.6 are slightly lower than those reported by Serne et al. (1993), the differences are small, likely caused by slight differences in analytical technique, and are not considered significant for most experimental applications in which standards would be used. Greater particle density (2.76) for the 14.3-meter (47-foot) sample is probably a reflection of a greater number of basalt particles in the Hanford formation $\mathrm{H} 1$ unit. In contrast, relatively low particle densities for the PPlc subunit are a direct reflection of the lower density for caliche (i.e., calcium carbonate).

\subsubsection{Calcium Carbonate and Organic Carbon Content}

Carbon results for borehole 299-W22-48 are shown in Table 5.7; the calculated calcium carbonate equivalent (in terms of grams of calcite per gram of oven-dry sediment) is also presented. In general, the

Table 5.6. Particle Densities for Selected Sediment Samples from Borehole 299-W22-48

\begin{tabular}{||c|c|c|c||}
\hline $\begin{array}{c}\text { Depth } \\
\text { (ft bgs) }\end{array}$ & Stratigraphic Unit & $\begin{array}{c}\text { Particle Density } \\
\left(\mathbf{g} / \mathbf{c m}^{\mathbf{3}} \mathbf{)}\right.\end{array}$ & $\begin{array}{c}\text { Standard Deviation } \\
(\mathbf{3} \text { trials })\end{array}$ \\
\hline \hline 39.5 & $\mathrm{H} 1 \mathrm{a}$ & 2.682 & 0.005 \\
\hline 47 & $\mathrm{H} 1$ & 2.762 & 0.003 \\
\hline 91.5 & $\mathrm{H} 2$ & 2.667 & 0.034 \\
\hline 101.5 & $\mathrm{H} 2$ & 2.620 & 0.016 \\
\hline 136 & $\mathrm{PPlz}$ & 2.661 & 0.003 \\
\hline 140 & $\mathrm{PPlz}$ & 2.680 & 0.007 \\
\hline 146 & $\mathrm{PPlc}$ & 2.535 & 0.011 \\
\hline 148 & PPlc & 2.604 & 0.012 \\
\hline 163.5 & Rtf & 2.651 & 0.011 \\
\hline (a) Multiply by 0.3048 to convert to meters. \\
\hline
\end{tabular}


Table 5.7. Calcium Carbonate and Organic Carbon Content (wt $\%$ ) for Sediment Samples from Borehole 299-W22-48

\begin{tabular}{|c|c|c|c|c|c|}
\hline $\begin{array}{c}\text { Depth } \\
\text { (ft bgs) }^{(\text {a) }}\end{array}$ & $\begin{array}{c}\text { Stratigraphic } \\
\text { Unit }\end{array}$ & $\begin{array}{c}\text { Total Carbon } \\
(\%)\end{array}$ & $\begin{array}{c}\text { Inorganic } \\
\text { Carbon (\%) } \\
\end{array}$ & $\begin{array}{c}\text { Inorganic as } \\
\mathrm{CaCO}_{3}(\%) \\
\end{array}$ & $\begin{array}{c}\text { Organic Carbon } \\
(\%)\end{array}$ \\
\hline 29.5 & H1a & 0.18 & 0.16 & 1.33 & 0.02 \\
\hline 32 & H1a & 0.14 & 0.10 & 0.83 & 0.04 \\
\hline 39.5 & H1a & 0.24 & 0.21 & 1.75 & 0.03 \\
\hline 47 & $\mathrm{H} 1$ & 0.20 & 0.15 & 1.25 & 0.05 \\
\hline 56 & $\mathrm{H} 1$ & 0.28 & 0.22 & 1.83 & 0.06 \\
\hline 74.5 & $\mathrm{H} 2$ & 0.29 & 0.24 & 2.00 & 0.05 \\
\hline 74.5 & $\mathrm{H} 2$ & 0.31 & 0.26 & 2.17 & 0.05 \\
\hline 91.5 & $\mathrm{H} 2$ & 0.26 & 0.22 & 1.83 & 0.04 \\
\hline 101.5 & $\mathrm{H} 2$ & 0.43 & 0.39 & 3.25 & 0.04 \\
\hline 106.5 & $\mathrm{H} 2$ & 0.25 & 0.22 & 1.83 & 0.03 \\
\hline 115.5 & $\mathrm{H} 2$ & 0.27 & 0.26 & 2.17 & 0.01 \\
\hline 136 & $\mathrm{PPlz}$ & 0.40 & 0.35 & 2.92 & 0.05 \\
\hline 143.5 & PPlc & 0.52 & 0.44 & 3.67 & 0.08 \\
\hline 146 & PPlc & 4.78 & 4.60 & 38.37 & 0.17 \\
\hline 148.5 & PPlc & 4.64 & 4.56 & 38.00 & 0.08 \\
\hline 151 & Rtf & 0.16 & 0.13 & 1.08 & 0.03 \\
\hline 163.5 & Rtf & 0.12 & 0.09 & 0.75 & 0.03 \\
\hline 170 & Rtf & 0.15 & 0.13 & 1.08 & 0.02 \\
\hline 172.5 & Rtf & 0.15 & 0.14 & 1.17 & 0.01 \\
\hline 187 & Rtf & 0.02 & 0.01 & 0.08 & 0.01 \\
\hline 192 & Rwi(e) & 0.02 & 0.01 & 0.08 & 0.01 \\
\hline
\end{tabular}

calcium carbonate values for the Hanford formation, which range between about 1 and $5 \mathrm{wt} \%$, are typical for those reported elsewhere (e.g., Last et al. 1989). Samples from the PPlc subunit between 44.4 and 44.8 meters (146 and 149 feet) bgs have naturally high calcium carbonate (up to $40 \mathrm{wt} \%$ ) due to pedogenic alteration and secondary cementation with calcium carbonate. The calcium carbonate content decreases sharply again in the underlying upper Ringold unit (Rtf), which lies below the PPlc (Figure 2.19).

The method used to measure the organic carbon relies on subtracting the inorganic carbon from the total carbon in the sample; for such low carbon values this method is not very accurate. The low values for organic carbon are within the ranges generally reported for sediment at the Hanford Site but if more accurate values are desired then a different, more sensitive method should be used.

\subsubsection{Bulk Chemical Composition}

The bulk chemical composition of core samples from borehole 299 W22-48, as determined by x-ray fluorescence (XRF) and converted to oxides (see Section 3.2.5), is shown in Table 5.8. We have 
Table 5.8. Bulk Chemical Composition of Sediment Samples from Borehole 299-W22-48 (wt\% as oxides)

\begin{tabular}{|c|c|c|c|c|c|c|c|c|}
\hline $\begin{array}{c}\text { Depth } \\
\text { (ft bgs) }^{(a)}\end{array}$ & 39.5 & 47 & 91.5 & 101.5 & 136 & 146 & 148.5 & 163.5 \\
\hline Stratigraphic Unit & H1a & H1 & H2 & H2 & PPlz & PPlc & PPIc & Rtf \\
\hline \multicolumn{9}{|l|}{ Oxides } \\
\hline $\mathrm{Na}_{2} \mathrm{O}$ & 2.25 & 2.68 & 2.26 & 2.25 & 1.62 & 0.63 & 1.06 & 2.01 \\
\hline $\mathrm{MgO}$ & 3.32 & 4.23 & 3.00 & 3.35 & 4.14 & 7.24 & 4.16 & 2.97 \\
\hline $\mathrm{CO}_{2}$ & 0.84 & 0.60 & 0.88 & 1.56 & 1.40 & 18.39 & 18.24 & 0.36 \\
\hline $\mathrm{Al}_{2} \mathrm{O}_{3}$ & 14.19 & 14.55 & 13.13 & 13.36 & 13.21 & 6.24 & 8.03 & 13.11 \\
\hline $\mathrm{SiO}_{2}$ & 70.17 & 62.15 & 72.20 & 72.31 & 67.39 & 36.43 & 43.47 & 73.91 \\
\hline $\mathrm{P}_{2} \mathrm{O}_{5}$ & $<0.21$ & $<0.25$ & $<0.20$ & $<0.21$ & $<0.20$ & $<0.32$ & $<0.32$ & $<0.19$ \\
\hline $\mathrm{SO}_{3}$ & 0.08 & 0.12 & 0.06 & 0.09 & 0.06 & 0.39 & 0.32 & 0.06 \\
\hline $\mathrm{Cl}$ & 0.04 & $<0.02$ & 0.04 & 0.04 & 0.03 & $<0.02$ & $<0.02$ & 0.04 \\
\hline $\mathrm{K}_{2} \mathrm{O}$ & 2.52 & 1.49 & 2.61 & 2.52 & 2.31 & 0.97 & 1.52 & 2.90 \\
\hline $\mathrm{CaO}$ & 3.16 & 7.72 & 3.16 & 3.24 & 3.37 & 24.08 & 20.90 & 2.08 \\
\hline $\mathrm{TiO}_{2}$ & 0.61 & 1.53 & 0.52 & 0.59 & 0.64 & 0.55 & 0.39 & 0.54 \\
\hline $\mathrm{V}_{2} \mathrm{O}_{5}$ & 0.01 & 0.05 & 0.01 & 0.01 & 0.01 & 0.02 & 0.01 & 0.01 \\
\hline $\mathrm{Cr}_{2} \mathrm{O}_{3}$ & 0.00 & 0.01 & 0.01 & 0.01 & 0.01 & 0.00 & 0.01 & 0.00 \\
\hline $\mathrm{MnO}$ & 0.07 & 0.14 & 0.06 & 0.06 & 0.06 & 0.25 & 0.05 & 0.05 \\
\hline $\mathrm{Fe}_{2} \mathrm{O}_{3}$ & 4.00 & 9.64 & 3.46 & 3.89 & 4.13 & 3.41 & 3.06 & 3.36 \\
\hline $\mathrm{SrO}$ & 0.04 & 0.04 & 0.04 & 0.04 & 0.03 & 0.04 & 0.04 & 0.03 \\
\hline $\mathrm{BaO}$ & 0.09 & 0.07 & 0.09 & 0.09 & 0.07 & 0.04 & 0.05 & 0.08 \\
\hline Total & 101.61 & 105.28 & 101.75 & 103.63 & 98.67 & 99.01 & 101.65 & 101.70 \\
\hline
\end{tabular}

assumed that the iron present in the sediment is all ferric oxide though there may be some reduced (ferrous oxide) iron as well. We have adjusted the total content to reflect the presence of calcium carbonate by converting the calcium carbonate in Table 5.7 back to percent carbon dioxide and adding it to the XRF totals.

The data in Table 5.8 suggest two trends in bulk chemical composition that are a direct reflection of the geology. The most obvious trend is the substantial increase in calcium oxide and carbon dioxide in the calcic PPlc subunit (44.4 to 44.8 meters or 146 to 149 feet bgs). Less striking is a decrease in potassium oxide and increases in calcium oxide and iron oxide in the gravelly Hanford formation $\mathrm{H} 1 \mathrm{unit}$ (14.3 meters or 47 feet bgs), compared to the strata above and below. This trend is consistent with the higher basalt content for coarser-grained facies of the Hanford formation. Basalt is composed of the minerals plagioclase and pyroxene, which are more concentrated in the elements calcium and iron, respectively. There also appears to be a decrease in sodium oxide and an increase in magnesium oxide in the PPlz subunit at 41.4 meters (136 feet) bgs relative to the overlying $\mathrm{H} 2$ unit of the Hanford formation. Similar trends are noted in samples from borehole 299-W22-50 (to be discussed later) and probably represent differences in the mineralogy and/or grain size of the various sediment types. 
The calculated mass balances range between $98 \%$ and $105 \%$ with a mean of $101 \pm 2 \mathrm{wt} \%$ for the 14 samples.

\subsubsection{Mineralogy}

The mineralogy of the bulk, as well as the silt- and clay-size fractions from selected depths from boreholes 299-W22-48 and -50 was determined by x-ray diffraction (XRD) techniques (see Section 3.2.6). The results for both boreholes are so similar that the data will only be presented once here and in Appendix H. In fact, aside from differences in the amount of calcite present in the PPlc subunit between the two boreholes, the overall XRD-determined mineralogy for a given geologic unit is almost identical. Table 5.9 presents the semiquantitative mineralogical distribution for the bulk sediment samples and Table 5.10 presents data for the clay-size fraction only from borehole 299-W22-48.

Sediment in both boreholes was largely dominated by quartz ( $45 \%$ to $95 \%$ ), plagioclase feldspar ( $\sim 10 \%$ to $20 \%$ ), and alkali feldspar ( $20 \%$ to $40 \%)$. Minor amounts of mica, chlorite, and amphibole were also detected in the samples. As expected, the Plio-Pleistocene unit caliche (44.4 to 44.8 meters or 146 to 149 feet bgs) in borehole 299-W22-48 is predominantly composed of calcite ( 40\%). Lesser mineral constituents included quartz ( $20 \%$ to $25 \%)$, plagioclase feldspar ( $10 \%$ to $20 \%)$, and potassium feldspar $(<10 \%)$.

Additionally, the silt fraction from selected depths was examined by XRD and appeared similar to the bulk sediment in mineral content. XRD patterns of the bulk and silt fractions along with semiquantitative measurements of the non-clay minerals in the bulk sediment are presented in Appendix $\mathrm{H}$ for both boreholes.

Table 5.9. Semiquantitative Mineral Content (wt \%) for Sediment Samples from Borehole 299-W22-48-Bulk Sediment Sample

\begin{tabular}{|c|c|c|c|c|c|}
\hline $\begin{array}{c}\text { Sample Depth } \\
\text { (ft bgs) }^{\text {(a) }}\end{array}$ & Quartz & K-Feldspar & Na-Feldspar & Calcite & Tota \\
\hline 39.5 (H1a) & 60 & $<<5$ & 20 & ND & 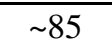 \\
\hline 47 (H1) & 20 & $<5$ & 15 & 10 & $\sim 50$ \\
\hline $91.5(\mathrm{H} 2)$ & 45 & 40 & 15 & ND & $\begin{array}{l}\sim 100 \\
\end{array}$ \\
\hline $101.5(\mathrm{H} 2)$ & 95 & $<5$ & 20 & ND & $\sim 115$ \\
\hline 136 (PPlz) & 80 & 30 & 10 & ND & $\sim 120$ \\
\hline 146 (PPlc) & 25 & $<5$ & 10 & 40 & $\sim>80$ \\
\hline 148.5 (PPlc) & 25 & 10 & 20 & 40 & $\sim 95$ \\
\hline 163.5 (Rtf) & 65 & 20 & 10 & ND & $\sim 95$ \\
\hline
\end{tabular}


Table 5.10. Semiquantitative Mineral Content (wt\%) for Sediment Samples from Borehole 299-W22-48-Clay-Size Fraction Only

\begin{tabular}{|c|c|c|c|c|c|c|c|c|}
\hline $\begin{array}{c}\text { Sample Depth } \\
\text { (ft bgs) } \\
\text { (a) } \\
\text { (Stratigraphic Unit) }\end{array}$ & Quartz & $\underset{\mathbf{r}}{\text { Feldspa }}$ & Calcite & $\begin{array}{c}\text { Smectit } \\
\mathbf{e}\end{array}$ & Illite & $\begin{array}{c}\text { Chlorit } \\
\text { e }\end{array}$ & $\begin{array}{c}\text { Kaolinit } \\
\mathbf{e}\end{array}$ & Total \\
\hline 39.5 (H1a) & $<<5$ & $<<5$ & Trace & 25 & 20 & 15 & $<<5$ & $\begin{array}{l}\sim 75 \\
\sim 5\end{array}$ \\
\hline $47(\mathrm{H} 1)$ & $<5$ & $<5$ & 5 & 10 & 10 & 10 & $<5$ & 250 \\
\hline $91.5(\mathrm{H} 2)$ & $<5$ & $<5$ & Trace & 20 & 35 & 20 & $<5$ & $\sim 90$ \\
\hline $101.5(\mathrm{H} 2)$ & 10 & $<5$ & Trace & 25 & 35 & 35 & 10 & $\sim 120$ \\
\hline $136(\mathrm{PPlz})$ & 10 & $<5$ & Trace & 20 & 30 & 20 & 10 & $\sim 95$ \\
\hline 146 (PPlc) & $<5$ & $<5$ & 40 & 15 & 10 & 10 & $<5$ & $\sim 90$ \\
\hline 148.5 (PPlc) & $<5$ & $<5$ & 40 & $<5$ & 10 & $<5$ & $<5$ & $\sim 85$ \\
\hline 163.5 (Rtf) & 10 & $<5$ & ND & 30 & 50 & 30 & $<5$ & $\sim 130$ \\
\hline
\end{tabular}

The clay fraction of sediment samples from both boreholes is dominated by the following four major clay minerals: smectite $(17.0 \AA)$, illite $(10.0 \AA)$, chlorite $(14.1 \AA)$, and kaolinite $(7.0 \AA)$. The individual XRD patterns of magnesium (II) -saturated, ethylene-glycol solvated clay fractions are presented in Appendix H. The smectite (001) basal reflection expanded to $17 \AA$ when saturated with ethylene glycol. Illite had a (001) basal reflection of $10.0 \AA$ and a (002) basal reflection of $5.0 \AA$. Presence of chlorite was confirmed by the (001) basal reflection at $14.1 \AA$, in addition to the (003) and (004) reflections at $4.74 \AA$ and $3.52 \AA$, respectively. The identification of kaolinite is based on the (002) reflection. The first two basal reflections for kaolinite, (001) and (002), have d-spacing of $7.1 \AA$ and $3.58 \AA$, which overlap the chlorite (002) and (004) basal reflections, making identification difficult. Careful examination of the XRD patterns from both boreholes showed a kaolinite (002) reflection on the shoulder of the chlorite (004) reflection. Minor amounts of quartz, feldspar, calcite, and amphibole were detected in the clay fraction of both boreholes, along with substantial amounts of calcite from the PPlc subunit (44.4 to 44.8 meters or 146 to 149 feet bgs) in borehole 299-W22-48. Additionally, transmission electron microscopy (TEM) analysis of the clay fractions confirmed the presence of kaolinite and identified trace amounts of minerals such as iron oxide, anatase, apatite, and sepiolite.

The XRD semiquantitative measurements of minerals in the clay fraction are given in Appendix H. Quantitative measurements of the clay minerals were made after the removal of calcite, and measurements of non-clay minerals (calcite, quartz, amphibole, and feldspar) were made prior to any treatments. Overall, smectite $(17.1 \AA)$ ranged in concentration from 10 to 30 (wt\%). Illite $(10 \AA)$ concentrations ranged from $\sim 10 \%$ to $50 \%$ and chlorite $(14.1 \AA$ ) concentrations were a little less ( 5 to $35 \mathrm{wt} \%)$. Minor amounts of kaolinite ( $\sim 5 \%$ to $10 \%$ ) were also detected. Quartz, feldspar, and amphiboles made up less than $\sim 15 \mathrm{wt} \%$ of the clay fraction. Approximately $40 \mathrm{wt} \%$ calcite was detected in the clay fraction from the PPlc subunit (44.4 and 45.1 meters or 146 and 148.5 feet bgs) in borehole 299-W22-48, which is consistent with the amount of calcium carbonate measured via inorganic carbon analysis (see Section 5.1.4). Less calcite ( $25 \mathrm{wt} \%$ ) was observed within the PPlc unit in borehole 299-W22-50. 
Total mass balance for the clay fraction ranged from a low of $45 \mathrm{wt} \%$ to a high of $130 \mathrm{wt} \%$. Recoveries ranging from $80 \%$ to $120 \%$ are considered acceptable for XRD semiquantification (Newman 1987). Low recoveries for semiquantitative measurements by XRD can be attributed to several factors. The clay fractions having a significant amount of calcite removed during treatment generally produced low recoveries. The <2-micron fractions in borehole 299-W22-48 (14.3 meters or 47 feet bgs) and borehole 299-W22-50 (50, 60, and 140 feet bgs) had calcite concentrations between 5 to $25 \mathrm{wt} \%$. After treatment to remove calcite from these depths, the amount of clay remaining was not adequate to prepare a sample valid for semiquantitative measurements. Sample degradation (peeling, curling clay substrates) also added to the problem.

The only consistent trend in the mineral content of samples from borehole 299-W22-48 is the substantial increase in calcite, relative to other minerals, for the PPlc subunit. This trend is noted in both the bulk sample as well as the $\leq 2$-micron fraction.

Analysis of illites by TEM from borehole 299-W22-48 (39, 91.5, and 163.5 feet bgs) and 299-W2250 (15.8 and 35.3 meters or 50 and 116 feet bgs) showed large angular platy particles. Figure 5.3 is an example of a typical illite particle with minor amounts of iron. Using data from TEM analysis and assuming all iron as iron (III), the following structural formula was calculated from data collected from 10 illite particles in sample 49.8 meters ( 163.5 feet) bgs:

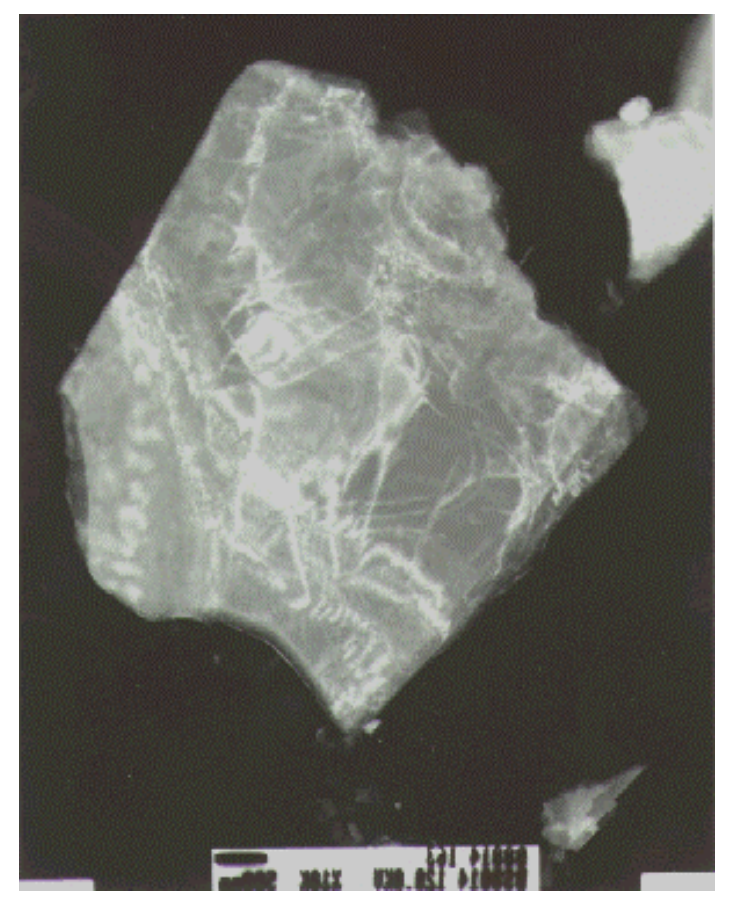

Figure 5.3. Typical Illite Particle from Borehole 299-W22-48 (163.5 feet bgs) 


$$
\left[\mathrm{K}_{0.74} \mathrm{Ca}_{0.02} \mathrm{Na}_{0.02}\right]^{+0.80}\left[\left(\mathrm{Al}_{1.62} \mathrm{Mg}_{0.29} \mathrm{Fe}_{0.16} \mathrm{Ti}_{0.02}\right)^{+0.0}\left(\mathrm{Si}_{3.19} \mathrm{Al}_{0.81}\right)^{-0.81}\right]^{-0.81} \mathrm{O}_{10}(\mathrm{OH})_{2}
$$

As in muscovite, the layer charge in illite originates from the substitution of $\mathrm{Al}^{3+}$ for $\mathrm{Si}^{4+}$ in the tetrahedral sheet. No excess layer charge is created with the minor substitutions of $\mathrm{Mg}^{2+}, \mathrm{Fe}^{3+}$, and $\mathrm{Ti}^{4+}$ for $\mathrm{Al}^{3+}$ in the octahedral sheet. The interlayer charge of +0.80 balances the charge on the $2: 1$ silicate structure. Iron content varied from a low of 0.04 to a high of 0.26 atoms per $\mathrm{O}_{10}(\mathrm{OH})_{2}$. Examination of illites from four other depths showed similar chemistry and morphology to the illites in the 49.8-meter (163.5-foot) bgs depth sample.

Chlorite particles were typically found at all depths in both boreholes. The particles were characterized as large platy particles with angular edges. Figure 5.4 is an example of a chlorite particle from the Hanford formation $\mathrm{H} 2$ unit in borehole 299-W22-48 (27.9 meters or 91.5 feet bgs). The chlorite particle is the large platy particle in the lower half of the figure. Chemistry of the chlorite particles ranged between magnesium-rich and iron-rich varieties. Assuming all the iron is ferrous, a structural formula was developed for similar chlorite particles examined from 27.9 meters (91.5 feet) bgs in borehole 299-W22-48:

$$
\left[\left(\mathrm{Ca}_{0.03}\right]^{+0.06}\left[\left(\mathrm{Al}_{1.54} \mathrm{Mg}_{2.44} \mathrm{Fe}_{1.51} \mathrm{Ti}_{0.02}\right)^{+0.60}\left(\mathrm{Si}_{3.31} \mathrm{Al}_{0.69}\right)^{-0.69}\right] \mathrm{O}_{10}(\mathrm{OH})_{8}\right.
$$

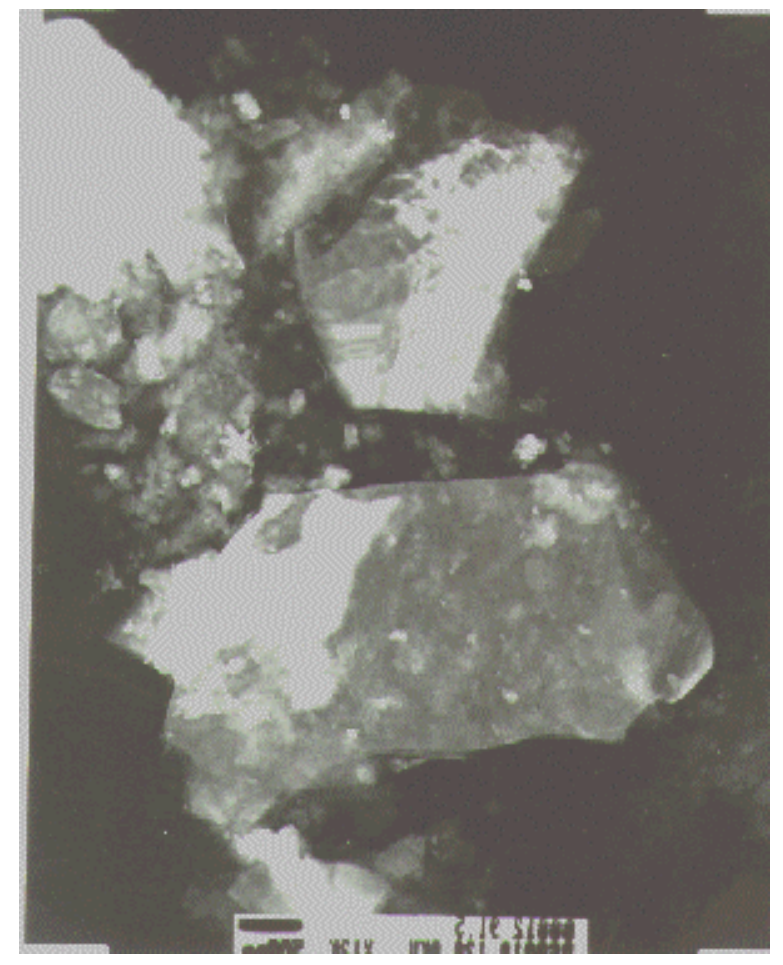

Figure 5.4. Chlorite Particle from Borehole 299-W22-48 (91.5 ft bgs) 
The layer charge of -0.69 resulting from the $\mathrm{Al}^{+3}$ substituting for $\mathrm{Si}^{+4}$ in the tetrahedral sheet is compensated by the charge derived from substitution in the octahedral sheet. $\mathrm{Fe}^{+2}$ content varied from a low of 1.22 to a high of 1.57 atoms per $\mathrm{O}_{10}(\mathrm{OH})_{8}$ whereas $\mathrm{Mg}^{+2}$ ranged from a low of 1.72 to a high of 3.38 atoms per $\mathrm{O}_{10}(\mathrm{OH})_{8}$. Minor amounts of $\mathrm{Ti}^{+4}$ were routinely detected in chlorite particles along with trace amounts of $\mathrm{Ca}^{+2}, \mathrm{Na}^{+1}$, and $\mathrm{K}^{+1}$.

Smectite clay mineralogy was examined by TEM and was mostly limited to the smaller size particles ( $<0.5$ microns $)$ in the sample. Figure 5.5 is an example of fine delicate smectite flakes with thin curled edges common to the Rtf unit 49.8 meters (163.5 feet) bgs in borehole 299-W22-48.

Chemical composition of the smectites was hard to establish, due in part to the difficulty of isolating the aggregates from other minerals in the sample during TEM analysis. Considering this limitation, a structural formula was developed using data collected from an average smectite particle at the 49.8-meter (163.5-foot) depth in borehole 299-W22-48:

$$
\left[\left(\mathrm{Ca}_{0.05} \mathrm{Mg}_{0.10}\right)\right]^{+0.30}\left[\left(\mathrm{Al}_{0.54} \mathrm{Mg}_{0.56} \mathrm{Fe}_{1.07} \mathrm{Ti}_{0.01}\right)^{-0.01}\left(\mathrm{Si}_{3.72} \mathrm{Al}_{0.28}\right)^{-0.28}\right]^{-0.29} \mathrm{O}_{10}(\mathrm{OH})_{4}
$$

Substitution of $\mathrm{Al}^{3+}$ into the tetrahedral site for $\mathrm{Si}^{4+}$ causes a layer charge of -0.28 , which is balanced by the interlayer cations, $\mathrm{Mg}^{2+}$ and $\mathrm{Ca}^{2+}$. Occupying octahedral sites are trivalent cations $\left(\mathrm{Al}^{3+}, \mathrm{Fe}^{3+}\right)$ and, in lesser amounts, the divalent cation $\left(\mathrm{Mg}^{2+}\right)$. Trace amounts of $\mathrm{Ti}^{4+}$ were also detected in the octahedral sites of most smectites. Although only a few smectites were examined from

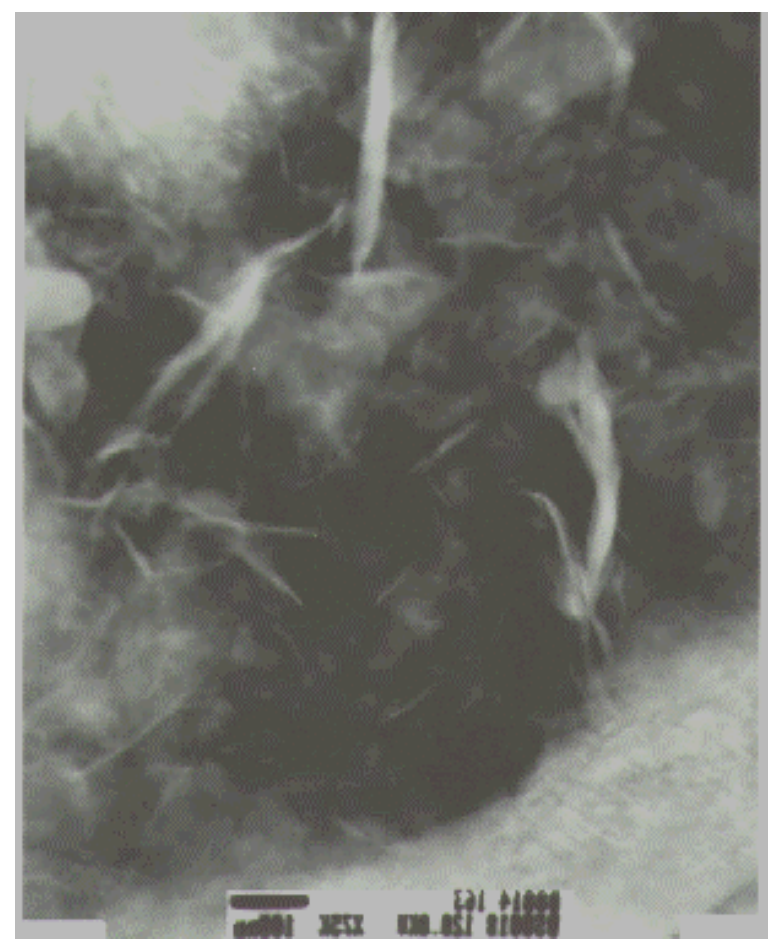

Figure 5.5. Thin Smectite Flakes from the Rtf Unit (163.5 ft bgs) in Borehole 299-W22-48 
each depth by TEM, minor variations in chemistry were limited to the proportions of individual cations occupying octahedral sites. Smectite particles had $\mathrm{Fe}^{3+}$ ranging between 0.24 and 1.07, atoms per $\mathrm{O}_{10}(\mathrm{OH})_{4}$, which caused variations in the octahedral $\mathrm{Al}^{3+}$ content.

Kaolinite particles were platy in habit and often consisted of aggregates of smaller individual particles. Figure 5.6 is a very well-defined kaolinite particle with the characteristic hexagonal morphology.

Most kaolinite particles in borehole samples did not have a well-defined morphology like that in Figure 5.6 and, thus, were not easily identified by appearance. The structural formula developed from TEM data collected from kaolinite particles in borehole 299-W22-48 (27.9 meters or 91.5 feet bgs) is:

$$
\left(\mathrm{Al}_{3.99} \mathrm{Fe}_{0.02}\right)\left(\mathrm{Si}_{3.96} \mathrm{Al}_{0.04}\right) \mathrm{O}_{10}(\mathrm{OH})_{8}
$$

The ideal structure for kaolinite in $\mathrm{A}_{4} \mathrm{Si}_{4} \mathrm{O}_{10}(\mathrm{OH})_{8}$. The small amount of iron substitution into the octahedral sheet leads to a slight excess positive charge while the small substitution of $\mathrm{Al}^{3+}$ for $\mathrm{Si}$ in the tetrahedral sheet leads to a comparable excess negative charge. All kaolinites examined by TEM from both boreholes had some degree of $\mathrm{Fe}^{3+}$ substitution for $\mathrm{Al}^{3+}$ in the octahedral layer.

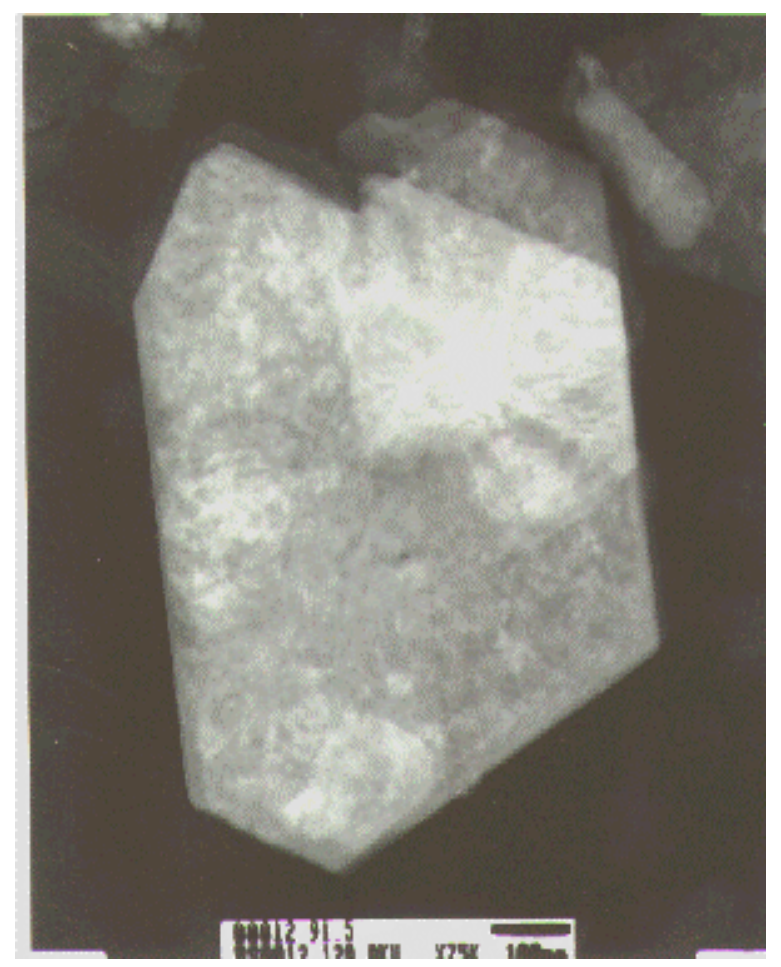

Figure 5.6. Kaolinite Particle from the H2 Unit in Borehole 299-W22-48 (91.5 ft bgs) 


\subsubsection{Cation Exchange Capacity}

Values for cation exchange capacity collected for sediment samples in borehole 299-W22-48 are presented in Table 5.11. Results are reported using two different techniques, one by Polemio and Rhoades (1977) and the other by Amrhein and Suarez (1990), described in Section 3.2.7.

The greatest cation exchange capacity in Table 5.11 is associated with the PPlc subunit. The reason for this is uncertain in light of the XRD results, which indicate that the PPLc contains overall fewer clay minerals (Table 5.10). Clay minerals are generally thought to have a greater cation exchange capacity than other minerals. The PPlc subunit represents a well-developed calic paleosol that underwent extensive weathering and alteration, including translocation and concentration of clay minerals. The calcium carbonate cement in the PPlc subunit probably includes abundant clay-size particles, along with other grain-size fractions. We believe that clay particles are likely abundant in the PPlc unit but tightly bound together by the cement, which didn't disaggregate during sieving.

As reported for the composite samples (Section 4.7), the results obtained with the two different cation exchange capacity methods vary significantly. The Amrhein and Suarez method yields lower results than the Polemio and Rhoades technique. There is a large variation in the Polemio and Rhoades results for the 27.9-meter (91.5-foot) bgs sample and the Amrhein and Suarez results for the 45.3-meter (148.5-foot) bgs sample but, in general, the reproducibility for the other 12 sets of triplicates is good. It would appear that the Polemio and Rhoades method may not correct for calcium carbonate dissolution or, less likely, the Amrhein and Suarez method overcorrects. Presently, it is unclear which cation exchange capacity method is the most accurate.

The cation exchange capacity results from the Plio-Pleistocene unit presented in Table 5.11 are inconsistent with those from a previous study performed on contaminated sediment from borehole 41-0939 (Myers et al. 1998) located within the SX Tank Farm. In the 41-09-39 borehole, <2-millimeter-size sediment was analyzed for cation exchange capacity using the Polemio and Rhoades method; results are presented in Table 5.12. Comparing results from the same method in Tables 5.11 and 5.12, it is apparent

Table 5.11. Comparison of Cation Exchange Capacity (meq/100 g) Between Sediment Samples from Borehole 299-W22-48 Using Two Different Analytical Methods

\begin{tabular}{||c|c|c|c||}
\hline Depth (ft bgs) $^{(\mathbf{a})}$ & Stratigraphic Unit & $\begin{array}{c}\text { Polemio and } \\
\text { Rhoades (1977) }\end{array}$ & $\begin{array}{c}\text { Amrhein and Suarez } \\
\text { (1990) }\end{array}$ \\
\hline \hline 39.5 & $\mathrm{H} 1 \mathrm{a}$ & $16.5 \pm 3.9$ & $6.1 \pm 0.2$ \\
\hline 91.5 & $\mathrm{H} 2$ & $13.3 \pm 7.0$ & $4.8 \pm 0.4$ \\
\hline 101.5 & $\mathrm{H} 2$ & $16.3 \pm 1.0$ & $6.0 \pm 0.4$ \\
\hline 136 & $\mathrm{PPlz}$ & $25.2 \pm 3.0$ & $8.9 \pm 2.5$ \\
\hline 146 & $\mathrm{PPlc}$ & $39.6 \pm 5.6$ & $19.4 \pm 2.2$ \\
\hline 148.5 & $\mathrm{PPlc}$ & $26.7 \pm 0.8$ & $13.2 \pm 5.1$ \\
\hline 163.5 & Rtf & $15.7 \pm 1.7$ & $5.2 \pm 0.2$ \\
\hline \multicolumn{4}{|l|}{} \\
\hline (a) Multiply by 0.3048 to convert to meters.
\end{tabular}


Table 5.12. Additional Cation Exchange Capacity Data Obtained from Sediment Samples in Borehole 41-09-39 (from Myers et al. 1998)

\begin{tabular}{||c|c|c||}
\hline Sample Number & Stratigraphic Unit & CEC (meq/100 g) \\
\hline \hline $2 \mathrm{C} / \mathrm{D}$ & $\mathrm{PPlz}$ & 13.1 \\
\hline $2 \mathrm{~A} / \mathrm{B}$ & $\mathrm{PPlz}$ & 14.7 \\
\hline $3 \mathrm{~A} / \mathrm{B}$ & $\mathrm{PPlz}$ & 15.6 \\
\hline $10 \mathrm{~A} / \mathrm{B}$ & $\mathrm{PPlz}$ & 15.3 \\
\hline $12 \mathrm{~A} / \mathrm{B}$ & $\mathrm{PPlc}$ & 9.4 \\
\hline $17 \mathrm{~A} / \mathrm{B}$ & $\mathrm{Rtf}$ & 14.7 \\
\hline $38 \mathrm{~A} / \mathrm{B}$ & $\mathrm{Rwi}(\mathrm{e})$ & 1 \\
\hline $47 \mathrm{~A} / \mathrm{B}$ & $\mathrm{Rwi}(\mathrm{e})$ & 2.9 \\
\hline $58 \mathrm{~A} / \mathrm{B}$ & $\mathrm{Rwi}(\mathrm{e})$ & 3 \\
\hline
\end{tabular}

that cation exchange capacity is about 3 times less for the PPlc subunit and about 1.5 times less for the PPlz subunit within the 41-09-39 borehole. We believe that the data in Table 5.11 may be biased high, based on data in Table 12 et al. (1988). Kaplan et al. (1998) published a set of cation exchange capacity values for eight samples from a Hanford formation sand sequence in the 200 East Area (borehole 299E17-21). Their values ranged from 2.3 to $11 \mathrm{meq} / 100 \mathrm{~g}$. Those values, though generally low, are more comparable to the values obtained by the Amrhein and Suarez method in this study. Interestingly, Kaplan et al. (1998) used the Polemio and Rhoades technique.

\subsubsection{Exchangeable Base Cations}

The results of base cation exchange, obtained via ammonium acetate extraction (see Section 3.2.8), are presented in Tables 5.13 and 5.14. Table 5.13 shows the base cations and iron, manganese, and silicon dissolved or displaced from the sediment. Calcium and magnesium (especially within the PPlc subunit) dominate the cations extracted by the ammonium acetate solution. The PPlc also shows higher concentrations of silicon are dissolved during the extraction. Table 5.14 shows the sum of the base cations displaced/dissolved from the sediment compared to the estimates of the cation exchange capacity presented in Section 5.1.7. In general, the sum of the displaced base cations falls between the values for the two cation exchange capacity measurement techniques, except for the two PPlc samples where the sum of the base cations is slightly lower than the Amhrein and Suarez estimates. The base cations that are displaced are dominated by alkaline earth elements (calcium and magnesium). The contribution of the alkali metals (sodium and potassium) to the natural distribution of exchangeable cations is small $(<10 \%)$. 
Table 5.13. Exchangeable Base Cation Composition of Sediment Samples in Borehole 299-W22-48

\begin{tabular}{|c|c|c|c|c|c|c|c|c|c|}
\hline \multirow{2}{*}{$\begin{array}{c}\text { Sampling Depth } \\
\text { (ft bgs) }^{\text {(a) }}\end{array}$} & \multicolumn{6}{|c|}{$\mathrm{meq} / \mathrm{L}$} & \multicolumn{3}{|c|}{$\mu \mathrm{g} / \mathrm{L}$} \\
\hline & Ba & $\mathrm{Ca}$ & $\mathbf{K}$ & Mg & $\mathrm{Sr}$ & $\mathrm{Na}$ & $\mathbf{F e}$ & Mn & Si \\
\hline 39.5 [H1a] & 0.07 & 27.60 & 0.89 & 3.13 & 0.04 & 1.01 & $<0.25$ & 0.782 & 8.58 \\
\hline $47[\mathrm{H} 1]$ & 0.14 & 37.08 & 2.13 & 6.04 & 0.07 & 1.45 & $<0.25$ & 1.119 & 9.74 \\
\hline $91.5[\mathrm{H} 2]$ & 0.08 & 34.82 & 1.02 & 7.12 & 0.08 & 1.17 & $<0.25$ & 0.101 & 8.34 \\
\hline $101.5[\mathrm{H} 2]$ & 0.11 & 40.09 & 1.16 & 7.20 & 0.08 & 1.25 & $<0.25$ & 0.050 & 9.02 \\
\hline 136 [PPlz] & 0.14 & 38.05 & 1.23 & 7.45 & 0.08 & 0.95 & $<0.25$ & 0.238 & 10.56 \\
\hline 146 [PPlc] & 0.11 & 42.09 & 1.29 & 18.30 & 0.10 & 1.57 & $<0.25$ & $<0.125$ & 35.77 \\
\hline 148.5 [PPlc] & 0.07 & 37.62 & 0.92 & 11.91 & 0.09 & 0.93 & $<0.25$ & 0.013 & 32.73 \\
\hline 163.5 [Rtf] & 0.06 & 26.83 & 0.80 & 5.63 & 0.05 & 0.57 & $<0.25$ & 0.623 & 9.85 \\
\hline 192 [Rwi(e)] & 0.12 & 14.43 & 1.62 & 6.62 & 0.05 & 0.96 & $<0.25$ & 0.836 & 10.19 \\
\hline
\end{tabular}

Table 5.14. Comparison of the Base Cation Sum and Cation Exchange Capacity Measurements from Sediment Samples in Borehole 299-W22-48

\begin{tabular}{|c|c|c|c|c|c|c|c|c|c|}
\hline \multirow{4}{*}{$\begin{array}{c}\text { Sampling Depth } \\
\text { (ft bgs) }^{(\text {a) }}\end{array}$} & \multirow{2}{*}{\multicolumn{7}{|c|}{ Exchangeable Base Cations }} & \multicolumn{2}{|c|}{ Cation Exchange Capacity } \\
\hline & & & & & & & & \begin{tabular}{|c|} 
Polemio and \\
Rhoades (1977) \\
\end{tabular} & $\begin{array}{l}\text { Amrhein and } \\
\text { Suarez (1990) }\end{array}$ \\
\hline & \multicolumn{7}{|c|}{ meq/100 g } & \multicolumn{2}{|c|}{ meq/100 g } \\
\hline & $\mathbf{B a}$ & $\mathbf{C a}$ & $\mathbf{K}$ & Mg & $\mathrm{Sr}$ & $\mathrm{Na}$ & Sum & & \\
\hline $39.5[\mathrm{H} 1 \mathrm{a}]$ & 0.017 & 6.454 & 0.208 & 0.731 & 0.010 & 0.236 & 7.66 & $16.5 \pm 3.9$ & $6.1 \pm 0.2$ \\
\hline $47[\mathrm{H} 1]$ & 0.033 & 8.683 & 0.498 & 1.414 & 0.017 & 0.340 & 10.99 & not done & not done \\
\hline $91.5[\mathrm{H} 2]$ & 0.018 & 8.145 & 0.239 & 1.665 & 0.018 & 0.274 & 10.36 & $13.3 \pm 7.0$ & $4.8 \pm 0.4$ \\
\hline $101.5[\mathrm{H} 2]$ & 0.026 & 9.383 & 0.272 & 1.686 & 0.019 & 0.292 & 11.68 & $16.3 \pm 1.0$ & $6.0 \pm 0.4$ \\
\hline $136[\mathrm{PPlz}]$ & 0.033 & 8.911 & 0.287 & 1.744 & 0.018 & 0.223 & 11.22 & $25.2 \pm 3.0$ & $8.9 \pm 2.5$ \\
\hline 146 [PPlc] & 0.025 & 9.849 & 0.302 & 4.281 & 0.024 & 0.368 & 14.85 & $39.6 \pm 5.6$ & $19.4 \pm 2.2$ \\
\hline 148.5 [PPlc] & 0.017 & 8.801 & 0.216 & 2.786 & 0.020 & 0.218 & 12.06 & $26.7 \pm 0.8$ & $13.2 \pm 5.1$ \\
\hline 163.5 [Rtf] & 0.014 & 6.275 & 0.186 & 1.317 & 0.012 & 0.133 & 7.94 & $15.7 \pm 1.7$ & $5.2 \pm 0.2$ \\
\hline 192 [Rwi(e)] & 0.027 & 3.376 & 0.378 & 1.548 & 0.012 & 0.224 & 5.57 & not done & not done \\
\hline
\end{tabular}

\subsubsection{1:1 Sediment-to-Water Extraction}

The 1:1 sediment-to-water extract results for samples from borehole 299-W22-48 sediment are shown in Tables 5.15 to 5.18. Later, in the discussion of the characterization of the core materials, we compare the chemical composition of the dilution-corrected 1:1 water extracts with actual porewater obtained by ultracentrifugation. For some constituents, the water extracts, when corrected for dilution with deionized water, give an accurate measure of the concentration within the native porewater. For other constituents, water extract data, when dilution-corrected back to the porewater, over-predicts the 
Table 5.15. pH, Electrical Conductivity, Alkalinity, and Anions in Water Extracts from Sediment Samples in Borehole 299-W22-48

\begin{tabular}{|c|c|c|c|c|c|c|c|c|c|c|}
\hline \multicolumn{2}{|c|}{ Constituent } & \multirow[t]{2}{*}{ pH } & \multirow{2}{*}{$\begin{array}{c}\text { EC } \\
\mu \mathrm{S} / \mathrm{cm} \\
\end{array}$} & \multirow{2}{*}{$\begin{array}{c}\text { Alk } \\
\mathrm{mg} / \mathrm{L} \\
\mathrm{CaCO}_{3} \\
\end{array}$} & \multirow{2}{*}{$\begin{array}{c}\mathrm{F} \\
\mathrm{mg} / \mathrm{L} \\
\end{array}$} & \multirow{2}{*}{$\begin{array}{c}\mathrm{Cl} \\
\mathrm{mg} / \mathrm{L} \\
\end{array}$} & \multirow{2}{*}{$\begin{array}{l}\mathrm{NO}_{2} \\
\mathrm{mg} / \mathrm{L}\end{array}$} & \multirow{2}{*}{$\begin{array}{l}\mathrm{NO}_{3} \\
\mathrm{mg} / \mathrm{L} \\
\end{array}$} & \multirow{2}{*}{$\begin{array}{l}\mathrm{PO}_{4} \\
\mathrm{mg} / \mathrm{L} \\
\end{array}$} & \multirow{2}{*}{$\begin{array}{l}\mathrm{SO}_{4} \\
\mathrm{mg} / \mathrm{L} \\
\end{array}$} \\
\hline $\begin{array}{c}\text { Sample } \\
\text { (ft bgs) }^{(\mathbf{a})}\end{array}$ & $\begin{array}{c}\text { Stratigraphic } \\
\text { Unit }\end{array}$ & & & & & & & & & \\
\hline 1 & \begin{tabular}{|l|}
$\mathrm{H} 1 \mathrm{a}$ \\
\end{tabular} & & & & 1.56 & $=1.27$ & $\begin{array}{c}<0.1 \\
\end{array}$ & 7.06 & 0.21 & 2.42 \\
\hline 6 & H1a & & & & 1.90 & 0.42 & $<0.1$ & 7.94 & $<0.1$ & 5.48 \\
\hline 9.5 & H1a & & & & 1.43 & 0.39 & $<0.1$ & 5.89 & 0.27 & 8.79 \\
\hline 12.5 & H1a & & & & 3.04 & 0.32 & $<0.1$ & 4.37 & 0.24 & 5.64 \\
\hline 14.5 & H1a & & & & 2.65 & 0.30 & $<0.1$ & 4.46 & 0.29 & 14.62 \\
\hline 17 & H1a & & & & 2.66 & 0.35 & $<0.1$ & 7.10 & 0.37 & 15.20 \\
\hline 19.5 & H1a & & & & 1.74 & 0.72 & $<0.1$ & 9.79 & $<0.1$ & 15.70 \\
\hline 22 & H1a & & & & 1.03 & 0.49 & $<0.1$ & 14.50 & 0.35 & 16.90 \\
\hline 24.5 & $\mathrm{H} 1 \mathrm{a}$ & & & & 0.95 & 0.37 & $<0.1$ & 5.27 & 0.34 & 18.20 \\
\hline 27 & $\mathrm{H} 1 \mathrm{a}$ & & & & 1.39 & 0.49 & $<0.1$ & 11.00 & 0.28 & 18.30 \\
\hline 29.5 & $\mathrm{H} 1 \mathrm{a}$ & 7.38 & 224 & 47.94 & $0.95^{*}$ & $0.32^{*}$ & $<0.1$ & $7.89^{*}$ & $0.27^{*}$ & $20.68^{*}$ \\
\hline 32 & H1a & 7.97 & 171 & 41.60 & 0.62 & 0.26 & $<0.1$ & 6.97 & 0.30 & 9.14 \\
\hline 34.3 & H1a & & & & 0.79 & 0.39 & $<0.1$ & 5.20 & 0.63 & 9.88 \\
\hline 37 & H1a & & & & 0.72 & 1.43 & $<0.1$ & 11.90 & 0.28 & 14.80 \\
\hline 39.5 & $\mathrm{H} 1 \mathrm{a}$ & 7.39 & 180 & 33.14 & 0.55 & 0.65 & $<0.1$ & 13.75 & $<0.24$ & 14.75 \\
\hline 42 & H1 & & & & 0.74 & 0.43 & $<0.1$ & 3.99 & 0.13 & 11.85 \\
\hline 44.5 & H1 & & & & 0.63 & 0.42 & $<0.1$ & 3.69 & 0.18 & 18.40 \\
\hline 47 & H1 & 7.30 & 126 & 28.91 & $0.58^{* *}$ & $0.24^{* *}$ & $<0.1$ & $2.76^{* *}$ & $0.13^{* *}$ & $9.26^{* *}$ \\
\hline 50 & H1 & & & & 0.65 & 0.84 & $<0.1$ & 10.90 & 0.25 & 12.10 \\
\hline 53.5 & H1 & & & & 0.49 & 0.53 & $<0.1$ & 2.46 & $<0.1$ & 10.10 \\
\hline 56 & H1 & 7.20 & 142 & NA & 0.45 & 1.05 & $<0.1$ & 1.00 & 0.13 & 11.47 \\
\hline 57.5 & H1 & & & & 0.57 & 1.72 & $<0.1$ & 7.07 & 0.12 & 13.40 \\
\hline 74.5 & $\mathrm{H} 2$ & 7.395 & 216 & 36.00 & 0.50 & 5.06 & $<0.1$ & 7.28 & 0.33 & 24.06 \\
\hline 91.5 & $\mathrm{H} 2$ & & & & 0.60 & 4.83 & $<0.1$ & 8.44 & 0.39 & 13.60 \\
\hline 101.5 & $\mathrm{H} 2$ & & & & 0.63 & 5.48 & $<0.1$ & 9.82 & 0.34 & 17.15 \\
\hline 106.5 & $\mathrm{H} 2$ & 7.70 & 177 & 33.84 & 0.33 & 6.45 & $<0.1$ & 5.19 & $<0.1$ & 10.40 \\
\hline 115.5 & $\mathrm{H} 2$ & 7.39 & 182 & 38.07 & 0.36 & 2.28 & $<0.1$ & 7.55 & 0.38 & 12.30 \\
\hline 136 & $\mathrm{PPlz}$ & 7.20 & 214 & 40.19 & 0.45 & 1.32 & $<0.1$ & 22.70 & 0.50 & 11.90 \\
\hline 143.5 & $\mathrm{PPlz}$ & 7.12 & 186 & 34.55 & 0.27 & 0.71 & $<0.1$ & 16.20 & 0.35 & 11.10 \\
\hline 146 & PPlc & 7.39 & 441 & 47.47 & 0.91 & 3.57 & $<0.1$ & 75.20 & 0.17 & 44.40 \\
\hline 148.5 & PPlc & 7.48 & 291 & 41.6 & 1.27 & 1.84 & $<0.1$ & 42.80 & $<0.1$ & 16.90 \\
\hline 151 & Rtf & 7.56 & 208 & 49.35 & 1.21 & 1.68 & $<0.1$ & 4.16 & $<0.1$ & 5.45 \\
\hline 163.5 & Rtf & 7.46 & 117 & 29.96 & 0.49 & 0.45 & $<0.1$ & 6.95 & 0.11 & 1.69 \\
\hline 170 & Rtf & 7.40 & 116 & 31.02 & 0.46 & 0.49 & $<0.1$ & 7.34 & 0.21 & 1.84 \\
\hline 172.5 & Rtf & 7.33 & 190 & 31.73 & 0.50 & 0.40 & $<0.1$ & 1.96 & $<0.1$ & 1.50 \\
\hline 187 & Rtf & 7.58 & 53 & 15.51 & 0.48 & 0.59 & $<0.1$ & 9.91 & $<0.1$ & 1.86 \\
\hline 192 & Rwi(e) & 7.78 & 120 & 18.33 & 1.37 & 1.55 & $<0.1$ & 9.10 & 0.29 & 10.00 \\
\hline $\begin{array}{l}\text { (a) Multi } \\
* \text { Data in bc } \\
* * \text { Data in } i \\
\text { NA = Not }\end{array}$ & $\begin{array}{l}\text { 1s average } \\
\text { ic is the ave } \\
\text { alyzed. }\end{array}$ & conve & mete & & & & & & & \\
\hline
\end{tabular}


Table 5.16. Major Cations in Water Extracts from Sediment Samples in Borehole 299-W22-48. Cation concentration measured by ICP method.

\begin{tabular}{|c|c|c|c|c|c|c|c|c|c|c|c|c|}
\hline $\begin{array}{c}\text { Sample Depth } \\
\text { (ft bgs) }^{(\mathbf{a})} \\
\text { [Stratigraphic } \\
\text { Unit] }\end{array}$ & $\underset{\mathrm{mg} / \mathrm{L}}{\mathrm{Na}}$ & $\underset{\mathrm{mg} / \mathrm{Lg}}{\mathrm{Mg}}$ & $\begin{array}{c}\mathbf{A l} \\
\mu \mathrm{g} / \mathbf{L}\end{array}$ & $\begin{array}{c}\mathrm{Si} \\
\mathrm{mg} / \mathrm{L}\end{array}$ & $\underset{\mu \mathbf{g} / \mathbf{L}}{\mathbf{P}}$ & $\begin{array}{c}\mathrm{S} \\
\mathrm{mg} / \mathrm{L}\end{array}$ & $\underset{\mathrm{mg} / \mathrm{L}}{\mathrm{K}}$ & $\begin{array}{c}\mathrm{Ca} \\
\mathrm{mg} / \mathrm{L}\end{array}$ & $\begin{array}{c}\text { Mn } \\
\mu \mathrm{g} / \mathrm{L}\end{array}$ & $\begin{array}{c}\mathbf{F e} \\
\mu \mathrm{g} / \mathbf{L}\end{array}$ & $\begin{array}{c}\mathrm{Sr} \\
\mu \mathrm{g} / \mathrm{L}\end{array}$ & $\begin{array}{c}\mathbf{B a} \\
\mu \mathbf{g} / \mathbf{L}\end{array}$ \\
\hline $29.5[\mathrm{H} 1 \mathrm{a}]$ & 28.97 & 1.42 & (35) & 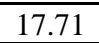 & (91) & $\begin{array}{l}7.18 \\
\end{array}$ & $\begin{array}{l}4.67 \\
\end{array}$ & (26.78 & (1) & 499.2 & 29.7 & 27.6 \\
\hline $32.0[\mathrm{H} 1 \mathrm{a}]$ & 21.10 & 1.16 & (49) & 16.46 & (113) & 2.95 & 4.12 & 6.00 & (1) & 68.8 & 21.1 & 12.2 \\
\hline $39.5[\mathrm{H} 1 \mathrm{a}]$ & 20.09 & 1.24 & (29) & 10.57 & $<500$ & 4.54 & 3.83 & 6.66 & (1) & (17) & 24.3 & 15.5 \\
\hline $47.0[\mathrm{H} 1]$ & 12.70 & 1.07 & (48) & 10.46 & (2) & 3.26 & 2.93 & 5.28 & (1) & 42.5 & 25.4 & 21.2 \\
\hline $56.0[\mathrm{H} 1]$ & 15.36 & 2.29 & 50.7 & 9.06 & (135) & 4.00 & 4.70 & 8.89 & (3) & 43.1 & 37.4 & (5) \\
\hline 74.5 [H2] & 16.45 & 3.56 & 76.1 & 9.55 & (83) & 8.98 & 4.36 & 10.75 & (1) & 45.0 & 62.0 & 17.3 \\
\hline $91.5[\mathrm{H} 2]$ & 19.14 & 2.86 & 286 & 12.80 & (197) & 5.30 & 3.47 & 9.55 & (2) & 93.2 & 49.9 & 17.0 \\
\hline $101.5[\mathrm{H} 2]$ & 20.19 & 2.75 & 272 & 13.64 & (169) & 6.36 & 3.45 & 11.95 & (3) & 90.9 & 59.3 & 29.9 \\
\hline $106.5[\mathrm{H} 2]$ & 14.21 & 2.15 & 85.0 & 8.94 & (36) & 4.14 & 3.60 & 9.65 & (1) & 63.2 & 48.5 & 16.9 \\
\hline $115.5[\mathrm{H} 2]$ & 14.81 & 2.27 & 54.8 & 11.33 & (21) & 4.94 & 3.36 & 10.47 & (1) & 58.7 & 57.1 & 27.9 \\
\hline $136.0[\mathrm{PPlz}]$ & 16.50 & 3.21 & 68.5 & 11.76 & (110) & 4.78 & 3.84 & 12.92 & (1) & 39.2 & 65.9 & 32.3 \\
\hline $143.5[\mathrm{PPlz}]$ & 11.32 & 3.66 & (10) & 8.83 & (88) & 4.21 & 3.27 & 11.23 & (1) & (8) & 61.0 & 29.5 \\
\hline 146.0 [PPIc] & 22.44 & 12.21 & (5) & 26.28 & $\begin{array}{l}\text { (207) } \\
\end{array}$ & 15.83 & 5.00 & 29.60 & (0) & (5) & 186 & 29.6 \\
\hline $148.5[\mathrm{PPlc}]$ & 15.29 & 7.52 & (8) & 28.10 & $<500$ & 6.40 & 3.99 & 18.47 & (0) & 95.5 & 121 & 24.9 \\
\hline $151.0[\mathrm{Rtf}]$ & 17.55 & 4.70 & (29) & 18.91 & (81) & 2.39 & 6.11 & 10.39 & (4) & (19) & 60.9 & 16.5 \\
\hline $163.5[\mathrm{Rtf}]$ & 7.24 & 2.68 & $(25)$ & 11.73 & $<500$ & 0.83 & 2.47 & 6.65 & (0) & (16) & 38.2 & 11.9 \\
\hline $170.0[\mathrm{Rtf}]$ & 7.13 & 2.93 & (31) & 12.78 & $<500$ & 0.89 & 2.82 & 7.30 & (2) & 33.2 & 41.3 & 44.6 \\
\hline $172.5[\mathrm{Rtf}]$ & 8.22 & 2.80 & (29) & 13.06 & (18) & 0.70 & 3.62 & 7.01 & (1) & (21) & 39.3 & 19.0 \\
\hline 187.0 [Rtf] & 4.74 & 0.51 & $(28)$ & 12.70 & (145) & 0.77 & 1.58 & 1.31 & (2) & 46.3 & (7) & (8) \\
\hline $192.0[$ Rwi(e) $]$ & 13.95 & 0.74 & 65.2 & 11.65 & (125) & 3.84 & 4.22 & 1.75 & (2) & 40.7 & (10) & 16.5 \\
\hline
\end{tabular}

porewater concentration because of dissolution of salts/minerals in the sediment. We also have converted the water extracts to a per gram of oven-dry sediment for comparison to geochemical results obtained by other methods (i.e., acid extraction and bulk chemical composition [XRF]).

The data in Tables 5.15 to 5.18 show that the water extracts are dominated by calcium, magnesium, sodium, bicarbonate (based on the $\mathrm{pH}$ and alkalinity data), sulfate, and nitrate. There are minor amounts of chloride, potassium, and dissolved silicon but no elevated levels of trace metals, except in the PPlc subunit. The PPlc water extract data show elevated levels of natural uranium and selenium as well as electrical conductivity (EC), alkalinity, calcium, magnesium, silicon, strontium, sulfate, and nitrate compared to the other geologic strata. In contrast, the Ringold Formation water extracts show lower alkalinity, barium, chromium, sodium, and uranium concentrations compared to the Hanford formation and Plio Pleistocene unit water extracts. In all but two instances the cation-anion balance in Table 5.18 agrees within $10 \%$, suggesting we have an internally consistent data set. Because the ratio of water to sediment used in the water extracts was 1:1, the data in Tables 5.15 through 5.18 with the units of $\mathrm{mg} / \mathrm{L}$ and $\mu \mathrm{g} / \mathrm{L}$ or meq/L also represent milligrams or milliequivalents per kilogram of soil, respectively. 
Table 5.17. Trace Metals in Water Extracts of Sediment Samples from Borehole 299-W22-48

\begin{tabular}{|c|c|c|c|c|c|c|c|c|c|c|c|c|}
\hline $\begin{array}{c}\text { Sample Depth } \\
\text { (ft bgs) }^{(a)} \\
\text { [Stratigraphic }^{\text {Unit] }}\end{array}$ & $\begin{array}{c}\mathbf{B} \\
\mu \mathrm{g} / \mathrm{L}\end{array}$ & $\begin{array}{l}\mathbf{C r} * \\
\mu \mathbf{g} / \mathbf{L}\end{array}$ & $\begin{array}{c}\text { Co } \\
\mu \mathbf{g} / \mathbf{L}\end{array}$ & $\begin{array}{c}\mathbf{N i} \\
\mu \mathrm{g} / \mathrm{L}\end{array}$ & $\begin{array}{r}\mathbf{C u} \\
\mu \mathbf{g} / \mathbf{L}\end{array}$ & $\begin{array}{c}\mathbf{Z n} \\
\mu \mathrm{g} / \mathrm{L}\end{array}$ & $\begin{array}{l}\text { As* } \\
\mu \mathbf{g} / \mathbf{L}\end{array}$ & $\begin{array}{r}\mathrm{Se}^{*} \\
\mu \mathrm{g} / \mathrm{L}\end{array}$ & $\begin{array}{l}\text { Mo* } \\
\mu \mathbf{g} / \mathbf{L}\end{array}$ & $\begin{array}{l}\text { Tc* } \\
\mu \mathbf{g} / \mathbf{L}\end{array}$ & $\begin{array}{l}\mathbf{P b} \mathbf{b}^{*} \\
\mu \mathrm{g} / \mathrm{L}\end{array}$ & $\begin{array}{r}\mathbf{U}^{*} \\
\mu \mathbf{g} / \mathbf{L}\end{array}$ \\
\hline 29.5 [H1a] & (8) & $(0.32)$ & $<10$ & $<100$ & $<25$ & 30.9 & 37.5 & $\begin{array}{l}(0.69) \\
(0.6)\end{array}$ & 3.97 & 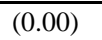 & $\begin{array}{c}(0.16) \\
\end{array}$ & 2.84 \\
\hline $32.0[\mathrm{H} 1 \mathrm{a}]$ & (3) & $(0.37)$ & 1.4 & $<100$ & $<25$ & 15.0 & 32.1 & $(0.15)$ & 2.35 & $(0.00)$ & $(0.03)$ & 1.47 \\
\hline 39.5 [H1a] & (0) & $(0.39)$ & $<10$ & $<100$ & $<25$ & 22.7 & 21.6 & (1.06) & 4.81 & $(0.00)$ & $(0.29)$ & 1.76 \\
\hline $47.0[\mathrm{H} 1]$ & $<100$ & $(0.19)$ & 1.1 & $<100$ & $<25$ & 22.3 & 9.45 & $(0.29)$ & 1.20 & $(0.00)$ & $(0.25)$ & 0.530 \\
\hline $56.0[\mathrm{H} 1]$ & (4) & $(0.07)$ & 1.0 & $<100$ & $<25$ & 16.3 & 9.52 & $(0.23)$ & 11.35 & $(0.00)$ & $(0.16)$ & 1.47 \\
\hline 74.5 [H2] & (6) & 0.470 & $<10$ & $<100$ & $<25$ & 23.1 & 21.6 & $(0.65)$ & 7.08 & $(0.00)$ & $(0.18)$ & 0.430 \\
\hline $91.5[\mathrm{H} 2]$ & 2003 & 0.551 & 1.3 & $<100$ & $<25$ & 15.7 & 22.5 & $(3.84)$ & 17.64 & $(0.00)$ & & 0.455 \\
\hline $101.5[\mathrm{H} 2]$ & 1996 & 0.985 & $<10$ & $<100$ & $<25$ & 20.0 & 19.2 & 5.77 & 24.2 & $<0.025$ & & 0.430 \\
\hline $106.5[\mathrm{H} 2]$ & (6) & 0.530 & $<10$ & $<100$ & $<25$ & 24.5 & 17.1 & $(2.25)$ & 12.1 & $(0.00)$ & $(0.22)$ & 0.375 \\
\hline $115.5[\mathrm{H} 2]$ & $(10)$ & 0.940 & 1.8 & $<100$ & $(0)$ & 26.9 & 21.2 & $(3.15)$ & 10.6 & $(0.00)$ & $(0.31)$ & 0.530 \\
\hline 136.0 [PPlz] & (8) & 0.665 & 1.5 & $<100$ & $<25$ & 44.1 & 26.4 & 12.9 & 9.5 & $(0.00)$ & $(0.14)$ & 0.510 \\
\hline 143.5 [PPlz] & (7) & $(0.21)$ & 1.1 & $<100$ & $<25$ & 25.6 & 9.20 & 6.55 & 17.3 & $<0.025$ & $(0.14)$ & 0.970 \\
\hline 146.0 [PPIc] & (11) & 1.86 & 1.4 & $<100$ & $<25$ & 29.3 & 8.44 & 36.50 & 57.2 & $(0.00)$ & $(0.08)$ & 7.90 \\
\hline 148.5 [PPlc] & (3) & 0.690 & $<10$ & $<100$ & $<25$ & 23.3 & 10.8 & 14.8 & 9.9 & $(0.00)$ & $(0.75)$ & 5.68 \\
\hline $151.0[\mathrm{Rtf}]$ & (4) & $(0.07)$ & 0.9 & $<100$ & (2) & 22.1 & 8.56 & $(3.22)$ & 7.58 & $(0.00)$ & $(0.04)$ & 2.48 \\
\hline 163.5 [Rtf] & $<100$ & $(0.05)$ & 2.0 & $<100$ & $<25$ & 27.8 & 15.0 & $(2.67)$ & 5.17 & $(0.00)$ & $(0.01)$ & 0.245 \\
\hline 170.0 [Rtf] & (0) & $(0.24)$ & 0.0 & $<100$ & $<25$ & 86.8 & 12.4 & (3.39) & 5.99 & $<0.025$ & $(0.22)$ & 0.565 \\
\hline 172.5 [Rtf] & (1) & $(0.17)$ & 2.2 & $<100$ & $<25$ & 23.8 & 10.6 & $(1.80)$ & 6.94 & $(0.00)$ & $(0.06)$ & 0.920 \\
\hline 187.0 [Rtf] & $<100$ & $(0.19)$ & 1.4 & $<100$ & $<25$ & 26.3 & 6.31 & 4.25 & 3.54 & $(0.00)$ & $(0.09)$ & 0.000 \\
\hline $192.0[\mathrm{Rwi}(\mathrm{e})]$ & (9) & $(0.26)$ & 0.8 & $<100$ & $<25$ & 96.7 & 6.80 & 5.78 & 7.14 & $<0.025$ & $(0.13)$ & 0.032 \\
\hline \multicolumn{13}{|c|}{$\begin{array}{l}\text { (a) Multiply by } 0.3048 \text { to convert to meters. } \\
\text { *ICP-MS instrument was used. }\end{array}$} \\
\hline
\end{tabular}

Some notable trends are seen in the water extract data. The calcic PPlc subunit is unique, geochemically, apparently because it is the only stratigraphic unit sampled that has gone through a long period of intense pedogenic alteration. Most noticeably, the PPlc has a significantly higher EC and is enriched in at least two anions (nitrate, sulfate) and several cations (silica, magnesium, calcium) (see Tables 5.15 and 5.16). The PPlc is also enriched in several trace elements including chromium, selenium, molybdenum, strontium, and uranium (see Table 5.17). At the same time, the PPlc is depleted in waterleachable aluminum relative to the other stratigraphic units. All these constituents were probably retained during soil-formation processes when this paloesol was developing during late Pliocene and/or early Pleistocene time.

Also noticeable in the water extracts, but less dramatic, are greater chloride contents in the Hanford formation $\mathrm{H} 2$ unit, 22.7 to 35.2 meters ( 74.5 to 115.5 feet) bgs and lower magnesium concentration in the upper portion of the Hanford formation sequence (Hanford formation H1a unit, $\leq 14$ meters or $\leq 47$ feet bgs) relative to the other stratigraphic units. The latter differences are not great and analyses of additional samples are needed to better substantiate and define chemical dissimilarities among different strata within the Hanford formation. 
Table 5.18. Charge Balance in Water Extracts of Sediment Samples from Borehole 299-W22-48

\begin{tabular}{|c|c|c|c|c|c|c|c|c|c|c|c|}
\hline $\begin{array}{c}\text { Sample Depth } \\
\text { (ft bgs) }^{\text {(a) }}\end{array}$ & $\begin{array}{c}\text { Alk } \\
\text { meq/L }\end{array}$ & $\begin{array}{c}F \\
\mathrm{meq} / \mathrm{L}\end{array}$ & $\begin{array}{c}\mathrm{Cl} \\
\mathrm{meq} / \mathrm{L}\end{array}$ & $\begin{array}{c}\mathrm{NO}_{3} \\
\mathrm{meq} / \mathrm{L}\end{array}$ & $\begin{array}{c}\mathrm{SO}_{4} \\
\mathrm{meq} / \mathrm{L}\end{array}$ & $\underset{\text { meq/L }}{\sum \text { An }}$ & $\begin{array}{c}\mathrm{Na} \\
\mathrm{meq} / \mathrm{L}\end{array}$ & $\begin{array}{c}\mathrm{Mg} \\
\mathrm{meq} / \mathrm{L}\end{array}$ & $\begin{array}{c}\mathrm{K} \\
\mathrm{meq} / \mathrm{L}\end{array}$ & $\begin{array}{c}\mathrm{Ca} \\
\mathrm{meq} / \mathrm{L}\end{array}$ & $\begin{array}{r}\sum \text { Cat } \\
\text { meq/L }\end{array}$ \\
\hline 29.5 [H1a] & 0.96 & 0.05 & 0.01 & 0.13 & 0.43 & 1.58 & 1.26 & 0.12 & 0.12 & 0.34 & 1.83 \\
\hline $32.0[\mathrm{H} 1 \mathrm{a}]$ & 0.83 & 0.03 & 0.01 & 0.11 & 0.19 & 1.17 & 0.92 & 0.10 & 0.11 & 0.30 & 1.42 \\
\hline 39.5 [H1a] & 0.66 & 0.03 & 0.02 & 0.22 & 0.31 & 1.24 & 0.87 & 0.10 & 0.10 & 0.33 & 1.41 \\
\hline $47.0[\mathrm{H} 1]$ & 0.58 & 0.03 & 0.01 & 0.04 & 0.19 & 0.85 & 0.55 & 0.09 & 0.07 & 0.26 & 0.98 \\
\hline $56.0[\mathrm{H} 1]$ & ND & 0.02 & 0.03 & 0.02 & 0.24 & & 0.67 & 0.19 & 0.12 & 0.44 & 1.42 \\
\hline 74.5 [H2] & 0.72 & 0.03 & 0.14 & 0.12 & 0.50 & 1.51 & 0.72 & 0.29 & 0.11 & 0.54 & 1.66 \\
\hline $91.5[\mathrm{H} 2]$ & ND & ND & ND & ND & ND & & 0.83 & 0.24 & 0.09 & 0.48 & 1.63 \\
\hline $101.5[\mathrm{H} 2]$ & ND & ND & ND & ND & ND & & 0.88 & 0.23 & 0.09 & 0.60 & 1.79 \\
\hline $106.5[\mathrm{H} 2]$ & 0.68 & 0.02 & 0.18 & 0.08 & 0.22 & 1.18 & 0.62 & 0.18 & 0.09 & 0.48 & 1.37 \\
\hline $115.5[\mathrm{H} 2]$ & 0.76 & 0.02 & 0.06 & 0.12 & 0.26 & 1.22 & 0.64 & 0.19 & 0.09 & 0.52 & 1.44 \\
\hline 136.0 [PPlz] & 0.80 & 0.02 & 0.04 & 0.37 & 0.25 & 1.48 & 0.72 & 0.26 & 0.10 & 0.64 & 1.72 \\
\hline 143.5 [PPlz] & 0.69 & 0.01 & 0.02 & 0.26 & 0.23 & 1.22 & 0.49 & 0.30 & 0.08 & 0.56 & 1.44 \\
\hline 146.0 [PPIc] & 0.95 & 0.05 & 0.10 & 1.21 & 0.92 & 3.24 & 0.98 & 1.00 & 0.13 & 1.48 & 3.58 \\
\hline 148.5 [PPlc] & 0.83 & 0.07 & 0.05 & 0.69 & 0.35 & 1.99 & 0.66 & 0.62 & 0.10 & 0.92 & 2.31 \\
\hline 151.0 [Rtf] & 0.99 & 0.06 & 0.05 & 0.07 & 0.11 & 1.28 & 0.76 & 0.39 & 0.16 & 0.52 & 1.82 \\
\hline 163.5 [Rtf] & 0.60 & 0.03 & 0.01 & 0.11 & 0.04 & 0.78 & 0.31 & 0.22 & 0.06 & 0.33 & 0.93 \\
\hline 170.0 [Rtf] & 0.62 & 0.02 & 0.01 & 0.12 & 0.04 & 0.82 & 0.31 & 0.24 & 0.07 & 0.36 & 0.99 \\
\hline 172.5 [Rtf] & 0.63 & 0.03 & 0.01 & 0.03 & 0.03 & 0.74 & 0.36 & 0.23 & 0.09 & 0.35 & 1.03 \\
\hline 187.0 [Rtf] & 0.31 & 0.03 & 0.02 & 0.16 & 0.04 & 0.55 & 0.21 & 0.04 & 0.04 & 0.07 & 0.35 \\
\hline $192.0[$ Rwi(e)] & 0.37 & 0.07 & 0.04 & 0.15 & 0.21 & 0.84 & 0.61 & 0.06 & 0.11 & 0.09 & 0.86 \\
\hline
\end{tabular}

Table 5.19 summarizes the ranges of major components of water extracts from borehole 299-W22-48 and contrasts the ranges among different stratigraphic units. The data reflects observations made above. Water extracts from the Hanford formation H1a unit are slightly enriched in sodium compared to the Hanford formation $\mathrm{H} 2$ unit, which is slightly enriched in chloride, magnesium, and calcium. More discussion is presented in Section 5.1.11 where the dilution-corrected porewaters will be compared to the actual porewaters obtained by ultracentrifugation.

\subsubsection{Acid Extraction}

$8 \mathrm{M}$ nitric acid extraction data are summarized in Tables 5.20 and 5.21. Two instruments were used to measure constituents released by acid extraction (see Section 3.2.10; these are the ICP and the inductively coupled plasma mass spectrometer (ICP-MS). Table 5.20 shows that chromium and lead analyses using the two independent instruments and techniques give excellent agreement. 
Table 5.19. Ranges of Parameters and Selected Ions Found in Water Extracts for Stratigraphic Units Sampled within Borehole 299-W22-48

\begin{tabular}{|c|c|c|c|c|c|c|c|c|}
\hline \multicolumn{2}{|c|}{ Stratigraphic Unit } & \begin{tabular}{|c|} 
Hanford \\
Formation \\
(Unit H1a) \\
\end{tabular} & \begin{tabular}{|c|} 
Hanford \\
Formation \\
(Unit H1a) \\
\end{tabular} & \begin{tabular}{|c|} 
Hanford \\
Formation \\
(Unit H1) \\
\end{tabular} & $\begin{array}{c}\text { Hanford } \\
\text { Formation } \\
\text { (Unit H2) } \\
\end{array}$ & $\begin{array}{l}\text { Upper Plio- } \\
\text { Pleistocene } \\
\text { Unit (PPlz) } \\
\end{array}$ & $\begin{array}{l}\text { Lower Plio- } \\
\text { Pleistocene } \\
\text { Unit (PPIc) } \\
\end{array}$ & $\begin{array}{c}\text { Ringold } \\
\text { Formation } \\
\text { (Rtf) } \\
\end{array}$ \\
\hline \multicolumn{2}{|c|}{ General Lithology } & $\begin{array}{c}\text { Sand and } \\
\text { gravel }\end{array}$ & Sand & $\begin{array}{c}\text { Sand and } \\
\text { gravel }\end{array}$ & $\begin{array}{c}\text { Sand and } \\
\text { silt }\end{array}$ & $\begin{array}{c}\text { Fine sand } \\
\text { and silt }\end{array}$ & Caliche & $\begin{array}{c}\text { Sand to } \\
\text { gravelly } \\
\text { sand } \\
\end{array}$ \\
\hline \multicolumn{2}{|c|}{$\begin{array}{c}\text { Depth Interval } \\
\text { (ft bgs) }^{\text {(a) }}\end{array}$} & $0-9$ & $9-41$ & $41-61$ & $61-135$ & $135-146$ & $146-149$ & $149-192$ \\
\hline & Units & & & & & & & \\
\hline $\mathrm{pH}$ & & & $7.4-8.0$ & $7.2-7.3$ & $7.4-7.7$ & $7.1-7.2$ & $7.4-7.5$ & $7.3-7.8$ \\
\hline $\mathrm{EC}$ & $\mu \mathrm{S} / \mathrm{cm}$ & & $170-220$ & $120-140$ & $180-220$ & $190-210$ & $300-450$ & $50-200$ \\
\hline Alk & \begin{tabular}{|l|}
$\mathrm{mg} / \mathrm{L}$ \\
$\mathrm{CaCO}_{3}$ \\
\end{tabular} & & $35-45$ & $30-35$ & 35 & $35-40$ & $40-50$ & $15-30$ \\
\hline $\bar{F}$ & $\mathrm{mg} / \mathrm{L}$ & $1.5-2.0$ & $0.5-3.0$ & $0.5-0.7$ & $0.3-0.6$ & $0.3-0.4$ & $1-1.3$ & $0.5-1.4$ \\
\hline$\overline{\mathrm{Cl}}$ & $\mathrm{mg} / \mathrm{L}$ & 0.4 & $0.3-1$ & $0.4-2$ & $2.0-6.0$ & $0.7-1.3$ & $2.0-4.0$ & $0.4-2.0$ \\
\hline $\mathrm{NO} 3$ & $\mathrm{mg} / \mathrm{L}$ & $6.0-8$ & $4.0-15$ & $1.0-10$ & $5.0-10$ & $16-23$ & $43-75$ & $2.0-10$ \\
\hline $\mathrm{SO} 4$ & $\mathrm{mg} / \mathrm{L}$ & $3.0-6$ & $5.0-20$ & $9.0-18$ & $10.0-25$ & $10.0-12$ & $20-45$ & $2.0-10$ \\
\hline $\mathrm{Na}$ & $\mathrm{mg} / \mathrm{L}$ & & $20-30$ & $12.0-15$ & $15-20$ & $11.0-16$ & $15-20$ & $5.0-17$ \\
\hline $\mathrm{Mg}$ & $\mathrm{mg} / \mathrm{L}$ & & $1.2-1.4$ & $1.1-2.3$ & $2.2-3.6$ & $3.2-3.7$ & $7.0-12$ & $0.5-5.0$ \\
\hline $\mathrm{Si}$ & $\mathrm{mg} / \mathrm{L}$ & & $11.0-18$ & $9.0-10$ & $9.0-14$ & $8.0-12$ & $26-28$ & $11.0-20$ \\
\hline $\mathrm{K}$ & $\mathrm{mg} / \mathrm{L}$ & & $3.8-4.7$ & $3.0-5$ & $3.4-4.6$ & $3.3-3.8$ & $4.0-5$ & $1.5-6.0$ \\
\hline $\mathrm{Ca}$ & $\mu \mathrm{g} / \mathrm{L}$ & & $6.0-7$ & $5.0-9$ & $10.0-12$ & $11.0-13$ & $20-30$ & $1.0-10$ \\
\hline $\mathrm{Sr}$ & $\mu \mathrm{g} / \mathrm{L}$ & & $20-30$ & $25-35$ & $50-60$ & $60-65$ & $120-200$ & $7.0-60$ \\
\hline $\mathrm{Ba}$ & $\mu \mathrm{g} / \mathrm{L}$ & & $15-30$ & $5.0-20$ & $17-30$ & $30-32$ & $25-30$ & $10.0-20$ \\
\hline $\mathrm{Cr}$ & $\mu \mathrm{g} / \mathrm{L}$ & & 0.3 & $0.1-0.2$ & $0.4-1.0$ & $0.2-0.7$ & $0.7-2$ & $0.1-0.2$ \\
\hline $\mathrm{U}$ & $\mu \mathrm{g} / \mathrm{L}$ & & $1.5-3.0$ & $0.5-1.5$ & $0.4-0.5$ & $0.5-1.0$ & $6.0-8$ & $0.0-1$ \\
\hline
\end{tabular}

The PPlc subunit shows very high acid-leachable calcium, magnesium, sodium, strontium, and sulfur (likely from sulfate), uranium, copper, and manganese and conversely low leachable iron compared to the other stratigraphic units measured. The high acid-leachable alkaline-earth cations represent the ready dissolution of carbonates. The high release rate of copper, manganese, and uranium also may represent substitution of these trace metals into the carbonate crystal lattice. The coarse-grained facies of the Hanford formation H1 unit shows relatively lower amounts of leachable aluminum, barium, calcium, chromium, iron, magnesium, manganese, potassium, strontium and uranium compared to other stratigraphic units. It is not clear whether this a reflection of the mineralogy (i.e., basaltic), or the fact that larger grains are not leached as efficiently as fine grains during the acid-leach process. The coarsegrained Ringold Formation [Rwi(e)] at 58.5 meters (192 feet) bgs produced a relatively small amount of acid-leachable calcium but a large amount of molybdenum. 
Table 5.20. Major Cations in Acid Extracts of Sediment Samples from Borehole 299-W22-48. Cation concentration $(\mu \mathrm{g} / \mathrm{g})$ measured by ICP method.

\begin{tabular}{|c|c|c|c|c|c|c|c|c|c|c|}
\hline $\begin{array}{c}\text { Element } \\
\mu \mathrm{g} / \mathrm{g}\end{array}$ & $\begin{array}{c}\text { Ft bgs }^{(a)} \\
39.5 \\
\end{array}$ & $\begin{array}{c}\text { Ft } \\
\text { bgs }^{(a)} \\
47 \\
\end{array}$ & $\begin{array}{c}\text { Ft } \\
\text { bgs }^{(a)} \\
77 \\
\end{array}$ & $\begin{array}{c}\text { Ft } \\
\text { bgs }^{(a)} \\
91.5 \\
\end{array}$ & 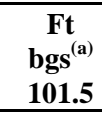 & $\begin{array}{c}\begin{array}{c}\text { Ft } \\
\text { bgs }^{(a)}\end{array} \\
136 \\
\end{array}$ & $\begin{array}{c}\begin{array}{c}\text { Ft } \\
\text { bgs }^{(a)}\end{array} \\
146 \\
\end{array}$ & 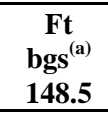 & 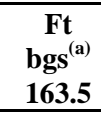 & $\begin{array}{c}\text { Ft } \\
\text { bgs }^{(a)} \\
192 \\
\end{array}$ \\
\hline & H1a & H1 & H2 & H2 & H2 & PPlz & PPlc & PPlc & Rtf & Rwi(e) \\
\hline $\mathrm{Na}$ & - - - & (- - & (- - & (- - & (- - - & - - - & $+\cdots$ & - - - & 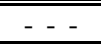 & - - - \\
\hline $\mathrm{Mg}$ & 4570 & 2245 & 5133 & 4022 & 5214 & 6551 & 20148 & 9586 & 4770 & 3700 \\
\hline $\mathrm{Al}$ & 6281 & 3264 & 7623 & 5394 & 7257 & 9935 & 6939 & 5950 & 6844 & 6023 \\
\hline $\mathrm{Si}$ & 35.8 & 20.1 & 26.8 & 85.5 & 14.7 & 7.5 & 11.0 & 17.8 & 15.8 & 16.4 \\
\hline $\mathrm{P}$ & 389.1 & 535.4 & 467.9 & 362.8 & 416.2 & 450.3 & 432.8 & 539.0 & 319.9 & 446.7 \\
\hline$S$ & 45.0 & 39.6 & 31.5 & 31.4 & 42.0 & 27.5 & 353.4 & 373.2 & 18.7 & 36.3 \\
\hline $\mathrm{K}$ & 1488 & 446.6 & 1467 & 1214 & 1522 & 1912 & 912.9 & 810.0 & 857.2 & 969.4 \\
\hline $\mathrm{Ca}$ & 7611 & 5209 & 8141 & 6680 & 8410 & 11447 & 148662 & 203457 & 4439 & 2808 \\
\hline $\mathrm{Ti}$ & 541.3 & 563.1 & 527.7 & 330.0 & 512.8 & 446.8 & 497.3 & 380.4 & 537.1 & 622.6 \\
\hline $\mathrm{Mn}$ & 275.5 & 122.2 & 273.3 & 234.5 & 274.3 & 274.5 & 1459.1 & 230.2 & 257.8 & 193.8 \\
\hline $\mathrm{Fe}$ & 12200 & 9397 & 12885 & 10049 & 12490 & 14524 & 9805 & 8776 & 13089 & 11767 \\
\hline $\mathrm{Sr}$ & 29.1 & 18.3 & 35.2 & 24.6 & 33.9 & 36.7 & 295.2 & 390.6 & 21.2 & 22.0 \\
\hline $\mathrm{Ba}$ & 80.3 & 43.8 & 69.3 & 60.5 & 80.4 & 107.2 & 128.0 & 73.2 & 46.9 & 113.3 \\
\hline
\end{tabular}

Table 5.22 presents the percentage of each element dissolved by the nitric acid compared to the bulk chemical composition determined by XRF. This comparison is critical to defining whether the strong acid digestion is in fact dissolving most of a given element. For contaminated sediment, we will compare the acid extract as a measure of the total concentration of contaminants in the samples. In the companion reports on SX tank farm containment sediments we will compare the amounts of a given element that are acid leached from comparable uncontaminated sediment to the values released by the contaminated sediment to attempt to understand the interactions of tank fluids with sediment and to estimate the degree of binding between given contaminants and affected sediment.

In general, for the sediment from borehole $299 \mathrm{~W} 22-48$, the acid extraction removes only $1 \%$ to $10 \%$ of the total mass of alkali metals (potassium and sodium), about $25 \%$ of the major alkaline earth metals (calcium and magnesium) and about $10 \%$ to $15 \%$ of the minor alkaline earths elements (barium and strontium). Among other elements, very little $<0.1 \%$ silicon, about $15 \%$ of the aluminum and titanium, about $40 \%$ to $60 \%$ of the iron and manganese, and $25 \%$ to $70 \%$ of the various trace metals are released during acid extraction. The amount of any element removed from the Hanford formation H1 unit (coarse sand and gravel) by acid digestion is less than for the other geologic strata, perhaps signifying that the larger particle sizes are leached less than smaller-grained particles, which have a relatively greater surface area.

In the two samples from the PPlc subunit the acid leached almost all the calcium and strontium and slightly more of several of the other elements when compared to other non-carbonate-rich strata. Most calcium and strontium in the PPlc appears to be combined with calcite (calcium carbonate) cement, which easily decomposes on contact with acid. Calcium in the other stratigraphic units is associated with silicates (e.g., pyroxene, plagioclase, etc.), which do not readily react with the acid leach. 
Table 5.21. Trace Metals ( $\mu \mathrm{g} / \mathrm{g})$ in Acid Extracts of Sediment Samples from Borehole 299-W22-48. Trace metals measured by ICP or ICP-MS methods.

\begin{tabular}{|c|c|c|c|c|c|c|c|c|c|c|}
\hline $\begin{array}{c}\text { Element } \\
\mu \mathrm{g} / \mathrm{g}\end{array}$ & $\begin{array}{c}\text { Ft bgs }^{(a)} \\
39.5 \\
\end{array}$ & $\begin{array}{c}\text { Ft bgs }^{(a)} \\
47 \\
\end{array}$ & $\begin{array}{c}\text { Ft bgs }{ }^{(a)} \\
77\end{array}$ & $\begin{array}{c}\text { Ft bgs }^{(a)} \\
91.5 \\
\end{array}$ & $\begin{array}{c}\text { Ft bgs }^{(a)} \\
101.5 \\
\end{array}$ & $\begin{array}{c}\text { Ft bgs }^{(a)} \\
136\end{array}$ & $\begin{array}{c}\text { Ft bgs }{ }^{(a)} \\
146\end{array}$ & $\begin{array}{c}\text { Ft bgs }^{(a)} \\
148.5 \\
\end{array}$ & $\begin{array}{c}\text { Ft bgs }^{(a)} \\
163.5 \\
\end{array}$ & $\begin{array}{c}\begin{array}{c}\text { Ft } \\
\text { bgs }^{(a)} \\
192\end{array} \\
\end{array}$ \\
\hline & H1a & H1 & H2 & H2 & H2 & PPlz & PPlc & PPlc & Rtf & Rwi(e) \\
\hline $\mathrm{Be}$ & 0.23 & $(0.14)$ & 0.27 & 0.21 & 0.24 & 0.39 & 0.22 & $(0.19)$ & 0.24 & 0.21 \\
\hline $\mathrm{B}$ & $(8.66)$ & 1.76 & 9.35 & 7.02 & 7.36 & 1.11 & 10.32 & 15.13 & 8.62 & $(1.79)$ \\
\hline $\mathrm{Cr}^{(\mathrm{A})}$ & 8.47 & 3.21 & 13.86 & 9.49 & 12.68 & 14.17 & 10.84 & 11.77 & 8.63 & 9.81 \\
\hline $\mathrm{Cr}$ & 8.59 & 3.12 & 12.75 & 8.86 & 12.06 & 13.35 & 9.87 & 10.18 & 8.17 & 9.28 \\
\hline $\mathrm{Co}$ & 5.82 & 4.56 & 6.61 & 5.09 & 6.05 & 8.23 & 5.51 & 4.68 & 5.64 & 6.00 \\
\hline $\mathrm{Ni}$ & 7.29 & 4.25 & 13.07 & 9.19 & 11.19 & 13.26 & 9.81 & 9.25 & 8.04 & 8.64 \\
\hline $\mathrm{Cu}$ & 7.26 & 7.61 & 8.93 & 8.34 & 7.92 & 13.50 & 16.93 & 9.90 & 6.59 & 9.21 \\
\hline $\mathrm{Zn}$ & 33.34 & 17.94 & 36.72 & 29.10 & 33.83 & 45.15 & 24.58 & 24.79 & 32.98 & 26.44 \\
\hline $\mathrm{As}^{(\mathrm{b}, \mathrm{c})}$ & $(2.25)$ & $(0.69)$ & $(4.41)$ & $(3.02)$ & $(2.99)$ & $(4.50)$ & $(5.96)$ & (19.07) & $(2.39)$ & $(1.20)$ \\
\hline $\mathrm{Se}^{(\mathrm{b})}$ & $(0.16)$ & 0.22 & $(0.16)$ & $(0.15)$ & $(0.14)$ & 0.22 & 0.54 & 0.71 & $(0.14)$ & 0.17 \\
\hline $\mathrm{Mo}^{(\mathrm{b})}$ & 0.05 & 0.05 & 0.09 & 0.07 & 0.08 & 0.06 & 0.33 & 0.08 & 0.07 & 0.78 \\
\hline $\mathrm{Tc}^{(\mathrm{b}, \mathrm{d}, \mathrm{e})}$ & $(0.00)$ & $<27.11$ & $(0.00)$ & $(0.00)$ & $(0.00)$ & $(2.27)^{(\mathrm{e})}$ & $(20.10)^{(\mathrm{e})}$ & $(17.42)^{(\mathrm{e})}$ & $(0.00)$ & $(0.00)$ \\
\hline $\mathrm{Ru}^{(\mathrm{b})}$ & $(0.002)$ & $(0.002)$ & $(0.002)$ & $(0.002)$ & $(0.001)$ & $(0.001)$ & $(0.004)$ & $(0.005)$ & $(0.002)$ & $(0.001)$ \\
\hline $\mathrm{Ag}^{(\mathrm{b})}$ & 0.03 & 0.03 & 0.04 & 0.04 & 0.04 & 0.06 & 0.06 & 0.05 & 0.02 & 0.04 \\
\hline $\mathrm{Cd}^{(\mathrm{b})}$ & 0.07 & 0.04 & 0.06 & 0.07 & 0.06 & 0.12 & 0.09 & 0.16 & 0.05 & 0.04 \\
\hline $\mathrm{Pb}^{(\mathrm{b})}$ & 4.42 & 1.57 & 5.47 & 4.58 & 4.66 & 9.04 & 3.19 & 3.24 & 4.74 & 3.99 \\
\hline $\mathrm{Pb}$ & 4.30 & 1.73 & 5.22 & 4.33 & 4.17 & 8.47 & 2.45 & 2.44 & 4.59 & 3.75 \\
\hline $\mathrm{U}$ & 0.53 & 0.25 & 0.59 & 0.50 & 0.48 & 0.68 & 3.55 & 3.22 & 0.53 & 0.48 \\
\hline \multicolumn{11}{|c|}{$\begin{array}{l}\text { Values in parenthesis are just below level of quantification but spectra looked good. Thus, a tentative value was attributed to data. } \\
\text { Values in bold are suspect because of poor spike recoveries and for B acid attack on digestion glassware may add additional B. } \\
\text { (a) Multiply by } 0.3048 \text { to convert to meters. } \\
\text { (b) ICP-MS instrument was used; when not noted, ICP was used. } \\
\text { (c) Data are suspect because of Ar-Cl molecular species at mass } 75 \text {. } \\
\text { (d) Check standard was reading high, values are suspect. } \\
\text { (e) Units for Tc are pCi/g. }\end{array}$} \\
\hline
\end{tabular}

Water extraction leaches far fewer of the elements shown in Table 5.22 than acid extraction. The only elements that have water leaches that exceed a few tenths of a percent of the amount that is acidleachable are sodium, sulfur (sulfate), and molybdenum; they water leach between $5 \%$ to $10 \%, 10 \%$ to $30 \%$, and $10 \%$ to $15 \%$ as much as the amount that acid leaches. Thus, the percentages of the total elements in the uncontaminated sediment that leach in water are less than a few percent of the total as determined by XRF. The contaminated sediment differ in that more mass is water-leachable for contaminants that are known to be mobile such as chromium (VI), technetium, molybdenum, sulfate, and nitrate (see Serne et al. 2002 a, b, c).

\subsubsection{Porewater Composition}

Porewater compositions were determined for two water samples from the Hanford formation $\mathrm{H} 2$ unit, extracted from sediment core with an ultracentrifuge (UFA) method (see Section 3.2.11). These data, which compared the calculated porewater compositions of the dilution-corrected water extracts, are presented in Tables 5.23 to 5.26. The chemical composition of UFA-extracted porewater (Table 5.23) suggest that the nitrate value for the sample from 27.9 meters ( 91.5 feet) bgs is erroneously high. 
Table 5.22. Mass Percent of Total Element Leached by Acid Extraction Compared to Bulk Chemical Composition. Bulk chemical composition measured by XRF method.

\begin{tabular}{|c|c|c|c|c|c|c|c|c|}
\hline $\begin{array}{c}\text { Element } \\
\%\end{array}$ & $\begin{array}{c}\text { Ft bgs }^{(a)} \\
39.5\end{array}$ & $\begin{array}{c}\text { Ft bgs }{ }^{(a)} \\
47\end{array}$ & $\begin{array}{c}\text { Ft bgs }^{(a)} \\
91.5\end{array}$ & $\begin{array}{c}\text { Ft bgs }^{(a)} \\
101.5\end{array}$ & $\begin{array}{c}\text { Ft bgs }^{(a)} \\
136\end{array}$ & $\begin{array}{c}\text { Ft bgs }^{(a)} \\
146\end{array}$ & $\begin{array}{c}\text { Ft bgs }^{(a)} \\
148.5\end{array}$ & $\begin{array}{c}\text { Ft bgs }{ }^{(a)} \\
163.5\end{array}$ \\
\hline & H1a & H1 & H2 & H2 & PPlz & PPlc & PPlc & Rtf \\
\hline $\mathrm{Na}$ & 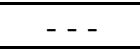 & ב- - & 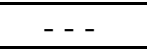 & 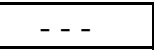 & 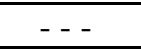 & 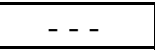 & 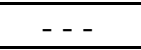 & 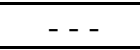 \\
\hline $\mathrm{Mg}$ & 22.85 & 8.80 & 22.22 & 25.81 & 26.20 & 46.11 & 38.19 & 26.65 \\
\hline $\mathrm{Al}$ & 8.36 & 4.24 & 7.76 & 10.26 & 14.21 & 21.03 & 14.00 & 9.86 \\
\hline $\mathrm{Si}$ & 0.01 & 0.01 & 0.03 & 0.00 & 0.0 & 0.01 & 0.01 & 0.00 \\
\hline $\mathrm{P}$ & $>43$ & $>49$ & $>41$ & $>46$ & $>51$ & $>31$ & $>39$ & $>38$ \\
\hline$S$ & 14 & 8 & $>13$ & 11 & $>12$ & 23 & 29 & $>8$ \\
\hline $\mathrm{K}$ & 7.1 & 3.6 & 5.6 & 7.3 & 10.0 & 11.3 & 6.4 & 3.6 \\
\hline $\mathrm{Ca}$ & 33.7 & 9.4 & 29.6 & 36.3 & 47.5 & 86.4 & 136.2 & 29.9 \\
\hline $\mathrm{Ti}$ & 14.9 & 6.1 & 10.5 & 14.4 & 11.7 & 15.1 & 16. & 16.5 \\
\hline $\mathrm{Mn}$ & 51.6 & 11.6 & 48.0 & 54.6 & 63.9 & 76.4 & 60.0 & 65.1 \\
\hline $\mathrm{Fe}$ & 43.6 & 13.9 & 41.5 & 45.9 & 50.3 & 41.1 & 41.0 & 55.8 \\
\hline $\mathrm{Sr}$ & 8.1 & 5.9 & 7.2 & 9.8 & 14.6 & 88.8 & 116.3 & 8.0 \\
\hline $\mathrm{Ba}$ & 10.5 & 7.5 & 7.6 & 9.8 & 17.0 & 35.4 & 17.1 & 6.7 \\
\hline $\mathrm{Cr}$ & 28.5 & 4.9 & 22.6 & 20.0 & 29.7 & 34.6 & 30.3 & 32.9 \\
\hline $\mathrm{Co}$ & $>11.0$ & $>5.1$ & $>10.4$ & $>11.4$ & $>15.2$ & $>9.5$ & $>8.7$ & $>11.3$ \\
\hline $\mathrm{Ni}$ & 45.0 & 13.3 & 49.4 & 50.4 & 56.0 & $\begin{array}{l}50.8 \\
\end{array}$ & 61.6 & 49.0 \\
\hline $\mathrm{Cu}$ & 53.0 & 29.3 & 59.2 & 49.8 & 61.1 & 71.7 & 52.7 & 37.4 \\
\hline $\mathrm{Zn}$ & 63.4 & 19.4 & 64.0 & 62.0 & 72.7 & 63.8 & 60.5 & 65.8 \\
\hline As & $>68.2$ & 11.2 & 70.2 & 76.8 & 59.2 & 78.4 & 104.2 & $>77.2$ \\
\hline $\mathrm{Se}$ & $>7.0$ & $>7.7$ & $>6.5$ & $>5.6$ & $>9.0$ & $>18.1$ & $>27.2$ & $>6.2$ \\
\hline Mo & $>2.2$ & 1.4 & $>2.9$ & $>3.2$ & $>2.1$ & $>10.1$ & $>4.4$ & $>3.6$ \\
\hline $\mathrm{Ru}$ & $>0.0$ & $>0.0$ & $>0.0$ & $>0.0$ & $>0.0$ & $>0.0$ & $>0.1$ & $>0.0$ \\
\hline $\mathrm{Ag}$ & 0.2 & $>0.4$ & $>0.5$ & $>0.4$ & $>0.6$ & $>0.5$ & $>0.7$ & $>0.3$ \\
\hline $\mathrm{Cd}$ & $>0.8$ & $>0.4$ & $>0.7$ & $>0.6$ & $>1.2$ & $>0.6$ & $>2.0$ & $>0.6$ \\
\hline $\mathrm{Pb}$ & 24.0 & 28.5 & 30.4 & 24.0 & 61.1 & 43.7 & 34.1 & 34.3 \\
\hline $\mathrm{U}$ & $>8.0$ & $>3.6$ & $>7.2$ & $>7.0$ & 9.1 & $>40.8$ & $>53.7$ & $>9.3$ \\
\hline
\end{tabular}

The charge balance for $91.5 \mathrm{ft}$ bgs porewater is poor while that for 101.5 feet is good (see Table 5.24). The nitrate analysis for porewater 91.5 feet appears to be too high. Further investigation found that the aliquot used for anion analysis had been mistakenly preserved with nitric acid. Thus the nitrate value is not correct. The values for all the other constituents are quite similar for the two porewaters. Natural vadose-zone porewaters are similar in chemical composition to the water extracts and groundwater, except they are more concentrated. The fluids from these two Hanford formation $\mathrm{H} 2$ unit sediment samples are dominated by calcium, magnesium, and sodium cations and by sulfate, chloride, nitrate, and bicarbonate anions. The sodium and nitrate values seem somewhat high compared to uncontaminated groundwater (Hartman et al. 2000) perhaps reflecting some anthropomorphic input of Hanford's two most ubiquitous chemical contaminants, sodium and nitrate. 
Table 5.23. pH, Electrical Conductivity, Alkalinity, Anions, Cations, and Trace Metals Measured in UFA-Extracted Porewater from Two Samples in Borehole 299-W22-48.

\begin{tabular}{|c|c|c|c|}
\hline \multirow[b]{2}{*}{ Analysis } & \multirow[b]{2}{*}{ Units } & \multicolumn{2}{|c|}{ Depth (ft bgs) $^{(a)}$} \\
\hline & & 91.5 & 101.5 \\
\hline Moisture & Wt \% & 19.14 & 21.62 \\
\hline pH & & 6.93 & 7.25 \\
\hline $\mathrm{EC}$ & $\mu \mathrm{S} / \mathrm{cm}$ & 1386 & 1316 \\
\hline Alk & $\mathrm{mg} / \mathrm{L} \mathrm{CaCO} 3$ & 57.11 & 54.29 \\
\hline $\mathrm{F}$ & $\mathrm{mg} / \mathrm{L}$ & 0.48 & 0.46 \\
\hline $\mathrm{Cl}$ & $\mathrm{mg} / \mathrm{L}$ & 98.2 & 95 \\
\hline $\mathrm{Br}$ & $\mathrm{mg} / \mathrm{L}$ & 0.83 & 0.78 \\
\hline $\mathrm{NO} 2$ & $\mathrm{mg} / \mathrm{L}$ & $<0.1$ & $<0.1$ \\
\hline NO3 & $\mathrm{mg} / \mathrm{L}$ & $941^{(0)}$ & 166 \\
\hline PO4 & $\mathrm{mg} / \mathrm{L}$ & $<0.1$ & $<0.1$ \\
\hline SO4 & $\mathrm{mg} / \mathrm{L}$ & 176 & 154 \\
\hline $\mathrm{Na}$ & $\mathrm{mg} / \mathrm{L}$ & 88.20 & 84.51 \\
\hline$\overline{\mathrm{Mg}}$ & $\mathrm{mg} / \mathrm{L}$ & 30.12 & 22.51 \\
\hline $\mathrm{Al}$ & $\mu \mathrm{g} / \mathrm{L}$ & (8) & (13) \\
\hline Si & $\mathrm{mg} / \mathrm{L}$ & 12.91 & 13.86 \\
\hline $\mathrm{P}$ & $\mu \mathrm{g} / \mathrm{L}$ & $(147)$ & $(80)$ \\
\hline $\mathrm{S}$ & $\mathrm{mg} / \mathrm{L}$ & 68.35 & 61.32 \\
\hline $\bar{K}$ & $\mathrm{mg} / \mathrm{L}$ & 12.07 & 11.02 \\
\hline $\mathrm{Ca}$ & $\mathrm{mg} / \mathrm{L}$ & 104.2 & 103.1 \\
\hline$\overline{\mathrm{Mn}}$ & $\mu \mathrm{g} / \mathrm{L}$ & (5) & $(7)$ \\
\hline $\mathrm{Fe}$ & $\mu \mathrm{g} / \mathrm{L}$ & (18) & 29.9 \\
\hline $\mathrm{Sr}$ & $\mu \mathrm{g} / \mathrm{L}$ & 521 & 477 \\
\hline $\mathrm{Ba}$ & $\mu \mathrm{g} / \mathrm{L}$ & 82.6 & 90.9 \\
\hline $\mathrm{B}$ & $\mu \mathrm{g} / \mathrm{L}$ & (55) & (46) \\
\hline $\mathrm{Cr}^{(\mathrm{c})}$ & $\mu \mathrm{g} / \mathrm{L}$ & 2.05 & 1.74 \\
\hline Co & $\mu \mathrm{g} / \mathrm{L}$ & 2.2 & 0.8 \\
\hline $\mathrm{Ni}$ & $\mu \mathrm{g} / \mathrm{L}$ & (0) & $<100$ \\
\hline $\mathrm{Cu}$ & $\mu \mathrm{g} / \mathrm{L}$ & (3) & (6) \\
\hline $\mathrm{Zn}$ & $\mu \mathrm{g} / \mathrm{L}$ & 160 & 75.6 \\
\hline $\mathrm{As}^{(\mathrm{c})}$ & $\mu \mathrm{g} / \mathrm{L}$ & 6.0 & 6.8 \\
\hline $\mathrm{Se}^{(\mathrm{c})}$ & $\mu \mathrm{g} / \mathrm{L}$ & 67.6 & 81.4 \\
\hline $\mathrm{Mo}^{(\mathrm{c})}$ & $\mu \mathrm{g} / \mathrm{L}$ & 25.1 & 25.0 \\
\hline$T c^{(c)}$ & $\mu \mathrm{g} / \mathrm{L}$ & $(0.00)$ & $(0.00)$ \\
\hline $\mathrm{Pb}^{(\mathrm{c})}$ & $\mu \mathrm{g} / \mathrm{L}$ & $(0.65)$ & $(0.48)$ \\
\hline $\mathrm{U}^{(c)}$ & $\mu \mathrm{g} / \mathrm{L}$ & 2.22 & 5.00 \\
\hline $\mathrm{Ag}^{(\mathrm{c})}$ & $\mu \mathrm{g} / \mathrm{L}$ & $(0.05)$ & 0.140 \\
\hline $\mathrm{Cd}^{(\mathrm{c})}$ & $\mu \mathrm{g} / \mathrm{L}$ & $(0.13)$ & 0.340 \\
\hline $\mathrm{Ru}^{(\mathrm{c})}$ & $\mu \mathrm{g} / \mathrm{L}$ & & \\
\hline $\begin{array}{ll}\text { (a) } & \text { Multiply } \\
\text { (b) Subseque } & \text { nitric aci } \\
& \text { Inductive } \\
\text { (c) } & \text { instrume } \\
\end{array}$ & $\begin{array}{l}048 \text { to convert } \\
\text { estigation shov }\end{array}$ & $\begin{array}{l}\text { eters. } \\
\text { ladvertan }\end{array}$ & $\begin{array}{l}\text { mination with } \\
\text {-MS) }\end{array}$ \\
\hline
\end{tabular}


Table 5.24. Charge Balance for UFA-Extracted Porewater from Two Sediment Samples in Borehole 299-W22-48

\begin{tabular}{|c|c|c|c|c|c|c|c|c|c|c|c|}
\hline $\begin{array}{c}\text { Units } \\
\text { ft } \\
\text { (bgs) }^{(\mathbf{a})}\end{array}$ & $\begin{array}{c}\text { Alk } \\
\text { (meq/L) }\end{array}$ & $\begin{array}{c}\mathbf{F} \\
(\mathrm{meq} / \mathrm{L})\end{array}$ & $\begin{array}{c}\mathrm{Cl} \\
(\mathrm{meq} / \mathrm{L})\end{array}$ & $\begin{array}{c}\mathrm{NO}_{3} \\
(\mathrm{meq} / \mathrm{L})\end{array}$ & $\begin{array}{c}\mathrm{SO}_{4} \\
(\mathrm{meq} / \mathrm{L}) \\
\end{array}$ & $\begin{array}{l}\sum \text { Anion } \\
\text { (meq/L) }\end{array}$ & $\begin{array}{c}\mathrm{Na} \\
(\mathrm{meq} / \mathrm{L})\end{array}$ & $\begin{array}{c}\mathrm{Mg} \\
\text { (meq/L) }\end{array}$ & $\begin{array}{c}\mathrm{K} \\
(\mathrm{meq} / \mathrm{L})\end{array}$ & $\begin{array}{c}\text { Ca } \\
(\mathrm{meq} / \mathrm{L})\end{array}$ & $\begin{array}{l}\sum \text { Cation } \\
\text { (meq/L) }\end{array}$ \\
\hline 91.5 & 1.14 & 0.03 & 2.77 & 15.18 & 3.67 & 22.79 & 3.83 & 2.48 & 0.31 & 5.21 & 11.85 \\
\hline 101.5 & 1.09 & 0.02 & 2.68 & 2.68 & 3.21 & 9.69 & 3.67 & 1.85 & 0.28 & 5.16 & 10.98 \\
\hline
\end{tabular}

Table 5.25. Theoretically Calculated Composition of Vadose-Zone Porewater (1:1 Sediment-to-Water Extracts Multiplied By Dilution Factor)

\begin{tabular}{|c|c|c|c|c|c|c|c|c|c|c|c|c|}
\hline $\begin{array}{l}\text { Constituent } \\
\text { Units }\end{array}$ & EC & Alk & $\mathbf{F}$ & $\mathbf{C l}$ & $\mathrm{NO}_{3}$ & $\mathrm{SO}_{4}$ & $\mathbf{N a}$ & Mg & $\mathbf{K}$ & Ca & Sr & $\mathbf{B a}$ \\
\hline Sample ft bgs ${ }^{(a)}$ & $\mu \mathrm{S} / \mathbf{c m}$ & $\mathrm{mg} / \mathrm{L} \mathrm{CaCO}_{3}$ & $\mathrm{mg} / \mathrm{L}$ & $\mathrm{mg} / \mathrm{L}$ & mg/L & mg/L & mg/L & $\mathrm{mg} / \mathrm{L}$ & $\mathrm{mg} / \mathrm{L}$ & $\mathrm{mg} / \mathrm{L}$ & $\mu \mathbf{g} / \mathbf{L}$ & $\mu \mathbf{g} / \mathbf{L}$ \\
\hline \multicolumn{13}{|c|}{ Hanford Formation Unit H1a (Sand) } \\
\hline 29.5 & 2115 & 452.7 & 9.0 & 3.0 & 74.5 & 195.3 & 273.6 & 13.4 & 44.1 & 64.0 & 280 & 261 \\
\hline 32 & 3211 & 781.1 & 11.6 & 4.9 & 130.9 & 171.6 & 396.2 & 21.8 & 77.4 & 112.7 & 396 & 229 \\
\hline 39.5 & 2279 & 419.5 & 7.0 & 8.2 & 174.1 & 186.7 & 254.3 & 15.7 & 48.5 & 84.3 & 308 & 196 \\
\hline \multicolumn{13}{|c|}{ Hanford Formation Unit H1 (Sand and Gravel) } \\
\hline 47 & 6705 & 1538.4 & 30.9 & 12.8 & 146.9 & 492.8 & 675.8 & 56.9 & 155.9 & 281.0 & 1352 & 1128 \\
\hline 56 & 3632 & & 11.5 & 26.9 & 25.6 & 293.4 & 392.9 & 58.6 & 120.2 & 227.4 & 957 & 128 \\
\hline \multicolumn{13}{|c|}{ Hanford Formation Unit H2 (Fine Sand and Silt) } \\
\hline 74.5 & 3296 & 549.3 & 7.6 & 77.2 & 111.1 & 367.1 & 251.0 & 54.3 & 66.5 & 164.0 & 946 & 264 \\
\hline 106.5 & 3221 & 615.8 & 6.0 & 117.4 & 94.4 & 189.3 & 258.6 & 39.1 & 65.5 & 175.6 & 883 & 308 \\
\hline 115.5 & 3442 & 719.9 & 6.8 & 43.1 & 142.8 & 232.6 & 280.1 & 42.9 & 63.5 & 198.0 & 1080 & 528 \\
\hline \multicolumn{13}{|c|}{ Upper Plio-Pleistocene Unit (PPlz) } \\
\hline 136 & 3753 & 704.8 & 7.9 & 23.1 & 398.1 & 208.7 & 289.4 & 56.3 & 67.3 & 226.6 & 1156 & 566 \\
\hline 143.5 & 4858 & 902.4 & 7.1 & 18.5 & 423.1 & 289.9 & 295.7 & 95.6 & 85.4 & 293.3 & 1593 & 771 \\
\hline \multicolumn{13}{|c|}{ Lower Plio-Pleistocene Unit (PPlc) } \\
\hline 146 & 2972 & 319.9 & 6.1 & 24.1 & 506.8 & 299.2 & 151.2 & 82.3 & 33.7 & 199.5 & 1254 & 199 \\
\hline 148.5 & 2144 & 306.4 & 9.4 & 13.6 & 315.3 & 124.5 & 112.6 & 55.4 & 29.4 & 136.1 & 891 & 183 \\
\hline \multicolumn{13}{|c|}{ Ringold Formation (Rtf) } \\
\hline 151 & 7430 & 1762.8 & 43.2 & 60.0 & 148.6 & 194.7 & 626.9 & 167.9 & 218.2 & 371.1 & 2175 & 589 \\
\hline 163.5 & 6225 & 1594.1 & 26.1 & 23.9 & 369.8 & 89.9 & 385.2 & 142.6 & 131.4 & 353.8 & 2033 & 633 \\
\hline 170 & 3878 & 1037.1 & 15.4 & 16.4 & 245.4 & 61.5 & 238.4 & 98.0 & 94.3 & 244.1 & 1381 & 1491 \\
\hline 172.5 & 3825 & 638.8 & 10.1 & 8.1 & 39.5 & 30.2 & 165.5 & 56.4 & 72.9 & 141.1 & 791 & 383 \\
\hline 187 & 2289 & 669.9 & 20.7 & 25.5 & 428.1 & 80.3 & 204.7 & 22.0 & 68.2 & 56.6 & 302 & 346 \\
\hline \multicolumn{13}{|c|}{ Ringold Formation (Rwi [e]) } \\
\hline 192 & 5427 & 828.9 & 62.0 & 70.1 & 411.5 & 452.2 & 630.9 & 33.5 & 190.8 & 79.1 & 452 & 746 \\
\hline
\end{tabular}


Table 5.26. Comparison of UFA-Extracted Porewater to Theoretically Calculated Porewater from the Hanford Formation H2 Unit in Borehole 299-W22-48

\begin{tabular}{|c|c|c|c|c|c|c|c|c|c|c|c|}
\hline & Alk & $\mathbf{F}$ & Cl & $\mathrm{NO}_{3}$ & $\mathrm{SO}_{4}$ & ¿Anions & $\mathrm{Na}$ & Mg & $\mathbf{K}$ & Ca & $\sum$ Cations \\
\hline Units & $\mathrm{meq} / \mathrm{L}$ & $\mathrm{meq} / \mathrm{L}$ & meq/L & $\mathrm{meq} / \mathrm{L}$ & $\mathrm{meq} / \mathrm{L}$ & $\mathrm{meq} / \mathrm{L}$ & $\mathrm{meq} / \mathrm{L}$ & $\mathrm{meq} / \mathrm{L}$ & $\mathrm{meq} / \mathrm{L}$ & $\mathrm{meq} / \mathrm{L}$ & meq/L \\
\hline \multicolumn{12}{|l|}{ ft (bgs) ${ }^{(a)}$} \\
\hline 74.5 & 10.99 & 0.40 & 2.18 & 1.79 & 7.65 & 23.01 & 10.91 & 4.47 & 1.70 & 8.19 & 25.27 \\
\hline $91.5^{*}$ & 1.14 & 0.03 & 2.77 & 15.18 & 3.67 & 22.79 & 3.83 & 2.48 & 0.31 & 5.21 & 11.85 \\
\hline $101.5^{*}$ & 1.09 & 0.02 & 2.68 & 2.68 & 3.21 & 9.69 & 3.67 & 1.85 & 0.28 & 5.16 & 10.98 \\
\hline 106.5 & 12.32 & 0.32 & 3.31 & 1.52 & 3.94 & 21.41 & 11.24 & 3.22 & 1.68 & 8.76 & 24.90 \\
\hline 115.5 & 14.40 & 0.36 & 1.22 & 2.30 & 4.85 & 23.12 & 12.18 & 3.53 & 1.63 & 9.88 & 27.21 \\
\hline $\begin{array}{c}\text { Agreement } \\
? \\
\end{array}$ & No & No & Yes & Yes & Yes & & No & Yes & No & Yes & \\
\hline
\end{tabular}

Table 5.25 shows the theoretical chemical composition of vadose-zone porewater calculated by assuming that the water extracts represent only solutes present in the native porewater. To convert back to the concentration in the porewater, one only needs to multiply by the dilution factor for the added deionized water. In Table 5.26, we compare the theoretical porewater composition for the neighboring water extracts with the two actual porewater analyses measured. All five data sets in Table 5.26 are from the Hanford formation $\mathrm{H} 2$ unit, composed of a sequence of laminated fine sands and silts above the PlioPleistocene unit (see Figure 2.19).

Table 5.26 suggests that the water extracts do dissolve excess carbonate, potassium, and sodium during the extraction. The bottom row indicates the qualitative agreement between the calculated porewater and actual porewater for each macro constituent. The additional carbonate alkalinity in water extracts is likely partly due to the dissolution of calcite. The excess potassium and sodium may come from the excess calcium-replacing cation-exchangeable alkali metals, though some potassium dissolution (source may be potassium-feldspar) has been noticed in longer-term water leach tests. Aside from carbonate alkalinity, the water extracts may not dissolve excess anions not already present in the natural porewater. As discussed in the other reports in this series (Serne et al. $2002 \mathrm{a}, \mathrm{b}, \mathrm{c}$ ), which characterize contaminated sediment that have come in contact with highly saline tank liquors, calculated values from water extracts agree more closely with UFA-extracted porewater data for sediments pore waters dominated by leaked tank fluids.

The dilution-corrected water extract data, as well as results from the two actual UFA-extracted porewater samples, versus depth in borehole 299-W22-48, are displayed graphically in Figures 5.7 to 5.9. Figure 5.7 illustrates variations in $\mathrm{pH}$ and EC, Figure 5.8 shows anions, and Figure 5.9 shows variations in cations versus depth. Figure 5.7 shows a fairly narrow range in $\mathrm{pH}$ values for the water extracts of the selected sediment samples. An exception is the 11.3-meter (37-foot) bgs sample within the lower portion of the Hanford formation $\mathrm{H} 1 \mathrm{a}$ unit, which has a significantly higher $\mathrm{pH}(\sim 8)$. This may not be significant, however, since most of the uppermost 18.3-meter (60-foot) sediment, including the Hanford formation 


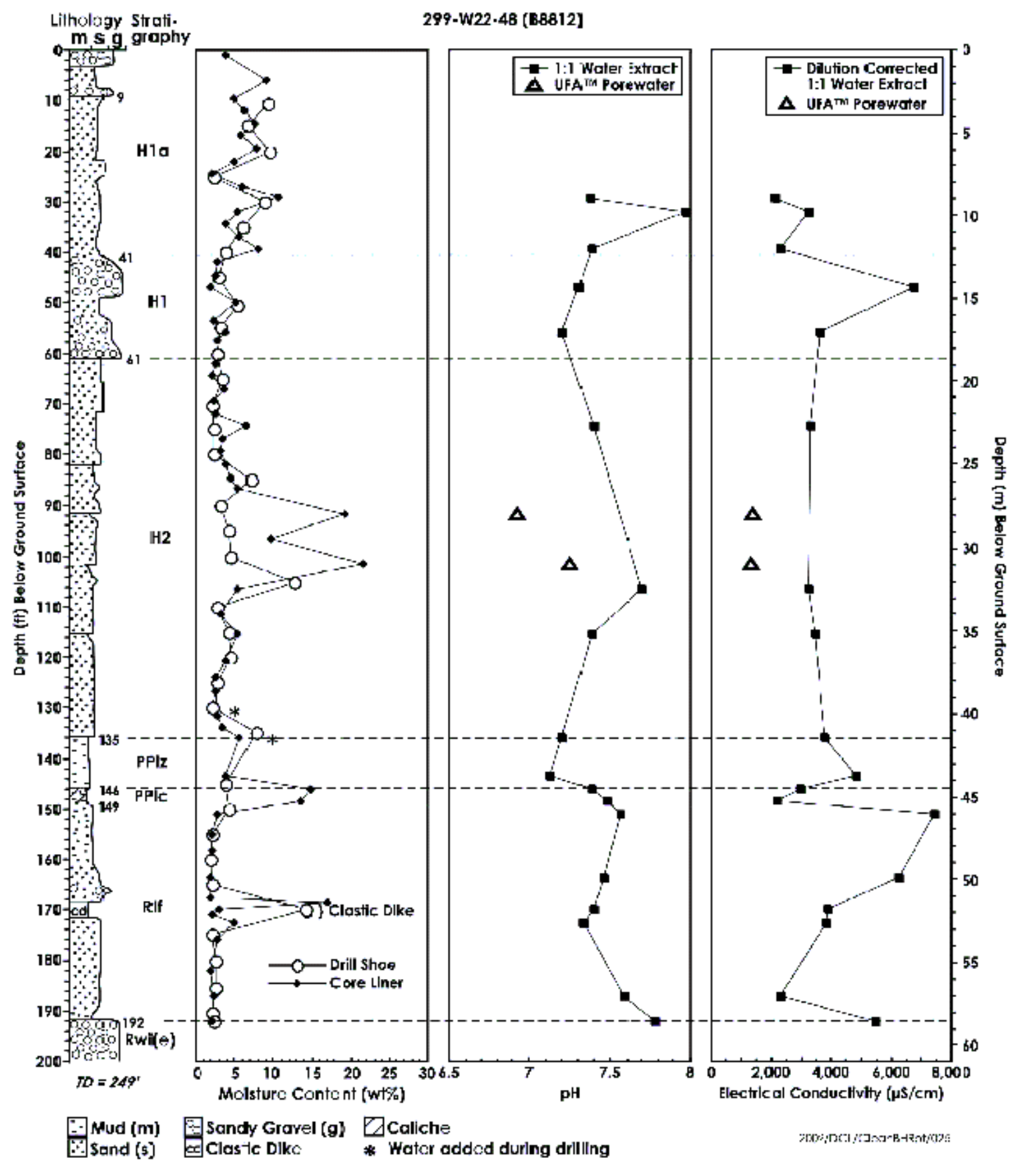

Figure 5.7. Moisture Content and Comparison of $\mathrm{pH}$ and Dilution-Corrected Electrical Conductivity of 1:1 Sediment-to-Water Extracts and UFA-Extracted Porewater from Sediment Samples in Borehole 299-W22-48 


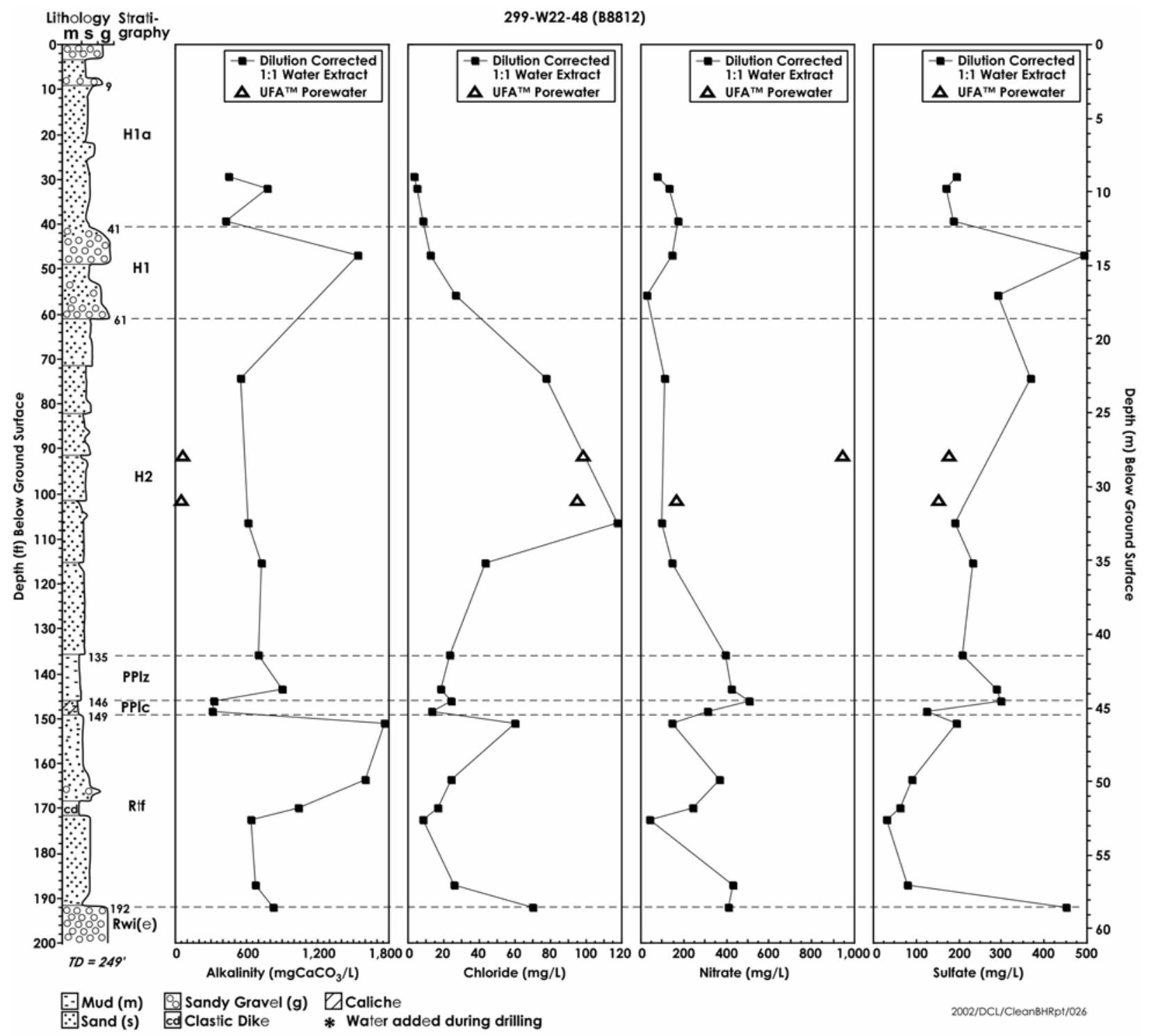

Figure 5.8. Comparison of Dilution-Corrected Anion Concentrations of 1:1 Sediment to Water Extracts and UFA-Extracted Porewaters from Sediment Samples in Borehole 299-W22-48

H1a unit, has been removed and mixed to form backfill within the SX Tank Farm. Below this higher pH spike, the profile is relatively uniform down to the top of the Ringold Formation. Just below the PPlc subunit, the $\mathrm{pH}$ is slightly elevated.

The EC profile shows three spikes, one at 14.3 meters ( 47 feet) bgs toward the top of the coarsegrained Hanford formation H1 unit, one each at the top of the two Ringold units (Rtf and Rwi(e)). The latter two spikes likely represent some evaporite dissolution and the sensitivity to the large dilution correction for very dry sediment. The spike at 14.3 meters (47 feet) bgs might represent the evaporates formed during the natural evapotranspiration cycle back when the Hanford Reservation had a natural 


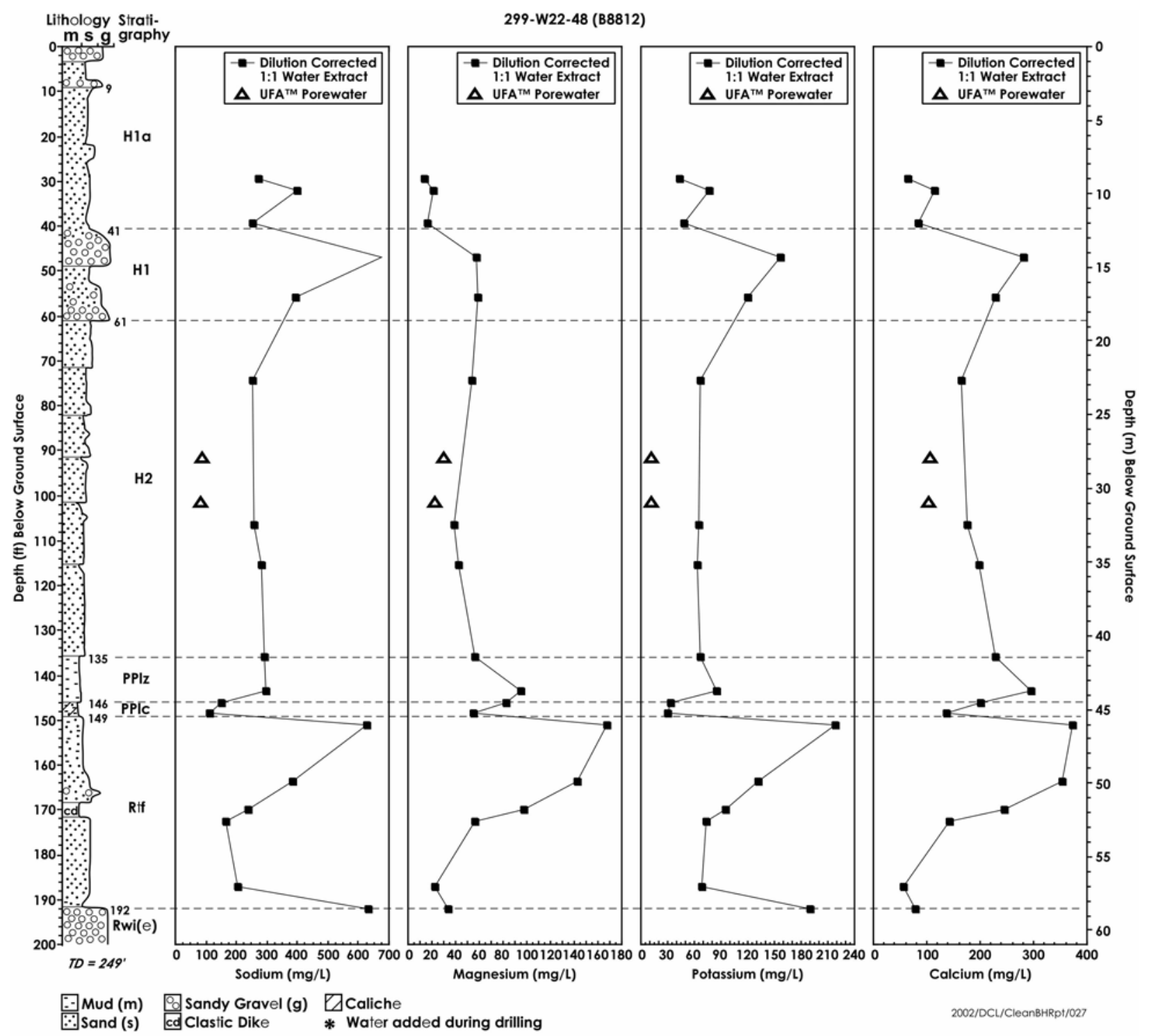

Figure 5.9. Comparison of Dilution-Corrected Cation Concentrations of 1:1 Water Extracts and UFA-Extracted Porewaters from Sediment Samples in Borehole 299-W22-48

vegetation cycle. This may represent a buried soil horizon or a zone of root penetration that transpired natural recharge back into the atmosphere leaving salts behind. For both the $\mathrm{pH}$ and EC, the values for the actual UFA-extracted porewaters are lower than the calculated porewaters (dilution-corrected 1:1 sediment-to-water extracts).

Figure 5.8 shows the anion profile for the vadose zone in borehole $299 \mathrm{~W}-22-48$. The alkalinity, which is a measure of bicarbonate, shows a peak at 14.3 meters (47 feet) bgs and then a second peak right below the PPlc subunit. The chloride shows a peak near $110 \mathrm{ft}$ bgs near the center of the Hanford formation $\mathrm{H} 2$ unit and a smaller peak just below the PPlc subunit. The nitrate profile does not vary significantly, except for a minor peak at the top of the PPlc subunit. The sulfate profile shows a similar 
peak as the alkalinity and EC profiles within the Hanford formation $\mathrm{H} 2$ unit (47 ft bgs) and second peak at the top of the Rwi(e) unit. The two actual porewater samples measured show lower values for the anions than the calculated porewaters based on the water extracts, excepting the nitrate value at $91.5 \mathrm{ft}$ bgs. As mentioned earlier, this datum is incorrect because of contamination during lab activities. The water extract procedure overestimates the composition of porewaters in the vadose sediment apparently because of some dissolution. However, for contaminated vadose zone sediments, the dilution-corrected water extracts represent a better estimate of actual contaminated porewater because the leaked tank fluids are much higher in salt content, making any minor contribution from dissolving salts from the sediment insignificant.

The cation profiles shown in Figure 5.9 show that the sample at 14.3 meters (47 feet) bgs is slightly elevated in calcium, potassium, and sodium compared to the rest of the Hanford formation sediment. All four plotted cations appear depleted in the PPlc subunit followed by a significant increase within the underlying Ringold Rtf unit. As with the anions, the two actual UFA-extracted porewater samples show lower concentrations of cations than the calculated porewater from the water-extract data. Again, this is interpreted as the result of dissolution of some of the sediment during water extraction. Therefore, estimates of porewater composition based on water extracts, presented in Table 5.25 and plotted in Figures 5.7 to 5.9, are biased high and should be used as upper limit values for the chemical composition of porewaters from the various strata.

\subsection{Analytical Results for Borehole 299-W22-50}

Laboratory analytical results of core samples from clean borehole 299-W22-50 are presented in this section. Sample depths, stratigraphic unit, and types of analyses performed are summarized in Table 5.27. Sampling depths for laboratory moisture analysis are listed in a separate table (Table 5.28).

\subsubsection{Mass Water Content}

For borehole 299-W22-50, every core segment between 6.04 and 53.9 meters (between 20 and 177.5 feet) bgs was opened and sampled for moisture content. Unlike borehole 299-W22-48, separate moisture samples were not collected in the field from the drive shoe. The moisture profile, along with the lithology, total gamma log, and neutron-neutron moisture log, is illustrated in Figure 2.18. Moisture, in combinaiton with geophysical logs and particle-size distribution, are useful for helping to define lithologic contacts. For example, the relatively low field moisture content between 15.8 and 19.2 meters (or 52 and 63 feet) bgs can be used to delineate coarser-grained strata within the Hanford formation H1 unit (see Figure 2.18).

The moisture content in this borehole is fairly uniform (5\% to $15 \mathrm{wt} \%$ ) between 6.04 and 36.6 meters (20 and 110 feet) bgs, with the exception of the coarser-grained Hanford formation H1 unit, which ranges between $2 \%$ to $8 \%$. Several moisture spikes occur at depths of about 115,127 , and $140 \mathrm{ft}$ bgs. The former appears to be within a finer-grained lens within the Hanford formation H2 unit, the middle spike occurs in the upper PPLz subunit just below the contact with the Hanford formation H2 unit. The 
Table 5.27. Sediment Core Samples Selected from Borehole 299-W22-50 for Laboratory Analysis

\begin{tabular}{|c|c|c|}
\hline $\begin{array}{l}\text { Depth (ft } \\
\text { bgs) }\end{array}$ & Stratigraphic Unit* & Analysis \\
\hline 20 & $\mathrm{H} 1 \mathrm{a}$ & $\mathrm{WL}, \mathrm{CaCO} 3$ \\
\hline 22.5 & H1a & WL, $\mathrm{CaCO} 3$ \\
\hline 25 & $\mathrm{H} 1 \mathrm{a}$ & WL, $\mathrm{CaCO} 3$ \\
\hline 27.5 & "H1a & $\mathrm{AL}, \mathrm{CaCO} 3$ \\
\hline 30 & H1a & $\mathrm{WL}, \mathrm{CaCO} 3$ \\
\hline 32.5 & H1a & $\mathrm{WL}, \mathrm{CaCO} 3$ \\
\hline 35 & H1a & $\mathrm{WL}, \mathrm{CaCO} 3$ \\
\hline 37.5 & H1a & $\mathrm{WL}, \mathrm{CaCO} 3$ \\
\hline 40 & H1a & $\mathrm{WL}, \mathrm{CaCO} 3$ \\
\hline 42.5 & H1a & $\mathrm{WL}, \mathrm{CaCO} 3$ \\
\hline 45 & H1a & $\mathrm{WL}, \mathrm{CaCO} 3$ \\
\hline 47.5 & H1a & $\mathrm{DS}, \mathrm{WL}, \mathrm{CaCO} 3$ \\
\hline 48.5 & H1a & DS \\
\hline 51 & H1a & DS, AL,WL, HY, XRD, XRF, PD, CaCO3, EBC \\
\hline 52.5 & H1a & $\mathrm{DS}, \mathrm{WL}, \mathrm{CaCO} 3$ \\
\hline 53.5 & $\mathrm{H} 1$ & DS \\
\hline 54.5 & $\mathrm{H} 1$ & $\mathrm{DS}, \mathrm{AL}, \mathrm{WL}, \mathrm{CaCO} 3$ \\
\hline 56 & $\mathrm{H} 1$ & $\mathrm{DS}, \mathrm{WL}, \mathrm{CaCO} 3$ \\
\hline 57.5 & $\mathrm{H} 1$ & DS \\
\hline 58.5 & $\mathrm{H} 1$ & $\begin{array}{c}\mathrm{DS} \\
\end{array}$ \\
\hline 60 & $\mathrm{H} 1$ & DS, AL,WL, HY, XRD, XRF, PD, CaCO3, EBC \\
\hline 61 & $\mathrm{H} 1$ & DS \\
\hline 62.5 & H1 & DS \\
\hline 63.5 & $\mathrm{H} 2$ & DS \\
\hline 65 & $\mathrm{H} 2$ & DS \\
\hline 66 & $\mathrm{H} 2$ & DS \\
\hline 67.5 & $\mathrm{H} 2$ & $\mathrm{AL}, \mathrm{WL}, \mathrm{CaCO} 3$ \\
\hline 68.5 & $\mathrm{H} 2$ & DS \\
\hline 70 & $\mathrm{H} 2$ & DS \\
\hline 76 & $\mathrm{H} 2$ & $\mathrm{WL}, \mathrm{CaCO} 3$ \\
\hline 96 & $\mathrm{H} 2$ & $\mathrm{AL}, \mathrm{WL}, \mathrm{CaCO} 3$ \\
\hline 111 & $\mathrm{H} 2$ & $\mathrm{WL}, \mathrm{CaCO} 3$ \\
\hline 115 & $\mathrm{H} 2$ & WL \\
\hline 116 & $\mathrm{H} 2$ & AL, WL, HY, XRD, XRF, PD, CaCO3, EBC, PW \\
\hline 130 & $\mathrm{PPlz}$ & WL, $\mathrm{CaCO} 3$ \\
\hline 135 & $\mathrm{PPlz}$ & $\mathrm{AL}, \mathrm{WL}, \mathrm{HY}, \mathrm{XRD}, \mathrm{XRF}, \mathrm{PD}, \mathrm{CaCO} 3, \mathrm{EBC}$ \\
\hline 140 & PPlc & AL, HY, XRD, XRF, PD, CaCO3, EBC, PW \\
\hline 141 & PPlc & $\mathrm{AL}, \mathrm{WL}, \mathrm{CaCO} 3$ \\
\hline 150.5 & Rtf & $\mathrm{AL}, \mathrm{WL}, \mathrm{CaCO} 3$ \\
\hline 160.5 & Rtf & $\mathrm{AL}, \mathrm{WL}, \mathrm{HY}, \mathrm{XRD}, \mathrm{XRF}, \mathrm{PD}, \mathrm{CaCO} 3, \mathrm{EBC}$ \\
\hline 174 & Rtf & WL, $\mathrm{CaCO} 3$ \\
\hline
\end{tabular}


Table 5.27. (Contd)

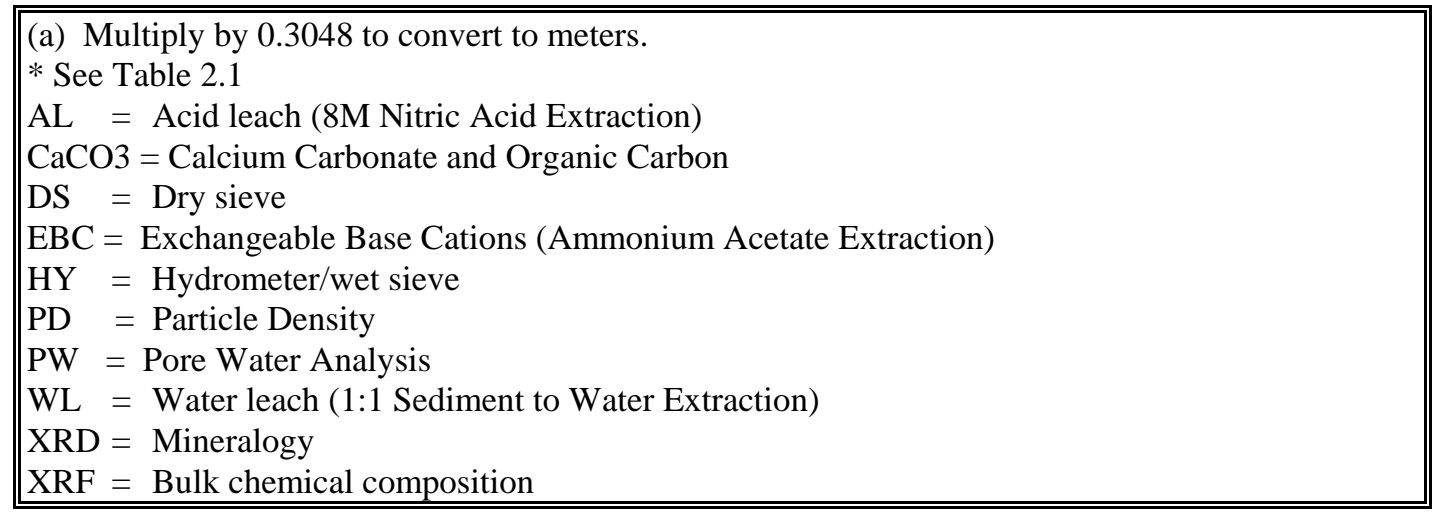

lowermost moisture spike (30 wt $\%$ ) lies within a finer-grained lens of the PPlc subunit. Below the PlioPleistocene unit, within the Ringold Rtf unit, the moisture content is consistently very low (few wt\%); however, the neutron-moisture log indicates moisture increases again with depth within the gravels of Ringold Rwi(e) unit (see Figure 2.18).

\subsubsection{Particle-Size Distribution}

Cores from each of the major stratigraphic units in borehole 299-W22-50 were analyzed for particlesize distribution. Two methods, dry sieving and wet sieving/hydrometer, were used (see Section 3.2.2). Most samples were dry sieved (Table 5.29), though many were also wet sieved (Table 5.30). Only two of the samples (15.5 and 18.3 meters or 51 and 60 feet bgs) were analyzed by both methods; a comparison of these is in Table 5.31. Dry sieving was limited to the Hanford formation while wet sieving/hydrometer was performed on the Plio-Pleistocene unit and Ringold Formation, as well as the Hanford formation.

Table 5.31 shows a comparison between the wet sieve/hydrometer and dry sieve data for the two samples that were analyzed using both methods. There is a significant difference in the two particle-size distributions for the coarse-grained Hanford formation H1 unit (18.3 meters or 60 feet) bgs. Based on the wet sieve/ hydrometer results, it appears many of the gravel clasts may be aggregates of sand and/or silt/clay. This is consistent with wet sieve results in borehole 299-W22-48, which have been demonstrated to produce more fines under wet sieving (see Table 5.6). However, it is possible that the large difference in particle-size distribution is because the two samples came from two different lithologic units within the same 6-inch-long core liner. In general, the wet sieve/hydrometer technique is more effective at disaggregating the sediment samples and, therefore, is believed to produce more accurate results.

Almost all past particle-size determinations on the Hanford Site have used the dry sieving technique, so historical particle-size distributions may be skewed to coarser distributions than obtained using the wet sieve/hydrometer method. 
Table 5.28. Moisture Content (wt \%) Measured in the Laboratory for Sediment Samples from Borehole 299-W22-50

\begin{tabular}{|c|c|c|c|c|c|c|c|}
\hline $\begin{array}{c}\begin{array}{c}\text { Depth } \\
\text { (ft bgs) }^{(a)}\end{array} \\
\end{array}$ & $\begin{array}{c}\text { Moisture } \\
\text { Content (\%) } \\
\end{array}$ & $\begin{array}{c}\text { Depth } \\
\text { (ft bgs) }^{(\mathbf{a})} \\
\end{array}$ & \begin{tabular}{|c|} 
Moisture \\
Content (\%) \\
\end{tabular} & $\begin{array}{c}\begin{array}{c}\text { Depth } \\
\text { (ft bgs) }^{(\mathbf{a})}\end{array} \\
\end{array}$ & \begin{tabular}{|c|} 
Moisture \\
Content (\%) \\
\end{tabular} & $\begin{array}{c}\text { Depth } \\
\text { (ft bgs) }^{(\mathbf{a})}\end{array}$ & $\begin{array}{c}\text { Moisture } \\
\text { Content (\%) } \\
\end{array}$ \\
\hline 20 & 7.33 & 58 & 1.96 & 97.5 & 8.65 & 136 & 17.01 \\
\hline 21 & 7.01 & 60 & 3.02 & 98.5 & 4.51 & 137.5 & 16.14 \\
\hline 22.5 & 14.46 & 61 & 1.62 & 100 & 6.15 & 138.5 & 14.08 \\
\hline 23.5 & 8.55 & 62.5 & 3.50 & 101 & 3.36 & 140 & 29.88 \\
\hline 25 & 5.80 & 63.5 & 2.43 & 102.5 & 5.79 & 141 & 8.29 \\
\hline 26 & 5.51 & 65 & 5.10 & 103.5 & 7.57 & 142.5 & 2.59 \\
\hline 27.5 & 11.47 & 66 & 3.69 & 105 & 7.55 & 143.5 & 2.45 \\
\hline 28.5 & 2.76 & 67.5 & 7.51 & 106 & 6.16 & 148 & 6.74 \\
\hline 30 & 12.56 & 68.5 & 5.53 & 107.5 & 11.52 & 149 & 2.86 \\
\hline 31 & 4.64 & 70 & 6.38 & 108.5 & 7.14 & 150.5 & 3.14 \\
\hline 32.5 & 8.72 & 71 & 4.50 & 110 & 7.18 & 151.5 & 2.60 \\
\hline 33.5 & 4.30 & 72.5 & 5.60 & 111 & 13.86 & 153 & 3.14 \\
\hline 35 & 8.94 & 73.5 & 4.48 & 112.5 & 6.99 & 154 & 2.80 \\
\hline 36 & 5.15 & 75 & 8.37 & 113.5 & 5.88 & 155.5 & 2.28 \\
\hline 37.5 & 6.86 & 76 & 10.30 & 115 & 10.17 & 156.5 & 2.18 \\
\hline 38.5 & 5.92 & 77.5 & 5.74 & 116 & 22.36 & 158 & 2.50 \\
\hline 40 & 5.07 & 78.5 & 7.32 & 117.5 & 5.42 & 159 & 2.03 \\
\hline 41 & 4.41 & 80 & 6.94 & 118.5 & 7.46 & 160.5 & 2.26 \\
\hline 42.5 & 7.14 & 81 & 3.61 & 120 & 8.09 & 161.5 & 1.90 \\
\hline 43.5 & 5.36 & 82.5 & 6.48 & 121 & 10.77 & 163 & 1.84 \\
\hline 45 & 7.87 & 83.5 & 6.92 & 122.5 & 4.95 & 164 & 1.89 \\
\hline 46 & 8.64 & 85 & 5.48 & 123.5 & 3.81 & 165.5 & 1.95 \\
\hline 47.5 & 10.60 & 86 & 3.99 & 125 & 4.93 & 166.5 & 3.48 \\
\hline 48.5 & 9.26 & 87.5 & 5.29 & 126 & 3.45 & 168 & 2.44 \\
\hline 50 & 10.37 & 88.5 & 3.65 & 127.5 & 10.61 & 169 & 1.78 \\
\hline 51 & 7.62 & 90 & 6.01 & 128.5 & 19.69 & 170.5 & 1.67 \\
\hline 52.5 & 2.55 & 91 & 2.28 & 130 & 6.31 & 171.5 & 1.61 \\
\hline 53.5 & 2.08 & 92.5 & 5.15 & 131 & 5.33 & 173 & 1.63 \\
\hline 55 & 8.26 & 93.5 & 7.66 & 132.5 & 10.85 & 174 & 1.74 \\
\hline 56 & 4.25 & 95 & 4.30 & 133.5 & 10.60 & 175.5 & 1.84 \\
\hline 57 & 2.35 & 96 & 8.97 & 135 & 10.00 & 176.5 & 1.92 \\
\hline
\end{tabular}


Table 5.29. Particle-Size Distributions (determined by dry sieving) for Sediment Samples from Borehole 299-W22-50

\begin{tabular}{|c|c|c|c|c|}
\hline $\begin{array}{c}\text { Depth } \\
\text { (ft bgs) }^{(a)}\end{array}$ & $\begin{array}{c}\text { Stratigraphic } \\
\text { Unit }\end{array}$ & $\begin{array}{l}\text { Gravel } \\
(\mathrm{wt} \%)\end{array}$ & $\begin{array}{c}\text { Sand } \\
(\mathrm{wt} \%)\end{array}$ & $\begin{array}{c}\text { Silt/Clay } \\
\text { (wt\%) }\end{array}$ \\
\hline 47.5 & H1a & 0.99 & 96.00 & 3.01 \\
\hline 48.5 & H1a & 0.01 & 92.45 & 7.55 \\
\hline 50 & H1a & 0.56 & 90.11 & 9.33 \\
\hline 51 & $\mathrm{H} 1 \mathrm{a}$ & 0.23 & 90.81 & 8.95 \\
\hline 52.5 & H1a & 4.82 & 90.55 & 4.63 \\
\hline 53.5 & $\mathrm{H} 1$ & 6.06 & 92.09 & 1.85 \\
\hline 54.5 & $\mathrm{H} 1$ & 3.95 & 96.05 & 0.00 \\
\hline 56 & $\mathrm{H} 1$ & 10.69 & 85.34 & 3.97 \\
\hline 57.5 & $\mathrm{H} 1$ & 4.55 & 93.95 & 1.50 \\
\hline 58.5 & $\mathrm{H} 1$ & 48.62 & 49.38 & 2.01 \\
\hline 60 & $\mathrm{H} 1$ & 86.63 & 12.04 & 1.33 \\
\hline 61 & H1 & 50.91 & 45.67 & 3.42 \\
\hline 62.5 & $\mathrm{H} 2$ & 0.99 & 96.00 & 3.01 \\
\hline 63.5 & $\mathrm{H} 2$ & 1.70 & 96.75 & 1.56 \\
\hline 65 & $\mathrm{H} 2$ & 0.26 & 94.51 & 5.23 \\
\hline 66 & $\mathrm{H} 2$ & 1.35 & 96.69 & 1.97 \\
\hline 68.5 & $\mathrm{H} 2$ & 0.00 & 92.23 & 7.77 \\
\hline 70 & $\mathrm{H} 2$ & 2.28 & 92.22 & 5.51 \\
\hline
\end{tabular}

Table 5.30. Particle-Size Distributions Determined by Wet Sieving/Hydrometer Method for Borehole 299-W22-50

\begin{tabular}{|c|c|c|c|c|c||}
\hline $\begin{array}{c}\text { Sample } \\
\text { (ft bgs) }^{(\mathbf{a})}\end{array}$ & $\begin{array}{c}\text { Stratigraphic } \\
\text { Unit }\end{array}$ & $\begin{array}{c}\text { Gravel } \\
\text { (wt\%) }\end{array}$ & $\begin{array}{c}\text { Sand } \\
\text { (wt\%) }\end{array}$ & $\begin{array}{c}\text { Silt } \\
\text { (wt\%) }\end{array}$ & $\begin{array}{c}\text { Clay } \\
\text { (wt\%) }\end{array}$ \\
\hline \hline 51 & H1a & 0.03 & 81.84 & 15.42 & 2.71 \\
\hline 60 & H1 & 35.93 & 43.84 & 17.33 & 2.9 \\
\hline 116 & H2 & 0.00 & 63.84 & 33.86 & 2.29 \\
\hline 135 & PPlz & 0.00 & 8.76 & 80.79 & 10.46 \\
\hline 140 & PPlc & 0.00 & 11.91 & 83.7 & 4.38 \\
\hline 160.5 & Rtf & 5.17 & 82.88 & 9.64 & 2.31 \\
\hline
\end{tabular}

(a) Multiply by 0.3048 to convert to meters. 
Table 5.31. Comparison of Particle-Size Distributions Using the Dry Versus Wet Sieving/Hydrometer Methods for Borehole 299-W22-50

\begin{tabular}{|c|c|c|c|c|c|}
\hline $\begin{array}{c}\text { Depth } \\
\text { (ft bgs) }^{(\text {a) }}\end{array}$ & $\begin{array}{c}\begin{array}{c}\text { Stratigraphic } \\
\text { Unit }\end{array} \\
\end{array}$ & Sieve Method & $\begin{array}{l}\text { Gravel } \\
(\mathrm{wt} \%)\end{array}$ & $\begin{array}{c}\text { Sand } \\
(\mathrm{wt} \%)\end{array}$ & $\begin{array}{c}\text { Silt/Clay } \\
\text { (wt\%) }\end{array}$ \\
\hline \multirow[t]{2}{*}{51} & \multirow[t]{2}{*}{ H1a } & Dry & 0.23 & 90.81 & 8.95 \\
\hline & & Wet/Hydrometer & 0.03 & 81.84 & 18.13 \\
\hline \multirow[t]{2}{*}{60} & \multirow[t]{2}{*}{ H1 } & Dry & 86.63 & 12.04 & 1.33 \\
\hline & & Wet/Hydrometer & 35.93 & 43.84 & 20.23 \\
\hline
\end{tabular}

Figure 5.10 shows the particle-size distribution (determined using wet sieve/hydrometer method) for the three shallower samples from the Hanford formation units while Figure 5.11 shows the distribution of the three other samples from the Plio-Pleistocene unit and Ringold Formation. Particle-size distribution plots confirm that the gravelly sand of the Hanford formation $\mathrm{H} 1$ unit is much coarser and more poorly sorted than the other Hanford formation units. Both Plio-Pleistocene subunits (PPlz and PPlc) are relatively fine-grained compared to the underlying Rtf unit. However, because the PPlc subunit is moderately to strongly cemented with pedogenic calcium carbonate, it is not possible to completely disaggregate the sample prior to wet sieving, thus the particle-size distribution is not totally representative of this unit.

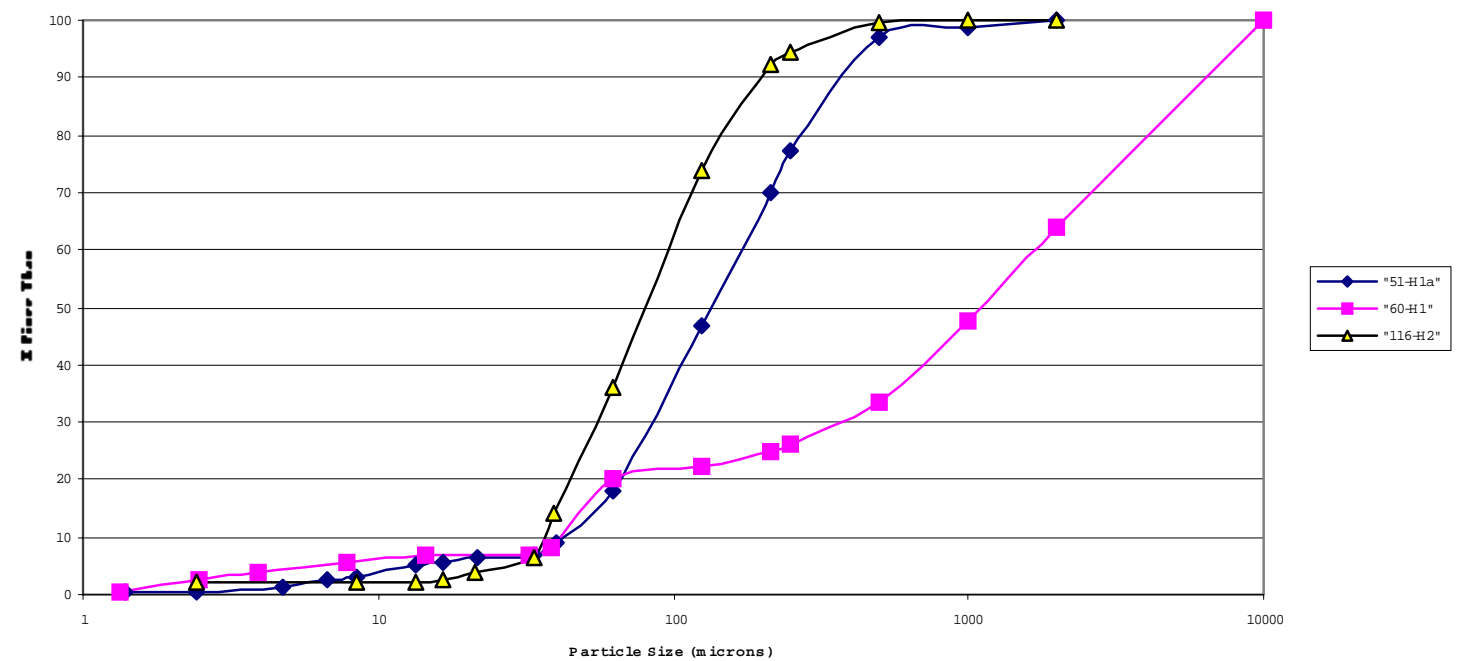

Figure 5.10. Particle-Size Distribution Curves of Sediment Samples from the Hanford Formation at Borehole 299-W22-50 


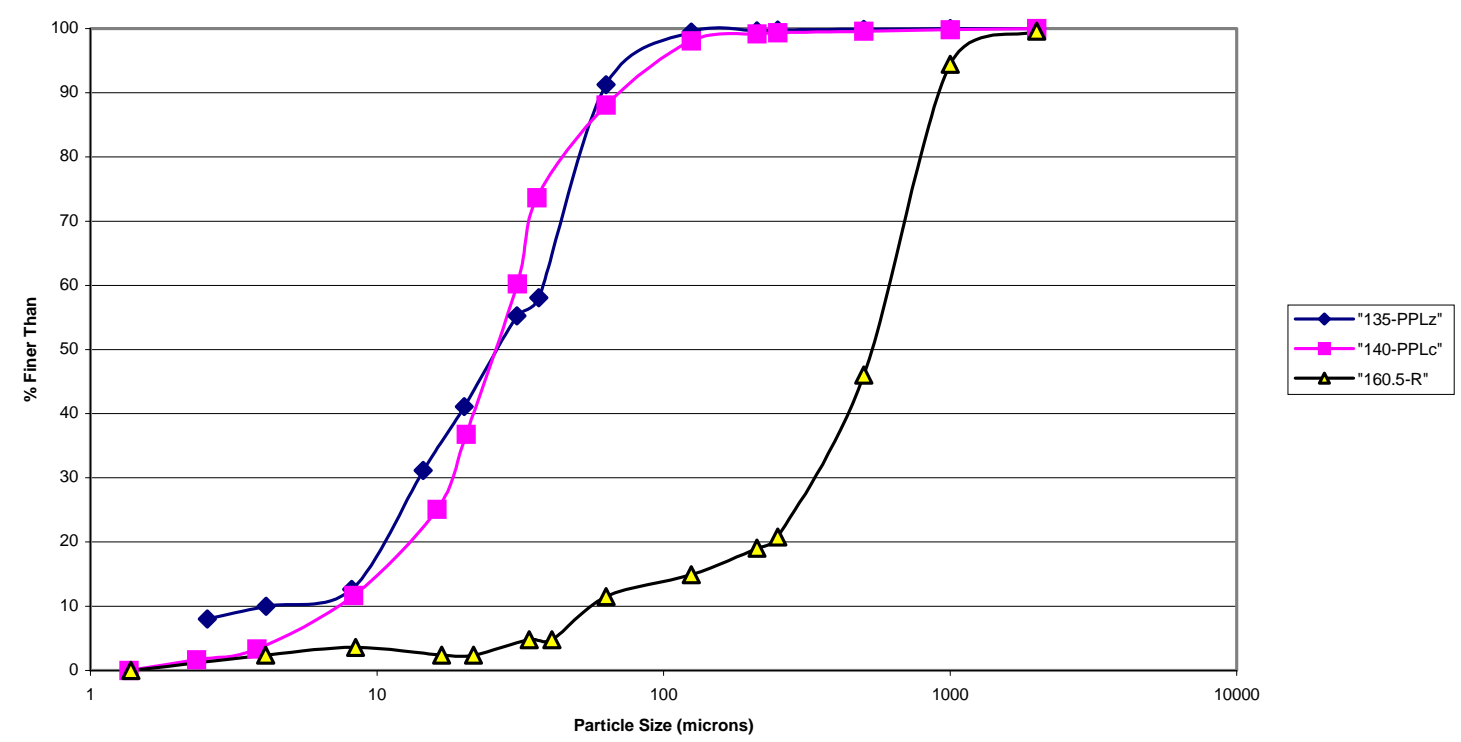

Figure 5.11. Particle-Size Distribution Curves of Sediment Samples from the Plio-Pleistocene Unit and Ringold Formation at Borehole 299-W22-50

\subsubsection{Particle Density}

The particle density of bulk grains for selected core samples from borehole 299-W22-50 is presented in Table 5.32. Results are similar to those reported for borehole 299-W22-48 in this report (see Table 5.6), but slightly lower than some of those reported previously in Serne et al. (1993), which ranged from 2.70 to $2.82 \mathrm{~g} / \mathrm{cm}^{3}$.

Table 5.32. Particle Densities for Sediment Samples from Borehole 299-W22-50

\begin{tabular}{|c|c|c|c||}
\hline Sample Name & Stratigraphic Unit & $\begin{array}{c}\text { Particle Density } \\
\left(\mathbf{g} / \mathbf{c m}^{\mathbf{3}}\right)\end{array}$ & $\begin{array}{c}\text { Standard Deviation } \\
\text { (3 trials) }\end{array}$ \\
\hline \hline 51 & H1a & 2.626 & 0.014 \\
\hline 60 & H1 & 2.735 & 0.016 \\
\hline 116 & H2 & 2.694 & 0.017 \\
\hline 135 & H2 & 2.652 & 0.007 \\
\hline 140 & PPlc & 2.680 & 0.007 \\
\hline 160.5 & Rtf & 2.656 & 0.011 \\
\hline
\end{tabular}




\subsubsection{Calcium Carbonate and Organic Carbon Content}

The calcium carbonate equivalent and organic carbon content of the bulk sediment for selected depths from borehole 299-W22-50 are presented in Table 5.33.

Table 5.33. Calcium Carbonate and Organic Carbon Content (wt $\%$ ) for Sediment Samples from Borehole 299-W22-50

\begin{tabular}{|c|c|c|c|c|c|}
\hline $\begin{array}{c}\text { Sampling Depth } \\
\text { (ft bgs) }^{\text {(a) }} \\
\end{array}$ & $\begin{array}{c}\text { Stratigraphic } \\
\text { Unit }\end{array}$ & $\begin{array}{c}\text { Total } \\
\text { Carbon (\%) } \\
\end{array}$ & $\begin{array}{c}\text { Inorganic } \\
\text { Carbon (\%) } \\
\end{array}$ & $\begin{array}{c}\text { Inorganic as } \\
\mathrm{CaCO}_{3}(\%) \\
\end{array}$ & $\begin{array}{c}\text { Organic } \\
\text { Carbon (\%) } \\
\end{array}$ \\
\hline 20 & $\mathrm{H} 1 \mathrm{a}$ & 0.28 & 0.23 & 1.92 & 0.05 \\
\hline 22.5 & H1a & 0.29 & 0.25 & 2.08 & 0.04 \\
\hline 25 & $\mathrm{H} 1 \mathrm{a}$ & 0.21 & 0.14 & 1.17 & 0.07 \\
\hline 27.5 & H1a & 0.21 & 0.17 & 1.42 & 0.04 \\
\hline 30 & H1a & 0.23 & 0.19 & 1.58 & 0.04 \\
\hline 32.5 & H1a & 0.18 & 0.13 & 1.08 & 0.05 \\
\hline 35 & H1a & 0.23 & 0.18 & 1.50 & 0.05 \\
\hline 37.5 & H1a & 0.23 & 0.19 & 1.58 & 0.04 \\
\hline 40 & H1a & 0.22 & 0.19 & 1.58 & 0.03 \\
\hline 42.5 & H1a & 0.26 & 0.21 & 1.75 & 0.05 \\
\hline 45 & H1a & 0.28 & 0.22 & 1.83 & 0.06 \\
\hline 47.5 & H1a & 0.29 & 0.24 & 2.00 & 0.05 \\
\hline 51 & H1a & 0.27 & 0.23 & 1.92 & 0.04 \\
\hline 52.5 & H1a & 0.21 & 0.18 & 1.50 & 0.03 \\
\hline 54.5 & $\mathrm{H} 1$ & 0.26 & 0.2 & 1.67 & 0.06 \\
\hline 56 & $\mathrm{H} 1$ & 0.25 & 0.23 & 1.92 & 0.02 \\
\hline 60 & $\mathrm{H} 1$ & 0.32 & 0.29 & 2.42 & 0.03 \\
\hline 67.5 & $\mathrm{H} 2$ & 0.27 & 0.22 & 1.83 & 0.05 \\
\hline 76 & $\mathrm{H} 2$ & 0.23 & 0.21 & 1.75 & 0.02 \\
\hline 96 & $\mathrm{H} 2$ & 0.26 & 0.24 & 2.00 & 0.02 \\
\hline 111 & $\mathrm{H} 2$ & 0.36 & 0.31 & 2.58 & 0.05 \\
\hline 115 & $\mathrm{H} 2$ & 0.31 & 0.25 & 2.08 & 0.06 \\
\hline 116 & $\mathrm{H} 2$ & 0.26 & 0.22 & 1.83 & 0.04 \\
\hline 130 & $\mathrm{PPlz}$ & 0.43 & 0.35 & 2.92 & 0.08 \\
\hline 135 & $\mathrm{PPlz}$ & 0.49 & 0.4 & 3.33 & 0.09 \\
\hline 140 & PPlc & 0.28 & 0.23 & 1.92 & 0.05 \\
\hline 141 & PPlc & 1 & 0.92 & 7.67 & 0.08 \\
\hline 150.5 & Rtf & 0.1 & 0.07 & 0.58 & 0.03 \\
\hline 160.5 & Rtf & 0.08 & 0.04 & 0.33 & 0.04 \\
\hline 174 & Rtf & 0.03 & 0 & 0.00 & 0.03 \\
\hline
\end{tabular}


The calcium carbonate equivalent (in terms of grams of calcite per gram of oven-dry sediment) are low for all samples except the depths at 41.2 through 43 meters (or 135 through 141 feet) bgs for borehole 299-W22-50. Geologist descriptions (Appendices A and B) in combination with the geophysical logs (Figure 2.18) indicate the presence of a carbonate-rich zone (PPlc) at a depth of about 42.1 to 43.5 meters (138 to 143 feet) bgs. However, unlike borehole 299-W22-48, the data presented in Table 5.33 do not show a well-defined calcic zone in borehole 299-W22-50. We believe a carbonate-rich zone is present but representative aliquots with calcic cement dominating were not chosen for analysis.

The method used to measure the organic carbon relies upon subtracting the inorganic carbon from the total carbon in the sample and for such low carbon values is not accurate. The low values for organic carbon are within the ranges generally reported for Hanford sediment but if more accurate values are desired a different method that is more sensitive should be used.

\subsubsection{Bulk Chemical Composition}

The elemental composition, determined by XRF (see Section 3.2.5) and converted to oxides of the bulk sediment from borehole 299-W22-50, is shown in Table 5.34. We have assumed that the iron present in the sediment is all ferric oxide though there may be some reduced iron (ferrous oxide) also present. The total content has been adjusted to reflect the presence of calcium carbonate by converting the calcium carbonate in Table 5.33 back to percent carbon dioxide and adding it to the XRF totals.

The bulk chemical composition of the sediment samples from borehole 299-W22-50 show that silica is most abundant, followed by alumina. These are followed, in decreasing order, by iron, calcium, magnesium, sodium, potassium, titanium oxides, and carbonate. The calculated mass balances range between $96.95 \%$ and $101.76 \%$ with a mean of $99.95 \pm 1.75 \%$ for the 6 samples. We consider these measurements as outstanding mass balance. The amount of iron and calcium is greater in the coarsergrained units of the Hanford formation (Units H1a and H1), which is consistent with a higher concentration of basaltic particles in these units.

\subsubsection{Mineralogy}

A total of five bulk sediment samples and the clay fractions ( $<2$ microns) from borehole 299-W22-50 were characterized by XRD methods (see Section 3.2.6). The semiquantitative mass results are presented in Table 5.35. The mineralogy of both the bulk sediment and the clay-size fraction are quite similar to the samples from the same stratigraphic units previously reported for borehole 299-W22-48. Therefore, the reader is referred to the discussion previously presented in Section 5.1.6 for details.

\subsubsection{Cation Exchange Capacity}

No cation exchange measurements are available for sediment samples from borehole 299-W22-50. 
Table 5.34. Bulk Chemical Composition of Sediment Samples from Borehole 299-W22-50 (\% as Oxides)

\begin{tabular}{||c|c|c|c|c|c|c||}
\hline Depth (ft bgs) $^{(\mathbf{a})}$ & $\mathbf{5 1} \mathbf{f t}$ & $\mathbf{6 0} \mathbf{f t}$ & $\mathbf{1 1 6} \mathbf{f t}$ & $\mathbf{1 3 5} \mathbf{f t}$ & $\mathbf{1 4 0} \mathbf{f t}$ & $\mathbf{1 6 0 . 5} \mathbf{f t}$ \\
\hline Stratigraphic Unit & $\mathbf{H 1 a}$ & $\mathbf{H 1}$ & $\mathbf{H 2}$ & $\mathbf{P P I z}$ & $\mathbf{P P l c}$ & $\mathbf{R t f}$ \\
\hline Oxides & & & & & & \\
\hline \hline $\mathrm{Na}_{2} \mathrm{O}$ & 2.09 & 2.56 & 2.37 & 1.47 & 1.85 & 3.02 \\
\hline $\mathrm{MgO}$ & 3.55 & 3.33 & 3.80 & 4.31 & 3.80 & 2.67 \\
\hline $\mathrm{CO}_{2}$ & 0.92 & 1.16 & 0.88 & 1.60 & 0.92 & 0.16 \\
\hline $\mathrm{Al}_{2} \mathrm{O}_{3}$ & 12.09 & 13.08 & 13.70 & 14.30 & 13.26 & 11.41 \\
\hline $\mathrm{SiO}_{2}$ & 63.86 & 64.61 & 69.42 & 66.00 & 68.46 & 68.89 \\
\hline $\mathrm{P}_{2} \mathrm{O}_{5}$ & $<0.22$ & $<0.27$ & $<0.21$ & $<0.20$ & $<0.21$ & $<0.20$ \\
\hline $\mathrm{SO}_{3}$ & 0.11 & 0.15 & 0.08 & 0.06 & 0.06 & 0.06 \\
\hline $\mathrm{Cl}$ & $<0.016$ & $<0.016$ & 0.046 & 0.044 & 0.035 & 0.020 \\
\hline $\mathrm{K}_{2} \mathrm{O}$ & 1.79 & 1.77 & 2.46 & 2.63 & 2.33 & 1.71 \\
\hline $\mathrm{CaO}$ & 5.30 & 5.96 & 3.78 & 3.76 & 3.38 & 3.37 \\
\hline $\mathrm{TiO}_{2}$ & 1.24 & 1.10 & 0.65 & 0.73 & 0.81 & 0.70 \\
\hline $\mathrm{V}_{2} \mathrm{O}_{5}$ & 0.04 & 0.03 & 0.01 & 0.01 & 0.01 & 0.02 \\
\hline $\mathrm{Cr}_{2} \mathrm{O}_{3}$ & 0.01 & 0.01 & 0.01 & 0.01 & 0.01 & 0.00 \\
\hline $\mathrm{MnO}$ & 0.12 & 0.10 & 0.07 & 0.08 & 0.07 & 0.08 \\
\hline $\mathrm{Fe} \mathrm{O}_{3}$ & 8.00 & 7.33 & 4.13 & 4.78 & 4.52 & 4.51 \\
\hline $\mathrm{SrO}$ & 0.04 & 0.04 & 0.05 & 0.03 & 0.04 & 0.05 \\
\hline $\mathrm{BaO}$ & 0.07 & 0.08 & 0.09 & 0.07 & 0.08 & 0.07 \\
\hline $\mathrm{Total}$ & 99.46 & 101.59 & 101.76 & 100.10 & 99.83 & 96.95 \\
\hline $\mathrm{Multiply} \mathrm{by} \mathrm{0.3048} \mathrm{to} \mathrm{convert} \mathrm{to} \mathrm{meters.}$ & & & \\
\hline \multicolumn{2}{|l|}{}
\end{tabular}

Table 5.35. Semiquantitative Mineral Content of Sediment Samples from Borehole 299-W22-50

\begin{tabular}{|c|c|c|c|c|c|c|c|c|}
\hline \multicolumn{9}{|c|}{ Semiquantification of Minerals in Bulk Samples (wt\%) } \\
\hline \multicolumn{2}{|c|}{$\begin{array}{l}\text { Sample Depth (ft bgs) } \\
\text { [Stratigraphic Unit] }\end{array}$} & Quartz & \multicolumn{2}{|c|}{ K-Feldspar } & Na-Feldspar & \multicolumn{2}{|c|}{ Calcite } & Total \\
\hline \multicolumn{2}{|c|}{ (51 [H1a] } & 60 & \multicolumn{2}{|c|}{10} & 25 & & ND & $\sim 95$ \\
\hline \multicolumn{2}{|l|}{60 [H1] } & 45 & \multicolumn{2}{|c|}{10} & 25 & & ND & $\sim 80$ \\
\hline \multicolumn{2}{|l|}{$116[\mathrm{H} 2]$} & 45 & \multicolumn{2}{|c|}{15} & 30 & & ND & $\sim 90$ \\
\hline \multicolumn{2}{|l|}{$135[\mathrm{PPlz}]$} & 60 & \multicolumn{2}{|c|}{5} & 15 & & ND & $\sim 80$ \\
\hline \multicolumn{2}{|l|}{140 [PPlc] } & 60 & \multicolumn{2}{|c|}{10} & 15 & & ND & $\sim 85$ \\
\hline \multicolumn{2}{|l|}{160.5 [Rtf] } & 50 & \multicolumn{2}{|c|}{10} & 30 & & ND & $\sim 90$ \\
\hline & Semiq & Intification & f Minerals & Clay-Size & Fraction & t\%) & & \\
\hline $\begin{array}{c}\text { Sample Depth (ft bgs) } \\
\text { [Stratigraphic Unit] }^{(\mathbf{a})}\end{array}$ & Quartz & Feldspar & Calcite & Smectite & Illite & Chlorite & Kaolinite & Total \\
\hline $51[\mathrm{H} 1 \mathrm{a}]$ & 5 & $<5$ & 10 & 30 & 15 & 10 & 10 & $\sim 85$ \\
\hline $60[\mathrm{H} 1]$ & 5 & 5 & 25 & 5 & 15 & 10 & 10 & $\sim 75$ \\
\hline $116[\mathrm{H} 2]$ & 10 & $<5$ & Trace & 30 & 30 & 35 & 10 & $\sim 120$ \\
\hline $135[\mathrm{PPlz}]$ & 5 & $<5$ & $<5$ & 30 & 30 & 30 & 10 & $\sim 115$ \\
\hline $140[\mathrm{PPlc}]$ & 10 & $<5$ & $<5$ & 15 & 10 & 10 & 5 & $\sim \sim 60$ \\
\hline $160.5[\mathrm{Rtf}]$ & 5 & 5 & Trace & 10 & 15 & 15 & 10 & $\sim 60$ \\
\hline
\end{tabular}




\subsubsection{Exchangeable Base Cations}

The exchangable base cations and a few selected trace metals obtained using ammonium acetate extraction (see Section 3.2.8) are shown in Table 5.36. The sum of extractable cations is shown in Table 5.37. All uncontaminated sediment samples from the Hanford Site show that calcium and magnesium dominate (>90\% of total displaceable cations) the exchange sites. The sum of the base cations for the sediment from borehole 299-W22-50 cannot be compared with other methods to measure the cation exchange capacity because further testing was not performed. The sum of the base cations does not closely follow the trend of increasing total exchangeable cations with finer-grained particle-size distribution in that the coarse-grained Hanford formation $\mathrm{H} 1$ unit shows a relatively high sum compared to the fine-grained PPlz subunit, which shows a lower sum.

Table 5.36. Exchangeable Base Cations for Sediment Samples from Borehole 299-W22-50

\begin{tabular}{|c|c|c|c|c|c|c|c|c|c|}
\hline \multirow{2}{*}{$\begin{array}{l}\text { Sampling Depth (ft } \\
\text { bgs) } \\
\text { [Stratigraphic Unit] }\end{array}$} & \multicolumn{6}{|c|}{$\mathrm{meq} / \mathrm{L}$} & \multicolumn{3}{|c|}{$\mu \mathbf{g} / \mathbf{L}$} \\
\hline & Ba & Ca & $\mathbf{K}$ & Mg & $\mathrm{Sr}$ & $\mathrm{Na}$ & $\mathbf{F e}$ & Mn & Si \\
\hline $51[\mathrm{H} 1 \mathrm{a}]$ & 0.07 & 52.20 & 3.14 & 10.55 & 0.13 & 1.54 & $<0.25$ & 0.015 & 13.90 \\
\hline 60 [H1] & 0.06 & 45.90 & 2.06 & 6.28 & 0.07 & 1.40 & $<0.25$ & 0.415 & 22.26 \\
\hline $116[\mathrm{H} 2]$ & 0.13 & 31.91 & 0.66 & 4.04 & 0.06 & 0.85 & $<0.25$ & 0.598 & 8.42 \\
\hline 116 Dup [H2] & 0.12 & 29.76 & 0.59 & 3.86 & 0.06 & 0.79 & $<0.25$ & 0.540 & 8.05 \\
\hline $135[\mathrm{PPlz}]$ & 0.17 & 42.18 & 1.60 & 11.10 & 0.09 & 1.27 & $<0.25$ & 0.484 & 9.70 \\
\hline 140 [PPlc] & 0.12 & 33.08 & 1.14 & 7.59 & 0.06 & 0.92 & $<0.25$ & 0.413 & 9.89 \\
\hline 160.5 [Rtf] & 0.06 & 24.99 & 1.16 & 4.80 & 0.06 & 0.65 & $<0.25$ & 2.139 & 9.82 \\
\hline
\end{tabular}

Table 5.37. Comparison of the Base Cation Sum and Cation Exchange Capacity Measurements from Borehole 299-W22-50

\begin{tabular}{|c|c|c|c|c|c|c|c|c|c|}
\hline \multirow{4}{*}{$\begin{array}{l}\text { Sampling Depth (ft } \\
\text { bgs) }{ }^{(\mathrm{a})} \text { [Stratigraphic } \\
\text { Unit] }\end{array}$} & \multirow{2}{*}{\multicolumn{7}{|c|}{ Exchangeable Base Cations }} & \multicolumn{2}{|c|}{ Cation Exchange Capacity } \\
\hline & & & & & & & & \multirow{2}{*}{\begin{tabular}{|c|}
$\begin{array}{c}\text { Polemio and } \\
\text { Rhoades } \\
\text { (1977) }\end{array}$ \\
\end{tabular}} & \multirow{2}{*}{\begin{tabular}{|c|}
$\begin{array}{c}\text { Amrhein } \\
\text { and Suarez } \\
(1990)\end{array}$ \\
\end{tabular}} \\
\hline & \multicolumn{7}{|c|}{ 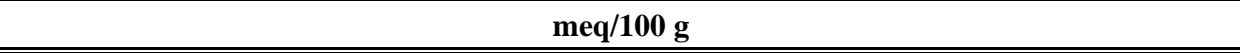 } & & \\
\hline & Ва & Ca & $\mathbf{K}$ & Mg & $\mathrm{Sr}$ & $\mathrm{Na}$ & Sum & ND & ND \\
\hline 51 [H1a] & 0.017 & 12.207 & 0.733 & 2.467 & 0.030 & 0.359 & 15.81 & ND & ND \\
\hline $60[\mathrm{H} 1]$ & 0.015 & 10.745 & 0.483 & 1.469 & 0.015 & 0.327 & 13.05 & ND & ND \\
\hline 116 [H2] & 0.030 & 7.469 & 0.154 & 0.946 & 0.015 & 0.200 & 8.81 & ND & ND \\
\hline 116 Dup [H2] & 0.028 & 6.965 & 0.139 & 0.903 & 0.014 & 0.186 & 8.23 & ND & ND \\
\hline 135 [PPlz] & 0.040 & 10.005 & 0.379 & 2.632 & 0.022 & 0.300 & 13.38 & ND & ND \\
\hline 140 [PPlc] & 0.028 & 7.742 & 0.266 & 1.777 & 0.015 & 0.215 & 10.04 & ND & ND \\
\hline 160.5 [Rtf] & 0.013 & 5.872 & 0.272 & 1.127 & 0.014 & 0.153 & 7.45 & ND & ND \\
\hline
\end{tabular}




\subsubsection{1:1 Sediment-to-Water Extraction}

The 1:1 sediment-to-water extracts results for core samples from borehole 299-W22-50 are presented in Tables 5.38 to 5.41. Later, we compare the chemical composition of dilution-corrected water extracts with actual porewater obtained by ultracentrifugation. For some constituents the water extracts, when corrected for dilution with deionized water, provide an accurate measure of the concentration within the native porewater. For other constituents, the amount found in the water extract, when dilution-corrected back to the porewater, over-predicts the porewater concentration because of dissolution of salts/minerals in the sediment samples. We have also converted them to a per gram of oven-dry sediment and relate the values reported on a sediment basis to the amount extracted by strong nitric acid and the bulk chemical composition as determined by XRF.

The data in Tables 5.38 to 5.41 show that the most water-soluble constituents are calcium, magnesium, sodium, bicarbonate, sulfate, and nitrate. There are minor amounts of chloride, potassium, and dissolved silicon and no evidence of elevated levels of trace metals. Water extracts from the PPlc subunit show slightly elevated levels of selenium compared to other strata. The bottom of the PPlc also shows slightly elevated EC, alkalinity, calcium, magnesium, silicon, strontium, sulfate, and nitrate compared to the other stratigraphic units. Water extracts from the Ringold Formation show lower alkalinity, barium, chromium, sodium, and uranium concentrations than those for either the Hanford formation or the Plio-Pleistocene unit.

Most noteworthy in the water extract profile for borehole 299-W22-50 (Figure 5.12) is highly waterleachable $\mathrm{pH}$ and $\mathrm{EC}$ within the coarse-grained Hanford formation $\mathrm{H} 1$ unit at 18.3 meters (60 feet) bgs (Figure 5.12). Alkalinity and a number of other constituents (i.e., calcium, chromium, strontium, potassium, sodium, sulfate and chloride) are also elevated at this depth. Possible causes for these high values are the presence of gypsum (calcium sulfate) at the 18.3-meter (60-foot) depth, introduction of disposed wastewater via lateral spreading from nearby waste sites, or leaking water lines in the area.

Table 5.42 presents the range in concentration for several constituents for the different stratigraphic units sampled in borehole 299-W22-50. Ringold Formation sediment samples show low values for waterleachable alkalinity, sulfate, sodium, potassium, and alkaline earths (barium, calcium, and strontium). The PPlc water extracts are low in potassium compared to other stratigraphic units. Conversely, water extracts of the Plio-Pleistocene unit have high alkalinity and uranium concentrations. Of particular interest are water extracts from the Hanford formation $\mathrm{H} 2$ unit (i.e., 96, 111, and $115 \mathrm{ft}$ bgs), which indicate anomalously high chloride and nitrate concentrations compared to other stratigraphic units (Table 5.38).

In 17 of 28 instances, the cation-anion balance from water extracts listed in Table 5.41 agrees within $15 \%$, suggesting an internally consistent data set. The remaining 11 data sets show a low anion charge, however, perhaps reflecting some bias in the alkalinity measurements. Because the ratio of water to sediment used in the water extracts was 1:1, the data in Tables 5.38 through 5.41 with the units of $\mathrm{mg} / \mathrm{L}$ and $\mu \mathrm{g} / \mathrm{L}$ or meq/L also represent milligrams or milliequivalents per kilogram of soil. 
Table 5.38. $\mathrm{pH}$, Electrical Conductivity, Alkalinity, and Anions in Water Extracts of Sediment Samples from Borehole 299-W22-50

\begin{tabular}{|c|c|c|c|c|c|c|c|c|c|c|}
\hline \multicolumn{2}{|c|}{ Constituent Sample } & \multirow[t]{2}{*}{ pH } & \multirow{2}{*}{$\begin{array}{c}\text { EC } \\
\mu \mathrm{S} / \mathbf{c m} \\
\end{array}$} & \multirow{2}{*}{$\begin{array}{c}\text { Alk } \\
\mathrm{mg} / \mathrm{L} \\
\mathrm{CaCO}_{3}\end{array}$} & \multirow{2}{*}{$\begin{array}{c}\text { F } \\
\text { mg/L }\end{array}$} & \multirow{2}{*}{$\begin{array}{c}\mathrm{Cl} \\
\mathrm{mg} / \mathrm{L}\end{array}$} & \multirow{2}{*}{$\begin{array}{l}\mathrm{NO}_{2} \\
\mathrm{mg} / \mathrm{L} \\
\end{array}$} & \multirow{2}{*}{$\begin{array}{c}\mathrm{NO}_{3} \\
\mathrm{mg} / \mathrm{L} \\
\end{array}$} & \multirow{2}{*}{$\begin{array}{c}\mathrm{PO}_{4} \\
\mathrm{mg} / \mathrm{L}\end{array}$} & \multirow{2}{*}{$\begin{array}{c}\mathrm{SO}_{4} \\
\mathrm{mg} / \mathrm{L}\end{array}$} \\
\hline ft (bgs) ${ }^{(a)}$ & $\begin{array}{c}\text { Stratigraphic } \\
\text { Unit }\end{array}$ & & & & & & & & & \\
\hline 20 & $\mathrm{H} 1 \mathrm{a}$ & 7.78 & 188 & 52.88 & 0.72 & 0.45 & $<0.1$ & 5.89 & 0.1 & 8.56 \\
\hline 22.5 & H1a & 7.72 & 221 & 26.79 & 0.74 & 1.08 & $<0.1$ & 4.51 & $<0.1$ & 13.52 \\
\hline 25 & H1a & 7.68 & 214 & 31.73 & 0.72 & 0.76 & $<0.1$ & 3.42 & 0.2 & 9.78 \\
\hline 27.5 & H1a & 7.60 & 214 & 48.65 & 0.7 & 1.88 & $<0.1$ & 0.63 & 0.1 & 19.56 \\
\hline 30 & H1a & 7.65 & 217 & 39.48 & 0.63 & 4.85 & $<0.1$ & 2.64 & 0.15 & 20.5 \\
\hline 32.5 & H1a & 7.67 & 186 & 43.01 & 0.56 & 1.62 & $<0.1$ & 2.51 & 0.33 & 11.64 \\
\hline 35 & H1a & 7.49 & 222 & 50.06 & 0.68 & 0.82 & $<0.1$ & 0.68 & 0.29 & 13.85 \\
\hline 37.5 & H1a & 7.84 & 203 & 45.12 & 0.61 & 0.67 & $<0.1$ & 0.57 & $<0.1$ & 12.51 \\
\hline 40 & H1a & 7.03 & 184 & 47.24 & 0.5 & 0.57 & $<0.1$ & 0.36 & $<0.1$ & 11.49 \\
\hline 42.5 & H1a & 7.11 & 223 & 54.29 & 0.58 & 0.99 & $<0.1$ & 1.15 & 0.16 & 17.54 \\
\hline $45^{*}$ & H1a & $7.46 \pm 0.1$ & $224 \pm 3$ & $35 \pm 19$ & $0.60 \pm 0.05$ & $0.82 \pm 0.01$ & $<0.1$ & $1.46 \pm 0.52$ & $<0.1$ & $17.6 \pm 1.1$ \\
\hline 47.5 & H1a & 7.40 & 224 & 34.55 & 0.57 & 0.83 & $<0.1$ & 0.46 & $<0.1$ & 16.37 \\
\hline 51 & H1a & 7.90 & 181 & 56.40 & 0.59 & 0.45 & $<0.1$ & 3.09 & 0.1 & 8.62 \\
\hline 52.5 & H1a & 7.44 & 181 & 32.43 & 0.39 & 0.85 & $<0.1$ & 0.72 & $<0.1$ & 16.15 \\
\hline 54.5 & H1 & 7.32 & 216 & 54.99 & 0.47 & 1.34 & $<0.1$ & 0.25 & $<0.1$ & 19.18 \\
\hline 56 & H1 & 7.35 & 129 & 25.38 & 0.28 & 0.54 & $<0.1$ & 1.25 & 0.12 & 8.37 \\
\hline 60 & H1 & 10.33 & 553 & 60.63 & 0.41 & 9.33 & $<0.1$ & 1.82 & $<0.1$ & 35.71 \\
\hline 67.5 & $\mathrm{H} 2$ & 9.00 & 276 & & 0.38 & 4.84 & $<0.1$ & 5.49 & 0.21 & 21.9 \\
\hline 76 & $\mathrm{H} 2$ & 8.55 & 223 & 21.86 & 0.36 & 4.4 & $<0.1$ & 8.85 & 0.18 & 29.7 \\
\hline $96^{*}$ & $\mathrm{H} 2$ & $7.44 \pm 0.02$ & $298 \pm 15$ & $35 \pm 5$ & $0.39 \pm 0.06$ & $23.7 \pm 13$ & $<0.1$ & $10.0 \pm 1.0$ & $0.20 \pm 0.06$ & $28.7 \pm 1.0$ \\
\hline 111 & $\mathrm{H} 2$ & 7.45 & 296 & 58.52 & 0.49 & 11.47 & $<0.1$ & 25.51 & 0.15 & 23.01 \\
\hline 115 & $\mathrm{H} 2$ & 7.51 & 309 & 55.70 & 0.51 & 14.41 & $<0.1$ & 29.8 & 0.17 & 16.6 \\
\hline 130 & $\mathrm{PPlz}$ & 7.66 & 231 & 89.54 & 0.41 & 2.01 & $<0.1$ & 6.32 & 0.16 & 9.63 \\
\hline 135 & $\mathrm{PPlz}$ & 8.50 & 226.5 & 62.04 & 0.46 & 2.31 & $<0.1$ & 20.99 & 0.2 & 18.02 \\
\hline 141 & PPlc & 8.12 & 246 & $67 \pm 36$ & $0.80 \pm 0.08$ & $3.3 \pm 0.5$ & $<0.1$ & $11 \pm 1.3$ & $<0.1$ & $22 \pm 2.8$ \\
\hline 150.5 & Rtf & 7.77 & 191 & 6.35 & 1.1 & 1.49 & $<0.1$ & $<0.1$ & $<0.1$ & 8.62 \\
\hline 160.5 & Rtf & 7.74 & 135 & 31.02 & 0.62 & 0.76 & $<0.1$ & $<0.1$ & $<0.1$ & 3.13 \\
\hline 174 & Rtf & 7.75 & 88 & 18.33 & 0.99 & 4.77 & $<0.1$ & 10.9 & 0.13 & 2.57 \\
\hline
\end{tabular}

\subsubsection{Acid Extraction}

The results of $8 \mathrm{M}$ nitric acid extraction for sediment samples from borehole 299-W22-50 are presented in Tables 5.43 and 5.44. Samples of the PPlc subunit in borehole 299-W22-50 contain less calcium carbonate cement than in borehole 299-W22-48 and, thus, shows only mildly high acid-leachable calcium, lead, and strontium as well as conversely low-leachable iron, compared to the other stratigraphic units. The high acid-leachable alkaline-earth cations represent the rapid dissolution of carbonates. Unlike the PPlc subunit in borehole 299-W22-48, there is no high release of copper, manganese, and 
Table 5.39. Major Cations in Water Extracts of Sediment Samples from Borehole 299-W22-50 (ICP)

\begin{tabular}{|c|c|c|c|c|c|c|c|c|c|c|c|c|c|}
\hline $\begin{array}{c}\text { Depth } \\
\text { ft } \\
\text { (bgs) }^{(\mathbf{a})}\end{array}$ & $\begin{array}{c}\text { Strati- } \\
\text { graphic } \\
\text { Unit }\end{array}$ & $\begin{array}{c}\mathrm{Na} \\
(\mathrm{mg} / \mathrm{L})\end{array}$ & $\begin{array}{c}\text { Mg } \\
(\mathrm{mg} / \mathrm{L})\end{array}$ & $\begin{array}{c}\text { Al } \\
(\mu \mathrm{g} / \mathrm{L})\end{array}$ & $\begin{array}{c}\mathrm{Si} \\
(\mathrm{mg} / \mathrm{L})\end{array}$ & $\begin{array}{c}\mathbf{P} \\
\mu \mathbf{g} / \mathbf{L}\end{array}$ & $\begin{array}{c}\mathrm{S} \\
(\mathrm{mg} / \mathrm{L})\end{array}$ & $\begin{array}{c}\mathrm{K} \\
(\mathrm{mg} / \mathrm{L})\end{array}$ & $\begin{array}{c}\mathrm{Ca} \\
(\mathrm{mg} / \mathrm{L})\end{array}$ & $\begin{array}{c}\text { Mn } \\
(\mu \mathrm{g} / \mathrm{L})\end{array}$ & $\begin{array}{c}\mathbf{F e} \\
(\mu \mathrm{g} / \mathrm{L})\end{array}$ & $\begin{array}{c}\text { Sr } \\
(\mu \mathrm{g} / \mathrm{L})\end{array}$ & $\begin{array}{c}\mathbf{B a} \\
(\mu \mathrm{g} / \mathrm{L})\end{array}$ \\
\hline 20 & $\mathrm{H} 1 \mathrm{a}$ & 19.63 & 1.65 & (29) & 16.34 & (33) & 3.11 & 5.40 & 7.14 & (0) & 33.9 & 31.6 & 16.9 \\
\hline 22.5 & $\mathrm{H} 1 \mathrm{a}$ & 24.74 & 2.08 & (45) & 16.61 & $<500$ & 4.76 & 6.48 & 9.49 & (1) & 96.2 & 40.2 & 20.0 \\
\hline 25 & H1a & 20.05 & 1.40 & (30) & 14.22 & (91) & 3.51 & 5.41 & 6.32 & (0) & 30.6 & 27.5 & 18.5 \\
\hline 27.5 & $\mathrm{H} 1 \mathrm{a}$ & 22.40 & 2.35 & (38) & 15.60 & (42) & 7.10 & 6.69 & 10.72 & (2) & 76.7 & 48.1 & 28.8 \\
\hline 30 & $\mathrm{H} 1 \mathrm{a}$ & 20.15 & 2.42 & (20) & 17.47 & (59) & 7.18 & 5.98 & 11.24 & $(0)$ & 45.6 & 52.1 & 19.9 \\
\hline 32.5 & $\mathrm{H} 1 \mathrm{a}$ & 19.79 & 1.67 & (23) & 15.40 & (91) & 4.48 & 4.86 & 7.95 & (0) & 26.3 & 34.6 & 18.2 \\
\hline 35 & $\mathrm{H} 1 \mathrm{a}$ & 25.40 & 2.15 & (30) & 16.63 & (54) & 5.56 & 6.82 & 10.91 & (1) & 31.7 & 49.0 & 26.3 \\
\hline 37.5 & $\mathrm{H} 1 \mathrm{a}$ & 22.52 & 1.97 & (21) & 16.02 & (80) & 5.08 & 6.37 & 9.98 & (0) & 33.2 & 44.7 & 19.8 \\
\hline 40 & H1a & 18.18 & 2.07 & (28) & 15.41 & (37) & 4.72 & 6.18 & 9.98 & $(0)$ & 27.5 & 46.3 & 23.5 \\
\hline 42.5 & $\mathrm{H} 1 \mathrm{a}$ & 22.12 & 2.62 & (25) & 17.63 & $<500$ & 6.85 & 7.09 & 12.86 & (0) & (22) & 55.9 & 17.5 \\
\hline 45 & $\mathrm{H} 1 \mathrm{a}$ & 21.62 & 2.52 & (30) & 18.01 & (50) & 7.06 & 7.19 & 12.28 & (0) & (22) & 55.5 & 21.3 \\
\hline 47.5 & $\mathrm{H} 1 \mathrm{a}$ & 22.33 & 2.63 & (25) & 17.90 & (41) & 6.47 & 7.31 & 13.13 & (0) & (23) & 59.9 & 21.1 \\
\hline 51 & $\mathrm{H} 1 \mathrm{a}$ & 17.25 & 1.84 & (22) & 17.61 & (126) & 3.39 & 5.20 & 9.15 & (0) & 35.2 & 39.9 & 13.7 \\
\hline 52.5 & H1a & 15.17 & 2.17 & (34) & 13.94 & (52) & 6.26 & 5.57 & 10.12 & (0) & (19) & 46.3 & 20.3 \\
\hline 54.5 & H1 & 19.45 & 2.79 & (36) & 15.40 & (56) & 7.31 & 6.56 & 12.72 & (1) & 33.7 & 58.3 & 27.5 \\
\hline 56 & H1 & 11.06 & 1.77 & (47) & 9.01 & (76) & 3.20 & 4.09 & 5.74 & (1) & (21) & 26.8 & 14.6 \\
\hline 60 & $\mathrm{H} 1$ & 28.12 & 0.03 & 379 & 28.04 & (145) & 13.61 & 10.05 & 51.55 & $<10$ & (7) & 176 & 44.9 \\
\hline 67.5 & $\mathrm{H} 2$ & 16.36 & 3.03 & 103 & 10.67 & (154) & 8.21 & 4.69 & 12.62 & (1) & 109 & 56.8 & 15.3 \\
\hline 76 & $\mathrm{H} 2$ & 16.34 & 2.79 & 75.1 & 10.51 & (81) & 10.64 & 4.01 & 14.10 & (0) & 59.7 & 58.7 & 16.4 \\
\hline 96 & $\mathrm{H} 2$ & 23.18 & 4.29 & (27) & 9.95 & (139) & 11.20 & 5.93 & 19.17 & (0) & (18) & 85.6 & 26.7 \\
\hline 111 & $\mathrm{H} 2$ & 22.41 & 3.93 & (14) & 11.51 & (67) & 9.01 & 5.66 & 17.85 & (0) & (11) & 79.7 & 30.1 \\
\hline 115 & $\mathrm{H} 2$ & 24.33 & 4.15 & (26) & 10.23 & (51) & 6.75 & 5.49 & 18.50 & (3) & 33.1 & 85.4 & 35.5 \\
\hline 116 & $\mathrm{H} 2$ & 17.48 & 2.14 & 308 & 14.43 & (257) & 4.05 & 2.66 & 10.45 & (2) & 98.6 & 46.1 & 25.8 \\
\hline 130 & $\mathrm{PPlz}$ & 18.37 & 4.03 & (29) & 9.96 & (78) & 4.13 & 3.78 & 16.15 & (2) & (19) & 71.8 & 28.6 \\
\hline 135 & $\mathrm{PPlz}$ & 20.96 & 4.61 & (13) & 10.58 & (179) & 7.07 & 4.72 & 15.73 & $(0)$ & (12) & 70.3 & 28.7 \\
\hline 140 & PPlc & 17.01 & 3.51 & 277 & 14.99 & (131) & 6.16 & 3.04 & 11.41 & (3) & 117 & 57.4 & 34.0 \\
\hline 141 & PPlc & 20.13 & 5.28 & (20) & 21.56 & (33) & 8.93 & 4.71 & 17.09 & (0) & (13) & 82.9 & 22.7 \\
\hline 150.5 & Rtf & 17.33 & 3.31 & 370 & 13.81 & (129) & 3.87 & 4.63 & 10.44 & 15.2 & 352 & 59.6 & 15.3 \\
\hline 160.5 & Rtf & 10.02 & 2.33 & (38) & 13.98 & (88) & 1.52 & 3.60 & 8.41 & (2) & (24) & 40.5 & 16.8 \\
\hline 174 & Rtf & 6.69 & 0.90 & 106 & 13.81 & $(123)$ & 1.13 & 2.20 & 2.98 & (2) & 44.7 & (14) & (5) \\
\hline
\end{tabular}


Table 5.40. Trace Metals in Water Extracts of Sediment Samples from Borehole 299-W22-50

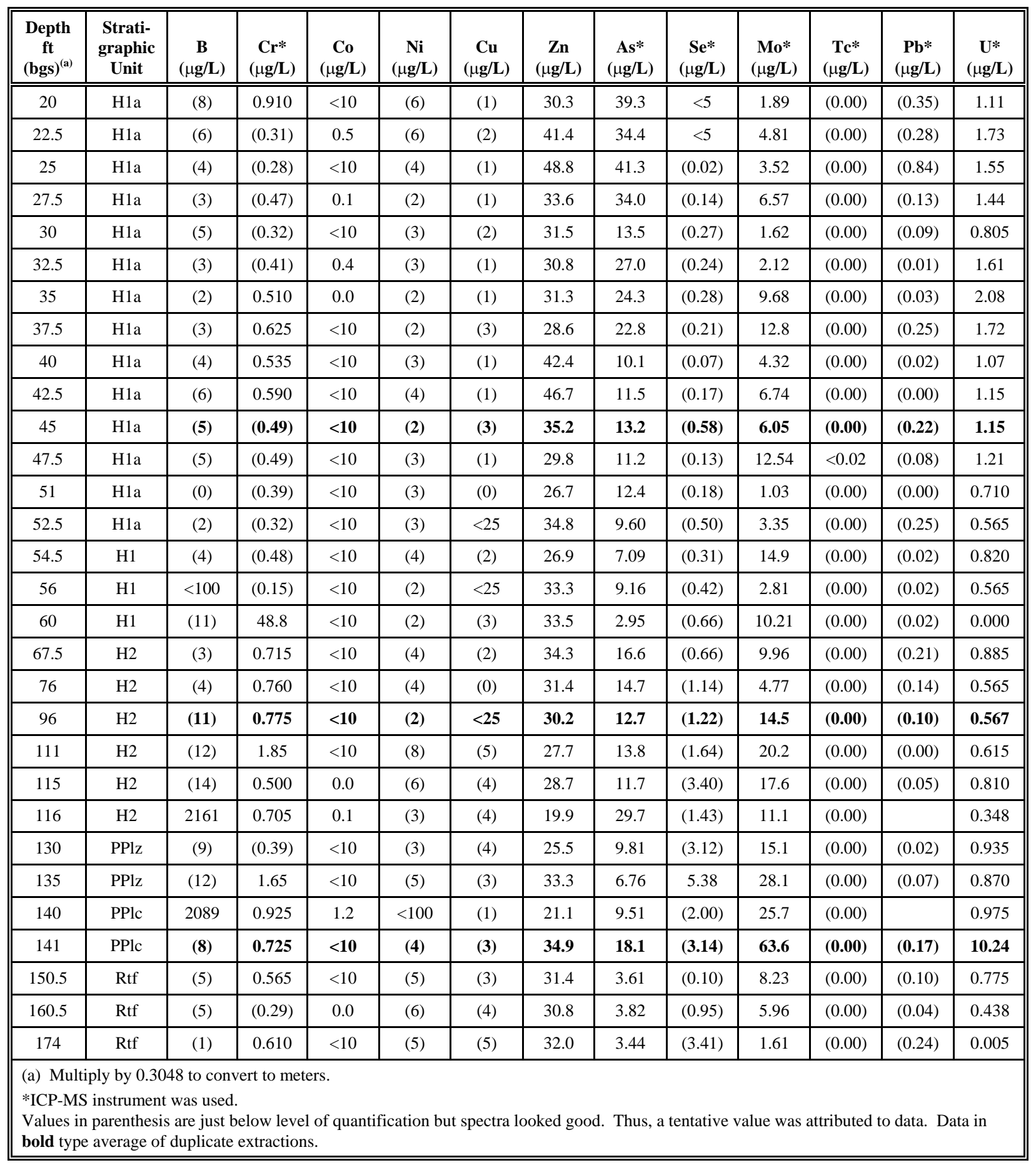


Table 5.41. Charge Balance for Water Extracts of Sediment Samples from Borehole 299-W22-50

\begin{tabular}{|c|c|c|c|c|c|c|c|c|c|c|c|c|}
\hline $\begin{array}{c}\text { Depth } \\
\text { ft } \\
\text { (bgs) }^{(\mathbf{a})}\end{array}$ & $\begin{array}{c}\text { Strati- } \\
\text { graphic } \\
\text { Unit }\end{array}$ & $\begin{array}{c}\text { Alk } \\
(\mathrm{meq} / \mathrm{L})\end{array}$ & $\begin{array}{c}F \\
(\mathrm{meq} / \mathrm{L})\end{array}$ & $\begin{array}{c}\mathrm{Cl} \\
(\mathrm{meq} / \mathrm{L})\end{array}$ & $\begin{array}{c}\mathrm{NO}_{3} \\
(\mathrm{meq} / \mathrm{L})\end{array}$ & $\begin{array}{c}\mathrm{SO}_{4} \\
(\mathrm{meq} / \mathrm{L})\end{array}$ & $\begin{array}{l}\sum \text { Anion } \\
(\mathrm{meq} / \mathrm{L})\end{array}$ & $\begin{array}{c}\mathrm{Na} \\
(\mathrm{meq} / \mathrm{L})\end{array}$ & $\begin{array}{c}\text { Mg } \\
(\mathrm{meq} / \mathrm{L})\end{array}$ & $\begin{array}{c}\mathrm{K} \\
(\mathrm{meq} / \mathrm{L})\end{array}$ & $\begin{array}{c}\mathrm{Ca} \\
(\mathrm{meq} / \mathrm{L})\end{array}$ & $\begin{array}{l}\sum \text { Cation } \\
\text { (meq/L) }\end{array}$ \\
\hline 20 & H1a & 1.06 & 0.04 & 0.01 & 0.10 & 0.18 & 1.38 & 0.85 & 0.14 & 0.14 & 0.36 & 1.49 \\
\hline 22.5 & H1a & 0.54 & 0.04 & 0.03 & 0.07 & 0.28 & 0.96 & 1.08 & 0.17 & 0.17 & 0.47 & 1.89 \\
\hline 25 & H1a & 0.63 & 0.04 & 0.02 & 0.06 & 0.20 & 0.95 & 0.87 & 0.12 & 0.14 & 0.32 & 1.44 \\
\hline 27.5 & H1a & 0.97 & 0.04 & 0.05 & 0.01 & 0.41 & 1.48 & 0.97 & 0.19 & 0.17 & 0.54 & 1.88 \\
\hline 30 & H1a & 0.79 & 0.03 & 0.14 & 0.04 & 0.43 & 1.43 & 0.88 & 0.20 & 0.15 & 0.56 & 1.79 \\
\hline 32.5 & H1a & 0.86 & 0.03 & 0.05 & 0.04 & 0.24 & 1.22 & 0.86 & 0.14 & 0.12 & 0.40 & 1.52 \\
\hline 35 & H1a & 1.00 & 0.04 & 0.02 & 0.01 & 0.29 & 1.36 & 1.10 & 0.18 & 0.17 & 0.55 & 2.00 \\
\hline 37.5 & $\mathrm{H} 1 \mathrm{a}$ & 0.90 & 0.03 & 0.02 & 0.01 & 0.26 & 1.22 & 0.98 & 0.16 & 0.16 & 0.50 & 1.80 \\
\hline 40 & H1a & 0.94 & 0.03 & 0.02 & 0.01 & 0.24 & 1.23 & 0.79 & 0.17 & 0.16 & 0.50 & 1.62 \\
\hline 42.5 & $\mathrm{H} 1 \mathrm{a}$ & 1.09 & 0.03 & 0.03 & 0.02 & 0.37 & 1.53 & 0.96 & 0.22 & 0.18 & 0.64 & 2.00 \\
\hline 45 & H1a & 0.99 & 0.00 & 0.00 & 0.00 & 0.00 & 0.99 & 0.94 & 0.21 & 0.18 & 0.61 & 1.95 \\
\hline 47.5 & H1a & 0.69 & 0.03 & 0.02 & 0.01 & 0.34 & 1.09 & 0.97 & 0.22 & 0.19 & 0.66 & 2.03 \\
\hline 51 & H1a & 1.13 & 0.03 & 0.01 & 0.05 & 0.18 & 1.40 & 0.75 & 0.15 & 0.13 & 0.46 & 1.49 \\
\hline 52.5 & $\mathrm{H} 1 \mathrm{a}$ & 0.65 & 0.02 & 0.02 & 0.01 & 0.34 & 1.04 & 0.66 & 0.18 & 0.14 & 0.51 & 1.49 \\
\hline 54.5 & $\mathrm{H} 1$ & 1.10 & 0.02 & 0.04 & 0.00 & 0.40 & 1.57 & 0.85 & 0.23 & 0.17 & 0.64 & 1.88 \\
\hline 56 & $\mathrm{H} 1$ & 0.51 & 0.01 & 0.02 & 0.02 & 0.17 & 0.73 & 0.48 & 0.15 & 0.10 & 0.29 & 1.02 \\
\hline 60 & H1 & 1.21 & 0.02 & 0.26 & 0.03 & 0.74 & 2.27 & 1.22 & 0.00 & 0.26 & 2.58 & 4.06 \\
\hline 67.5 & $\mathrm{H} 2$ & 0.00 & 0.02 & 0.14 & 0.09 & 0.46 & 0.70 & 0.71 & 0.25 & 0.12 & 0.63 & 1.71 \\
\hline 76 & $\mathrm{H} 2$ & 0.44 & 0.02 & 0.12 & 0.14 & 0.62 & 1.34 & 0.71 & 0.23 & 0.10 & 0.70 & 1.75 \\
\hline 96 & $\mathrm{H} 2$ & 0.61 & 0.00 & 0.00 & 0.00 & 0.00 & 0.61 & 1.01 & 0.35 & 0.15 & 0.96 & 2.47 \\
\hline 111 & $\mathrm{H} 2$ & 1.17 & 0.03 & 0.32 & 0.41 & 0.48 & 2.41 & 0.97 & 0.32 & 0.14 & 0.89 & 2.34 \\
\hline 115 & $\mathrm{H} 2$ & 1.11 & 0.03 & 0.41 & 0.48 & 0.35 & 2.37 & 1.06 & 0.34 & 0.14 & 0.93 & 2.47 \\
\hline 116 & $\mathrm{H} 2$ & -- & -- & -- & -- & -- & -- & 0.76 & 0.18 & 0.07 & 0.52 & 1.53 \\
\hline 130 & $\mathrm{PPlz}$ & 1.79 & 0.02 & 0.06 & 0.10 & 0.20 & 2.17 & 0.80 & 0.33 & 0.10 & 0.81 & 2.04 \\
\hline 135 & $\mathrm{PPlz}$ & 1.24 & 0.02 & 0.07 & 0.34 & 0.38 & 2.04 & 0.91 & 0.38 & 0.12 & 0.79 & 2.20 \\
\hline 140 & PPlc & -- & -- & -- & -- & -- & -- & 0.74 & 0.29 & 0.08 & 0.57 & 1.68 \\
\hline 141 & PPlc & 1.85 & 0.00 & 0.00 & 0.00 & 0.00 & 1.85 & 0.88 & 0.43 & 0.12 & 0.85 & 2.29 \\
\hline 150.5 & Rtf & 0.13 & 0.06 & 0.04 & 0.00 & 0.18 & 0.41 & 0.75 & 0.27 & 0.12 & 0.52 & 1.67 \\
\hline 160.5 & Rtf & 0.62 & 0.03 & 0.02 & 0.00 & 0.07 & 0.74 & 0.44 & 0.19 & 0.09 & 0.42 & 1.14 \\
\hline 174 & Rtf & 0.37 & 0.05 & 0.13 & 0.18 & 0.05 & 0.78 & 0.29 & 0.07 & 0.06 & 0.15 & 0.57 \\
\hline
\end{tabular}




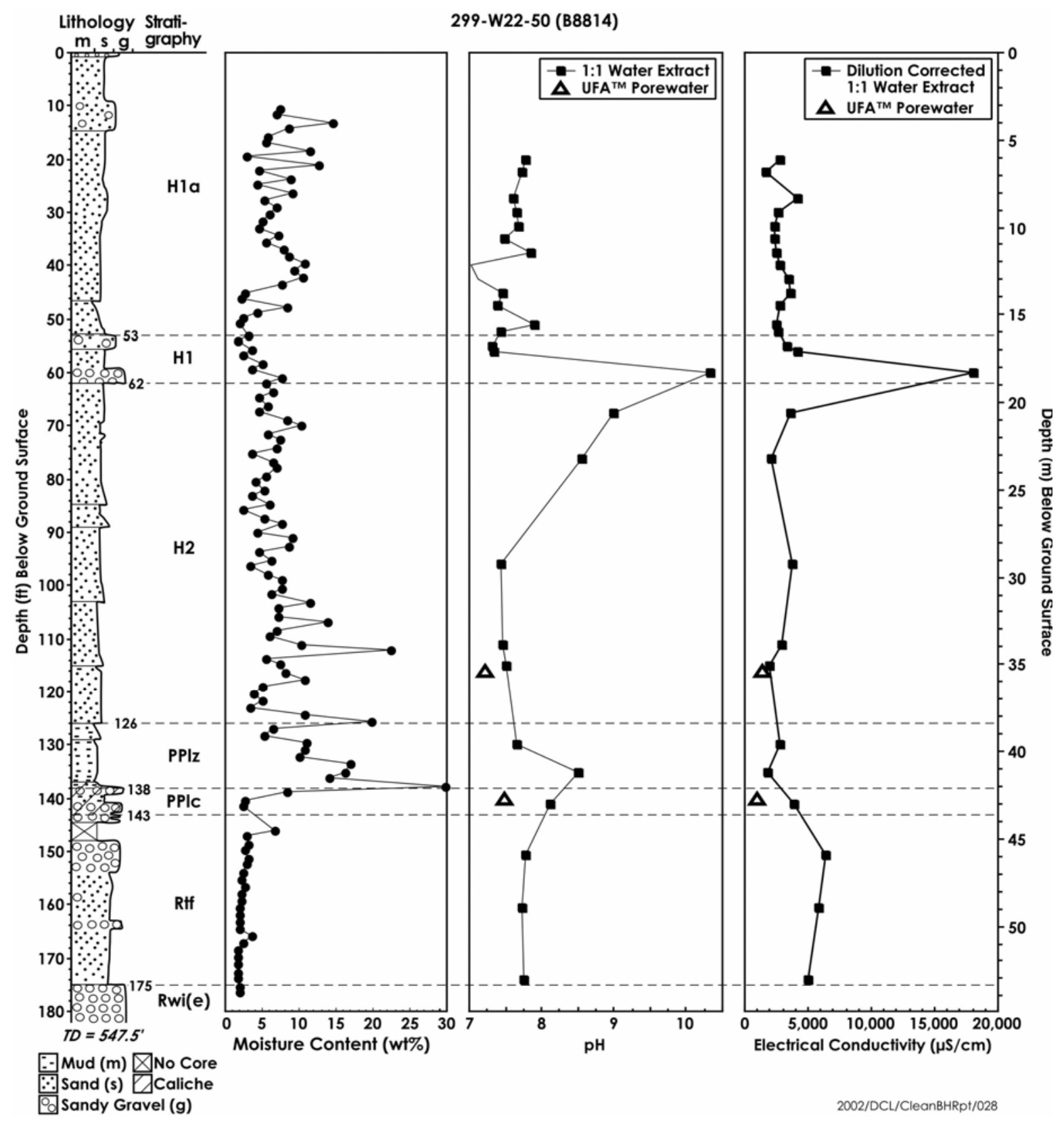

Figure 5.12. Moisture Content, 1:1 Sediment-to-Water Extract, $\mathrm{pH}$, and Electrical Conductivity Data Versus Depth in Borehole 299-W22-50 
Table 5.42. Ranges of Parameters and Selected Ions Found in Water Extracts for Stratigraphic Units Sampled Within Borehole 299-W22-50

\begin{tabular}{|c|c|c|c|c|c|c|c|c|}
\hline $\begin{array}{c}\text { Stratigraphic } \\
\text { Unit }\end{array}$ & & $\begin{array}{l}\text { Hanford } \\
\text { Formation } \\
\text { (Unit H1a) }\end{array}$ & $\begin{array}{c}\text { Hanford } \\
\text { Formation } \\
\text { (Unit H1a) }\end{array}$ & $\begin{array}{c}\text { Hanford } \\
\text { Formation } \\
\text { (Unit H1) }\end{array}$ & $\begin{array}{c}\text { Hanford } \\
\text { Formation } \\
\text { (Unit H2) } \\
\end{array}$ & $\begin{array}{l}\text { Upper Plio- } \\
\text { Pleistocene } \\
\text { Unit (PPlz) }\end{array}$ & $\begin{array}{l}\text { Lower Plio- } \\
\text { Pleistocene } \\
\text { Unit (PPlc) }\end{array}$ & $\begin{array}{c}\text { Ringold } \\
\text { Formation } \\
\text { (Rtf) } \\
\end{array}$ \\
\hline Lithology & & $\begin{array}{c}\text { Sand and } \\
\text { Gravel }\end{array}$ & Sand & $\begin{array}{c}\text { Sand and } \\
\text { Gravel }\end{array}$ & $\begin{array}{c}\text { Sand and } \\
\text { Silt }\end{array}$ & $\begin{array}{c}\text { Fine Sand } \\
\text { and Silt }\end{array}$ & Caliche & $\begin{array}{c}\text { Sand to } \\
\text { Gravelly } \\
\text { Sand } \\
\end{array}$ \\
\hline $\begin{array}{c}\text { Depth Interval } \\
\text { (ft bgs) }^{(a)}\end{array}$ & & 0 to 14 & 14 to 53 & 53 to 62 & 62 to 126 & 126 to 138 & 138 to 143 & 143 to 175 \\
\hline & Units & & & & & & & \\
\hline $\mathrm{pH}$ & & --- & $7.7-7.8$ & $7.3-10.3$ & $7.4-9.0$ & $7.6-8.5$ & 8.1 & $7.7-7.8$ \\
\hline EC & $\mu \mathrm{S} / \mathrm{cm}$ & --- & $180-220$ & $130-550$ & $220-310$ & $220-230$ & 250 & $100-200$ \\
\hline Alk & $\mathrm{mg} / \mathrm{L}$ & --- & $30-56$ & $25-60$ & $22-60$ & $60-90$ & $60-70$ & $6-30$ \\
\hline $\mathrm{F}$ & $\mathrm{mg} / \mathrm{L}$ & --- & $0.5-0.7$ & $0.3-0.5$ & $0.4-0.5$ & $0.4-0.5$ & 0.8 & $0.6-1.2$ \\
\hline $\mathrm{Cl}$ & $\mathrm{mg} / \mathrm{L}$ & --- & $0.6-4.8$ & $0.5-9.3$ & $4-23$ & $2-3$ & 3 & $1-5$ \\
\hline $\mathrm{NO} 3$ & $\mathrm{mg} / \mathrm{L}$ & --- & $0.4-5.9$ & $0.2-2.0$ & $5-30$ & $6-21$ & 11 & $0-10$ \\
\hline $\mathrm{SO} 4$ & $\mathrm{mg} / \mathrm{L}$ & --- & $8.6-20.5$ & $8-36$ & $16-30$ & $9-18$ & $20-25$ & $2-10$ \\
\hline $\mathrm{Na}$ & $\mathrm{mg} / \mathrm{L}$ & --- & $15-25$ & $11-28$ & $16-24$ & $18-21$ & $17-20$ & $6-10$ \\
\hline $\mathrm{Mg}$ & $\mathrm{mg} / \mathrm{L}$ & --- & $1.4-2.6$ & $0-3$ & $2-4$ & 4- 4.5 & $3.5-5.5$ & $1-2.5$ \\
\hline $\mathrm{Si}$ & $\mathrm{mg} / \mathrm{L}$ & --- & $14-18$ & $9-28$ & $10-14$ & $10-11$ & $15-22$ & $13-14$ \\
\hline $\mathrm{K}$ & $\mathrm{mg} / \mathrm{L}$ & --- & $5.0-7.5$ & $4-10$ & $4-11$ & $3.8-4.8$ & $3.0-4.7$ & $2-4$ \\
\hline $\mathrm{Ca}$ & $\mathrm{mg} / \mathrm{L}$ & --- & $6-13$ & $6-50$ & $10-20$ & $15-16$ & $11-17$ & $3-8$ \\
\hline $\mathrm{Sr}$ & $\mu \mathrm{g} / \mathrm{L}$ & --- & $27-60$ & $25-175$ & $45-85$ & $70-72$ & $55-85$ & $15-40$ \\
\hline $\mathrm{Ba}$ & $\mu \mathrm{g} / \mathrm{L}$ & --- & $13-26$ & $15-45$ & $15-35$ & $28-29$ & $23-34$ & $5-17$ \\
\hline $\mathrm{Cr}$ & $\mu \mathrm{g} / \mathrm{L}$ & --- & $0.4-0.9$ & $0.2-50$ & $0.7-1.8$ & $0.4-1.6$ & $0.7-0.9$ & $0.3-0.6$ \\
\hline $\mathrm{U}$ & $\mu \mathrm{g} / \mathrm{L}$ & --- & $0.6-2.0$ & $0-0.8$ & $0.4-0.9$ & $0.9-1.0$ & $1-10$ & $0.0-0.8$ \\
\hline
\end{tabular}

uranium that may represent substitution of these trace metals into the carbonate crystal lattice. The coarse-grained Hanford formation $\mathrm{H} 1$ unit produced relatively low amounts of leachable aluminum, calcium, iron, manganese, potassium, and strontium compared to the other units. This is probably a function of the relatively larger particle sizes and less surface area of the Hanford formation $\mathrm{H} 1$ unit, which are not leached as efficiently as fine particles during the acid-leach process. The Ringold Formation shows lower amounts of acid-leachable aluminum, barium, calcium, manganese, potassium, and strontium than other units. The finer-grained Hanford formation unit H1a shows high acid-leachable iron and sodium, unlike the same strata at borehole 299-W22-48. Again, the PlioPleistocene unit shows high acid-leachable aluminum and magnesium, perhaps coincident with higher clay content. 
Table 5.43. Major Cations ( $\mu \mathrm{g} / \mathrm{g})$ in Acid Extracts of Sediment Samples from Borehole 299-W22-50. Measured using ICP method.

\begin{tabular}{|c|c|c|c|c|c|c|c|c|c|c|c|c|}
\hline \multirow{2}{*}{$\begin{array}{c}\text { Element } \\
(\mu \mathrm{g} / \mathrm{g})\end{array}$} & $\begin{array}{c}\mathbf{f t} \mathbf{b g s}^{(\mathbf{a})} \\
27.5\end{array}$ & $\begin{array}{c}\text { ft bgs } \\
51\end{array}$ & $\begin{array}{c}\mathbf{f t} \\
\text { bgs }^{(\mathbf{a})} \\
54.5\end{array}$ & $\begin{array}{c}\mathbf{f t} \\
\text { bgs }^{(a)} \\
60\end{array}$ & $\begin{array}{c}\mathbf{f t ~ b g s}^{(\mathbf{a})} \\
67.5\end{array}$ & $\begin{array}{c}\mathbf{f t} \\
\text { bgs }^{(\mathrm{a})} \\
96\end{array}$ & $\begin{array}{c}\mathbf{f t} \\
\text { bgs }^{(a)} \\
116\end{array}$ & $\begin{array}{c}\mathbf{f t} \\
\text { bgs }^{(\mathbf{a})} \\
\mathbf{1 3 5}\end{array}$ & $\begin{array}{c}\mathbf{f t} \\
\text { bgs }^{(a)} \\
140\end{array}$ & $\begin{array}{c}\mathbf{f t} \\
\text { bgs }^{(a)} \\
141\end{array}$ & $\begin{array}{c}\mathbf{f t} \\
\text { bgs }^{(\mathbf{a})} \\
150.5\end{array}$ & $\begin{array}{c}\mathbf{f t} \\
\text { bgs }^{(a)} \\
160.5\end{array}$ \\
\hline & H1a & H1a & H1 & H1 & H2 & H2 & H2 & H2 & PPlc & PPlc & Rtf & Rtf \\
\hline $\mathrm{Na}$ & 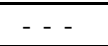 & 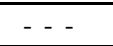 & $\ldots$ & $\ldots$ & $\ldots$ & $\ldots$ & $\ldots$ & $\ldots$ & -- & $\ldots$ & $\ldots$ & $\ldots$ \\
\hline $\mathrm{Mg}$ & 5523 & 5,318 & 4,293 & 2,717 & 6,360 & 5,137 & 6,507 & 7,766 & 7,019 & 5,020 & 3,333 & 3,823 \\
\hline $\mathrm{Al}$ & 8,245 & 10,251 & 6,311 & 3,711 & 9,097 & 8,388 & 10,940 & 16268 & 9,828 & 6,220 & 5,402 & 5,939 \\
\hline $\mathrm{Si}$ & 64.67 & 18.22 & 37.68 & 10.56 & 23.37 & 27.19 & 4.59 & 13.34 & 13.46 & 11.00 & 22.83 & 32.66 \\
\hline$P$ & 915.7 & 773.0 & 630.8 & 834.4 & 565.2 & 502.5 & 553.0 & 484.9 & 864.6 & 489.8 & 507.1 & 510.9 \\
\hline$S$ & 73.75 & 71.86 & 49.10 & 229.95 & 51.92 & 33.36 & 25.78 & 27.00 & 32.27 & 102.13 & 36.99 & 37.47 \\
\hline $\mathrm{K}$ & 1,486 & 1,435 & 1,132 & 561 & 1,998 & 1696 & 2,302 & 2,541 & 1,926 & 887 & 718 & 701 \\
\hline $\mathrm{Ca}$ & 10,577 & 1,1316 & 8,421 & 14,424 & 10,802 & 8,622 & 9,991 & 13,341 & 11,254 & 34,412 & 3,862 & 3,954 \\
\hline $\mathrm{Ti}$ & $1,203.2$ & $1,818.8$ & 789.1 & 464.9 & 601.1 & 677.1 & 748.1 & 872.1 & 507.9 & 470.7 & 809.0 & 783.6 \\
\hline $\mathrm{Mn}$ & 424.4 & 444.5 & 293.7 & 144.9 & 349.3 & 280.4 & 310.1 & 412.3 & 300.3 & 430.0 & 198.7 & 226.9 \\
\hline $\mathrm{Fe}$ & 23,264 & 26451 & 14,965 & 10,619 & 15,069 & $\begin{array}{c}12,89 \\
8 \\
\end{array}$ & 17,210 & 21,168 & 16,361 & 10,439 & 11,380 & 12,401 \\
\hline $\mathrm{Sr}$ & 42.32 & 47.63 & 33.07 & 31.44 & 43.61 & 37.12 & 46.75 & 45.17 & 38.45 & 83.65 & 25.88 & 24.99 \\
\hline $\mathrm{Ba}$ & 121.5 & 107.1 & 74.7 & 63.2 & 80.3 & 74.4 & 101.9 & 124.5 & 109.1 & 78.4 & 48.8 & 50.5 \\
\hline
\end{tabular}

Table 5.44. Trace Metals $(\mu \mathrm{g} / \mathrm{g})$ in Acid Extracts of Sediment Samples from Borehole 299-W22-50. Measured using ICP or ICP-MS method.

\begin{tabular}{|c|c|c|c|c|c|c|c|c|c|c|c|c|}
\hline \multirow{2}{*}{$\begin{array}{c}\text { Element } \\
(\mu \mathrm{g} / \mathrm{g})\end{array}$} & $\begin{array}{c}\mathbf{f t} \mathbf{b g s}^{(\mathbf{a})} \\
27.5 \\
\end{array}$ & $\begin{array}{c}f t b g s^{(a)} \\
51 \\
\end{array}$ & $\begin{array}{c}\text { ft bgs }{ }^{(a)} \\
55 \\
\end{array}$ & $\begin{array}{c}\text { ft bgs }{ }^{(a)} \\
60 \\
\end{array}$ & $\begin{array}{c}f t \text { bgs }^{(a)} \\
67.5 \\
\end{array}$ & $\begin{array}{c}f t \text { bgs }^{(a)} \\
96 \\
\end{array}$ & $\begin{array}{c}\text { ft bgs }{ }^{(a)} \\
116 \\
\end{array}$ & $\begin{array}{c}f t \text { bgs } \\
135 \\
\end{array}$ & $\begin{array}{c}\text { ft bgs }^{(a)} \\
140 \\
\end{array}$ & $\begin{array}{c}f t \text { bgs }^{(a)} \\
141 \\
\end{array}$ & $\begin{array}{c}\text { ft bgs }^{(a)} \\
150.5 \\
\end{array}$ & $\begin{array}{c}f_{\text {ft bgs }}{ }^{(a)} \\
160.5 \\
\end{array}$ \\
\hline & H1a & H1a & H1 & H1 & H2 & H2 & H2 & H2 & PPlc & PPlc & Rtf & Rtf \\
\hline $\mathrm{Be}^{(\mathrm{b})}$ & (0.37) & (0.33) & (0.40) & $\begin{array}{l}(0.24) \\
\end{array}$ & (0.16) & (0.33) & (0.30) & $(0.36)$ & $(0.56)$ & $(0.40)$ & $(0.22)$ & $(0.17)$ \\
\hline $\mathrm{B}^{(\mathrm{b})}$ & 1.64 & 0.28 & 3.86 & 4.98 & 9.70 & 6.38 & 2.72 & 5.55 & 4.75 & 7.56 & 3.78 & 4.98 \\
\hline $\mathrm{Cr}^{(\mathrm{c})}$ & 9.78 & 8.97 & 8.78 & 4.25 & 14.96 & 15.69 & 19.49 & 19.32 & 16.65 & 9.36 & 7.44 & 7.88 \\
\hline $\mathrm{Cr}$ & 10.45 & 8.79 & 8.43 & 8.30 & 4.25 & 14.59 & 15.14 & 18.62 & 18.45 & 16.89 & 8.41 & 7.06 \\
\hline Co & 12.17 & 10.91 & 13.79 & 7.74 & 5.62 & 7.65 & 6.86 & 8.70 & 10.48 & 8.99 & 7.15 & 6.41 \\
\hline $\mathrm{Ni}$ & 11.17 & 10.33 & 8.94 & 8.49 & 5.36 & 13.69 & 12.61 & 17.45 & 15.87 & 16.94 & 9.70 & 8.25 \\
\hline $\mathrm{Cu}$ & 10.91 & 10.86 & 9.45 & 7.92 & 10.58 & 9.98 & 8.41 & 13.38 & 18.79 & 17.23 & 10.86 & 9.17 \\
\hline $\mathrm{Zn}$ & 47.71 & 43.65 & 47.50 & 32.14 & 35.96 & 44.08 & 35.76 & 49.19 & 55.24 & 45.14 & 25.27 & 25.39 \\
\hline $\mathrm{As}^{(\mathrm{c}, \mathrm{d})}$ & (4.76) & (2.04) & $(1.65)$ & $(1.00)$ & (3.78) & $(4.02)$ & (6.16) & $(4.56)$ & $(2.65)$ & (3.64) & (1.06) & $(1.30)$ \\
\hline $\mathrm{Se}^{(\mathrm{c})}$ & 0.35 & 0.33 & 0.24 & 0.35 & 0.15 & 0.16 & 0.18 & 0.27 & 0.29 & 0.16 & 0.22 & 0.17 \\
\hline $\mathrm{Mo}^{(\mathrm{c})}$ & 0.10 & 0.09 & 0.09 & 0.12 & 0.10 & 0.09 & 0.10 & 0.09 & 0.08 & 0.28 & 0.22 & 0.14 \\
\hline $\mathrm{Tc}^{(\mathrm{b}, \mathrm{c})}$ & 1.20 & 2.52 & 0.00 & 0.00 & 2.49 & 0.00 & 2.29 & 2.39 & 0.00 & 5.93 & 0.00 & $<29.80$ \\
\hline $\mathrm{Ru}^{(\mathrm{c})}$ & $\begin{array}{l}(0.001) \\
\end{array}$ & $(0.001)$ & $\begin{array}{l}(0.001) \\
\end{array}$ & $(0.001)$ & $(0.001)$ & $(0.001)$ & $(0.001)$ & $\begin{array}{l}(0.001) \\
\end{array}$ & $(0.002)$ & $(0.001)$ & $(0.001)$ & $(0.001)$ \\
\hline $\mathrm{Ag}^{(\mathrm{c})}$ & 0.06 & 0.06 & 0.05 & 0.05 & 0.05 & 0.04 & 0.05 & 0.06 & 0.07 & 0.03 & 0.03 & 0.05 \\
\hline $\mathrm{Cd}^{(\mathrm{c})}$ & 0.09 & 0.08 & 0.06 & 0.06 & 0.07 & 0.06 & 0.12 & 0.14 & 0.11 & 0.07 & 0.04 & 0.05 \\
\hline $\mathrm{Pb}^{(\mathrm{c})}$ & 5.06 & 4.28 & 3.69 & 2.65 & 6.28 & 5.16 & 6.31 & 10.45 & 8.34 & 2.93 & 2.52 & 3.96 \\
\hline $\mathrm{Pb}$ & 5.57 & 4.94 & 4.09 & 3.96 & 2.89 & 5.70 & 4.78 & 5.64 & 9.33 & 8.79 & 2.44 & 2.28 \\
\hline $\mathrm{U}$ & 0.82 & 0.68 & 0.51 & 0.45 & 0.74 & 0.82 & 0.78 & 0.97 & 1.20 & 1.29 & 0.40 & 0.39 \\
\hline $\begin{array}{l}\text { (a) Mult } \\
\text { (b) B ch } \\
\\
\text { B.) } \\
\text { (c) ICP- } \\
\text { Values in } \\
\text { (d) Arse }\end{array}$ & $\begin{array}{l}\text { ly by } 0.30 \\
\text { k standarc } \\
S \text { instrum } \\
\text { renthesis }\end{array}$ & $\begin{array}{l}8 \text { to conve } \\
\text { was readil } \\
\text { nt was use } \\
\text { re just bel }\end{array}$ & $\begin{array}{l}\text { to meters } \\
\text { high valu } \\
\text { when not } \\
\text { level of }\end{array}$ & $\begin{array}{l}\text { s are suspe } \\
\text { loted, ICP } \\
\text { dantificati }\end{array}$ & $\begin{array}{l}\text { (B valu } \\
\text { as used. } \\
\text { but spect }\end{array}$ & looked & 1. Thus & entative & was a & buted to & may a & Iditional \\
\hline
\end{tabular}


Table 5.45 expresses the percentage of each element released during nitric acid extraction in relation to the bulk chemical composition of the sediment as determined by XRF. In general, the acid extraction removes only $1 \%$ to $10 \%$ of the total alkali metals (potassium and sodium), about $25 \%$ of the major alkaline earth metals (calcium and magnesium), and less (about $10 \%$ to 20\%) of the minor alkaline earths (barium or strontium, very little of the silicon, about $15 \%$ of the aluminum and titanium, about $40 \%$ to $60 \%$ of the iron and manganese, and $25 \%$ to $70 \%$ of the various trace metals. The amount of any element removed from the Hanford formation $\mathrm{H} 1$ unit and to some degree the Ringold Formation coarse sands by

Table 5.45. Percent of Total Element (XRF) in Sediment Samples Leached by Acid Extraction of Sediment Samples in Borehole 299-W22-50

\begin{tabular}{|c|c|c|c|c|c|c|}
\hline Depth (ft bgs) $^{(a)}$ & 51 & 60 & 116 & 135 & 140 & 160.5 \\
\hline Stratigraphic Unit & H1a & H1 & H2 & PPlz & PPlc & Rtf \\
\hline $\mathrm{Na}$ & ב--- & $\begin{array}{l}--- \\
\end{array}$ & $\begin{array}{l}--- \\
\end{array}$ & ב--- & ב--- & ב--- \\
\hline $\mathrm{Mg}$ & 24.9 & 13.5 & 28.4 & 29.9 & 30.6 & 23.7 \\
\hline $\mathrm{Al}$ & 16.0 & 5.4 & 15.1 & 21.5 & 14.0 & 9.8 \\
\hline $\mathrm{Si}$ & 0.0 & 0.0 & 0.0 & 0.0 & 0.0 & 0.0 \\
\hline $\mathrm{P}$ & $>79.7$ & 71.9 & $>60.1$ & $>55.7$ & $>95.0$ & $>57.4$ \\
\hline$S$ & 16.7 & 38.3 & 7.6 & $>10.8$ & $>12.4$ & $>14.4$ \\
\hline $\bar{K}$ & 9.7 & 3.8 & 11.3 & 11.6 & 10.0 & 4.9 \\
\hline $\mathrm{Ca}$ & 29.9 & 33.9 & 36.9 & 49.7 & 46.6 & 16.4 \\
\hline $\mathrm{Ti}$ & 24.4 & 7.1 & 19.1 & 19.9 & 10.5 & 18.7 \\
\hline $\mathrm{Mn}$ & 46.6 & 17.9 & 56.3 & 67.0 & 57.4 & 39.1 \\
\hline $\mathrm{Fe}$ & 47.3 & 20.7 & 59.6 & 63.3 & 51.8 & 39.3 \\
\hline $\mathrm{Sr}$ & 14.6 & 9.4 & 11.9 & 17.7 & 12.3 & 5.9 \\
\hline $\mathrm{Ba}$ & 17.4 & 9.3 & 13.3 & 18.7 & 15.6 & 7.7 \\
\hline $\mathrm{Cr}^{(\mathrm{b})}$ & $>21.7$ & 8.3 & 33.3 & 33.5 & 34.5 & $>26.8$ \\
\hline Co & $>13.5$ & $>9.9$ & $>12.0$ & $>14.3$ & $>17.8$ & $>10.9$ \\
\hline $\mathrm{Ni}$ & 46.6 & 26.4 & 37. & 60.2 & 59.0 & 42.3 \\
\hline $\mathrm{Cu}$ & 44.3 & 34.3 & 42.2 & 46.6 & 88.2 & 51.5 \\
\hline $\mathrm{Zn}$ & 48.9 & 34.4 & 55.2 & 64.0 & 86.9 & 46.8 \\
\hline $\mathrm{As}^{(\mathrm{b}, \mathrm{c})}$ & 35.8 & 23.8 & 68.4 & 46.5 & 32.3 & 40.8 \\
\hline $\mathrm{Se}^{(\mathrm{b})}$ & $>12.8$ & $>13.4$ & $>7.5$ & $>11.3$ & $>12.2$ & $>7.4$ \\
\hline $\mathrm{Mo}^{(\mathrm{b})}$ & $>4.5$ & 3.0 & $>4.9$ & $>4.1$ & $>3.4$ & $>8.0$ \\
\hline $\mathrm{Ru}^{(\mathrm{b})}$ & $>0.0$ & $>0.0$ & $>0.0$ & $>0.0$ & $>0.0$ & $>0.0$ \\
\hline $\mathrm{Ag}^{(\mathrm{b})}$ & 0.8 & 0.5 & $>0.7$ & $>0.8$ & $>1.0$ & $>0.6$ \\
\hline $\mathrm{Cd}^{(\mathrm{b})}$ & $>0.9$ & $>0.7$ & $>1.4$ & $>1.6$ & $>1.3$ & $>0.6$ \\
\hline $\mathrm{Pb}^{(\mathrm{b})}$ & 62.1 & 26.5 & 48.6 & 59.7 & 57.2 & 34.1 \\
\hline $\mathrm{U}$ & $>12.4$ & $>8.0$ & $>14.3$ & $>16.4$ & 21.4 & $>7.7$ \\
\hline
\end{tabular}


acid digestion, is less than for the other geologic units signifying that the coarse sand consists of mostly unweathered primary minerals. The acid leach process releases most of the calcium and magnesium, and slightly more of several of the trace metal elements from the calcic PPlc subunit (42.6-meter or 140-foot depth) compared to noncalcareous strata. These relationships hold true for sediment samples from borehole 299-W22-48 as well.

Nitric acid is much more effective at leaching than 1:1 sediment-to-water solutions, which were discussed in Section 5.2.9. The only elements where water extraction exceeds a few tenths of a percent of the amount that the acid leached are sodium, sulfur (sulfate), and molybdenum; they water-leach between $5 \%$ to $10 \%, 10 \%$ to $30 \%$, and $10 \%$ to $15 \%$ as much as the amount that acid leaches, respectively. Thus, the percentages of the total elements in the uncontaminated sediment that leach in water is less than a few percent of the total as determined by XRF. The contaminated sediment differs in that more mass is waterleachable for contaminants that are known to be mobile, such as chromium (IV), molybdenum, nitrate, sulfate, and technetium (see Serne et al. 2002 a, b, c for further discussion).

\subsubsection{Porewater Composition}

Actual porewater was extracted and measured from two sediment samples in borehole 299-W22-50 via ultracentrifugation (Table 5.46). The two samples selected for analysis came from the Hanford formation $\mathrm{H} 2$ unit (35.3 meters or 116 feet bgs) and the PPlc subunit (42.6 meters or 140 feet bgs).

The $\mathrm{pH}, \mathrm{EC}$, and alkalinity, as well as concentration of cations, anions, and trace metals, were measured using the same techniques as used for the water extracts (see Section 5.2.9); these are listed in Table 5.46. The charge balance for UFA-extracted porewater from the two sediment samples is presented in Table 5.47.

The chemical composition of the UFA-extracted porewater suggests that the nitrate values for both the 35.3 and 42.6 meters (116 and 140 feet) bgs are higher than normal for uncontaminated vadose zone sediment (see Table 5.45). The values for all the constituents are quite similar for the two porewaters despite the fact that the shallower sample is from the Hanford formation $\mathrm{H} 2$ unit and the deeper sample is from the PPlc subunit. Natural vadose-zone porewaters are quite similar in chemical composition to sediment water extracts and groundwater, except they are more concentrated. These two fluids are dominated by calcium, magnesium, and sodium cations and by bicarbonate, chloride, nitrate, and sulfate anions (see Tables 6.46 and 6.47). The nitrate and sodium values seem somewhat high compared to uncontaminated groundwater, perhaps reflecting some manmade input of Hanford's two most ubiquitous chemicals - nitrate and sodium.

The UFA extractions represent actual porewater that may have been in contact (and in equilibrium) with the sediment for hundreds to thousands of years. However, it may be difficult to nearly impossible, and thus costly, to extract porewater from some of the drier vadose-zone sediments on the Hanford Site. Therefore, we attempted to compare UFA-extracted porewater with the dilution-corrected 1:1 sediment 
Table 5.46. pH, Electrical Conductivity, Alkalinity, Cations, Anions, and Trace Metals for UFA-Extracted Porewater from Sediment Samples within Borehole 299-W22-50

\begin{tabular}{|c|c|c|c|}
\hline \multirow[b]{2}{*}{ Constituent } & \multirow[b]{2}{*}{ Units } & \multicolumn{2}{|c|}{ ft bgs ${ }^{(a)}$} \\
\hline & & 116 & 140 \\
\hline Moisture & wt $\%$ & 22.61 & 29.67 \\
\hline $\mathrm{pH}$ & & 7.21 & 7.49 \\
\hline $\mathrm{EC}$ & $\mu \mathrm{S} / \mathrm{cm}$ & 1415 & 956 \\
\hline Alk & $\mathrm{mg} / \mathrm{L} \mathrm{CaCO} 3$ & 46.53 & 88.84 \\
\hline $\mathrm{F}$ & $\mathrm{mg} / \mathrm{L}$ & 0.58 & 0.38 \\
\hline $\mathrm{Cl}$ & $\mathrm{mg} / \mathrm{L}$ & 119.4 & 25.47 \\
\hline $\mathrm{Br}$ & $\mathrm{mg} / \mathrm{L}$ & 0.69 & 0.34 \\
\hline $\mathrm{NO}_{2}$ & $\mathrm{mg} / \mathrm{L}$ & $<0.1$ & $<0.1$ \\
\hline $\mathrm{NO}_{3}$ & $\mathrm{mg} / \mathrm{L}$ & 243.8 & 96.5 \\
\hline $\mathrm{PO}_{4}$ & $\mathrm{mg} / \mathrm{L}$ & $<0.1$ & 0.96 \\
\hline $\mathrm{SO}_{4}$ & $\mathrm{mg} / \mathrm{L}$ & 122.3 & 178 \\
\hline $\mathrm{Na}$ & $\mathrm{mg} / \mathrm{L}$ & 90.31 & 69.21 \\
\hline $\mathrm{Mg}$ & $\mathrm{mg} / \mathrm{L}$ & 23.23 & 22.02 \\
\hline $\mathrm{Al}$ & $\mu \mathrm{g} / \mathrm{L}$ & $<100$ & $(13)$ \\
\hline $\mathrm{Si}$ & $\mathrm{mg} / \mathrm{L}$ & 15.07 & 17.07 \\
\hline $\mathrm{P}$ & $\mu \mathrm{g} / \mathrm{L}$ & $(175)$ & $(178)$ \\
\hline$S$ & $\mathrm{mg} / \mathrm{L}$ & 49.98 & 67.73 \\
\hline $\mathrm{K}$ & $\mathrm{mg} / \mathrm{L}$ & 12.16 & 9.53 \\
\hline $\mathrm{Ca}$ & $\mathrm{mg} / \mathrm{L}$ & 109.2 & 75.2 \\
\hline $\mathrm{Mn}$ & $\mu \mathrm{g} / \mathrm{L}$ & (7) & 13.1 \\
\hline $\mathrm{Fe}$ & $\mu \mathrm{g} / \mathrm{L}$ & (13) & 43.1 \\
\hline $\mathrm{Sr}$ & $\mu \mathrm{g} / \mathrm{L}$ & 498 & 328 \\
\hline $\mathrm{Ba}$ & $\mu \mathrm{g} / \mathrm{L}$ & 144 & 90.1 \\
\hline $\mathrm{B}$ & $\mu \mathrm{g} / \mathrm{L}$ & (46) & (54) \\
\hline $\mathrm{Cr}^{*}$ & $\mu \mathrm{g} / \mathrm{L}$ & 0.675 & 1.10 \\
\hline Co & $\mu \mathrm{g} / \mathrm{L}$ & $<10$ & $<10$ \\
\hline $\mathrm{Ni}$ & $\mu \mathrm{g} / \mathrm{L}$ & (8) & (6) \\
\hline $\mathrm{Cu}$ & $\mu \mathrm{g} / \mathrm{L}$ & (8) & (11) \\
\hline $\mathrm{Zn}$ & $\mu \mathrm{g} / \mathrm{L}$ & 51.0 & 45.4 \\
\hline As* & $\mu \mathrm{g} / \mathrm{L}$ & 8.7 & 4.16 \\
\hline $\mathrm{Se}^{*}$ & $\mu \mathrm{g} / \mathrm{L}$ & 20.4 & 35.7 \\
\hline Mo* & $\mu \mathrm{g} / \mathrm{L}$ & 37.3 & 59.8 \\
\hline $\mathrm{Tc}^{*}$ & $\mu \mathrm{g} / \mathrm{L}$ & $(0.04)$ & $(0.00)$ \\
\hline $\mathrm{Pb}^{*}$ & $\mu \mathrm{g} / \mathrm{L}$ & $(0.35)$ & $(0.27)$ \\
\hline $\mathrm{U}^{*}$ & $\mu \mathrm{g} / \mathrm{L}$ & 1.26 & 4.86 \\
\hline $\mathrm{Ag}^{*}$ & $\mu \mathrm{g} / \mathrm{L}$ & $(0.10)$ & $(0.05)$ \\
\hline $\mathrm{Cd}^{*}$ & $\mu \mathrm{g} / \mathrm{L}$ & $(0.26)$ & $(0.16)$ \\
\hline $\mathrm{Ru}^{*}$ & $\mu \mathrm{g} / \mathrm{L}$ & $(0.02)$ & $(0.02)$ \\
\hline
\end{tabular}


Table 5.47. Charge Balance for UFA-Extracted Porewater from

Sediment Samples in Borehole 299-W22-50

\begin{tabular}{||c|c|c|c|c|c|c|c|c|c|c|c||}
\hline $\begin{array}{c}\mathbf{f t} \\
\text { (bgs) }^{(\mathbf{a})}\end{array}$ & $\begin{array}{c}\mathbf{A l k} \\
(\mathbf{m e q} / \mathbf{L})\end{array}$ & $\begin{array}{c}\mathbf{F} \\
(\mathbf{m e q} / \mathbf{L})\end{array}$ & $\begin{array}{c}\mathbf{C l} \\
(\mathbf{m e q} / \mathbf{L})\end{array}$ & $\begin{array}{c}\mathbf{N O}_{3} \\
(\mathbf{m e q} / \mathbf{L})\end{array}$ & $\begin{array}{c}\mathbf{S O}_{4} \\
(\mathbf{m e q} / \mathbf{L})\end{array}$ & $\begin{array}{c}\sum \text { Anion } \\
(\mathbf{m e q} / \mathbf{L})\end{array}$ & $\begin{array}{c}\text { Na } \\
(\mathbf{m e q} / \mathbf{L})\end{array}$ & $\begin{array}{c}\mathbf{M g} \\
(\mathbf{m e q} / \mathbf{L})\end{array}$ & $\begin{array}{c}\mathbf{K} \\
(\mathbf{m e q} / \mathbf{L})\end{array}$ & $\begin{array}{c}\text { Ca } \\
(\mathbf{m e q} / \mathbf{L})\end{array}$ & $\begin{array}{c}\sum \mathbf{C a t i o n} \\
(\mathbf{m e q} / \mathbf{L})\end{array}$ \\
\hline \hline 116 & 0.93 & 0.03 & 3.37 & 3.93 & 2.55 & 10.82 & 3.93 & 1.91 & 0.31 & 5.46 & 11.62 \\
\hline 140 & 1.78 & 0.02 & 0.72 & 1.56 & 3.71 & 7.78 & 3.01 & 1.81 & 0.24 & 3.76 & 8.83 \\
\hline
\end{tabular}

(a) Multiply by 0.3048 to convert to meters.

to water extracts. This comparison is shown in Tables 5.48 to 5.50 where the dilution-corrected water extracts (i.e., calculated porewater compositions) are listed along with the values obtained from actual porewater extracted with the UFA.

Table 5.48 shows the theoretical chemical composition of vadose zone porewater calculated by assuming that the water extracts represent the actual solutes present in the native porewater. To convert back to the concentration of the porewater, multiply by the dilution factor for the added deionized water.

We did not perform water extracts on aliquots of sediment from the same core sleeves that we ultracentrifuged so we cannot make direct comparisons. However, if we assume that the sediment in proximity should have similar pore chemistry, then comparisons can be made. In Tables 5.49 and 5.50, we compare calculated porewater compositions for neighboring water extracts with the two actual UFAextracted porewater samples. The comparisons require that we look at data from three different stratigraphic units: the Hanford formation $\mathrm{H} 2$ unit, and the upper and lower Plio-Pleistocene subunits (PPlz and PPlc, respectively). Tables 5.49 and 5.50 indicate that water leaching does dissolve excess carbonate, fluoride, potassium, and sodium from sediment within the Hanford formation $\mathrm{H} 2$ unit, compared to the native porewater. For the calcic (PPlc) sample, all the major chemical species are higher in the theoretically calculated pore fluid suggesting that water leaches material and, thus, we cannot accurately predict the actual porewater composition for this sediment type. The theoretically calculated composition is much higher than the actual porewater because the water leaching dissolves a significant portion of the carbonates and other salts. The additional carbonate alkalinity is likely due to partial dissolution of calcite. The excess potassium and sodium may come from the excess calcium replacing cation-exchangeable alkali metals during the water extraction process, though some potassium dissolution (perhaps potassium-feldspar is the source) has been noticed in longer-term water leach tests.

Aside from carbonate alkalinity, the water extracts may not dissolve excess anions not already present in the native porewater of non-calcareous sediment. As will be discussed in the other reports in this series (Serne et al. $2002 \mathrm{a}, \mathrm{b}, \mathrm{c}$ ), which report on contaminated sediment that contain highly saline tank fluids, water extracts multiplied by the dilution factor agree more closely with UFA-extracted porewater from vadose zone contaminated sediment because the tank fluid in porewaters contains such high concentrations that it dwarfs the contribution from dissolution/ion exchange displacement from the sediment during the water extraction process. 
Table 5.48. Calculated Composition of Vadose-Zone Porewater (1:1 Sediment-to-Water Extracts Multiplied By Dilution Factor)

\begin{tabular}{|c|c|c|c|c|c|c|c|c|c|c|c|c|}
\hline $\begin{array}{l}\text { Constituent } \\
\text { Units }\end{array}$ & EC & Alk & $\mathbf{F}$ & Cl & NO3 & SO4 & $\mathrm{Na}$ & Mg & $\mathbf{K}$ & Ca & $\mathrm{Sr}$ & Ba \\
\hline $\begin{array}{l}\text { Sample } \\
\text { ft bgs }\end{array}$ & $\mu \mathbf{S} / \mathbf{c m}$ & $\begin{array}{c}\mathrm{mg} / \mathrm{L} \\
\mathrm{CaCO}_{3}\end{array}$ & $\mathrm{mg} / \mathrm{L}$ & $\mathbf{m g} / \mathrm{L}$ & $\mathbf{m g} / \mathbf{L}$ & $\mathbf{m g} / \mathbf{L}$ & mg/L & $\mathbf{m g} / \mathbf{L}$ & $\mathbf{m g} / \mathbf{L}$ & $\mathbf{m g} / \mathbf{L}$ & $\mu \mathbf{g} / \mathbf{L}$ & $\mu \mathbf{g} / \mathbf{L}$ \\
\hline \multicolumn{13}{|c|}{ Hanford Formation H1a Unit (Sand) } \\
\hline 20 & 2,799 & 787 & 10.7 & 6.7 & 87.7 & 127.4 & 292.2 & 24.6 & 80.4 & 106.3 & 470.4 & 251.6 \\
\hline 22.5 & 1,679 & 203 & 5.6 & 8.2 & 34.3 & 102.7 & 187.9 & 15.8 & 49.2 & 72.1 & 305.3 & 151.9 \\
\hline 27.5 & 4,165 & 617 & 14.0 & 14.8 & 66.6 & 190.3 & 390.2 & 27.2 & 105.3 & 123.0 & 535.2 & 360.0 \\
\hline 30 & 2,626 & 597 & 8.6 & 23.1 & 7.7 & 240.1 & 274.9 & 28.8 & 82.1 & 131.6 & 590.3 & 353.5 \\
\hline 32.5 & 2,301 & 419 & 6.7 & 51.4 & 28.0 & 217.4 & 213.7 & 25.7 & 63.4 & 119.2 & 552.5 & 211.0 \\
\hline 35 & 2,298 & 531 & 6.9 & 20.0 & 31.0 & 143.8 & 244.5 & 20.6 & 60.0 & 98.2 & 427.5 & 224.8 \\
\hline 37.5 & 2,527 & 570 & 7.7 & 9.3 & 7.7 & 157.7 & 289.1 & 24.5 & 77.6 & 124.2 & 557.8 & 299.4 \\
\hline 40 & 2,839 & 631 & 8.5 & 9.4 & 8.0 & 175.0 & 315.0 & 27.6 & 89.1 & 139.6 & 625.2 & 276.9 \\
\hline 42.5 & 3,470 & 891 & 9.4 & 10.7 & 6.8 & 216.7 & 342.8 & 39.0 & 116.5 & 188.2 & 873.1 & 443.1 \\
\hline 45 & 3,570 & 869 & 9.3 & 15.8 & 18.4 & 280.8 & 354.1 & 41.9 & 113.5 & 205.9 & 894.8 & 280.1 \\
\hline 47.5 & 2,804 & 438 & 7.5 & 10.3 & 18.3 & 220.3 & 270.6 & 31.5 & 90.0 & 153.7 & 694.7 & 266.6 \\
\hline 51 & 2,510 & 387 & 6.4 & 9.3 & 5.2 & 183.4 & 250.2 & 29.5 & 81.9 & 147.1 & 671.2 & 236.4 \\
\hline 52.5 & 2,675 & 833 & 8.7 & 6.6 & 45.7 & 127.4 & 254.9 & 27.2 & 76.8 & 135.2 & 589.6 & 202.4 \\
\hline \multicolumn{13}{|c|}{ Hanford Formation H1 Unit (Gravel and Sand) } \\
\hline 55 & 3,289 & 837 & 7.2 & 20.4 & 3.8 & 292.0 & 296.2 & 42.5 & 99.9 & 193.7 & 887.7 & 418.7 \\
\hline 56 & 4,219 & 830 & 9.2 & 17.7 & 40.9 & 273.7 & 361.7 & 57.9 & 133.8 & 187.7 & 876.5 & 477.5 \\
\hline 60 & 18,009 & 1,974 & 13.4 & 303.8 & 59.3 & $1,162.9$ & 915.7 & 1.0 & 327.3 & $1,678.7$ & $5,731.5$ & $1,462.2$ \\
\hline \multicolumn{13}{|c|}{ Hanford Formation H2 Unit (Sand and Silt) } \\
\hline 67.5 & 3,591 & --- & 4.9 & 63.0 & 71.4 & 284.9 & 212.9 & 39.4 & 61.0 & 164.2 & 739.0 & 199.1 \\
\hline 76 & 2,113 & 207 & 3.4 & 41.7 & 83.9 & 281.4 & 154.8 & 26.4 & 38.0 & 133.6 & 556.2 & 155.4 \\
\hline 96 & 3,743 & 440 & 4.9 & 297.7 & 125.6 & 360.5 & 291.1 & 53.9 & 74.5 & 240.8 & $1,075.1$ & 335.3 \\
\hline 111 & 2,914 & 576 & 4.8 & 112.9 & 251.2 & 226.6 & 220.6 & 38.7 & 55.7 & 175.7 & 784.7 & 296.4 \\
\hline 115 & 1,933 & 348 & 3.2 & 90.1 & 186.4 & 103.8 & 152.2 & 26.0 & 34.3 & 115.7 & 534.2 & 222.1 \\
\hline 116 & -- & -- & -- & -- & -- & -- & 730.9 & 89.5 & 111.2 & 436.9 & $1,927.5$ & $1,078.7$ \\
\hline \multicolumn{13}{|c|}{ Upper Plio-Pleistocene Unit (PPlz) } \\
\hline 130 & 2,801 & 1,086 & 5.0 & 24.4 & 76.6 & 116.8 & 222.7 & 48.9 & 45.8 & 195.8 & 870.6 & 346.8 \\
\hline 135 & 1,829 & 501 & 3.7 & 18.6 & 169.5 & 145.5 & 169.2 & 37.2 & 38.1 & 127.0 & 567.5 & 231.7 \\
\hline \multicolumn{13}{|c|}{ Lower Plio-Pleistocene Unit (PPIc) } \\
\hline 140 & -- & -- & -- & -- & -- & -- & 288.0 & 59.4 & 51.5 & 193.2 & 971.8 & 575.6 \\
\hline 141 & 3,955 & 1,077 & 12.9 & 53.1 & 176.8 & 353.7 & 323.6 & 84.9 & 75.7 & 274.7 & $1,332.7$ & 364.9 \\
\hline \multicolumn{13}{|c|}{ Upper Ringold Unit (Rtf Member) (Sand) } \\
\hline 150.5 & 6,403 & 213 & 36.9 & 49.9 & $<3.4$ & 289.0 & 581.0 & 111.0 & 155.2 & 350.0 & $1,998.0$ & 512.9 \\
\hline 160.5 & 5,867 & 1,348 & 26.9 & 33.0 & $<4.3$ & 136.0 & 435.5 & 101.3 & 156.5 & 365.5 & $1,760.1$ & 730.1 \\
\hline 174 & 5,003 & 1,042 & 56.3 & 271.2 & 619.6 & 146.1 & 380.3 & 51.2 & 125.1 & 169.4 & (796) & (284) \\
\hline
\end{tabular}


Table 5.49. Comparison of UFA-Extracted Porewater to Calculated Porewater Based on Water Extract Data from Sediment Samples in Borehole 299-W22-50

\begin{tabular}{|c|c|c|c|c|c|c|c|c|c|c|c|c|}
\hline $\begin{array}{c}\text { Constituent } \\
\text { Units }\end{array}$ & EC & Alk & $\mathbf{F}$ & $\mathbf{C l}$ & $\mathrm{NO}_{3}$ & $\mathrm{SO}_{4}$ & $\mathbf{N a}$ & Mg & $\mathbf{K}$ & Ca & Sr & Ba \\
\hline $\begin{array}{l}\text { Sample } \\
\text { ft bgs }\end{array}$ & $\mu \mathrm{S} / \mathbf{c m}$ & $\mathrm{mg} / \mathrm{L} \mathrm{CaCO}_{3}$ & $\mathbf{m g} / \mathbf{L}$ & $\mathbf{m g} / \mathbf{L}$ & $\mathbf{m g} / \mathbf{L}$ & $\mathbf{m g} / \mathbf{L}$ & $\mathbf{m g} / \mathbf{L}$ & $\mathbf{m g} / \mathbf{L}$ & $\mathbf{m g} / \mathbf{L}$ & $\mathbf{m g} / \mathbf{L}$ & $\mu \mathbf{g} / \mathbf{L}$ & $\mu \mathbf{g} / \mathbf{L}$ \\
\hline \multicolumn{13}{|c|}{ Hanford Formation H2 Unit (Sand and Silt) } \\
\hline 111 & 2,914 & 576 & 4.8 & $1,12.9$ & 251.2 & 226.6 & 220.6 & 38.7 & 55.7 & 175.7 & 784.7 & 296.4 \\
\hline 115 & 1,933 & 348 & 3.2 & 90.1 & 186.4 & 103.8 & 152.2 & 26 & 34.3 & 115.7 & 534.2 & 222.1 \\
\hline 116 & 1,415 & 46.53 & 0.58 & 119.4 & 243.8 & 122.3 & 90.3 & 23.2 & 12.2 & 109.2 & 498 & 144 \\
\hline \multicolumn{13}{|c|}{ Upper Plio-Pleistocene Unit ( PPlz Facies) (Fine Sand and Silt) } \\
\hline 130 & 2,801 & 1,086 & 5 & 24.4 & 76.6 & 116.8 & 222.7 & 48.9 & 45.8 & 195.8 & 870.6 & 346.8 \\
\hline 135 & 1,829 & 501 & 3.7 & 18.6 & 169.5 & 145.5 & 169.2 & 37.2 & 38.1 & 127 & 567.5 & 231.7 \\
\hline \multicolumn{13}{|c|}{ Lower Plio-Pleistocene Unit (PPlc) (Caliche) } \\
\hline 140 & 956 & 88.84 & 0.38 & 25.47 & 96.5 & 178 & 69.2 & 22 & 9.5 & 75.2 & 328 & 90.1 \\
\hline 141 & 3,955 & 1,077 & 13 & 53 & 177 & 354 & 324 & 85 & 76 & 275 & 1,333 & 365 \\
\hline \multicolumn{13}{|c|}{$\begin{array}{l}\text { (a) Multiply by } 0.3048 \text { to convert to meters. } \\
\text { (b) The two values in bold are the actual UFA-extracted porewater while the other values are calculated from the 1:1 sediment } \\
\text { to-water extracts by dilution correction. }\end{array}$} \\
\hline
\end{tabular}

Table 5.50. Comparison of UFA-Extracted Porewater to Calculated Porewater Charge Balance Based on Water Extracts of Sediment Samples from Borehole 299-W22-50

\begin{tabular}{|c|c|c|c|c|c|c|c|c|c|c|c|}
\hline $\begin{array}{c}\text { Constituent } \\
\text { Units }\end{array}$ & Alk & $\mathbf{F}$ & $\mathbf{C l}$ & NO3 & SO4 & $\mathbf{N a}$ & Mg & $\mathbf{K}$ & Ca & $\begin{array}{c}\text { Anions } \\
\Sigma\end{array}$ & $\begin{array}{c}\text { Cations } \\
\Sigma\end{array}$ \\
\hline $\begin{array}{l}\text { Sample } \\
\text { ft bgs }\end{array}$ & meq/L & meq/L & $\mathbf{m e q} / \mathbf{L}$ & meq/L & $\mathrm{meq} / \mathrm{L}$ & $\mathrm{meq} / \mathrm{L}$ & $\mathbf{m e q} / \mathbf{L}$ & meq/L & $\mathrm{meq} / \mathrm{L}$ & $\mathbf{m e q} / \mathbf{L}$ & $\mathbf{m e q} / \mathrm{L}$ \\
\hline \multicolumn{12}{|c|}{ Hanford Formation Unit H2 (Sand and Silt) } \\
\hline 111 & 11.52 & 0.25 & 3.18 & 4.05 & 4.72 & 9.59 & 3.19 & 1.42 & 8.77 & 23.73 & 22.97 \\
\hline 115 & 6.96 & 0.17 & 2.54 & 3.01 & 2.16 & 6.62 & 2.14 & 0.88 & 5.77 & 14.84 & 15.41 \\
\hline 116 & 0.93 & 0.03 & 3.37 & 3.93 & 2.55 & 3.93 & 1.91 & 0.31 & 5.45 & 10.81 & 11.60 \\
\hline \multicolumn{12}{|c|}{ Upper Plio-Pleistocene Unit (PPlz) (Fine Sand and Silt) } \\
\hline 130 & 21.72 & 0.26 & 0.69 & 1.24 & 2.43 & 9.68 & 4.02 & 0.92 & 9.77 & 26.34 & 24.39 \\
\hline 135 & 10.02 & 0.19 & 0.52 & 2.73 & 3.03 & 7.36 & 3.06 & 0.97 & 6.34 & 16.50 & 17.73 \\
\hline \multicolumn{12}{|c|}{ Lower Plio-Pleistocene Unit (PPlc) (Caliche) } \\
\hline 140 & 1.78 & 0.02 & 0.72 & 1.56 & 3.71 & 3.01 & 1.81 & 0.24 & 3.75 & 7.78 & 8.81 \\
\hline 141 & 21.54 & 0.68 & 1.50 & 2.85 & 7.37 & 14.07 & 6.99 & 1.94 & 13.71 & 33.94 & 36.70 \\
\hline \multicolumn{12}{|c|}{ (a) Multiply by 0.3048 to convert to meters. } \\
\hline
\end{tabular}


In Tables 5.49 and 5.50, we present calculated porewater compositions for two samples from the PPlz subunit, even though we have no actual UFA-extracted porewater data for this unit in borehole 299-W2250. The data are shown to allow some comparison between the porewater from the two mineralogically and granulometrically diverse sediment types. It can be seen from the two tables that chemical composition of the porewaters for the different sediment types is quite variable and more samples would need to be run to narrow the variability to the point that subtle differences could be used to aid in fate and transport predictions for the contaminants of concern.

Figure 5.12 shows the $\mathrm{pH}$ and the dilution-corrected EC in the water extracts versus depth in borehole 299-W22-50. The data in Figure 5.12 suggests that there is either a high pH, readily water-leachable natural mineral near the bottom of the coarse-grained Hanford formation $\mathrm{H} 1$ unit or that manmade fluids have migrated laterally along the contact with the underlying finer-grained Hanford formation $\mathrm{H} 2$ unit. The $\mathrm{pH}$ of the two UFA-extracted porewater samples are lower (more neutral) than the $\mathrm{pH}$ values for the water extracts but the actual porewater EC is not very different from the dilution-corrected water extracts. As mentioned, the PPlc subunit does promote some extra dissolution during water extraction. Figure 5.13 shows the dilution-corrected anion concentrations in the water extracts versus stratigraphy. All the anions excepting nitrate, show a sharp peak at the bottom of the Hanford formation $\mathrm{H} 1$ unit, which suggests that this sample has some readily soluble carbonate and sulfate (i.e., calcite and/or gypsum) or some other evaporites. The anion data for the actual UFA-extracted porewater sample from the Hanford formation $\mathrm{H} 2$ unit agrees very well with the calculated porewater composition from water extracts but the other UFA-extracted sample from the PPlc unit shows lower anion concentrations than the calculated porewater based on water extraction because the calcic sediments are especially prone to dissolution. Figure 5.14 shows the dilution-corrected cations in the water extracts vs. depth in borehole 299-W22-50. Again, there is a significant spike in calcium, potassium and sodium in the calculated porewater at the base of the Hanford formation $\mathrm{H} 1$ unit. In contrast, the magnesium concentration is depleted for this sample. If the material that is readily dissolving in this sample is the typical calcite and gypsum, we would expect elevated magnesium and perhaps only small enrichments in potassium and sodium. We speculate that this zone is enriched in readily soluble calcium, potassium, and sodium carbonates, chlorides, and sulfates from natural evapotranspiration. The sediment calcium carbonate data for the base of the Hanford H1 unit in Table 5.33 shows a slight enrichment in carbonate ( $0.5 \%$ to $1 \%$ ) compared to adjacent samples but the XRD mineralogical analyses did not show any distinct differences.

As with the anions, the actual cation composition of the UFA-extracted porewaters show good agreement for the sample from the Hanford formation $\mathrm{H} 2$ unit but lower cation values than calculated porewater samples from the calcic PPlc subunit. 


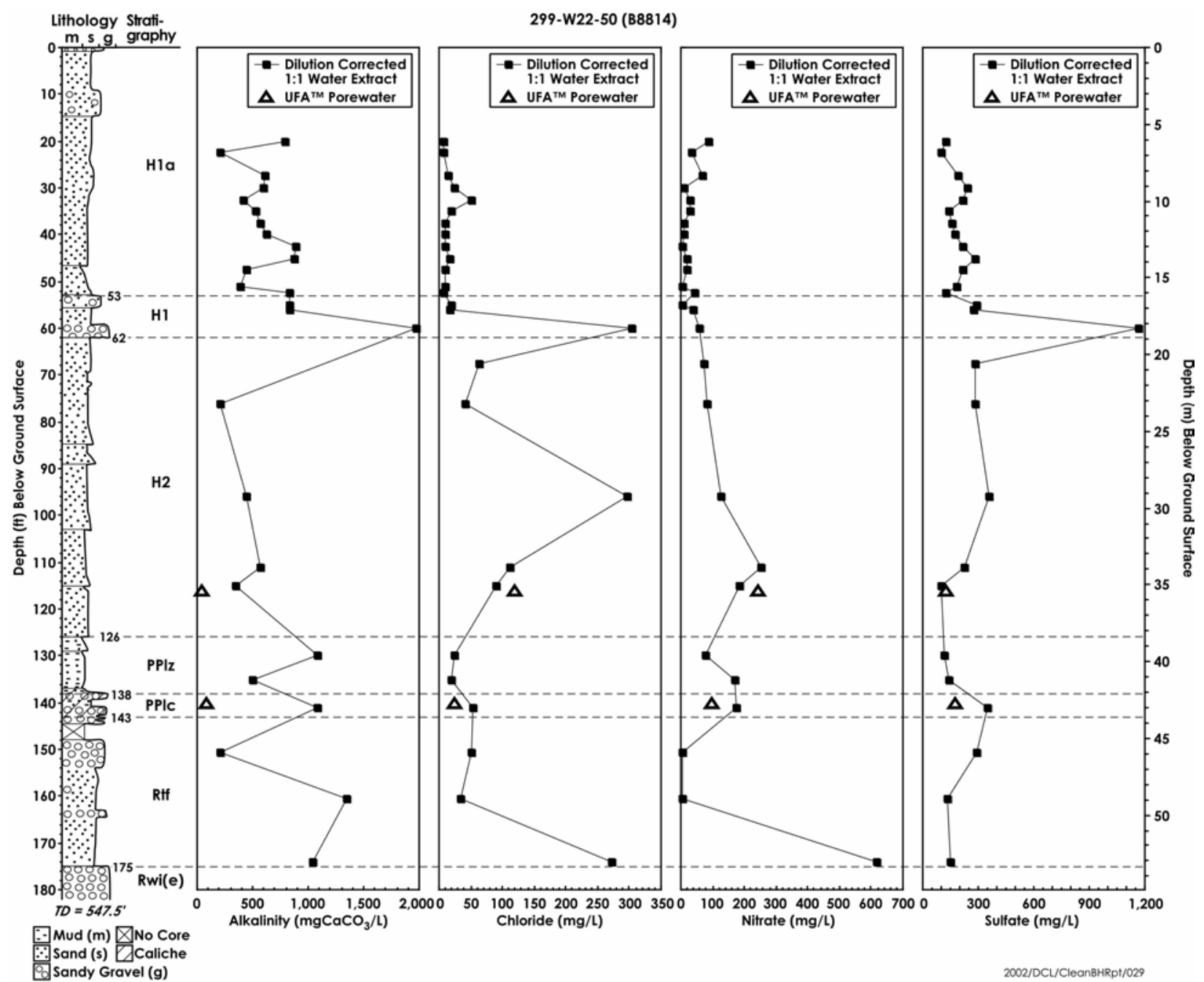

Figure 5.13. Calculated and UFA-Extracted Porewater Concentration of Anions Versus Depth in Borehole 299-W22-50

\subsection{Discussion: Comparison Between Boreholes 299-W22-48 and 299-W22-50}

The moisture profiles in the two RCRA boreholes show similar trends in the same sediment types, though the moisture spikes in borehole 299-W22-48 within the Hanford formation H2 unit indicate a greater absolute moisture content. Both boreholes show several moist zones in the Hanford formation $\mathrm{H} 2$ unit, associated with thin finer-grained lenses that are common in this facies of the Hanford formation. Both boreholes also show higher moisture within the PPlc subunit. Another higher-moisture zone occurs at the contact between the Hanford formation $\mathrm{H} 2$ unit and underlying fine-grained Plio-Pleistocene mud (PPlz) subunit. As discussed in companion documents on contaminated sediment, the moisture content itself is not indicative as to whether a certain strata is draining or accumulating water. 


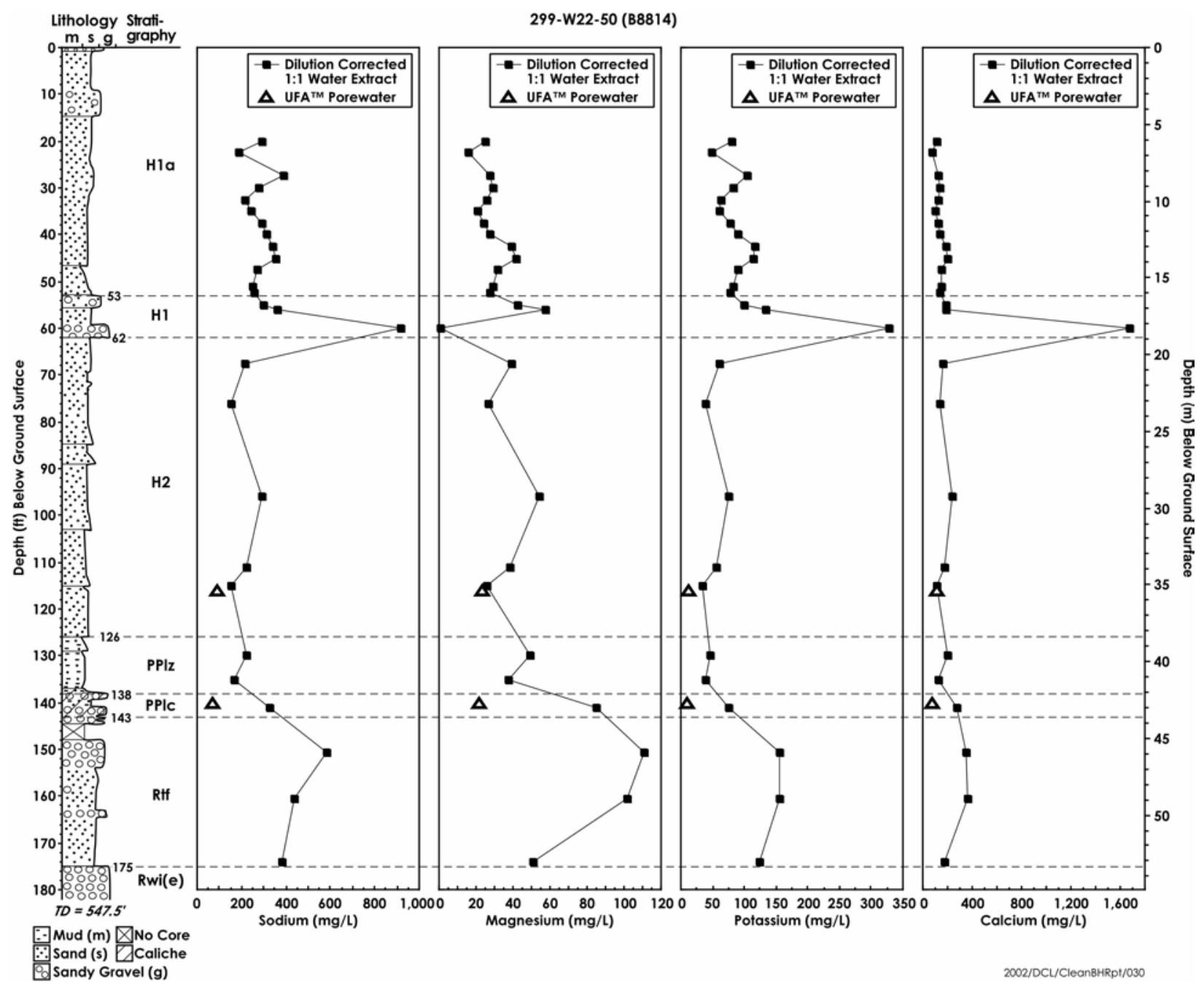

Figure 5.14. Calculated and UFA-Extracted Porewater Concentrations of Cations Versus Depth in Borehole 299-W22-50

No significant differences were detected in particle-size distribution, total chemical composition (oxide content), or mineralogy between samples from the same stratigraphic units in the two boreholes. The PPlc subunit in borehole 299-W22-48, however, is much better defined and more enriched in calcite compared to borehole 299-W22-50.

The water extract data for the sample at the base of the Hanford formation H1 unit in borehole 299W22-50 shows a high $\mathrm{pH}$ and high EC/anion/cation spike that is not present in borehole 299-W22-48, though there is a muted increase in EC at about the same relative position. Currently, we do not have an explanation for the high water extract values at the base of the Hanford formation H1 unit. We did not observe pedogenic alteration upon visual inspection that might indicate past evaporation might be the cause. The other cause may be the lateral spreading of Hanford waste waters or water line leakage along the geologic contact. Both borehole water extract profiles suggest that there are higher water-leachable nitrate concentrations in the lower portion of the Ringold Formation (Rwi[e]) than within shallower strata. 
We speculate that the elevated nitrate is manmade nitrate that was present in the groundwater when the water table was much shallower (closer to the ground surface). Aside from the one spike (elevated concentrations) in the Hanford formation H1 unit at borehole 299-W22-50, the calculated porewater cation concentrations are quite similar in the same sediment types for the two boreholes. There are higher concentrations of magnesium and potassium leachable in the Ringold Formation at both boreholes than in the overlying Hanford formation sediment. This undoubtedly is related to geologic age and degree of weathering. 


\subsection{Summary and Conclusions}

Cores from two boreholes near the SX Tank Farm and four large-quantity grab samples from outcrop sediment on the Hanford Site have been characterized to better understand the fate of contaminants that have leaked from underground storage tanks at the Hanford Site. Completion of a suite of physical, mineralogical, and geochemical analyses on two "clean" boreholes has resulted in well-characterized samples that can be considered as standards for geologic strata that underlie waste facilities at Hanford. Many of these standards are now available to researchers throughout the country for experiments relative to environmental problems at the Hanford Site. In general, these standards represent baseline or background sediment mostly free of contact with any fluids associated with Hanford's waste facilities.

The geology under the SX Tank Farm forms the framework through which the contaminants move, and provides the basis with which to interpret and extrapolate the physical and geochemical properties that control the migration and distribution of contaminants. Of particular interest are the interrelationships between the coarser- and finer-grained facies, and the degree of contrast in their physical and geochemical properties. For the two boreholes, lithologic sections were constructed using detailed geologic descriptions and geophysical logs. In some cases the results of laboratory analyses (e.g., particle-size distribution, moisture, calcium carbonate content) helped to refine the resulting stratigraphic and lithologic interpretations.

Our conceptual model of the 67-meter (220-foot)-thick vadose zone beneath the SX Tank Farm consists of seven stratigraphic units. These include two members of the Ringold Formation (member of Wooded Island/Unit E [Rwi(e)] and member of Taylor Flat [Rtf]), two Plio-Pleistocene subunits (very fine sand to mud sequence [PPlz] and a carbonate-rich paleosol sequence [PPlc]), and three units of the Hanford formation (H1a, H1, and H2). Most of the Hanford formation H1a unit was removed during excavation of the SX Tank Farm and replaced with backfill to a depth of about 17 meters (55 feet). All but the Hanford formation strata dip slightly toward the southwest.

Sediment samples from the various stratigraphic units were analyzed and characterized in the laboratory for the following parameters:

- mass water content

- particle-size distribution

- particle density

- calcium carbonate and organic carbon contents

- bulk chemical composition

- mineralogy

- cation exchange capacity

- exchangeable base cation distribution

- water leach (1:1 sediment-to-water extraction) 
- acid leach (8M nitric acid extraction)

- UFA-extracted porewater composition.

Physical properties, such as particle-size distribution and moisture content, also vary according to lithology. Strata with finer particle sizes (e.g., lower Hanford formation), and the top of PPlc subunit with its high cement/clay content, retain more moisture in the vadose zone. High moisture is also associated with a sub-vertical clastic dike within the upper Ringold unit (Rtf) in borehole 299-W22-48. Of the two methods used to determine particle size distribution (dry sieve and wet sieve/hydrometer), the wet sieve method is superior to the dry sieve method, especially in fine-grained sediments, which tend to cling together during dry sieving. Unfortunately, almost all earlier particle size characterization at Hanford was done using the dry sieve method.

Past studies have shown that sediments in the vadose zone are dominated by quartz, potassium- and plagioclase-feldspar, basalt, and other lithic fragments with minor amounts of mica, amphibole, calcite, and other trace minerals (Tallman et al. 1979). The x-ray diffraction (XRD) work done for this study is in agreement with past work and shows that the sediment is 25 to $95 \mathrm{wt} \%$ quartz, 5 to (possibly) $40 \mathrm{wt} \%$ potassium feldspar, 10 to $20 \mathrm{wt} \%$ plagioclase feldspar, and 0 to $40 \mathrm{wt} \%$ calcite with trace to minor amounts of amphibole, mica, and chlorite.

Mineralogical and geochemical variations, some significant, exist between the different stratigraphic units, as a result of differing depositional environments and sources for the sediments. For example, calcite-rich samples are associated with the lower Plio-Pleistocene subunit (PPlc), which unlike other stratigraphic units, underwent significant pedogenic alteration. In addition to high calcium oxide the PPlc subunit is relatively high in magnesium oxide, which co-precipitated with calcium during pedogenesis. Vadose-zone sediments contain very little organic carbon. The organic carbon is slightly greater for the PPlc subunit (up to $0.2 \mathrm{wt} \%$ ), compared to all the other units, which are all $<0.1 \mathrm{wt} \%$ carbon. Calcium carbonate content, calculated from the amount of inorganic carbon present, approaches $40 \mathrm{wt} \%$ for the PPlc subunit; all other units are generally less than a few wt $\%$ calcium carbonate. The concentration of major elements such as silica, iron, and calcium, varies significantly because of different ratios of quartzo-feldspathic to basaltic detritus in the Hanford versus Ringold formations. Samples high in potassium oxide may reflect the relatively high illite content of the Ringold Formation and finer-grained portions of the Hanford formation.

Clay minerals, measured semiquantitatively using XRD, include smectite, illite, chlorite, and kaolinite. Overall, within the clay sized fraction of the sediments smectite ranged in concentration from 10 to 30 (wt $\%$ ). Illite concentrations ranged from $\sim 10 \%$ to $50 \%$ and chlorite concentrations were a little less ( $\sim 5$ to $35 \mathrm{wt} \%)$. Minor amounts of kaolinite ( $\sim 5 \%$ to $10 \%)$ were also detected. Quartz, feldspar, and amphiboles made up less than $\sim 15 \mathrm{wt} \%$ of the clay fraction. The only consistent trend in the mineral content of samples is the substantial increase in calcite, relative to other minerals, for the PPlc subunit. This trend is noted in both the bulk sample as well as the $\leq 2$-micron fraction. 
Base cations, displaced via ammonium acetate extraction, are dominated by alkaline earth elements (calcium and magnesium), especially within the PPlc subunit. The relative contribution of the alkali metals (sodium and potassium) to the natural distribution of exchangeable cations is small $(<10 \%)$.

Though some relationships can be made comparing cation exchange capacity to the lithology, mineralogy and grain-size distribution of some samples, enough discrepancies exist to make most comparisons tentative. Cation exchange capacity was measured using two analytical techniques, each of which provided significantly different results. More work is needed to establish the best way to measure cation exchange capacities on sediments from the Hanford Site.

The results from the 1:1 sediment-to-water extracts are similar for samples from both of the clean boreholes. This gives credence to the representativeness of the results. Also, most, but not all, results yield a reasonable charge balance among cations and anions. There is one sample in borehole 299-W2250 near the base of the coarse-grained Hanford formation $\mathrm{H} 1$ unit that shows high $\mathrm{pH}$, electrical conductivity (EC), and water-leachable cations and anions, but it appears to be natural and perhaps was caused by dissolution of natural evaporites (see below).

Porewater in the vadose zone was evaluated via a comparison of a few actual UFA-extracted porewater samples with a larger data set of 1:1 sediment-to-water extracts. Water extracts are in agreement with actual porewaters for only a limited number of constituents and the water extracts generally produced higher chemical concentrations than those found in the actual porewater sampled from the same interval and thus the water extracts should be considered maximum values. The concentrations of many constituents in the water extracts of the four composite sediment samples are similar to those in the two sampled boreholes. A few exceptions are higher calcium, chloride, magnesium, sodium, and sulfate in the sediment composite samples relative to the clean borehole samples, probably as a result of natural near-surface recharge and leaching, which does not occur at depth within borehole samples. As expected, the calcic PPlc subunit yielded significantly different water extract results than the Hanford or Ringold formation samples. Water leachate from the PPlc produced relatively higher EC, alkalinity, cations (silicon, calcium, magnesium), anions (nitrate and sulfate), as well as trace elements (selenium, strontium, copper, manganese, and uranium). Elevated concentrations of these parameters, combined with depleted aluminum, are a reflection of the pedogenic origin for the PPlc subunit. Differences among samples from the Ringold and Hanford formations are generally small (except water-extractable magnesium and potassium, which are higher for the older Ringold Formation) and not consistent among all samples. This is not surprising considering the wide range in mineral and physical properties for these samples.

Most noteworthy in the water extract profile for borehole $299 \mathrm{~W} 22-50$ is high water-leachable $\mathrm{pH}$, alkalinity, EC, calcium, chloride, chromium, strontium, and sulfate at the base of the coarser-grained facies (H1 unit) of the Hanford formation. We speculate that one possible cause is natural evaporites or gypsum in the sediment from past pedogenic processes. However, no paleosols or anything else unusual was observed in geologic/geophyscal logs at this depth. However, gypsum and other evaporites were not observed in these Hanford sediments, except for calcite in PPlc subunit. The other explanation is 
horizontal spreading of waste water from Hanford activities or from water line leaks. Thus, the elevated porewater concentrations at the base of the $\mathrm{H} 1$ unit at borehole $299 \mathrm{~W} 22-50$ warrants further study.

In general, acid extraction is effective at removing from sediment samples, in decreasing order, $25 \%$ to $70 \%$ of the total trace metals, $40 \%$ to $60 \%$ of the iron and manganese, about $25 \%$ of the major alkaline earth metals (calcium and magnesium), about $15 \%$ of the aluminum and titantium, about $10 \%$ to $15 \%$ of the minor alkaline earths (barium and strontium), $1 \%$ to $10 \%$ of the alkali metals (potassium and sodium). In contrast, negligible amounts of silicon $(<0.03 \%)$ are removed during acid extraction. The amount of any element removed from the coarse-grained Hanford formation $\mathrm{H} 1$ unit by acid digestion is less than for the other stratigraphic units, perhaps due to the larger particle sizes, which have overall less surface area and are thus less prone to leaching. Acid extraction within the calcic PPlc releases almost all the calcium and strontium and slightly more of several of the other elements when compared to other noncalcic sediment samples. Most calcium and strontium in the PPlc subunit are combined with carbonate, which readily decomposes in contact with acid. Calcium in the other units is associated with silicates (e.g., pyroxene, plagioclase, etc.), which do not readily react with the acid leach.

For researchers interested in performing additional analyses on the four composite sediment samples, 30 kilograms of Ringold Silt, 200 kilograms of Hanford Coarse Sand (roughly equivalent to the Hanford formation $\mathrm{H} 1$ unit), 200 kilograms of Hanford Fine Sand (equivalent to the Hanford formation H2 unit), and 60 kilograms of the Borehole Fine Sand (also representative to the Hanford formation $\mathrm{H} 2$ unit) are available for scientific study. Also available are 30 kilograms each of caliche (equivalent to the PPlc subunit) and Ringold Formation sands (equivalent to the Rtf unit) from the White Bluffs that have yet to be characterized. Interested researchers may also obtain core samples from the remaining sleeves in the two clean boreholes (299-W22-48 and -50) reported herein. 


\subsection{References}

ASA - American Society of Agronomy. 1986. Methods of soil analysis-part 1, $2^{\text {nd }}$ edition physical and mineralogical methods. A Klute (ed.), SSSA Book Series 5, Soil Science Society of America, Madison, Wisconsin.

ASA - American Society of Agronomy. 1996. Methods of soil analysis-part 3 chemical methods. DL Sparks (ed.), SSSA Book Series 5, Soil Science Society of America, Madison, Wisconsin.

ASTM. 1993. "Standard practice for description and identification of soils (visual-manual procedure)." D 2488 - 93, American Society for Testing and Materials, West Conshohocken, Pennsylvania.

Amrhein C and DL Suarez. 1990. "Procedure for determining sodium-calcium selectivity in calcareous and gypsiferous soils.” Soil Sci. Soc. Am. J. 54:999-1007.

Baker VR, BN Bjornstad, AJ Busacca, KR Fecht, EP Kiver, UL Moody, JG Rigby, DF Stradling, and AM Tallman. 1991. "Quaternary geology of the Columbia Plateau.” In Quaternary Nonglacial Geology; Conterminous U.S.: Boulder, Colorado, R. B. Morrison (ed.), Geological Society of America, The Geology of North America, v. K-2.

Bjornstad BN. 1984. Suprabasalt stratigraphy with and adjacent to the reference repository location. SD-BWI-DP-039, Rockwell Hanford Operations, Richland, Washington.

Bjornstad BN. 1990. Geohydrology of the 218-W-5 Burial Ground, 200 West Area, Hanford Site. PNL-7336, Pacific Northwest Laboratory, Richland, Washington.

Bjornstad BN, KR Fecht, and CJ Pluhar. 2001. "Long history of Pre-Wisconsin, Ice Age cataclysmic floods: evidence from southeastern Washington State.” Journal of Geology 109:695-713.

Brindley GW and G Brown (eds.). 1980. "Crystal structures of clay minerals and their x-ray identification: Monograph 5.” Mineralogical Society, London, United Kingdom.

Brown DJ. 1960. An eolian deposit beneath 200-West Area. HW-67549, General Electric Company, Richland, Washington.

Caggiano JA. 1992. Borehole completion package for CY 1990 RCRA wells at the single-shell tanks. WHC-SD-EN-DP-041, Westinghouse Hanford Company, Richland, Washington.

Caggiano JA. 1993. Borehole completion package for the CY 1991 and CY 1992 RCRA wells at singleshell tanks. WHC-SD-EN-DP-042, Westinghouse Hanford Company, Richland, Washington. 
Connelly MP, BH Ford, and JV Borghese. 1992. Hydrogeologic model for the 200 West groundwater area. WHC-SD-EN-T-014, Westinghouse Hanford Company, Richland Washington.

DOE. 1988. Consultation draft site characterization plan. DOE/RW-0164, 9 volumes, U.S. Department of Energy, Richland, Washington.

DOE. 1993. 200 West groundwater aggregate area management study report. DOE/RL-92-16, Rev. 0, U.S. Department of Energy, Richland Operations Office, Richland, Washington.

DOE. 1996. Vadose zone characterization project at the Hanford tank farms, SX Tank Farm report. Final Draft, U.S. Department of Energy, Richland, Washington.

DOE/RL. 1994. Hanford Site background: Part 1, soil background for nonradioactive analytes.

DOE/RL-92-24, U.S. Department of Energy, Richland Operations Office, Richland, Washington, 2 volumes.

DOE/RL. 1999. Phase 1 RCRA facility investigation/corrective measures study work plan for the SST Waste Management Areas. DOE/ RL-99-36, Rev. 0, U.S. Department of Energy, Richland Operations Office, Richland, Washington.

EPA. 2000. Test methods for evaluating solid waste, physical/chemical methods. EPA publication SW-846, online version http://www.epa.gov/epaoswer/hazwaste/test/sw846.htm.

Fecht KR, KA Lindsey, DG Horton, GV Last, and SP Reidel. 1999. An atlas of clastic injection dikes of the Pasco Basin and vicinity. BHI-01103, Rev. 0, Bechtel Hanford Inc., Richland, Washington.

Fecht KR and WH Price. 1977. Granulometric Data 241-SX Tank Farm Monitoring Well Sediments. RHO-LD-18. Rockwell Hanford Operations, Richland, Washington.

Fecht KR and DC Weekes. 1996. Geologic field inspection of the sedimentary sequence at the Environmental Restoration Disposal Facility. BHI-00230, Bechtel Hanford, Inc., Richland, Washington.

Folk RL. 1968. Petrology of Sedimentary Rocks. Hemphill’s, publisher, Austin, Texas. 170 p.

Hartman MJ, LF Morasch, and WD Webber (eds.). 2000. Hanford Site groundwater monitoring for fiscal year 1999. PNNL-13116, Pacific Northwest National Laboratory, Richland, Washington.

Horton DG and VG Johnson. 2000. Borehole data package for wells 299-W22-48, 299-W22-49, and 299-W22-50 at Single-Shell Tank Waste Management Area S-SX. PNNL-13200, Pacific Northwest National Laboratory, Richland, Washington. 
Jackson ML. 1969. Soil chemical analysis - Advanced course-2 $2^{\text {nd }}$ edition. Department of Soil Science, University of Wisconsin, Madison, Wisconsin.

Johnson V and CJ Chou. 1998. Results of Phase I groundwater quality assessment for Single-Shell Tank Waste Management Areas S-SX at the Hanford Site. PNNL-11810, Pacific Northwest National Laboratory, Richland, Washington.

Johnson VG, TE Jones, SP Reidel, and MI Wood. 1999. Subsurface conditions description for the S-SX Waste Management Area. HNF-4936, Rev. 0, Lockheed Martin Hanford Corporation, Richland, Washington.

Kaplan DI, KE Parker, and IV Kutnyakov. 1998. Radionuclide distribution coefficients for sediments collected from Borehole 299-E17-21: Final report for Subtask 1a. PNNL-11996, Pacific Northwest National Laboratory, Richland, Washington.

Khaleel R, TE Jones, AJ Knepp, FM Mann, DA Myers, PM Rogers, RJ Serne, and MI Wood. 2000. Modeling data package for S-SX field investigation report (FIR). RPP-6296, Rev. 0, CH2M HILL Hanford Group, Inc., Richland, Washington.

Last GV, BN Bjornstad, MP Bergeron, DW Wallace, DR Newcomer, JA Schramke, MA Chamness, CS Cline, SP Airhart, and JS Wilbur. 1989. Hydrogeology of the 200 Areas low-level burial grounds An interim report. PNL-6820, 2 Volumes, Pacific Northwest Laboratory, Richland, Washington.

Lewis RE, BN Bjornstad, and SS Teel. 1993. Buried megaripples at the Hanford Site, Benton County, Washington. Geological Society of America Abstracts with Programs, v. 25, no. 6, p A-67.

Lindsey KA. 1996. The Miocene to Pliocene Ringold Formation and associated deposits of the ancestral Columbia River system, south-central Washington and north-central Oregon. Open-File Report 96-8, Washington Division Geology and Earth Resources, Olympia, Washington.

Lindsey KA, SE Kos, and KD Reynolds. 2000. Vadose zone geology of Boreholes 299-W22-50 and 299-W23-19 S-SX Waste Management Area Hanford Site, south-central Washington. RPP-6149 Rev. 0, Daniel B. Stephens \& Associates, Richland, Washington.

Lindsey KA, MP Connelly, and BN Bjornstad. 1992. Geologic setting of the 200 West Area: An update. WHC-SD-EN-TI-008, Westinghouse Hanford Company, Richland, Washington.

Lindsey KA, JL Slate, GK Jaeger, KJ Swett, and RB Mercer. 1994. Geologic setting of the low-level burial grounds. WHC-SD-EN-TI-290, Westinghouse Hanford Company, Richland, Washington.

Myers CW and SM Price. 1979. Geologic studies of the Columbia Plateau -- A status report. RHO-BWI-ST-4, Rockwell Hanford Operations, Richland, Washington. 
Myers CW and SM Price (eds.). 1981. Subsurface Geology of the Cold Creek Syncline, RHO-BWI-ST-14, Rockwell Hanford Operations, Richland, Washington.

Myers DA, DL Parker, G Gee, VG Johnson, GV Last, RJ Serne, and DJ Moak. 1998. Findings of the extension of Borehole 41-09-39, 241-SX Tank Farm. HNF-2855, Lockheed Martin Hanford Company, Richland, Washington.

Newman ACD. (ed.). 1987. Chemistry of clays and clay minerals, Monograph No 6, Mineralogical Society, London, United Kingdom.

Polemio M and JD Rhoades. 1977. "Determining cation exchange capacity: A new procedure for calcareous and gypsiferous soils.” Soil Sci. Soc. Am. J. 41:524-528.

Price WH and KR Fecht. 1976. Geology of the 241-SX Tank Farm. ARH-LD-134, Atlantic Richfield Hanford Company, Richland, Washington.

Reynolds DM and RC Reynolds Jr. 1989. X-ray diffraction and the identification and analysis of clay minerals, Oxford University Press, New York.

Rhoads K, BN Bjornstad, RE Lewis, SS Teel, KJ Cantrell, RJ Serne, LH Sawyer, JL Smoot, JE Szecsody, MS Wigmosta, and SK Wurstne. 1994. Estimation of the release and migration of nickel through soils and groundwater at the Hanford Site 218-E-12B Burial Ground. PNL-9791, Pacific Northwest Laboratory, Richland, Washington.

Rhoades JD. 1982. “Cation exchange capacity.” In Methods of Soil Analysis-Part 2, Chemical and Microbiological Properties, AL Page et al. (ed.), Agronomy Monograph 9, Soil Science Society of America, Madison, Wisconsin.

Sanders R and V LeGore. 2000. Energy dispersive X-Ray fluorescence spectroscopy using BEP approach with the Kevex 770/8000 system. PNNL Operating Procedure AGG-RAL-XRF-1, Pacific Northwest National Laboratory, Richland, Washington.

Serne RJ, CW Lindenmeier, JL Conca, JA Campbell, VL LeGore, JE Amonette, KJ Cantrell, and MI Wood. 1993. Solid-waste leach characteristics and contaminant-sediment interactions. Vol. 1: Batch leach and adsorption tests and sediment characterization. PNL-8889, Pacific Northwest Laboratory, Richland, Washington.

Serne RJ, GV Last, GW Gee, HT Schaef, DC Lanigan, CW Lindenmeier, RE Clayton, VL LeGore, RD Orr, MJ O’Hara, CF Brown, DS Burke, AT Owen, IV Kutnyakov, and TC Wilson. 2002a. Characterization of vadose zone sediment, Part 3: Borehole 41-09-39 in the S-SX Waste Management Area. PNNL-13757-3, Pacific Northwest National Laboratory, Richland, Washington. 
Serne RJ, GV Last, HT Schaef, DC Lanigan, CW Lindenmeier, CC Ainsworth, RE Clayton, VL LeGore, MJ O’Hara, CF Brown, RD Orr, IV Kutnyakov, TC Wilson, KB Wagnon, BA Williams, and DS Burke. 2002b. Characterization of vadose zone sediment, Part 4: Slant borehole SX-108 in the S-SX Waste Management Area. PNNL-13757-4, Pacific Northwest National Laboratory, Richland, Washington.

Serne RJ, HT Schaef, BN Bjornstad, DC Lanigan, GW Gee, CW Lindenmeier, RE Clayton, VL LeGore, MJ O’Hara, CF Brown, RD Orr, GV Last, IV Kutnyakov, DS Burke, TC Wilson, and BA Williams. 2002c. Characterization of vadose zone sediment, Part 2: Borehole 299 W23-19 [SX -115] in the S-SX Waste Management Area. PNNL-13757-2, Pacific Northwest National Laboratory, Richland, Washington.

Slate JL. 1996. "Buried carbonate paleosols developed in Pliocene-Pleistocene deposits of the Pasco Basin, south-central Washington.” USA: Quaternary International, 34-36:191-196.

Slate JL. 2000. Nature and variability of the Plio-Pleistocene unit in the 200 West Area of the Hanford Site. BHI-01203, Rev. 0, Bechtel Hanford, Inc., Richland, Washington.

Sobczyk SM. 2000. Subsurface Interpretation of the SX Tank Farm Hanford Site, Washington Based on Gamma-Ray Logging, Nez Perce Tribe ERWM Program.

Tallman AM, KR Fecht, MC Marratt, and GV Last. 1979. Geology of the separations areas, Hanford Site, south-central Washington. RHO-ST-23, Rockwell Hanford Operations, Richland, Washington.

Weekes DC, BH Ford, and GK Jaeger. 1996. Preoperational baseline and site characterization report for the Environmental Restoration Disposal Facility. BHI-00270, Bechtel Hanford, Inc., Richland, Washington.

Wentworth CK. 1922. “A grade scale and class terms for clastic sediments.” Journal of Geology, 30:377-392. 


\section{Appendix A}

Summary of Field Geologists' Sample Descriptions for Borehole 299-W22-48 (contains 8 pages) and Borehole 299-W22-50 (contains 8 pages) 


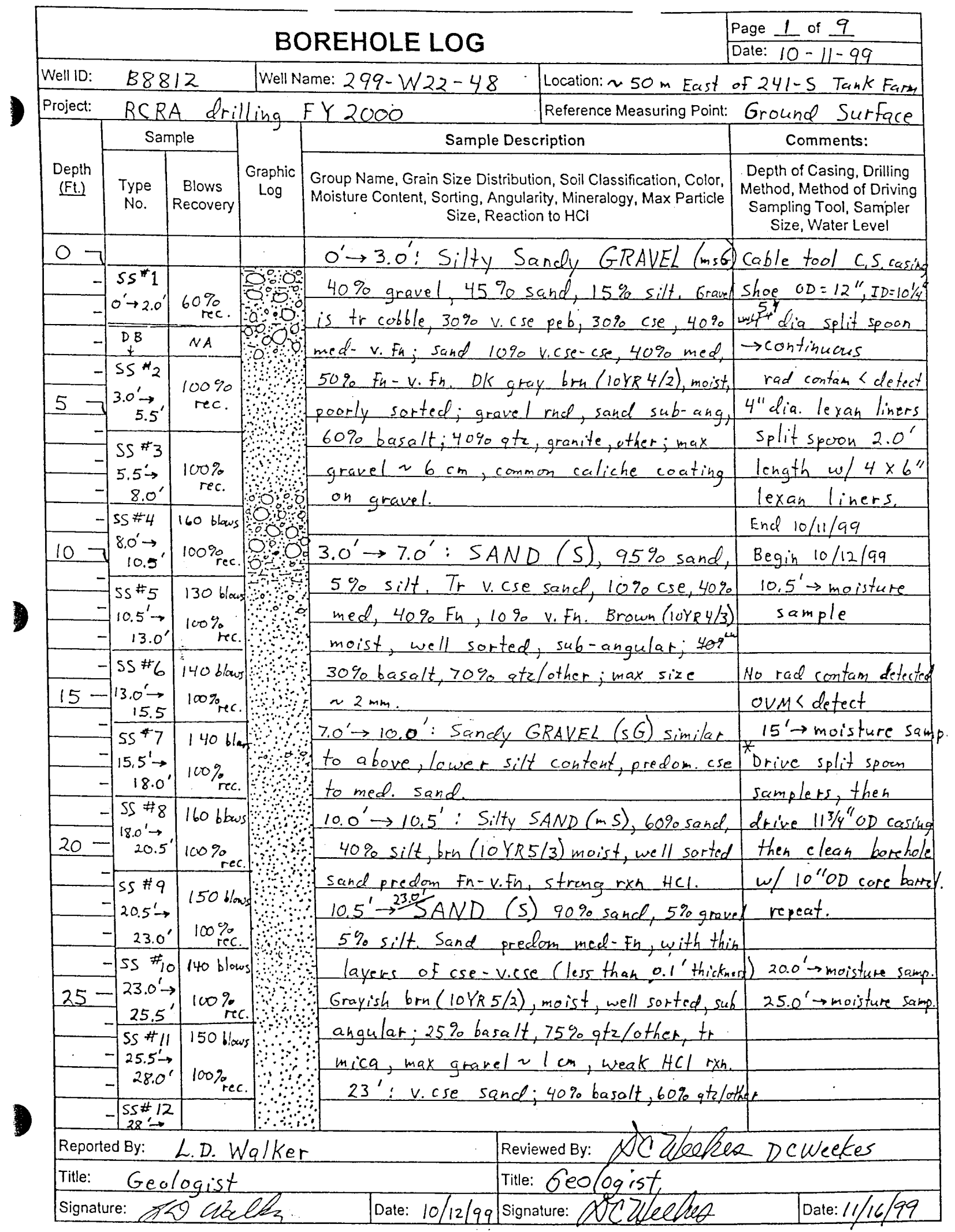




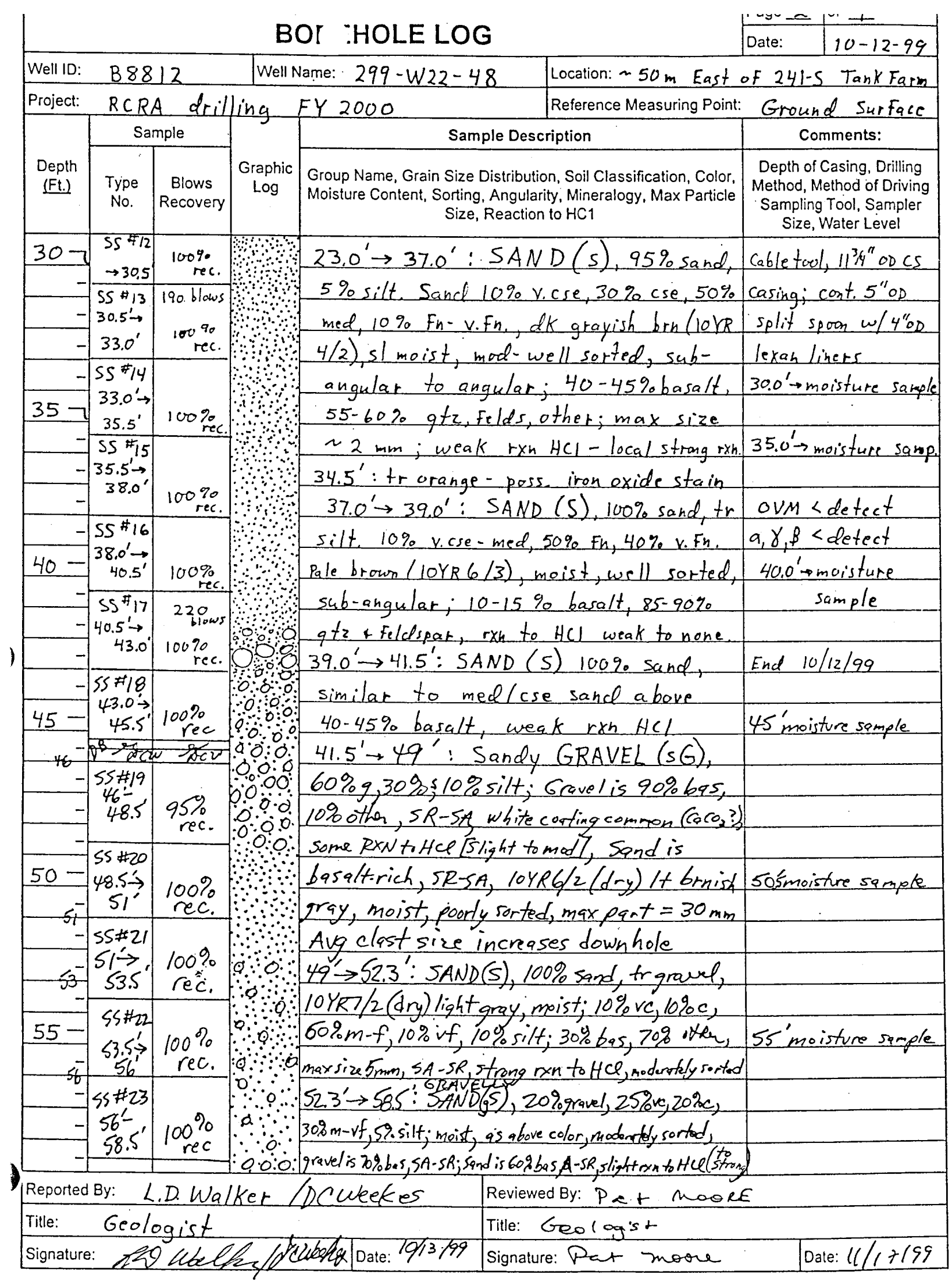

BHI.EE-183 (12/97) 


\begin{tabular}{|c|c|c|c|c|c|c|}
\hline & & & & & & Fage $\geq$ of 1 \\
\hline & & & $B C$ & OF_HOLE LOG & & Date: $\quad 10 / 13 / 99$ \\
\hline Well ID: & B88 & 12 & Well $\mathrm{N}$ & lame: $299-W 22-$ & Location: $\sim 50 \mathrm{~m}$ Eqst of & $f_{241-5}$ Tank Farm \\
\hline Project: & RCR & A Drill & $\operatorname{ling} F y$ & YZO00 & Reference Measuring Point: & Ground Surface \\
\hline & & mple & & Samp & ple Description & Comments: \\
\hline $\begin{array}{l}\text { Depth } \\
\text { (Ft.) }\end{array}$ & $\begin{array}{l}\text { Type } \\
\text { No. }\end{array}$ & $\begin{array}{c}\text { Blows } \\
\text { Recovery }\end{array}$ & $\begin{array}{l}\text { Graphic } \\
\text { Log }\end{array}$ & $\begin{array}{r}\text { Group Name, Grain Size D } \\
\text { Moisture Content, Sorting, } \\
\text { Size, }\end{array}$ & $\begin{array}{l}\text { Distribution, Soil Classification, Color, } \\
\text { Angularity, Mineralogy, Max Particle } \\
\text { Reaction to HC1 }\end{array}$ & $\begin{array}{c}\text { Depth of Casing, Drilling } \\
\text { Method, Method of Driving } \\
\text { Sampling Tool, Sampler } \\
\text { Size, Water Level }\end{array}$ \\
\hline & 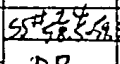 & $1002 \pi c_{1}$ & 0.00 & $58.5^{\prime} \rightarrow 61^{\prime}:$ Sandy & GRAVEL (SG) $50 \%$ graid, & $\begin{array}{l}55 \text { \$2, s stopeda at } \\
59.5 \text { due to rock }\end{array}$ \\
\hline & $D B$ & & & $50 \%$ sand, moist col & loras above, vpoorly sorted, & $\begin{array}{l}\text { moisture sample at } \\
60^{\prime} \text { from drive barrel }\end{array}$ \\
\hline & $65 \% 25$ & $100 \%$ & & gravels are bosaltrich, $S A$ & q-Rjsandis bisalt-rich, A-SRi & \\
\hline & $63^{\prime}$ & rec. & & $\bmod t$ strong $\mathrm{ren}$ to $\mathrm{HCC}$ & e, large racks@595, at leart 10cm & ' \\
\hline & $55 \$ 26$ & & & $61^{\prime} \rightarrow 76^{\prime}: S A N D$ & (s) tr grav, $20 \% v c-c, 30 \%$ & i \\
\hline & $\begin{array}{l}63^{-} \\
65.5^{\prime}\end{array}$ & $\begin{array}{l}100 \% \\
\text { rec. }\end{array}$ & & $m, 40 \%$ f-if, $10 \%$ silt & I, $G$ is basaltrich, $S A-S R$; Sand $t$ & $65^{\prime}$ moisture sample \\
\hline & $4<5 \# 27$ & & & is $30 \%$ tas, $70 \%$ atr tor & the, $A-S A$, strongmontoHCl, & \\
\hline & $65.5-$ & $100 \%$ & & Maxpart $\sim 4 m$ m, str & rong rento HCe & \\
\hline & $68^{\prime}$ & rec. & & Q65'sand is mo & ostlyc-m & End of shift 10/3//99 \\
\hline & $55 * 28$ & & & $68^{\prime}$-weak $r \times n$ & $\mathrm{HCl}$ & Begin 10/14/99 \\
\hline & $\begin{array}{l}68^{\prime} \rightarrow \\
70.5^{\prime}\end{array}$ & 10090 & & & & \\
\hline & $\frac{10.5}{55 *_{29}}$ & rec. & & & & $70.0^{\prime}$ moisture sampk \\
\hline & $70.5^{\prime} \rightarrow$ & & & & & \\
\hline & $73^{\prime}$ & rec. & & & & \\
\hline & $55^{*} 30$ & & & $73.5^{\prime} \rightarrow 74.5^{\prime}:$ sane & d predom. med-Fine & \\
\hline $75^{-}$ & $\begin{array}{l}73^{\prime} \rightarrow \\
75.5^{\prime}\end{array}$ & $\begin{array}{l}100 \% \\
\text { rec. }\end{array}$ & & $15 \%$ basalt, 85 & $5 \%$ itz/otier, weak $\mathrm{HCl} r \mathrm{rm}$. & $75.0^{\prime}$ moisture sample \\
\hline & $S S{ }^{*}{ }_{31}$ & rec. & & $74.5^{\prime}$ sand CS & se-med as above. & \\
\hline & $75.5^{\prime} \rightarrow$ & & & & & \\
\hline & $78^{\prime}$ & $\begin{array}{r}10070 \\
\text { rec. }\end{array}$ & & $76^{\prime} \rightarrow 79^{\prime}: S A N$ & $D(s) ; 100 \%$ sand, tr silt. & \\
\hline & $55{ }^{*} 32$ & & & $2090 \mathrm{med}, 60 \% \mathrm{Fn}, 2$ & 209 v. Fn; pale Grown $\left(10 \gamma_{86} / 3\right)$ & $80.0^{\prime}$ moisture scimple \\
\hline $8 \overline{-}$ & $88^{\prime} \rightarrow$ & $100 \%$ & & St. moist, well sorte & ed; SA-SR;10.15\% basalt, & \\
\hline & $55_{33}^{*}$ & & $\because$ & $85-90 \%$ ate/other & $; \max$ size $\sim / \mathrm{mm}$, weak rmo Ho & \\
\hline & $80.5 \stackrel{33}{\rightarrow}$ & & & & & \\
\hline & $83^{\prime}$ & $\begin{array}{r}100 \% \\
\text { rec. } \\
\end{array}$ & औ & $79 \rightarrow 81.5^{\prime}:$ SAND & (s) med-cse sandas & \\
\hline & $55 * 34$ & & 6 & above. & & \\
\hline$-8 \overline{5}$ & $\begin{array}{l}83^{\prime} \rightarrow \\
85.5^{\prime}\end{array}$ & $100 \%$ & 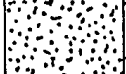 & $81.5^{\prime} \rightarrow 89.0^{\prime}: 5 A$ & NDD $(S)$; predom. Fine sand & $85.0^{\prime}$ moisture sampl \\
\hline & $\frac{85.5}{55^{\# 3}}$ & -2 & 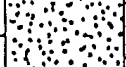 & as $76-79$ & & \\
\hline & $85.5^{\prime} \rightarrow$ & & & & & \\
\hline & $88.0^{\prime}$ & rec. & & & & \\
\hline & $5 s \# 36$ & $100 \%$ & $\because$ & & & \\
\hline Reported & $\mathrm{dBy}:$ D & CWee & $\operatorname{kes} 1$ & L.D.Walker & Reviewed By: P at moore & \\
\hline Title: & Geof & ogist & & & Title: Geologist & \\
\hline Signature & e: $\$$ & - Weete & $1 / 2$ & The Date:11/16/99 & Signature: $P_{\text {et }}$ more & Date: $11 / 17 / 99$ \\
\hline
\end{tabular}

BHI-EE-183 (12/97) 


\begin{tabular}{|c|c|c|c|c|c|c|}
\hline & \multirow{2}{*}{\multicolumn{5}{|c|}{ BO EHOLE LOG }} & Page 4 of 1 \\
\hline & & & & & & Date: $\quad 10 / 14 / 99$ \\
\hline Well ID: & \multicolumn{2}{|c|}{$B 8812$} & \multicolumn{2}{|c|}{ Well Name: $299-W / 22-48$} & \multicolumn{2}{|c|}{ Location: $50 \mathrm{~m} E$ of $241-5$ Tank Farm } \\
\hline Project: & \multicolumn{2}{|c|}{ RCRA } & illing & $F Y 2000$ & \multicolumn{2}{|c|}{ Reference Measuring Point: Ground surface } \\
\hline \multirow[b]{2}{*}{$\begin{array}{l}\text { Depth } \\
\text { (Ft.) }\end{array}$} & \multicolumn{2}{|c|}{ Sample } & \multirow[b]{2}{*}{$\begin{array}{c}\text { Graphic } \\
\text { Log }\end{array}$} & \multicolumn{2}{|c|}{ Sample Description } & Comments: \\
\hline & $\begin{array}{l}\text { Type } \\
\text { No. }\end{array}$ & $\begin{array}{c}\text { Blows } \\
\text { Recovery }\end{array}$ & & \multicolumn{2}{|c|}{$\begin{array}{c}\text { Group Name, Grain Size Distribution, Soil Classification, Color, } \\
\text { Moisture Content, Sorting, Angularity, Mineralogy, Max Particle } \\
\text { Size, Reaction to HCl }\end{array}$} & \begin{tabular}{|c|} 
Depth of Casing, Drilling \\
Method, Method of Driving \\
- Sampling Tool, Sampler \\
Size, Water Level \\
\end{tabular} \\
\hline \multirow{2}{*}{$90^{-}$} & \multirow{2}{*}{$\begin{array}{r}55^{\# 3} 36 \\
88-90.5^{\prime} \\
\end{array}$} & \multirow{2}{*}{$\begin{array}{r}10090 \\
\text { rec. }\end{array}$} & \multirow[b]{2}{*}{ : } & \multicolumn{2}{|c|}{$89.0^{\prime} \rightarrow 91.5^{\prime}:$ SAND $(s)$ med-cse as } & $8^{3 / 4} 4 O D C s$ casing \\
\hline & & & & \multicolumn{2}{|c|}{ described aboue } & $90.0^{\prime}$ moisture sample \\
\hline & \multirow{2}{*}{$\begin{array}{r}55 * 37 \\
90.5^{\prime} \rightarrow \\
93^{\prime}\end{array}$} & \multirow{2}{*}{$\begin{array}{r}100 \% \\
\text { rec. }\end{array}$} & $\because$ & \multicolumn{2}{|c|}{$91.5^{\prime} \rightarrow 92.5^{\prime}:$ slightly Silty SAND (m) S) } & \\
\hline & & & & \multicolumn{2}{|c|}{$85 \%$ sand, $15 \%$ silt, similar to Fh } & \\
\hline & \multirow{2}{*}{$\left|\begin{array}{c}55 * 38 \\
93^{\prime} \rightarrow \\
955^{\prime}\end{array}\right|$} & \multirow{3}{*}{$\begin{array}{r}100 \% \\
\text { rec. }\end{array}$} & \multirow{2}{*}{0} & \multicolumn{2}{|c|}{ sand described above. No rxu HCl } & \\
\hline & & & & \multicolumn{2}{|c|}{$92.5^{\prime} \rightarrow 93.0^{\prime}:$ SAND (S) predom. cse- } & $95.0^{\prime}$ moisture sample \\
\hline & $\frac{95.5}{55 \# 20}$ & & 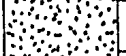 & \multicolumn{2}{|c|}{ med strong $r \times h \mathrm{HCl}$} & SS \#38 very \\
\hline & $\begin{array}{l}35.39 \\
9.5 .5^{\prime} \rightarrow\end{array}$ & $100 \%$ & 6 & $93.0^{\prime} \rightarrow 101.8^{\prime}: \mathrm{S}$ & SAND $(s)$ tr VCS-cse, & loose sand \\
\hline- & & rec. & 4 & $20 \% \mathrm{med}, 50 \%$ & Fn, 3090 V. Fn, fr silt. & \\
\hline- & $5 S \# 40$ & & & Brown $(10 Y R 5 / 3)$ & si moist, well sorted- & \\
\hline $100-$ & $98^{\prime} \rightarrow$ & $\begin{array}{r}100 \% \\
\text { rec. }\end{array}$ & $\because$ & $\bmod$ sort.; $S A-S$ & $R ; 15 \%$ basalt, $85 \%$ atz & $100^{\prime}$ moisture sample \\
\hline & $\frac{100.5}{s 5 \# 41}$ & & & other, tr mica, & $\max \operatorname{size} 2 / \mathrm{mm}, \mathrm{s} / \mathrm{rxn} \mathbb{H}$ & EL End 10/14/99 \\
\hline & $100.5^{\prime} \rightarrow$ & $100 \%$ & & $101.8^{\prime} \rightarrow 134.5^{\prime}: 5 t$ & AND (s) $100 \%$ vf $-f$ sand, $s$ & Sharp contacte 101.8' \\
\hline$x+2$ & $103^{\prime}$ & rec. & & to sitt, $10 Y_{R} 5 / 3 \mathrm{~cm}$ & oist) krown, moist, vwell & \\
\hline & $\left|\begin{array}{l}55 \# 49 \\
103 \rightarrow\end{array}\right|$ & $100 \%$ & $\because \because$ & Sorted, strongront & to HCl, thin zones of & \\
\hline $105^{-}$ & 105.54 & rec. & $\because$ & medium $-v f$ sand & & $105^{\prime}$ moisture sample \\
\hline & $\begin{array}{l}55 \# 48 \\
1055^{\prime}-\end{array}$ & $100 \%$ & $\because \because$ & & & \\
\hline & $108^{\prime}$ & rec. & $\therefore \because$ & & & \\
\hline & Sst4at & $100 \%$ & & & & \\
\hline Ho- & $110.5^{1}$ & rec & $\therefore \because$ & & & $110^{\prime}$ moisture sample \\
\hline & $55 \# 45$ & & & & & \\
\hline & $110.5 \frac{9}{113}$ & $\begin{array}{c}100 \% \\
r e c\end{array}$ & & & & \\
\hline & $\frac{113}{55 \# 46}$ & & $\because \because \because$ & & & \\
\hline & $113 \rightarrow$ & $\begin{array}{l}100 \% \\
\text { rec. }\end{array}$ & $\therefore \because \because \because \because$ & & & 115 moisture samole \\
\hline 115 & 115.5 & & $\because \because$ & & & \\
\hline & $\left|\begin{array}{ll}55 \# 4,7 \\
115.5^{\prime} \rightarrow\end{array}\right|$ & $100 \%$ & 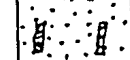 & & & Possible clastic dikelet \\
\hline & $118^{\prime}$ & rec. & $\because \because \because \because$ & & & (2) 116.5 !' I'verticle chyey \\
\hline & $\mid \begin{array}{l}55 \neq \# 48 \\
118^{\prime} \rightarrow 20.5^{\prime}\end{array}$ & $100 \%$ rec & $c \because \because \because \because$ & & & sitt(6rown \\
\hline Reportec & d By: $\quad L$ & D.D. Wa & alker & - Dcweekes & Reviewed By: Pat Moore & \\
\hline Title: & Geolc & ogist & & & Geologist & \\
\hline Signatur & & Otek & $M_{3}$ & Eubeled Date: $10 / 14 / 99$ & Signature: Pat moone & Date: $1 / 17129$ \\
\hline
\end{tabular}

BHI-EE-183 (12/97) 


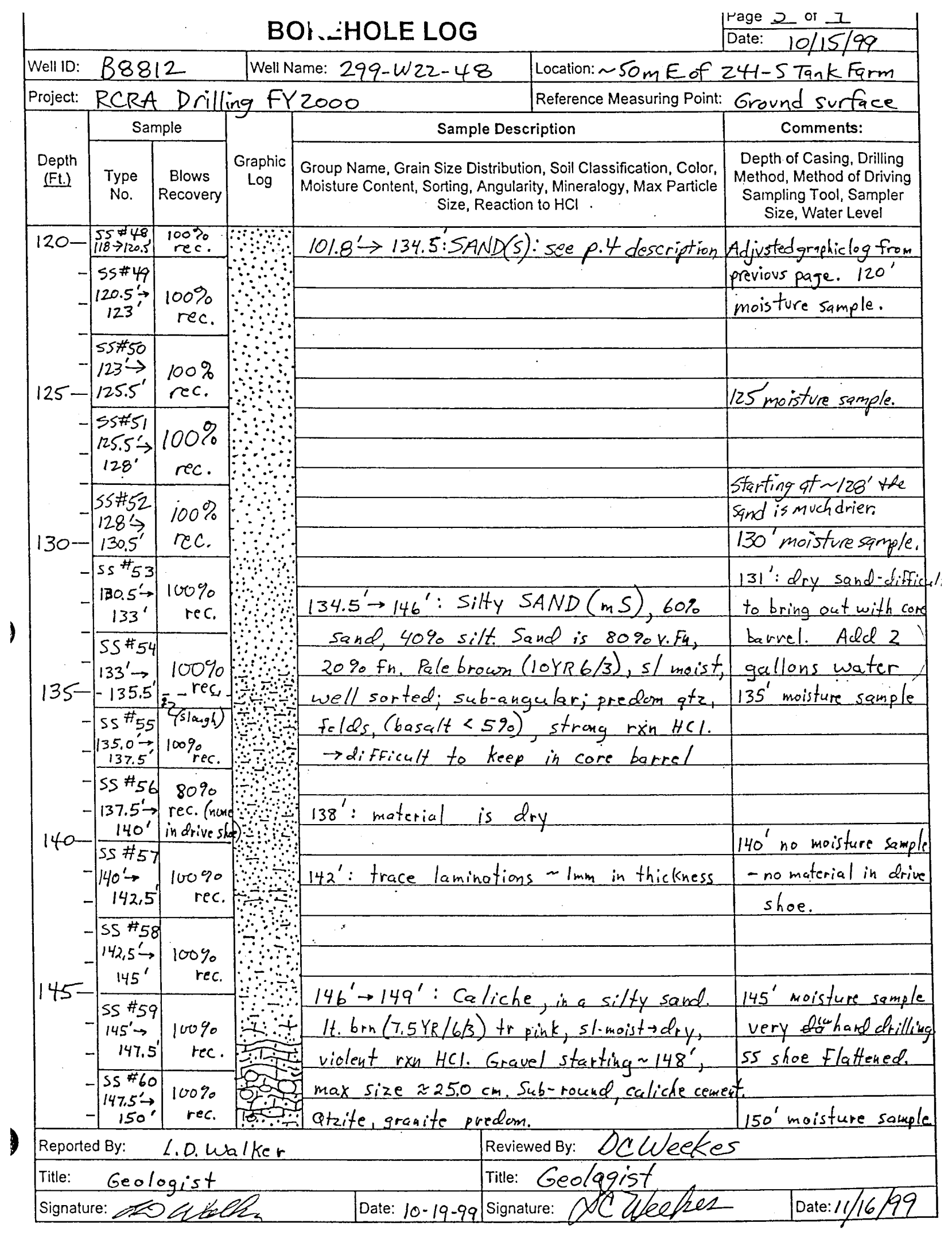

BHI-EE-183 (12/97) 


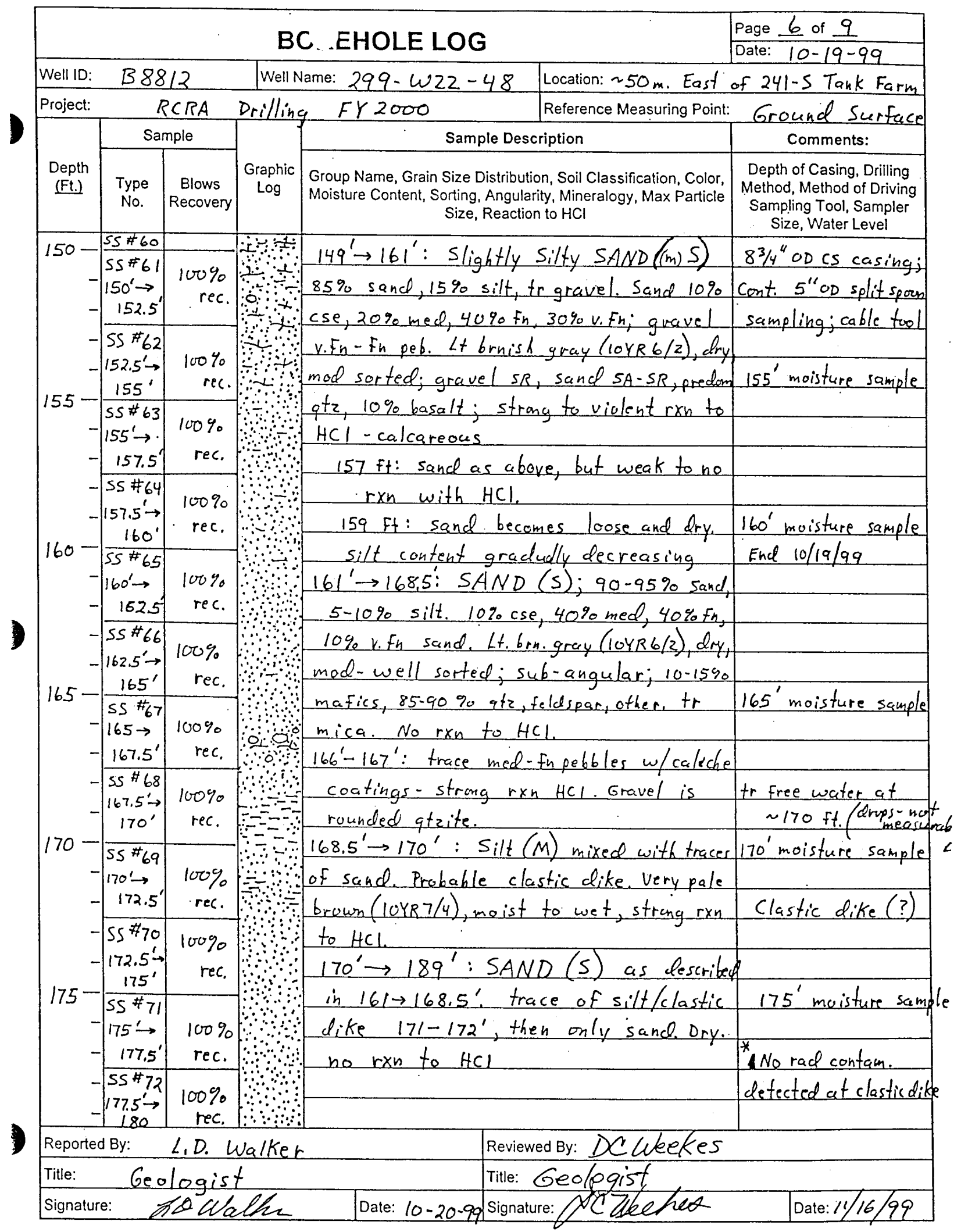

BHI-EE-183 (12/97) 


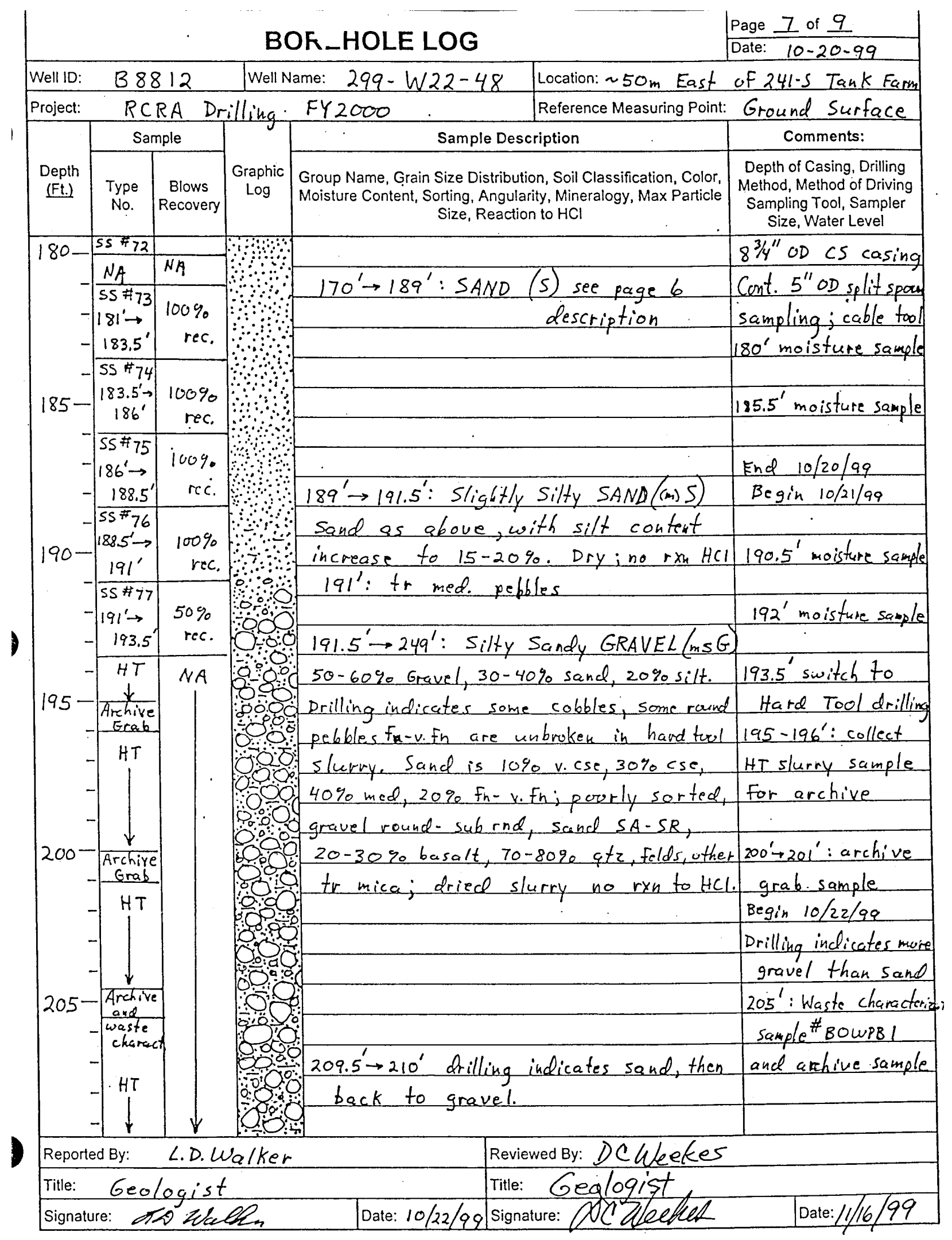

BHI-EE-183 (12/97) 


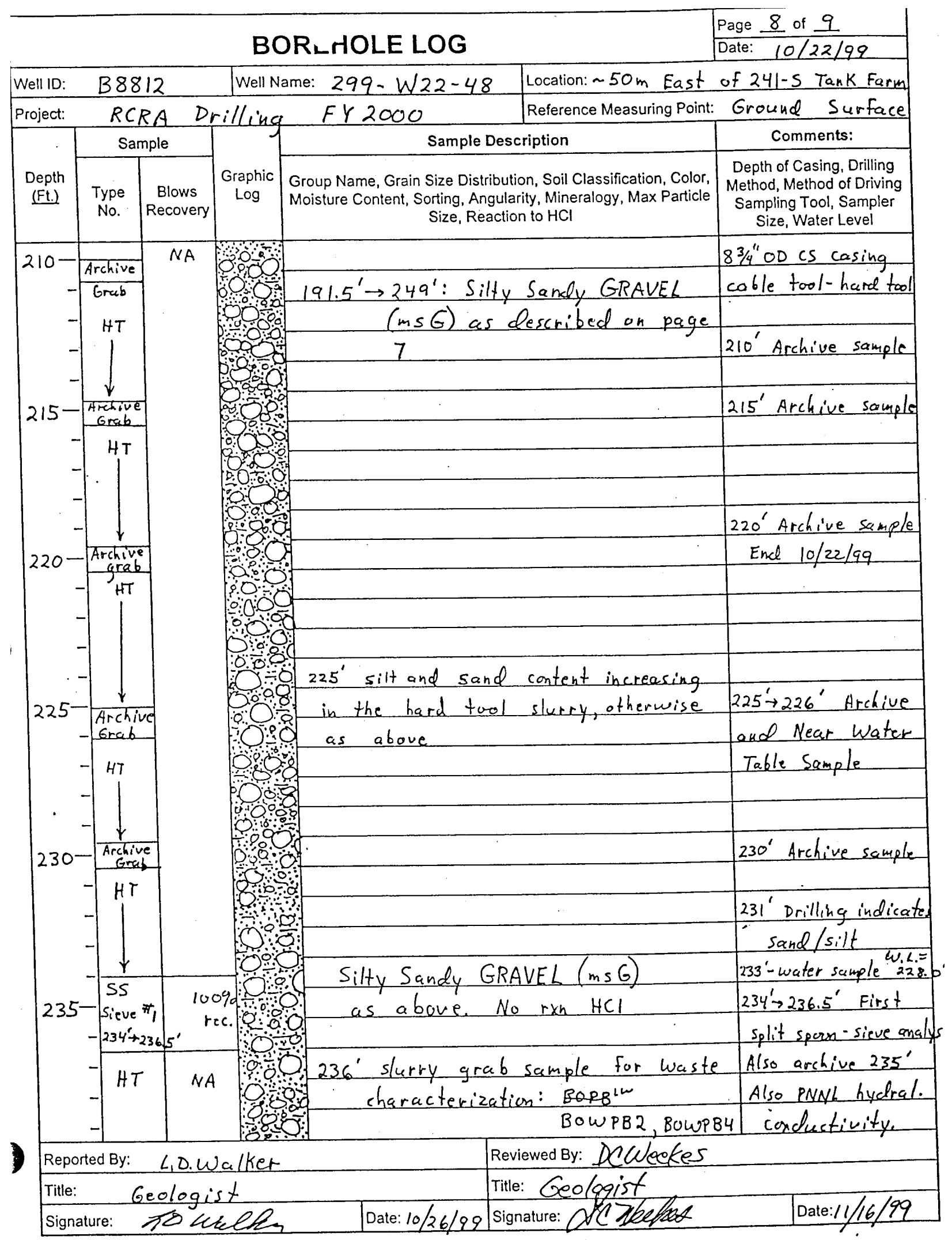

BHI-EE-183 (12/97) 


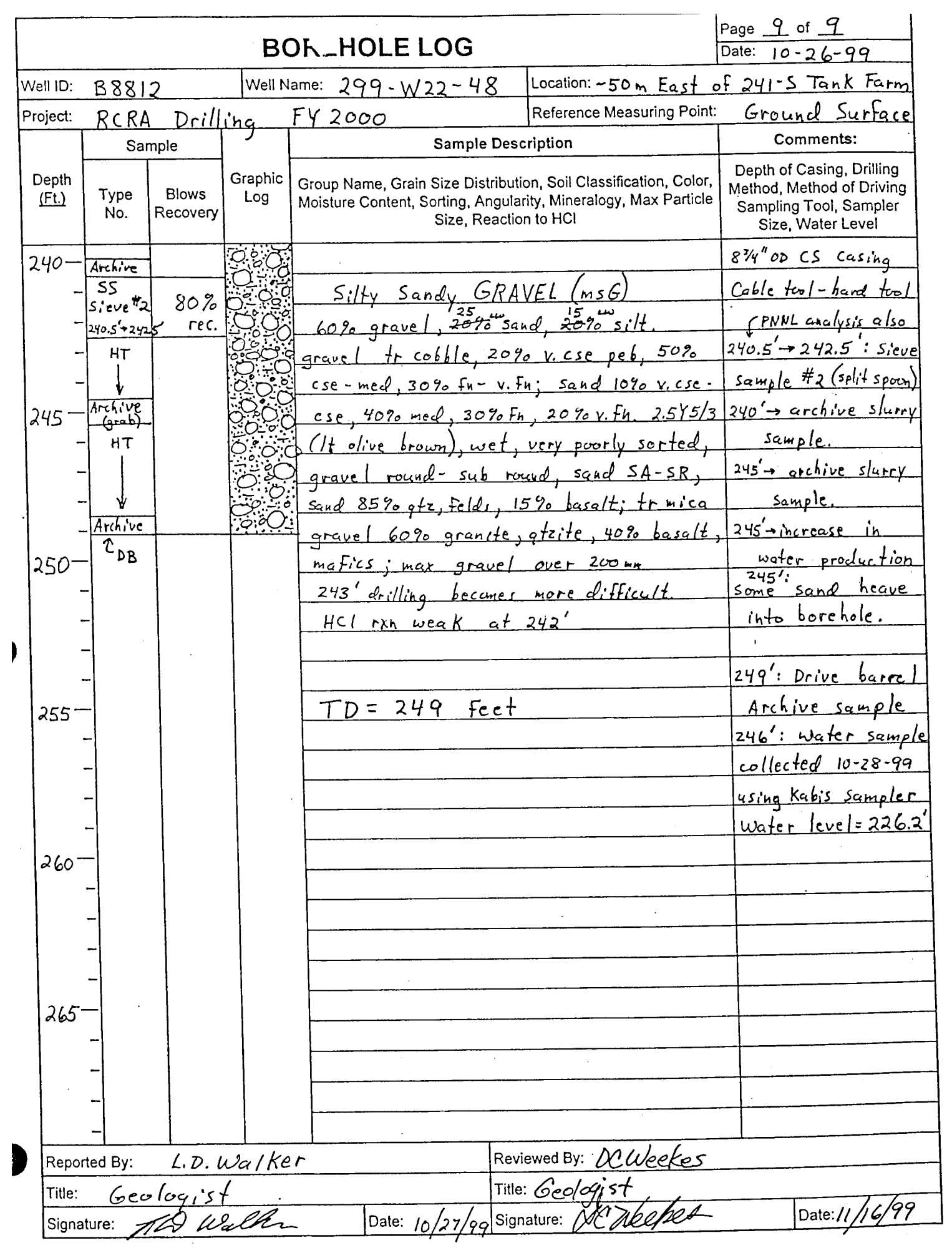

BHI-EE-183 (12/97) 


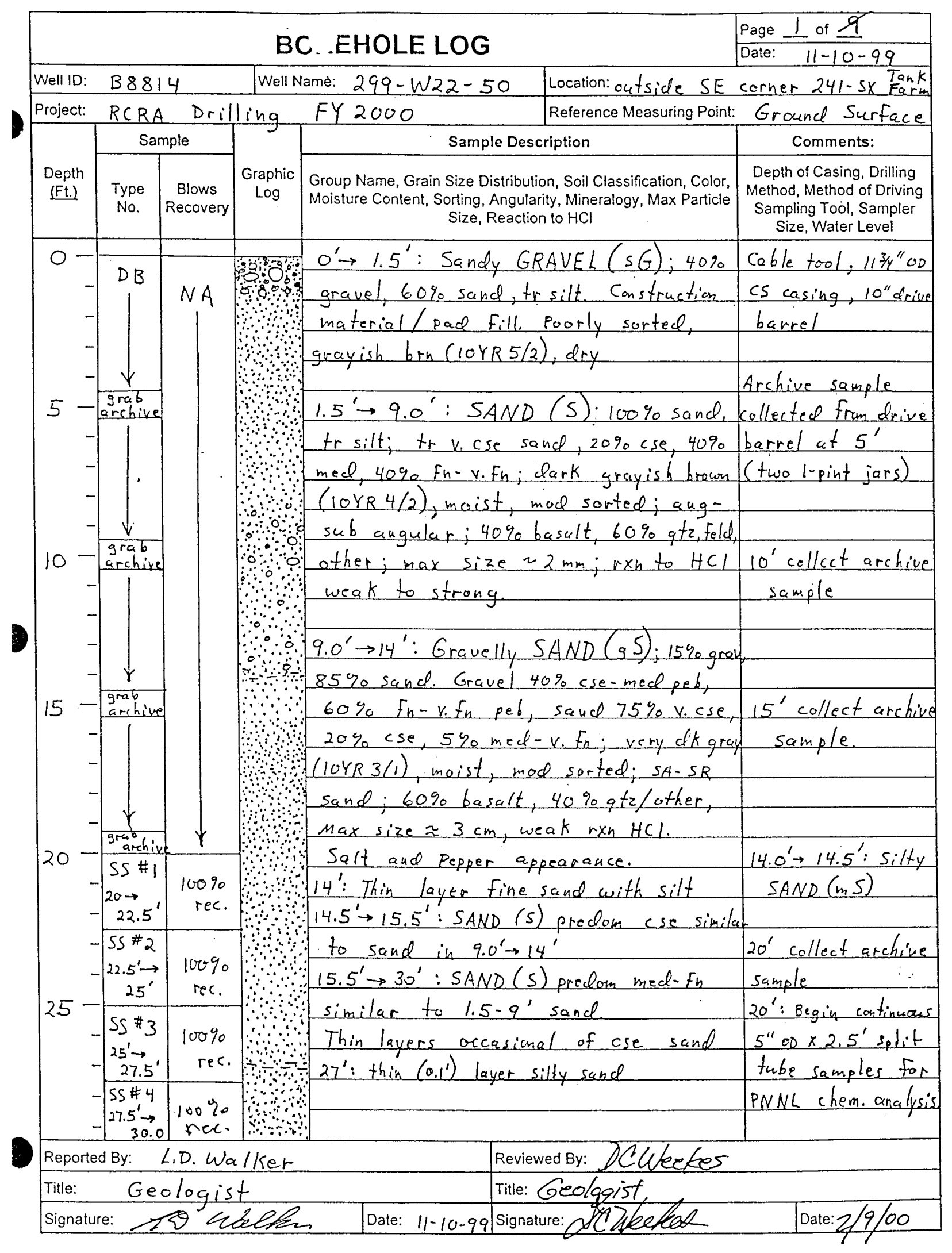

BHI-EE-183 (12/97) 


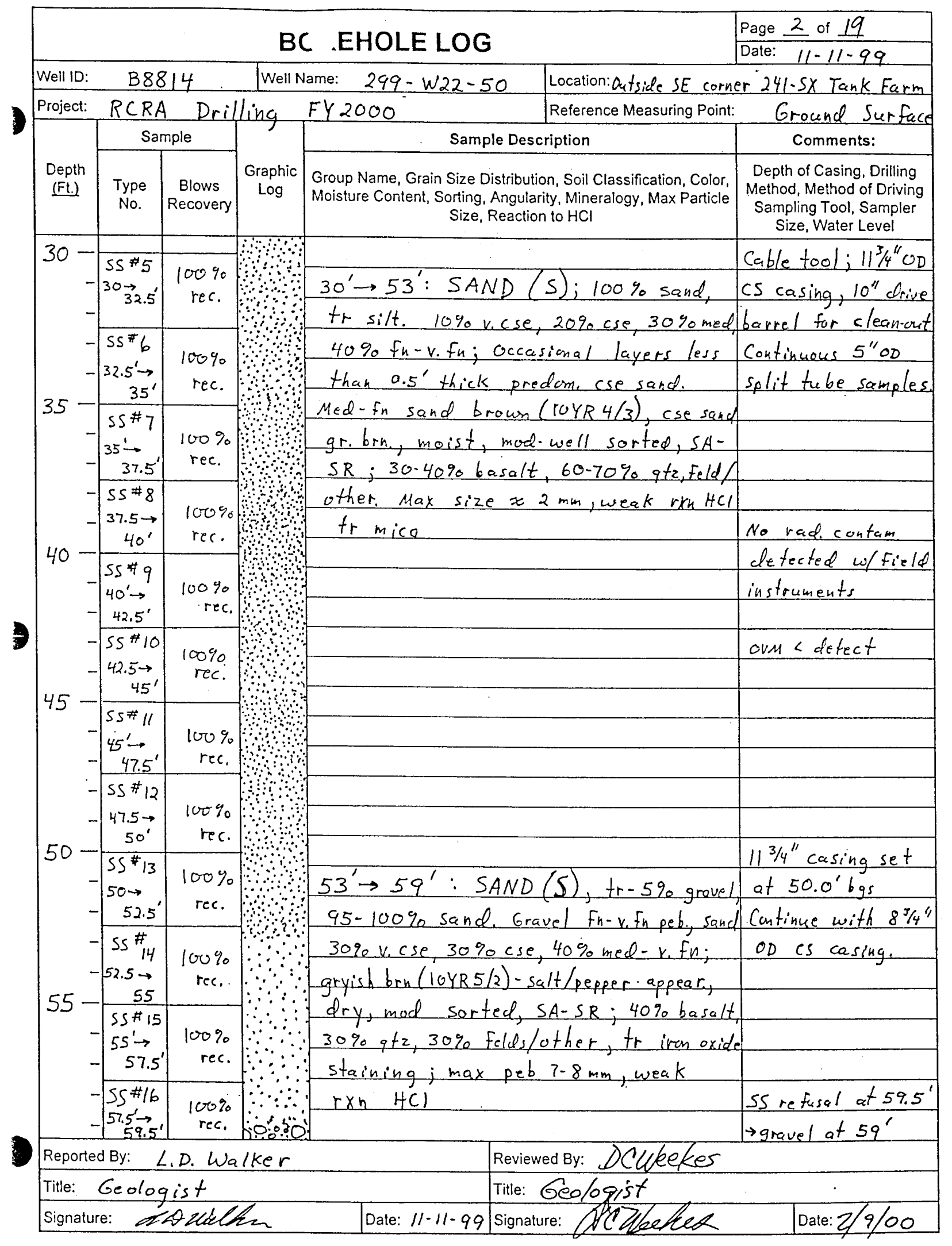




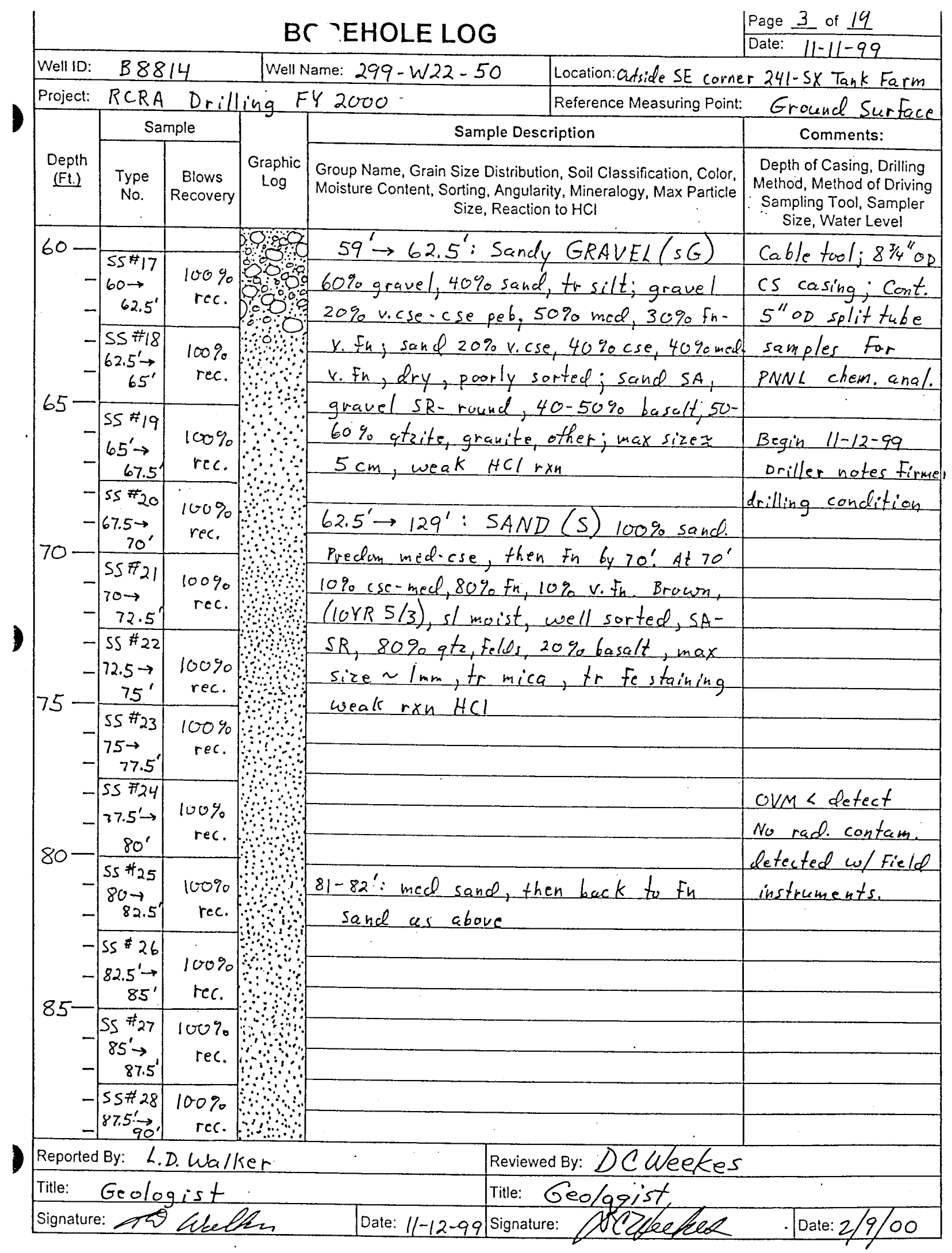

BHI-EE-183 (12/97) 


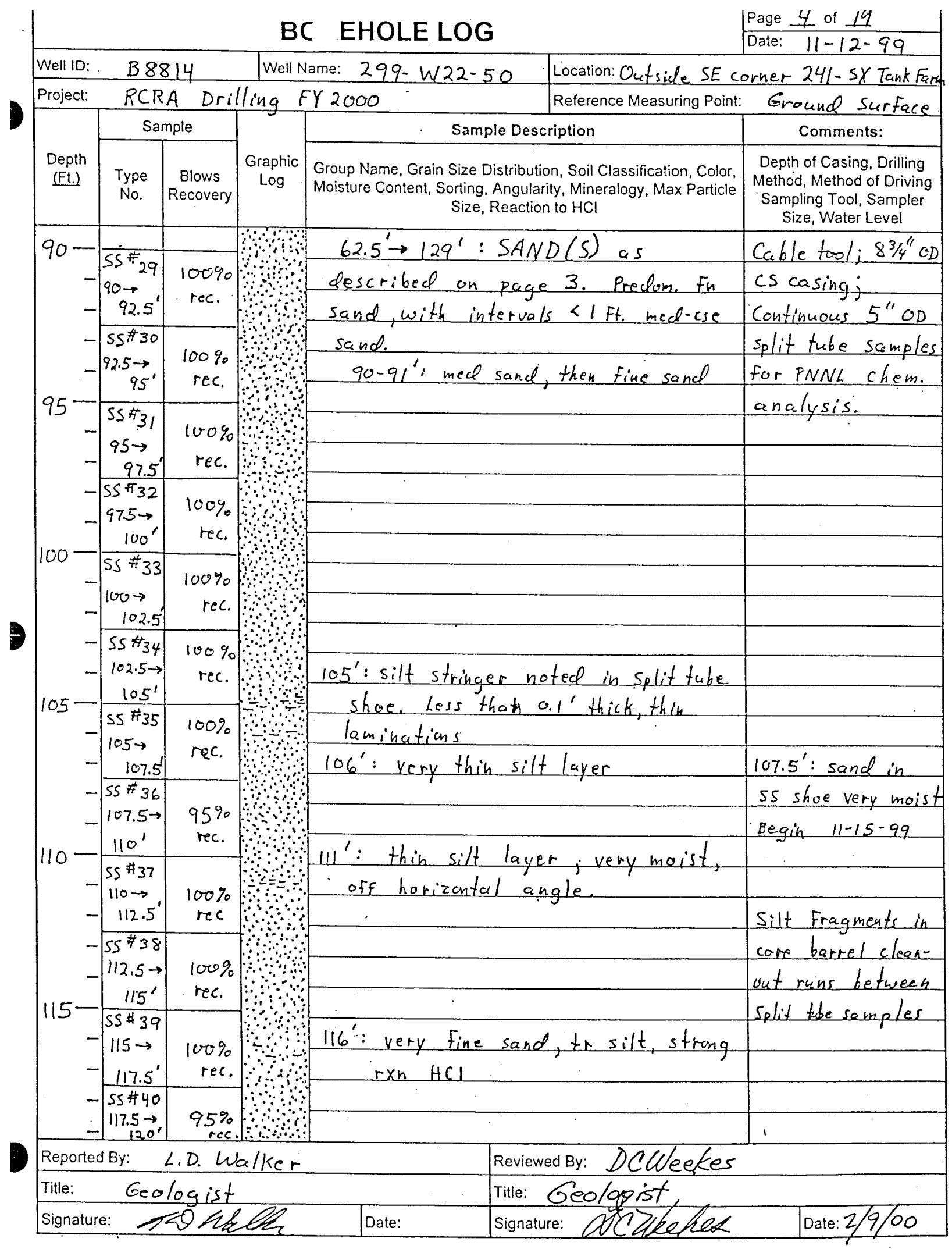

BHI-EE-183 (12/97) 


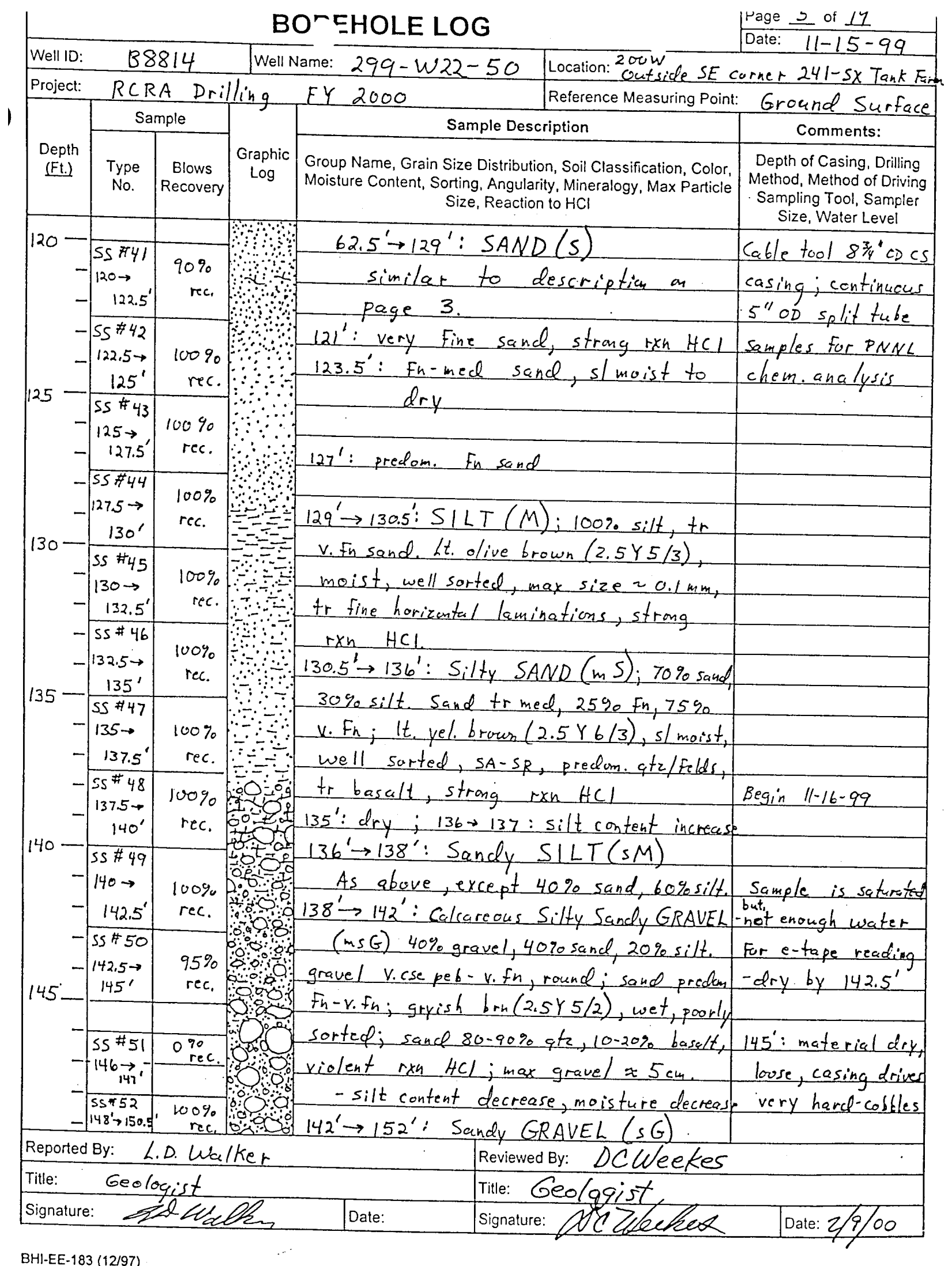




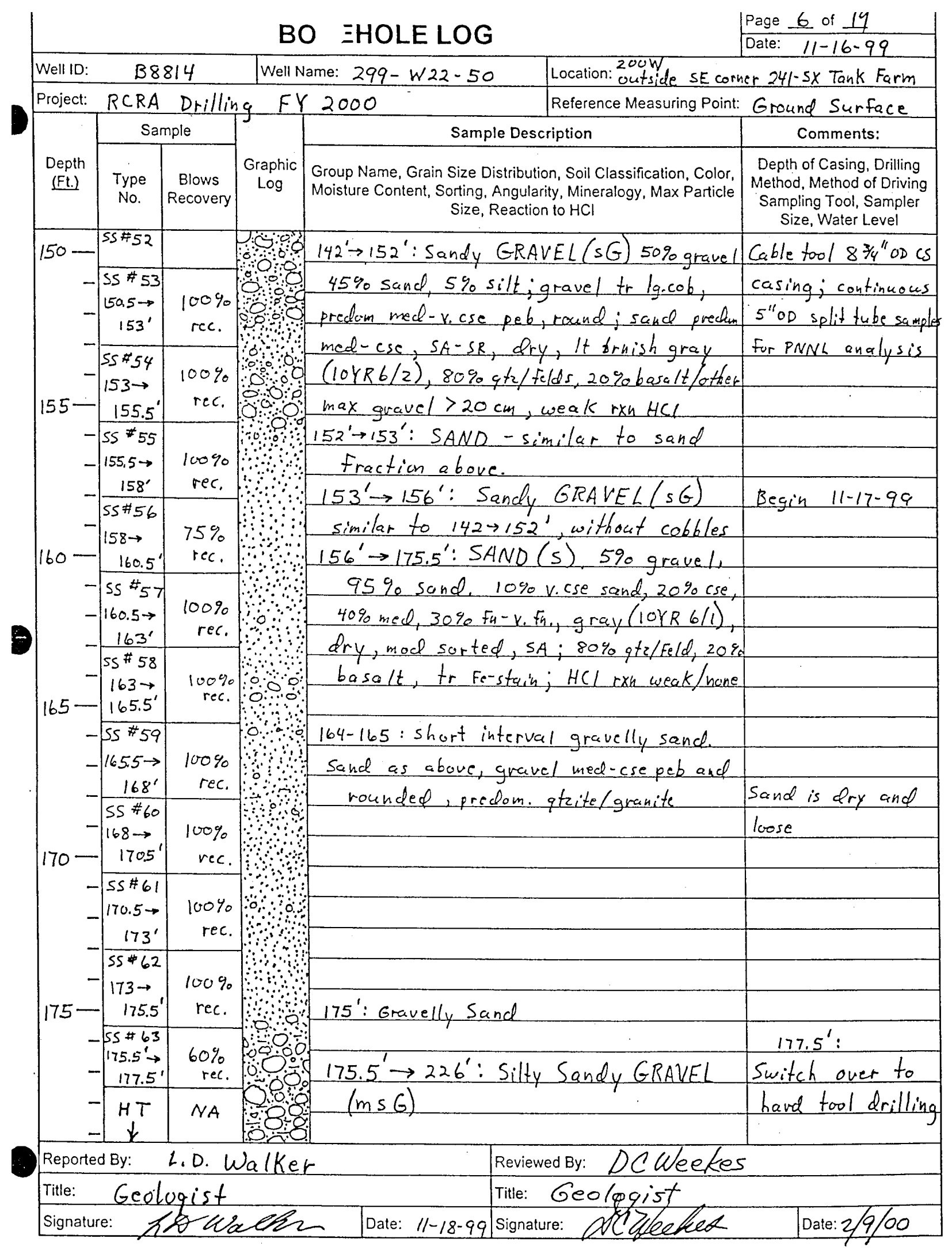

BHI-EE-183 (12/97) 


\begin{tabular}{|c|c|c|c|c|c|c|}
\hline \multirow{2}{*}{\multicolumn{6}{|c|}{ BO. .ЕHOLE LOG }} & Page 7 of 14 \\
\hline & & & & & & Date: $\quad 11-18-99$ \\
\hline Well ID: & \multicolumn{2}{|c|}{ B 8814} & \multicolumn{2}{|c|}{ Well Name: $299-W / 22-50$} & \multicolumn{2}{|c|}{ Location: $200 \mathrm{~W}$ outside SE corner 241-SX Tank Farm } \\
\hline Project: & $R C R$ & & \multicolumn{2}{|c|}{ Drilling FY 2000} & Reference Measuring Point: & Ground Surface \\
\hline \multirow[b]{2}{*}{$\begin{array}{l}\text { Depth } \\
\text { (Ft.) }\end{array}$} & \multicolumn{2}{|c|}{ Sample } & \multirow[b]{2}{*}{$\begin{array}{c}\text { Graphic } \\
\text { Log }\end{array}$} & \multicolumn{2}{|c|}{ Sample Description } & Comments: \\
\hline & $\begin{array}{l}\text { Type } \\
\text { No. }\end{array}$ & $\begin{array}{c}\text { Blows } \\
\text { Recovery }\end{array}$ & & \multicolumn{2}{|c|}{$\begin{array}{c}\text { Group Name, Grain Size Disfribution, Soil Classification, Color, } \\
\text { Moisture Content, Sorting, Angularity, Mineralogy, Max Particle } \\
\text { Size, Reaction to } \mathrm{HCl}\end{array}$} & \begin{tabular}{|c|} 
Depth of Casing, Drilling \\
Method, Method of Driving \\
Sampling Tool, Sampler \\
Size, Water Level
\end{tabular} \\
\hline \multirow{5}{*}{$180-$} & & \multirow[t]{28}{*}{ NA } & \multirow{5}{*}{ 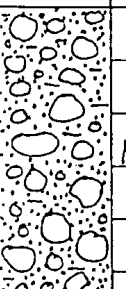 } & \multirow{2}{*}{\multicolumn{2}{|c|}{ 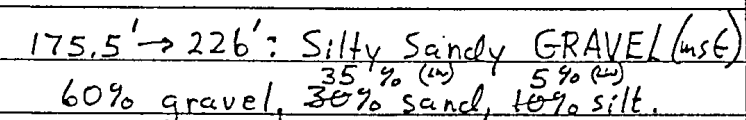 }} & Cable tool $83 / 4^{2}$ ODCS \\
\hline & \multirow{4}{*}{$\begin{array}{l}\text { Archive } \\
\text { grab }\end{array}$} & & & & & casing; hard tool \\
\hline & & & & \multicolumn{2}{|c|}{ From last split spoon: gravel 10\% cobble, } & \\
\hline & & & & \multicolumn{2}{|c|}{$40 \%$ vicse-cse peb, $30 \%$ med, $20 \% F_{h}-v$. Fh. } & 180.5': Grab sample \\
\hline & & & & \multirow{2}{*}{\multicolumn{2}{|c|}{$\begin{array}{l}\text { Sand } 20 \% \text { v.cse-cse, } 20 \% \text { med, } 40 \% \text { fh, } \\
20 \% \text { k. Fn. Lt brnish gray }(104 R 6 / 2) \text {, }\end{array}$}} & For archive \\
\hline $185-1$ & \multirow{2}{*}{$\frac{\text { Archive }}{\text {-grab }}$} & & (1) & & & \\
\hline & & & 00 & \multicolumn{2}{|c|}{ dry; poorly sorted; grave $R-S R$, saud } & $185^{\prime}$ : Archive grab \\
\hline \multirow[t]{2}{*}{-} & \multirow[t]{2}{*}{$H T$} & & 00 & \multicolumn{2}{|c|}{$\begin{array}{l}S R-S A ; 70 \% \text { gtz/granitic, } 30 \% \text { basalt, } \\
\text { Max gravel size }>10 \mathrm{~cm} \text { (infrared budrilliual }\end{array}$} & sample \\
\hline & & & $\begin{array}{ll}0 \\
0 \\
0 & 0 \\
0 & 0\end{array}$ & \multicolumn{2}{|c|}{ HCL kxh weak to hone. } & 190 ': Archive grab \\
\hline $190-$ & Grab & & 000 & & & sample and chem. \\
\hline & & & 0 & Drilling indica & tes smaller grovels - & analysis for PNNL \\
\hline- & $H T$ & & 0000 & no cobbles, bu & et perhaps cemented. & \\
\hline- & & & 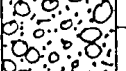 & & & $105^{\prime}$. Grob scum - - \\
\hline $195-$ & Grab & & \% & & & $\begin{array}{l}195 \text { : Grab Sample- } \\
\text { Archive and chem. }\end{array}$ \\
\hline & & & 0 & & & \\
\hline- & $H T$ & & $0 \div 000.00$ & & & \\
\hline & & & 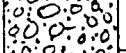 & & & \\
\hline- & & & 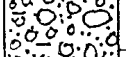 & & & 200': Grab sample - \\
\hline $200-$ & Grab & & 1000 & & & archive and \\
\hline & & & 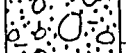 & & & Chemical analysis \\
\hline & & & 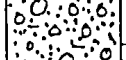 & & 1 & \\
\hline & & & $\because 0: 0$ & & & \\
\hline- & & & 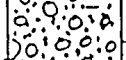 & & & $205^{\prime}:$ Grab semple - \\
\hline $205-$ & $6 r a b$ & & $\mid \begin{array}{ll}0 \\
0000\end{array}$ & & & archive and \\
\hline- & & & 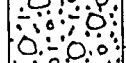 & & & chemical analysis \\
\hline- & & & $(0,0$ & $208^{\prime} \rightarrow 209^{\prime}:$ Drill ro & ate increase - then slows & Begin $11-22-99$ \\
\hline & & & 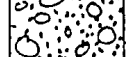 & at $209^{\prime}$ Poss & sible sand content & \\
\hline- & & & 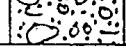 & increase $208 \rightarrow$ & $209^{\prime}$ & \\
\hline Reported & d By: & L.D. Wa & Ker & & Reviewed By: DCWeeke & \\
\hline Title: & Geol & legist & & & Title: Geologist, & \\
\hline Signature & e: 12 & abe & E & Date: $11-22-99$ & Signature: $D(1$ leafeed & Date: $2 / 9 / 00$ \\
\hline
\end{tabular}

BHI-EE-183 (12/97) 


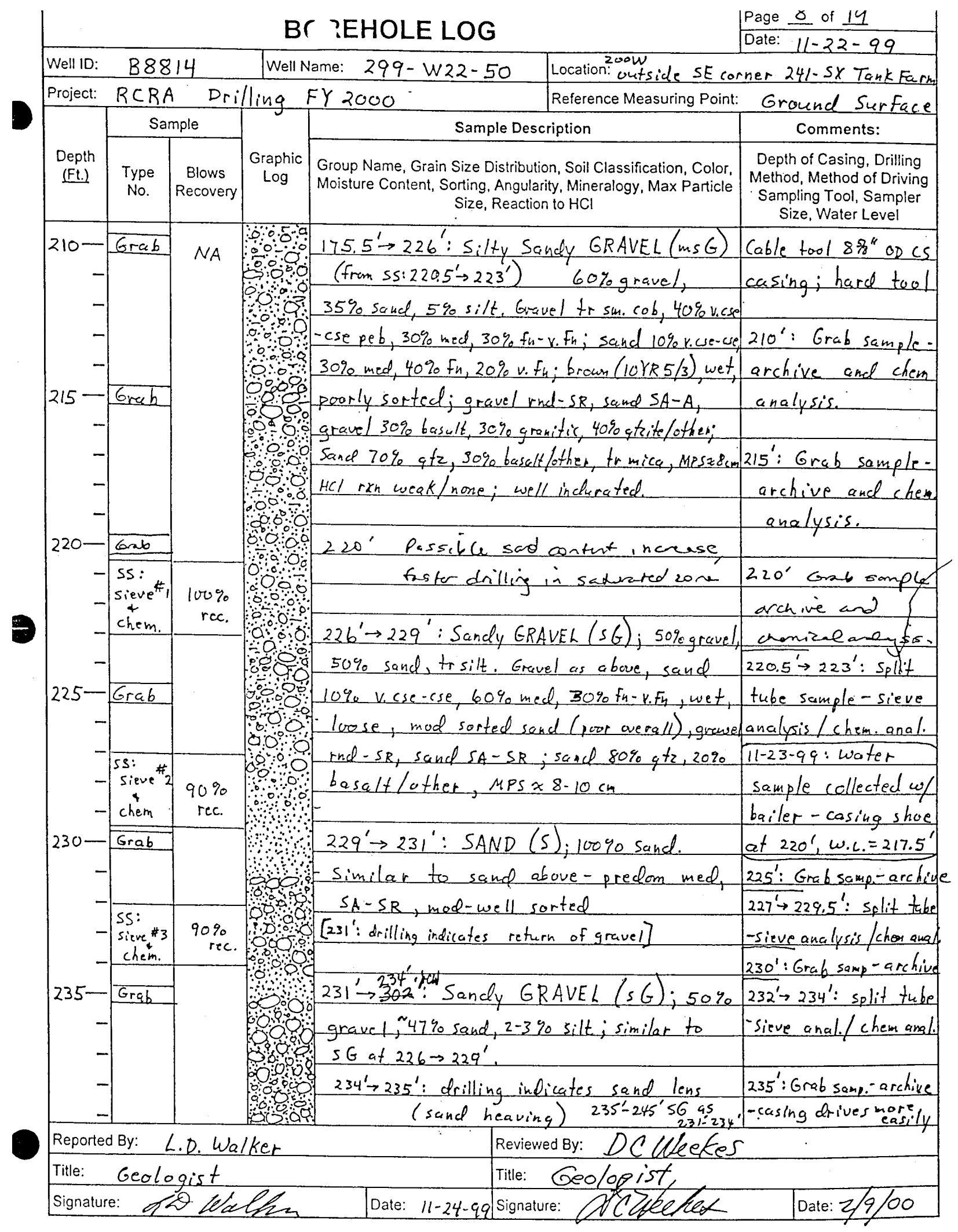




\section{Appendix B}

\section{Summary of Geologists' Core Sample Descriptions}

from Borehole 299-W22-48 


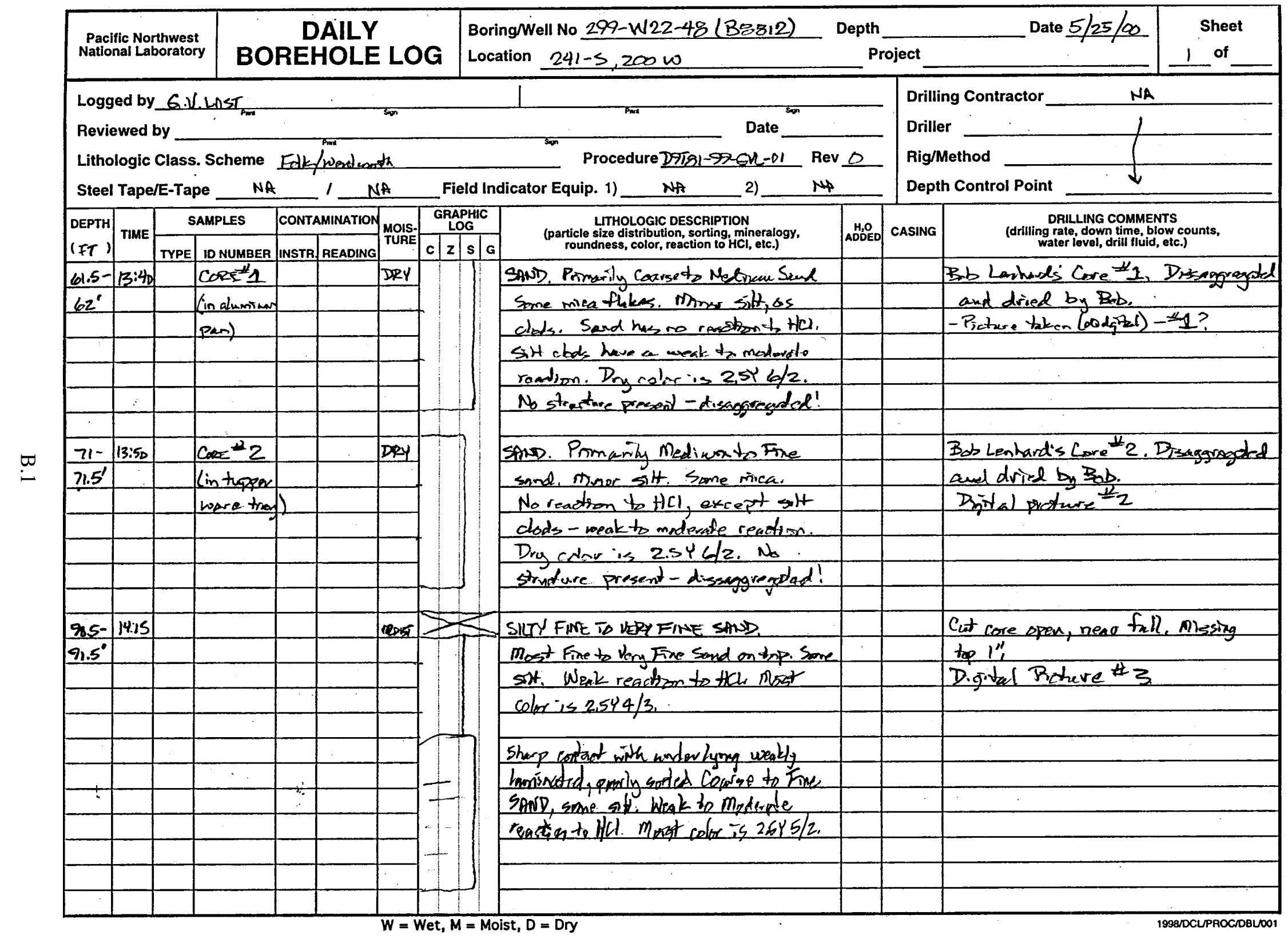




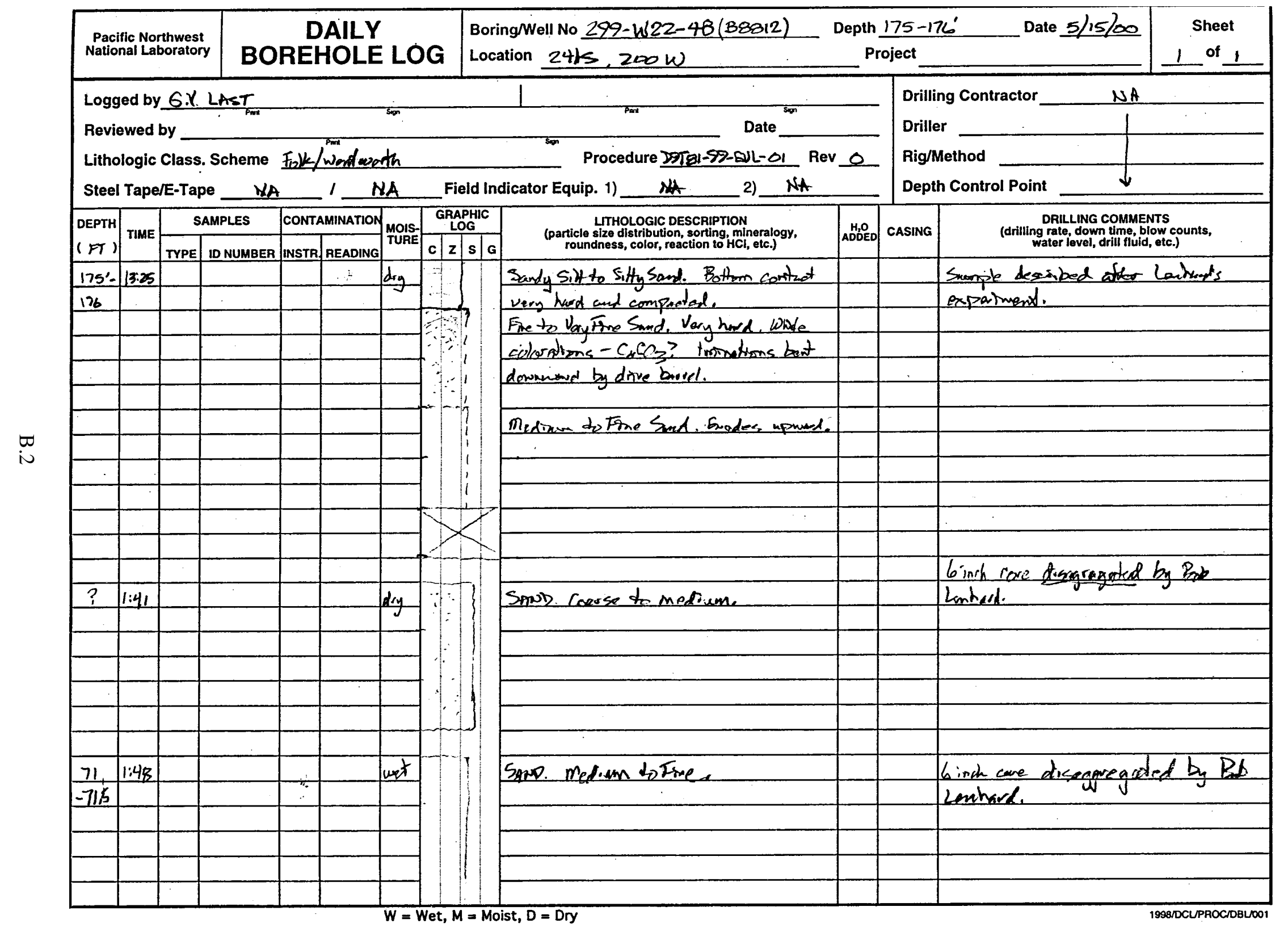




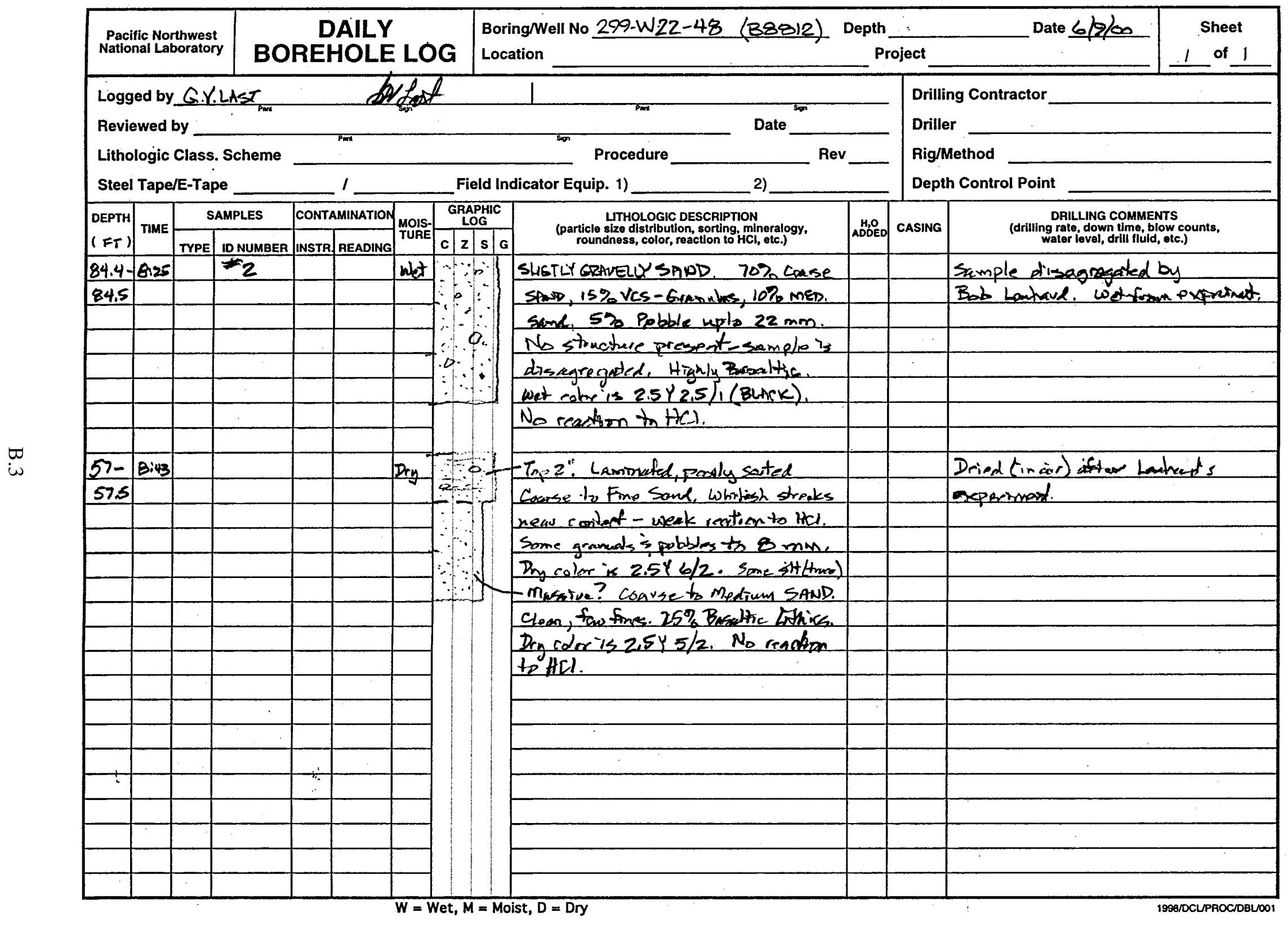




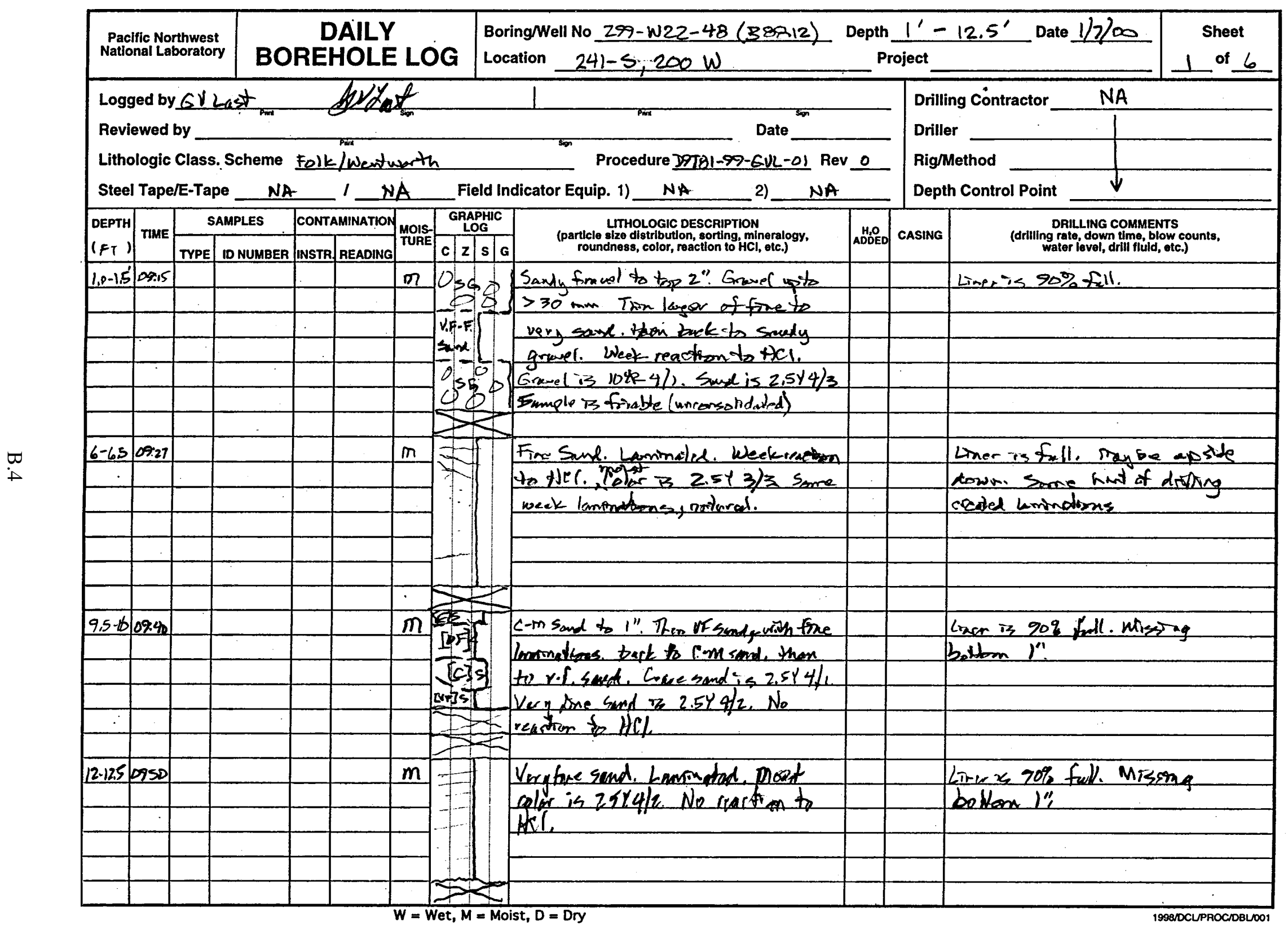




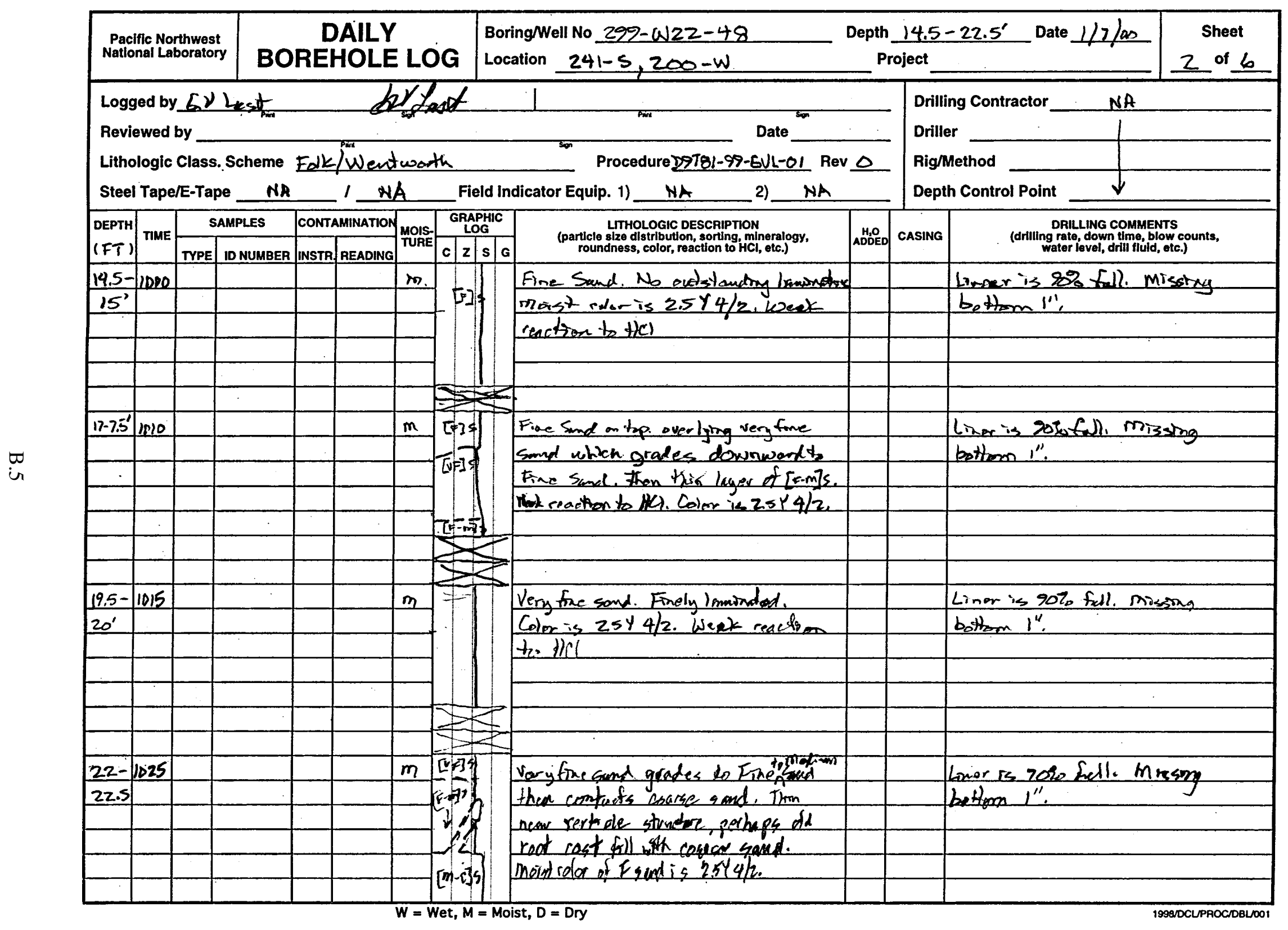




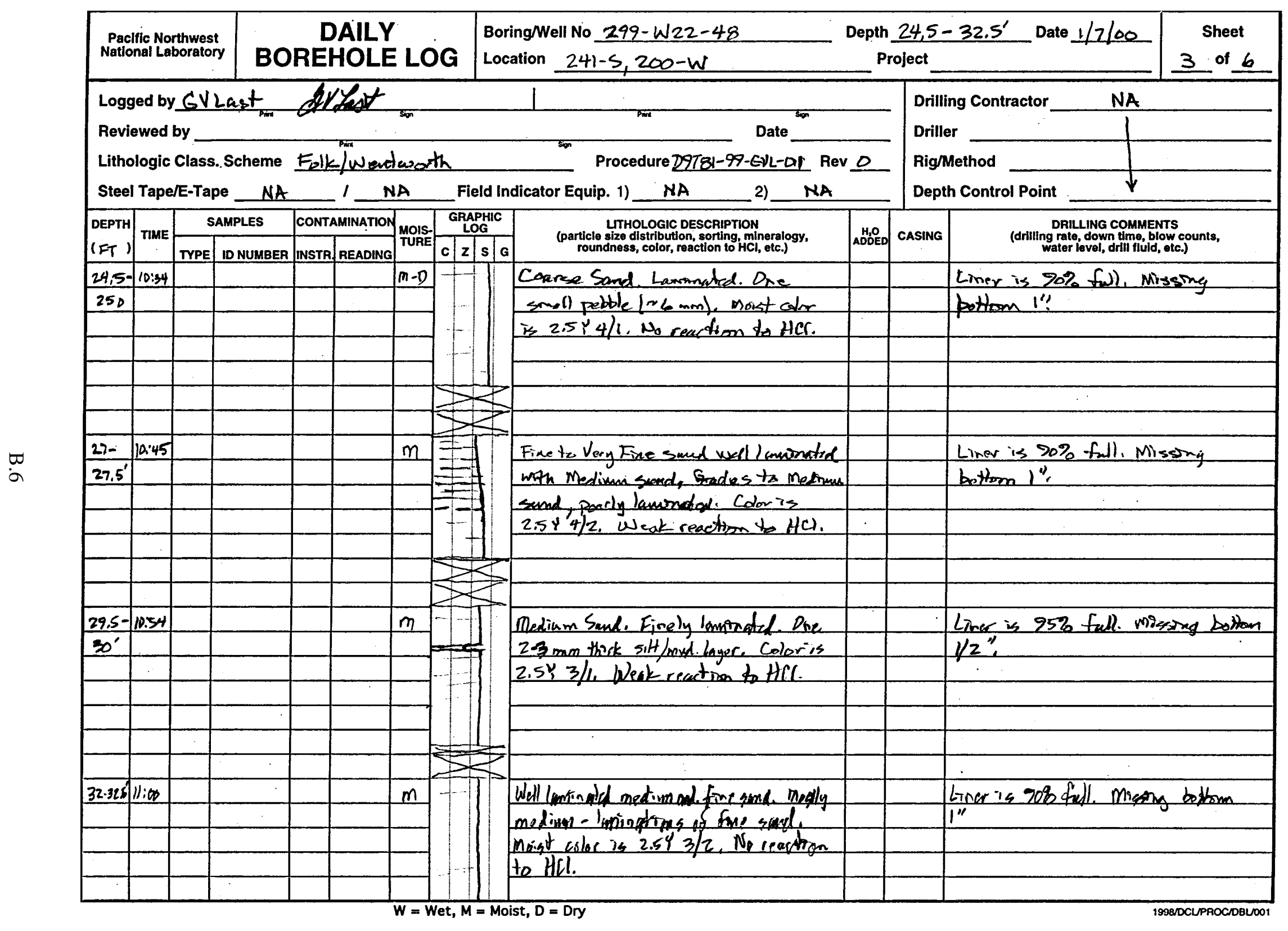




\begin{tabular}{|c|c|c|c|c|c|c|c|c|c|c|c|c|}
\hline \multicolumn{3}{|c|}{$\begin{array}{l}\text { Pacifflc Northwest } \\
\text { National Laboratory }\end{array}$} & \multicolumn{5}{|c|}{$\begin{array}{l}\text { DAILY } \\
\text { BOREHOLE LOG }\end{array}$} & $\begin{array}{l}\text { Boring/Well No } 299-w 22-48 \\
\text { Location } 241-5,200-w\end{array}$ & \multicolumn{3}{|c|}{$\begin{array}{l}\text { Depth } 34.5-45^{\prime} \text { Date } 1 / 7 / 00 \\
\text { Project }\end{array}$} & $\begin{array}{l}\text { Sheet } \\
4 \text { of } 6 \\
\end{array}$ \\
\hline $\begin{array}{l}\text { Logge } \\
\text { Reviel } \\
\text { Lithol } \\
\text { Steel }\end{array}$ & $\begin{array}{l}\text { ed by } \\
\text { wed b } \\
\text { ogic } C \\
\text { Tape/ }\end{array}$ & $\begin{array}{l}\text { GVL } \\
\text { Class. } \\
\text { E-Tape }\end{array}$ & $\begin{array}{l}\text { Last } \\
\text { Scheme } E \\
\text { N NA }\end{array}$ & Enel & $\begin{array}{l}\text { ow } \\
\text { Wentwe } \\
1 \quad N A\end{array}$ & anth & Field & 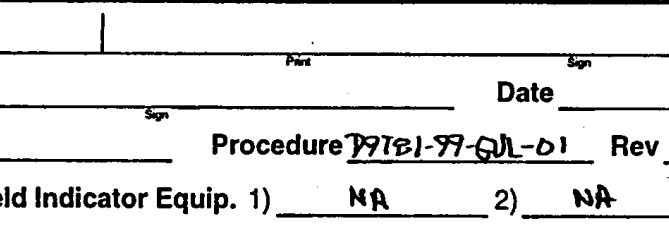 & $D$ & \multicolumn{3}{|c|}{\begin{tabular}{l|l} 
Drilling Contractor $\quad$ NA \\
Driller & \\
Rig/Method & \\
Depth Control Point $\quad \downarrow$
\end{tabular}} \\
\hline \multirow{2}{*}{ DEPTH } & \multirow{2}{*}{ TIME } & \multicolumn{2}{|c|}{ SAMPLES } & \multicolumn{2}{|c|}{ CONTAMINATION } & \multirow{2}{*}{$\begin{array}{ll}\text { MOIS- } \\
\text { TURE } \\
\end{array}$} & $\begin{array}{l}\text { GRAPHIC } \\
\text { LOG } \\
\end{array}$ & \multirow{2}{*}{ 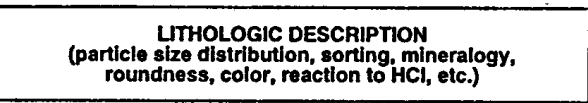 } & \multirow{2}{*}{$\begin{array}{c}\text { HoO } \\
\text { AODEO }\end{array}$} & \multirow{2}{*}{ CASING } & \multirow{2}{*}{\multicolumn{2}{|c|}{ 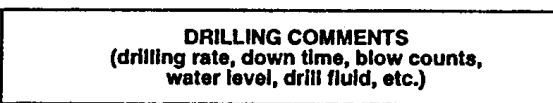 }} \\
\hline & & TYPE & ID NUMBER II & INSTR A & READING & & \begin{tabular}{l|l|l|l|l|}
$c$ & $z$ & $s$ \\
\end{tabular} & & & & & \\
\hline \multirow{3}{*}{$34.5-$} & $1: 14$ & & & & & $n-1$ & & 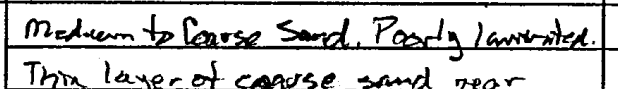 & & \multicolumn{3}{|c|}{ Liner is 920 complote. } \\
\hline & & & & & & & & \multicolumn{2}{|l|}{ bottorm, mant color is $2.5 \mathrm{Y} 4 / \mathrm{l}$. } & & & \\
\hline & & & & & & & & Ne reaction to $\mathrm{ACl}$. & & & & \\
\hline & & & & & & & & & & & & \\
\hline \multirow{2}{*}{$37-$} & $11: 15$ & & & & & $\mathbf{m}$ & \multirow{2}{*}{19} & Fing sand. looks foirly minssive. & & & LTuer is go\% complate & \\
\hline & & & & & & & & Wieud hases sitt 2 me in covolav, & & & LOCD PAIEOSSOL?) & \\
\hline & & & & & & & it) & almest resembles clasthe onter - & & & & \\
\hline & & & & & & & 1 & but to thay stans. Sitficr on & & & & \\
\hline & & & & & & & 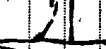 & exges of care Sone day molvials. & & & & \\
\hline & & & & & & & & morist edor is 2.5 Y 4)z. Weak renetion & & & & \\
\hline 39.5- & $11: 21$ & & & & & $m$ & Fis] & Mecium Sarl L Laninded. Tro & & & Lieer $\&>0 b$ complete & \\
\hline 40 & & & & & & & 7 & forini upuerd seavences $\sim 6^{\prime \prime}$ & & & & \\
\hline & & & & & & & 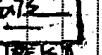 & padedges. (olor is $2,5(4) 2$, wea) & & & & \\
\hline & & & & & & & 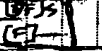 & reaction to $\mathrm{HCl}$. & & & & \\
\hline & & & & & & & $\sum$ & & & & & \\
\hline $42-$ & $\|: 28$ & & & & & $m$ & & Matro supated ganth. Clacts up to & & & Lines is ipto fedl. & \\
\hline 42.5 & & & & & & & sh & is an (cource pebale). Somitis & & & & \\
\hline & & & & & & & & Fine to veru rarse $2.645 / 1$ (most dow) & & & & \\
\hline & & & & & & & & Caltehe closts-strims readton. & & & & \\
\hline & & & & & & & & & & & & \\
\hline $44.5-$ & $11: 36$ & & & & & $m$ & & 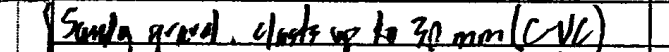 & & & Loned is apq fall. & \\
\hline $45^{\prime}$ & & & & & & & 4h & 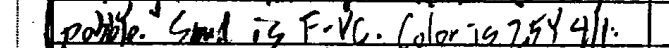 & & & & \\
\hline & & & & & & & & 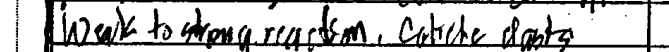 & & & & \\
\hline & & & & & & & & & & & & \\
\hline
\end{tabular}




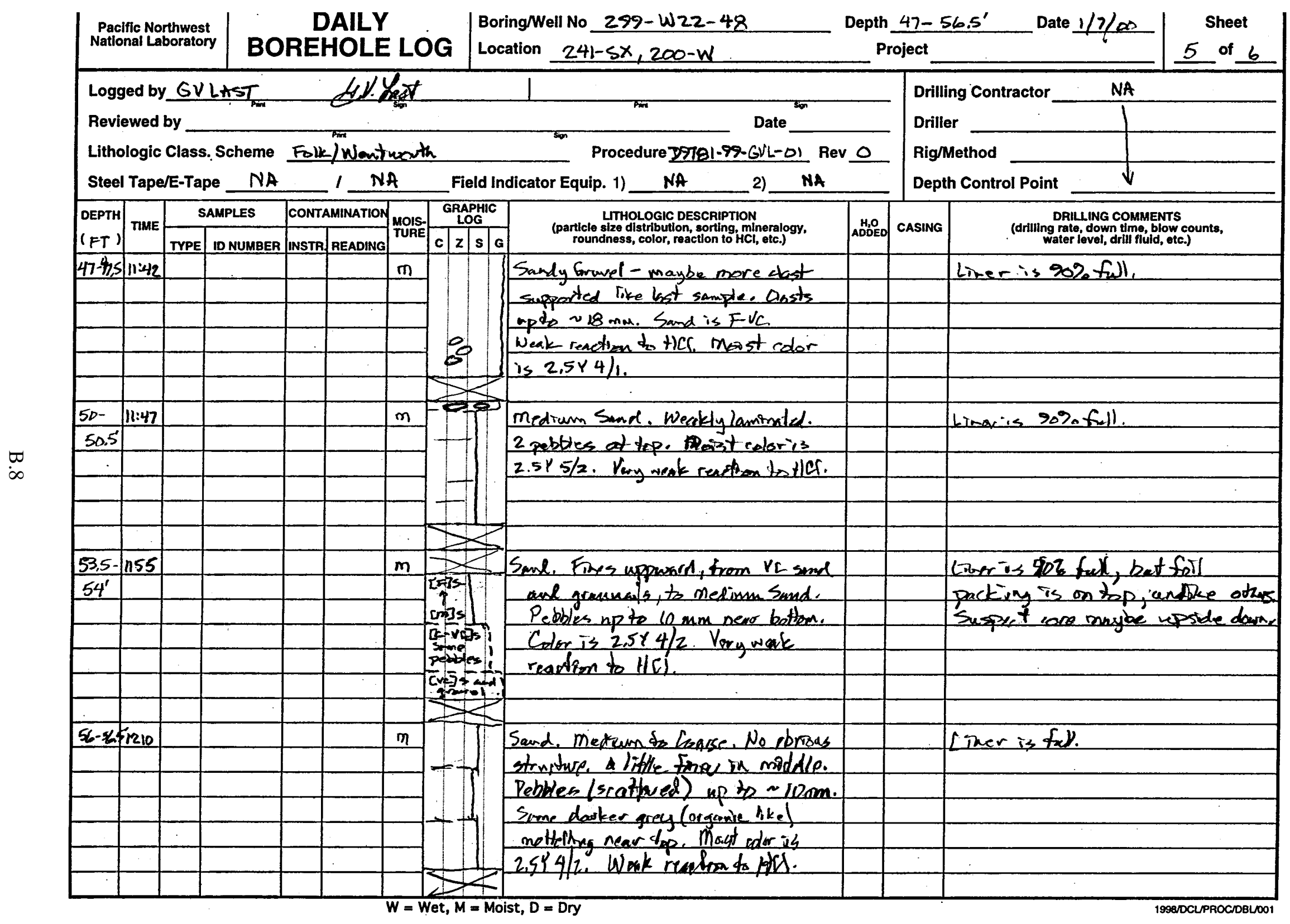




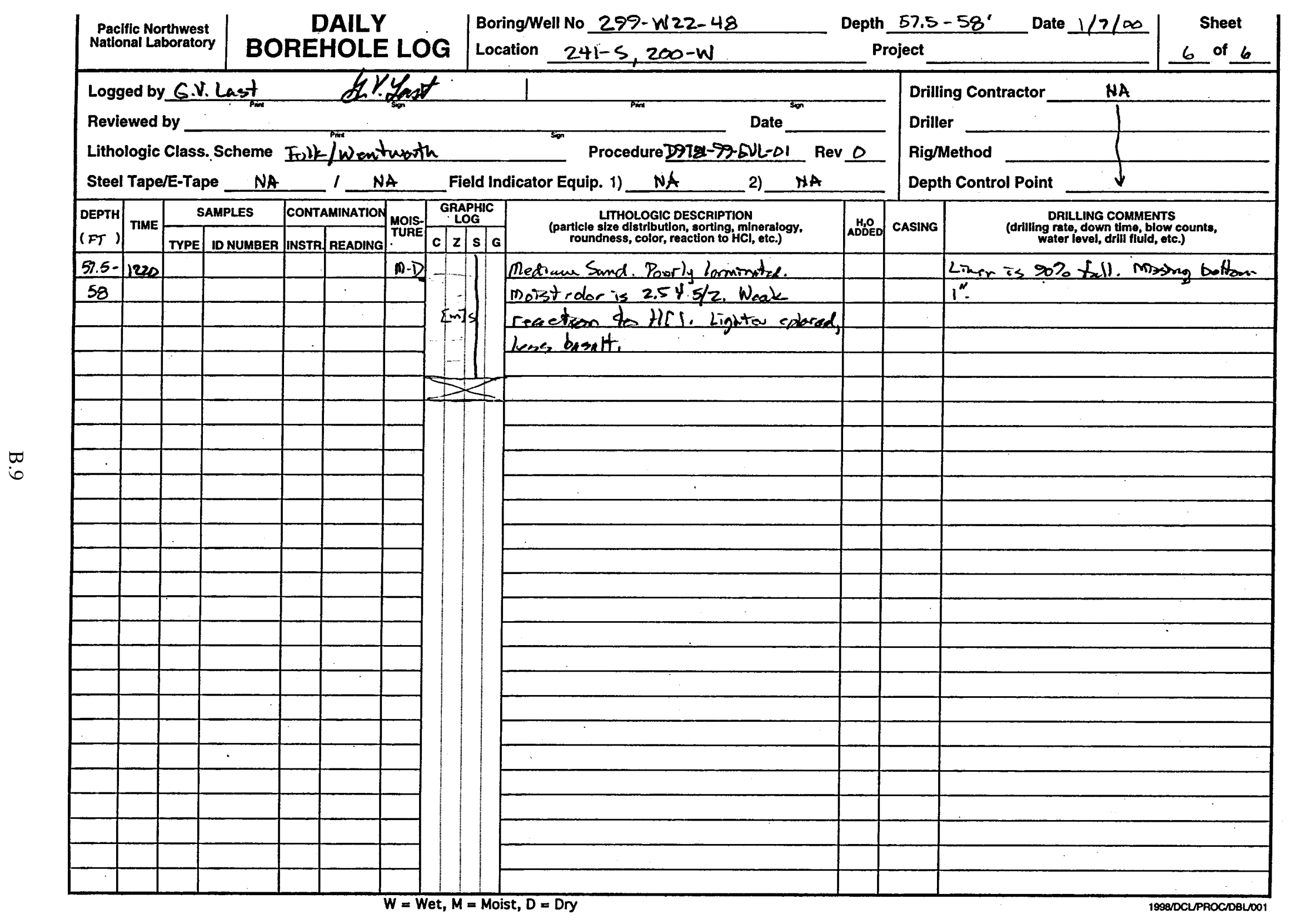




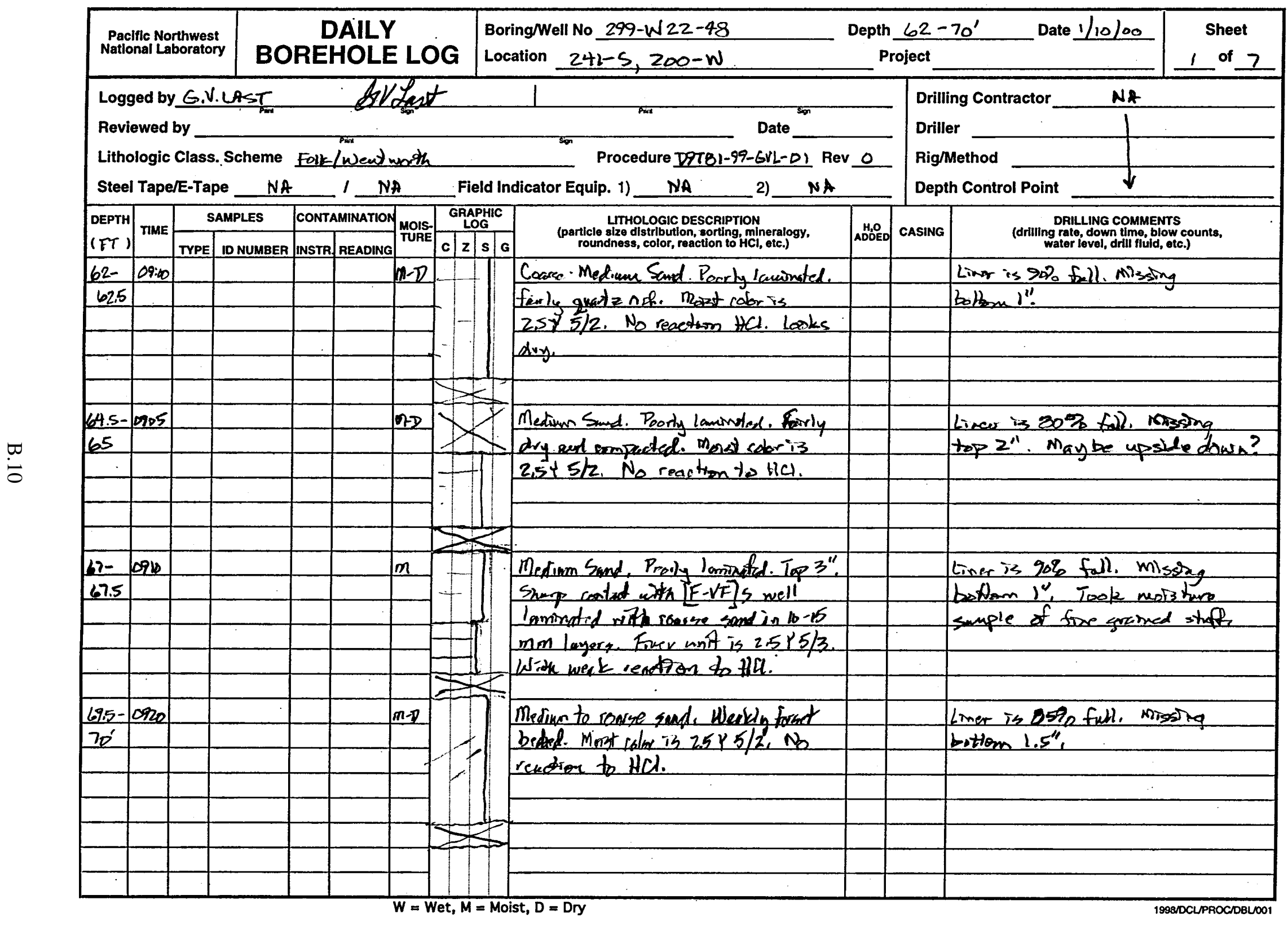




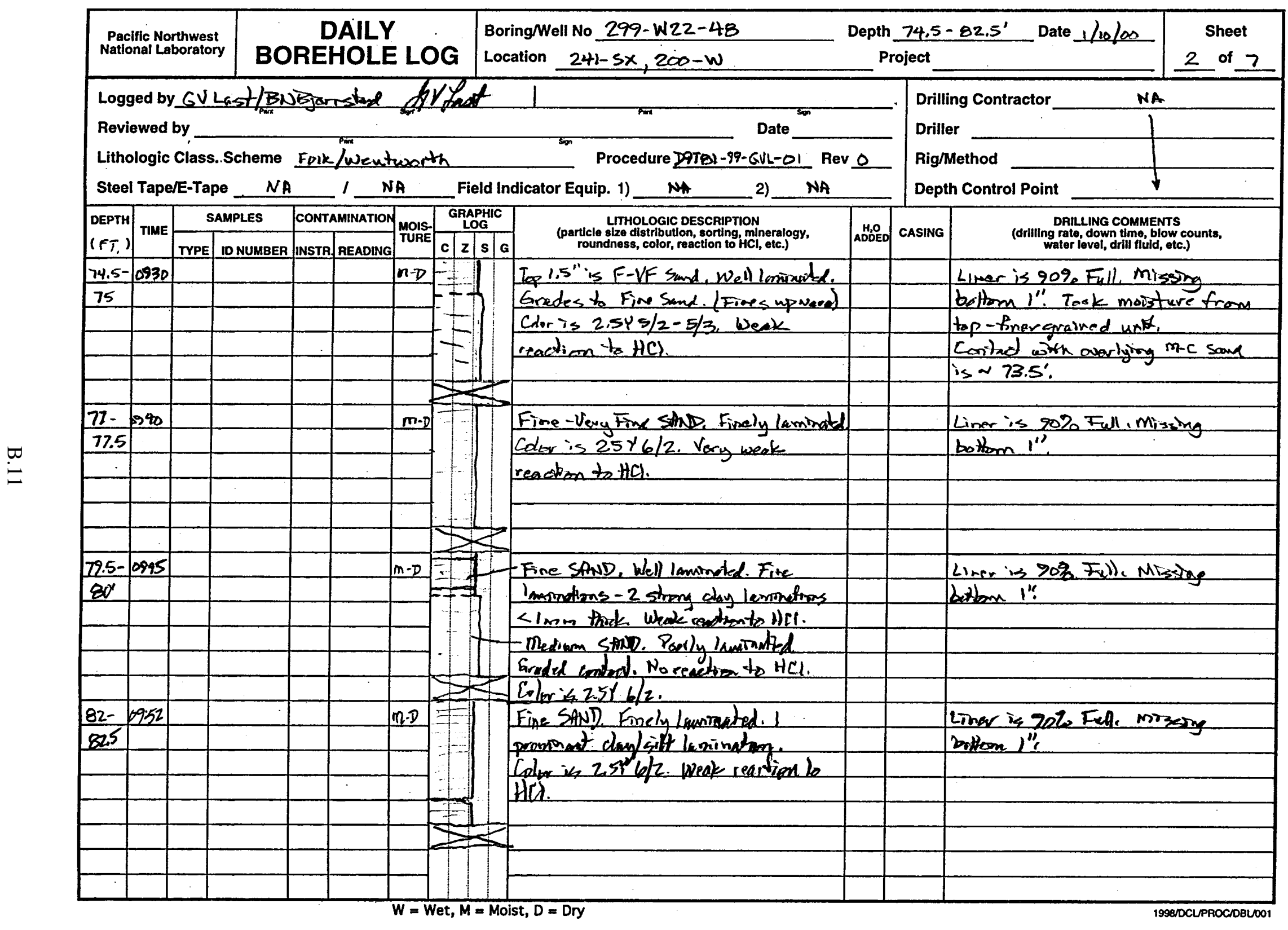




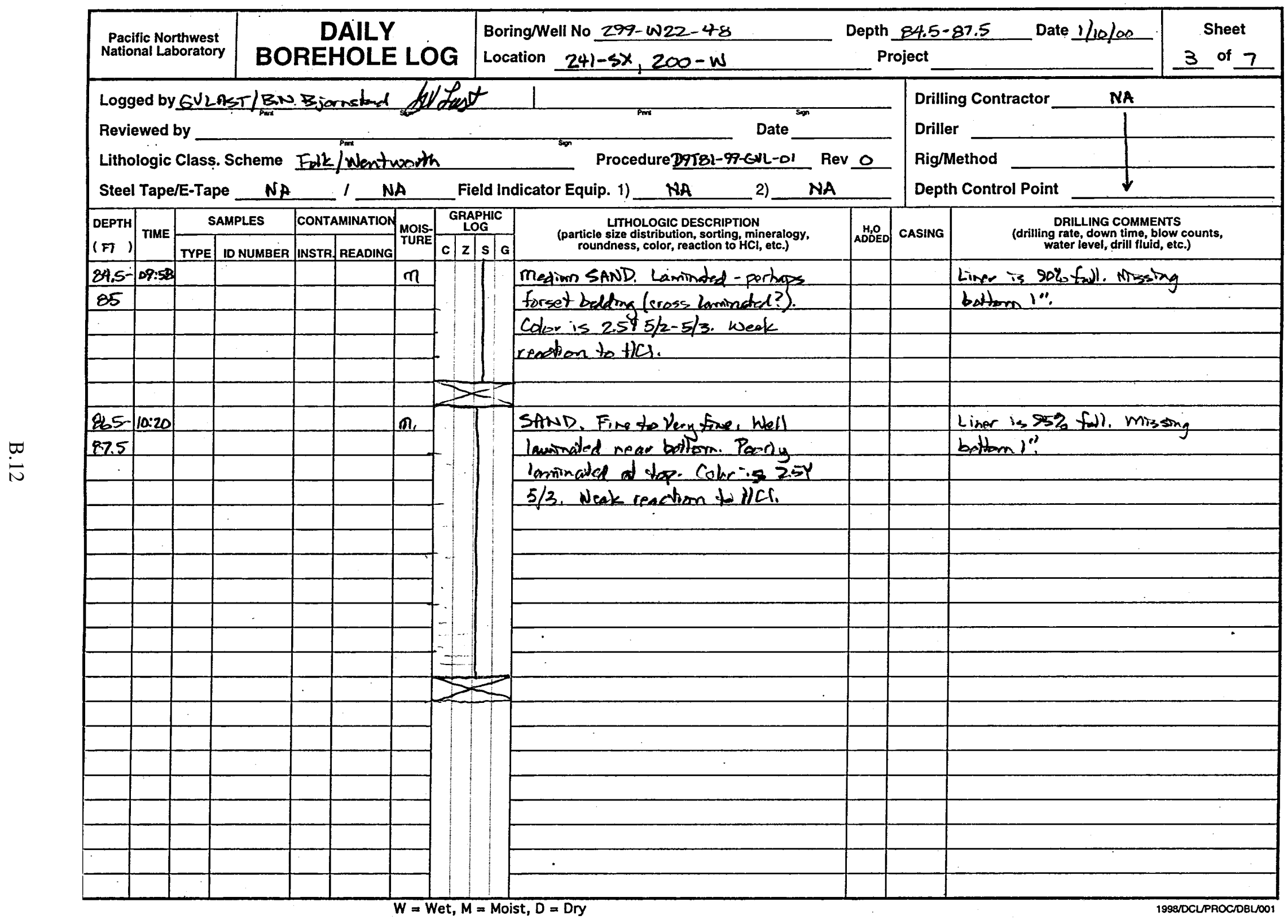




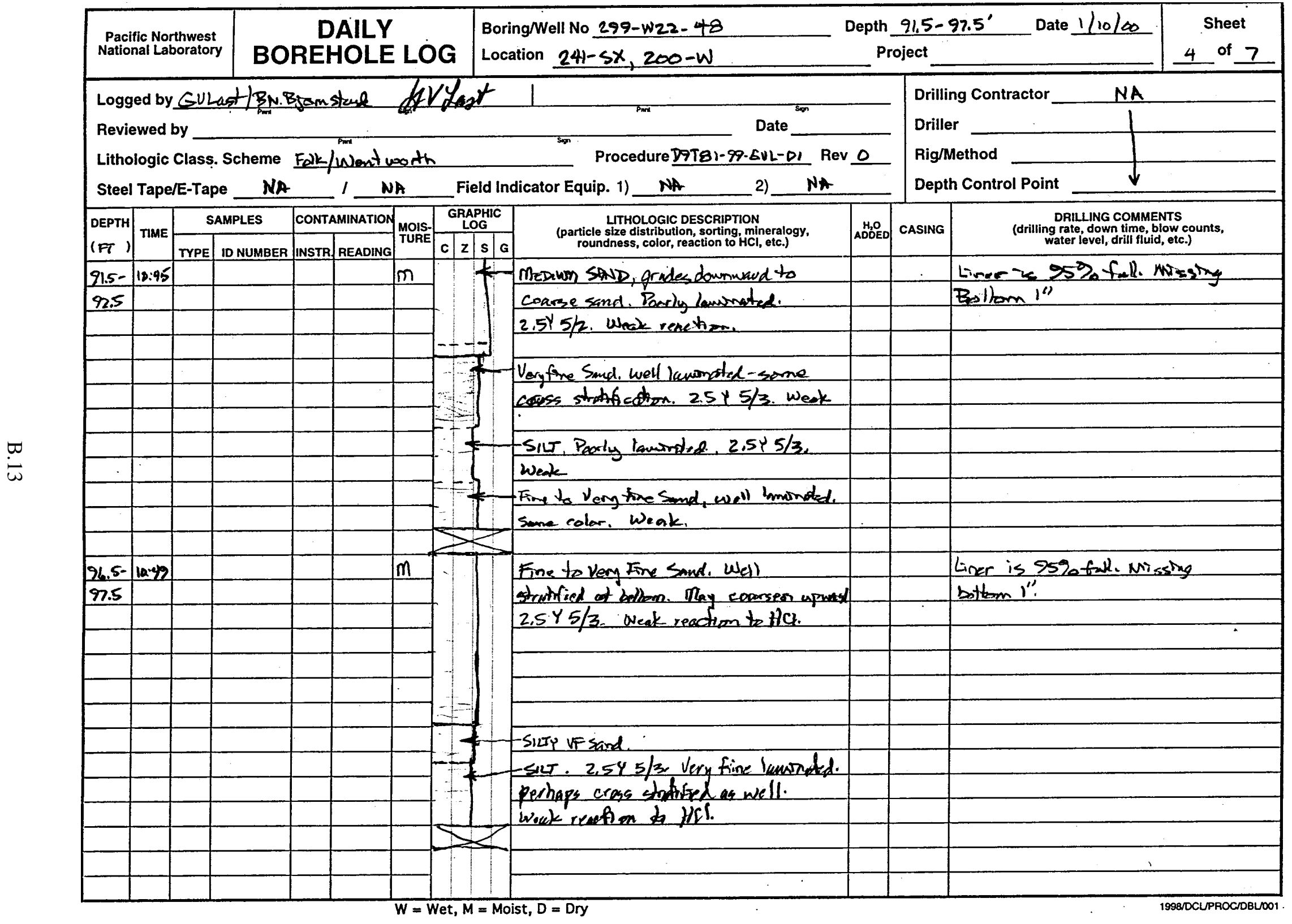




\begin{tabular}{|c|c|c|c|c|c|c|c|c|c|c|c|c|}
\hline \multicolumn{3}{|c|}{$\begin{array}{l}\text { Pacific Northwest } \\
\text { National Laboratory }\end{array}$} & \multicolumn{5}{|c|}{$\begin{array}{l}\text { DAILY } \\
\text { BOREHOLE LOG }\end{array}$} & $\begin{array}{l}\text { Boring/Well No } 299-w 22-48 \\
\text { Location } 241-5 x, 200-w\end{array}$ & \multicolumn{3}{|c|}{$\begin{array}{l}\text { Depth } 101.5-107.5 \text { Date } 1 / 1,0 / 00 \\
\text { Project }\end{array}$} & $\begin{array}{l}\text { Sheet } \\
5 \text { of } 7 \\
\end{array}$ \\
\hline \multirow{2}{*}{\multicolumn{10}{|c|}{ 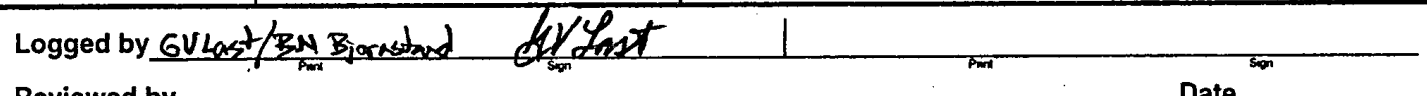 }} & \multirow{4}{*}{\multicolumn{3}{|c|}{$\begin{array}{l}\text { Drilling Contractor } \\
\text { Driller } \\
\text { Rig/Method } \\
\text { Depth Control Point }\end{array}$}} \\
\hline \multirow{2}{*}{\multicolumn{10}{|c|}{$\begin{array}{l}\text { Reviewed by } \\
\text { Lithologic Class. Scheme Folk/Wentwooth }\end{array}$}} & & & \\
\hline & & & & & & & & & & & & \\
\hline \multicolumn{10}{|c|}{ Steel Tape/E-Tape $N A{ }^{\prime}$ NA } & & & \\
\hline \multirow{2}{*}{$\begin{array}{l}\text { DEPTH } \\
\left(F_{L} .\right)\end{array}$} & \multirow{2}{*}{ TIME } & \multicolumn{2}{|c|}{ SAMPLES } & \multicolumn{2}{|c|}{ CONTAMINATION } & \multirow{2}{*}{ MOIS. } & \begin{tabular}{|l} 
GRAPHIC \\
LOG \\
\end{tabular} & \multirow{2}{*}{ 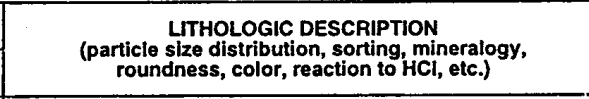 } & \multirow{2}{*}{\begin{tabular}{|l|l|}
$A, O$ \\
$A D O E D$
\end{tabular}} & \multirow{2}{*}{ CASING } & \multirow{2}{*}{\multicolumn{2}{|c|}{$\begin{array}{l}\text { DRILLING COMMENTS } \\
\text { (drilling rate, down time blow counts, } \\
\text { water level, drill fluid, etc.) }\end{array}$}} \\
\hline & & TYPE & ID NUMBER & INSTR & READING & & \begin{tabular}{|l|l|l|}
$c$ & $z$ & $s$ \\
\end{tabular} & & & & & \\
\hline \multirow{2}{*}{$101.5-1$} & $11: 00$ & & & & & $m$ & \multirow[b]{4}{*}{ \pm} & \multirow{3}{*}{ 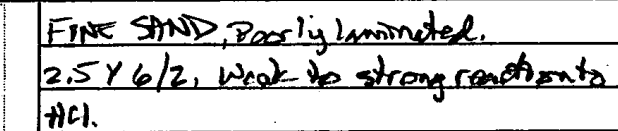 } & & & \multicolumn{2}{|c|}{ Liwer is $98 \%$ Fall, misoing } \\
\hline & & & & & & & & & & & \multicolumn{2}{|c|}{ bottom '". Toak wosture } \\
\hline & & & & & & & & & & & \multicolumn{2}{|c|}{ SMNRE From FiNEST LNT. } \\
\hline 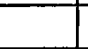 & & & & & & & & 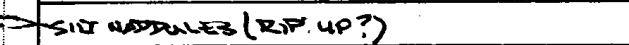 & & & & \\
\hline & & & & & & $m$ & & siv, massive, $2.514 / 3-5 / 3$ & & & & \\
\hline & & & & & & & & weak readion to t/cl. & & & & \\
\hline & & & & & & & & & & & & \\
\hline & & & & & & $m$ & & - S14 to Vary Fine swerd. Very findu & & & & \\
\hline & & & & & & & & lamindel $2.5 \times 4 / 3-5 / 3$ & & & & \\
\hline & & & & & & & & & & & & \\
\hline & & & & & & & & & & & & \\
\hline & & & & & & & & & & & & \\
\hline $106.5-1$ & 11015 & & & & & $M$ & & $m-F$ SAND Psoriy lanimated. $2.5 Y \mathrm{~L} / \mathrm{z}$ & & & LiNer is $95 \%$ Fale. & $\operatorname{nissin} 5$ \\
\hline 107.5 & & & & & & & & wetr Rencthon da $H C l$ & & & Bertom I". & \\
\hline & & & & & & & & & & & & \\
\hline & & & & & & & & & & & & \\
\hline & & & & & & & & SILIR UF. SAND. Vurg fudy laninded. 2.5454 & w & 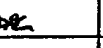 & & \\
\hline & & & & & & & & SAWD DBADES LP WARD FROM & & & & \\
\hline & & & & & & & & meqian to Fand. & & & & \\
\hline & & & & & & & & & & & & \\
\hline & & & & & & & & $\sec x \cos \sin x$ & & & & \\
\hline & & & & & & & & LENE-VERYFNE SKND. & & & & \\
\hline & & & & & & & & & & & & \\
\hline & & & & & & & 2 & & & & & \\
\hline & & & & & & & & & & & & \\
\hline & & & & & & & 1 & & & & & \\
\hline
\end{tabular}




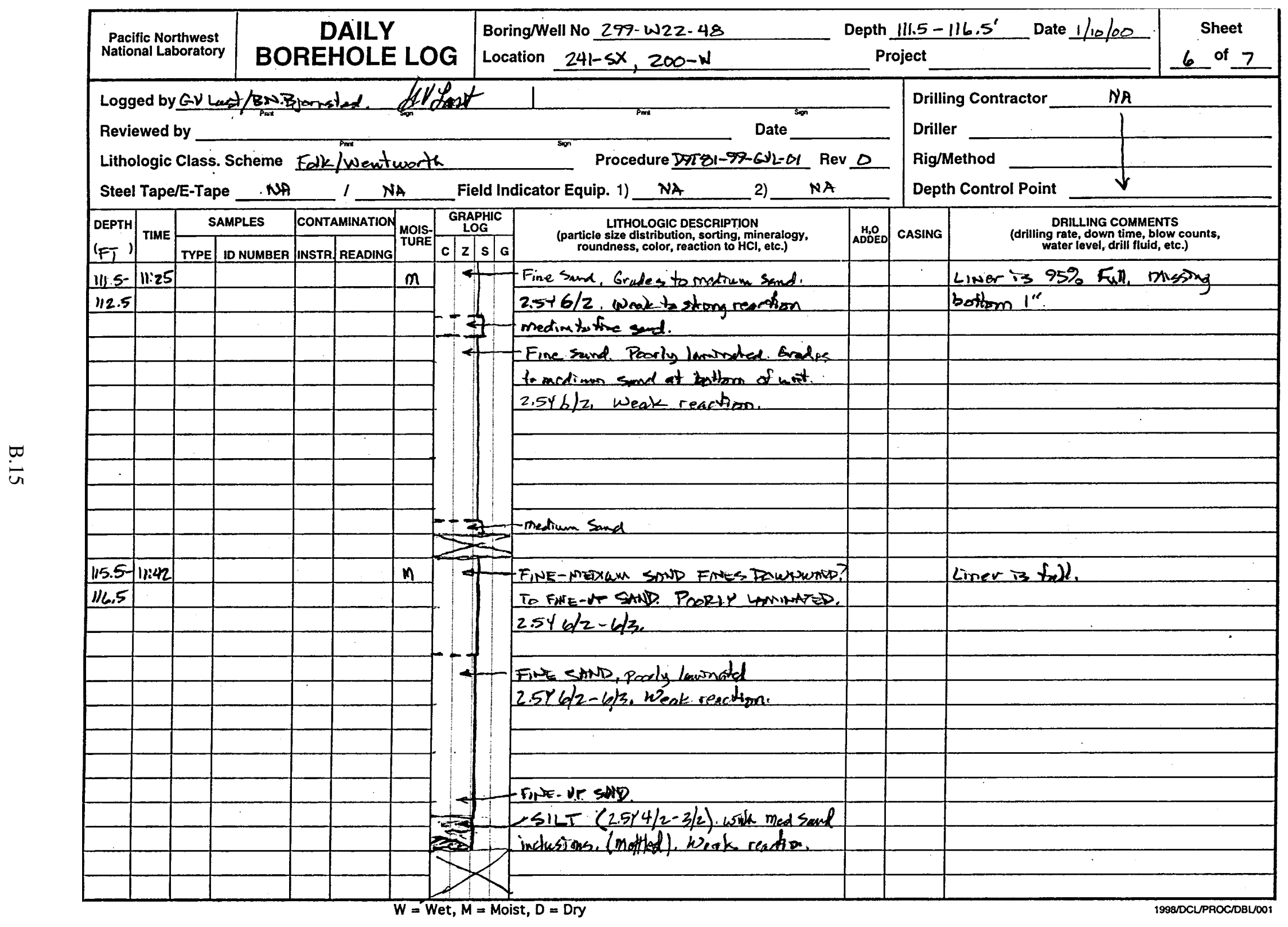




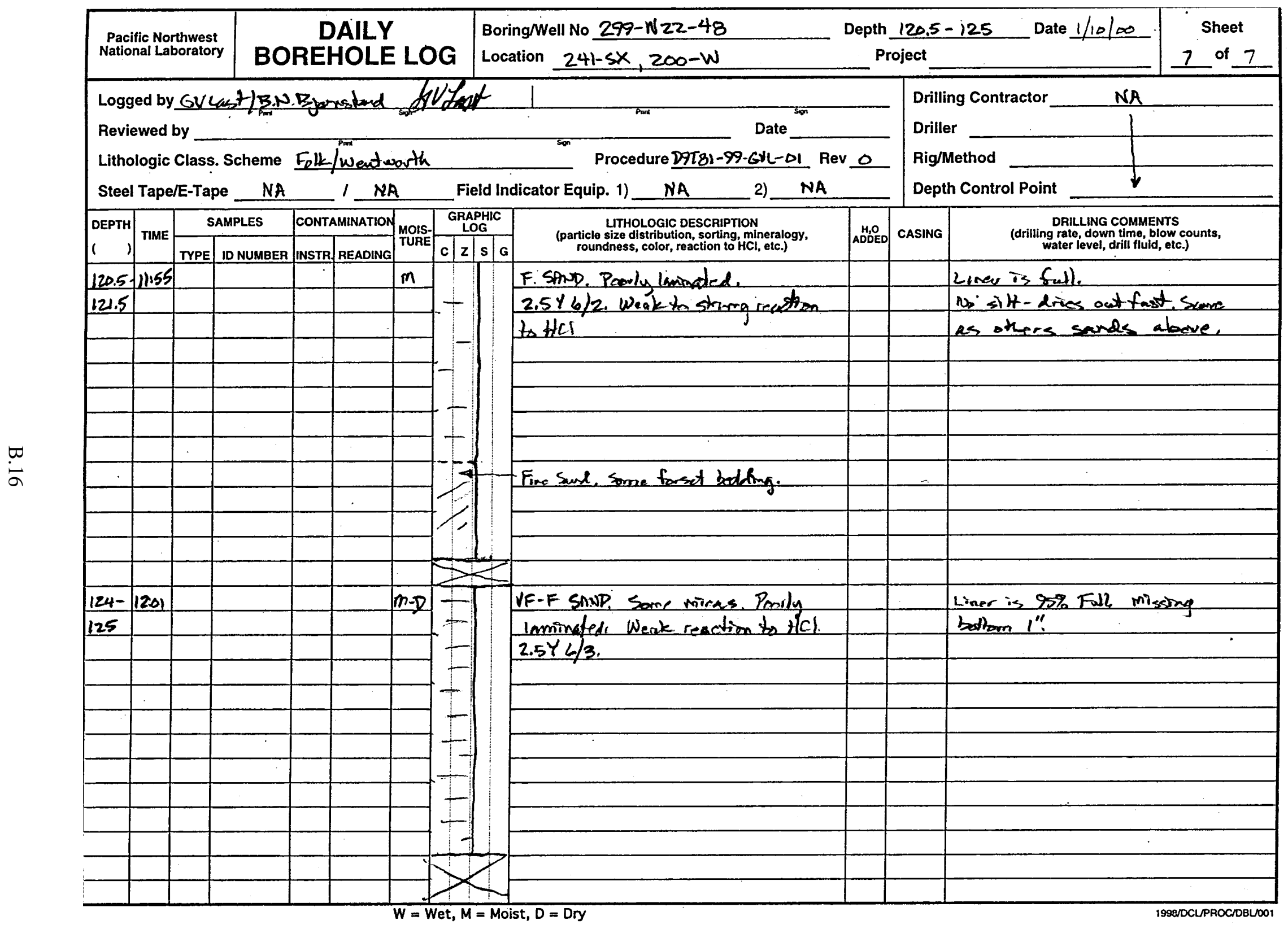




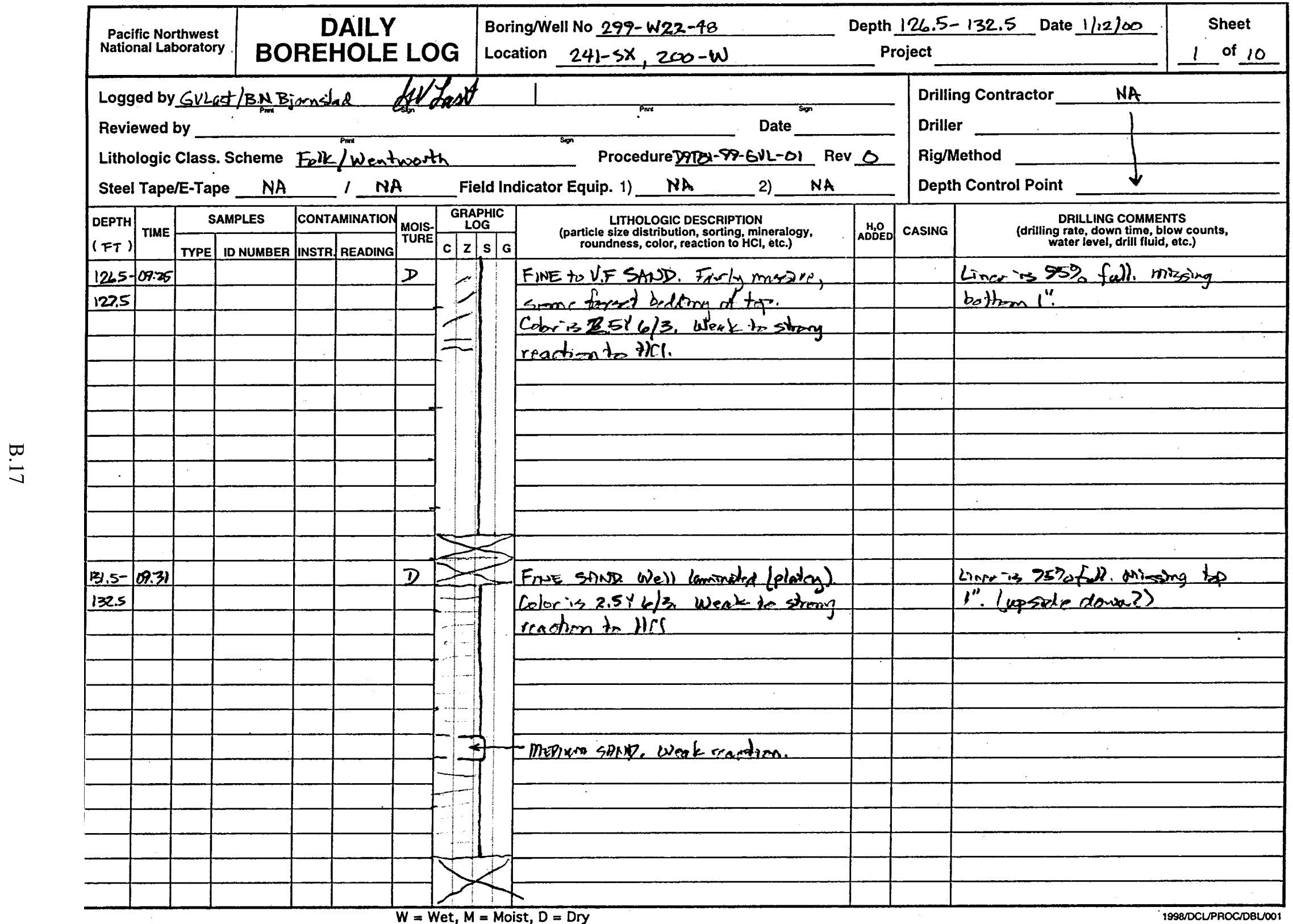




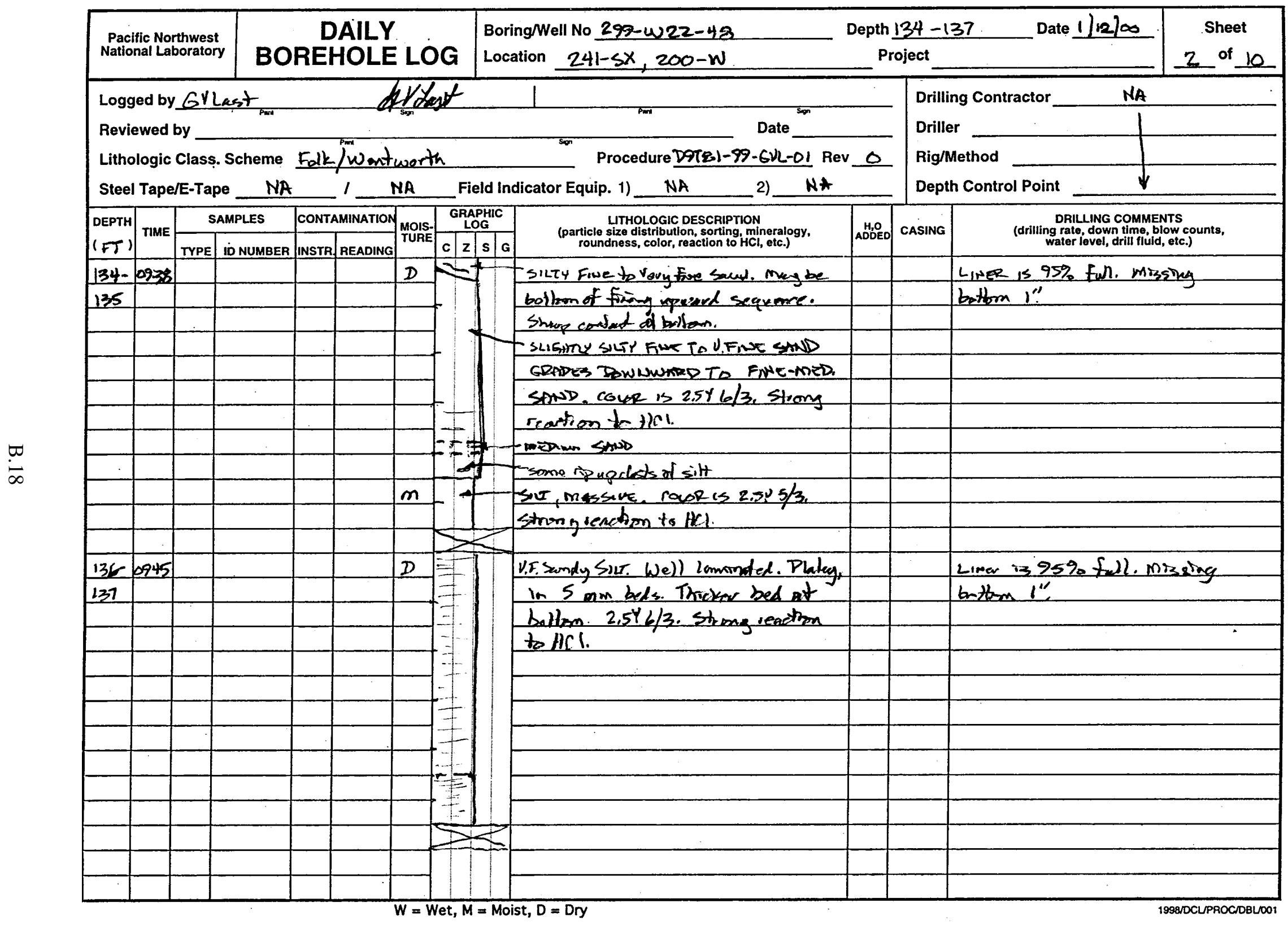




\begin{tabular}{|c|c|c|c|c|c|c|c|c|c|c|c|c|}
\hline \multicolumn{3}{|c|}{$\begin{array}{l}\text { Pacific Northwest } \\
\text { National Laboratory }\end{array}$} & \multicolumn{4}{|c|}{$\begin{array}{l}\text { DAILY } \\
\text { BOREHOLE LOG }\end{array}$} & & $\begin{array}{l}\text { Boring/Well No } 299-w) 22-48 \\
\text { Location } 241-5 x, 200-W\end{array}$ & \multicolumn{3}{|c|}{ Depth $143.5-147$ Date 1/12/00 } & $\begin{array}{l}\text { Sheet } \\
3 \quad \text { of } 10 \\
\end{array}$ \\
\hline \multicolumn{10}{|c|}{$\begin{array}{lll}\text { Logged by GV Last } & \text { GeVtest } & 1\end{array}$} & \multirow{4}{*}{\multicolumn{3}{|c|}{\begin{tabular}{l|l} 
Drilling Contractor NA \\
Driller \\
Rig/Method \\
Depth Control Point
\end{tabular}}} \\
\hline \multirow{2}{*}{\multicolumn{10}{|c|}{$\begin{array}{l}\text { Reviewed by } \\
\text { Lithologic Class. Scheme Folk/Wentwerth }\end{array}$}} & & & \\
\hline & & & & & & & & Procedure $99[81-99-6 h-01$ & & & & \\
\hline \multicolumn{10}{|c|}{ Steel Tape/E-Tape NA ${ }^{\prime} N_{A}$} & & & \\
\hline \multirow{2}{*}{$\begin{array}{l}\text { DEPTH } \\
(F,)^{\prime}\end{array}$} & \multirow{2}{*}{ TIME } & \multicolumn{2}{|c|}{ SAMPLES } & \multicolumn{2}{|c|}{ CONTAMINATION } & \multirow{2}{*}{\begin{tabular}{|l|l|} 
MOIS- \\
TURE
\end{tabular}} & $\begin{array}{c}\text { GRAPHIC } \\
\text { LOG } \\
\end{array}$ & \multirow{2}{*}{ 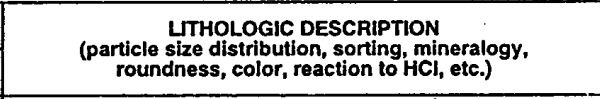 } & \multirow{2}{*}{$\mid \begin{array}{ll}A, 0 \\
A D O E D \\
A\end{array}$} & \multirow{2}{*}{ CASING } & \multirow{2}{*}{\multicolumn{2}{|c|}{$\begin{array}{l}\text { DRILLING COMMENTS } \\
\text { (drilling rate, ounn time, blow counts, } \\
\text { water ievel, drilit fluid, etc.) }\end{array}$}} \\
\hline & & TYPE & ID NUMBER & IINSTR & READING & & \begin{tabular}{|l|l|l|l|}
$c$ & $z$ & s. & G \\
\end{tabular} & & & & & \\
\hline 143.5 . & 1000 & & & & & $D$ & & \multirow{2}{*}{ 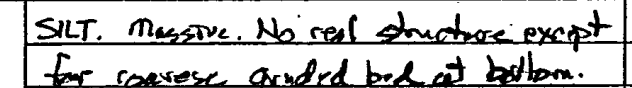 } & & & \multicolumn{2}{|c|}{ LiNex is $75 \%$ Fell. Mbering } \\
\hline \multirow{4}{*}{144.5} & & & & & & & & & & & bothom l", & J \\
\hline & & & & & & & & Sme dark spots throughront. & & & & \\
\hline & & & & & & & & Color is $2.546 / 2$. Strong renction & & & & \\
\hline & & & & & & & & to $\mathrm{HCl}$. & & & & \\
\hline & & & & & & & & & & & & \\
\hline & & & & & & & & & & & & \\
\hline & & & & & & & & & & & & \\
\hline & & & & & & & & & & & & \\
\hline & & & & & & & & Every Fine s & & & & \\
\hline & & & & & & & & & & & 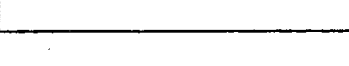 & \\
\hline $146-$ & 10:25 & & & & & $\mathrm{Dm}$ & & 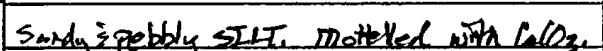 & & & Liner is 95\% Full $N$ & ary \\
\hline 147 & & & & & & & & Color is $2.5 \times 5 / 3,2.547 / 3$. & & & bettem $\mathrm{I}^{2}$ & \\
\hline & & & & & & & & Peve stomg reection to HCl, Sme & & & & \\
\hline & & & & & & & & rer, dak bluks. & & & & \\
\hline & & & & & & & & & & & & \\
\hline & & & & & & & & & & & & \\
\hline & & & & & & & & clast - op to 2 rem (breken) & & & & \\
\hline & & & & & & & & 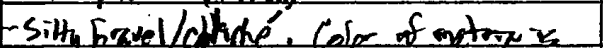 & & & & \\
\hline & & & & & & & & 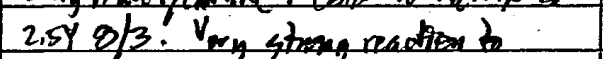 & & & & \\
\hline & & & & & & & & $\mathrm{Ha}$ & & & & \\
\hline & & & & & & & To & & & & & \\
\hline & & & & & & & 5 & & & & & \\
\hline & & & & & & & & & & & & \\
\hline & & & & & & & & & & & & \\
\hline
\end{tabular}




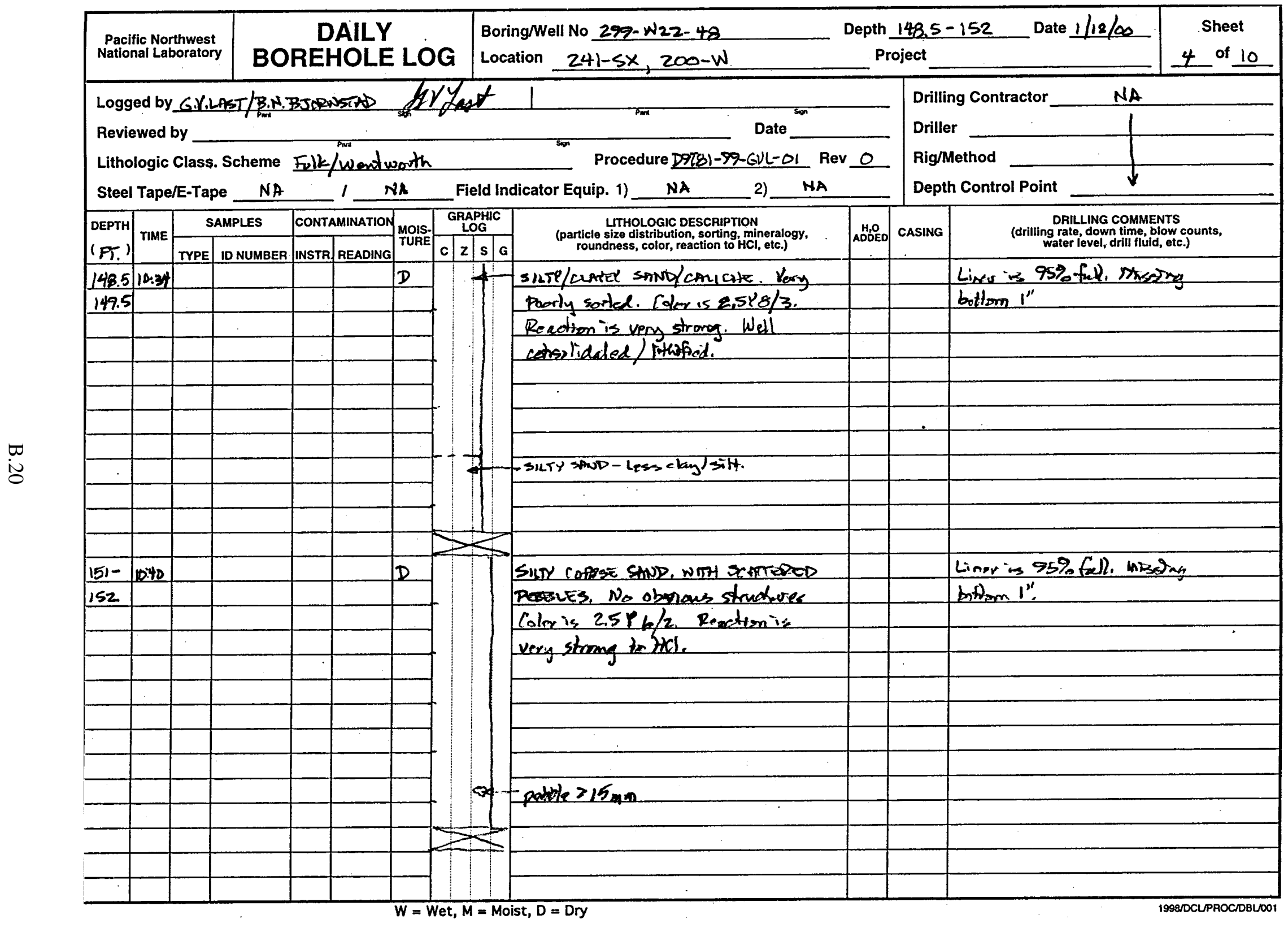




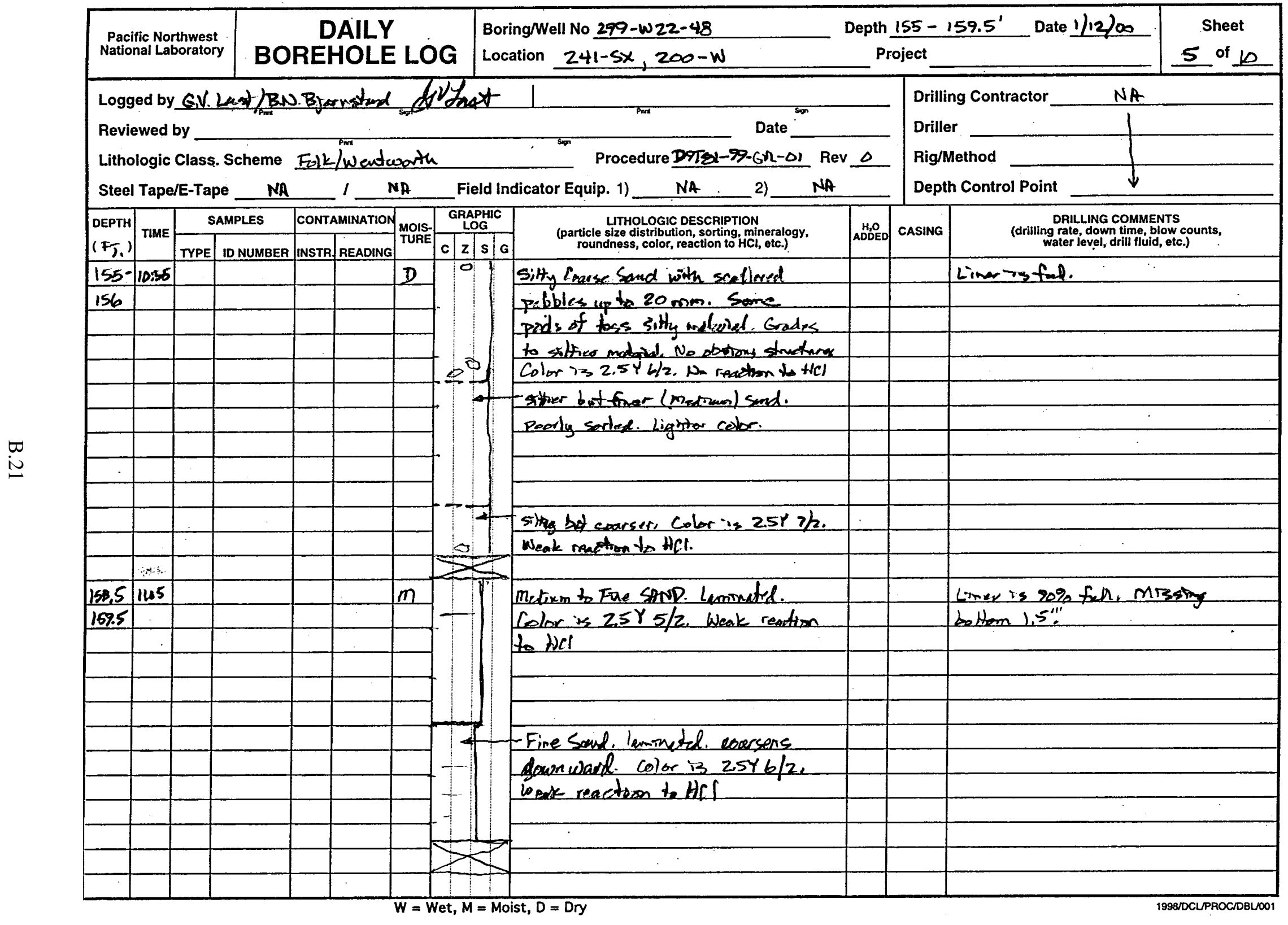




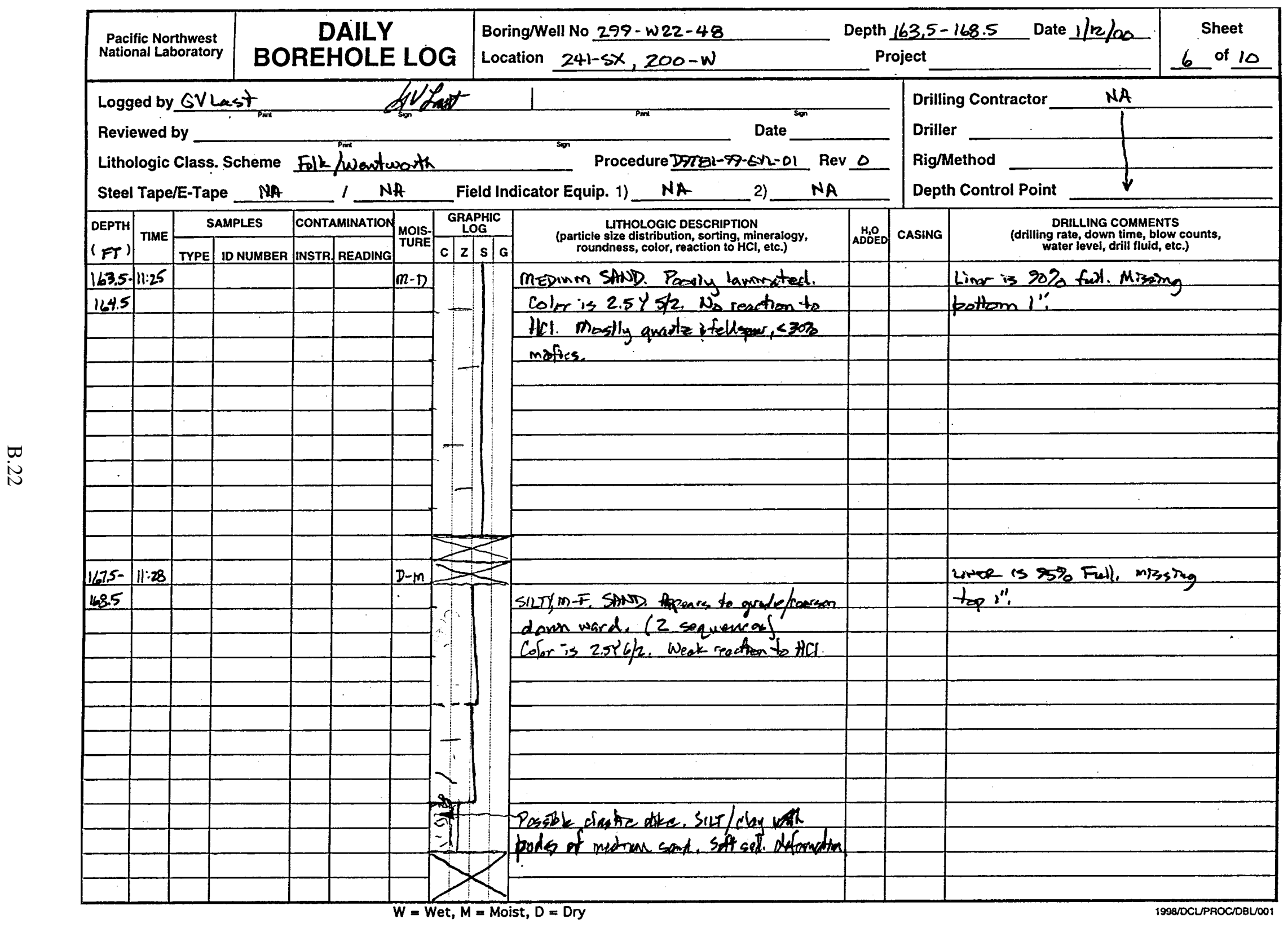




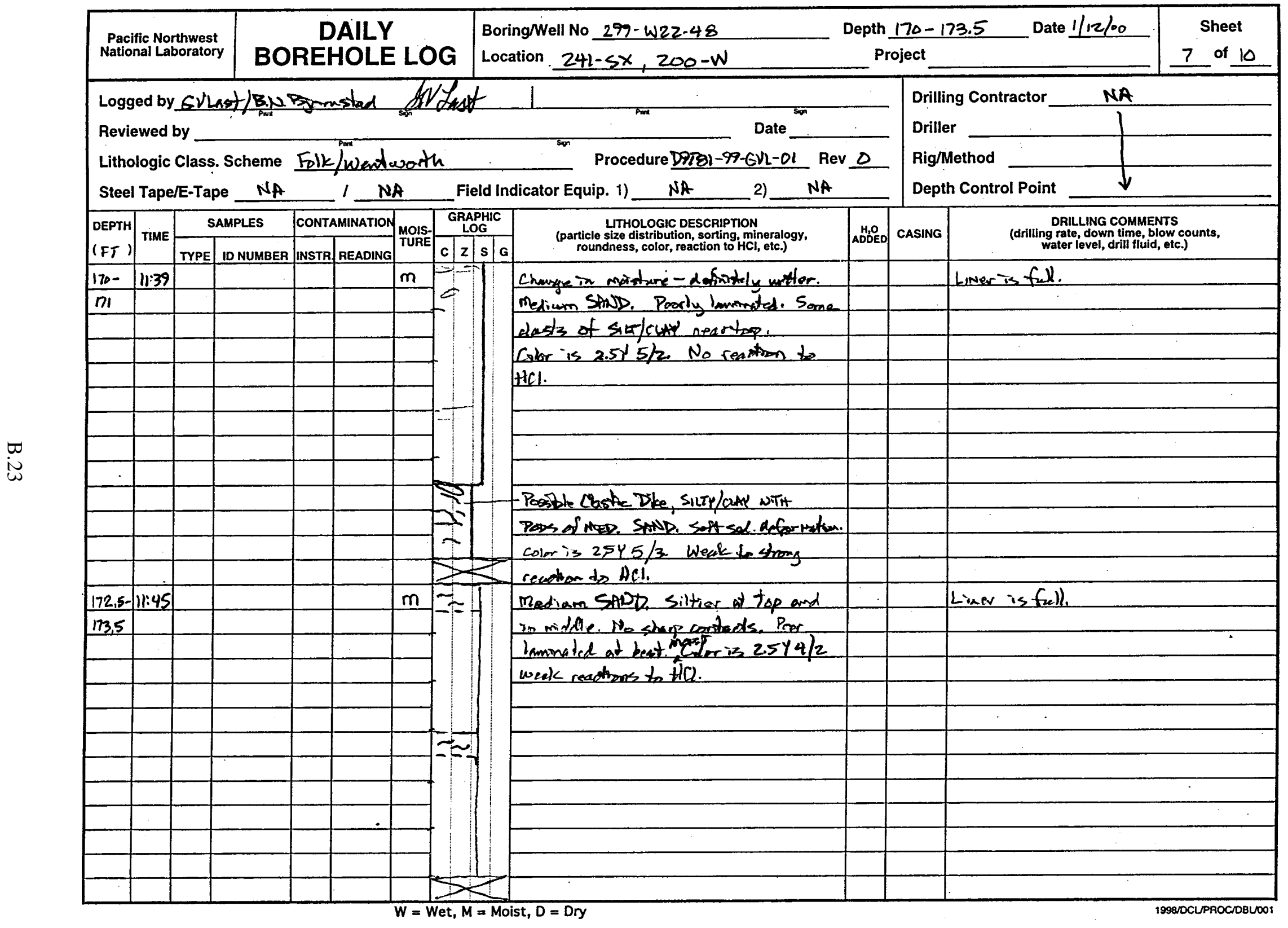




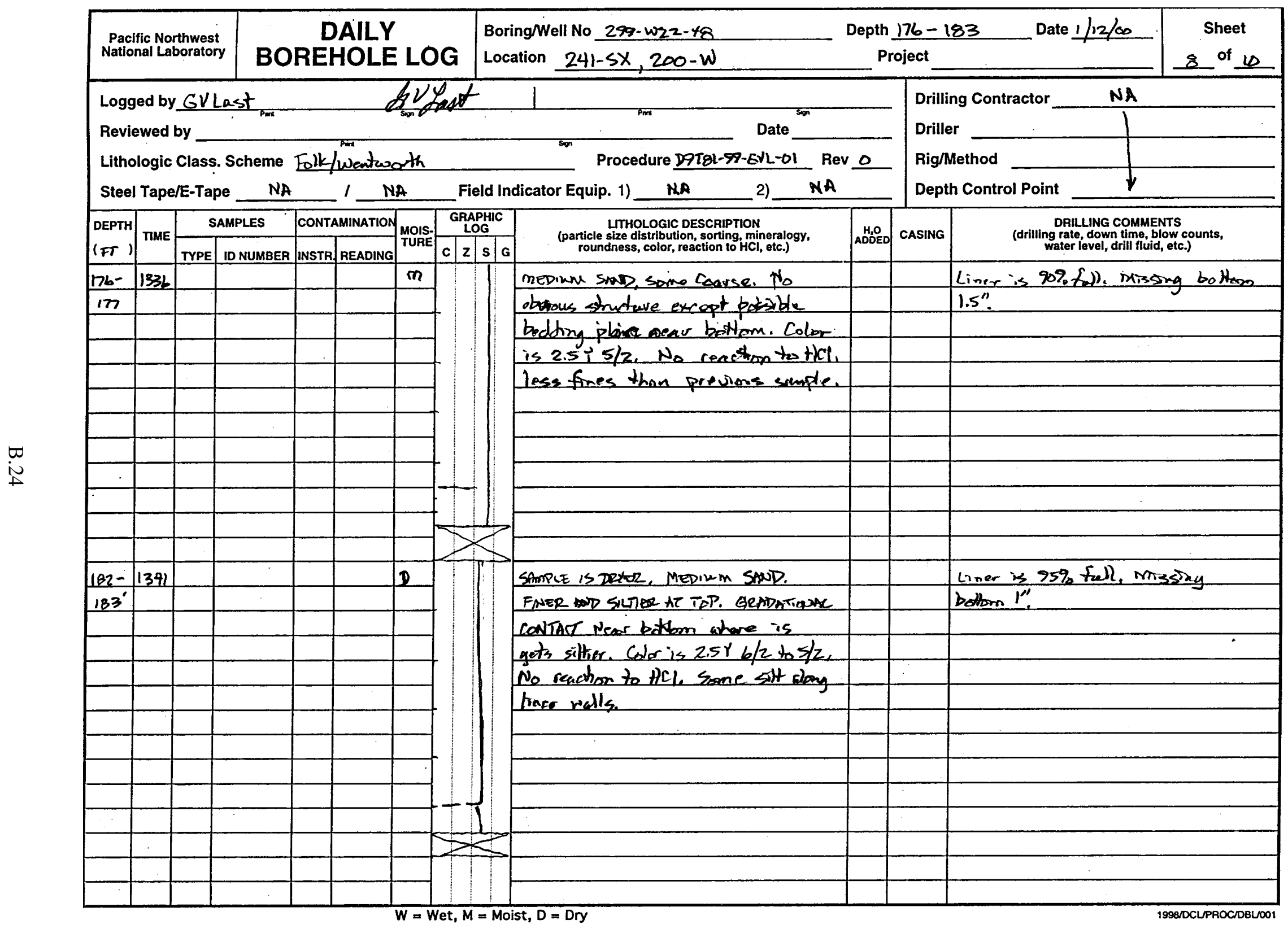




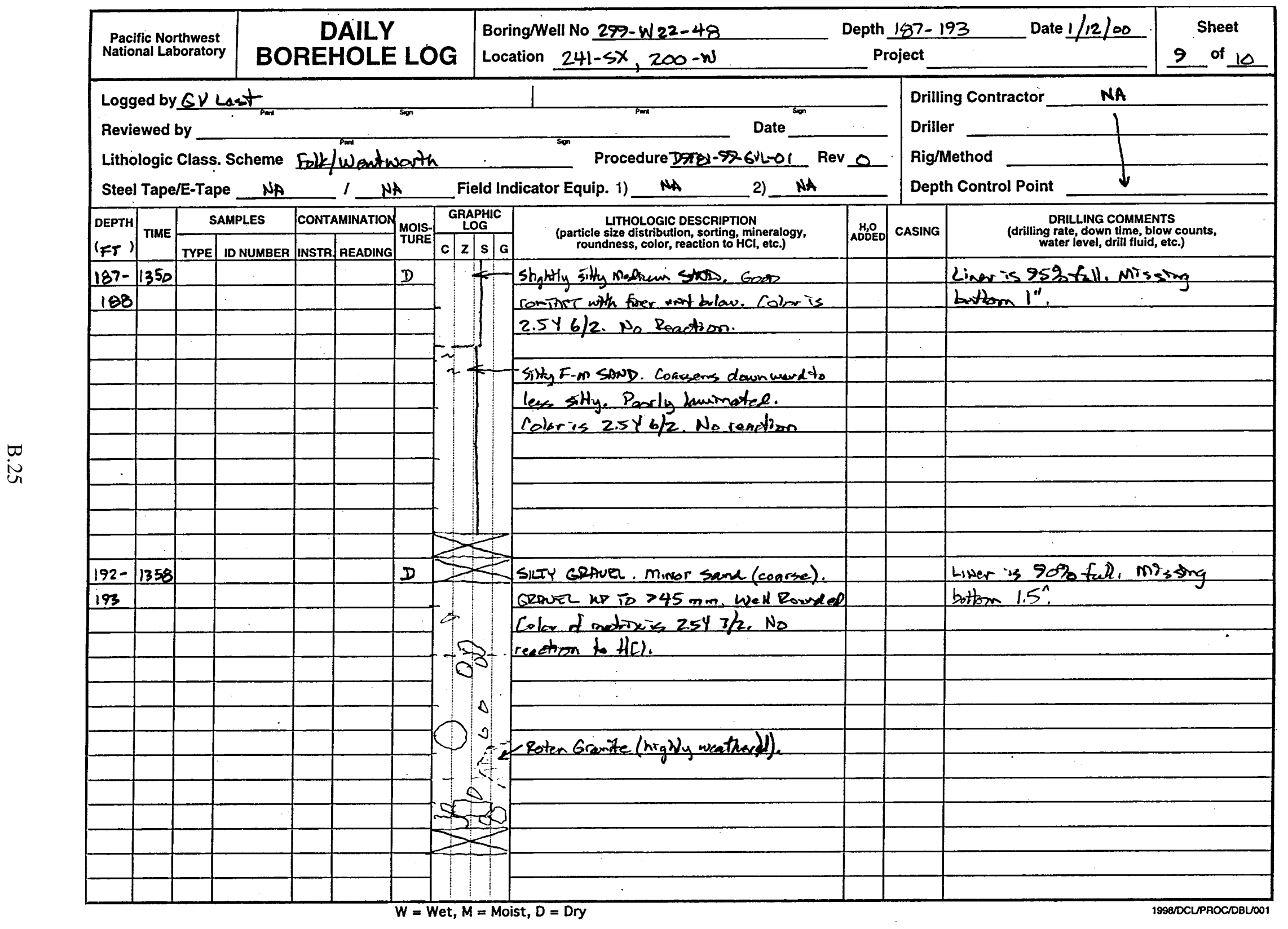




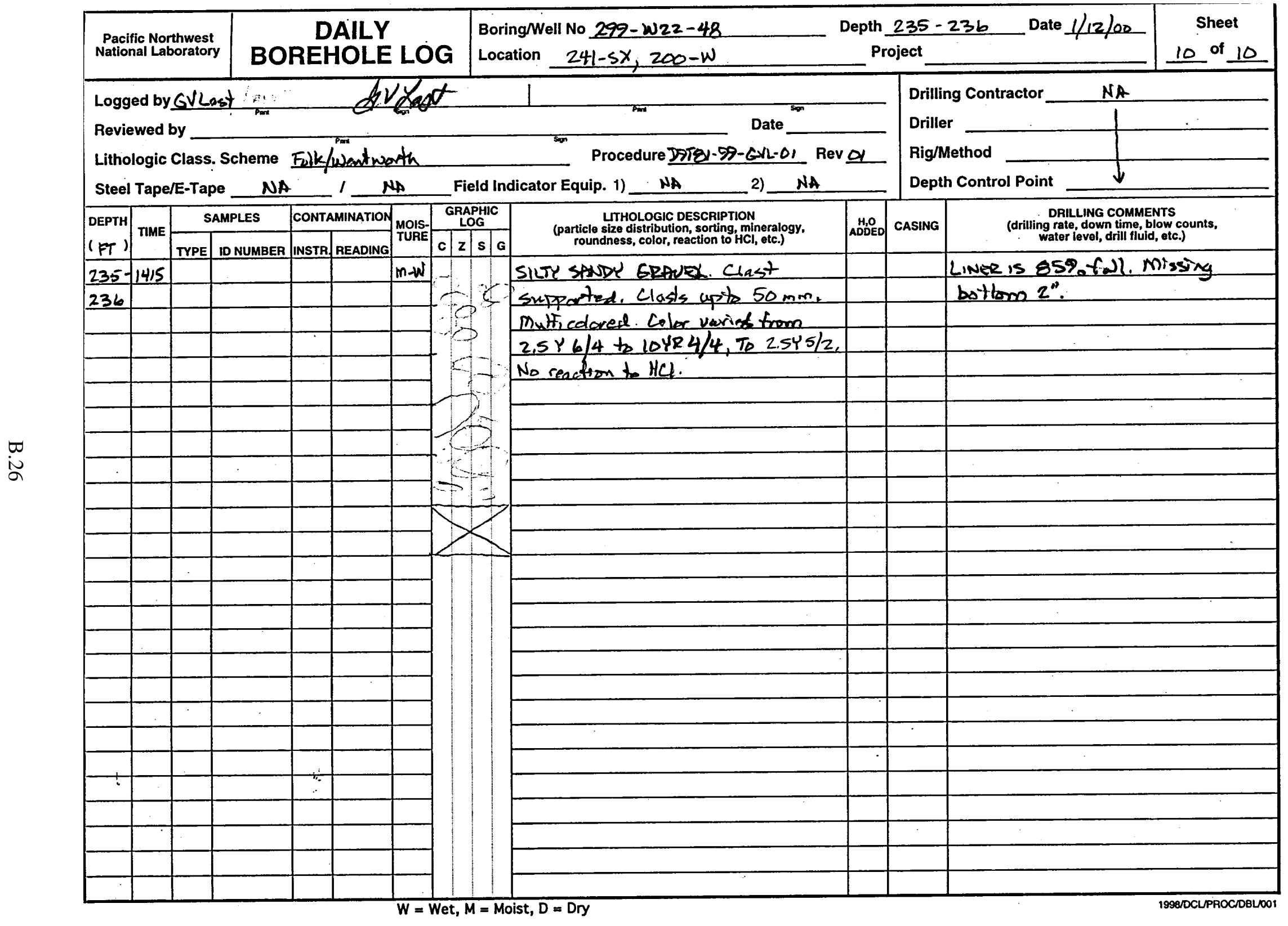




\section{Appendix C}

Summary Geophysical Logs for Borehole 299-W22-48 (9 pages) and Borehole 299-W22-50 (9 pages) 


\section{RLS Spectral Gamma Survey \\ Waste Management Technical Services}

\section{LOG HEADER}

Project: RCRA drilling 1999

Well: 299-W22-48

Borehole Information

\begin{tabular}{|c|c|c|c|}
\hline Well \# 299-W22-48 & Water Depth & Total Depth & h $\underline{245} \mathrm{ft}$ \\
\hline Elevation Reference $\underline{\mathrm{n} / \mathrm{a}}$ & Elevation & $\underline{\mathrm{n} / \mathrm{a}} \quad \mathrm{ft}$ & \\
\hline Depth Reference Ground Surface & Casing Stickup & 11.75 in. $-0.38^{\prime}, 8.625$ in. $-1.0^{\prime}$ & \\
\hline Casing Diameter 11.75 in. & Depth Interval & 0 to $50 \mathrm{ft} \quad$ Thickness & 0.5 in \\
\hline Casing Diameter $\underline{8.625}$ in. & Depth Interval & $\underline{0 \text { to } 245 \mathrm{ft}}$ & 0.5 in \\
\hline
\end{tabular}

\section{Logging Information}

\begin{tabular}{|c|c|}
\hline Log Type: & HPGe Spectral Gamma \\
\hline Company & Waste Management Technical Services \\
\hline Logging Engineers & J.E. Meisner \\
\hline Instrument Series & RLSG07000S00.0 \\
\hline Logging Unit & RLS-1 \\
\hline Depth Interval & $\begin{array}{l}0^{\prime} \text { to } 166.0^{\prime} \\
161.0^{\circ} \text { to } 245.5^{\prime}\end{array}$ \\
\hline Instrument Calibration Date & October 8,1999 \\
\hline Calibration Report & WHC-SD-EN-TI-292, Rev. 0 \\
\hline
\end{tabular}

\section{Analysis Information}

$\begin{array}{ll}\text { Company } & \text { Waste Management Technical Services } \\ \text { Analyst } & \text { Steven Kos } \\ \text { Date } & \text { March 13,2000 } \\ \text { Depth Reference } & \text { Ground Surface }\end{array}$

Notes Spectral gamma measurements were acquired at 0.5 - $\mathrm{ft}$ depth intervals at a logging speed of $1.0 \mathrm{ft}$. min. 


\section{RLS Spectral Gamma Survey \\ Waste Management Technical Services}

Project: RCRA Drilling 1999

Well: 299-W22-48

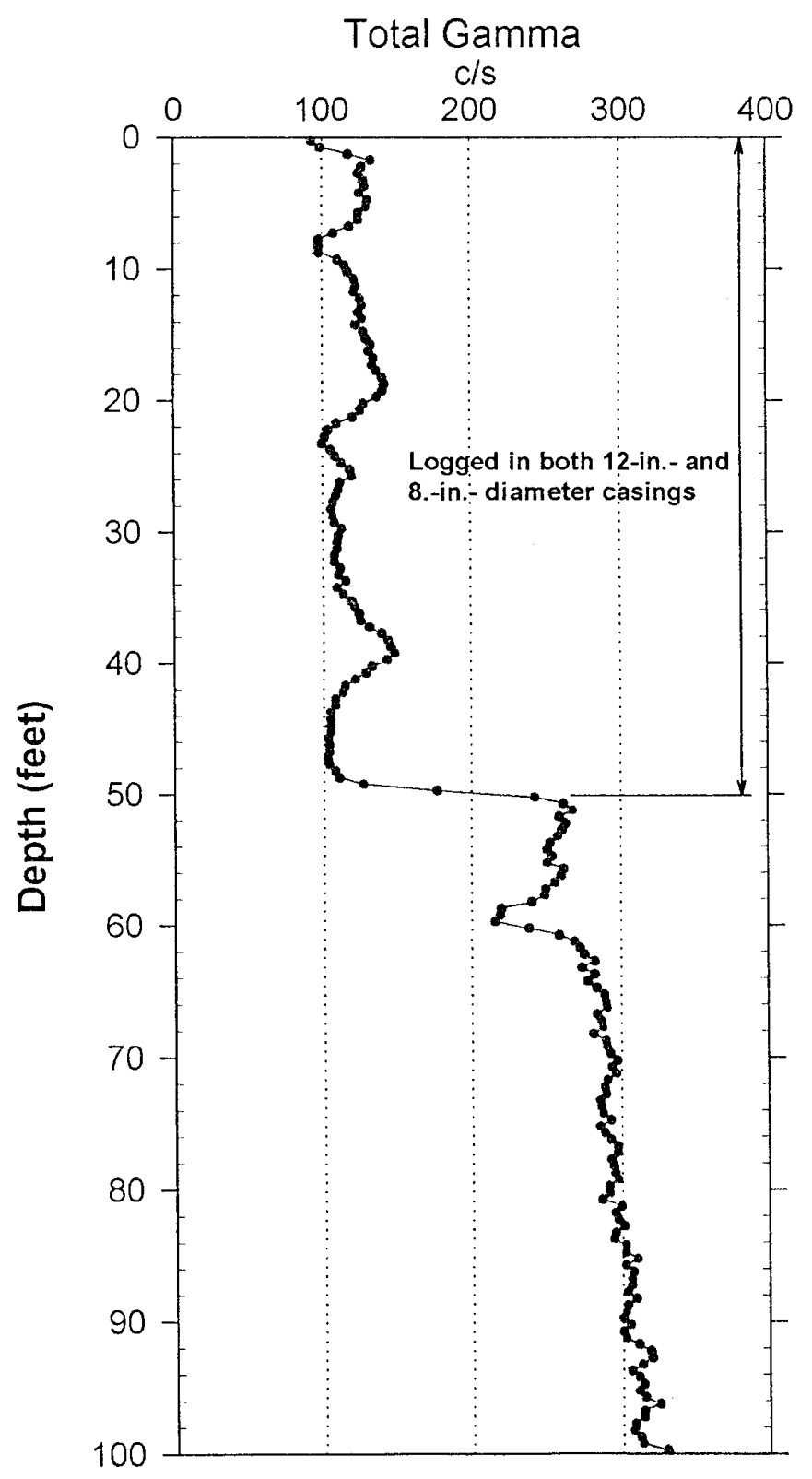

Log Date: Oct. 27, 1999

Depth Datum: Ground Level

Potassium Uranium Thorium
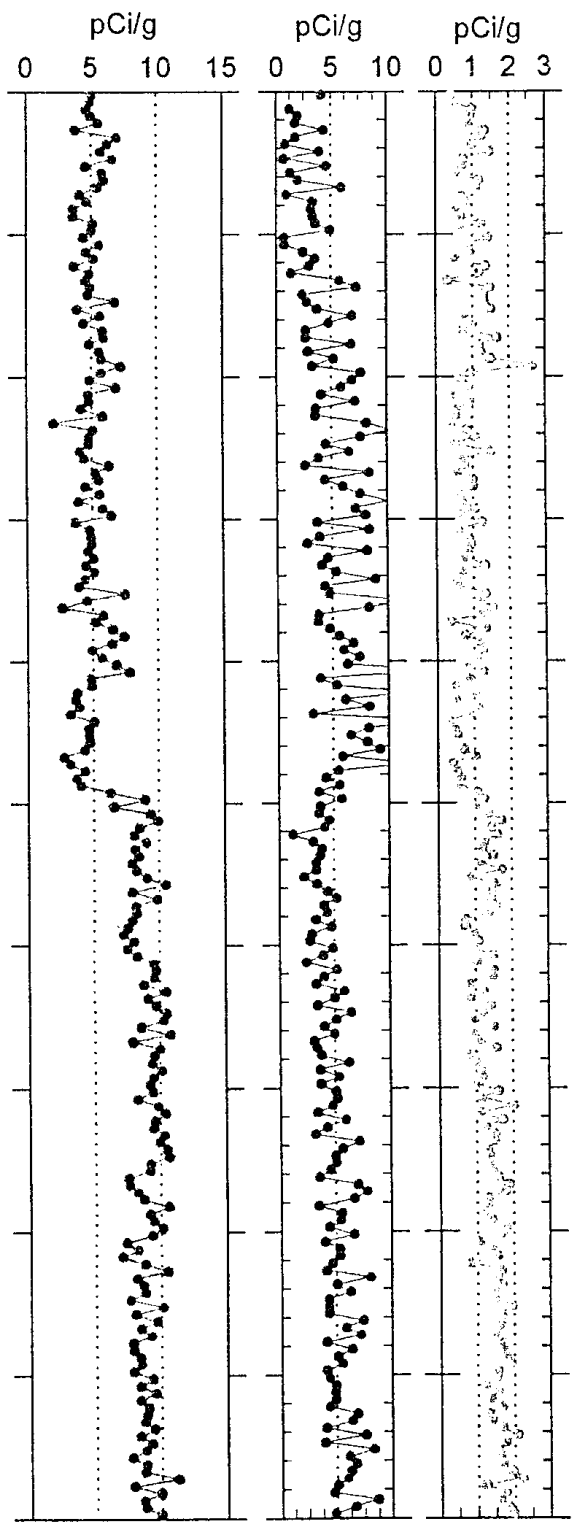


\section{RLS Spectral Gamma Survey \\ Waste Management Technical Services}

Project: RCRA Drilling 1999

Well: $299-W 22-48$
Log Date: Oct. 27, 1999

Depth Datum: Ground Level

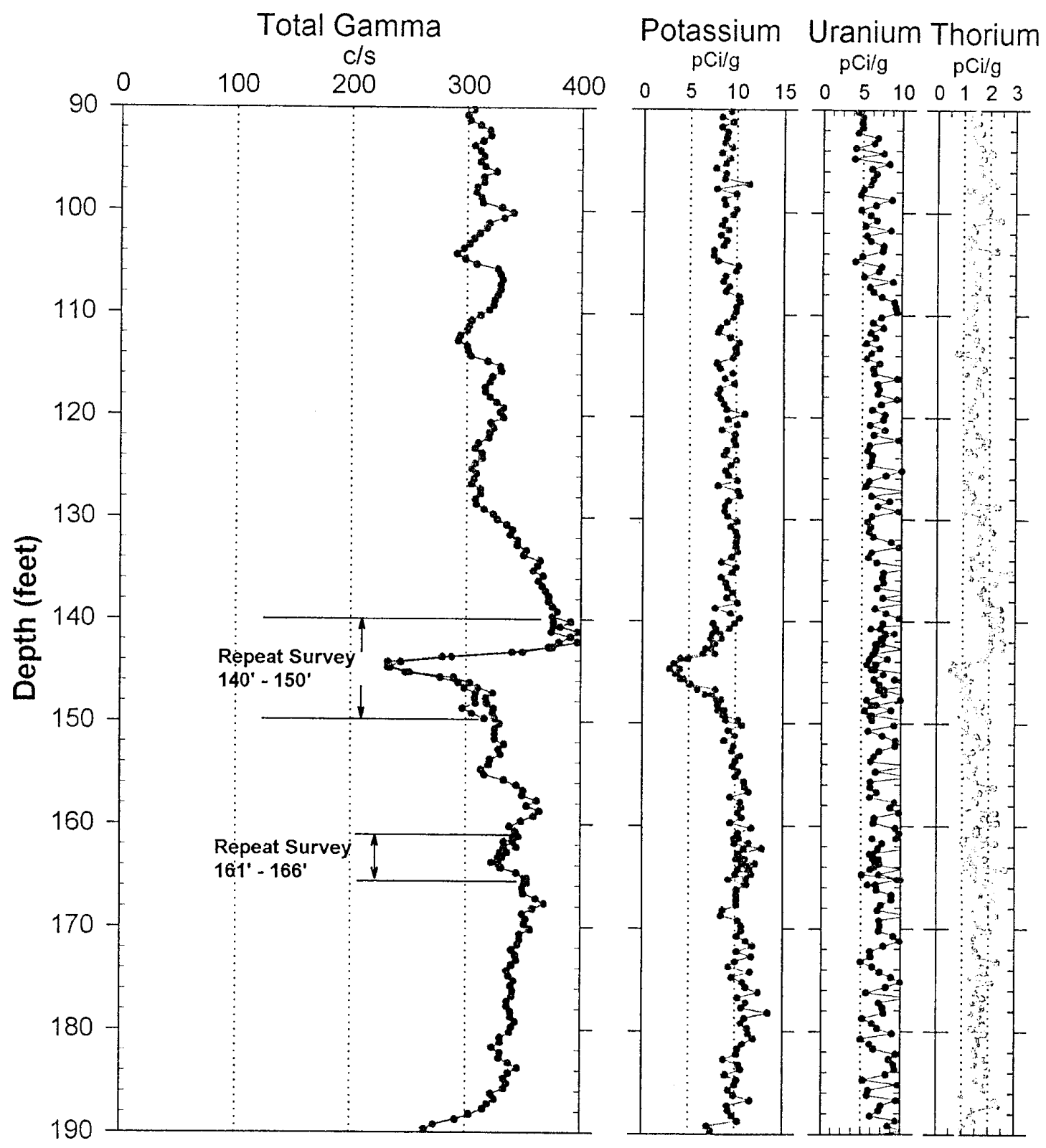


KLS Spectral Gamma Survey
Waste Management Technical Services

Project: RCRA Drilling 1999

Log Date: Oct. 27, 1999

Well: 299-W22-48

Depth Datum: Ground Level

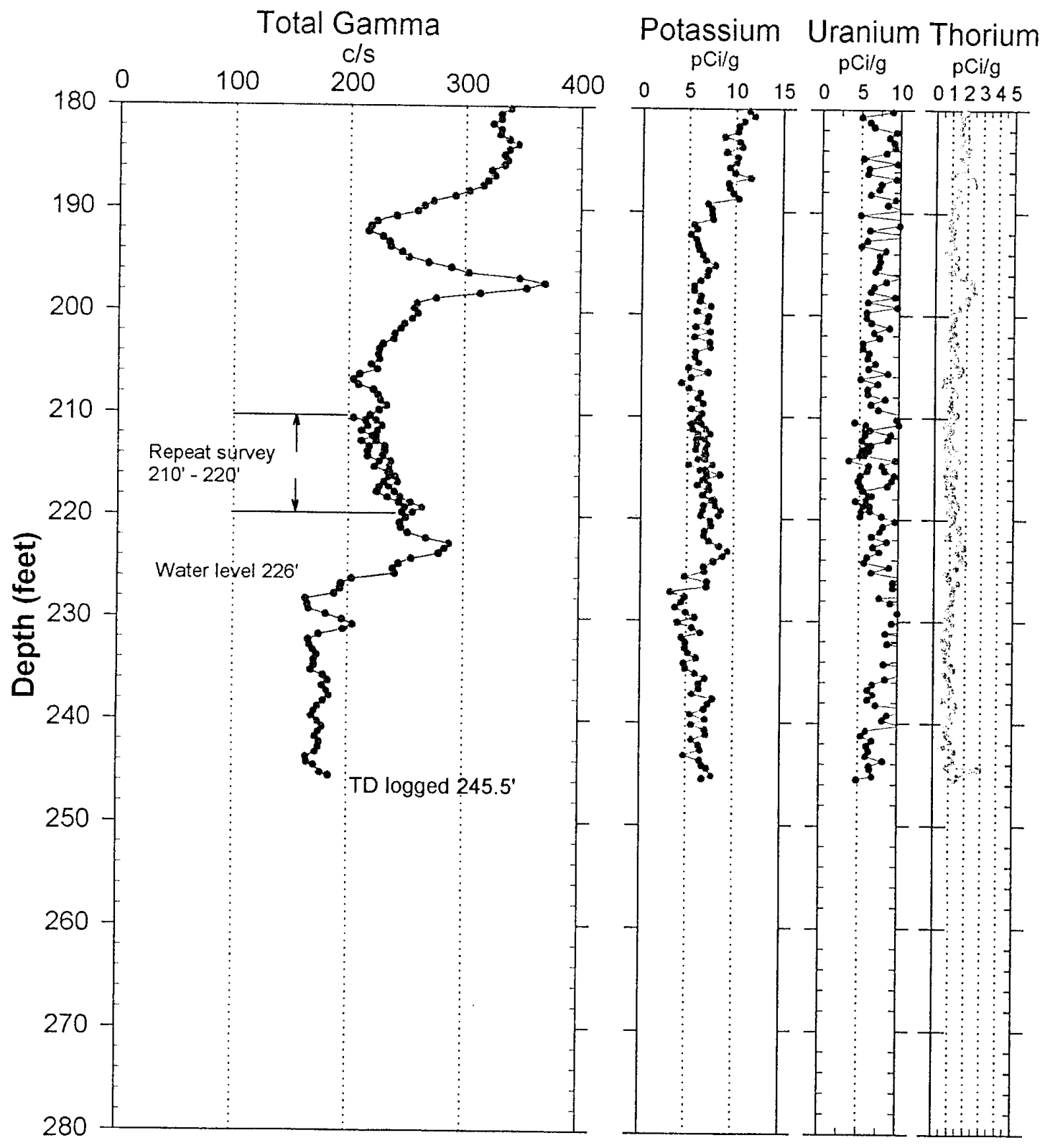




\section{RLS Neutron-Neutron Moisture Survey \\ Waste Management Technical Services}

\section{LOG HEADER}

Project: RCRA drilling 1999

Well: $299-W 22-48$

\section{Borehole Information}

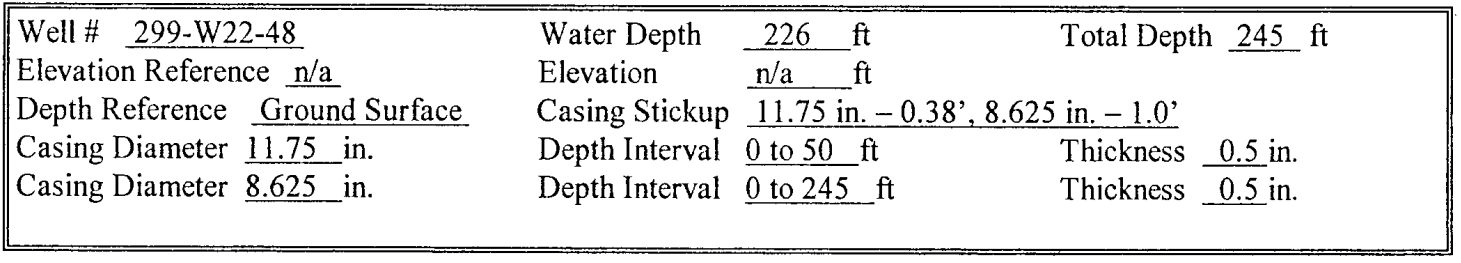

\section{Logging Information}

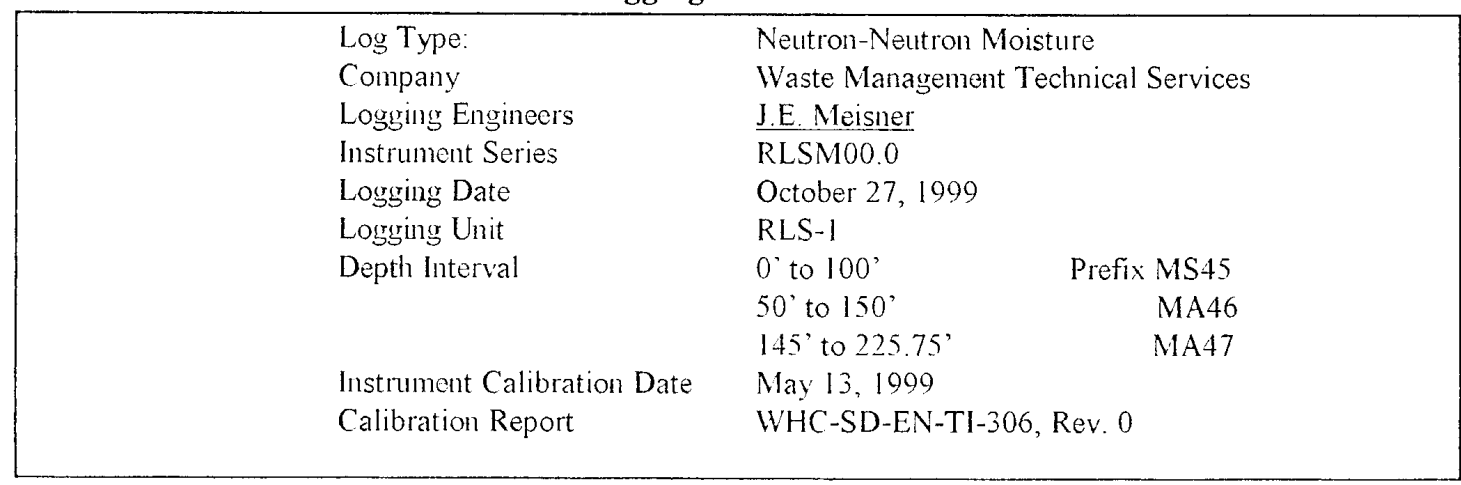

\section{Analysis Information}

$\begin{array}{ll}\text { Company } & \text { Waste Management Technical Services } \\ \text { Aulyst } & \text { Steven Kos } \\ \text { Date } & \text { March 15,2000 } \\ \text { Depth Reference } & \text { Ground Surface }\end{array}$

Notes The moisture measurements were acquired at $0.250-\mathrm{ft}$ depth intervals at a logging speed of $1.0 \mathrm{ft}$ per minute. 


\section{Neutron-Neutron Moisture Survey}

\section{Waste Management Technical Services}

Project: RCRA Drilling 1999 Log Date :October 27, 1999

Borehole: 299-W22-48

Depth Datum: Ground Level

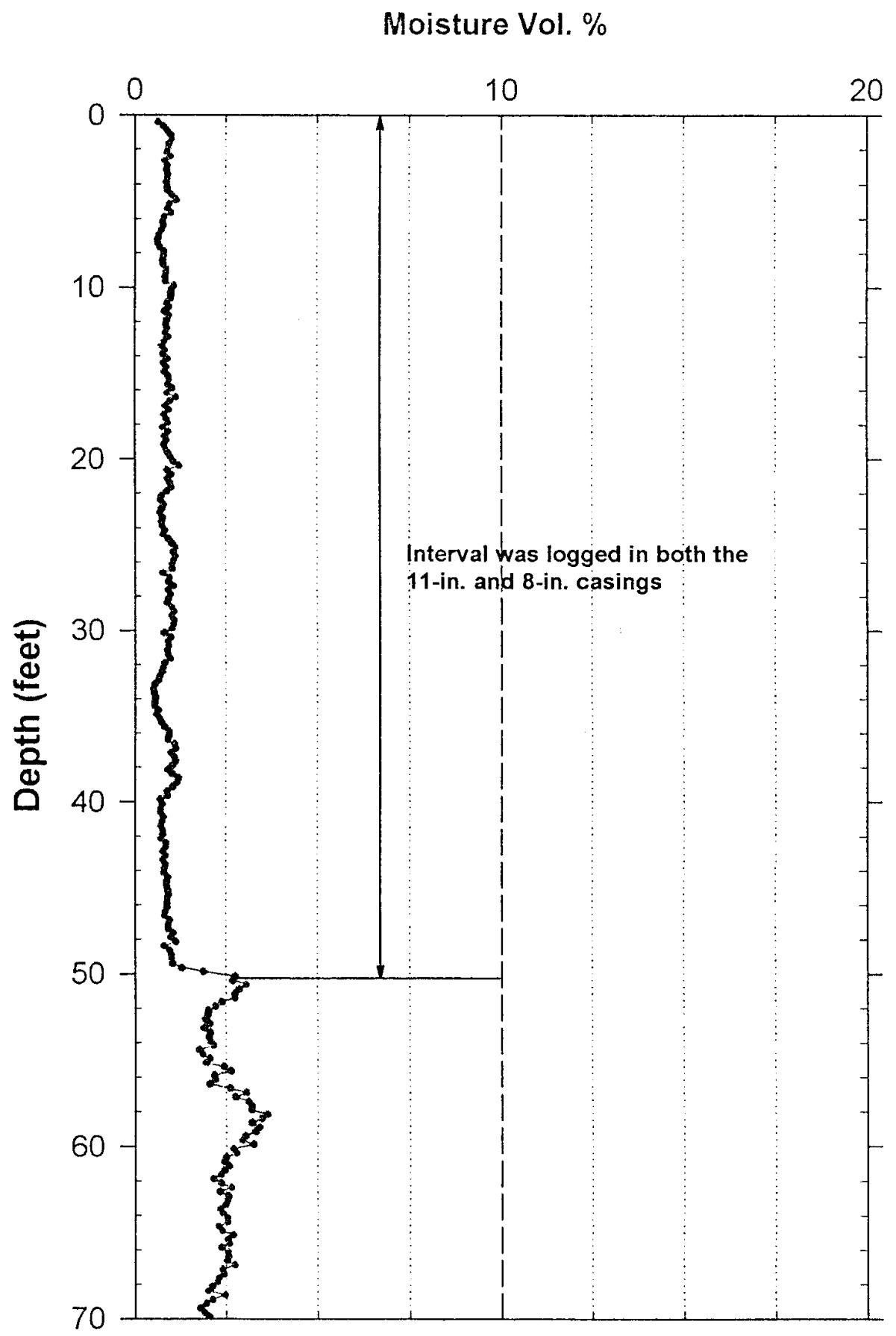




\section{Neutron-Neutron Moisture Survey}

Waste Management Technical Services

Project: RCRA Drilling 1999 Log Date :October 27, 1999

Borehole: 299-W22-48 Depth Datum: Ground Level

Moisture Vol. \%

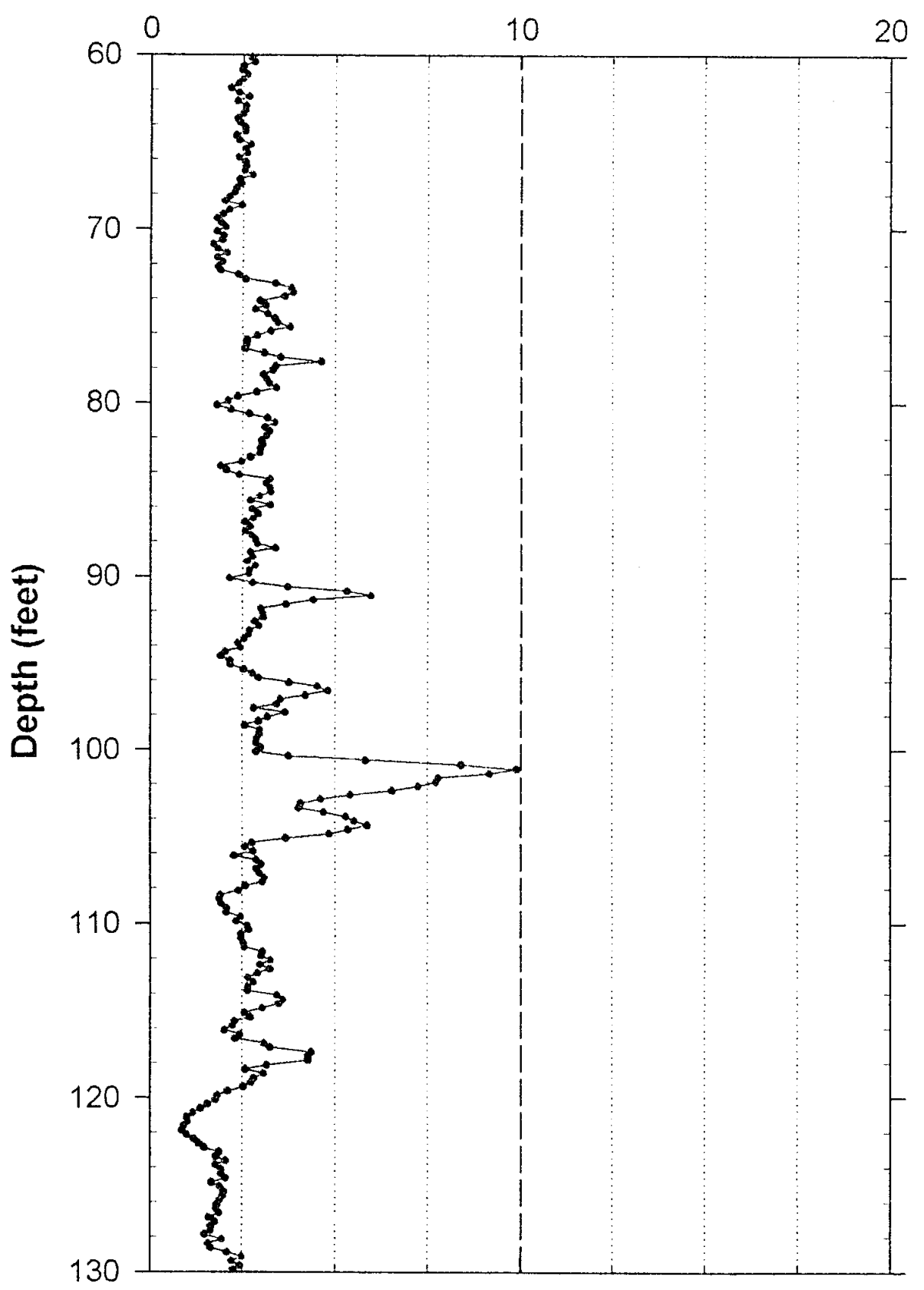




\section{Neutron-Neutron Moisture Survey}

Waste Management Technical Services

Project: RCRA Drilling 1999 Log Date :October 27, 1999 Borehole: 299-W22-48

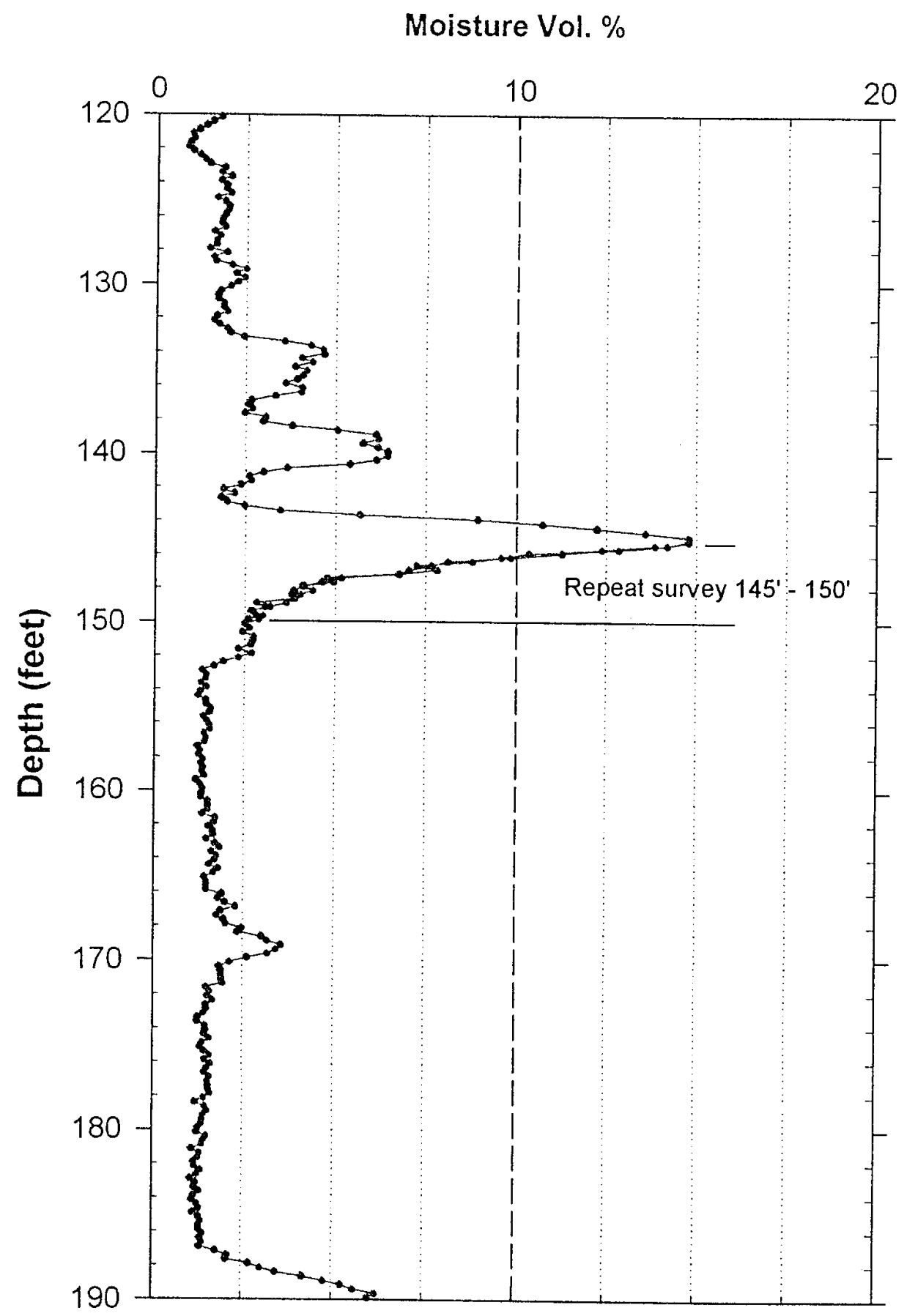




\section{Neutron-Neutron Moisture Survey}

Waste Management Technical Services

Project: RCRA Drilling 1999

Borehole: 299-W22-48
Log Date : October 27, 1999

Depth Datum: Ground Level

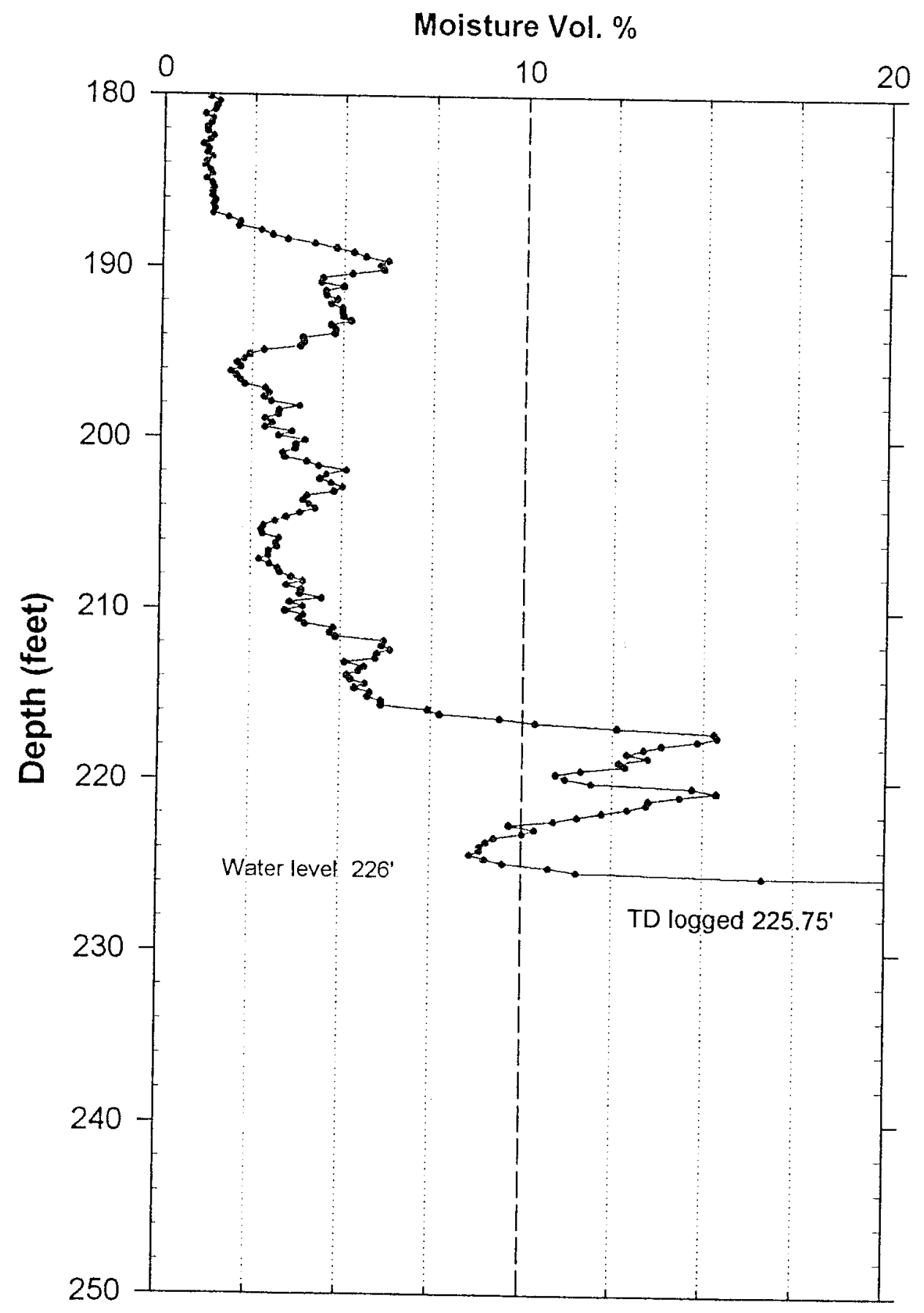

C.9 


\section{RLS Spectral Gamma/Sodium Iodide Survey \\ Waste Management Technical Services}

\section{LOG HEADER}

Project: RCRA drilling 1999

Well: 299-W22-50

\section{Borehole Information}

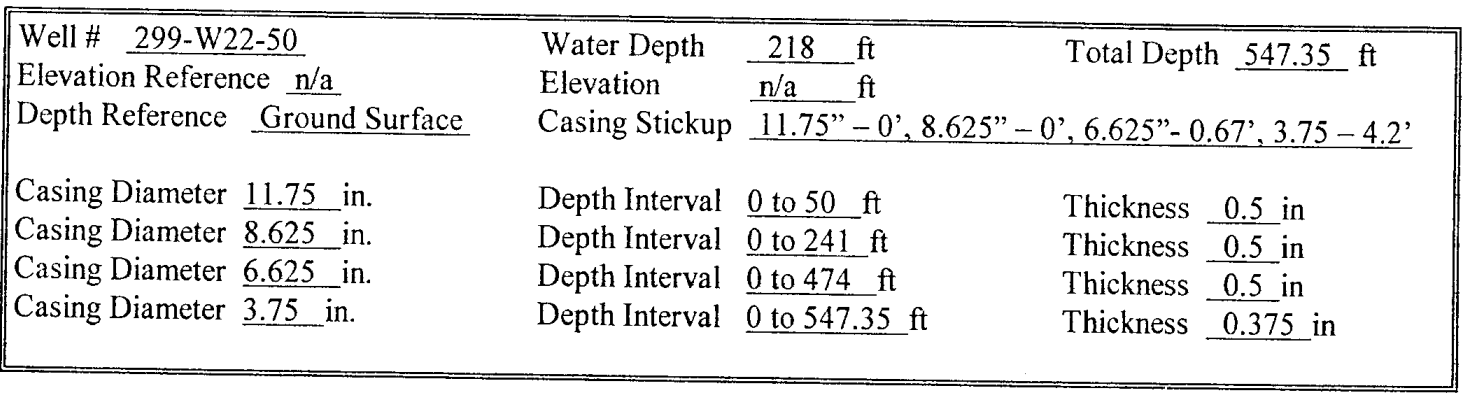

\section{Logging Information}

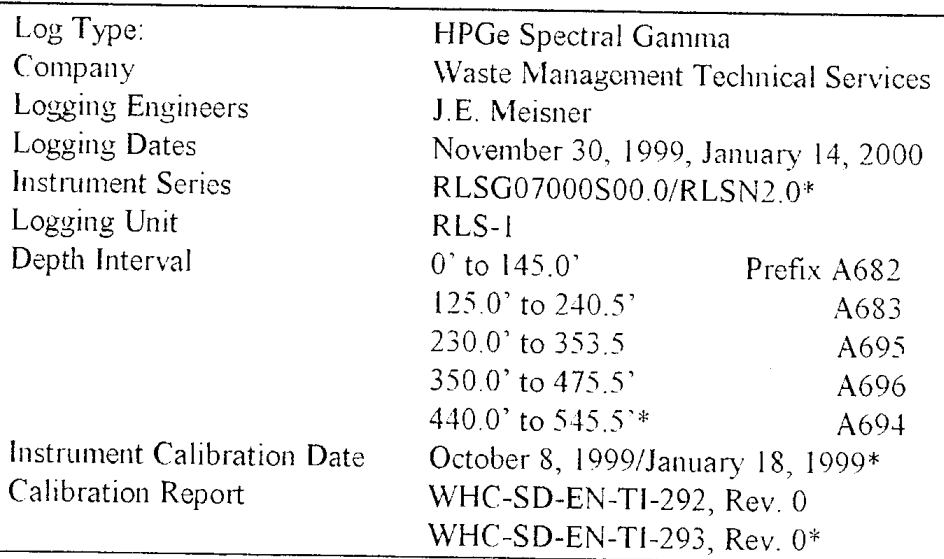

"Bottom of the borehole was logged with a sodium iodide detector designated RLSN2.0

\section{Analysis Information}

$\begin{array}{ll}\text { Company } & \text { Waste Management Technical Services } \\ \text { Analyst } & \text { Steven Kos } \\ \text { Date } & \text { March 13,2000 } \\ \text { Depth Reference } & \text { Ground Surface }\end{array}$

Notes HGPe spectral gamma and sodium iodide logging tools were utilized to log this borehole. Measurements were acquired with both of these tools at 0.5 -ft depth increments at a logging speed of $1.0 \mathrm{ft}$ per minute. 


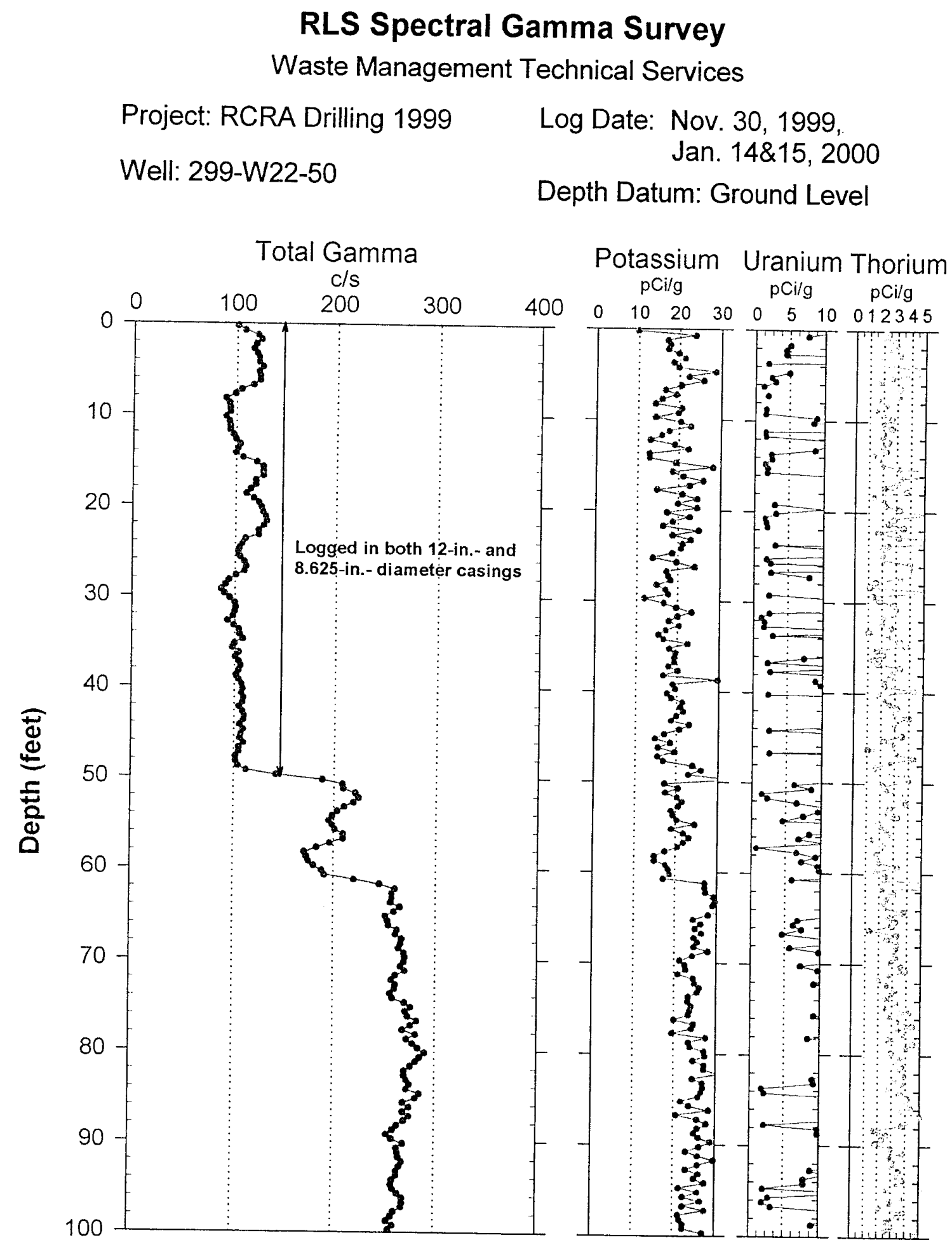




\section{RLS Spectral Gamma Survey \\ Waste Management Technical Services}

Project: RCRA Drilling 1999

Well: $299-W 22-50$
Log Date: Nov. 30, 1999, Jan. 14\&15, 2000

Depth Datum: Ground Level

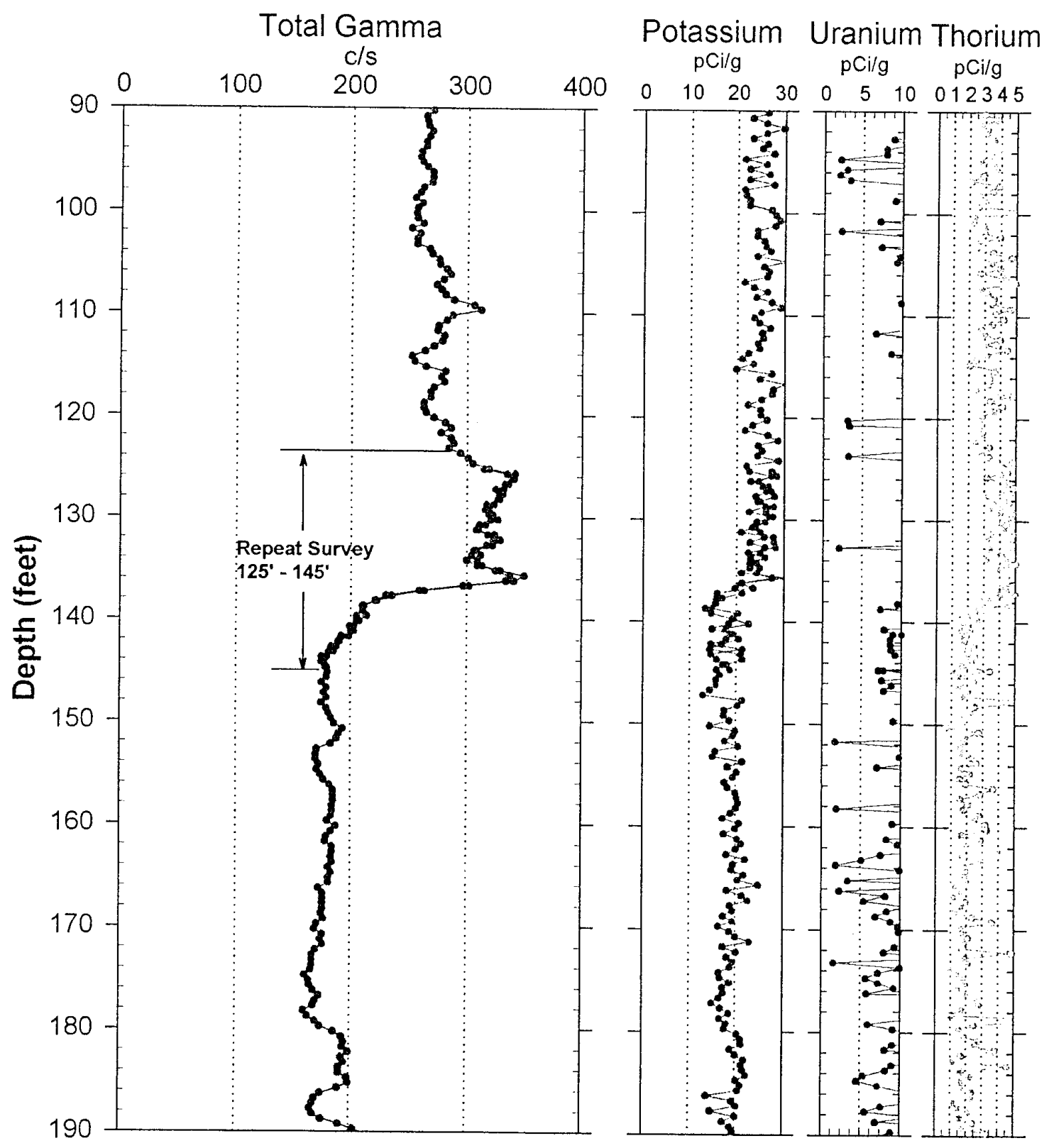




\section{KLS Spectral Gamma Survey \\ Waste Management Technical Services}

Project: RCRA Drilling 1999

Well: 299-W22-50

Log Date: Nov. 30, 1999

Jan.14\&15, 2000

Depth Datum: Ground Level

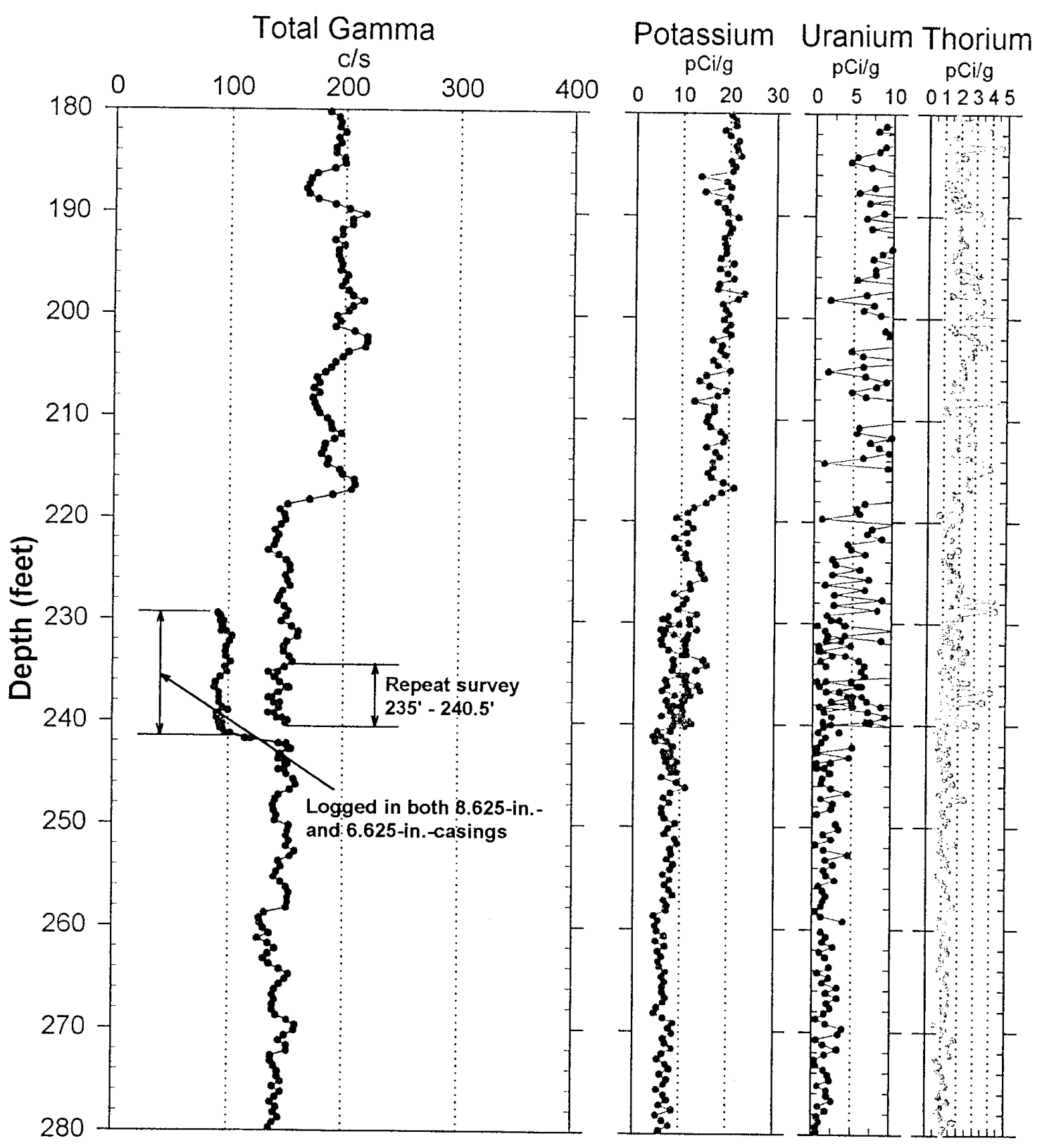




\section{RLS Neutron-Neutron Moisture Survey \\ Waste Management Technical Services}

\section{LOG HEADER}

Project: RCRA drilling 1999

Well: $299-W 22-50$

\section{Borehole Information}

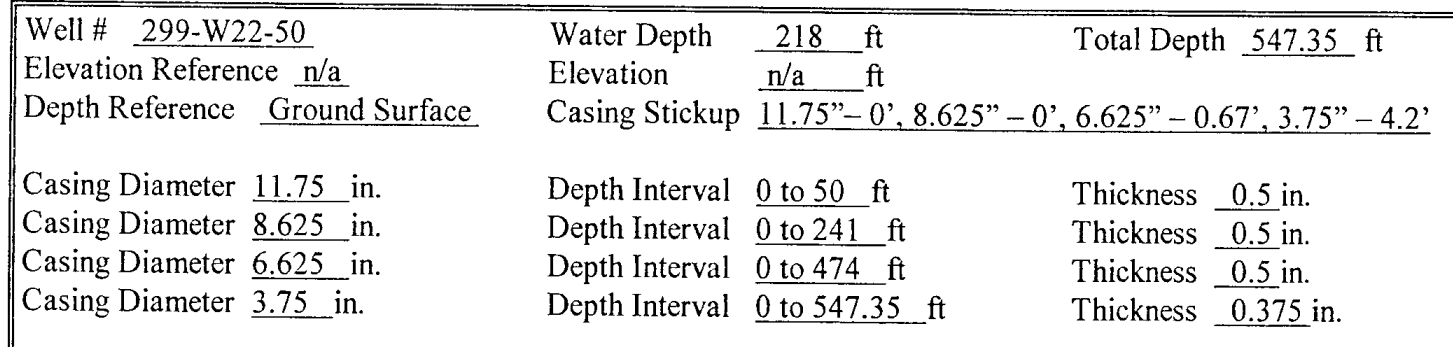

\section{Logging Information}

\begin{tabular}{|c|c|}
\hline Log Type: & Neutron-Neutron Moisture \\
\hline Company & Waste Management Technical Services \\
\hline Logging Engineers & J.E. Meisner \\
\hline Instrument Series & $\overline{\operatorname{RLSM} 100.0}$ \\
\hline Logging Date & November 30,1999 \\
\hline Logging Unit & RLS-1 \\
\hline Depth Interval & $\begin{array}{l}0^{\prime} \text { to } 150^{\prime} \\
145^{\circ} \text { to } 218.3^{\prime}\end{array}$ \\
\hline Instrument Calibration Date & May 13, 1999 \\
\hline Calibration Report & WHC-SD-EN-TI-306, Rev. 0 \\
\hline
\end{tabular}

Analysis Information

$\begin{array}{ll}\text { Company } & \text { Waste Management Technical Services } \\ \text { Analyst } & \text { Steven Kos } \\ \text { Date } & \text { December } 16,1999 \\ \text { Depth Reference } & \text { Ground Surface }\end{array}$

Notes The moisture measurements were acquired at 0.250 -ft depth intervals at a logging speed of $1.0 \mathrm{ft}$ per minute. 


\title{
Neutron-Neutron Moisture Survey
}

\author{
Waste Management Technical Services
}

Project: RCRA Drilling 1999 Log Date: November 30, 1999 Borehole: 299-W22-50 Depth Datum: Ground Level

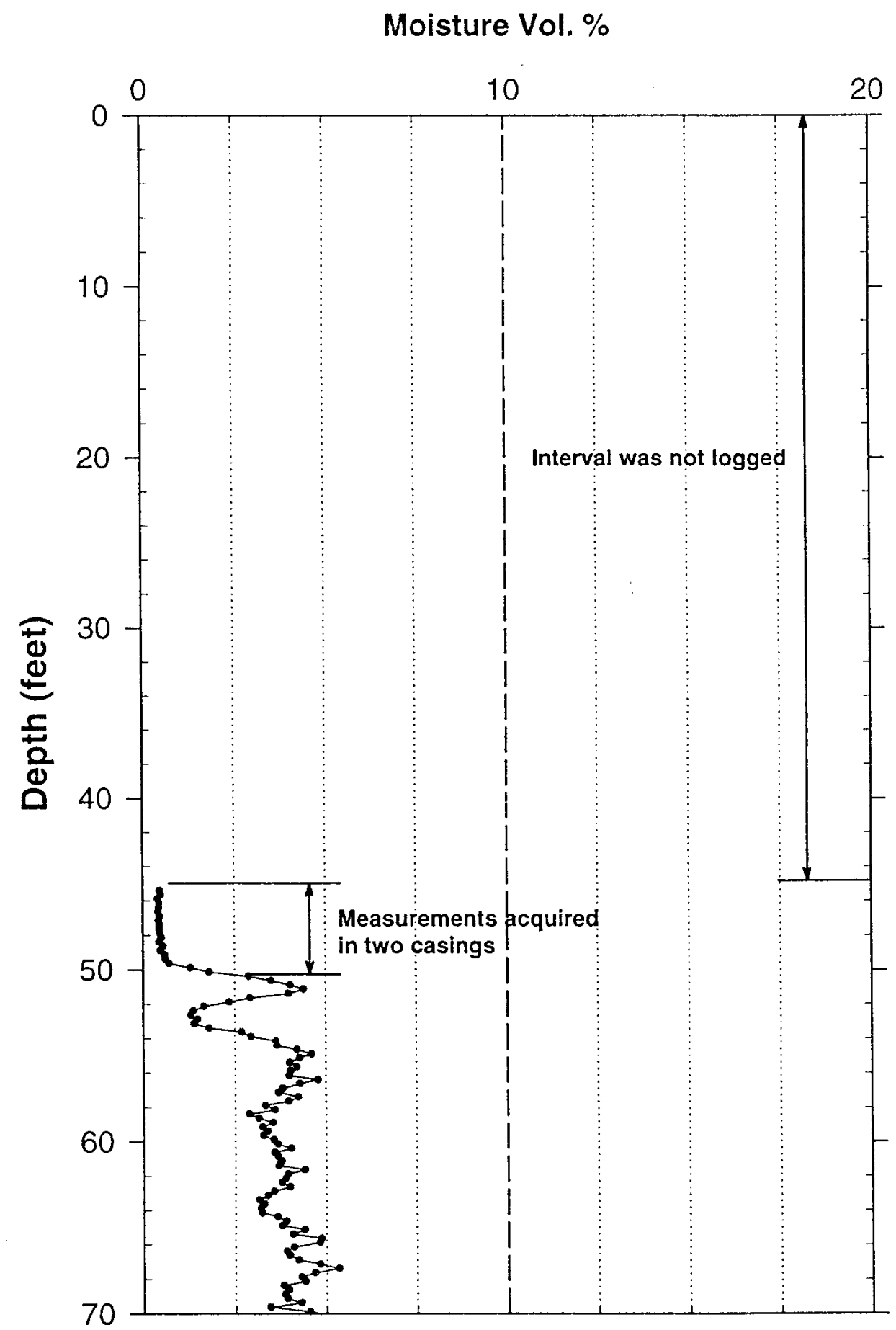




\section{Neutron-Neutron Moisture Survey \\ Waste Management Technical Services}

Project: RCRA Drilling 1999

Borehole: 299-W22-50
Log Date: November 30, 1999

Depth Datum: Ground Level

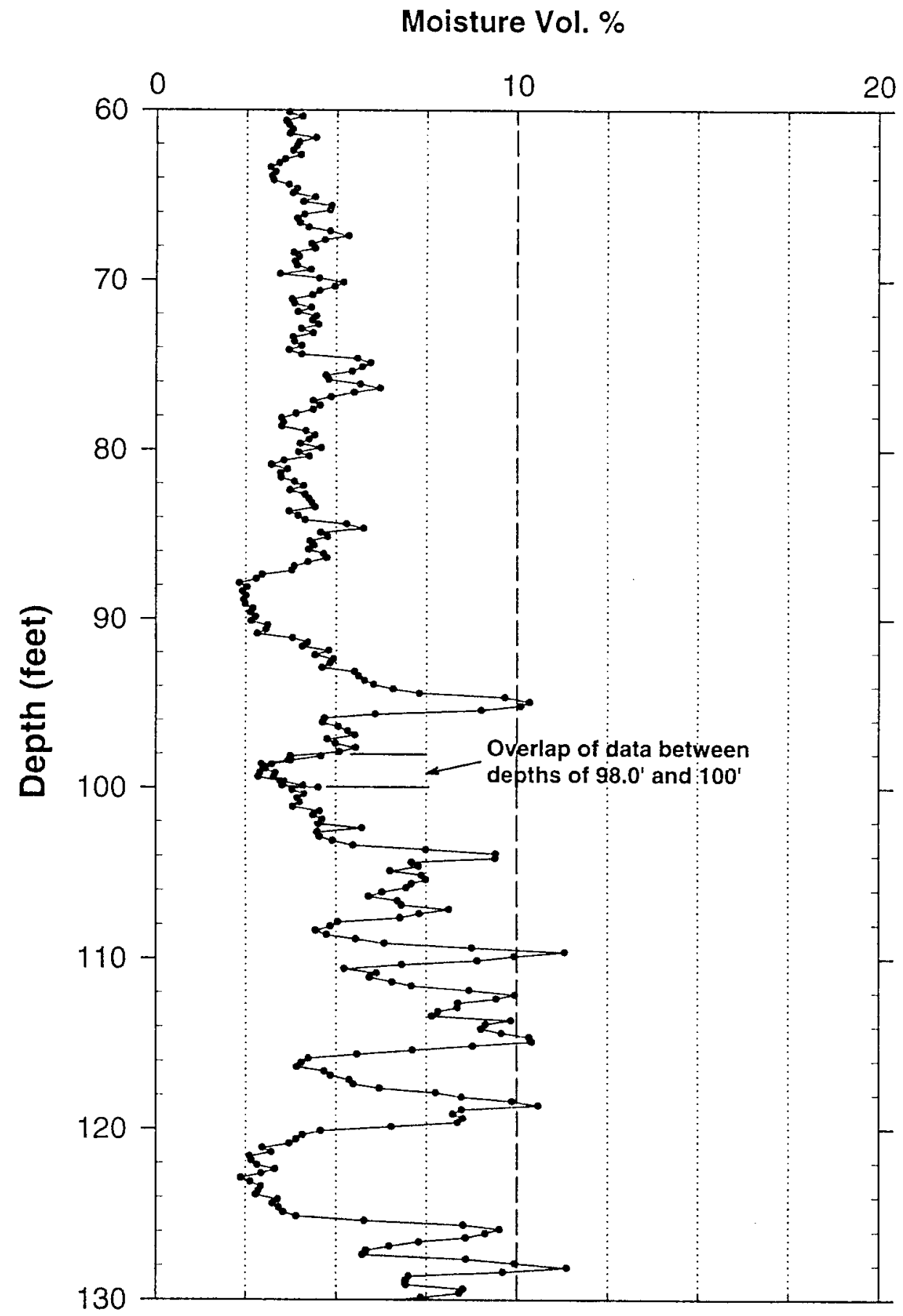

C.16 


\section{RLS Neutron-Neutron Moisture}

Waste Management Technical Services

Project: RCRA Drilling 1999 Log Date: November 30,1999 Borehole: 299-W22-50 Depth Datum: Ground Level

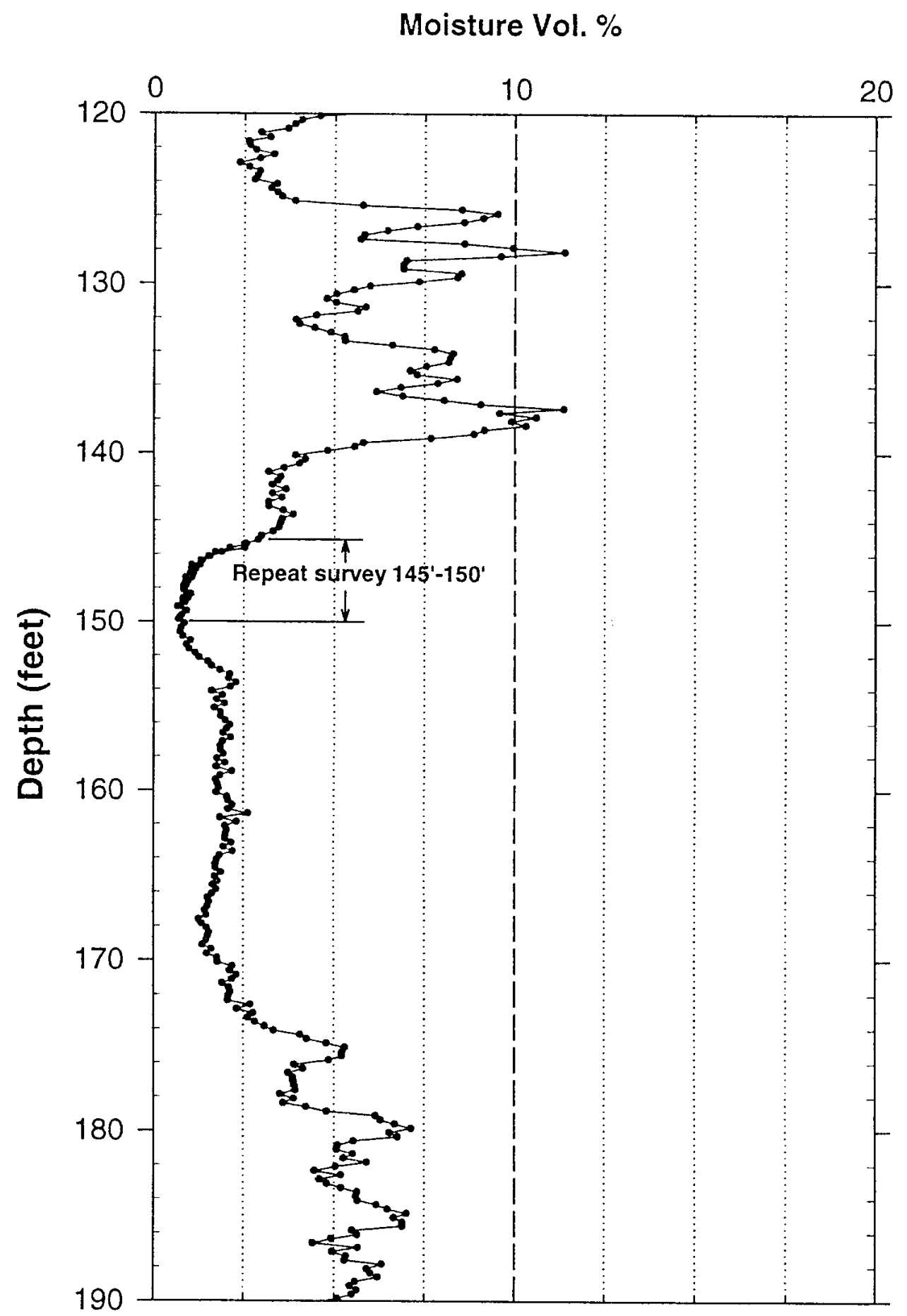




\section{Neutron-Neutron Moisture Survey}

Waste Management Technical Services

Project: RCRA Drilling 1999 Log Date: November 8,1999 Borehole: 299-W22-50 Depth Datum: Ground Level

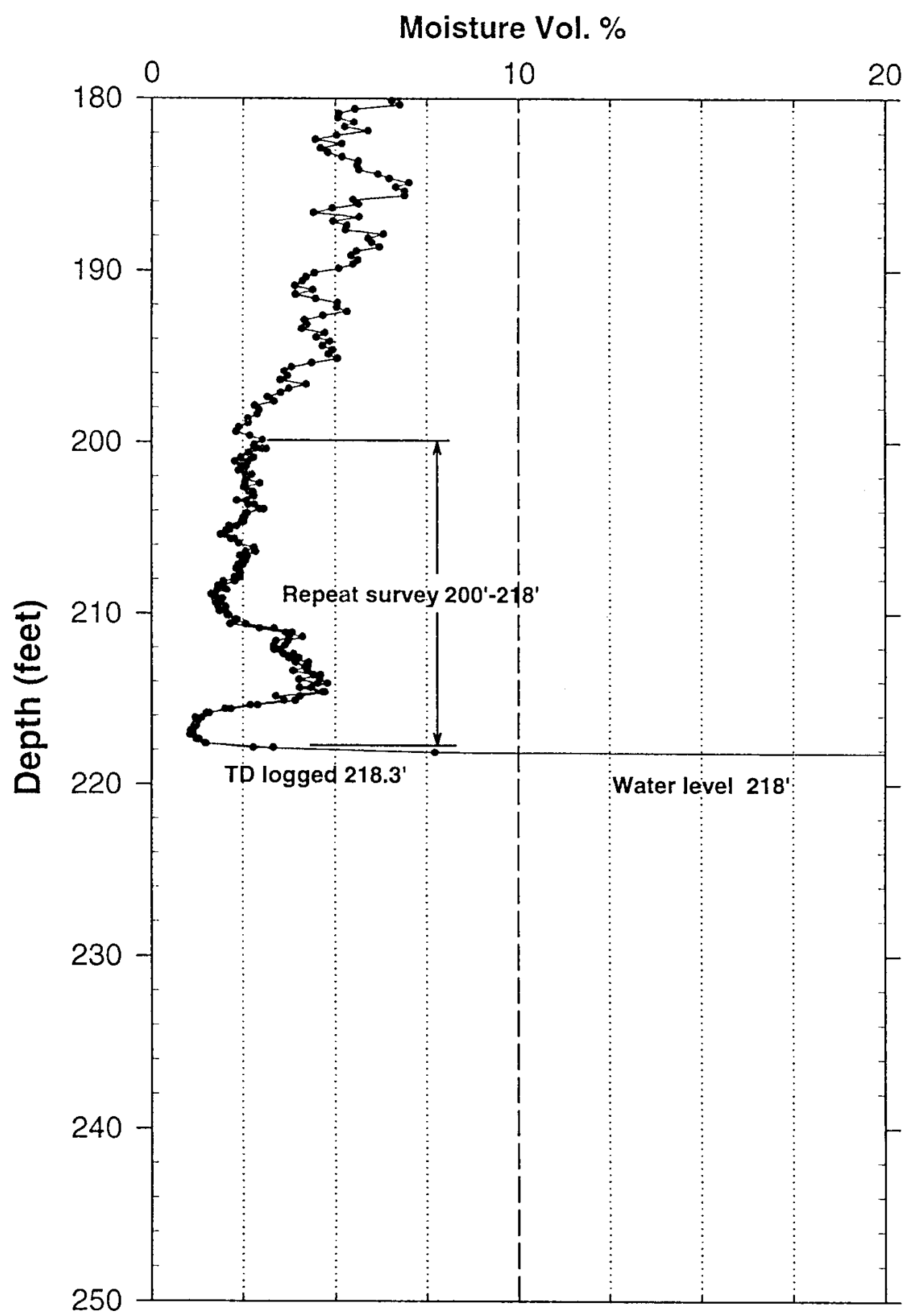


Appendix D

Particle-Size Results from Seven Boreholes in Vicinity of the S-SX Tank Farm 


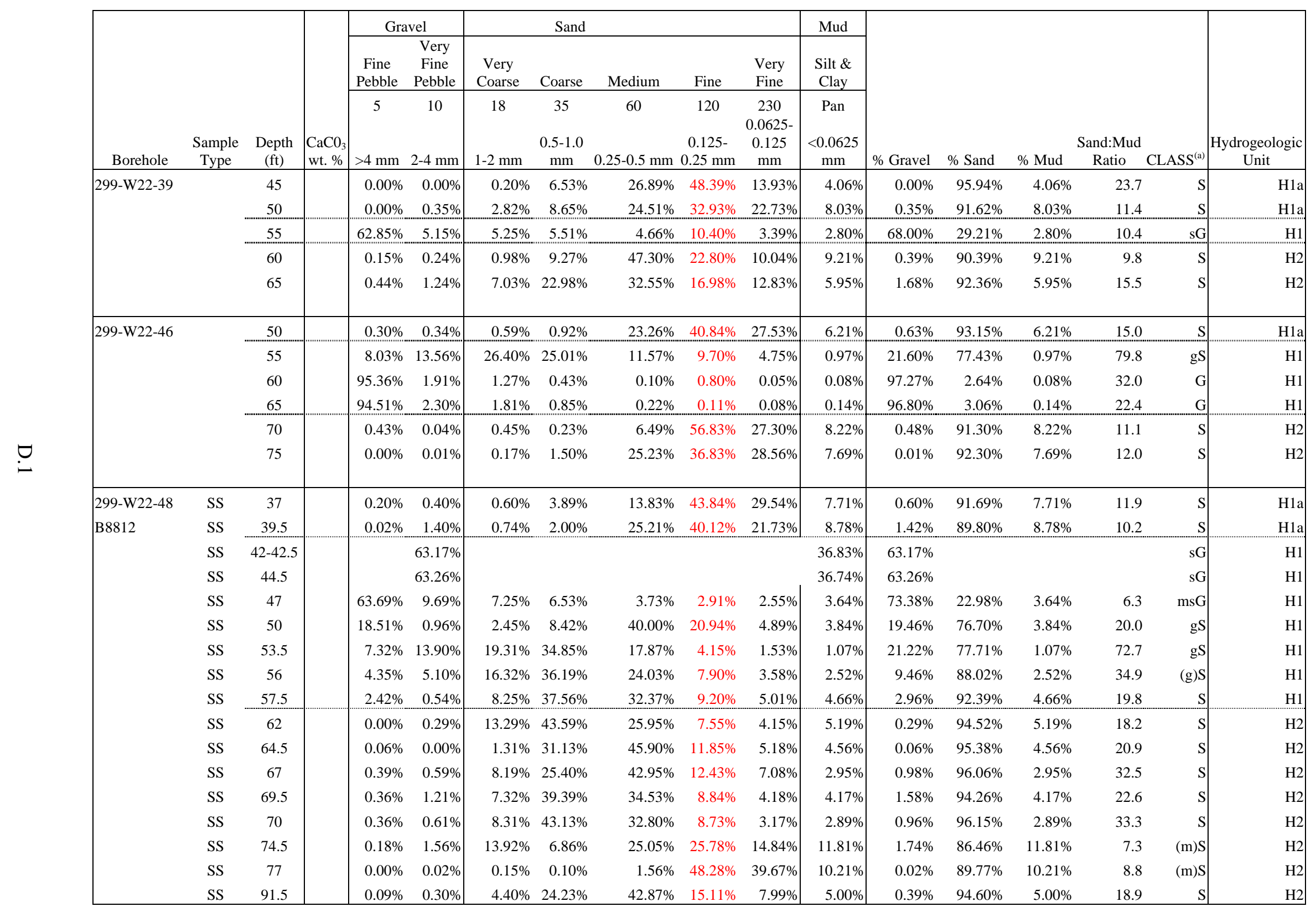




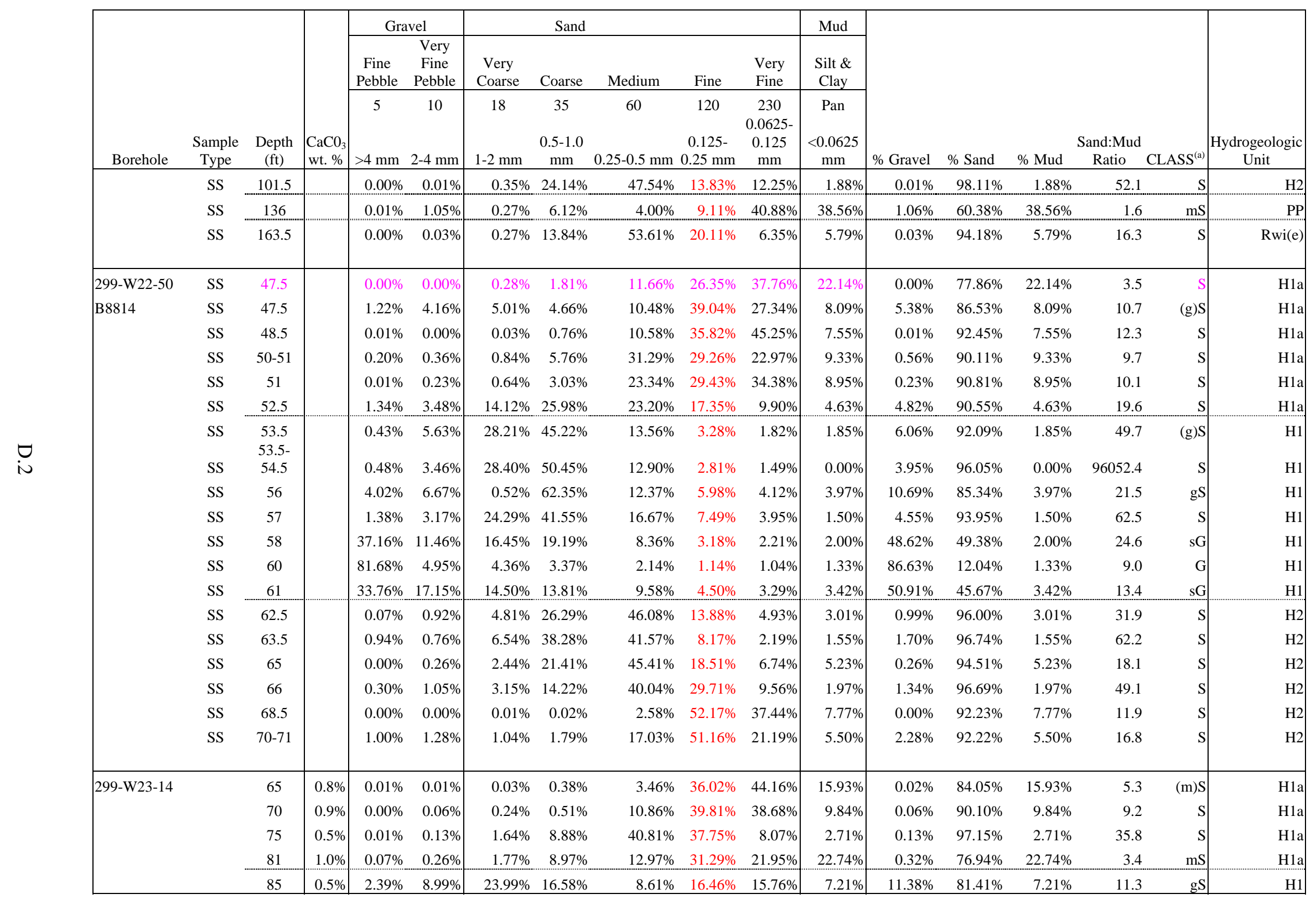




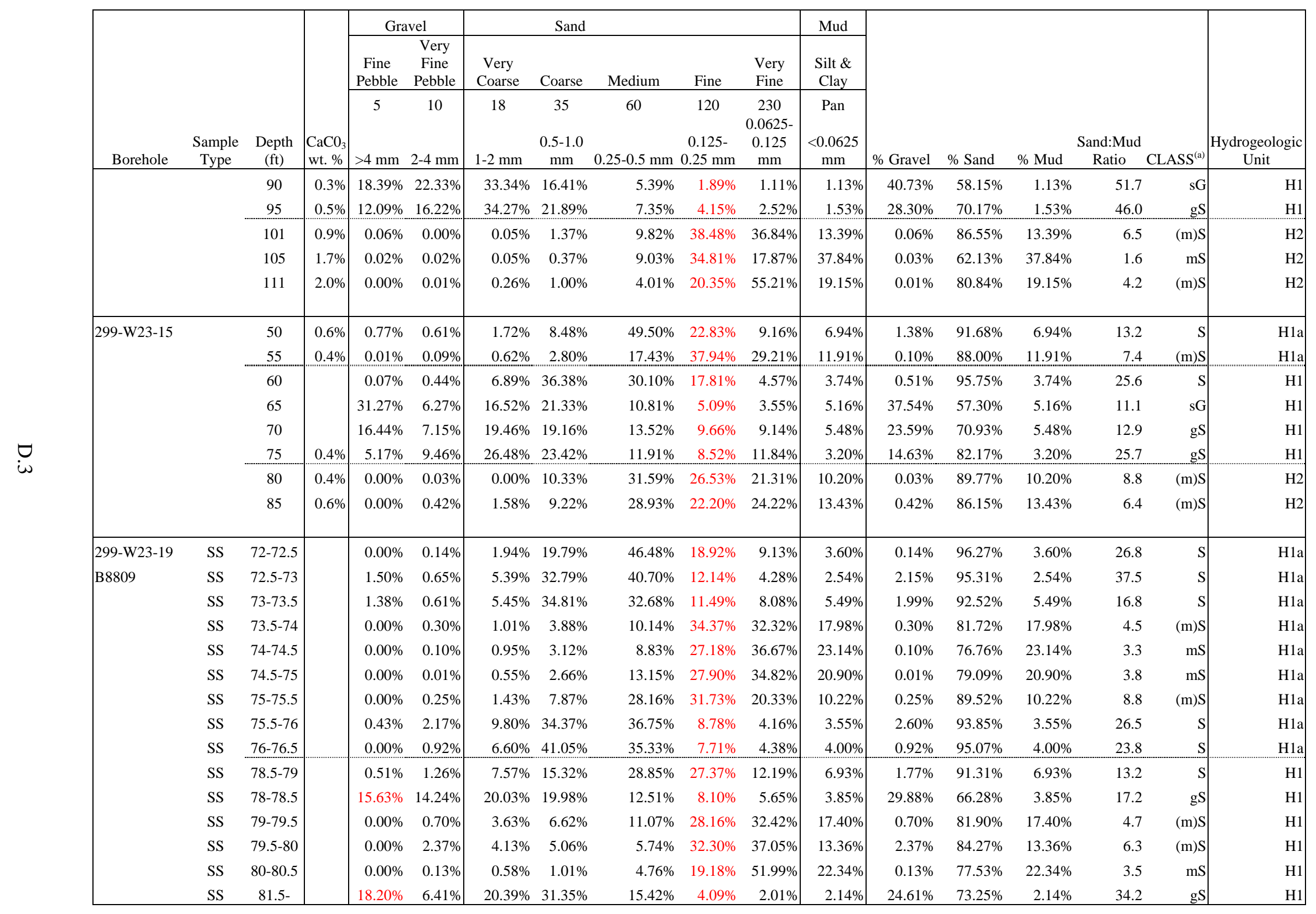




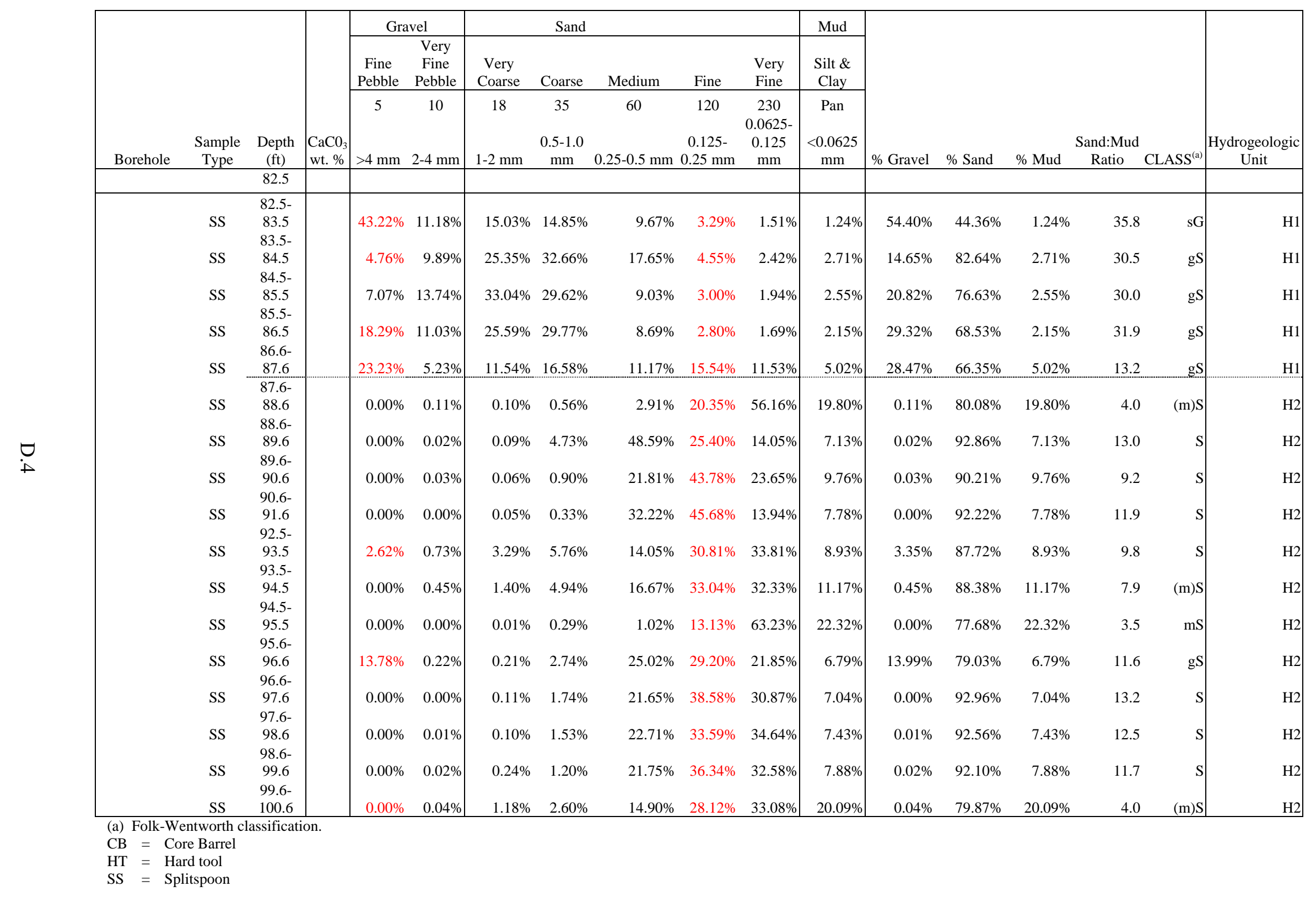




\section{Appendix E}

Inventory of Core Sleeves from Borehole 299-W22-48 
LRB 57096

299-W22-48

BOREHOLE B8812 SAMPLE INVENTORY

STORAGE LOCATION IN BLDG 3720/rm 608

\begin{tabular}{|c|c|c|}
\hline SAMPLE \# & Depth (ft) & Container \\
\hline B8812-0.5 & $0.5-1$ & 6" Liner \\
\hline B8812-1 & $1-1.5$ & 6" Liner \\
\hline B8812-1.5 & $1.5-2$ & 6" Liner \\
\hline B8812-3 & $3-3.5$ & 6" Liner \\
\hline B8812-3.5 & $3.5-4$ & 6" Liner \\
\hline B8812-4 & $4-4.5$ & 6" Liner \\
\hline B8812-4.5 & $4.5-5$ & 6" Liner \\
\hline B8812-5.5 & $5.5-6$ & 6" Liner \\
\hline B8812-6 & $6-6.5$ & 6" Liner \\
\hline B8812-6.5 & $6.5-7$ & 6" Liner \\
\hline B8812-7 & $7-7.5$ & 6" Liner \\
\hline B8812-8 & $8-8.5$ & 6" Liner \\
\hline B8812-8.5 & $8.5-9$ & 6" Liner \\
\hline B8812-9 & $9-9.5$ & 6" Liner \\
\hline B8812-9.5 & $9.5-10$ & 6" Liner \\
\hline B8812-10.5 & $10.5-11$ & 6" Liner \\
\hline B8812-11 & $11-11.5$ & 6" Liner \\
\hline B8812-11.5 & $11.5-12$ & 6" Liner \\
\hline B8812-12 & $12-12.5$ & 6" Liner \\
\hline B8812-13 & $13-13.5$ & 6" Liner \\
\hline B8812-13.5 & $13.5-14$ & 6" Liner \\
\hline B8812-14 & $14-14.5$ & 6" Liner \\
\hline B8812-14.5 & $14.5-15$ & 6" Liner \\
\hline B8812-15.5 & $15.5-16$ & 6" Liner \\
\hline B8812-16 & $16-16.5$ & 6" Liner \\
\hline B8812-16.5 & $16.5-17$ & 6" Liner \\
\hline B8812-17 & $17-17.5$ & 6" Liner \\
\hline B8812-18 & $18-18.5$ & 6" Liner \\
\hline B8812-18.5 & $18.5-19$ & 6" Liner \\
\hline B8812-19 & $19-19.5$ & 6" Liner \\
\hline B8812-19.5 & $19.5-20$ & 6" Liner \\
\hline B8812-20.5 & $20.5-21$ & 6" Liner \\
\hline
\end{tabular}

\begin{tabular}{|c|c|c|}
\hline SAMPLE \# & Depth (ft) & Container \\
\hline B8812-49 & $49-49.5$ & 6" Liner \\
\hline B8812-49.5 & $49.5-50$ & 6" Liner \\
\hline B8812-50 & $50-50.5$ & 6" Liner \\
\hline B8812-51 & $51-51.5$ & 6" Liner \\
\hline B8812-51.5 & $51.5-52$ & 6" Liner \\
\hline B8812-52 & $52-52.5$ & 6" Liner \\
\hline B8812-52.5 & 52.5-53 & 6" Liner \\
\hline B8812-53.5 & $53.5-54$ & 6" Liner \\
\hline B8812-54 & $54-54.5$ & 6" Liner \\
\hline B8812-54.5 & 54.5-55 & 6" Liner \\
\hline B8812-55 & 55-55.5 & 6" Liner \\
\hline B8812-56 & $56-56.5$ & 6" Liner \\
\hline B8812-56.5 & 56.5-57 & 6" Liner \\
\hline B8812-57 & $57-57.5$ & 6" Liner \\
\hline B8812-57.5 & $57.5-58$ & 6" Liner \\
\hline B8812-58.5 & 58.8-59 & 6" Liner \\
\hline B8812-60.5 & $60.5-61$ & 6" Liner \\
\hline B8812-61 & $61-61.5$ & 6" Liner \\
\hline B8812-61.5 & $61.5-62$ & 6" Liner \\
\hline B8812-62 & $62-62.5$ & 6" Liner \\
\hline B8812-63 & 63-63.5 & 6" Liner \\
\hline B8812-63.5 & 63.5-64 & 6" Liner \\
\hline B8812-64 & $64-64.5$ & 6" Liner \\
\hline B8812-64.5 & $64.5-65$ & 6" Liner \\
\hline B8812-65.5 & $65.5-66$ & 6" Liner \\
\hline B8812-66 & $66-66.5$ & 6" Liner \\
\hline B8812-66.5 & $66.5-67$ & 6" Liner \\
\hline B8812-67 & $67-67.5$ & 6" Liner \\
\hline B8812-68 & $68-68.5$ & 6" Liner \\
\hline B8812-68.5 & $68.5-69$ & 6" Liner \\
\hline B8812-69 & 69-69.5 & 6" Liner \\
\hline B8812-69.5 & 69.5-70 & 6" Liner \\
\hline
\end{tabular}

\begin{tabular}{|c|c|c|}
\hline SAMPLE \# & Depth $(\mathrm{ft})$ & Container \\
\hline B8812-110.5 & $110.5-111.5$ & 12" Liner \\
\hline B8812-111.5 & $111.5-112.5$ & 12" Liner \\
\hline B8812-113 & $113-114$ & 12" Liner \\
\hline B8812-114 & 114-115 & 12" Liner \\
\hline B8812-115.5 & $115.5-116.5$ & 12" Liner \\
\hline B8812-116.5 & $116.5-117.5$ & 12" Liner \\
\hline B8812-118 & $\begin{array}{l}118-119 \\
\end{array}$ & 12" Liner \\
\hline B8812-119 & $119-120$ & 12" Liner \\
\hline B8812-120.5 & $120.5-121.5$ & 12" Liner \\
\hline B8812-121.5 & $121.5-122.5$ & 12" Liner \\
\hline B8812-123 & $123-124$ & 12" Liner \\
\hline B8812-124 & 124-125 & 12" Liner \\
\hline B8812-125.5 & $125.5-126.5$ & 12" Liner \\
\hline B8812-126.5 & $126.5-127.5$ & 12" Liner \\
\hline B8812-128 & $128-129$ & 12" Liner \\
\hline B8812-129 & $129-130$ & 12" Liner \\
\hline B8812-130.5 & $130.5-131.5$ & 12" Liner \\
\hline B8812-131.5 & $131.5-132.5$ & 12" Liner \\
\hline B8812-133 & 133-134 & 12" Liner \\
\hline B8812-134 & 134-135 & 12" Liner \\
\hline B8812-135 & $135-136$ & 12" Liner \\
\hline B8812-136 & 136-137 & 12" Liner \\
\hline B8812-137.5 & $137.5-138.5$ & 12" Liner \\
\hline B8812-138.5 & $138.5-139.5$ & 12" Liner \\
\hline B8812-140 & 140-141 & 12" Liner \\
\hline B8812-141 & $141-142$ & 12" Liner \\
\hline B8812-142.5 & $142.5-143.5$ & 12" Liner \\
\hline B8812-143.5 & $143.5-144.5$ & 12" Liner \\
\hline B8812-145 & $145-146$ & 12" Liner \\
\hline B8812-146 & 146-147 & 12" Liner \\
\hline B8812-147.5 & $147.5-148.5$ & 12" Liner \\
\hline B8812-148.5 & $148.5-149.5$ & $12 "$ Liner \\
\hline
\end{tabular}


LRB 57096

299-W22-48

BOREHOLE B8812 SAMPLE INVENTORY

STORAGE LOCATION IN BLDG 3720/rm 608

\begin{tabular}{|c|c|c|}
\hline B8812-21 & $21-21.5$ & 6" Liner \\
\hline B8812-21.5 & $21.5-22$ & $6 "$ Liner \\
\hline B8812-22 & $22-22.5$ & $6 "$ Liner \\
\hline B8812-23 & $23-23.5$ & $6 "$ Liner \\
\hline B8812-23.5 & $23.5-24$ & $6 "$ Liner \\
\hline B8812-24 & $24-24.5$ & $6 "$ Liner \\
\hline B8812-24.5 & $24.5-25$ & $6 "$ Liner \\
\hline B8812-25.5 & $25.5-26$ & $6 "$ Liner \\
\hline B8812-26 & $26-26.5$ & $6 "$ Liner \\
\hline B8812-26.5 & $26.5-27$ & $6 "$ Liner \\
\hline B8812-27 & $27-27.5$ & $6 "$ Liner \\
\hline B8812-28 & $28-28.5$ & $6 "$ Liner \\
\hline B8812-28.5 & $28.5-29$ & $6 "$ Liner \\
\hline B8812-29 & $29-29.5$ & $6 "$ Liner \\
\hline B8812-29.5 & $29.5-30$ & $6 "$ Liner \\
\hline B8812-30.5 & $30.5-31$ & $6 "$ Liner \\
\hline B8812-31 & $31-31.5$ & $6 "$ Liner \\
\hline B8812-31.5 & $31.5-32$ & $6 "$ Liner \\
\hline B8812-32 & $32-32.5$ & $6 "$ Liner \\
\hline B8812-33 & $33-33.5$ & $6 "$ Liner \\
\hline B8812-33.5 & $33.5-34$ & $6 "$ Liner \\
\hline B8812-34 & $34-34.5$ & $6 "$ Liner \\
\hline B8812-34.5 & $34.5-35$ & $6 "$ Liner \\
\hline B8812-35.5 & $35.5-36$ & $6 "$ Liner \\
\hline B8812-36 & $36-36.5$ & $6 "$ Liner \\
\hline B8812-36.5 & $36.5-37$ & $6 "$ Liner \\
\hline B8812-37 & $37-37.5$ & $6 "$ Liner \\
\hline B8812-38 & $38-38.5$ & $6 "$ Liner \\
\hline B8812-38.5 & $38.5-39$ & $6 "$ Liner \\
\hline B8812-39 & $39-39.5$ & $6 "$ Liner \\
\hline B8812-39.5 & $39.5-40$ & $6 "$ Liner \\
\hline B8812-40.5 & $40.5-41$ & $6 "$ Liner \\
\hline B8812-41 & $41-41.5$ & $6 "$ Liner \\
\hline & & \\
\hline & &
\end{tabular}

\begin{tabular}{|c|c|c|}
\hline B8812-70.5 & $70.5-71$ & 6" Liner \\
\hline B8812-71 & $71-71.5$ & 6" Liner \\
\hline B8812-71.5 & 71.5-72 & 6" Liner \\
\hline B8812-72 & $72-72.5$ & 6" Liner \\
\hline B8812-73 & $73-73.5$ & 6" Liner \\
\hline B8812-73.5 & 73.5-74 & 6" Liner \\
\hline B8812-74 & $74-74.5$ & 6" Liner \\
\hline B8812-74.5 & $74.5-76$ & 6" Liner \\
\hline B8812-75.5 & $75.5-76$ & 6" Liner \\
\hline B8812-76 & 76-76.5 & 6" Liner \\
\hline B8812-76.5 & $76.5-77$ & 6" Liner \\
\hline B8812-77 & $77-77.5$ & 6" Liner \\
\hline B8812-78 & $78-78.5$ & 6" Liner \\
\hline B8812-78.5 & 78.5-79 & 6" Liner \\
\hline B8812-79 & $79-79.5$ & 6" Liner \\
\hline B8812-79.5 & $79.5-80$ & 6" Liner \\
\hline B8812-80.5 & $80.5-81$ & 6" Liner \\
\hline B8812-81 & $81-81.5$ & 6" Liner \\
\hline B8812-81.5 & $81.5-82$ & 6" Liner \\
\hline B8812-82 & $82-82.5$ & 6" Liner \\
\hline B8812-83 & $83-83.5$ & 6" Liner \\
\hline B8812-83.5 & $83.5-84$ & 6" Liner \\
\hline B8812-84 & $84-84.5$ & 6" Liner \\
\hline B8812-84.5 & $84.5-85$ & 6" Liner \\
\hline B8812-85.5 & $85.5-86.5$ & 12" Liner \\
\hline B8812-86.5 & $86.5-87.5$ & 12" Liner \\
\hline B8812-88 & $88-89$ & 12" Liner \\
\hline B8812-89 & $89-90$ & 12" Liner \\
\hline B8812-90.5 & $90.5-91.5$ & 12" Liner \\
\hline B8812-91.5 & $91.5-92.5$ & 12" Liner \\
\hline B8812-93 & 93-94 & 12" Liner \\
\hline B8812-94 & $94-95$ & 12" Liner \\
\hline B8812-95.5 & $95.5-96.5$ & 12" Liner \\
\hline
\end{tabular}

\begin{tabular}{|c|c|c|}
\hline B8812-150 & $150-151$ & 12" Liner \\
\hline B8812-151 & $151-152$ & 12" Liner \\
\hline B8812-152.5 & $152.5-153.5$ & 12" Liner \\
\hline B8812-153.5 & $153.5-154.5$ & $12 "$ Liner \\
\hline B8812-155 & $155-156$ & 12" Liner \\
\hline B8812-154 & $156-157$ & 12" Liner \\
\hline B8812-157.5 & $157.5-158.5$ & 12" Liner \\
\hline B8812-158.5 & $158.5-159$ & 12" Liner \\
\hline B8812-160 & 160-161 & 12" Liner \\
\hline B8812-161 & $161-162$ & 12" Liner \\
\hline B8812-162.5 & $162.5-163.5$ & 12" Liner \\
\hline B8812-163.5 & $163.5-164.5$ & 12" Liner \\
\hline B8812-165 & $165-166$ & 12" Liner \\
\hline B8812-166 & $166-167$ & 12" Liner \\
\hline B8812-167.5 & $167.5-168.5$ & 12" Liner \\
\hline B8812-168.5 & $168.5-169.5$ & 12" Liner \\
\hline B8812-170 & 170-171 & 12" Liner \\
\hline B8812-171 & $171-172$ & 12" Liner \\
\hline B8812-172.5 & $172.5-173.5$ & 12" Liner \\
\hline B8812-173.5 & $173.5-174$ & 12" Liner \\
\hline B8812-175 & 175-176 & 12" Liner \\
\hline B8812-176 & $176-177$ & 12" Liner \\
\hline B8812-177.5 & $177.5-178.5$ & 12" Liner \\
\hline B8812-178.5 & $178.5-179.5$ & 12" Liner \\
\hline B8812-181 & 181-182 & 12" Liner \\
\hline B8812-182 & $182-183$ & 12" Liner \\
\hline B8812-183.5 & $183.5-184.5$ & 12" Liner \\
\hline B8812-184.5 & $184.5-185.5$ & 12" Liner \\
\hline B8812-186 & 186-187 & 12" Liner \\
\hline B8812-187 & $187-188$ & 12" Liner \\
\hline B8812-188.5 & $188.5-189.5$ & 12" Liner \\
\hline B8812-189.5 & $189.5-190.5$ & 12" Liner \\
\hline B8812-192 & 192-193 & 12" Liner \\
\hline
\end{tabular}


LRB 57096

299-W22-48

\section{BOREHOLE B8812 SAMPLE INVENTORY}

STORAGE LOCATION IN BLDG 3720/rm 608

\begin{tabular}{|c|c|c|}
\hline B8812-41.5 & $41.5-42$ & 6" Liner \\
\hline B8812-42 & $42-42.5$ & 6" Liner \\
\hline B8812-43 & $43-43.5$ & 6" Liner \\
\hline B8812-43.5 & $43.5-44$ & 6" Liner \\
\hline B8812-44 & $44-44.5$ & 6" Liner \\
\hline B8812-44.5 & $44.5-45$ & $6 "$ Liner \\
\hline B8812-46 & $46-46.5$ & $6 "$ Liner \\
\hline B8812-46.5 & $46.5-47$ & $6 "$ Liner \\
\hline B8812-47 & $47-47.5$ & 6 " Liner \\
\hline B8812-47.5 & $47.5-48$ & $6 "$ Liner \\
\hline B8812-48.5 & $48.5-49$ & $6 "$ Liner \\
\hline
\end{tabular}

\begin{tabular}{|c|c|c|}
\hline B8812-96.5 & $96.5-97.5$ & 12 " Liner \\
\hline B8812-98 & $98-99$ & 12 " Liner \\
\hline B8812-99 & $99-100$ & $12 "$ Liner \\
\hline B8812-100.5 & $100.5-101.5$ & 12 " Liner \\
\hline B8812-101.5 & $101.5-102.5$ & 12 " Liner \\
\hline B8812-103 & $103-104$ & 12 " Liner \\
\hline B8812-104 & $104-105$ & $12 "$ Liner \\
\hline B8812-105.5 & $105.5-106.5$ & $12 "$ Liner \\
\hline B8812-106.5 & $106.5-107.5$ & $12^{\prime \prime}$ Liner \\
\hline B8812-108 & $108-109$ & $12 "$ Liner \\
\hline B8812-109 & $109-110$ & $12 "$ Liner \\
\hline
\end{tabular}

\begin{tabular}{|c|c|c|}
\hline B8812-195 & $195-196$ & $\begin{array}{c}2-1 \text { gal. } \\
\text { plastic }\end{array}$ \\
\hline B8812-200 & $200-201$ & $\begin{array}{c}2-1 \text { gal. } \\
\text { plastic }\end{array}$ \\
\hline B8812-205 & 205 & $\begin{array}{c}2-1 \text { gal. } \\
\text { plastic }\end{array}$ \\
\hline B8812-210 & 210 & $\begin{array}{c}2-1 \text { gal. } \\
\text { plastic }\end{array}$ \\
\hline B8812-215 & 215 & $\begin{array}{c}2-1 \text { gal. } \\
\text { plastic }\end{array}$ \\
\hline B8812-220 & 220 & $\begin{array}{c}2-1 \text { gal. } \\
\text { plastic }\end{array}$ \\
\hline B8812-225 & $225-226$ & $\begin{array}{c}3-1 \text { gal. } \\
\text { plastic }\end{array}$ \\
\hline B8812-230 & 230 & $\begin{array}{c}2-1 \text { gal. } \\
\text { plastic }\end{array}$ \\
\hline B8812-235 & $235-236$ & 12 Liner \\
\hline B8812-241 & $241-242$ & 12 " Liner \\
\hline
\end{tabular}




\section{Appendix F}

Inventory of Core Sleeves from Borehole 299-W22-50 


\section{BOREHOLE B8814 SAMPLE INVENTORY}

STORAGE LOCATION IN BLDG 3720

$299 \mathrm{~W}-22-50$

\begin{tabular}{|c|c|c|}
\hline SAMPLE \# & Depth (ft) & Container \\
\hline B8814-20 & $20.0-21.0$ & $12 "$ liner \\
\hline B8814-21 & $21.0-22.0$ & 12" liner \\
\hline B8814-22.5 & $22.5-23.5$ & $12 "$ liner \\
\hline B8814-23.5 & $23.5-24.5$ & 12" liner \\
\hline B8814-25 & $25.0-26.0$ & $12 "$ liner \\
\hline B8814-26 & $26.0-27.0$ & 12" liner \\
\hline B8814-27.5 & $27.5-28.5$ & 12" liner \\
\hline B8814-28.5 & $28.5-29.5$ & 12" liner \\
\hline B8814-30.0 & $30.0-31.0$ & 12" liner \\
\hline B8814-31 & $31.0-32.0$ & 12" liner \\
\hline B8814-32.5 & $32.5-33.5$ & 12 " liner \\
\hline B8814-33.5 & $33.5-34.5$ & 12" liner \\
\hline B8814-35.0 & $35.0-36.0$ & $12 "$ liner \\
\hline B8814-36 & $36.0-37.0$ & 12" liner \\
\hline B8814-37.5 & $37.5-38.5$ & 12 "liner \\
\hline B8814-38.5 & $38.5-39.5$ & $12 "$ liner \\
\hline B8814-40.0 & $40.0-41.0$ & $12 "$ liner \\
\hline B8814-41 & $41.0-42.0$ & 12 " liner \\
\hline B8814-42.5 & $42.5-43.5$ & $12 "$ liner \\
\hline B8814-43.5 & $43.5-44.5$ & 12" liner \\
\hline B8814-45.0 & $45.0-46.0$ & 12" liner \\
\hline B8814-46.0 & $46.0-47.0$ & 12" liner \\
\hline B8814-47.5 & $47.5-48.5$ & $12 "$ liner \\
\hline B8814-48.5 & $48.5-49.5$ & $12 "$ liner \\
\hline B8814-50.0 & $50.0-51.0$ & 12" liner \\
\hline B8814-51.0 & $51.0-52.0$ & $12 "$ liner \\
\hline B8814-52.5 & $52.5-53.5$ & $12 "$ liner \\
\hline B8814-53.5 & $53.5-54.5$ & $12 "$ liner \\
\hline B8814-55.0 & $55.0-56.0$ & 12" liner \\
\hline B8814-56.0 & $56.0-57.0$ & 12" liner \\
\hline B8814-57.0 & $57.0-58.0$ & $12 "$ liner \\
\hline B8814-58.0 & $58.0-59.0$ & 12 " liner \\
\hline
\end{tabular}

\begin{tabular}{|c|c|c|}
\hline SAMPLE \# & Depth (ft) & Container \\
\hline B8814-102.5 & $102.5-103.5$ & $12^{\prime \prime}$ liner \\
\hline B8814-103.5 & $103.5-104.5$ & $12^{\prime \prime}$ liner \\
\hline B8814-105.0 & $105.0-106.0$ & $12^{\prime \prime}$ liner \\
\hline B8814-106.0 & $106.0-107.0$ & $12^{\prime \prime}$ liner \\
\hline B8814-107.5 & $107.5-108.5$ & $12^{\prime \prime}$ liner \\
\hline B8814-108.5 & $108.5-109.5$ & $12^{\prime \prime}$ liner \\
\hline B8814-110.0 & $110.0-111.0$ & $12^{\prime \prime}$ liner \\
\hline B8814-111.0 & $111.0-112.0$ & $12^{\prime \prime}$ liner \\
\hline B8814-112.5 & $112.5-113.5$ & $12^{\prime \prime}$ liner \\
\hline B8814-113.5 & $113.5-114.5$ & $12^{\prime \prime}$ liner \\
\hline B8814-115.0 & $115.0-116.0$ & $12^{\prime \prime}$ liner \\
\hline B8814-116.0 & $116.0-117.0$ & $12^{\prime \prime}$ liner \\
\hline B8814-117.5 & $117.5-118.5$ & $12^{\prime \prime}$ liner \\
\hline B8814-118.5 & $118.5-119.5$ & $12^{\prime \prime}$ liner \\
\hline B8814-120.0 & $120.0-121.0$ & $12^{\prime \prime}$ liner \\
\hline B8814-121.0 & $121.0-122.0$ & $12^{\prime \prime}$ liner \\
\hline B8814-122.5 & $122.5-123.5$ & $12^{\prime \prime}$ liner \\
\hline B8814-123.5 & $123.5-124.5$ & $12^{\prime \prime}$ liner \\
\hline B8814-125.0 & $125.0-126.0$ & $12^{\prime \prime}$ liner \\
\hline B8814-126.0 & $126.0-127.0$ & $12^{\prime \prime}$ liner \\
\hline B8814-127.5 & $127.5-128.5$ & $12^{\prime \prime}$ liner \\
\hline B8814-128.5 & $128.5-129.5$ & $12^{\prime \prime}$ liner \\
\hline B8814-130.0 & $130.0-131.0$ & $12^{\prime \prime}$ liner \\
\hline B8814-131.0 & $131.0-132.0$ & $12^{\prime \prime}$ liner \\
\hline B8814-132.5 & $132.5-133.5$ & $12^{\prime \prime}$ liner \\
\hline B8814-133.5 & $133.5-134.5$ & $12^{\prime \prime}$ liner \\
\hline & & \\
\hline B8814-135.0 & $135.0-136.0$ & $12^{\prime \prime}$ liner \\
\hline B8814-136.0 & $136.0-137.0$ & $12^{\prime \prime}$ liner \\
\hline B8814-137.5 & $137.5-138.5$ & $12^{\prime \prime}$ liner \\
\hline B8814-138.5 & $138.5-139.5$ & $12^{\prime \prime}$ liner \\
\hline B8814-140.0 & $140.0-141.0$ & $12^{\prime \prime}$ liner \\
\hline & $141.0-142.0$ & $12^{\prime \prime}$ liner \\
\hline
\end{tabular}

\begin{tabular}{|c|c|c|}
\hline SAMPLE \# & Depth (ft) & Container \\
\hline B8814-230 & 230 & 2-1 pt. glass \\
\hline B8814-232.5 & $232.5-233.5$ & 12" liner \\
\hline B8814-235 & 235 & 2-1 pt. glass \\
\hline B8814-240 & 240 & 2-1 pt. glass \\
\hline B8814-245 & 245 & 2-1qt. glass \\
\hline B8814-250 & 250 & 2-1qt. glass \\
\hline B8814-255 & 255 & 2-1qt. glass \\
\hline B8814-260 & 260 & 2-1qt. glass \\
\hline B8814-265 & 265 & 2-1qt. glass \\
\hline B8814-270 & 270 & 2-1qt. glass \\
\hline B8814-275 & 275 & 2-1 pt. glass \\
\hline B8814-280 & 280 & 2-1 pt. glass \\
\hline B8814-285 & 285 & 2-1 pt. glass \\
\hline B8814-290 & 290 & 2-1 pt. glass \\
\hline B8814-295 & 295 & 2-1 pt. glass \\
\hline B8814-300 & 300 & 2-1 pt. glass \\
\hline B8814-305 & 305 & 2-1 pt. glass \\
\hline B8814-310 & 310 & 2-1 pt. glass \\
\hline B8814-315 & 315 & 2-1 pt. glass \\
\hline B8814-320 & 320 & 2-1 pt. glass \\
\hline B8814-325 & 325 & 2-1qt. glass \\
\hline B8814-330 & 330 & 2-1qt. glass \\
\hline B8814-335 & 335 & 4-1qt. glass \\
\hline B8814-340 & 340 & 2-1qt. glass \\
\hline B8814-345 & 345 & 2-1qt. glass \\
\hline B8814-350 & 350 & 1 pt \& 1qt \\
& & glass \\
\hline B8814-355 & 355 & 2-1qt. glass \\
\hline B8814-360 & 360 & 2-1qt. glass \\
\hline B8814-365 & 365 & 2-1qt. glass \\
\hline B8814-370 & 370 & 2-1qt. glass \\
\hline B8814-375 & 375 & 2-1qt. glass \\
\hline B8814-380 & 380 & 2-1qt. glass \\
\hline & & \\
\hline
\end{tabular}




\section{BOREHOLE B8814 SAMPLE INVENTORY}

STORAGE LOCATION IN BLDG 3720

$299 \mathrm{~W}-22-50$

\begin{tabular}{|c|c|c|}
\hline SAMPLE \# & Depth (ft) & Container \\
\hline B8814-60.0 & $60.0-61.0$ & 12" liner \\
\hline B8814-61.0 & $61.0-62.0$ & $12 "$ liner \\
\hline B8814-62.5 & $62.5-63.5$ & 12 " liner \\
\hline B8814-63.5 & $63.5-64.5$ & 12" liner \\
\hline B8814-65.0 & $65.0-66.0$ & $12 "$ liner \\
\hline B8814-66.0 & $66.0-67.0$ & 12" liner \\
\hline B8814-67.5 & $67.5-68.5$ & 12 " liner \\
\hline B8814-68.5 & $68.5-69.5$ & 12" liner \\
\hline B8814-70 & $70.0-71.0$ & 12" liner \\
\hline B8814-71 & $71.0-72.0$ & 12" liner \\
\hline B8814-72.5 & $72.5-73.5$ & $12 "$ liner \\
\hline B8814-73.5 & $73.5-74.5$ & 12" liner \\
\hline B8814-75.0 & $75.0-76.0$ & 12" liner \\
\hline B8814-76.0 & $76.0-77.0$ & 12 " liner \\
\hline B8814-77.5 & $77.5-78.5$ & 12 " liner \\
\hline B8814-78.5 & $78.5-79.5$ & 12" liner \\
\hline B8814-80.0 & $80.0-81.0$ & $12 "$ liner \\
\hline B8814-81.0 & $81.0-82.0$ & $12 "$ liner \\
\hline B8814-82.5 & $82.5-83.5$ & $12 "$ liner \\
\hline B8814-83.5 & $83.5-84.5$ & 12" liner \\
\hline B8814-85.0 & $85.0-86.0$ & 12" liner \\
\hline B8814-86.0 & $86.0-87.0$ & 12" liner \\
\hline B8814-87.5 & $87.5-88.5$ & 12" liner \\
\hline B8814-88.5 & $88.5-89.5$ & 12" liner \\
\hline B8814-90.0 & $90.0-91.0$ & 12" liner \\
\hline B8814-91.0 & $91.0-92.0$ & 12" liner \\
\hline B8814-92.5 & $92.5-93.5$ & $12 "$ liner \\
\hline B8814-93.5 & $93.5-94.5$ & $12 "$ liner \\
\hline B8814-95.0 & $95.0-96.0$ & 12 " liner \\
\hline B8814-96.0 & $96.0-97.0$ & 12" liner \\
\hline B8814-97.5 & $97.5-98.5$ & $12 "$ liner \\
\hline B8814-98.5 & $98.5-99.5$ & 12" liner \\
\hline
\end{tabular}

\begin{tabular}{|c|c|c|}
\hline SAMPLE \# & Depth $(\mathrm{ft})$ & Container \\
\hline B8814-142.5 & $142.5-143.5$ & $12 "$ liner \\
\hline B8814-143.5 & $143.5-144.5$ & 12" liner \\
\hline B8814-148.0 & $148.0-149.0$ & 12" liner \\
\hline B8814-149.0 & $149.0-150.0$ & $12 "$ liner \\
\hline B8814-150.5 & $150.5-151.5$ & 12" liner \\
\hline B8814-151.5 & $151.5-152.5$ & 12" liner \\
\hline B8814-153.0 & $153.0-154.0$ & $12 "$ liner \\
\hline B8814-154.0 & $154.0-155.0$ & $12 "$ liner \\
\hline B8814-155.5 & $155.5-156.5$ & 12 " liner \\
\hline B8814-156.5 & $156.5-157.5$ & 12" liner \\
\hline B8814-158.0 & $158.0-159.0$ & 12" liner \\
\hline B8814-159.0 & $159.0-160.0$ & 12" liner \\
\hline B8814-160.5 & $160.5-161.5$ & 12 " liner \\
\hline B8814-161.5 & $161.5-162.5$ & 12 " liner \\
\hline B8814-163.0 & $163.0-164.0$ & 12 " liner \\
\hline B8814-164.0 & $164.0-165.0$ & $12 "$ liner \\
\hline B8814-165.5 & $165.5-166.5$ & 12 " liner \\
\hline B8814-166.5 & $166.5-167.5$ & 12" liner \\
\hline B8814-168.0 & $168.0-169.0$ & 12" liner \\
\hline B8814-169.0 & $169.0-170.0$ & 12" liner \\
\hline B8814-170.5 & $170.5-171.5$ & 12 " liner \\
\hline B8814-171.5 & $171.5-172.5$ & $12 "$ liner \\
\hline B8814-173.0 & $173.0-174.0$ & $12 "$ liner \\
\hline B8814-174.0 & $174.0-175.0$ & 12" liner \\
\hline B8814-175.5 & $175.5-176.5$ & 12" liner \\
\hline B8814-176.5 & $176.5-177.0$ & 12" liner \\
\hline B8814-210 & 210 & 2-1 pt. glass \\
\hline B8814-215 & 215 & 2-1 pt. glass \\
\hline B8814-215 & 215 & 2-1 gal.plastic \\
\hline B8814-220 & 220 & 2-1 gal.plastic \\
\hline B8814-220 & 220 & 2-1 pt. glass \\
\hline B8814-221.5 & $221.5-222.5$ & $12 "$ liner \\
\hline
\end{tabular}

\begin{tabular}{|c|c|c|}
\hline SAMPLE \# & Depth (ft) & Container \\
\hline B8814-385 & 385 & 2-1qt. glass \\
\hline B8814-390 & 390 & 2-1qt. glass \\
\hline B8814-395 & 395 & 2-1qt. glass \\
\hline B8814-400 & 400 & 2-1qt. glass \\
\hline B8814-405 & 405 & 2-1qt. glass \\
\hline B8814-410 & 410 & 2-1qt. glass \\
\hline B8814-415 & 415 & 2-1qt. glass \\
\hline B8814-420 & 420 & 2-1qt. glass \\
\hline B8814-425 & 425 & 2-1qt. glass \\
\hline B8814-430 & 430 & 2-1qt. glass \\
\hline B8814-435 & 435 & 2-1qt. glass \\
\hline B8814-440 & 440 & 2-1qt. glass \\
\hline B8814-445 & 445 & 2-1qt. glass \\
\hline B8814-450 & 450 & 2-1qt. glass \\
\hline B8814-455 & 455 & 2-1qt. glass \\
\hline B8814-459 & $459-460$ & 12" liner \\
\hline B8814-460 & 460 & 2-1qt. glass \\
\hline B8814-465 & 465 & 2-1qt. glass \\
\hline B8814-475 & 475 & 2-1qt. glass \\
\hline B8814-490 & 490 & 1 pt. glass \\
\hline B8814-500 & 500 & 3-1 pt. glass \\
\hline B8814-505 & 505 & 3-1 pt. glass \\
\hline B8814-510 & 510 & 3-1 pt. glass \\
\hline B8814-515 & 515 & 3-1 pt. glass \\
\hline B8814-520 & 520 & 3-1 pt. glass \\
\hline B8814-525 & 525 & 3-1 pt. glass \\
\hline B8814-530 & 530 & 3-1 pt. glass \\
\hline B8814-535 & 535 & 3-1 pt. glass \\
\hline B8814-540 & 540 & 3-1 pt. glass \\
\hline B8814-545 & 545 & 3-1 pt. glass \\
\hline
\end{tabular}




\section{BOREHOLE B8814 SAMPLE INVENTORY}

STORAGE LOCATION IN BLDG 3720

$299 \mathrm{~W}-22-50$

\begin{tabular}{|c|r|c|}
\hline SAMPLE \# & Depth (ft) & Container \\
\hline B8814-100.0 & $100.0-101.0$ & 12 " liner \\
\hline B8814-101.0 & $101.0-102.0$ & 12 " liner \\
\hline
\end{tabular}

\begin{tabular}{|c|c|c|}
\hline SAMPLE \# & Depth (ft) & Container \\
\hline B8814-225 & 225 & 2-1 pt. glass \\
\hline B8814-228 & $228-229$ & 12 liner \\
\hline
\end{tabular}




\section{Appendix G}

Some Mineralogical Analyses of the Composite Sediment Samples 


\section{Appendix G}

\section{Some Mineralogical Analyses of the Composite Sediment Samples}

Table G.1. Semiquantification of Non-Clay Minerals in Composite Samples (wt\%)

\begin{tabular}{|l|c|c|c|c|}
\hline Sample ID & Quartz & K-Feldspar & Na-Feldspar & Calcite \\
\hline Borehole Fine Sand & 50 & 10 & 20 & nd \\
\hline Hanford Fine Sand & 80 & 10 & 20 & nd \\
\hline Hanford Coarse Sand & 55 & 5 & 15 & nd \\
\hline Ringold Sand & 30 & 5 & 5 & $<5$ \\
\hline
\end{tabular}

Table G.2. Semiquantification of Minerals in the Clay Fraction from Composite Samples (wt\%)

\begin{tabular}{|l|c|c|c|c|c|c|}
\hline Sample ID & Quartz & Feldspar & Smectite & Illite & Chlorite & Kaolinite \\
\hline Borehole Fine Sand & 5 & $<5$ & 30 & 40 & 20 & 5 \\
\hline Hanford Fine Sand & 5 & $<5$ & 30 & 15 & 15 & 10 \\
\hline Hanford Coarse Sand & 5 & $<5$ & 30 & 15 & 15 & 5 \\
\hline Ringold Sand & 10 & $<5$ & 35 & 35 & 20 & nd \\
\hline
\end{tabular}




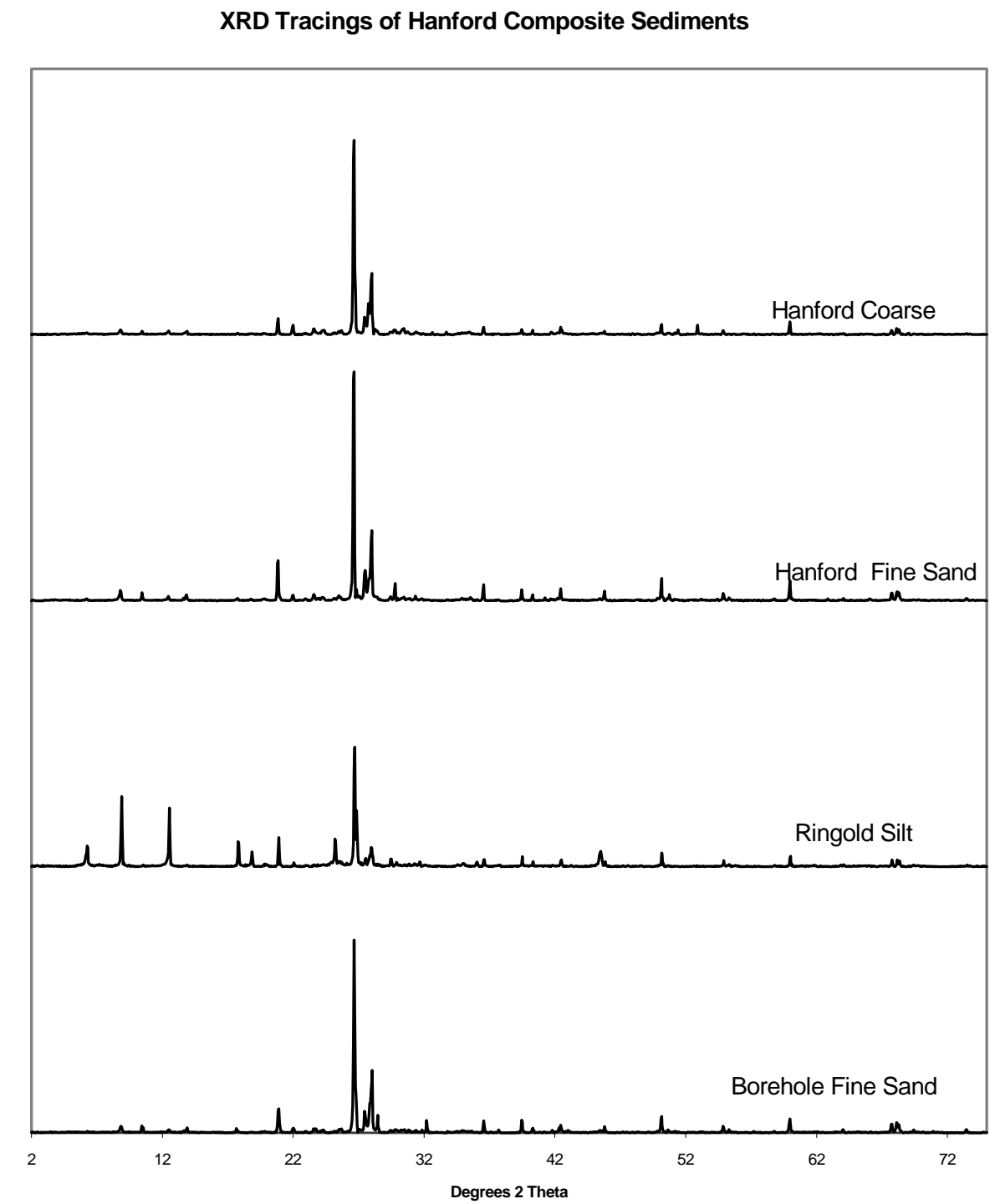

Figure G.1. Bulk Sediment XRD Patterns 


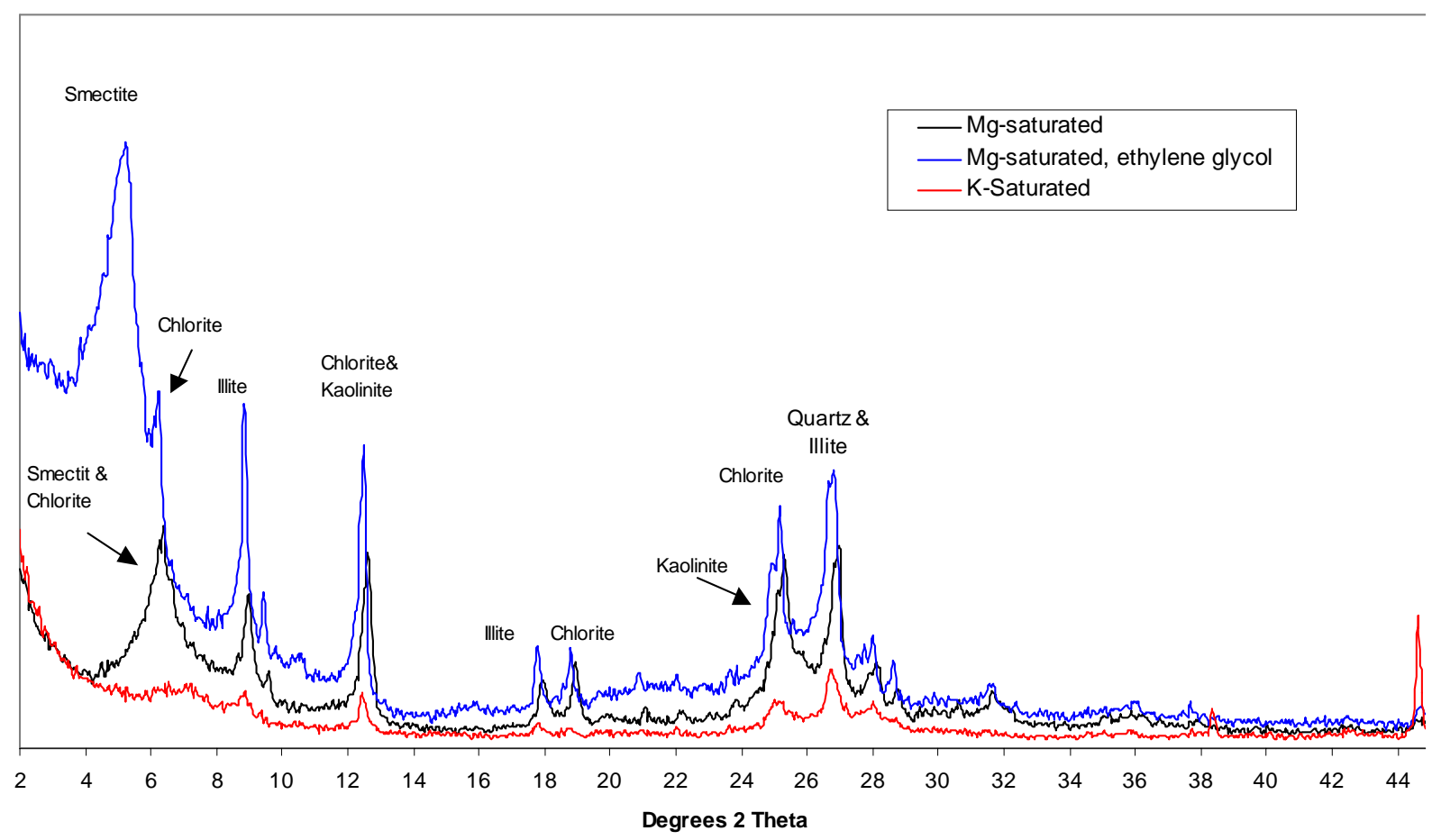

Figure G.2. Diffractogram for Clay-Size Particles in Hanford Fine Sand

XRD Tracings of Hanford Coarse Sand Clay Fraction

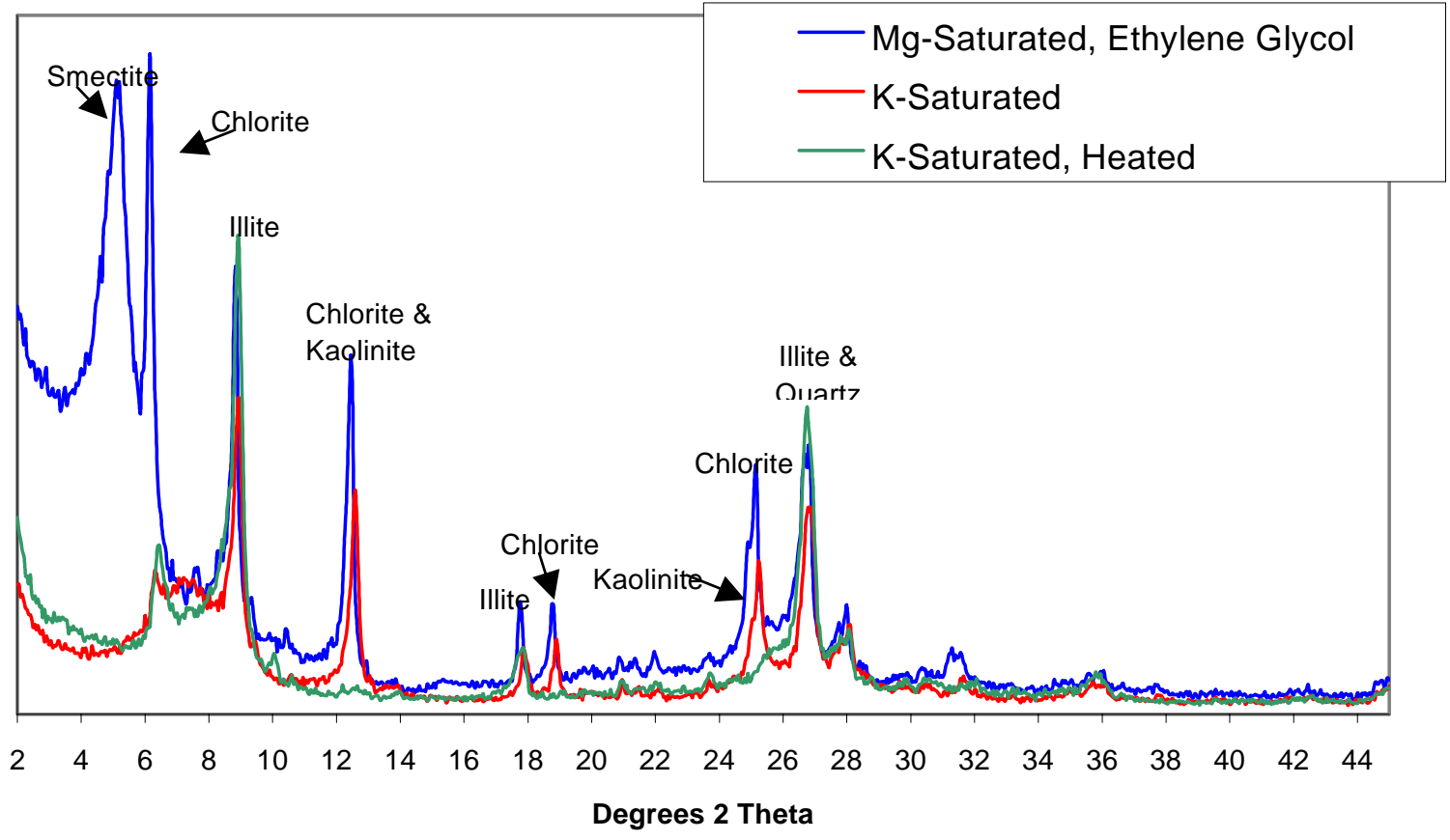

Figure G.3. Diffractogram for Clay-Size Particles in Hanford Coarse Sand 


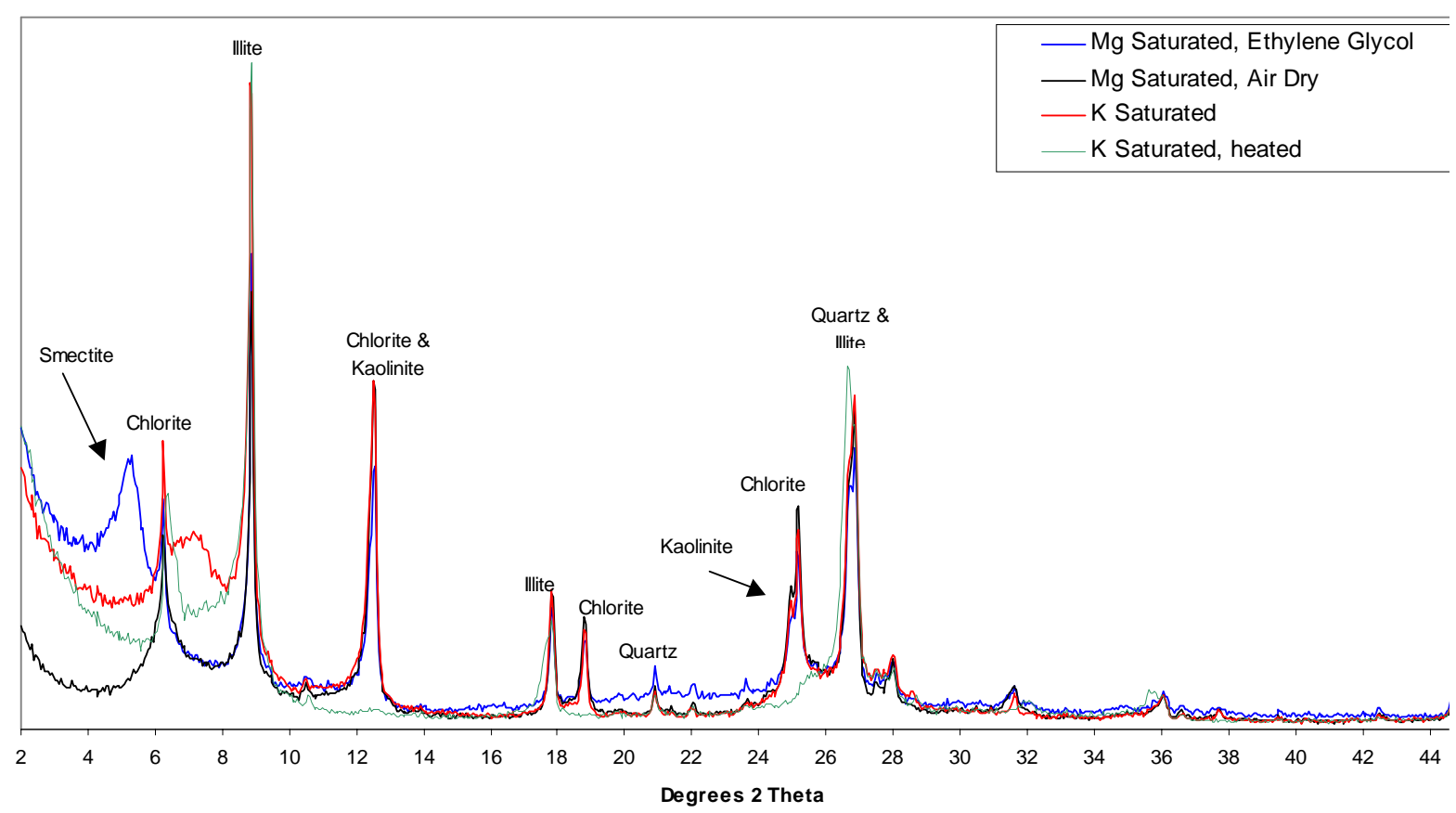

Figure G.4. Diffractogram for Clay-Size Particles in Borehole Fine Sand

XRD Tracing of Ringold Silt Clay Fraction

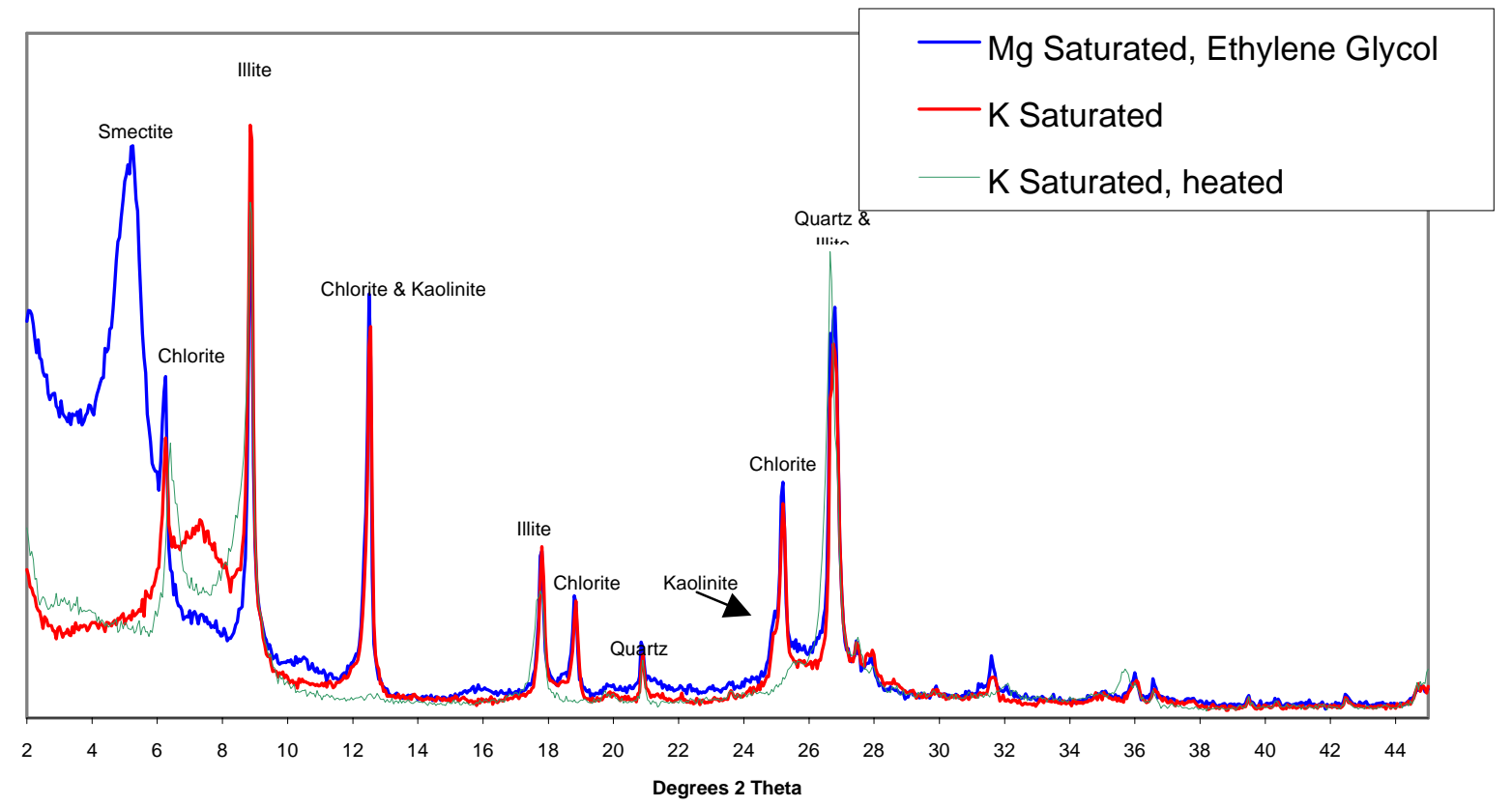

Figure G.5. Diffractogram for Clay-Size Particles in Ringold Silt 


\section{Appendix H}

Some Mineralogical Analyses from Boreholes 299-W22-48 and -50 


\section{Appendix H}

\section{Details on XRD for Boreholes 299-W22-48 and -50}

Table H.1. Semiquantitative Mineral Content for Boreholes 299-W22-48 and -50 Bulk Sediment (wt\%)

\begin{tabular}{|c|c|c|c|c|c|}
\hline Borehole 299-W22-48 & Quartz & K-Feldspar & Plagioclase & Calcite & Total \\
\hline 39.5' (H1a) & 60 & $<5$ & 20 & ND $^{*}$ & $\sim 85$ \\
\hline 47' (H1) & 20 & $<5$ & 15 & 10 & $\sim 50$ \\
\hline 91.5' (H2) & 45 & 40 & 15 & ND & $\sim 100$ \\
\hline 101.5' (H2) & 95 & $<5$ & 20 & ND & $\sim 115$ \\
\hline 136' (PPLz) & 80 & 30 & 10 & ND & $\sim 120$ \\
\hline 146' (PPlc) & 25 & $<5$ & 10 & 40 & $\sim 80$ \\
\hline 148.5' (PPlc) & 25 & 10 & 20 & 40 & $\sim 95$ \\
\hline 163.5' (Rtf) & 65 & 20 & 10 & ND & $\sim 95$ \\
\hline Borehole 299-W22-50 & 60 & 10 & 25 & ND & $\sim 95$ \\
\hline 50' (H1a) & 45 & 10 & 25 & ND & $\sim 80$ \\
\hline 60' (H1) & 45 & 15 & 30 & ND & $\sim 90$ \\
\hline 116' (H2) & 60 & 5 & 15 & ND & $\sim 80$ \\
\hline 135' (PPlz) & 60 & 10 & 15 & ND & $\sim 85$ \\
\hline 140' (PPl) & 50 & 10 & 30 & ND & $\sim 90$ \\
\hline 160.5' (Rtf)
\end{tabular}

$* \mathrm{ND}=$ none detected

Table H.2. Semiquantitative Measurements of Minerals in the Clay Fraction from Boreholes 299-W22-48 and -50 (wt\%)

\begin{tabular}{|c|c|c|c|c|c|c|c|c|}
\hline Depth (ft) & Quartz & Feldspar & Calcite & Smectite & Illite & Chlorite & Kaolinite & Total \\
\hline \multicolumn{9}{|c|}{ Borehole 299-W22-48 } \\
\hline 39.5’ ( H1a) & $<5$ & $<5$ & $\mathrm{Tr}$ & 25 & 20 & 15 & $<5$ & $\sim 75$ \\
\hline $47^{\prime} *(\mathrm{H} 1)$ & $<5$ & $<5$ & 5 & 10 & 10 & 10 & $<5$ & $\sim 50$ \\
\hline 91.5’ (H2) & $<5$ & $<5$ & $\operatorname{Tr}$ & 20 & 35 & 20 & $<5$ & $\sim 90$ \\
\hline $101.5^{\prime}(\mathrm{H} 2)$ & 10 & $<5$ & $\mathrm{Tr}$ & 25 & 35 & 35 & 10 & $\sim 120$ \\
\hline 136' (PPlz) & 10 & $<5$ & $\operatorname{Tr}$ & 20 & 30 & 20 & 10 & $\sim 95$ \\
\hline $146 *$ (PPlc) & $<5$ & $<5$ & 40 & 15 & 10 & 10 & $<5$ & $\sim 90$ \\
\hline 148.5** (PPlc) & $<5$ & $<5$ & 40 & $<5$ & 10 & $<5$ & $<5$ & $\sim 85$ \\
\hline 163.5' (Rtf) & 10 & $<5$ & $\mathrm{Nd}$ & 30 & 50 & 30 & $<5$ & $\sim 130$ \\
\hline \multicolumn{9}{|c|}{ Borehole 299-W22-50 } \\
\hline $50^{\prime}$ (H1a) & 5 & $<5$ & 10 & 30 & 15 & 10 & 10 & $\sim 85$ \\
\hline $60^{\prime}(\mathrm{H} 1)$ & 5 & 5 & 25 & 5 & 15 & 10 & 10 & $\sim 75$ \\
\hline 116' (H2) & 10 & $<5$ & $\operatorname{Tr}$ & 30 & 30 & 35 & 10 & $\sim 120$ \\
\hline 135’ (PPlz) & 5 & $<5$ & $<5$ & 30 & 30 & 30 & 10 & $\sim 115$ \\
\hline 140’ (PPlc) & 10 & $<5$ & $<5$ & 15 & 10 & 10 & 5 & $\sim 60$ \\
\hline 160.5’ (Rtf) & 5 & 5 & $\operatorname{Tr}$ & 10 & 15 & 15 & 10 & $\sim 60$ \\
\hline
\end{tabular}


Table H.3. XRF Analysis of Clay Fraction from Borehole 299-W22-48 (wt\%)

\begin{tabular}{|c|c|c|c|c|c|c|c|}
\hline Sample Depth (ft bgs) & $\mathrm{H} 1 \mathrm{a}$ & H1 & $\mathrm{H} 2$ & $\mathrm{H} 2$ & $\mathrm{PPlz}$ & PPlc & Rtf \\
\hline Strat. Unit & 39.5 & 47 & 91.5 & 101.5 & 136 & 146 & 163.5 \\
\hline \multicolumn{8}{|l|}{ Oxide } \\
\hline $\mathrm{Na}_{2} \mathrm{O}$ & NM & NM & NM & NM & NM & NM & NM \\
\hline $\mathrm{MgO}$ & NM & NM & NM & NM & NM & NM & NM \\
\hline $\mathrm{CO}_{2}$ & NM & NM & NM & NM & NM & NM & NM \\
\hline $\mathrm{Al}_{2} \mathrm{O}_{3}$ & 13.74 & 13.57 & 16.66 & 15.23 & 17.43 & 5.61 & 13.90 \\
\hline $\mathrm{SiO}_{2}$ & 42.50 & 50.38 & 48.78 & 46.00 & 51.24 & 25.62 & 45.89 \\
\hline $\mathrm{P}_{2} \mathrm{O}_{5}$ & 0.47 & 0.75 & 0.67 & 0.71 & 0.58 & 0.82 & 0.49 \\
\hline $\mathrm{SO}_{3}$ & 0.16 & 0.19 & 0.22 & 0.21 & 0.21 & 0.35 & 0.18 \\
\hline $\mathrm{Cl}$ & 1.31 & 0.35 & 1.00 & 2.50 & 0.13 & 0.44 & 1.54 \\
\hline $\mathrm{K}_{2} \mathrm{O}$ & 2.09 & 1.60 & 2.76 & 2.42 & 2.61 & 0.57 & 2.44 \\
\hline $\mathrm{CaO}$ & 2.98 & 4.46 & 1.94 & 1.15 & 1.95 & 29.05 & 1.19 \\
\hline $\mathrm{TiO}_{2}$ & 0.76 & 1.07 & 0.80 & 0.81 & 0.76 & 0.17 & 0.72 \\
\hline $\mathrm{V}_{2} \mathrm{O}_{5}$ & 0.03 & 0.02 & 0.02 & 0.02 & 0.02 & 0.01 & 0.02 \\
\hline $\mathrm{Cr}_{2} \mathrm{O}_{3}$ & 0.01 & 0.01 & 0.01 & 0.01 & 0.01 & 0.00 & 0.01 \\
\hline $\mathrm{MnO}$ & 0.18 & 0.15 & 0.17 & 0.18 & 0.11 & 0.30 & 0.31 \\
\hline $\mathrm{Fe}_{2} \mathrm{O}_{3}$ & 10.78 & 12.01 & 10.24 & 10.19 & 10.10 & 2.98 & 10.20 \\
\hline $\mathrm{SrO}$ & 0.02 & 0.03 & 0.02 & 0.01 & 0.01 & 0.03 & 0.02 \\
\hline $\mathrm{BaO}$ & 0.03 & 0.05 & 0.04 & 0.04 & 0.04 & 0.01 & 0.05 \\
\hline
\end{tabular}


Table H.4. XRF Analysis of Clay Fraction from Borehole B8814 (wt\%)

\begin{tabular}{|c|c|c|c|c|}
\hline Sample Depth (ft bgs) & $\mathrm{H} 1 \mathrm{a}$ & $\mathrm{H} 1$ & $\mathrm{PPlz}$ & PPlc \\
\hline Strat. Unit & 50 & 60 & 135 & 140 \\
\hline \multicolumn{5}{|l|}{ Oxide } \\
\hline $\mathrm{NaO}$ & NM & NM & NM & NM \\
\hline $\mathrm{MgO}$ & NM & NM & NM & NM \\
\hline $\mathrm{CO}_{2}$ & NM & NM & NM & NM \\
\hline $\mathrm{Al} 2 \mathrm{O}_{3}$ & 12.90 & 11.55 & 17.69 & 14.98 \\
\hline $\mathrm{SiO}_{2}$ & 46.96 & 43.54 & 48.46 & 45.14 \\
\hline $\mathrm{P}_{2} \mathrm{O}_{5}$ & 0.58 & 0.71 & 0.60 & 0.55 \\
\hline $\mathrm{SO}_{3}$ & 0.22 & 0.27 & 0.21 & 0.19 \\
\hline $\mathrm{Cl}$ & 0.20 & 0.14 & 1.14 & 0.44 \\
\hline $\mathrm{K} 2 \mathrm{O}$ & 1.36 & 1.62 & 2.30 & 2.02 \\
\hline $\mathrm{CaO}$ & 5.51 & 12.76 & 2.10 & 3.02 \\
\hline $\mathrm{TiO}_{2}$ & 0.82 & 0.85 & 0.67 & 0.68 \\
\hline $\mathrm{V}_{2} \mathrm{O}_{5}$ & 0.02 & 0.02 & 0.02 & 0.02 \\
\hline $\mathrm{Cr} 2 \mathrm{O}_{3}$ & 0.01 & 0.01 & 0.01 & 0.01 \\
\hline $\mathrm{MnO}$ & 0.15 & 0.14 & 0.12 & 0.10 \\
\hline $\mathrm{Fe} 2 \mathrm{O}_{3}$ & 11.79 & 9.78 & 9.39 & 10.67 \\
\hline $\mathrm{SrO}$ & 0.02 & 0.04 & 0.01 & 0.02 \\
\hline $\mathrm{BaO}$ & 0.03 & 0.06 & 0.03 & 0.04 \\
\hline \multicolumn{5}{|l|}{ NM-not measured } \\
\hline
\end{tabular}


XRD Tracings of Bulk Samples From Borehole B8812

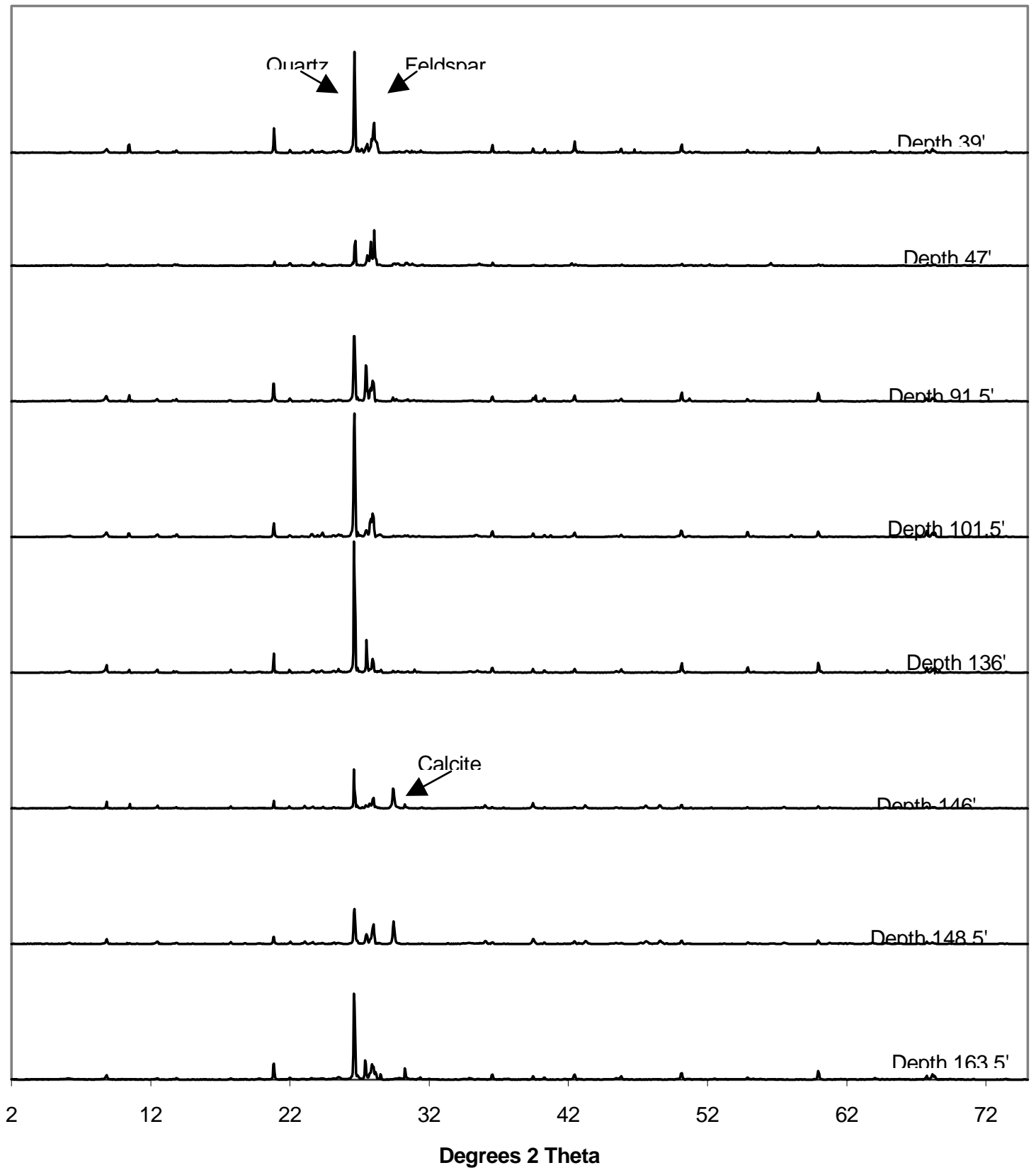

Figure H.1. XRD Pattern for Bulk Samples from 299-W22-48 (B8812) 
XRD Tracings of the Silt Fraction From Selected Depths in Borehole B8812

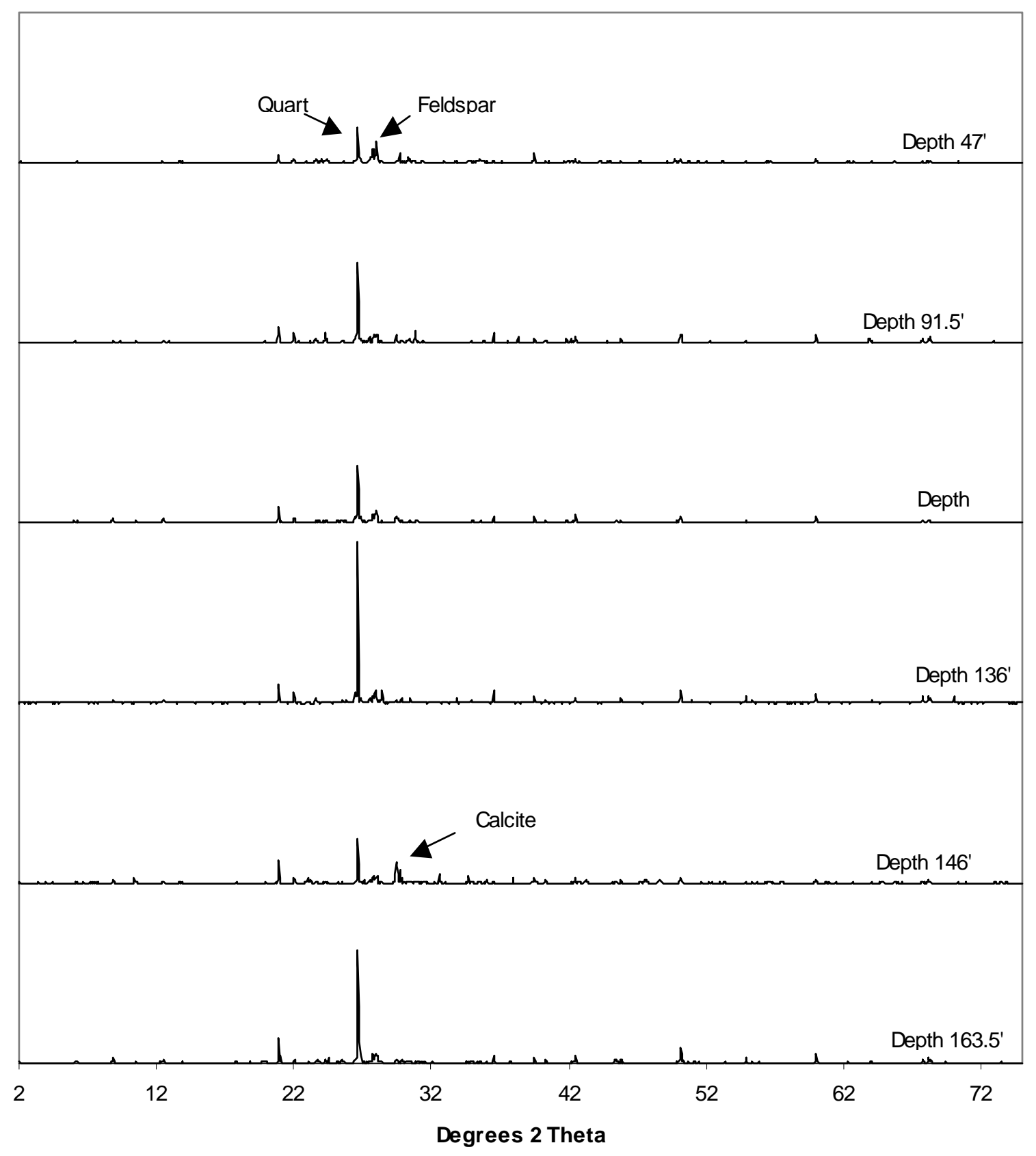

Figure H.2. XRD Patterns for the Silt Fraction from 299-W22-48 


\section{B8812 XRD Tracings of Clay Fraction}

(Mg Satruated, Ethylene Glycol)

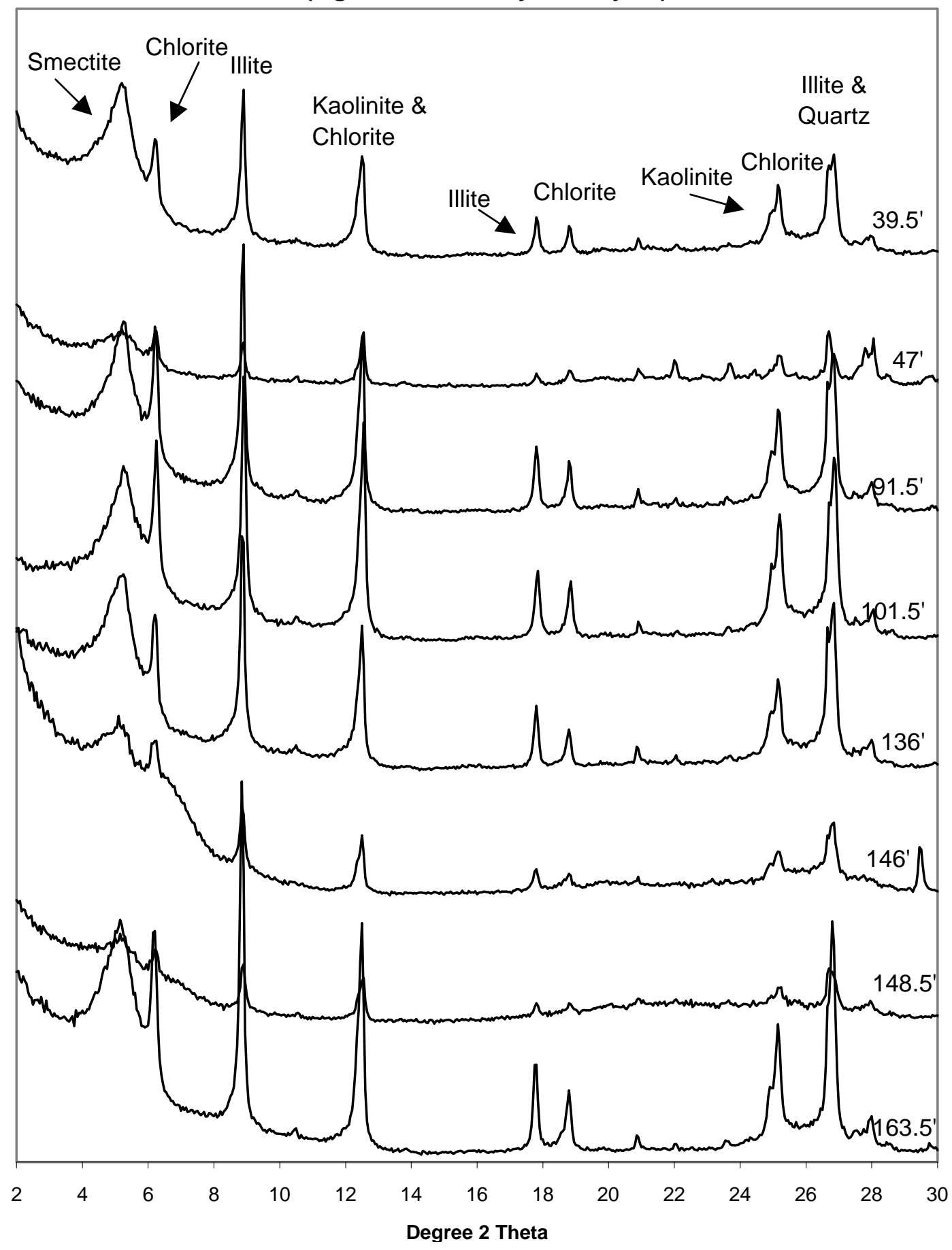

Figure H.3. XRD Patterns for Clay Fraction from 299-W22-48 
XRD Patterns of Sediments from Borehole B8814

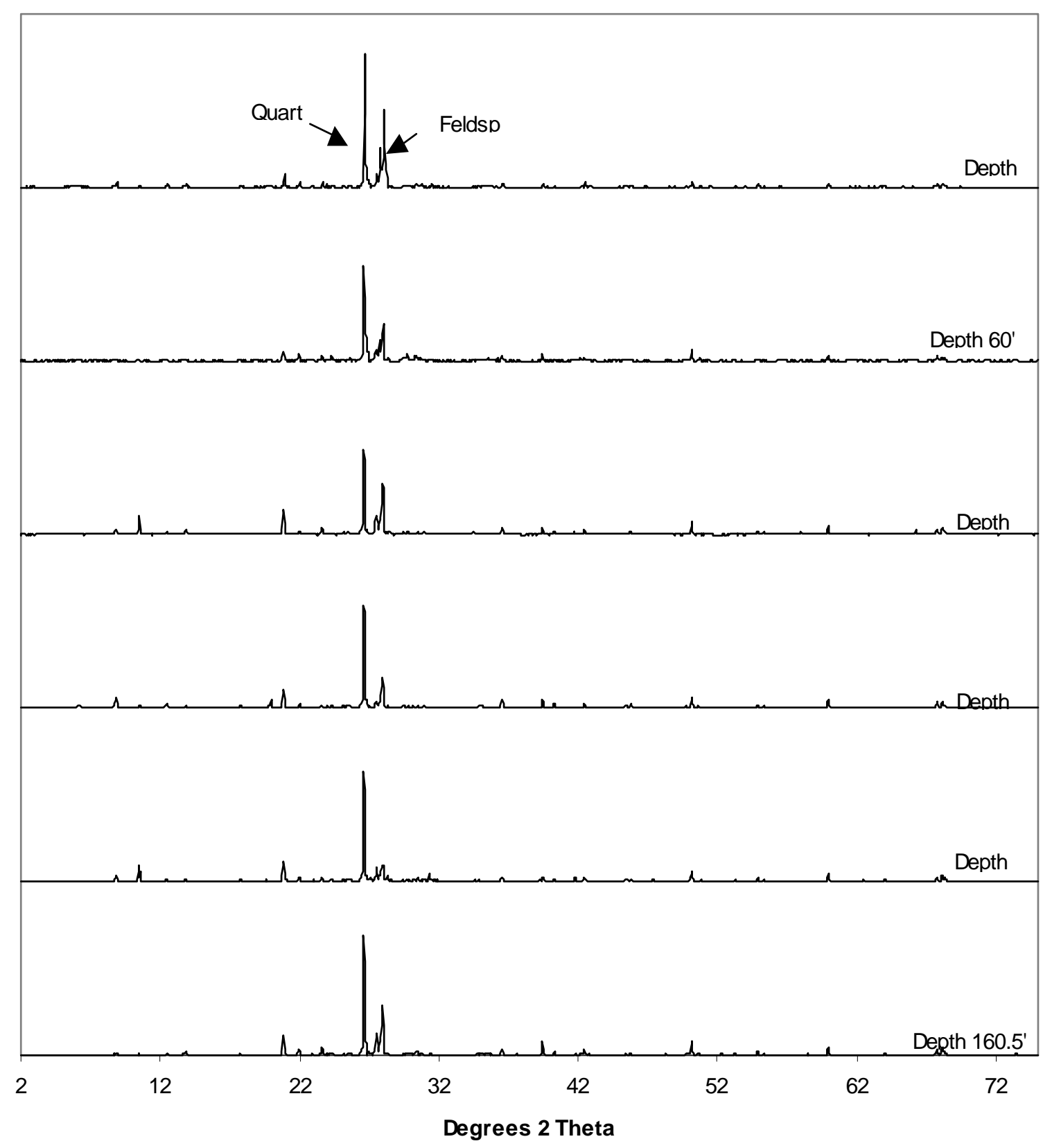

Figure H.4. XRD Patterns for Bulk Sediment from 299-W22-50 (B8814) 
XRD Patterns of the Silt Fraction From Sediments in Borehole B8814

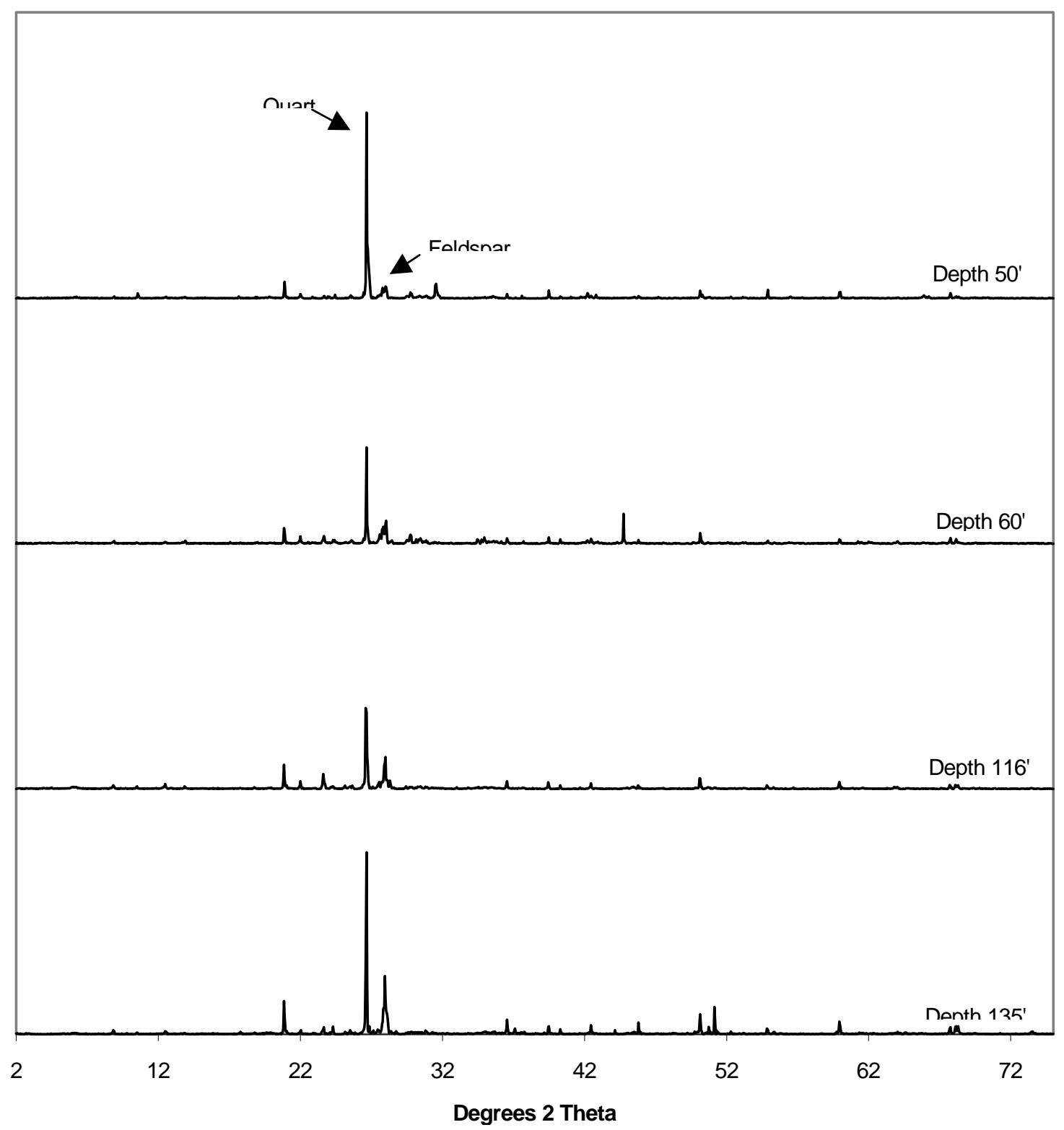

Figure H.5. XRD Patterns for Silt Fraction from 299-W22-50 


\section{XRD Patterns of the Clay From B8814}

(Mg Saturated \& Ethlyene Glycol)

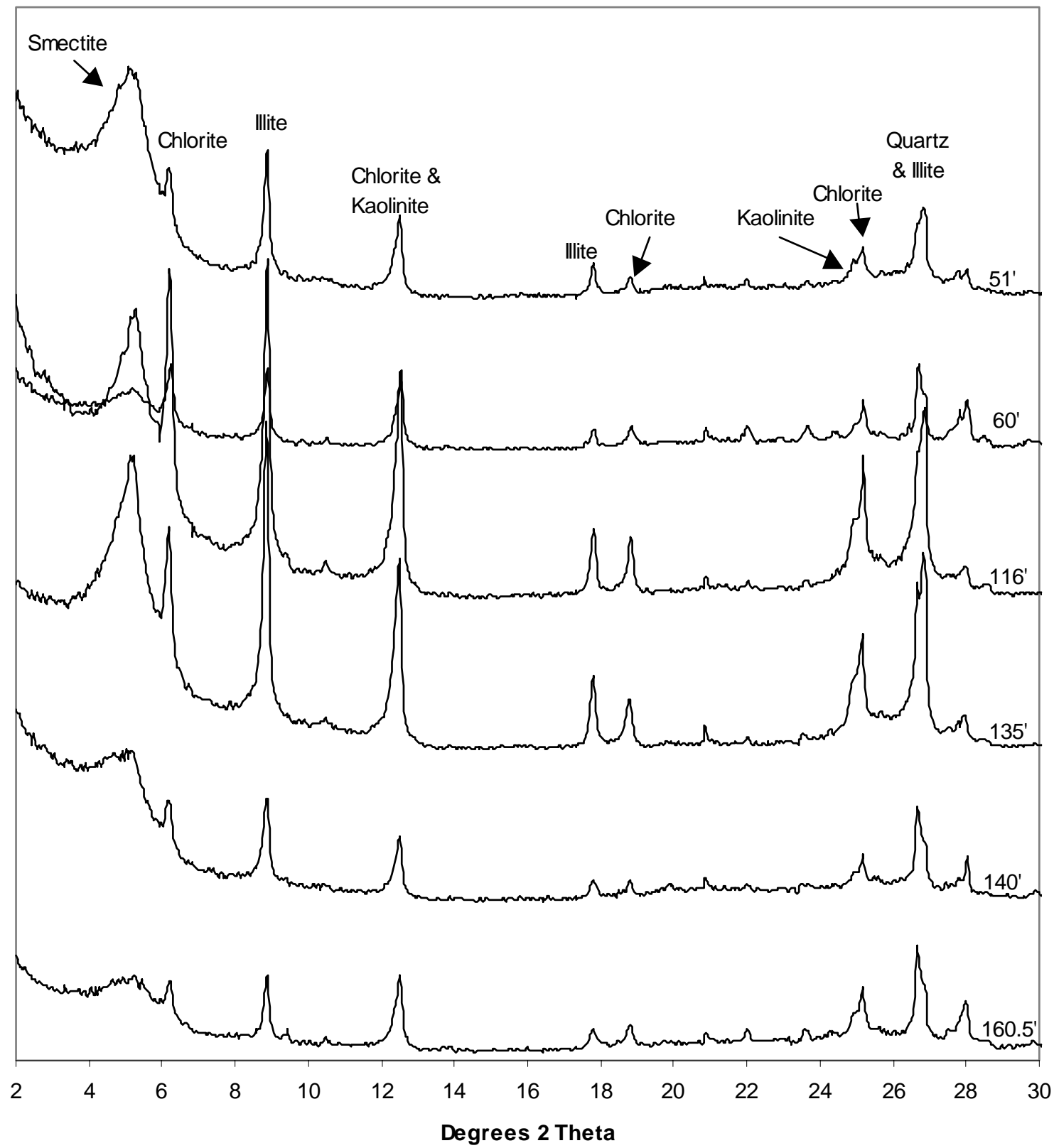

Figure H.6. XRD Patterns for Clay Fractions from 299-W22-50 (B8814) 
PNNL-13757-1

\section{Distribution}

No. of

Copies

ONSITE

CH2M HILL Hanford Group, Inc.

Anthony J. Knepp (10 CD)

Fredrick M. Mann

U.S. Department of Energy

Robert M. Yasek

U.S. Department of Ecology

Joseph Caggiano
No. of

Copies

Pacific Northwest National Laboratory

R. Jeff Serne (50 CD) K6-81

Clark W. Lindenmeier P8-37

George V. Last K6-81

Bruce N. Bjornstad K6-81

Duane G. Horton K6-81

H. Todd Schaef K6-81

H6-60

B5-18

1 hard copy and $1 \mathrm{CD}$ except as noted.

Distr.1 